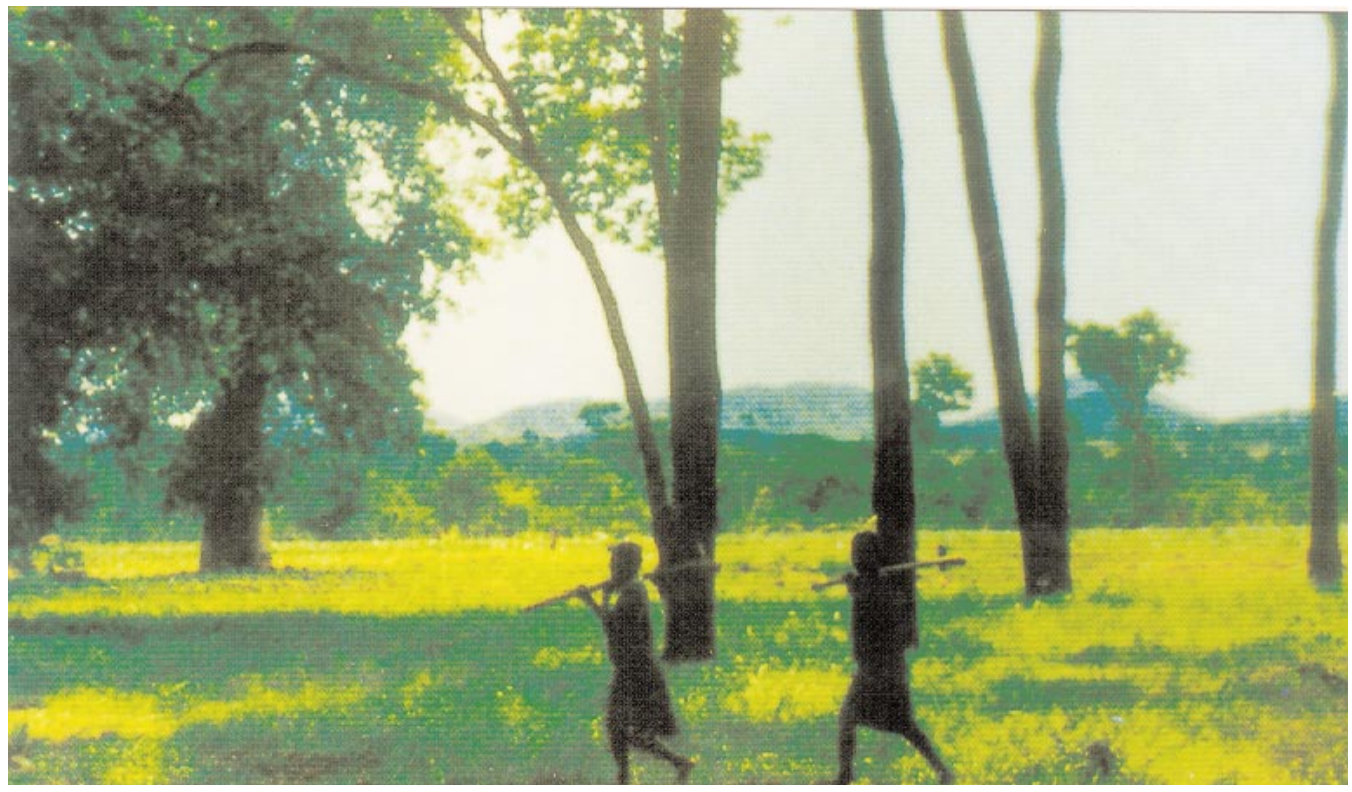

\title{
The Miombo in Transition: Woodlands and Welfare in Africa
}

Edited by Bruce Campbell

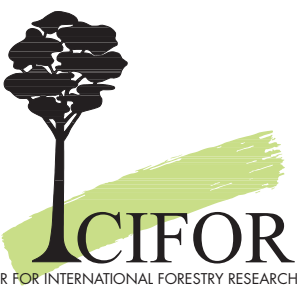


THE MIOMBO IN TRANSITION:

WOODLANDS AND WELFARE IN AFRICA 


\section{THE MIOMBO IN TRANSITION: WOODLANDS AND WELFARE IN AFRICA}

Edited by:

Bruce Campbell

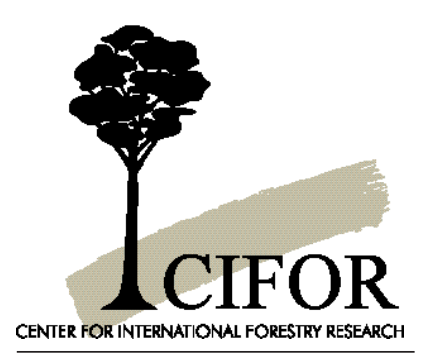

Center for International Forestry Research (CIFOR), Bogor, Indonesia 
(C) 1996 by Center for International Forestry Research All rights reserved. Published 1996.

Printed in Malaysia

ISBN: 979-8764-07-2

Center for International Forestry Research

Bogor, Indonesia

Mailing address: PO Box 6596 JKPWB, Jakarta 10065, Indonesia 


\section{Contents}

Acknowledgements

The reviewers

ix

Contributors

Chapter 1: Miombo woodlands and their use: overview and key issues

Bruce Campbell, Peter Frost and Neil Byron

The 'social forest': the significance of miombo woodlands 1

Bio-physical characteristics of miombo woodlands 3

Key issues and questions $\quad 5$

\section{Chapter 2: The ecology of miombo woodlands}

Peter Frost

Introduction

Climate, geology, landform and soils $\quad 14$

Composition and structure 19

$\begin{array}{ll}\text { Functioning } & 27\end{array}$

Dynamics $\quad 50$

Future research directions $\quad 55$

Chapter 3: Population biology of miombo trees

Emmanuel Chidumayo and Peter Frost

Introduction $\quad 59$

$\begin{array}{ll}\text { Phenology } & 59\end{array}$

Fruiting and dispersal $\quad 61$

Seed germination $\quad 63$

$\begin{array}{ll}\text { Regeneration } & 65\end{array}$

$\begin{array}{ll}\text { Growth } & 68\end{array}$

$\begin{array}{ll}\text { Mortality } & 68\end{array}$

$\begin{array}{ll}\text { Discussion and conclusions } & 71\end{array}$

Chapter 4: Miombo woodlands in the wider context: macro-economic and inter-sectoral influences

Salome Misana, Claude Mung'ong'o and Billy Mukamuri

Introduction $\quad 73$

$\begin{array}{ll}\text { Historical perspectives on miombo woodland utilisation } & 73\end{array}$

National policies and their impact on woodland use and cover $\quad 84$

$\begin{array}{ll}\text { Inter-sectoral linkages and conclusions } & 98\end{array}$ 


\section{Chapter 5: Rural households and miombo woodlands:} use, value and management

Jeanette Clarke, William Cavendish and Claire Coote

Introduction

Goods and services derived from miombo woodlands 102

The value of miombo woodlands to rural households 111

$\begin{array}{lr}\text { Customary woodland management practices } & 118\end{array}$

Determinants of miombo woodland use and management 124

Conclusions 135

\section{Chapter 6: Trade in woodland products from the miombo region}

Tim Brigham, Alex Chihongo and Emmanuel Chidumayo

Introduction

137

$\begin{array}{ll}\text { Production/harvesting of miombo products } & 139\end{array}$

The transformation of miombo products (processing, transporting and marketing) 149

$\begin{array}{ll}\text { Consumption of miombo woodland products } & 161\end{array}$

Impacts on economic sustainability 168

$\begin{array}{ll}\text { Suggestions for further research } & 174\end{array}$

\section{Chapter 7: Managing miombo woodland}

Emmanuel Chidumayo, James Gambiza and Isla Grundy

Introduction

Managing woody resources 176

Grazing management 186

$\begin{array}{ll}\text { Fire management } & 189\end{array}$

Managing non-wood forest products 191

Resolving conflicting management objectives in the face of scarcity 192

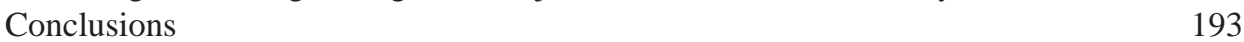

Chapter 8: Institutional arrangements governing the use and the management of miombo woodlands

Frank Matose and Liz Wily

Introduction

Property regimes and tenurial niches 195

Historical changes in institutional arrangements in the miombo region 198

Forest legislative framework: case studies 203

Summary of current situation $\quad 207$

Lessons from elsewhere 208

Current trends: towards community-based management 211

The way forward 216 
Chapter 9: Miombo woodlands and rural livelihoods: options and opportunities

Bruce Campbell and Neil Byron

Determinants of change in miombo woodland use and value 221

Rural livelihoods and miombo woodland products 223

Changing markets 224

Local institutional arrangements 226

Macro-economic and inter-sectoral influences $\quad 227$

Management options 228

The ecological framework and sustainability 228

$\begin{array}{ll}\text { Options and opportunities } & 230\end{array}$

References 231

Index to scientific names $\quad 263$ 


\section{Acknowledgements}

We acknowledge the Center for International Forestry Research (CIFOR), which provided the funds and stimulus for this book. I thank Neil Byron for his assistance and guidance. My experience and outlook has been favourably enhanced by the support I have received from numerous people. I would like to mention a few, namely Mike Swift who gave me the spring board into miombo woodlands, Peter Frost who was always around to answer questions, Felicitie Nengomasha who provided excellent secretarial support, and Bevlyne Sithole, my wife, who put up with fourteen hour working days and was a constant source of assistance and inspiration. Ron Ayling of the International Development Research Centre (Canada) deserves special mention for his interest and support of our research efforts. IDRC has funded much of our research in the miombo region. Finally I thank Godwin Kowero and Manuel Ruiz Pérez, both of CIFOR, for their input into the book.

\section{The reviewers}

A book is only as good as its reviewers. Each chapter was reviewed in draft and final form, in each case by at least two reviewers per chapter. For their excellent work I thank the following:

Mr M. Arnold, Oxford Forestry Institute

Mr T. Brigham, Consultant

Mr G. Broekhoven, World Conservation Union

Dr N. Byron, Center for International Forestry Research

Prof E. Chidumayo, University of Zambia

Dr T. Cunningham, WWF/UNESCO/KEW "People and Plants Initiative"

Dr P. Dewees, World Bank

Prof L. Fortmann, University of California at Berkeley

Prof P. Frost, Institute of Environmental Studies, University of Zimbabwe

Dr I. Gordon, Macaulay Land Use Research Institute, UK

Dr I. Grundy, Southern Alliance for Indigenous Resources

Dr W. de Jong, Centre for International Forestry Research

Prof R. Malimbwi, Sokoine University of Agriculture

Dr J. McGregor, St Anthony's College, Oxford

Dr T. Muller, Department of Research and Specialist Services

Dr A. Rodgers, Food and Agriculture Organisation of the United Nations

Prof R. Sanford, University of Denver

Ms B. Sithole, Centre for Applied Social Sciences, University of Zimbabwe

Dr R. Scholes, Environmentek, CSIR, South Africa

Dr I. Scoones, University of Sussex

Dr N. Byron and Dr I. Grundy read the entire manuscript. 


\section{Contributors}

Ms J. Abbot

University College London, Department of Anthropology,

Gower Street, London WC1E 6BT, U.K.

Mr M. Arnold

19 Hayward Road, Oxford OX2 8LN, U.K.

Mr I. Bond

WWF Programme Office,

PO Box CY1409, Causeway, 8437, Harare, Zimbabwe

Mr T. Brigham

743 - 21st St, New Westminster, B.C. Canada, V3M 4X8

Dr N. Byron

Center for International Forestry Research,

PO Box 6596 JKPWB, Jakarta 10065, Indonesia

Prof B.M. Campbell

Institute of Environmental Studies, University of Zimbabwe,

PO Box MP167, Mt Pleasant, Harare, Zimbabwe

Mr W. Cavendish

Centre for the Study of African Economies, Institute of Economics and Statistics, University of Oxford, Oxford OX1 3UL, U.K.

Prof E.N. Chidumayo

Dept of Biological Sciences, University of Zambia,

PO Box 32379, Lusaka, Zambia

Mr A. Chihongo

Tanzania Forestry Research Institute, TAFORI,

Box 1854, Morogoro, Tanzania

Ms J. Clarke

Environmentek, CSIR,

PO Box 395, Pretoria 0001, South Africa 
Dr C. Coote

Forestry Research Institute of Malawi,

Box 270, Zomba, Malawi

Dr T. Cunningham

People \& Plants, WWF/UNESCO/KEW,

PO Box 42, Betty's Bay 7141, South Africa

Dr P. Densanker

Michigan Tech. University, School of Forestry and Wood Products, 1400 Townsend Drive, Houghton, M149931, Michigan, U.S.A.

Ms C. Dzerefos

Wits Rural Facility,

P. Bag X420, Acornhoek 1360, South Africa

Dr L. Fortmann

Department of Environmental Science, Policy and Management, 211 Mulford Hall, University of California, Berkeley, CA94720-3114, U.S.A.

Prof P.G.H. Frost

Institute of Environmental Studies, University of Zimbabwe,

PO Box MP167, Mt Pleasant, Harare, Zimbabwe

Mr J. Gambiza

Department of Biological Sciences University of Zimbabwe,

PO Box MP167, Mt Pleasant, Harare, Zimbabwe

Ms I. Grundy

24 George Walker Rd, Hatfiled, Harare, Zimbabwe

Mr G.W. Howard

IUCN, PO Box 68200, Nairobi, Kenya

Mr J. Luhunga

Department of Forestry,

PO Box 30048, Lilongwe 3, Malawi

Dr R. Malimbwi

Faculty of Forestry, Sokoine University of Agriculture,

PO Box 3009, Morogoro, Tanzania 
Mr F. Matose

Forestry Research Centre, Forestry Commission,

PO Box HG595, Highlands, Harare, Zimbabwe

Prof G. Matzke

Geography Program, Department of Geosciences, Oregon State University, Wilkinson Hall 104, Corvallis, Oregon, U.S.A 97331

Prof S.B. Misana

Dept of Geography, University of Dar es Salaam,

Box 35049, Dar es Salaam, Tanzania

Dr B. Mukamuri

Institute of Environmental Studies, University of Zimbabwe, PO Box MP167, Mt Pleasant, Harare, Zimbabwe

Dr C. Mung'ong'o

Institute of Resource Assessment, University of Dar es Salaam, P.O.Box 35097, Dar es Salaam, Tanzania

Mr B. Mwakalombe

Misamfu Research Centre,

Box 410055, Kasama, Zambia

Dr C. Nhira

Centre for Applied Social Science, University of Zimbabwe, PO Box MP167, Mt Pleasant, Harare, Zimbabwe

Dr W. Rodgers

Biodiversity Support Programme,

PO Box 2, Dar es Salaam, Tanzania

Mr J. Salehe

Biodiversity Support Programme,

PO Box 2, Dar es Salaam, Tanzania

Dr R. Scholes

Environmentek, CSIR,

PO Box 395, Pretoria 0001, South Africa

Mr C. Shackeleton

Department of Environmental Affairs,

Drum Rock Complex, P. Bag 11233, Nelspruit 1200, South Africa 
Ms S. Shackleton

Department of Environmental Affairs,

Drum Rock Complex, P. Bag 11233, Nelspruit 1200, South Africa

Ms B. Sithole

Centre for Applied Social Sciences, University of Zimbabwe, PO Box MP167, Mt Pleasant, Harare, Zimbabwe

Mr A. Sitoe

Faculty of Forestry, Universidade Eduardo Mondlane,

C.P. 257, Maputo, Mozambique

Dr L. Wily

Box 68228, Nairobi, Kenya 


\title{
Chapter 1
}

\section{MIOMBO WOODLANDS AND THEIR USE: OVERVIEW AND KEY ISSUES}

\author{
Bruce Campbell, Peter Frost and Neil Byron
}

\section{The 'social forest': the significance of miombo woodlands}

Contrary to popular belief, savannas, not forests, are the most widespread vegetation in tropical Africa (White 1983). The savanna areas are where most of Africa's population live. Thus, in Africa, an interest in the 'social forest' (sensu Nhira and Fortmann 1993), inevitably leads to a focus on people in savanna areas. Of the savannas in the southern hemisphere, by far the most common is miombo woodland (Boxes 1.1 and 1.2).

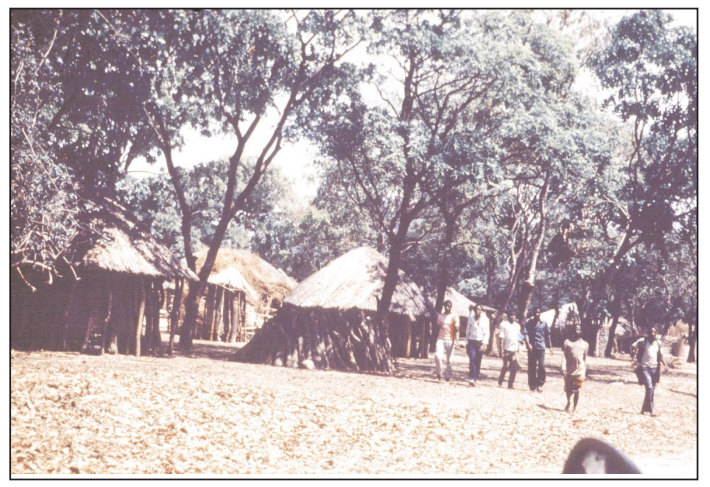

Living among miombo trees: a village in Zambia (photo: P. Frost)
Human population densities over much of the miombo zone are still low in comparison with other savanna areas of Africa under similar climatic conditions, though this is changing rapidly. The density of domestic livestock is also relatively low. The reasons are complex and reflect, at least in part, interrelationships among geology, soils, plant production and quality, wildlife and disease (Bell 1982). The main traditional form of land use involves cultivation of small fields of sorghum, millet, maize and pulses, either under some form of shifting agriculture, usually involving ash fertilisation and hand cultivation, or, in drier regions free from the disease trypanosomiasis, in conjunction with rearing livestock which provide the necessary draught power for cultivation (Puzo 1978). Despite the relatively small human populations, particularly in the wetter regions, much of the woodland has been, and continues to be, modified by people, principally through the removal of woodland cover (Chidumayo 1989a). Human activities are therefore important in the dynamics of miombo ecosystems (Morris 1970).

The resources of miombo woodlands are central to the livelihood systems of millions of rural and urban dwellers (Lawton 1982; 
Campbell et al. 1991a; Bradley and Dewees 1993; Chapter 5). We estimate that in 1990, 40 million people inhabited areas covered by, or formerly covered by miombo woodland, with an additional 15 million urban dwellers relying on miombo wood or charcoal as a source of energy.

Cropping systems in the miombo region depend on the woodland to varying degrees, as a bush fallow in the chitemene ash fertilisation system (Box 2.4), for leaf litter in Zimbabwean systems and, indirectly, for manure fertilisation, the miombo woodland providing the bulk of the graze and browse for livestock. A range of products from the woodlands supports rural living, from medicines and food to building timber and fuel (Figure 1.1).

\section{Box 1.1 What is miombo woodland?}

'Miombo' is a colloquial term used to describe those central, southern and eastern African woodlands dominated by the genera Brachystegia, Julbernardia and/or Isoberlinia, three closely related genera from the legume family (Fabaceae, subfamily Caesalpinioideae). There are 21 species of Brachystegia in miombo woodland and three species of each of the related genera (White 1983).

Over most of its range, mature undisturbed miombo is a closed deciduous nonspinescent woodland. It generally occurs on geologically old, nutrient-poor soils in the uni-modal rainfall zone. The shrub layer is variable in density and composition. The ground cover varies from a dense coarse grass growth to a sparse cover of herbs and small grasses. Fires are a characteristic feature of miombo woodlands.
The woodlands are not only the source of material goods, they are also central to the spiritual needs of the people, with specified trees and even blocks of woodland being conserved by communities for cultural reasons. Sacred groves associated with spirits of the dead or with territorial rain deities are found throughout the miombo region (Morris 1995).

Miombo woodland also provides products for towns and cities of the region, the most important of which is fuel. A host of other products are marketed (Chapter 6).

Miombo woodland is not only locally significant; some of the major rivers in southern, central and eastern Africa rise in areas covered by miombo woodland, most notably the Zambezi

\section{Box 1.2 \\ The 'feel' of miombo woodland}

D. B. Burtt, 1946, quoted from Rodgers, (in press a)

"A month before the rains set in, the miombo covered hills burst all at once into reds, salmons, pinks and coppery tinges of all hues as the Brachystegia trees flush into young leaf and, within a week, all this riot of colour has blended into a forest of the freshest green carpeted with legions of flowers.

In full leaf the miombo is delightfully cool and shady, and the scanty grass a pleasure to walk through.

In the dry season, what a change! The whole miombo forest becomes entirely leafless, while grass fires burn up all the grass and leaf litter. The sun beats down unmercifully and whichever way one turns there is the same view, the grey stems of miombo trees fading into the shimmering distance. The buzz of insect life has vanished, except for the sharp hiss of tsetse fly." 


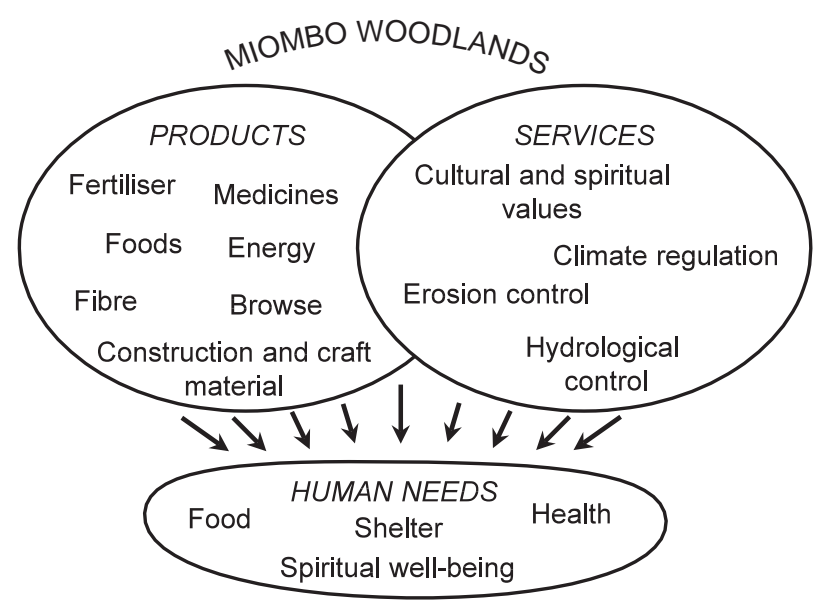

Figure 1.1 Goods and services provided by miombo woodlands. covering the Central African plateau and its escarpments. Within this region, miombo extends from Tanzania and southern Zaire in the north to Zimbabwe in the south, and across the continent from Angola, through Zambia, to Malawi and Mozambique (Figure 1.2). It thus spans the continent from east to west, and from near the equator to below the Tropic of Capricorn.

In geological time, miombo woodlands, or at least certain elements of them, have expanded and contracted across the centre of the continent, with evidence of their presence far south of the current distribution (Box 1.3). It is hypothesised that small River. Thus the quantity and quality of much of the region's water depends on activities within the woodland. Perhaps even more significant is the global importance of miombo woodland. Widespread burning across the miombo region could influence atmospheric chemistry and, ultimately, climate. Does miombo woodland act as a sink or a source of carbon? (Box 2.2).

\section{Bio-physical characteristics of miombo woodlands}

\section{Distribution}

A vast portion of southern, central and eastern Africa is covered by miombo woodlands. Millington et al. (1994) put the figure at more than 2.7 million $\mathrm{km}^{2}$, though the actual coverage is open to question as their concept of 'miombo' is confused (some patches of miombo woodland are excluded from their concept, while nonmiombo areas are included).

These woodlands form the dominant element of the Zambezian phytochorological region (White 1983), an area of about 3.8 million $\mathrm{km}^{2}$ changes in climate can have major impacts on the dynamics of the woodland.

\section{Ecological features}

Miombo comprises the woodland-dominated end of the spectrum of savanna formations (Box 1.4). Mature, relatively undisturbed stands typically comprise a 10-20 m high, single storey, partly closed canopy of mostly pinnate-leafed trees; a discontinuous understorey of broadleafed shrubs; and an often sparse but continuous herbaceous layer of forbs, small sedges, and caespitose, heliophytic $\mathrm{C}_{4}$ grasses. The biomass of large mammals is low and dominated by large-bodied species. Communities with a similar structure and sharing many of the dominant genera, except Brachystegia and Julbernardia, occur to the north and south of the main miombo zone (Figure 1.2).

The structure of miombo woodland is distinctive, a result of the characteristics of the dominant trees. Most of the species of the key genera have slender boles with initially sharply ascending branches which eventually spread out to support the light, shallow, often umbrella- 
shaped canopy. Miombo woodland is largely briefly deciduous, many of the dominant tree species only losing their leaves for a short period in the late dry season. In drier areas, it may be completely deciduous while in moister areas it may be virtually evergreen.

Soils of miombo woodland are typically nutrient-poor. The mean annual rainfall ranges from 650 to $1400 \mathrm{~mm}$, most of it falling in one season, summer (Chapter 2). Associated with miombo, but lacking most or all of the miombo dominants, is a range of other vegetation (White 1983). These other types are often inextricably linked to miombo woodland, through the flow of materials and goods, or the movement of livestock and people. Miombo woodland is a typical example of a moist-dystrophic savanna (Frost et al. 1986). Where soils are less nutrient-poor and/or where rainfall is lower, miombo woodland gives way to arid-eutrophic savannas, as described below.

\section{Associated vegetation types}

Arid-eutrophic savannas, such as Acacia savanna, mopane (Colophospermum mopane) woodland and other dry savanna woodlands (White 1983), are found in the large valleys of the Zambezi and Luangwa Rivers, within the miombo region, and as one moves south and south west from the main miombo region into drier areas. In Tanzania, grassland and Acacia savanna replace miombo woodland on the nutrient-rich volcanic soils, in drier areas and in areas with two rainfall peaks (Rodgers in press a). Open woodland dominated by Combretum spp. with a tall grass understorey, occurs on more fertile soils in lower catenary positions adjacent to miombo woodland on the upper slopes. Fire-induced tall grass savannas (chipya) with scattered fire-tolerant trees (Pterocarpus angolensis, Burkea africana, Erythrophleum africanum and mixed woodlands and thickets dominated by Combretum spp., Acacia spp., Afzelia quanzensis, Pericopsis angolensis, occur on nutrient-rich soils ('Upper Valley Soils', Trapnell and Clothier 1937) derived from limestone and mica schists. Acaciadominated woodlands occupy the broad, shallow, poorly drained depressions and drainage lines. Finally, spinescent, evergreen thickets associated with high (up to $15 \mathrm{~m}$ ) termitaria are found throughout miombo and associated vegetation types.

In the west of the miombo zone, dry evergreen forest and deciduous closed woodland occur on Kalahari sands, which cover a large portion of Zambia, Zimbabwe and Angola. These areas are dominated by Cryptosepalum pseudotaxus where water-tables are seasonally high, and by Baikiaea plurijuga on deeper, better drained sands. In areas of high rainfall, miombo woodland gives way to evergreen forest, as found along the northern limit of miombo woodland in Angola and Zaire. A similar transition occurs on the Mozambican coastal plain, which is dominated by forest and scrub forest.

Fire-sensitive evergreen thickets and partly evergreen woodland occur on deep soils and in lower, wetter catenary positions adjacent to chipya. This juxtaposition of infertile miombo and other, more fertile, moister and productive vegetation types may be important in maintaining populations of large wild and domestic herbivores in miombo woodlands, dependent on the extent and degree of interspersion of the vegetation types.

Dambos are distinctive features of the miombo region; they occupy seasonally waterlogged shallow valley depressions (Box 4.1). The dambos largely form the headwater reaches of drainage lines of the unrejuvenated surface of the central plateau. Dambos are hygrophilous, largely treeless grasslands, and in some areas can cover up to one-third of the landscape (Whitlow 1985a; 1985b). Evergreen groundwater forests (mushitu) occur in the perennially moist central parts of dambos in areas of higher rainfall.

The north-south range of mountains of the eastern parts of the miombo zone are characterised by afro-montane vegetation, grasslands and forests (White 1983), forming archipelagolike islands within a sea of miombo woodland. 


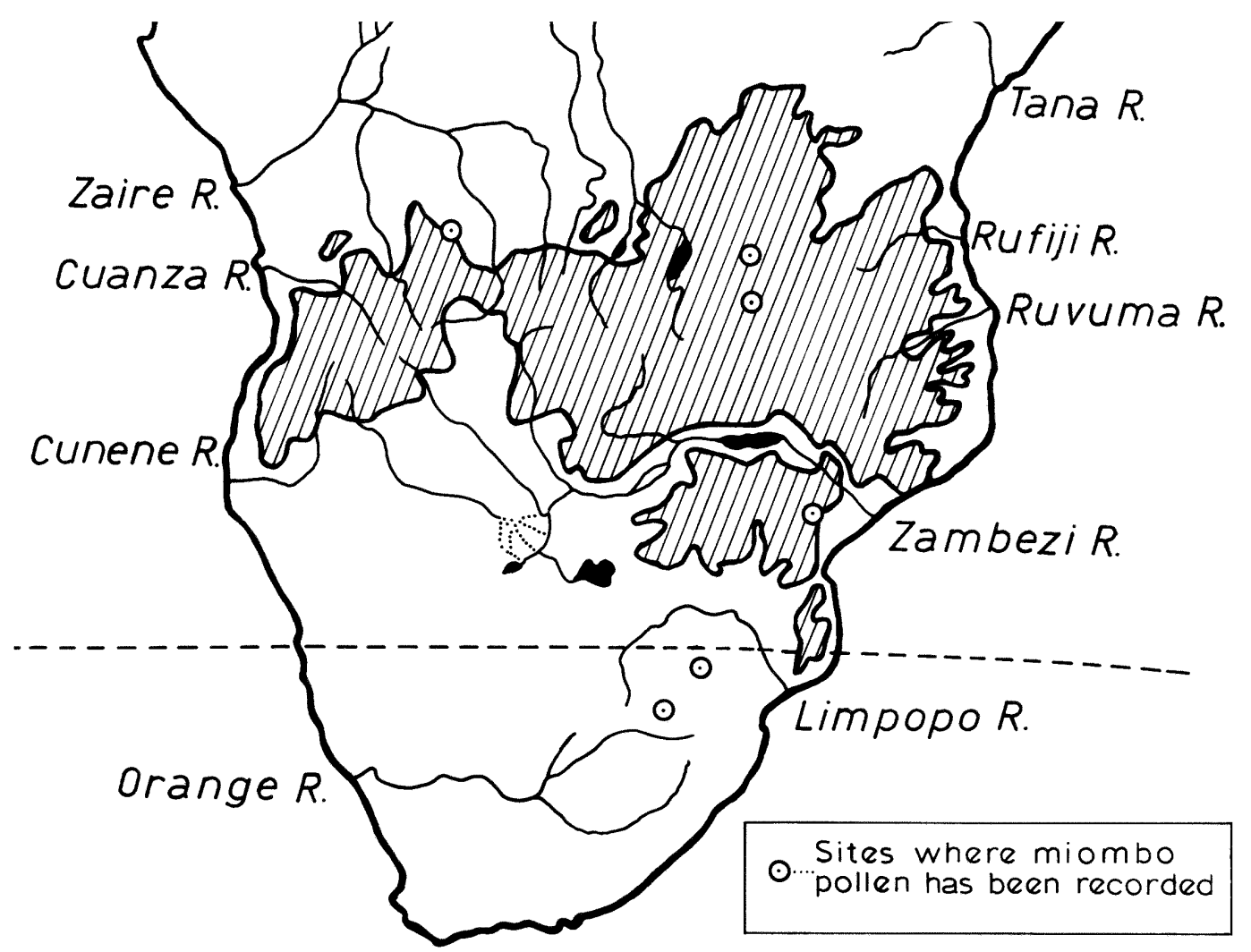

Figure 1.2 Distribution of miombo woodland. Sites where pollen of miombo woodland has been recorded are shown.

\section{Key issues and questions}

If miombo woodland is a crucial component of life in the region, as is argued above and in the chapters that follow, then our central concerns should be with change. It is estimated that half a million hectares of woodland are cleared annually in seven countries of the miombo region (Shaba 1993). How and why are the miombo systems, people's use patterns and perceptions, and the benefits derived from miombo woodland changing? We need to ask how the yields of goods and services from miombo woodlands can be optimised to ensure their sustainability and their equitable distribution (Figure 1.3).

Answers to these questions will require studies from several disciplinary fields, ranging from detailed local studies of households and ecological 


\section{Box 1.3 \\ Palaeohistory of miombo woodlands}

\section{Peter Frost}

A detailed reconstruction of the past environments and vegetation of Central Africa is hampered by a paucity of well preserved and accurately dated pollen profiles (Scott 1984). Moreover, most of the dominant species in miombo are insect pollinated and do not produce large amounts of pollen; they are likely, therefore, to be under-represented in pollen spectra. Sediment cores containing Brachystegia pollen and covering various periods of the past 38000 years have been recovered from the highlands of Zimbabwe (Tomlinson 1974), at the present upper altitudinal limit of Brachystegia; at sites in northern Zambia (Clark and Van Zinderen Bakker 1964; Livingstone 1971); in Angola (Van Zinderen Bakker and Clark 1962), close to the current lower altitudinal limit of Brachystegia, adjacent to the lowland tropical forests of the Zaire Basin; and in South Africa (Scott 1982; 1983), well beyond the present southern limit of miombo woodland (Figure 1.2).

Brachystegia appears to have been widespread across Central Africa prior to the major glaciation of the northern hemisphere, but at the height of the glaciation, around 19000 years BP, the vegetation was initially more open, with Compositae, Cliffortia and Cyathea dominant, later replaced by Podocarpus, Olea, Myrica and Ericaceae (Scott 1984). The vegetation zones of the central plateau were probably displaced to lower altitudes and latitudes as the climate cooled. Brachystegia pollen appears sporadically in sediments dated 23370 years BP, and both earlier and later than 19000 years BP, from Naboomspruit, South Africa (Scott 1982), a site over $350 \mathrm{~km}$ south west of the present-day distribution limits of the genus.

With the return of warmer conditions during the Holocene, Brachystegia again became prominent in the plateau vegetation. Subsequent expansions and contractions are suggested by increases in pollen in late-Holocene sediments from the Inyanga highlands, Zimbabwe, where the genus had become well established by 4670 years BP (Tomlinson 1974); by traces of pollen in 2000-4000 year-old sediments from Naboomspruit (Scott 1982); and by its occurrence in sediments dated at less than 1000 years BP from both Naboomspruit and Pretoria, South Africa (Scott 1982; 1983). These expansions and contractions during the late Pleistocene and Holocene may have contributed both to speciation and to subsequent widespread hybridisation among the Brachystegia species (Lawton 1963).

The dispersability of most miombo dominants, including Brachystegia, is low. The dominant species have explosively dehiscent pods which produce a limited seed shadow (Strang 1966; Ernst 1988). Thus the past occurrence of Brachystegia at sites well beyond its present range suggests that conditions then must have been particularly favourable. Whether this applied to other miombo species as well is not clear since neither the rate of spread, nor the direction, need necessarily have been the same for all species. The marked contraction in the geographic range of Brachystegia in recent times (over $350 \mathrm{~km}$ in less than 1000 years) suggests either a sudden change in climate, something for which there is no evidence (Scott 1984), or that relatively minor shifts in temperature and moisture regimes during the past 1000 years have triggered marked changes in population dynamics. 


\section{Box 1.4 \\ Miombo: savanna, woodland or forest?}

Peter Frost

Miombo has variously been classed as savanna (Huntley 1982; Frost et al. 1986), woodland (White 1983) and forest (Freson et al. 1974; Malaisse 1978a), a reflection of the long-standing argument among ecologists in Africa over how best to categorise those wooded formations in areas receiving markedly seasonal rainfall. Two approaches to the problem have been adopted. First, to differentiate vegetation on the basis of physiognomy on the assumption that vegetation types with similar form have similar ecological functioning, whereas those with contrasting physiognomies function differently. On these grounds, it has been suggested that use of the term 'savanna' should be discontinued, because it "has been defined in so many different ways that it is no longer possible to use it in a precise classificatory sense" (White 1983). This has led to a proliferation of descriptive terms such as woodland, bushland, thicket and wooded grassland, with qualifiers to reflect biogeographic affinities. Thus miombo has been categorised by White (1983) as Zambezian miombo woodland.

The alternative approach has been to recognise that there is a hierarchy of factors affecting vegetation structure and functioning - climate at a regional scale, soil properties at the landscape level, and various kinds of disturbance modifying composition and structure locally - and to group together those systems experiencing broadly similar environmental conditions and driving forces. Thus functionally related vegetation may differ physiognomically depending on local differences in soils and disturbance regime. In this context, the term 'savanna' was resurrected to encompass "those tropical and some near-tropical ecosystems characterised by a continuous herbaceous cover consisting mostly of heliophilous $\mathrm{C}_{4}$ grasses and sedges that show clear seasonality related to water stress. Woody species (shrubs, trees, palms) occur but seldom form a continuous cover paralleling that of the grassy layer" (Frost et al. 1986). This definition explicitly includes physiognomic formations ranging from edaphic and lightly wooded grasslands, through bushland, thickets and open woodlands, to closed canopy woodlands such as miombo.

At a global level, more mesic miombo has been classed as a 'seasonally dry tropical forest', the term reflecting the dominance and structural complexity of the woody component and the presence of a seasonal drought period (Bullock et al. 1995). Miombo occurs alongside semi-evergreen forest in the higher rainfall zones of Central Africa (White 1983) and has been considered to be successional to it (Freson et al. 1974). Interestingly, the lowland evergreen forests of the Zaire basin and East African coastal zone are the only vegetation types outside miombo to have a number of species of Brachystegia (cyanometroides, laurentii, leonensis and milbraedii), Julbernardia (magnistipulata, pellegriniana and seretii) and Isoberlinia (scheffleri).

What then is miombo? Over most of its range, mature undisturbed miombo is physiognomically a closed deciduous woodland within the spectrum of savanna ecosystems (Walker 1981, Huntley 1982, ), grading into seasonal dry forest at above $1200 \mathrm{~mm}$ mean annual precipitation. Nevertheless, at any point there can be considerable heterogeneity in tree height, canopy cover and herbaceous structure, reflecting the variation in soils and the impacts of fire, land use, herbivory and other disturbances. The overriding feature that gives coherence to this diversity is the floristic uniformity of the vegetation, namely the dominance of genera in the family Fabaceae, subfamily Caesalpinioideae, particularly Brachystegia, Julbernardia and Isoberlinia. 


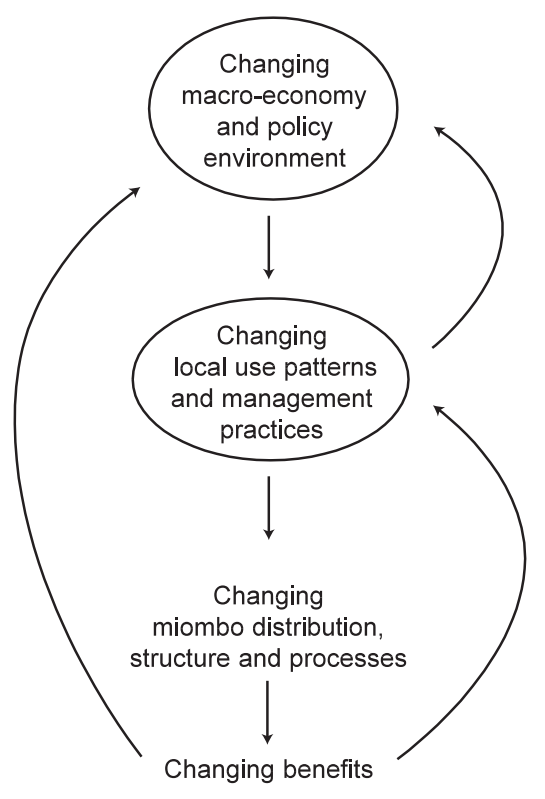

Figure 1.3 The central focus of the book: change in miombo woodland.

plots to broader investigations of macro-economic issues and the global environment. For a full understanding of changes in miombo woodlands and in the livelihood systems derived therefrom, the changes have to be linked to processes at the local level (households, communities, stands of miombo woodland) and at the national, regional and global levels (macro-economic and watershed levels).

The book is divided into eight substantive chapters. Some of the key issues within each chapter are briefly introduced below. While the central focus is miombo woodland, associated vegetation types are intricately linked to miombo, and, where appropriate, examples of how people use the environment, and how policies impinge on utilisation have been drawn from the non-miombo associated vegetation.

\section{Ecological issues}

In Chapter 2 we review some of the structural and functional characteristics of miombo ecosystems, and the driving variables, including human activities. In Chapter 3 the population ecology of dominant miombo trees is examined, and related to the goods provided by miombo woodlands.

A major task for ecologists is to elucidate the bio-physical framework within which miombo woodland functions, as this framework will set the limits of utilisation. For instance, the nutrient poverty of the soils of the miombo region has major implications for agricultural and forestry activities. The host of ecological factors needs to be investigated, ranging from soil nutrients, soil moisture and frost, to tsetse fly, large mammals and fire. And more important than single-factor analyses, is the need to investigate how the factors interact in space and time, as it is believed that interactions of determinants are more important than determinants acting alone (Frost et al. 1986).

Within this analysis of the determinants, a major focus will be on ecological productivity. What utilisation is possible, and what are the ecological consequences of utilisation? We hypothesise that the ecological impacts of miombo woodland use depend on the floristic composition of the woodland, and the nature and intensity of utilisation, especially in relation to the status of the determinants at the time and after utilisation (Chidumayo 1993a; Peters 1994).

\section{Miombo woodland in the wider context}

Chapter 4 explores the relationship between what happens at the local level and the wider economy. As change in miombo use and coverage is an important issue, it is necessary to analyse the patterns of social and economic changes occurring in the region and to relate these changes to environmental variables. The dynamics of miombo woodland can only be fully discussed in the context of agriculture and land use (Bradley and Dewees 1993). Central to Chapter 4 
is the hypothesis that macro-economic factors and national policies in sectors other than forestry (e.g. interest rates, agricultural pricing policies, revenue systems, legislation, structural adjustment) have an impact, at a local level, on the use and management of miombo woodland, which in turn affects its distribution, structure and functioning (Katerere et al. 1993; Ruiz 1995).

The macro-economic framework must not be seen only in the context of national policies; the globalisation of economies and international pressures on developing countries must also be considered. For instance, is miombo woodland a global asset, in terms of biodiversity or as a carbon sink, and would such a perspective affect how it is used (e.g. debt-for-nature swaps)? In the era of free trade (and potential substitution), what will become of local markets for miombo woodland products? How do international trade policies (e.g. CITES) influence utilisation?

\section{Rural households and miombo woodland: use, value and management}

Chapter 5 focuses on the thesis that woodland products and services are crucial to the livelihood systems of rural dwellers in the miombo region (Bradley and Dewees 1993). The authors explore the full range of products and services obtained from woodlands and show how these contribute to livelihood systems (subsistence requirements, income, labour allocation, etc.). Non-market values of miombo woodland, such as those relating to power, spirituality and cultural heritage (Shepherd 1992; Morris 1995) are also investigated.

Understanding how collection, use, value and marketing of wild resources is differentiated by wealth, gender, age and ecological situation is essential to assess the overall economic value of miombo woodlands (Guijt et al. 1995). It is also essential to understand the changes that occur through time.
Patterns of differentiation in relation to gender need to be explored, given that women are so heavily dependent on woodland product activities and given the marked differentiation between male and female involvement (Working Group on Gender and Forestry 1995). Communities are not homogenous groups, and it is highly likely that certain wealth strata may benefit to a greater extent than others from miombo woodland use. Current thinking suggests that it is the poorer households who are more dependent on woodlands (de Beer and McDermott 1989; Bradley and Dewees 1993; Arnold 1995).

\section{Commercialisation of miombo woodland products}

Chapter 6 focuses on miombo products that are traded in the market place, and explores the nature and impacts of marketing. Central issues in this chapter revolve around the driving forces of commercialisation, its impact on local rules and regulations, and the relationship between commercialisation and sustainability. While the marketing of firewood and charcoal to cities has received some attention, and can result in considerable benefits to producer households (Monela et al. 1993), other miombo woodland resources have received little attention because the informal nature of the marketing systems results in underreporting in official surveys.

One limitation in the marketing of non-wood forest products is the frequent lack of continuity of supply of woodland products, both in quality and quantity (Anderson 1993; Ruiz 1995). We need to ask whether through commercialisation can people respond to the needs of the market for a constant, uniform product with elastic supply.

Marketing of woodland products may be a key component of household livelihood systems. What kinds of households and who in the household benefit from income generated by the sale of which miombo woodland products? Following Arnold (1995), we hypothesise that it is the poorer 
households that benefit most from woodlandbased enterprises. However, in line with the arguments of Dove (1993), we suggest that this hypothesis only holds for low-value resources; when resources are high-value they tend to be appropriated by elite groups.

\section{Managing miombo woodlands}

Chapter 7 investigates the options for managing miombo woodlands. The challenge for miombo managers is to incorporate a wide variety of objectives in their management operations, elements of forestry, wildlife and livestock production, apiculture, etc. A further challenge is to adapt management strategies within the context of common property resources.

The technical options are examined in terms of our knowledge of miombo woodland ecology (Chapters 2 and 3). What are the upper limits to productivity? How can these be achieved? And how do we manage systems that may be partially event-driven and in which interactions among determinants may be more important than the determinants by themselves? How can forestry principles be applied in communal areas, and is it possible to build on local, 'indigenous' management practices?

\section{Institutional arrangements governing use of miombo woodland}

Chapter 8 examines the property regimes, tenurial niches, and legislative frameworks for trees and woodlands that are found in the miombo region, and describes how these have changed historically. The chapter then explores lessons from elsewhere before examining future possibilities.

Miombo woodlands are mostly used communally. Thus an analysis of the household use of woodland products has to be anchored in the debate on the status and use of communal resources, and the complex interactions among a number of factors, not least of which are the nature of tenurial control and the state of local and government institutions (Sithole and Bradley 1995).

The role of the government in regulating natural resource exploitation is being questioned, both from pragmatic and ethical viewpoints. What new or modified institutional arrangements for natural resource management are required and how can they be supported? Devolution of authority over natural resource management is now well-advanced in the case of wildlife in some miombo areas, through CAMPFIRE-type approaches, where local communities play an active role in the management of the resources, and in the generation and distribution of benefits (Murombedzi 1991). Can similar models be applied to a broader spectrum of woodland resources?

\section{The future of miombo woodlands}

Chapter 9 attempts to synthesise the material presented throughout the book by presenting general conceptual models indicating the key driving forces for change in miombo woodland use. The key issues emerging from the different disciplinary perspectives are summarised, and the gaps in our knowledge are highlighted. The discussion inevitably leads to a vision of the future of miombo woodlands: whether current use is sustainable; whether governments can provide an enabling policy framework for sustainable use; how commercialisation can improve livelihoods on a sustainable basis; whether devolution and empowerment are feasible; and whether recent promising institutional arrangements concerning wildlife can be adapted for a wide range of miombo products? 


\section{Chapter \\ 2}

\section{THE ECOLOGY OF MIOMBO WOODLANDS}

\section{Peter Frost}

\section{Introduction}

Miombo woodland is the most extensive tropical seasonal woodland and dry forest formation in Africa (perhaps even globally), covering an estimated 2.7 million $\mathrm{km}^{2}$ in regions receiving $>700$ $\mathrm{mm}$ mean annual rainfall on nutrient-poor soils. It is often portrayed as the archetype of the 'moist-dystrophic' savannas of Africa (Huntley 1982). Miombo woodland is distinguished from other African savanna, woodland and forest formations by the dominance of tree species in the family Fabaceae, subfamily Caesalpinioideae, particularly in the genera Brachystegia, Julbernardia and Isoberlinia (Box 1.4). The diversity of canopy tree species is low, although the overall species richness of the flora is high (Box 2.1). Among other distinctive features are the number of tree species with meso- and microphyllous compound leaves (van der Meulen and Werger 1984); the flush of new leaves before the rains (Tuohy and Choinski 1990); the dominance of tree species with ectomycorrhizae (Högberg 1982; 1992; Högberg and Piearce 1986); and the low numbers and biomass of large herbivores (Bell 1982). Previous syntheses and literature reviews of aspects of miombo woodland ecology include those by Malaisse (1978a), Celander (1983), Gauslaa (1989) and Chidumayo (1993a), though none of these has presented a detailed overview of miombo woodland functioning. This chapter reviews some key structural and functional features of miombo woodland and the factors that are thought to determine them. Further ecological information can be found in Chapter 3, which describes the population ecology of the dominant miombo trees, and Chapter 7, which examines the management issues in miombo woodland, including silvicultural aspects and fire and grazing management.

The aim of this chapter is to define the biophysical characteristics of miombo woodland, to provide a framework for understanding the potentials for, and constraints on, land and resource use, and as a basis to begin assessing the potential impacts of changes in land use and land cover on carbon sequestration and emissions to the atmosphere (Box 2.2). A number of questions need to be answered. What are the patterns of primary and secondary production in miombo woodland ecosystems and how do these differ from other African savanna systems? What factors regulate production in miombo woodland ecosystems? What are the patterns of nutrient 
cycling and how are these affected by changes in land use? What are the impacts of herbivory and fire on nutrient cycling and on vegetation struc- ture and composition? How do these features interact to determine the overall dynamics of miombo woodland?

\section{Box 2.1 The biodiversity of miombo woodlands}

\section{Alan Rodgers, J. Salehe and Geoff Howard}

The miombo woodland belt of tropical Africa is virtually synonymous with the Zambezian Phytochorion, the largest of White's (1983) Regional Centres of Endemism within Africa. Whilst internally the miombo is relatively homogenous in community composition (compared, for example, to the Afromontane forests), the Zambezian vegetation is extremely rich in plant species, many of which are endemic to the phytochorion (Brenan 1978; White 1983).

The miombo region has an estimated 8500 species of higher plants, over $54 \%$ of which are endemic. Of these 334 are trees (compared with 171 in the extensive and similar Sudanian woodlands found north of the equator). Zambia has perhaps the highest diversity of trees; and Zambia is the centre of endemism for Brachystegia, with 17 species (there is 1 in Kenya, 6 in south eastern Tanzania and 11 in western Tanzania). Generic endemism is low overall ( $<15 \%$ of the genera), with species linkages to the Sudanian and coastal formations. Species diversity and localised endemism is high in many herbaceous plant genera, such as Crotalaria (over 200 miombo species) and Indigofera. Areas of serpentine soils in Zimbabwe provide localised sites of speciation and endemism.

Sub-specific diversity is increasingly of interest within the miombo. The important timber tree Pterocarpus angolensis has a variety of ecological provenances of differing drought, fire and frost tolerance. Similarly there are a variety of growth forms of interest for timber production. Recent analysis of phenotypic variation within the marula tree, Sclerocarya caffra, has led to improved fruit production for commercial use.

Interest in animal diversity has been concentrated on larger mammals and avifauna (Rodgers in press b). There are large herbivores specific to the miombo, for instance sable antelope and Lichtenstein's hartebeest. Overall diversity of miombo wildlife is enhanced by the inclusion of habitat islands of non-miombo. The habitats along river terraces with more nutrient-rich soils than miombo soils and more palatable grasses, along the Rufiji, Luangwa and Zambezi valleys, for example, raise ungulate carrying capacity and variety. The swamp floodplains (e.g. Mweru, Rukwa and Moyowosi) play a similar role. Unbroken landscapes of miombo have much lower diversity.

The miombo woodland has a distinctive avifauna, with many endemic species, including the Miombo Grey Tit, Miombo Rock Thrush, Shelley's Sunbird and Stierling's Woodpecker. Out of Tanzania's 1300 bird species some 40-50 are miombo specialists (Britten 1980).

Generally, however, faunal richness is low, probably a consequence of the extreme harshness of the dry season, with a virtual seven-month drought often accompanied by intense fires. Insect and herpetofauna are impoverished. 


\section{Box 2.2 \\ Miombo woodlands and global change \\ Bob Scholes}

The phrase 'global change' describes the profound, extensive and accelerating impact which humans have had on the world's land surface, oceans and atmosphere in the past two hundred years. It has three main components: land-use change, atmospheric composition change and climate change. Miombo woodlands are actually or potentially involved in all three.

Land-use change is often the first consequence of population and economic growth. Woodlands very similar to miombo have already been transformed to cropland in South America and South East Asia. Low soil fertility, lack of infrastructure and the presence of diseases are the main factors which have preserved the miombo, and are all now subject to change. The acidity and low phosphorus status of the soil can be fixed with known and cost-effective agricultural techniques. Tsetse fly, a carrier of human and cattle diseases, has been eliminated over most of the area (Boxes 2.5 and 4.3). Regional political stability is likely to allow the infrastructure to improve. However, the human population growth rate in south central Africa is higher than the economic growth rate. Consequently the growing population will be fed partly by expansion of the cropped area, since there are insufficient resources for a general intensification of agriculture. Much of this expansion will be at the expense of the miombo woodlands (Solomon et al. 1993).

The conversion of miombo woodlands to short-duration croplands has two global consequences. The first is a release of carbon from the soil and biomass into the atmosphere. If half of the carbon in the top $30 \mathrm{~cm}$ of soil and all the carbon in woody biomass is released in half of the existing miombo extent in the next thirty years, the mean rate of release will be $0.2 \mathrm{Pg} \mathrm{C} \mathrm{yr}^{-1}$ (Scholes et al. in press). Current total carbon released from land-use change around the world is about $1 \mathrm{Pg} \mathrm{C} \mathrm{yr}^{-1}$ (Xue and Shukla 1993). The second consequence is a change in energy exchange at the land surface (increased reflectance of solar radiation and decreased surface roughness) which, if extensive enough, could result in increased atmospheric stability and a decrease in the formation of rain-generating convective storms (Xue and Shukla 1993).

Miombo woodlands generate a small, but significant fraction (0.5-5\%) of the trace gases, excluding carbon dioxide, which influence the radiation budget of the world (Andreae 1993; Scholes et al. in press). Three main emission processes are involved: fire, enteric fermentation by ruminants, and emissions from the soil. The gases are either 'greenhouse gases' themselves (such as methane), or are precursors to tropospheric ozone, a pollutant and greenhouse gas. Fires generate methane, carbon monoxide, nitric oxide and hydrocarbons, which combine to form ozone. They also generate smoke particles which help to counter-balance the greenhouse effect. Fires are not considered net carbon dioxide producers, since this gas is taken up again in the regrowth. Methane also originates from the charcoal-making industry (Chapter 6), from anaerobic conditions in dambo wetlands, from ruminants and, to a lesser extent, from termites. Nitric oxide is generated by microbial processes in the soil (especially following the first rains) and can combine with hydrocarbons produced by woodland vegetation to form ozone.

The greenhouse effect is likely to increase the mean temperature of the miombo region by $1-2^{\circ} \mathrm{C}$ in the next century, which by itself is not expected to alter the ecology or distribution of the woodlands significantly. Future trends in rainfall, which could have a profound effect, are not yet reliably predictable (Intergovernmental Panel on Climate Change 1996). 


\section{Climate, geology, landform and soils}

\section{Climate}

Miombo woodland is situated within the southern sub-humid tropical zone of Africa. About two-thirds of the region falls within the Köppen $\mathrm{C} w$ climate class, indicating a warm climate with a dry winter; the rest falls into the $\mathrm{A} w$ (hot climate with dry winter $-26 \%$ of 62 sites) and BSh (hot dry steppe $-8 \%$ ) climate classes. The $10-90 \%$ percentiles for mean annual precipitation and mean annual temperature are $710-1365 \mathrm{~mm}$ and $18.0-23.1^{\circ} \mathrm{C}$, respectively (Table 2.1). Coefficients of variation in annual rainfall are less than $30 \%$. More than $95 \%$ of annual rainfall occurs during a single 5-7 month wet season (Figure 2.1). A few sites in northern Tanzania and north eastern Angola have two wet seasons; these and some sites in south-eastern Mozambique receive $>5 \%$ of their annual rainfall during the dry months. The ratio of annual precipitation to evapotranspiration varies from 0.5 to 1.1 .

\section{Geology and geomorphology}

The distribution of miombo woodland is largely coincident with the flat-to-gently undulating landscapes of the African and post-African planation surfaces that form the Central African plateau (Cole 1986). These pediplains date from about 100-25 million years ago (mid-Cretaceous to mid-Tertiary) and 25-7 million years ago (Miocene), respectively, and have been preserved by periodic uplift and warping of the continental shield (King 1963; Lister 1987). The underlying geology of the plateau is largely Precambrian, comprising mainly Archean metavolcanics and metasediments of the Basement Complex and intrusive granites and granitic gneisses of varying ages. Extensive regional metamorphism has occurred on the flanks of these older cratons leading to the formation of banded gneisses, quartzites, and schists. In places on the plateau the Basement Complex rocks have been covered by a variety of mid- to late-Precambrian sedimentary formations (sandstones, conglomerates and dolomites) and intruded by narrow bands of

Table 2.1 Average climate characteristics of miombo woodland, based on an analysis of 115 rainfall stations and 62 temperature stations situated throughout the miombo region (source of date: Lebedev 1970).

\begin{tabular}{|c|c|c|c|c|c|c|}
\hline & \multirow[b]{2}{*}{ Median } & \multirow[b]{2}{*}{ Range } & & \multicolumn{2}{|c|}{ Percentiles } & \multirow[b]{2}{*}{$\mathrm{N}$} \\
\hline & & & & $\overline{10 \%}$ & $90 \%$ & \\
\hline Mean annual precipitation (mm) & 973 & 541 & 1721 & 710 & 1365 & 115 \\
\hline Length of dry season (months) & 6 & 3 & 7 & 4 & 7 & 115 \\
\hline $\begin{array}{l}\text { Rainfall in five driest months } \\
\text { (\% of mean annual precipitation) }\end{array}$ & 2.5 & 0.2 & 14.6 & 0.5 & 7.4 & 115 \\
\hline Mean annual temperature $\left({ }^{\circ} \mathrm{C}\right)$ & 20.6 & 14.9 & 25.3 & 18.0 & 23.1 & 62 \\
\hline $\begin{array}{l}\text { Mean temperature }\left({ }^{\circ} \mathrm{C}\right) \\
\text { coldest month }\end{array}$ & 16.9 & 10.7 & 24.6 & 13.6 & 20.5 & 62 \\
\hline hottest month & 23.3 & 17.1 & 27.5 & 20.4 & 25.9 & 62 \\
\hline
\end{tabular}



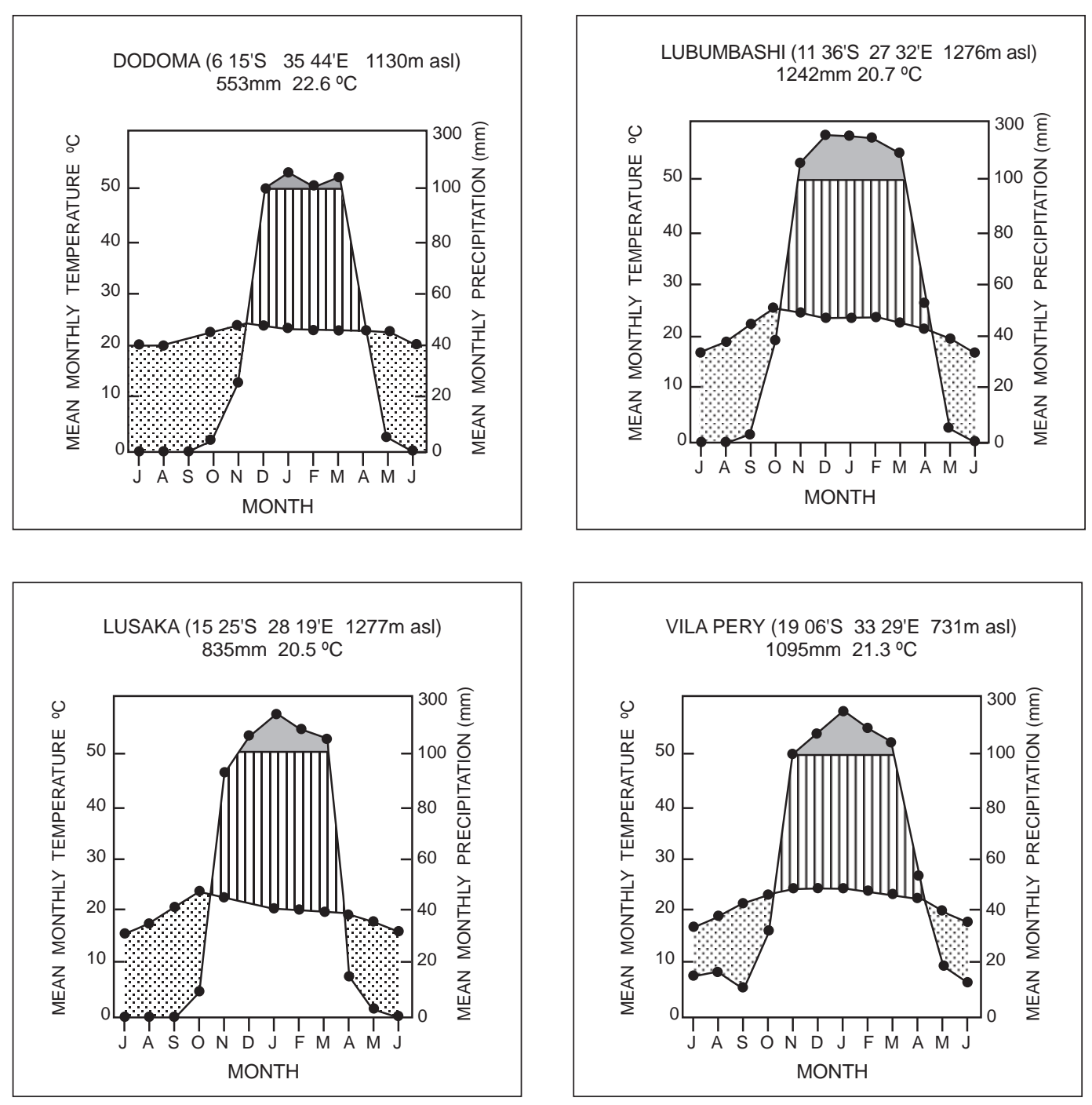

Figure 2.1 Climate diagrams for four localities across the range of miombo woodland: (a) Dodoma, Tanzania; (b) Lubumbashi, Zaire; (c) Lusaka, Zambia; and (d) Vila Pery, Mozambique.

basic rocks such as dolerite and gabbro. Where these produce nutrient-rich soils, vegetation types other than miombo woodland tend to predominate. In the west, miombo woodland extends marginally onto Kalahari Sands (an extensive consolidated sheet of wind- and water-borne sands that fills the Mega-Kalahari Basin), as well as onto sands on the Mozambique Plain. 


\section{Soils}

The combination of the crystalline nature of many of the rocks, low relief, moist climate, and warm temperatures has produced highly weathered soils that are often more than $3 \mathrm{~m}$ deep on the plateau. Shallow, stony soils are common along escarpments and inselbergs. Loamy sand, sandy loam and sandy clay loam textures predominate in both the top and subsoils. The amount of clay often increases substantially with depth, sometimes resulting in a marked texture contrast between the topsoil and subsoil (Figure 2.2). Nevertheless most of the soils have good to rapid permeability due to microaggregation of the clays. The soils are generally freely drained although drainage can be restricted locally by shallow depth, low relief, clay subsoils or indurated laterite. Nodular laterite is often present at variable depths, marking the past and sometimes present upper limits of a fluctuating watertable. The through-country drainage is sluggish and diffuse, a consequence of the relatively flat landscape (Young 1976).

The dominant soils in the higher rainfall zones are classed as Haplorthox and Haplustox in the USDA taxonomy (approximate FAO equivalents are Orthic, Rhodic and Xanthic Ferralsols); Paleustults and Palexerults (Ferric Acrisols). Haploxeralfs (Ferric Luvisols), Tropudalfs and Paleustults (Eutric Nitosols), and Paleudults and Tropudults (Dystric Nitosols) occur over basic rocks. The dominant soils in the lower rainfall zones are Ustropepts (Ferralic and Chromic Cambisols), Paleustalfs and Rhodoxeralfs (Chromic Luvisols), and Plinthustalfs (Plinthic Luvisols). Psamments (Arenosols) are wide-

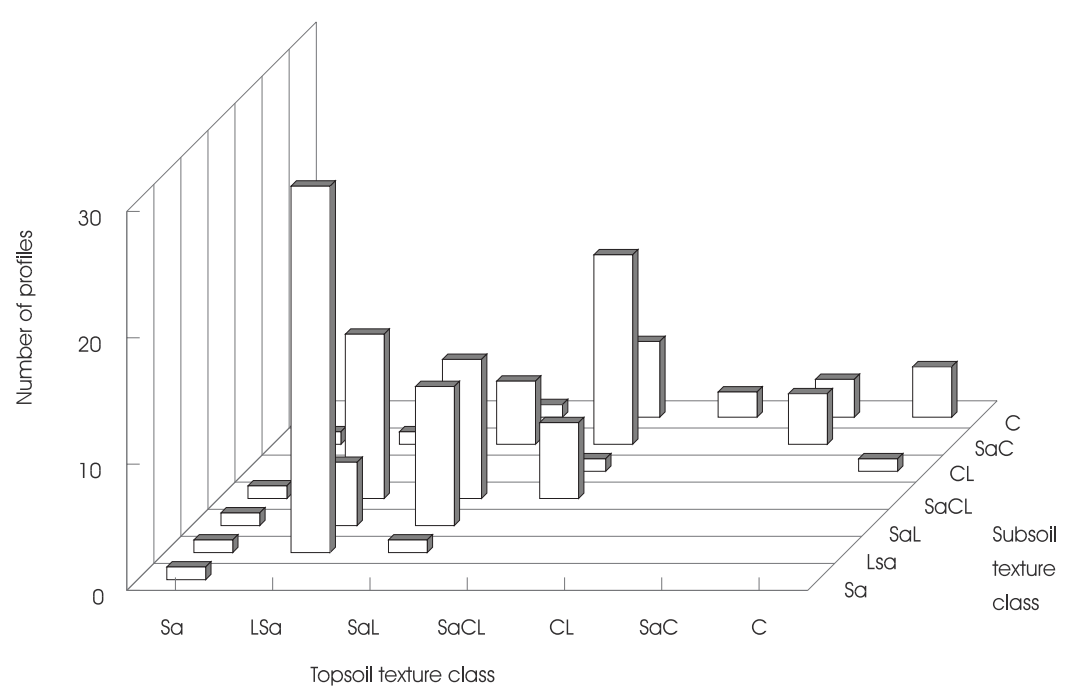

Figure 2.2 Frequency of occurrence (number of profiles) of different combinations of soil texture classes in topsoils $(0-20 \mathrm{~cm})$ and associated subsoils $(20-90 \mathrm{~cm})$ under miombo woodland in Central Africa ( $n=125$ profiles: data from Ballantyne 1956; Watson 1964; Webster 1965; Astle 1969; Young 1976; Malaisse 1978a; Purves et al. 1981; Stromgaard 1984b; Robertson 1984; Gill et al. 1988; Lenvain and Pauwelyn 1988; Asumadu and Weil 1988; King and Campbell 1994). 
spread along the south western margins on soils derived from aeolian Kalahari sand (Young 1976; FAO-Unesco 1977; Thompson and Purves 1978; Purves et al. 1981; Nyamapfene 1991; Anderson et al. 1993).

The soil moisture and temperature regimes of miombo woodland are generally ustic, meaning that soil moisture is present at a time when conditions are suitable for plant growth but is limited for at least 90 consecutive days at some time during the year (Watson and van Wambeke 1982; Eswaran 1988). Soil temperature regimes are isohyperthermic (mean annual soil temperatures greater than $22^{\circ} \mathrm{C}$, with less than $5^{\circ} \mathrm{C}$ difference between mean summer and winter soil temperatures), becoming isothermic above about $1200 \mathrm{~m}$ altitude (mean annual soil temperature of $15-22^{\circ} \mathrm{C}$, with mean summer and winter soil temperatures differing by less than $5^{\circ} \mathrm{C}$ : Watson and van Wambeke 1982; Eswaran 1988).

Miombo woodland soils are typically acid, have low cation exchange capacities (CEC), and are low in nitrogen, exchangeable cations (total exchangeable bases: TEB) and extractable phosphorus (Tables 2.2 and 2.3). Soils derived from Precambrian metavolcanics, metacarbonates and some biotite-rich gneisses have a marginally higher base status, as shown by the occasional high values for individual cations and phosphorus. What Table 2.2 does not show is the diversity in soil properties that can occur within a landscape. These include the diversity associated with catenas, the regular and repeatable sequences of soils down slopes (Watson 1964; Webster 1965; Young 1976), and the diversity due to the influence of termites (Jones 1989; 1990). Land-use practices such as chitemene slash-and-burn agriculture (Boxes 2.4 and 5.4; Araki 1993) may also have a long-term impact on soil properties and need further investigation.

Organic matter levels are generally low, except under densely wooded vegetation. Nevertheless, organic matter contributes substantially to cation exchange capacity in these soils.

Table 2.2 Chemical properties of soils under miombo. Data from Ballantyne (1956), Watson (1964), Webster (1965), Astle (1969), Purves et al. (1981) and relevant papers in Nyamapfene et al. (1988).

\begin{tabular}{|c|c|c|c|c|c|c|}
\hline & \multicolumn{2}{|c|}{ Topsoils $(0-20 \mathrm{~cm})$} & \multicolumn{3}{|c|}{ Subsoils $(20-50 \mathrm{~cm})$} & \multirow[b]{2}{*}{$\mathrm{N}$} \\
\hline & Mean & sd (range) & $\mathrm{N}$ & Mean & sd (range) & \\
\hline Carbon (\%) & 1.40 & $0.9(0.3-3.8)$ & 64 & 0.58 & $0.3(0.3-1.3)$ & 45 \\
\hline Nitrogen (\%) & 0.10 & $0.10(0.02-0.62)$ & 44 & 0.04 & $0.03(0.00-0.13)$ & 37 \\
\hline $\mathrm{pH}\left(\mathrm{H}_{2} \mathrm{O}\right)$ & 5.60 & $0.7(4.2-6.9)$ & 49 & 5.30 & $0.6(4.2-6.9)$ & 42 \\
\hline $\mathrm{pH}\left(\mathrm{CaCl}_{2}\right)$ & 5.00 & $0.5(3.9-6.1)$ & 53 & 5.00 & $0.4(4.3-5.9)$ & 24 \\
\hline Exch. $\mathrm{Ca}^{++}($me \%) & 2.72 & $3.00(0.00-15.00)$ & 84 & 1.74 & $2.72(0.05-11.80)$ & 60 \\
\hline Exch. $\mathrm{Mg}^{++}($me \%) & 1.46 & $1.85(0.00-8.40)$ & 84 & 1.35 & $2.52(0.00-16.03)$ & 60 \\
\hline Exch. $\mathrm{K}^{+}(\mathrm{me} \%)$ & 0.32 & $0.36(0.00-2.34)$ & 84 & 0.20 & $0.14(0.02-0.63)$ & 60 \\
\hline Exch. $\mathrm{Na}^{+}($me \%) & 0.06 & $0.10(0.01-0.48)$ & 47 & 0.05 & $0.05(0.01-0.20)$ & 30 \\
\hline TEB (me $100 \mathrm{~g}^{-1}$ ) & 4.74 & $4.65(0.35-20.78)$ & 73 & 3.43 & $4.96(0.10-27.02)$ & 62 \\
\hline $\mathrm{CEC}\left(\mathrm{me} 100 \mathrm{~g}^{-1}\right)$ & 7.56 & $5.31(1.80-25.10)$ & 71 & 6.30 & $5.27(0.31-26.75)$ & 61 \\
\hline Base saturation (\%) & 57.60 & $32.8(3.0-100.0)$ & 83 & 46.40 & $35.8(3.4-100.0)$ & 61 \\
\hline Extract. P (ppm) & 13.40 & $13.3(0.0-54.0)$ & 34 & 7.00 & $8.3(0.0-25.0)$ & 23 \\
\hline
\end{tabular}


Table 2.3 Soil nutrient data from various miombo sites. Where more than two data sets are available for a site, the profiles have been selected to show the range of variation present at the site.

\begin{tabular}{|c|c|c|c|c|c|c|c|c|c|c|c|c|c|}
\hline \multirow[b]{2}{*}{ Locality } & \multirow[b]{2}{*}{ Parent rock } & \multirow[b]{2}{*}{$\begin{array}{l}\text { Depth } \\
(\mathrm{cm})\end{array}$} & \multirow[b]{2}{*}{$\begin{array}{l}\mathrm{pH} \\
\text { (1) }\end{array}$} & \multirow[b]{2}{*}{$\begin{array}{l}\mathrm{C} \\
(\%)\end{array}$} & \multirow[b]{2}{*}{$\begin{array}{l}\mathrm{N} \\
(\%)\end{array}$} & \multicolumn{4}{|c|}{$\begin{array}{l}\text { Exchangeable cations } \\
\quad(\mathrm{meq} / 100 \mathrm{~g} \text { soil })\end{array}$} & \multirow{2}{*}{$\begin{array}{c}\text { BS } \\
\%\end{array}$} & \multirow{2}{*}{$\begin{array}{l}\text { TEB } \\
\text { meq } \\
100 \mathrm{~g}^{-1} \\
\text { clay }\end{array}$} & \multirow{2}{*}{$\begin{array}{l}\text { Extr. } \\
P \\
\text { ppm } \\
(2)\end{array}$} & \multirow[b]{2}{*}{ Ref } \\
\hline & & & & & & $\mathrm{Ca}$ & $\mathrm{Mg}$ & $\mathrm{K}$ & CEC & & & & \\
\hline \multicolumn{14}{|l|}{ ZAMBIA } \\
\hline Kasama & granite & $\begin{array}{r}0-10 \\
10-20\end{array}$ & $\begin{array}{l}4.9 \mathrm{a} \\
4.5\end{array}$ & $\begin{array}{l}1.09 \\
0.53\end{array}$ & $\begin{array}{l}- \\
-\end{array}$ & $\begin{array}{l}1.32 \\
0.47\end{array}$ & $\begin{array}{l}0.57 \\
0.29\end{array}$ & $\begin{array}{l}0.10 \\
0.04\end{array}$ & $\begin{array}{l}4.80 \\
3.08\end{array}$ & $\begin{array}{l}41 \\
26\end{array}$ & $\begin{array}{l}7 \\
4\end{array}$ & $\begin{array}{l}27 a \\
18\end{array}$ & 1 \\
\hline Kasama & granite & $\begin{array}{r}0-10 \\
10-20\end{array}$ & $\begin{array}{l}4.8 \mathrm{a} \\
4.5\end{array}$ & $\begin{array}{l}1.20 \\
0.74\end{array}$ & $\begin{array}{l}0.130 \\
0.090\end{array}$ & $\begin{array}{l}1.64 \\
0.57\end{array}$ & $\begin{array}{l}1.23 \\
0.22\end{array}$ & $\begin{array}{l}0.20 \\
0.15\end{array}$ & $\begin{array}{l}6.42 \\
4.89\end{array}$ & $\begin{array}{l}35 \\
19\end{array}$ & $\begin{array}{l}- \\
-\end{array}$ & $\begin{array}{l}6 \mathrm{f} \\
2\end{array}$ & 2 \\
\hline Luapula & $\begin{array}{l}\text { Precambrian } \\
\text { sediments }\end{array}$ & $\begin{array}{r}0-15 \\
40-50\end{array}$ & $\begin{array}{l}4.2 \mathrm{c} \\
4.3\end{array}$ & $\begin{array}{l}0.89 \\
0.30\end{array}$ & $\begin{array}{l}0.051 \\
0.028\end{array}$ & $\begin{array}{l}0.16 \\
0.24\end{array}$ & $\begin{array}{l}0.12 \\
0.11\end{array}$ & $\begin{array}{l}0.08 \\
0.05\end{array}$ & $\begin{array}{l}6.92 \\
5.16\end{array}$ & $\begin{array}{l}5 \\
8\end{array}$ & $\begin{array}{l}1 \\
1\end{array}$ & $\begin{array}{l}<1 b \\
<1\end{array}$ & 3 \\
\hline Chingola & $\begin{array}{l}\text { Basement } \\
\text { complex }\end{array}$ & $\begin{array}{r}0-10 \\
10-45\end{array}$ & $\begin{array}{l}5.4 \mathrm{c} \\
5.2\end{array}$ & $\begin{array}{l}1.90 \\
0.52\end{array}$ & $\begin{array}{l}0.091 \\
0.029\end{array}$ & $\begin{array}{l}0.70 \\
0.05\end{array}$ & $\begin{array}{l}0.55 \\
0.11\end{array}$ & $\begin{array}{l}0.47 \\
0.36\end{array}$ & $\begin{array}{l}9.42 \\
5.20\end{array}$ & $\begin{array}{l}18 \\
10\end{array}$ & $\begin{array}{l}4 \\
1\end{array}$ & $\begin{array}{l}- \\
-\end{array}$ & 4 \\
\hline Ndola & $\begin{array}{l}\text { Basement } \\
\text { complex }\end{array}$ & $\begin{array}{r}0-15 \\
15-30\end{array}$ & $\begin{array}{l}5.2 \mathrm{~b} \\
5.0\end{array}$ & $\begin{array}{l}0.86 \\
0.43\end{array}$ & $\begin{array}{l}0.068 \\
0.035\end{array}$ & $\begin{array}{l}0.15 \\
0.07\end{array}$ & $\begin{array}{l}0.24 \\
0.12\end{array}$ & $\begin{array}{l}0.11 \\
0.06\end{array}$ & $\begin{array}{l}3.10 \\
2.80\end{array}$ & $\begin{array}{r}16 \\
9\end{array}$ & $\begin{array}{l}7 \\
-\end{array}$ & $\begin{array}{l}4 c \\
-\end{array}$ & 5 \\
\hline $\begin{array}{l}\text { Kapiri- } \\
\text { Mposhi }\end{array}$ & $\begin{array}{l}\text { quartz-rich } \\
\text { gneiss }\end{array}$ & $\begin{array}{r}0-14 \\
14-23\end{array}$ & $\begin{array}{l}5.8 \mathrm{a} \\
6.1\end{array}$ & $\begin{array}{l}1.20 \\
0.50\end{array}$ & $\begin{array}{l}0.080 \\
0.030\end{array}$ & $\begin{array}{l}2.90 \\
2.20\end{array}$ & $\begin{array}{l}1.00 \\
0.80\end{array}$ & $\begin{array}{l}0.60 \\
0.50\end{array}$ & $\begin{array}{l}5.20 \\
3.80\end{array}$ & $\begin{array}{l}88 \\
94\end{array}$ & $\begin{array}{l}76 \\
18\end{array}$ & $\begin{array}{l}44 a \\
32\end{array}$ & 6 \\
\hline MALAWI & & & & & & & & & & & & & \\
\hline Kasungu & $\begin{array}{l}\text { biotite } \\
\text { gneiss }\end{array}$ & $\begin{array}{r}0-15 \\
15-30\end{array}$ & $\begin{array}{l}6.1 \mathrm{~b} \\
5.8\end{array}$ & $\begin{array}{l}1.89 \\
0.67\end{array}$ & $\begin{array}{l}0.120 \\
0.042\end{array}$ & $\begin{array}{l}9.79 \\
5.99\end{array}$ & $\begin{array}{l}4.21 \\
3.44\end{array}$ & $\begin{array}{l}0.78 \\
0.72\end{array}$ & $\begin{array}{l}15.00 \\
10.40\end{array}$ & $\begin{array}{l}100 \\
100\end{array}$ & $\begin{array}{l}- \\
-\end{array}$ & $\begin{array}{l}11 \mathrm{~b} \\
<1\end{array}$ & 7 \\
\hline Chitedze & gneiss & $\begin{array}{r}0-13 \\
13-30\end{array}$ & $\begin{array}{l}6.0 \mathrm{~b} \\
5.7\end{array}$ & $\begin{array}{l}1.30 \\
0.70\end{array}$ & $\begin{array}{l}0.100 \\
0.070\end{array}$ & $\begin{array}{r}15.30 \\
6.30\end{array}$ & $\begin{array}{l}1.50 \\
1.40\end{array}$ & $\begin{array}{l}1.20 \\
0.50\end{array}$ & $\begin{array}{l}18.80 \\
11.30\end{array}$ & $\begin{array}{l}96 \\
73\end{array}$ & $\begin{array}{l}50 \\
21\end{array}$ & $\begin{array}{l}25 \mathrm{e} \\
14\end{array}$ & 6 \\
\hline ZIMBABWE & & & & & & & & & & & & & \\
\hline Banket & epidiorite & $\begin{array}{r}0-15 \\
23-45\end{array}$ & $\begin{array}{l}4.8 \mathrm{a} \\
4.8\end{array}$ & $\begin{array}{l}- \\
-\end{array}$ & $\begin{array}{l}0.100 \\
-\end{array}$ & $\begin{array}{l}11.53 \\
11.61\end{array}$ & $\begin{array}{l}3.45 \\
3.75\end{array}$ & $\begin{array}{l}0.36 \\
0.18\end{array}$ & $\begin{array}{l}15.62 \\
15.58\end{array}$ & $\begin{array}{r}98 \\
100\end{array}$ & $\begin{array}{l}25 \\
24\end{array}$ & $\begin{array}{l}9 \mathrm{~b} \\
5\end{array}$ & 8 \\
\hline Banket & dacite & $\begin{array}{r}0-10 \\
20-35\end{array}$ & $\begin{array}{l}5.2 \mathrm{a} \\
4.5\end{array}$ & - & $\begin{array}{l}0.072 \\
-\end{array}$ & $\begin{array}{l}2.43 \\
1.22\end{array}$ & $\begin{array}{l}1.43 \\
2.35\end{array}$ & $\begin{array}{l}0.32 \\
0.20\end{array}$ & $\begin{array}{l}4.43 \\
4.36\end{array}$ & $\begin{array}{l}95 \\
88\end{array}$ & $\begin{array}{l}30 \\
19\end{array}$ & $\begin{array}{l}3 \mathrm{~b} \\
<1\end{array}$ & 8 \\
\hline Banket & granite & $\begin{array}{r}0-15 \\
30-45\end{array}$ & $\begin{array}{l}5.4 \mathrm{a} \\
5.3\end{array}$ & $\begin{array}{l}- \\
-\end{array}$ & $\begin{array}{l}0.050 \\
-\end{array}$ & $\begin{array}{l}2.11 \\
0.83\end{array}$ & $\begin{array}{l}0.33 \\
0.31\end{array}$ & $\begin{array}{l}0.14 \\
0.10\end{array}$ & $\begin{array}{l}2.80 \\
1.17\end{array}$ & $\begin{array}{r}93 \\
100\end{array}$ & $\begin{array}{l}37 \\
12\end{array}$ & $\begin{array}{l}16 b \\
2\end{array}$ & 8 \\
\hline Harare & granite & $\begin{array}{r}0-8 \\
43\end{array}$ & $\begin{array}{l}6.5 b \\
5.7\end{array}$ & $\begin{array}{l}1.02 \\
0.18\end{array}$ & $\begin{array}{l}0.068 \\
0.016\end{array}$ & $\begin{array}{l}2.20 \\
0.25\end{array}$ & $\begin{array}{l}0.90 \\
0.20\end{array}$ & $\begin{array}{l}0.28 \\
0.14\end{array}$ & $\begin{array}{l}3.86 \\
1.23\end{array}$ & $\begin{array}{l}91 \\
52\end{array}$ & $\begin{array}{r}31 \\
5\end{array}$ & $\begin{array}{l}45 \mathrm{~d} \\
20\end{array}$ & 9 \\
\hline Marondera & granite & $\begin{array}{r}0-11 \\
11-30\end{array}$ & $\begin{array}{l}4.6 \mathrm{a} \\
4.2\end{array}$ & $\begin{array}{l}1.18 \\
0.84\end{array}$ & $\begin{array}{l}0.081 \\
0.056\end{array}$ & $\begin{array}{l}1.10 \\
0.30\end{array}$ & $\begin{array}{l}0.70 \\
0.30\end{array}$ & $\begin{array}{l}0.20 \\
0.20\end{array}$ & $\begin{array}{l}3.80 \\
2.70\end{array}$ & $\begin{array}{l}55 \\
33\end{array}$ & $\begin{array}{r}11 \\
4\end{array}$ & $\begin{array}{l}- \\
-\end{array}$ & 10 \\
\hline Marondera & granite & $\begin{array}{r}0-9 \\
17-50\end{array}$ & $\begin{array}{l}6.6 b \\
5.8\end{array}$ & $\begin{array}{l}1.55 \\
0.41\end{array}$ & $\begin{array}{l}0.066 \\
0.015\end{array}$ & $\begin{array}{l}1.26 \\
0.44\end{array}$ & $\begin{array}{l}0.36 \\
0.22\end{array}$ & $\begin{array}{l}0.12 \\
0.21\end{array}$ & $\begin{array}{l}- \\
-\end{array}$ & - & $\begin{array}{l}9 \\
1\end{array}$ & $\begin{array}{l}16 \mathrm{a} \\
4\end{array}$ & 11 \\
\hline
\end{tabular}

Sources:

1. Stromgaard (1984a: 'undisturbed forest'); 2. Mapiki (1988: 'unburnt chitemene'); 3. Astle (1969: profiles 3 and 8); 4. Brocklington (1956: profile 106); 5. Trapnell et al. (1976); 6. Young (1976); 7. Robertson (1984: sites 21); 8. Purves et al. (1981: profiles 3-G-79, 4-G-77, 9-WW-79); 9. Watson (1964: profile 3); 10. Hudson and Gown (in Nyampfene 1991: profile Marondera 7G.2); 11. Hatton and Swift (pers. comm.: TSB site).

Notes:

1. $\mathrm{a}=\mathrm{pH}\left(\mathrm{CaCl}_{2}\right) ; \mathrm{b}=\mathrm{pH}\left(\mathrm{H}_{2} \mathrm{O}\right) ; \mathrm{c}=$ not stated.

2. Extractants used in P determination: $\mathrm{a}=$ Bray $\mathrm{I} ; \mathrm{b}=$ Anion exchange resin; $\mathrm{c}=$ Truog; $\mathrm{d}=\mathrm{NaOH}$; $\mathrm{e}=\mathrm{NH}_{4} \mathrm{~F} ; \mathrm{f}=$ not stated; - = not measured. 
The relationship between the cation exchange capacity of the soil and the amounts of clay and organic carbon in the A-horizon of 53 soil profiles under miombo woodland in Zambia and Zimbabwe is:

$$
\text { CEC }(\mathrm{me} \%)=0.119 \text { clay }(\%)+
$$$$
2.922 \text { organic carbon }(\%)-0.212
$$

$\left(\mathrm{R}^{2}=0.492, \mathrm{~F}_{2,51}=24.668, \mathrm{p}<0.0001\right.$ : data from Ballantyne 1956; Brocklington 1956; Watson 1964; Webster 1965; Astle 1969; Trapnell et al. 1976; Young 1976; Stromgaard 1984a; Mapiki 1988; Lenvain and Pauwelyn 1988; Hatton and Swift, pers. comm.). This regression suggests an average CEC value for clay of about $11.9 \mathrm{meq}$ $100 \mathrm{~g} \mathrm{clay}^{-1}$, indicating a predominance of $1: 1$ lattice clay minerals, mainly kaolinite, and an average CEC value for organic carbon of about $292 \mathrm{meq} 100 \mathrm{~g}^{-1}$. The variation in percentage carbon explains more of the variation in cation exchange capacity $\left(\mathrm{F}_{1,51}=31.678\right)$ than does variation in the amount of clay $\left(\mathrm{F}_{1,51}=17.657\right)$. The generally low CEC values of miombo woodland soils therefore reflects a combination of low organic matter levels and predominantly lowactivity clays.

These measures of CEC are based on extraction in ammonium acetate at $\mathrm{pH} 7$. Given the generally acid nature of the soils and the preponderance of kaolinite and iron and aluminium oxides, whose exchange capacity is $\mathrm{pH}$ dependent, effective cation exchange capacities (ECEC) will be lower than the recorded CEC. There are few data for miombo woodland, however. The average ECEC of the topsoils of a granite-derived soil (USDA approximation: kandiustalf) was $81 \%$ of the recorded $\mathrm{CEC}$ value at $\mathrm{pH} 7$, while that of the subsoil was 54\% (from data in Watson 1964). Lower values have been recorded in central Tanzania: $40 \%$ in the topsoil and $27 \%$ in the subsoil of an oxisol (Mnkeni and Akulumuka 1988). The low ECEC values are mostly associated with high levels of aluminium saturation.
The highly weathered plateau soils are said to be strongly Al-saturated, up to $70-90 \%$ for some Zambian soils (Chileshe and Ting-Tiang 1988), though other recorded values are lower, 25-50\% for subsoils (Watson 1964; Dynoodt and Mwambazi 1988; Mnkeni and Akulumuka 1988; Nyamapfene 1991).

Some of these soils have a correspondingly high capacity to fix phosphorus; recorded adsorption maxima range from $160-713 \mathrm{mg} \mathrm{kg}^{-1}$ for topsoils and 518-866 mg kg-1 for subsoils of oxisols and ultisols (Chinene and Lungu 1988; Mnkeni and Akulumuka 1988). In contrast, in drier regions, the phosphate sorption capacity of the less weathered and leached alfisols is lower and associated more with clay than with iron and aluminium oxides and, among the sesquioxides, with Fe rather than Al (Campbell 1973; Sibanda and le Mare 1984, both in Nyamapfene 1991). This is an important area for future research.

\section{Composition and Structure}

\section{Composition}

The dominance of the genera Brachystegia, Julbernardia and Isoberlinia (Fabaceae, subfamily Caesalpinioideae) makes miombo woodland floristically distinct from most other African woodlands (Box 2.1). These genera are seldom found outside miombo. Although this dominance by Caesalpinioideae is characteristic, their contribution to numbers and biomass varies widely within and between communities (Table 2.4). What factors favour this dominance is an interesting but as yet largely unanswered question, though the widespread occurrence of ectomycorrhizae in their roots may enable them to exploit porous, infertile soils more efficiently than groups lacking ectomycorrhizae (Högberg and Nylund 1981).

Miombo woodland has been described by Fanshawe (1969), Werger and Coetzee (1978), White (1983) and Cole (1986), among others. 
White (1983) divided miombo woodland into dry and wet miombo woodland. Dry miombo woodland occurs in southern Malawi, Mozambique and Zimbabwe, in areas receiving less than $1000 \mathrm{~mm}$ rainfall annually. Canopy height is less than $15 \mathrm{~m}$ and the vegetation is floristically impoverished. The dominant Brachystegia species of the wet miombo woodland are either absent or local in occurrence. Brachystegia spiciformis, B. boehmii and Julbernardia globiflora

Table 2.4 Percentage contribution of Caesalpinioideae to the composition and structure of various miombo communities.

\begin{tabular}{|c|c|c|c|c|c|}
\hline Locality & Stratum & $\begin{array}{l}\text { Stems } \\
\%\end{array}$ & $\begin{array}{l}\text { Basal area } \\
\%\end{array}$ & $\begin{array}{l}\text { Biomass } \\
\%\end{array}$ & Source \\
\hline \multicolumn{6}{|l|}{ TANZANIA } \\
\hline Lupa & trees & 20 & - & - & \multirow{2}{*}{$\begin{array}{l}\text { Boaler and Sciwale } \\
\text { (1966) }\end{array}$} \\
\hline Kabungu & trees & 71 & - & - & \\
\hline \multicolumn{6}{|l|}{ MALAWI } \\
\hline \multirow[t]{3}{*}{ Kasungu } & trees $\mathrm{TS}^{1}$ & - & 75 & - & \multirow[t]{3}{*}{ Robertson (1984) } \\
\hline & trees MS & - & 72 & - & \\
\hline & trees LS & - & 33 & - & \\
\hline \multicolumn{6}{|l|}{ ZAIRE } \\
\hline Kasapa & trees & 15 & - & - & Malaisse (1978a) \\
\hline \multicolumn{6}{|l|}{ ZAMBIA } \\
\hline Misamfu & trees & 54 & - & - & Rees (1974) \\
\hline \multirow[t]{3}{*}{ Ndola $^{2}$} & canopy trees & 84 & - & - & \multirow[t]{3}{*}{ Trapnell (1959) } \\
\hline & understorey trees & 18 & - & - & \\
\hline & shrubs & 15 & - & - & \\
\hline \multicolumn{6}{|l|}{ ZIMBABWE } \\
\hline Marondera & trees $(>2 \mathrm{~m})$ & 92 & 96 & 97 & Frost (unpubl.) \\
\hline \multirow[t]{2}{*}{ Sengwa WRA } & trees & 22 & - & 64 & \multirow[t]{2}{*}{ Martin (1974) } \\
\hline & shrubs & 27 & - & 21 & \\
\hline \multirow[t]{2}{*}{ Sengwa WRA } & trees $^{3}$ & 18 & 67 & 35 & \multirow[t]{2}{*}{ Guy (1989a) } \\
\hline & shrubs & 23 & - & 15 & \\
\hline \multirow[t]{2}{*}{ Gokwe North } & trees $^{3}$ & 35 & 30 & 68 & \multirow[t]{2}{*}{ Guy (1989a) } \\
\hline & shrubs & 25 & - & 32 & \\
\hline \multirow[t]{2}{*}{ Makoholi } & trees & 90 & 96 & - & \multirow{2}{*}{$\begin{array}{l}\text { Ward and Cleghorn } \\
\text { (1964) }\end{array}$} \\
\hline & shrubs & 61 & 59 & - & \\
\hline
\end{tabular}

Notes:

1. $\quad \mathrm{TS}=$ Upper slope sites

MS = Mid-slope sites

LS = Lower slope sites (Robertson 1984)

2. Protected plots (Trapnell 1959)

3. Minimum estimate only since a large number of unspecified trees and shrubs were classed under 'other' (Guy 1989a) 
are the dominant deciduous species. The herbaceous layer varies greatly in composition and biomass and includes grasses (mainly of the genera Hyparrhenia, Andropogon, Loudetia, Digitaria and Eragrostis, sedges, shrubs (particularly legumes such as Eriosema, Sphenostylis, Kotschya, Dolichos and Indigofera), and suppressed saplings of canopy trees.

Wet miombo woodland occurs over much of eastern Angola, northern Zambia, south western Tanzania and central Malawi in areas receiving more than $1000 \mathrm{~mm}$ rainfall per year. Canopy height is usually greater than $15 \mathrm{~m}$, reflecting the generally deeper and moister soils which create favourable conditions for growth. The vegetation is floristically rich and includes nearly all of the characteristic miombo species. Brachystegia floribunda, B. glaberrima, B. longifolia, B. wangermeeana, Julbernardia paniculata, Isoberlinia angolensis and Marquesia macroura are widely distributed. The understorey comprises a mixture of grasses, bracken (Pteridium aquilinum) and shrubs, including the monocot Aframomum biauriculatum. Despite the density of the overstorey, the dominant grasses are all heliophytic $\mathrm{C}_{4}$ species of Hyparrhenia, Andropogon and Loudetia. Many of the subordinate species, most notably Pteridium and Aframomum, also occur in adjoining evergreen forest patches and thickets (muhulu: Freson et al. 1974), which occur on pockets of deeper and more fertile soils (White 1983).

Some elements, most notably B. spiciformis, extend northwards along the Kenyan coast to the Shimba Hills, near Mombasa, and the ArabukoSokoke Forest, south of Malindi. These forests lie outside the main miombo woodland belt and are not considered part of miombo woodland (Keay 1959). Nevertheless, the presence of B. spiciformis parallels its occurrence in similar situations in coastal Mozambique. This may reflect the ability of B. spiciformis to out-compete other deciduous forest species on infertile, porous soils, a feature linked perhaps to having extensive ectomycorrhizae (Högberg and Nylund 1981).

Other vegetation formations in which Caesalpinioideae are dominant include the Isoberlinia-Daniellia-Burkea woodlands of West Africa ('Sudanian Isoberlinia and related woodlands', White 1983); Burkea savanna woodlands in South Africa, Namibia, Zimbabwe, Zambia and Malawi ('Zambezian undifferentiated woodland'); and Kalahari Sand woodlands dominated by Baikiaea plurijuga ('Zambezian dry deciduous forest and scrub forest'). In functional terms, Isoberlinia and Burkea woodlands can be considered to be impoverished miombo woodland (for a synthesis of the structure and functioning of Burkea savanna in South Africa see Scholes and Walker 1993). Baikiaea woodland may be functionally different because of the great depth, high permeability, low water-holding capacity, and extreme nutrient poverty of Kalahari sand. A further interesting distinction is that none of the dominant tree species on Kalahari sand, most of which belong to the Caesalpinioideae, have ectomycorrhizae; all are endomycorrhizal instead (Högberg and Piearce 1986).

Miombo woodland has been viewed by some to be sub-climax to evergreen or semievergreen forest, maintained as such by frequent fires and exploitation by people and wildlife (Freson et al. 1974; Lawton 1978). In part, this view arises from the frequent juxtaposition of miombo woodland and patches of evergreen forest in places where, on the surface, there appears to be little difference in the sites each occupies. Lawton (1978), for example, concluded that topographic and edaphic factors are relatively unimportant in determining vegetation pattern in miombo woodland in Zambia, though White (1983) noted that where evergreen forest occurs alongside miombo woodland it coincides with a transition to deeper soils, suggesting that there is an edaphic influence. 


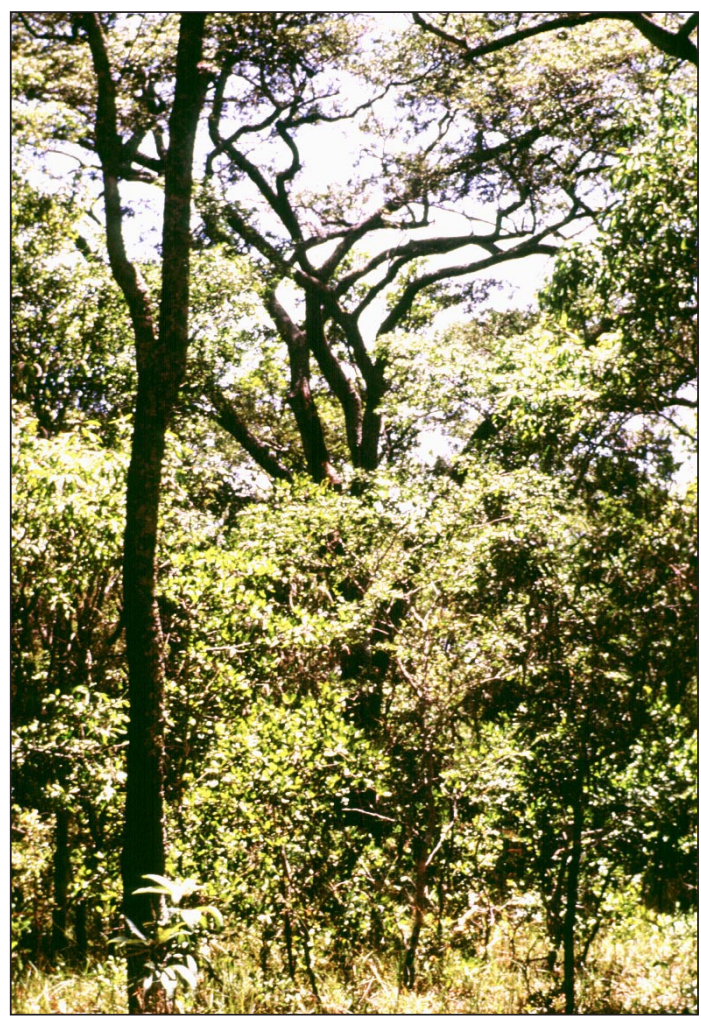

Mature miombo woodland, Lake Chivero, Zimbabwe. This photograph shows an unusually dense understorey of shrubs and saplings of canopy tree species (photo: P. Frost)

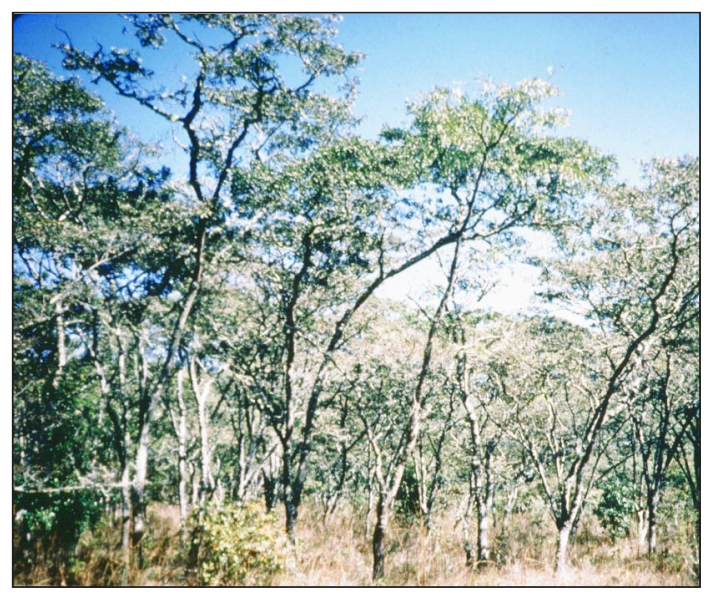

\section{Structure}

The composition and structure of miombo woodland appears superficially to be relatively uniform over large regions, suggesting a broad similarity in key environmental conditions. Woody plants comprise $95-98 \%$ of the aboveground biomass of undisturbed stands; grasses and herbs make up the remainder (Martin 1974; Malaisse 1978a; Chidumayo 1993a; Frost unpublished data). The woodlands typically comprise an upper canopy of pagoda- or umbrellashaped trees; a scattered layer, often absent, of subcanopy trees; a discontinuous understorey of shrubs and saplings; and a patchy layer of grasses, forbs and suffrutices. The uniformity in appearance is due in part to the remarkably similar physiognomy of the dominant canopy trees, no doubt a reflection of their origins in the Caesalpinioideae.

Differences in species composition and structure are more apparent at a local scale. The origin of these differences is unclear: geomorphic evolution of the landscape (Cole 1986); edaphic factors, principally soil moisture and soil nutrients (Astle 1969; Campbell et al. 1988); the effects of fire (Freson et al. 1974; Lawton 1978; Kikula 1986b); wildlife impacts (Anderson and Walker 1974; Thomson 1975; Guy 1981a; 1989); and past and present land use and other anthropogenic disturbances (Robertson 1984; Chidumayo 1987c), have all been implicated.

The density of woody plants (excluding those in the herbaceous layer) varies widely, 1500-4100 stems ha ${ }^{-1}$. Tree densities (trees defined as woody plants taller than $2 \mathrm{~m}$ ) range from 380-1400 ha-1 (Trapnell 1959; Ward and Cleghorn 1964; Boaler and Sciwale 1966; Strang

Dry miombo woodland, Zimbabwe Soil Biology and Fertility study site, Marondera, Zimbabwe. This woodland has a basal area of $10.1 \mathrm{~m}^{2} \mathrm{ha}^{-1}$ and an aboveground biomass of $42.5 \mathrm{Mg} \mathrm{DM} \mathrm{ha^{-1 }}$ (photo: P. Frost) 
Table 2.5 Biomass relationships in miombo woodlands. See text for references to sources of data used in calculating regression equations.

\begin{tabular}{|c|c|c|c|c|c|c|}
\hline $\begin{array}{l}\text { Dependent } \\
\text { variable }(\mathrm{Y})\end{array}$ & $\begin{array}{l}\text { Independent } \\
\text { variable }(\mathrm{X})\end{array}$ & Regression & $\mathrm{S}_{\mathrm{YX}}$ & r or $\mathbf{F}$ & df & $\mathrm{p}$ \\
\hline $\begin{array}{l}\text { Woody plant biomass } \\
\left(\mathrm{Mg} \mathrm{ha}^{-1}\right)\end{array}$ & $\begin{array}{l}\text { Mean annual rainfall } \\
(\mathrm{mm})\end{array}$ & $Y=0.14 X-56.21$ & 25.48 & 0.833 & 5 & $<0.05$ \\
\hline $\begin{array}{l}\text { Woody plant basal } \\
\text { area }\left(\mathrm{m}^{2} \mathrm{ha}^{-1}\right)\end{array}$ & $\begin{array}{l}\text { Mean annual rainfall } \\
(\mathrm{mm})\end{array}$ & $Y=0.01 X+4.14$ & 2.76 & 0.605 & 21 & $<0.01$ \\
\hline $\begin{array}{l}\text { Woody plant biomass } \\
\left(\mathrm{Mg} \mathrm{ha}^{-1)}\right.\end{array}$ & $\begin{array}{l}\text { Woody plant basal area } \\
\left(\mathrm{m}^{2} \mathrm{ha}^{-1)}\right.\end{array}$ & $Y=8.25 X-30.33$ & 17.30 & 0.898 & 18 & $<0.001$ \\
\hline $\begin{array}{l}\text { Stand volume } \\
\left(\mathrm{m}^{3} \mathrm{ha}^{-1}\right)\end{array}$ & $\begin{array}{l}\text { Woody plant basal area } \\
\left(\mathrm{m}^{2} \mathrm{ha}^{-1}\right)\end{array}$ & $Y=6.18 X^{0.86}$ & 0.48 & 88.87 & 1,62 & $<0.001$ \\
\hline $\begin{array}{l}\text { Herbage yield } \\
\left(\mathrm{kg} \mathrm{ha}^{-1} \mathrm{yr}^{-1}\right)\end{array}$ & $\begin{array}{l}\text { Mean annual rainfall } \\
(\mathrm{mm})\end{array}$ & $Y=2.43-0.001 X$ & 1.13 & 0.147 & 9 & NS \\
\hline
\end{tabular}

1974; Malaisse 1978a; Guy 1981a; Robertson 1984; Chidumayo 1985; Campbell et al. 1995c). Density is not apparently related to rainfall or to any other single factor. In contrast, tree height appears to be related to moisture availability and soil depth (Savory 1963; Grundy 1995a). Canopy dominants, such as B. spiciformis, B. longifolia, B. utilis and $J$. paniculata, growing on deep (>3 m), well-drained soils, can reach up to $27 \mathrm{~m}$ in wet miombo woodland but in general few of the trees grow taller than $20 \mathrm{~m}$.

The recorded basal area of trees in old-growth, mixed-age stands ranges from as little as $7 \mathrm{~m}^{2} \mathrm{ha}^{-1}$ on lithosols in southern Malawi at about $650 \mathrm{~mm}$ mean annual precipitation (Lowore et al.

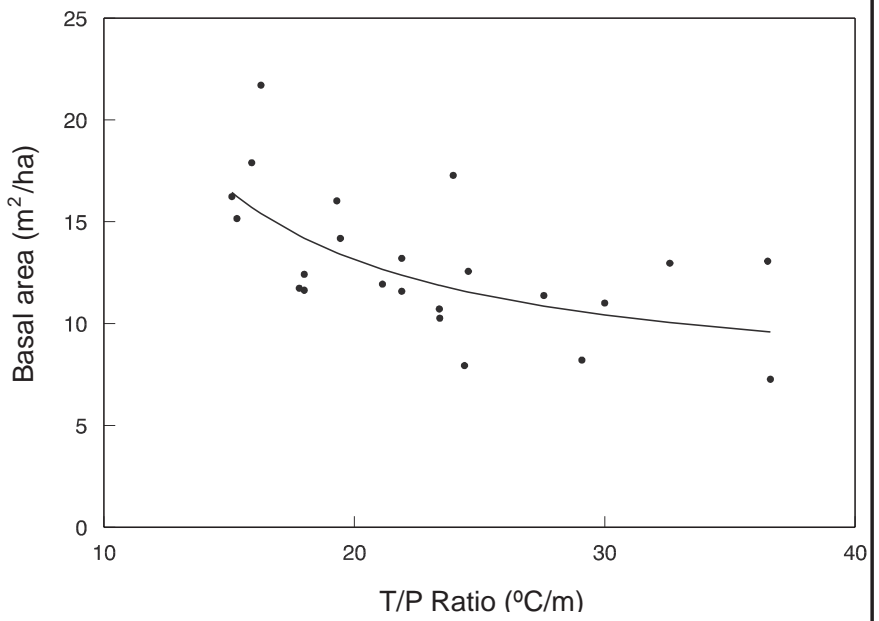

Figure 2.3 Woody plant basal area $\left(\mathrm{A}, \mathrm{m}^{2} \mathrm{ha}^{-1}\right)$ is an inverse function of the ratio of mean annual temperature $\left(\mathrm{T},{ }^{\circ} \mathrm{C}\right)$ to mean annual precipitation $(\mathrm{P}, \mathrm{m})$. The relationship is $\mathrm{A}=$ $6.571 \mathrm{e}^{13.885 / \mathrm{X}}$, where $\mathrm{X}=\mathrm{T} / \mathrm{P}$ ratio $\left(\mathrm{F}_{1,21}=13.40, \mathrm{p}=0.0015\right)$. Note the units for $P$. 1994a) to $22 \mathrm{~m}^{2} \mathrm{ha}^{-1}$ in wet miombo woodland on deep soils in Zaire at $1270 \mathrm{~mm}$ rainfall (Freson et al. 1974). Higher values (30$50 \mathrm{~m}^{2} \mathrm{ha}^{-1}$ ) have been recorded locally on small plots (Chidumayo 1985; Grundy 1995a). Most stands have basal areas of 7-19 $\mathrm{m}^{2} \mathrm{ha}^{-1}$ (Boaler and Sciwale 1966; Allen 1986; Chidumayo 1987c).
Stand basal area increases linearly with increasing mean annual rainfall (Table 2.5); with the ratio of annual rainfall to annual potential evapotranspiration (Chidumayo 1987d); and with the ratio of mean annual temperature to mean annual rainfall (Figure 2.3). 
Stand basal area provides an index of both the harvestable volume and aboveground woody biomass of miombo stands (Figures 2.4 and 2.5). Average harvestable volumes in dry miombo woodland range from $14 \mathrm{~m}^{3} \mathrm{ha}^{-1}$ in Malawi (Lowore et al. 1994a) to $59 \mathrm{~m}^{3} \mathrm{ha}^{-1}$ in Zambia, with a maximum value of $117 \mathrm{~m}^{3}$ ha $^{-1}$ (Chidumayo 1988d). Given the greater basal area of wet miombo stands, it can be assumed that stand volume will be correspondingly greater than these values; the only estimates of volume in wet miombo woodland are for managed woodlands (41-100 $\mathrm{m}^{3} \mathrm{ha}^{-1}$ : Endean 1968).

Mean biomass increases with increasing mean annual rainfall of a site (Figure 2.6). Reported values for aboveground biomass in individual stands range from less than 1.5 Mg ha $\mathrm{Mg}^{-1}$ f-6 year old coppice woodland regenerating under an imposed late dry-season fire regime (Chidumayo 1990) to $144 \mathrm{Mg} \mathrm{ha}^{-1}$ in mature miombo woodland in Zaire (Malaisse and Strand 1973) ${ }^{1}$. Aboveground biomass in oldgrowth, mixed-age stands averages about $55 \mathrm{Mg} \mathrm{ha}^{-1}$ in dry miombo woodland in Zambia and Zimbabwe (Martin 1974; Guy 1981a; Chidumayo 1991b; Frost unpublished data), and about $90 \mathrm{Mg} \mathrm{ha}^{-1}$ in old-growth stands in wet miombo woodland (Malaisse and Strand 1973; Malaisse 1978a; Chidumayo

$1 \quad 1 \mathrm{Mg}=1$ tonne $=1000 \mathrm{~kg}$. All biomass is on a dry matter basis.

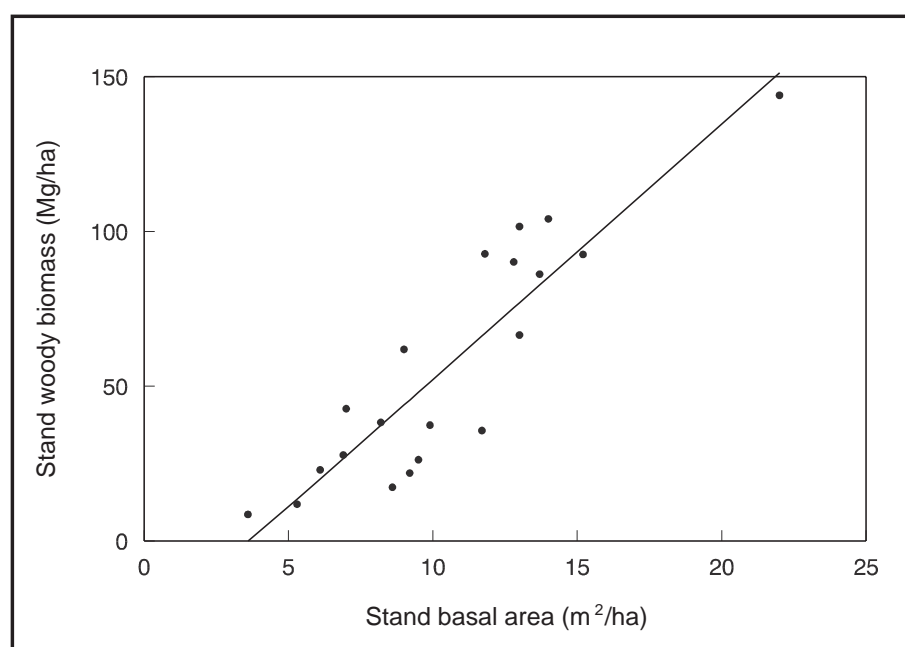

Figure 2.4 Stand biomass $\left(\mathrm{B}, \mathrm{Mg} \mathrm{ha}^{-1}\right)$ is linearly correlated with stand basal area $\left(\mathrm{A}, \mathrm{m}^{2} \mathrm{ha}^{-1}\right)$ : in miombo woodland: $\mathrm{B}=8.44 \mathrm{~A}-30.89(\mathrm{r}=0.901, \mathrm{df}=18)$. Data from Malaisse and Strand (1973), Freson et al. (1974), Guy (1981a), Chidumayo (1988d; 1990; 1991b), Frost (unpublished data).

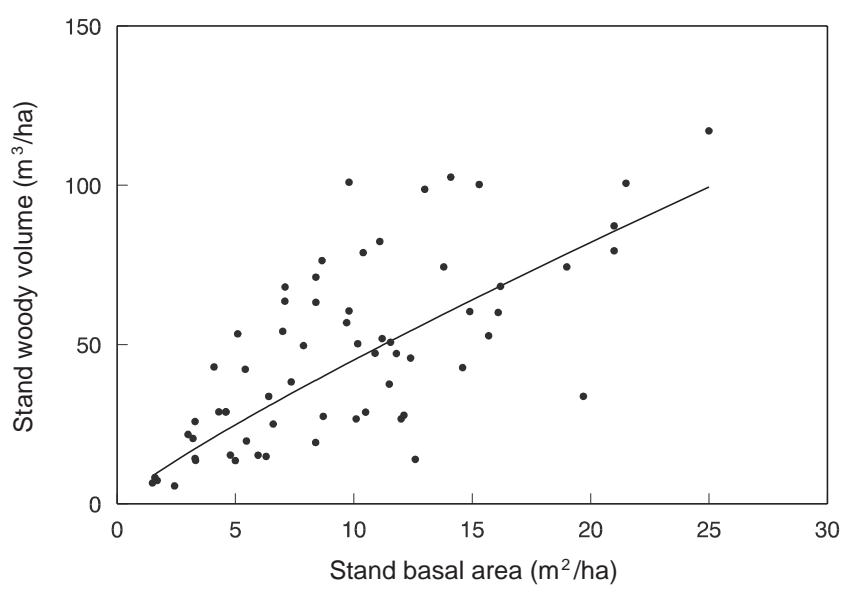

Figure 2.5: Relationship between stand volume $\left(\mathrm{V}, \mathrm{m}^{3} \mathrm{ha}^{-1}\right)$ and stand basal area $\left(\mathrm{A}, \mathrm{M}^{2} \mathrm{ha}^{-1}\right)$ in miombo woodlands: $\mathrm{V}=$ $6.18 \mathrm{~A}^{0.86}, \mathrm{~F}_{1,62}=88.87, \mathrm{p}<0.001$. Data from Endean (1968), Jones (1986), Chidumayo (1988d), Lowore et al. (1994a). 


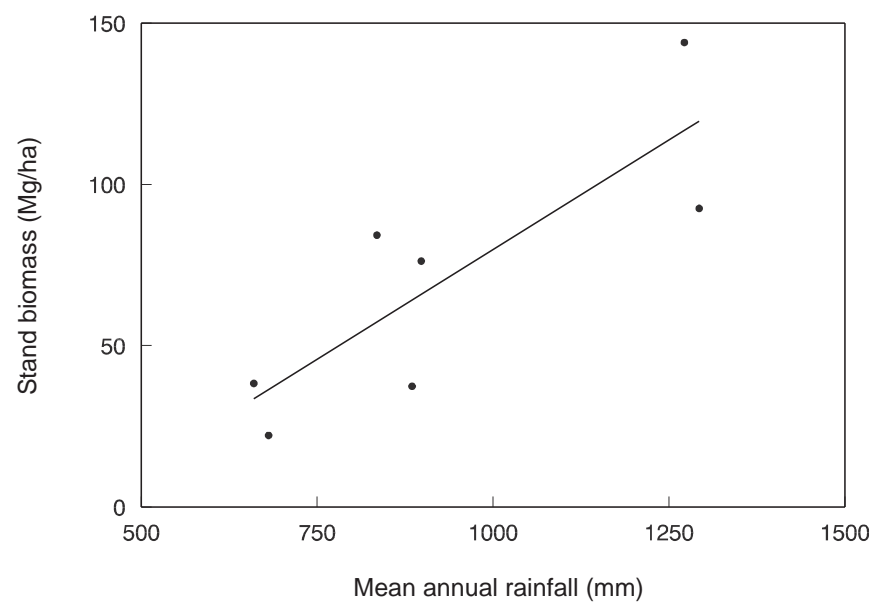

Figure 2.6 Aboveground woody biomass (B, $\left.\mathrm{Mg} \mathrm{ha}^{-1}\right)$ of oldgrowth, mixed-age stands of miombo woodland increases with mean annual rainfall $(\mathrm{P}, \mathrm{mm}): \mathrm{B}=0.14 \mathrm{P}-55.48(\mathrm{r}=$ 0.831 , df $=5$ ). See text for sources of the data.

1990). Most of these values have been derived from applying allometric equations that relate woody biomass to an index of plant size, usually diameter at breast height $(\mathrm{DBH}, 1.3 \mathrm{~m})$ or the product of DBH and tree height, to the enumerated and measured stands (Malimbwi et al. 1994; Grundy 1995b). Their applicability outside the area from which they were developed remains to be tested.

Much less is known about the amount of woody biomass belowground. Miombo species have horizontally and vertically extensive root systems. Maximum recorded lateral distances are $27 \mathrm{~m}$ (J. globiflora: Strang 1965) and $15 \mathrm{~m}$ (B. longifolia, B. spiciformis and J. paniculata: Savory 1963). The tap roots of these species can exceed $5 \mathrm{~m}$ in deep soils. Root biomass measured in old-growth stands of dry miombo woodland in central Zambia averaged $32.7 \mathrm{Mg} \mathrm{ha}^{-1}$ where the measured cordwood biomass averaged 41.8 $\mathrm{Mg} \mathrm{ha}^{-1}$ (Chidumayo 1993a). At a separate site, uncut for 21 years, cordwood made up $60 \%$ of the total aboveground biomass (Chidumayo 1993a). This would suggest a total aboveground woody biomass of 69.7 $\mathrm{Mg} \mathrm{ha}^{-1}$ at the sites where root biomass was measured. On this basis, root biomass comprised about $32 \%$ of the total stand biomass of $102 \mathrm{Mg} \mathrm{ha}^{-1}$. Chidumayo (1993a; 1995) used allometric equations to estimate a total woody biomass of $106 \mathrm{Mg} \mathrm{ha}{ }^{-1}$ in oldgrowth miombo sites in central Zambia, 67.2 $\mathrm{Mg} \mathrm{ha} \mathrm{ha}^{-1}$ (63\%) of which was aboveground and 38.8 $\mathrm{Mg} \mathrm{ha}{ }^{-1}$ (37\%) belowground. Overall, for these Zambian dry miombo sites, root biomass averaged $35 \%$ of total biomass or $53 \%$ of aboveground biomass. In contrast, in disturbed dry miombo woodland in central Tanzania, root biomass apparently accounted for only $20 \%$ of a total biomass of $33 \mathrm{Mg} \mathrm{ha}^{-1}$ (Malimbwi et al. 1994), a value which seems low. For wet miombo woodland, Malaisse and Strand (1973) report $35 \mathrm{Mg} \mathrm{ha}^{-1}$ for belowground biomass at a site in Zaire with an aboveground biomass of about $144 \mathrm{Mg} \mathrm{ha}^{-1}$. This too is only $20 \%$ of total biomass, but which might reflect a trend towards lower root: shoot ratios in wetter environments. In Burkea-Ochna woodland, which is similarly structured and floristically related to miombo woodland, but occurs in a drier environment, woody roots comprised $44 \%$ of total woody biomass (Rutherford 1984).

The total woody biomass for these few miombo stands is lower than the average for other tropical dry forests at equivalent ratios of mean annual temperature to mean annual rainfall (T/P), though they fall within the lower bound of the data set (Brown and Lugo 1982). More data 
on both aboveground and belowground biomass are called for, not only because of the need to calculate woodland standing stocks and sustainable production levels for fuelwood and timber, but also because of the need to assess the extent to which miombo woodlands are potential sources and sinks within the global carbon cycle (Box 2.3).

Aboveground herbaceous biomass in relatively undisturbed, mixed-aged stands of miombo woodland range from $0.1-4.0 \mathrm{Mg} \mathrm{ha}^{-1}$ (2-5\% of total aboveground biomass), with most of the recorded values being less than $2.0 \mathrm{Mg} \mathrm{ha}^{-1}$ (Ward and Cleghorn 1964; Boaler and Sciwale 1966; Freson 1973; Malaisse and Strand 1973; Martin 1974; Malaisse 1978a; Chidumayo 1993a; Frost unpublished). On average, forbs make up about $30 \%$ of this biomass, though this varies considerably among sites and between years.

Herbaceous biomass and mean annual rainfall are uncorrelated at a regional scale (Table 2.5), due partly perhaps to differences in measurement techniques but mostly to differences in the intensity of tree:grass interactions at different sites with varying woody plant biomass (see Dynamics page 50). In regenerating woodlands, herbaceous yield declines exponentially with increasing woody plant basal area (Figure 2.7; Robertson 1984). Simulation of the closure of the woodland canopy with increasing woody plant basal area, using an empirical relationship between crown area and basal diameter for B. spiciformis (Burrows and Strang 1964) as applied to various miombo stands with different size frequency distributions, reveals that woodland canopy cover reaches $100 \%$ (assuming that adjacent crowns do not overlap) at a woody plant basal area of about $10 \mathrm{~m}^{2} \mathrm{ha}^{-1}$. This is the point below which grass yield begins to increase sharply (Figure 2.7), suggesting shade cast by trees is the main factor suppressing grass growth. Interestingly, Malaisse (1978a) notes that a marked change in herbaceous species composition occurs at about $10 \mathrm{~m}^{2} \mathrm{ha}^{-1}$ woody plant basal area but gives no details.

\section{Faunal structure}

One of the striking features of miombo woodlands is the apparent paucity of animals, in terms of both the density of individuals and the biomass of populations, in contrast to the relatively high species richness and endemicity of some faunal groups (Box 2.1). This applies to birds (Benson and Stuart-Irwin 1966) and probably to other groups such as small mammals (Smithers and Wilson 1979), dung beetles (Gardiner 1995) and lepidoptera (Pinhey 1962), among others. Some groups, most notably the termites, show the opposite trends. Although the number of termite species is not notably higher than that found in

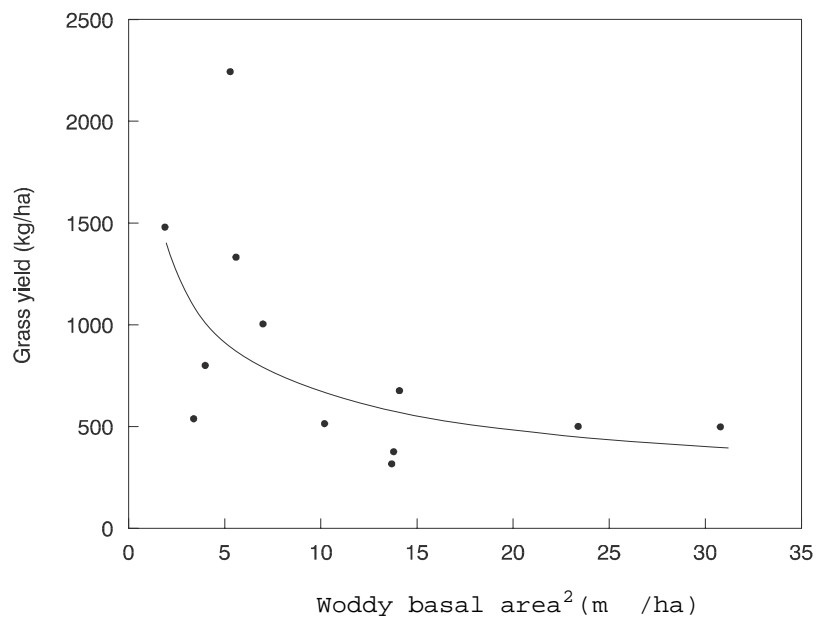

Figure 2.7 Variation in herbaceous yield $\left(\mathrm{Y}, \mathrm{Mg} \mathrm{ha}^{-1}\right)$ in relation to woody plant basal area $\left(\mathrm{A}, \mathrm{m}^{2} \mathrm{ha}^{-1}\right)$ in miombo woodland in Malawi: $\mathrm{Y}=1878.4 \mathrm{~A}^{-0.45}\left(\mathrm{~F}_{1.10}=6.570, \mathrm{p}=0.028\right)$. Data from Robertson 1984. 
non-miombo woodland vegetation (Mitchell 1980), densities and biomass are often higher (e.g. up to $17.5 \mathrm{~kg} \mathrm{ha}^{-1}$ in miombo woodland in Zaire: Malaisse 1978b). Given the concern about declining biodiversity globally, there is a need for more information on the patterns of diversity within miombo woodland and how these are being changed by fragmentation and transformation of habitat.

The average biomass density of indigenous large herbivores in conservation areas in which miombo woodland is the sole or main vegetation type is $2.2 \mathrm{Mg} \mathrm{DM}$ (dry matter) $\mathrm{km}^{-2}$ (Bell 1982; East 1984). Assuming that animal densities in miombo woodland are not artifacts of past hunting pressures or of confinement to small reserves established on marginal land (McNaughton and Georgiadis 1986), this biomass is only about $20-30 \%$ of the biomass expected at a comparable mean annual rainfall (about $960 \mathrm{~mm}$ ) in savanna communities underlain by volcanic rocks or sedimentary formations within rift valleys. Moreover, in contrast to the general trend for large herbivore biomass in African savannas to increase with increasing mean annual rainfall (Coe et al. 1976; Bell 1982; East 1984), herbivore biomass in miombo woodland declines as mean annual precipitation (MAP) increases:

Biomass density $\left(\mathrm{kg} \mathrm{DM} \mathrm{km}{ }^{-2}\right)=8886-6.84$ MAP (mm) (se. $\pm 1242, r=-0.770$, df $=9, \mathrm{p}<$ 0.05: data for localities 17, 36-41, 43, 45 in Bell 1982). The slope of the regression line is significantly different from zero $(\mathrm{t}=3.19$, df $=7$, $\mathrm{p}<0.05$ ). Elephant (Loxodonta africana) and buffalo (Syncerus caffer) make up 75-90\% of the biomass at most of these localities, although both species are more abundant in drier savannas on eutrophic soils (East 1984). Their large body sizes allow them to utilise the abundant lowquality plant matter present in miombo woodland. In addition, elephants can reach the substantial amounts of browse that are unavailable to other species.
Most of the antelope in miombo woodland are also relatively large-bodied. Species such as sable antelope (Hippotragus niger) roan antelope (H. equinus) and Lichtenstein's hartebeest (Alcelaphus lichtensteini) which are characteristic of miombo woodland, are specialist grazers that select high-protein, actively growing grass shoots from medium-height swards. To some extent, they offset periodic shortages of high-quality forage by moving seasonally between different landscape units and by selecting areas, such as those which have been recently burnt, which produce a brief but synchronous pulse of highquality food (Bell 1981). Such responses require large foraging areas, however, which in turn means low population densities. In contrast to grazers, specialist ungulate browsers are rare, a reflection of the shortage of browse during the latter part of the dry season, the poor nutritional quality, and general inaccessibility to the canopies of trees (Bell 1982; East 1984; Jachmann 1989).

\section{Functioning}

In addition to the distinctive floristic composition of miombo woodland, a number of other features stand out. These include the marked seasonality of plant production, growth and reproduction; generally low, but episodically high, levels of consumption by invertebrates; and highly variable rates of decomposition. These are driven directly or indirectly by the strongly seasonal rainfall, a low biomass of large herbivores, a relatively large biomass of termites, and frequent fires. The combination of sufficient but seasonally limited moisture for plant growth and nutrient-poor soils influences the patterns of both plant production and plant quality, which in turn influence the kinds and extent of herbivory and the frequency and intensity of fires. Through their reciprocal effects on plants and soils, these processes feed back to modify the moisture and nutrient regimes (Frost et al. 1986). 


\section{Soil moisture dynamics}

The soils of the upland plateaux of central and eastern Africa experience a period of soil moisture stress during at least part of the annual dry season (van Wambeke 1982). Moisture stress is conventionally taken to occur when soil moisture tensions fall below -1.5 Mpa, the permanent wilting point. Although some savanna plants are able to transpire at more negative soil moisture tensions, the amount of plant available moisture at these tensions is small (Scholes and Walker 1993). Moisture potentials in the top $30 \mathrm{~cm}$ of the soil are below permanent wilting point for 3 months each year. With increasing depth, soil moisture potentials are below this point for progressively shorter periods until beyond about $90 \mathrm{~cm}$ the soil generally remains moist throughout the year (Jeffers and Boaler 1966; Strang 1969; Alexandre 1977). This contrasts with drier savannas where the whole of the soil profile

\section{Box 2.3 \\ Miombo woodlands and carbon sequestration}

\section{Bob Scholes}

The miombo woodlands have a great potential to either add to the growing carbon dioxide content of the atmosphere, or help reduce it. In the event that substantial areas of miombo are cleared for cereal crop agriculture, 6-10 Pg of $\mathrm{C}$ could be released. If, on the other hand, the woodlands are managed to maximise carbon storage, a similar amount could be taken up (Scholes et al. in press). In both cases, about half of the change in carbon stocks occurs in the soil, and the rest in the biomass.

Net primary production in miombo woodlands is $900-1600 \mathrm{~g} \mathrm{~m}^{-2} \mathrm{yr}^{-1}$. The annual increment of the woody-plant biomass is no more than 3-4\% in mature stands. These rates, which define the upper limit of the sink strength, could increase slightly under an atmosphere high in carbon dioxide, but given the pervasive nutrient limitations, an increase in net primary production of greater than $15 \%$ is unlikely.

Land use change does not inevitably lead to reduced carbon density. Well-managed tropical pastures in comparable environments in South America can have a high carbon density, especially if the roots are deep (Fisher et al. 1994). Agricultural techniques which conserve biomass and build soil organic matter, such as agroforestry, could result in a landscape which is both agriculturally productive and rich in carbon.

The main technique for increasing carbon uptake in savanna woodlands is the reduction in fire frequency. Experiments in many parts of Africa, including some in miombo woodlands, have shown woody biomass and soil carbon to increase if fires are excluded (Trapnell et al. 1976). Permanent fire exclusion is virtually impossible in the strongly seasonal miombo climate, but a reduction in frequency from the current annual-to-triennial norm to once a decade is probably achievable at reasonable cost. This would simultaneously increase carbon dioxide uptake, and decrease the emission of methane and ozone precursors. The carbon uptake would last twenty to fifty years, as the woodlands reach a new equilibrium carbon density. The carbon-storage benefits of miombo management can be extended beyond the initial 20-50 year period by harvesting the timber sustainably, and either converting it to long-lived products such as furniture, or by using it as an energy source in place of fossil fuels.

In the long term, fires may help to sequester carbon. A small fraction of the carbon burned $(<1 \%)$ is converted to highly decay-resistant forms such as charcoal and soot (Andreae 1993). This is one of the few mechanisms by which carbon is removed from the biosphere for long periods of time. Coupled with the shading effect of smoke particles, the net long-term effect of fires on the global energy and carbon balance may be close to neutral. 
dries out to below permanent wilting point during the dry season.

The amount of rainfall entering the soil depends on how much is intercepted by the vegetation and on the infiltration characteristics of the soil surface. Miombo woodland tree canopies in Zaire intercept $18-20 \%$ of incoming rainfall annually; the herbaceous layer intercepts a further 16\% (Alexandre 1977; Malaisse 1978a). Interception by trees in dry miombo woodland in Zimbabwe is apparently much less, 3.4\%, though this is probably an underestimate (King and Campbell n.d.). How much is intercepted by the herbaceous layer at this site is not known, although a nearby grassland site intercepted $4 \%$ of incoming rainfall. In a physiognomically similar vegetation in South Africa, $18 \%$ of incoming rainfall was intercepted on average: $6 \%$ by the tree layer, $4 \%$ by the grass layer, and $8 \%$ by the litter (Scholes and Walker 1993).

Soil moisture levels are rapidly recharged at the start of the rains. Infiltration and percolation rates are generally high, depending on soil texture and organic matter content, soil surface structure and the extent of plant and litter cover. Although many miombo woodland soils are clayey, microaggregation of the clay particles imparts to them the infiltration and permeability characteristics of more sandy profiles. The size of these water-stable microaggregates is positively correlated with the amount of organic carbon in the soil, reaching an asymptote at $2 \%$ organic carbon (Elwell 1988; King and Campbell 1994). Because most miombo woodland soils have less carbon than this, small declines in organic matter content can greatly reduce stability, particularly if the aggregates are exposed to raindrop impact, mechanical deformation or animal hoof pressure.

\section{Plant water relations}

Apart from a study of seasonal changes in leaf moisture contents and osmotic potentials in Julbernardia globiflora, Brachystegia boehmii and B. spiciformis by Ernst and Walker (1973), little is known about the water relations of miombo plants. Most of the canopy trees flush some weeks before the first rains. The water content of newly flushed leaves is high (average: $66 \%$ ) but declines as the leaves harden, from when it remains relatively constant (average: $51 \%$ ) until the leaves are shed in the following dry season. Leaf osmotic potentials are slightly more variable: they are high in newly flushed leaves (average: $-1.04 \mathrm{MPa}$ ) but soon decline as the leaves harden (average: -1.68 MPa). Access to subsoil moisture reserves and water storage in the stems is probably important for maintaining an initially favourable water balance in these plants prior to the rains (Ernst and Walker 1973). Osmotic potentials rise gradually with the onset of the rains to an average of $-1.35 \mathrm{MPa}$ before declining to about -1.67 $\mathrm{MPa}$ in the dry season when moisture stress increases. In B. boehmii, $82-99 \%$ of the osmotic potential of the cell sap was under metabolic control, primarily through adjustments in the amounts of organic acids present (Ernst and Walker 1973). The minimum leaf water potentials of the three species are higher than those of the dominant trees in Burkea savanna (Scholes and Walker 1993), perhaps reflecting the more mesic nature of the miombo woodland site.

\section{Phenology}

The timing of flowering and fruiting are dealt with in Chapter 3. Here the focus is on the influence of seasonal variations in soil moisture on the duration of leaf retention and therefore on the length of the growing season. Most miombo trees and shrubs, including all of the dominant species, are deciduous, shedding their leaves during the dry season. Leaf fall peaks in July-August in dry miombo woodland (Swift et al. in prep.) and August-September in wet miombo woodland (Malaisse et al. 1975). About $91 \%$ of leaf litter falls during the dry season (May-October) in dry miombo woodland (Swift et al. in prep.) compared 
with only $64 \%$ in wet miombo woodland (Freson et al. 1974). The timing of leaf fall and the duration of the leafless period varies from year to year, depending on prevailing weather conditions and on the species. In years of below-average rainfall, leaves are shed early in the dry season, but in years of above-average rainfall many species retain their leaves late into the dry season. About $8 \%$ of the trees and $3 \%$ of the shrub species in miombo woodland in Zimbabwe are briefly deciduous, only shedding their leaves late in the dry season irrespective of the preceding wet season rainfall (e.g. Pseudolachnostylis maprouneifolia, Monotes spp.). Shallow-rooted species such as Lannea discolor and Vangueria infausta shed their leaves at the onset of the dry season and remain leafless until the next rainy season, after the leaves of most canopy species have already flushed.

The tendency for many species to retain their leaves long into the dry season is linked to their ability to access subsoil moisture. Most of the dominant trees are relatively deep-rooted (Savory 1963; Timberlake and Calvert 1993). Nevertheless, most species are intolerant of perched water tables and poorly aerated, seasonally waterlogged subsoils. Where they do occur on such sites, they are usually stunted and misshapen (Savory 1963). Seasonally waterlogged soils are usually occupied instead either by hygrophilous grasses or shallowrooted, evergreen trees and shrubs.

The flush of new leaves 4-8 weeks before the first spring rains is one of the characteristic features of miombo woodland (Chapter 3) and is quite different from patterns of leaf flush in other tropical deciduous forests and woodlands. The red colour of the leaves is striking, particularly those of Brachystegia spiciformis. This coloration is due to the synthesis of anthocyanins soon after bud burst and reaches a peak about 3 weeks later (Ernst 1988; Johnson and Choinski 1993). Although young leaves are photosynthetically active, the rate is initially low and less than the respiratory cost of maintenance (Tuohy and Choinski 1990; Johnson and Choinski 1993). The leaves and associated photosynthetic capacity develop rapidly, reaching an asymptote at about the time that the anthocyanins are fully metabolised (Johnson and Choinski 1993).

The precise function of the anthocyanins is unclear. They may absorb UV-B radiation and thereby protect the young leaves from damage (Bate and Ludlow 1978). Anthocyanins may also function to protect the leaves against pathogens and herbivores (Coley 1983; Coley and Aide 1989). Neither of these hypotheses has been fully tested in miombo woodland, although Jachmann (1989) has shown that young leaves of otherwise preferred miombo species are avoided by elephant. These leaves have a higher protein complexing capacity, linked to the high levels of proanthocyanidins, as well as higher lignin, steroidal saponin and total polyphenol contents. Whatever the advantage of anthocyanins, the development of a functioning canopy prior to the rains enables the plants to start production as soon as the rains start.

\section{Plant production and quality}

There have been no complete studies of woody plant production in miombo woodland. In part this is because of the difficulties of accurately determining how much photosynthate is allocated to the production of new leaves and shoots, to reproduction, and to stem and root growth. Most of the trees are deciduous and produce their new growth at or before the start of the rains (i.e. growth is determinate). Shoot production must therefore depend on carbohydrates and nutrient reserves stored from previous growing seasons (Rutherford 1984). Some species, notably $B$. boehmii, produce a small secondary flush of leaves midway through the growing season but in most species current growth is completed early in the growing season, after which the plants appear to replenish their drawn down reserves. New 
leaves and shoots damaged in late dry-season fires or eaten by herbivores are rapidly replaced, suggesting that the reserves are substantial and not usually depleted in a single growth event.

Annual aboveground shoot (leaf and current twig) production can therefore be estimated by applying allometric equations that relate leaf and shoot mass either to stem diameter, in the case of trees, or to canopy volume, in the case of shrubs, to measured individuals in a stand (Martin 1974; Guy 1981b; Chidumayo 1993a; Grundy 1995a; Frost unpublished data). The limited available data indicate that current growth comprises 1.5$11.5 \%$ (mean: $4.7 \%$ ) of total aboveground woody biomass (Table 2.6). Current growth measured in
Burkea-Ochna savanna using similar techniques comprised $8.2 \%$ (Rutherford 1984). Some of the variation undoubtedly reflects differences in the size structures of the stands since, within a stand, the ratio of current growth to aboveground biomass decreases as plants get larger (Martin 1974; Chidumayo 1990; Frost unpublished data). Thus stands composed of predominantly young or small trees produce proportionately more current growth per unit biomass than stands dominated by large trees.

The limited data on biomass and basal area increments suggests that growth rates in miombo are low (Table 2.7). Mean annual increments in biomass in regrowth woodlands in dry miombo

Table 2.6 Annual current growth (leaves, shoots), wood biomass and total aboveground biomass in some miombo communities.

\begin{tabular}{|c|c|c|c|c|c|}
\hline Locality & $\begin{array}{l}\text { Basal area } \\
\left(\mathrm{m}^{2} \mathrm{ha}^{-1}\right)\end{array}$ & $\begin{array}{l}\text { Wood } \\
\text { biomass } \\
\left(\mathrm{Mg} \mathrm{ha}^{-1}\right)\end{array}$ & $\begin{array}{l}\text { Current } \\
\text { growth } \\
\left(\mathrm{Mg} \mathrm{ha}^{-1}\right)\end{array}$ & $\begin{array}{l}\text { Total } \\
\text { biomass } \\
\left(\mathrm{Mg} \mathrm{ha}^{-1}\right)\end{array}$ & Source \\
\hline \multicolumn{6}{|l|}{ ZAIRE } \\
\hline Luiswishi & 21.7 & 141.70 & 2.23 & 143.93 & Malaisse and Strand (1973) \\
\hline Kasapa & 13.3 & 64.06 & 2.40 & 66.47 & Malaisse et al. $(1975)^{1}$ \\
\hline \multicolumn{6}{|l|}{ ZAMBIA } \\
\hline Chakwenga & 6.1 & 19.30 & 2.50 & 21.80 & Chidumayo $(1993 a)^{2}$ \\
\hline $\begin{array}{l}\text { Central } \\
\text { Province }\end{array}$ & - & 78.36 & 2.67 & 81.03 & Chidumayo $(1991 b)^{2}$ \\
\hline \multicolumn{6}{|l|}{ ZIMBABWE } \\
\hline Marondera & 10.1 & 39.73 & 2.74 & 42.47 & Frost (unpubl.) \\
\hline Sengwa & 9.2 & 22.50 & 0.53 & 23.03 & Guy (1981a) \\
\hline Sengwa & - & 21.16 & 1.15 & 22.31 & Martin (1974) \\
\hline Makoholi & 8.2 & 36.79 & 1.46 & 38.25 & Ward and Cleghorn (1964) \\
\hline
\end{tabular}

Notes:

1. Biomass values in the table calculated by applying the following equations to the size-frequency data given in the original papers on the structure of the woodlands:

- $\log _{10}$ Wood biomass $(\mathrm{kg})=3.97+2.63 \log _{10} \mathrm{DBH}(\mathrm{m})$ (Grundy 1995a).

- Current growth $(\mathrm{kg})=0.075 * \mathrm{DBH}(\mathrm{cm}) 1.443$ (Frost unpublished data).

2. Current growth values refer to leaves only. 
Table 2.7 Various measures of growth in regenerating miombo woodland. Values in parentheses are standard deviations. Values in bold are the sample sizes.

\begin{tabular}{llcccc}
\hline & \multicolumn{3}{c}{ Age of plots (yr) } & \\
\cline { 2 - 4 } & $1<10$ & $11-20$ & $21-50$ & $>50$ & Data source \\
\hline $\begin{array}{l}\text { RELATIVE BASAL AREA INCREMENT } \\
\left(\mathrm{m}^{2} \mathrm{~m}^{-2} \mathrm{yr}^{-1}\right)\end{array}$ & & & & \\
Regrowth after cultivation & & 0.109 & 0.041 & 0.010 & $\begin{array}{l}\text { Boaler and Sciwale } \\
\text { (1966) }\end{array}$ \\
Regrowth after cultivation & 0.254 & 0.082 & 0.036 & Robertson (1984) \\
$\begin{array}{l}\text { Dry miombo coppice plots } \\
\text { Wet miombo coppice plots }\end{array}$ & 0.188 & 0.084 & 0.032 & Chidumayo (1988d) \\
Regenerating coppice plot & 0.203 & 0.073 & 0.022 & Chidumayo (1987c) \\
Woodland thinned by 66-74 \% of & 0.023 & 0.015 & 0.014 & Chidumayo (1988c) \\
original basal area & & & & & Endean (1968) \\
\hline
\end{tabular}

MEAN ANNUAL INCREMENT IN VOLUME

$\left(\mathrm{m}^{3} \mathrm{ha}^{-1} \mathrm{yr}^{-1}\right)$

Dry miombo coppice plots

$1.95 \quad 1.97 \quad 2.00$

Chidumayo (1988d)

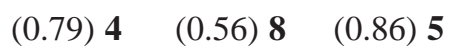

MEAN ANNUAL INCREMENT IN BIOMASS

$\left(\mathrm{Mg} \mathrm{ha}^{-1} \mathrm{yr}^{-1}\right)$

Dry miombo coppice plots

1.45

1.56

See note 1

$\begin{array}{lll}(0.61) & 4 & (0.44) \\ 8 & (0.67) 5\end{array}$

Dry miombo coppice plots

$\begin{array}{lr}1.41 & 1.95 \\ (-) & \end{array}$

Chidumayo (1991a)

Dry miombo coppice plots

$1.17 \quad 1.48$

(0.47) 5

Dry miombo coppice plots

(0.94)

Chidumayo (1993a)

Wet miombo coppice plots

2.15

(0.48) 4

(0.94) 5

2.65

3.37

Chidumayo (1990)

Early burn fire plots

0.60

1.68

Chidumayo (1990)

Note: 1. Calculated from mean annual increment in volume (Chidumayo 1988d) assuming wood density of miombo trees of $0.778 \mathrm{Mg} \mathrm{m}^{-3}$ (Frost unpublished) 


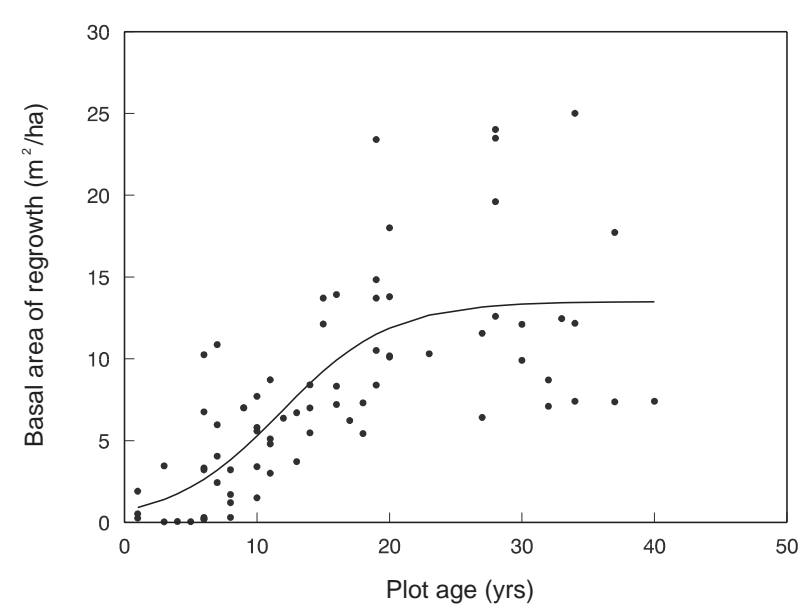

Figure 2.8 Stand basal area $\left(\mathrm{A}, \mathrm{M}^{2} \mathrm{ha}^{-1}\right)$ increases as a logistic function of the age of regrowth on miombo woodland coppice plots ( $\mathrm{t}, \mathrm{yrs}): \mathrm{A}=13.50 /\left(1+\left(17.74 *\left(0.79^{t}\right)\right)\right)$, $r^{2}=0.520$. See text for sources of data.

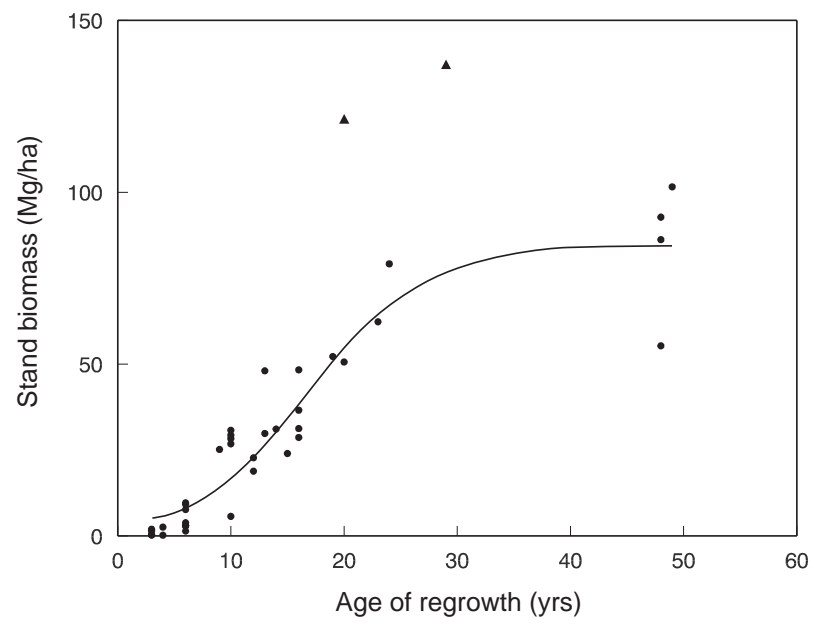

Figure 2.9 Stand biomass $\left(\mathrm{B}, \mathrm{Mg} \mathrm{ha}^{-1}\right)$ increases as a logistic function of the age of regrowth on miombo woodland coppice plots $(\mathrm{t}, \mathrm{yrs}): \mathrm{B}=84.20 /\left(1+\left(28.76^{*}\left(0.82^{\mathrm{t}}\right)\right)\right)$, $\mathrm{r}^{2}=0.886$. The regression line excludes the two uppermost points. See text for sources of the data. range from 1.2-2.0 $\mathrm{Mg} \mathrm{ha}^{-1}$ (Chidumayo 1991b; 1993a). Slightly higher rates are recorded in wet miombo: 2.2-3.4 Mg ha-1 (Chidumayo 1990). In Table 2.7 the biomass and volume does not show much variation with age, but there are significant relationships between the age of regrowth stands and both stand basal area and stand biomass when the data points are plotted individually (Figures 2.8 and 2.9, based on data from Strang 1974; Robertson 1984; Chidumayo 1987c; 1988a; 1990; 1991b). Using the regression equations to simulate average annual biomass increments and relative biomass increments with age, biomass production in regrowth woodland peaks at about 18-20 years, while relative increment declines monotonically from the outset (Figure 2.10).

The relationship between age and stand productivity can only properly be determined by long-term monitoring of changes in basal area and biomass on permanent plots (Chidumayo 1990). Such data are rare but still tend to support the overall conclusion that growth rates in both old-growth and regrowth miombo woodland are low.

Basal area in early burnt wet miombo woodland increased by only $27 \%$ in 27 years (Endean 1968), giving a relative basal area increment (RBAI) of only $0.009 \mathrm{~m}^{2} \mathrm{~m}^{-2} \mathrm{yr}^{-1}\left(0.9 \% \mathrm{yr}^{-1}\right)$. Growth rates on adjacent plots in which the woodland had been thinned by $66-74 \%$ of its original basal area were only marginally higher (RBAI $1.9 \%$ $\left.\mathrm{yr}^{-1}\right)$, though measurements were limited to trees $>15 \mathrm{~cm} \mathrm{DBH}$. Likewise, the average RBAI over 40 years for marked B. spiciformis and J. globiflora 
(both species combined) in protected dry miombo woodland in Zimbabwe were $2.7 \% \mathrm{yr}^{-1}$ for trees with $5-10 \mathrm{~cm}$ initial DBH and $2.0 \% \mathrm{yr}^{-1}$ for trees $>10 \mathrm{~cm}$ initial DBH (Figure 2.11). This is similar to the average $2.2 \% \mathrm{yr}^{-1} \mathrm{RBAI}$ calculated for trees $>10 \mathrm{~cm}$ DBH from data on changes in stem diameter over 3.9 years in wet miombo woodland in Zaire. The relative biomass increment of trees smaller than $10 \mathrm{~cm} \mathrm{DBH}$ was higher, $8.8 \% \mathrm{yr}^{-1}$ (data from Malaisse et al. 1975). Overall, this equates to an annual increase in wood biomass of 3.4 Mg DM ha ${ }^{-1} \mathrm{yr}^{-1}$.

The apparent rapid attenuation of growth rate with increasing size of these trees may reflect an increasing disparity between the rising cost of maintaining support tissues (stems, branches and, presumably, roots and their fungal associates) relative to the productive capacity and surface area of leaves. The formation of heartwood, a prominent feature in older miombo trees, may be one process by which a tree's metabolic costs of maintenance are reduced. Other possible consequences include reduced production of carbon-based secondary chemicals, resulting in less-effective defences against pathogens and herbivores, and reduced capacity to support ectomycorrhizae.
Annual herbaceous production, estimated by following concurrent changes in biomass and necromass through the growing season, range from almost 3.3 $\mathrm{Mg} \mathrm{ha}^{-1} \mathrm{yr}^{-1}$ in Zaire (Freson 1973 modified by Malaisse 1978a), to $1.5 \mathrm{Mg} \mathrm{ha}^{-1} \mathrm{yr}^{-1}$ in drier miombo woodland in Zimbabwe (grasses, 57\%, and forbs, 43\%: Frost et al. in prep.). Most other estimates of production (Weinmann 1948; Ward and Cleghorn 1964; Martin 1974) are based on measurements of yield made at the end of the growing season, a method which underestimates production because peak yields amount to only $25-35 \%$ of annual aboveground production measured throughout the growing season. Yield, however, can be used to estimate changes in grass production in response to variations in annual rainfall and to changes in woodland cover. At one site (Makoholi, Zimbabwe), where grass yields in woodland have been measured over a number of years, yield was significantly correlated with annual rainfall (Ward and Cleghorn 1964):

Yield $\left(\mathrm{Mg} \mathrm{ha}^{-1} \mathrm{yr}^{-1}\right)=0.001$ Rainfall $(\mathrm{mm})-0.326$. $\left(\mathrm{s}_{\mathrm{yx}}=6.24\right.$, df $\left.=2, \mathrm{r}=0.967, \mathrm{p}<0.05\right)$. Grass yields on an adjacent plot where the trees had been ringbarked were not significantly correlated with yearly rainfall. Although the yields on the
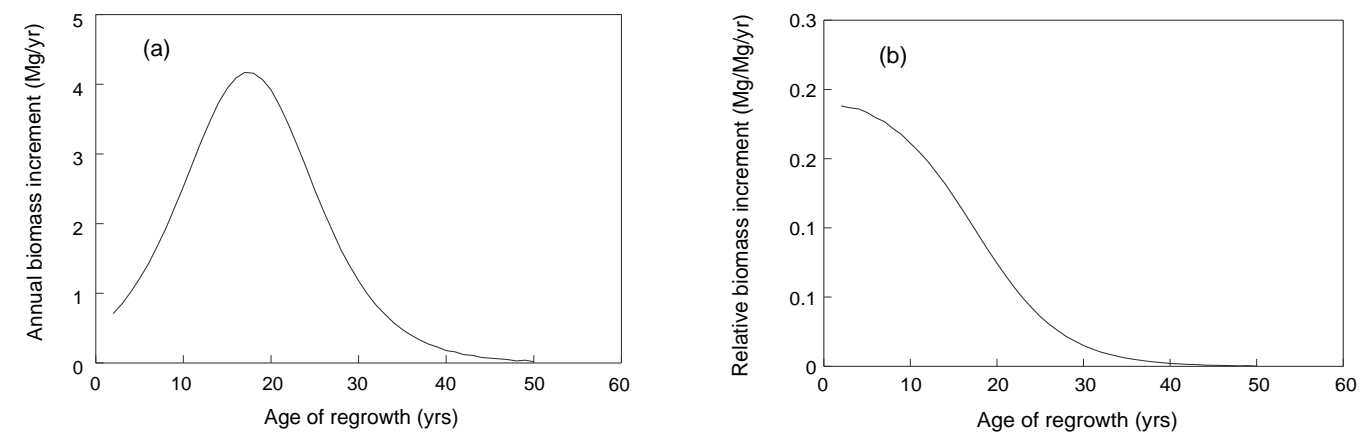

Figure 2.10 (a) Annual biomass increment $\left(\mathrm{Mg} \mathrm{ha}^{-1} \mathrm{yr}^{-1}\right)$ and (b) relative biomass increment $(\mathrm{Mg}$ $\mathrm{Mg}^{-1} \mathrm{yr}^{-1}$ ) estimated from the regression of stand biomass on stand age for various miombo woodland coppice plots. See Figure 2.9 for details. 
ringbarked plot were much higher, they varied less between years $(\mathrm{CV}$ $12 \%$ compared to $48 \%$ on the uncleared plots). This suggests that on highly porous soils, such as those at Makoholi, there is an upper limit to how much water is retained in the topsoil, where it is available to grasses, and that this amount is much less than the total annual rainfall. The excess simply drains into the subsoil.

Stumping or ringbarking trees results in an average $260 \%$ increase in herbaceous yield (s.d. 419, $\mathrm{n}=22$ : Ward and Cleghorn 1964; Barnes 1972; Chidumayo 1993a). The higher increases tend to be recorded in areas in which the herbaceous biomass under trees is least, and in dry years. Yields of 3$5 \mathrm{Mg} \mathrm{ha}^{-1}$ have been recorded on

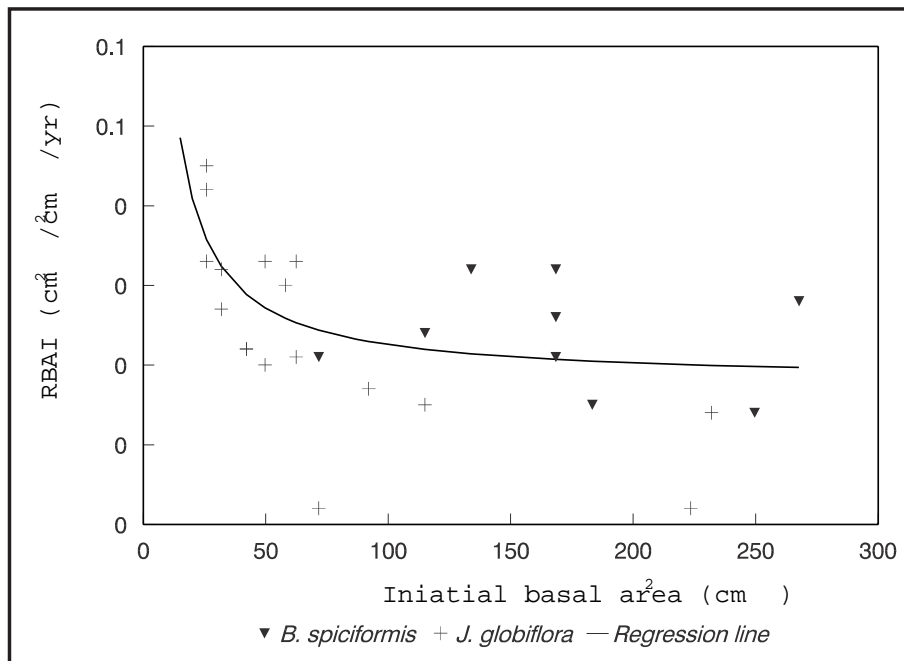

Figure 2.11 Relative basal increments $\left(\mathrm{cm}^{2} \mathrm{~cm}^{-2} \mathrm{yr}^{-1}\right)$ of marked individual Brachystegia spiciformis and Julbernardia globiflora over 40 years (1953-1993) at Marondera, Zimbabwe. The regression line $\mathrm{RBAI}=0.018+(0.458 /$ initial $\mathrm{BA})\left(\mathrm{F}_{1,22}\right.$ $=15.37, \mathrm{P}<0.001)$ excludes the two lowermost points. stumped experimental plots in dry miombo woodland in Zimbabwe, depending on the fire and grazing regimes (Boultwood and Rodel 1981). Yields in higher rainfall areas may be greater than this, though the nutrient quality of the grass is often poor. The extent to which recorded increases reflect, at least in part, greater nutrient availability resulting from the decomposition of the roots of the killed trees is unknown.

\section{Nutrient cycling}

Given the low nutrient status of most of the soils under miombo woodland, questions arise as to how important nutrients are in determining the productivity of miombo woodland; what the fate of primary production is and how this influences the rate of nutrient cycling; and in what ways and to what extent are miombo plants adapted to a nutrient-poor system. Although one can gain insights about the possibility of nutrient limitation on ecosystem functioning by reviewing patterns of leaf quality and nutrient-use efficiency, the extent of nutrient limitation, if any, and which nutrients are most limiting, can only be decided by appropriately designed field experiments (Jaramillo and Sanford 1995). Such experiments have yet to be conducted in miombo woodland.

\section{Leaf quality}

The nutrient content of the foliage of miombo plants is generally low, with apparent differences between canopy and understorey species, and between species that have nitrogen-fixing root nodules and those that do not (Table 2.8). The average nitrogen and phosphorus contents of mature leaves of a range of non-nodulated canopy species are $1.89 \% \mathrm{~N}$ (s.d. $0.37, \mathrm{n}=15$ ) and $0.19 \%$ P (s.d. 0.07, $\mathrm{n}=12$ ), with wide differences within and among species, even when growing under the same climatic and edaphic conditions (Ernst 1975; Lawton 1980; Jachmann and Bell 
1985; Högberg 1986). In contrast, the leaves of $\mathrm{N}$-fixing canopy trees apparently have higher $\mathrm{N}$ but similar P concentrations: $2.72 \% \mathrm{~N}$ (s.d. 0.78 , $\mathrm{n}=10$ ) and $0.17 \% \mathrm{P}($ s.d. $0.16, \mathrm{n}=3$ ), though the data are limited.

The generally higher nitrogen content of the leaves of species with potentially $\mathrm{N}$-fixing root nodules, compared to non- $\mathrm{N}$-fixing species, is well established for miombo woodland (Högberg 1986; Högberg and Piearce 1986). Species with the potential to fix nitrogen have, on average, $40 \%$ more $\mathrm{N}$ in their leaves than non- $\mathrm{N}$-fixing species. Mature leaves of understorey species appear to have higher average $\mathrm{N}$ and $\mathrm{P}$ concentrations than the non-nodulated canopy species and higher average $\mathrm{P}$ concentrations than nodulated species: $2.96 \% \mathrm{~N}$ (s.d. $1.16, \mathrm{n}=5$ ), $0.26 \% \mathrm{P}$ (s.d. 0.04, $\mathrm{n}=4$ ). Although the data, particularly for $\mathrm{P}$, are limited, the observed trend in $\mathrm{N}$ may reflect local enrichment through leaching from the canopy trees and associated lichens (R.L. Sanford jr, pers. comm.). Moreover, since less than $30 \%$ of the incident light penetrates the canopy in well-developed miombo stands (van der Meulen and Werger 1984), understorey plants are likely to have lower rates of carbon assimilation, and hence may experience carbon rather than nutrient limitation. The lower light levels can be offset to some extent by leaves having higher chlorophyll concentrations, and therefore higher $\mathrm{N}$ levels.

Whereas the concentrations of $\mathrm{Ca}, \mathrm{Mn}$ and $\mathrm{Fe}$ increase throughout the life span of a leaf, those of N, P and $\mathrm{K}$ decline as the leaf ages (Ernst 1975). The concentrations of $\mathrm{N}$ and $\mathrm{P}$ in senescing leaves of canopy trees are respectively about $34 \%$ and $23 \%$ lower than those of mature leaves; there are no data on the nutrient content of senescing leaves of $\mathrm{N}$-fixing or understorey species (Table 2.8). More data are needed, not only of those elements likely to be withdrawn by plants but also of elements such as $\mathrm{Ca}$ which are relatively immobile and which can be used to index actual changes in the amounts of N, P and K. Most of the current information gives element concentrations in percentage terms. Contemporaneous changes occurring in other components of senescing leaves may mask or, alternatively, amplify absolute changes in mobile elements when these are expressed as percentages. For example, Ernst (1975) calculated that B. spiciformis, B. boehmii and J. globiflora reabsorbed $26-40 \%$ of leaf nitrogen but only $6-20 \%$ of $\mathrm{P}$ and $\mathrm{K}$. When changes in the amounts of $\mathrm{N}$ and $\mathrm{P}$ in the leaves of these species are expressed relative to $\mathrm{Ca}$, an average of $64 \% \mathrm{~N}$ and $62 \% \mathrm{P}$ of the amounts present in new leaves were translocated the following dry season, substantially higher than that estimated in the original study (R.L. Sanford jr, pers. comm.).

Plant nutritional quality is also influenced by the amount of structural carbohydrates and the kinds and concentrations of secondary chemical compounds in tissues. The crude fibre content of woody plant leaves averages 38\% (range $21-62 \%$ : Jachmann and Bell 1985). Mean dry matter digestibility (52\%, range 34-66\%) does not vary greatly with leaf age (Rees 1974). Lignin levels in the leaves of a range of miombo trees, including Brachystegia and Julbernardia, are surprisingly low, ranging from less than $1 \%$ to about $8 \%$. The average concentration of total polyphenols is variable (range: 0-19\%: Jachmann 1989; Palo et al. 1993; Mtambanengwe and Kirchmann 1995). Non-N-fixing species have higher average total polyphenol levels and polyphenol:N ratios (10.2\% and 6.1 respectively) than $\mathrm{N}$-fixing species $(6.8 \%$ and 2.8 respectively: Palo et al. 1993). In view of the importance of plant chemistry in regulating both consumption and decomposition, a wider survey of secondary chemical and lignin levels in the leaves of miombo species is needed.

Grass nutritional quality is even lower than that of woody leaves: $1.3-2.2 \% \mathrm{~N}$ during the early growing season (November-December), falling to 
Table 2.8 Nitrogen and phosphorus concentrations of mature and senescent leaves of miombo woody plants. The superscripts refer to the sample size in cases where more than one data point was available. Sources are identified in the footnote.

\begin{tabular}{|c|c|c|c|c|c|c|c|}
\hline & \multicolumn{2}{|c|}{ Mature leaves } & \multicolumn{2}{|c|}{ Senescent leaves } & \multicolumn{2}{|c|}{ Seasonal change } & \multirow[b]{2}{*}{ Sources } \\
\hline & $\% \mathrm{~N}$ & $\% \mathrm{P}$ & $\% \mathrm{~N}$ & $\% \mathrm{P}$ & $\mathrm{N}(\%)$ & $\mathrm{P}(\%)$ & \\
\hline \multicolumn{8}{|l|}{ NON N-FIXING CANOPY SPECIES } \\
\hline Brachystegia boehmii & $1.76^{5}$ & $0.15^{4}$ & $1.04^{2}$ & $0.16^{2}$ & -41 & +7 & $1,2,3,4,5,8$ \\
\hline Brachystegia glaberrima & 1.92 & & 1.54 & & -20 & & 9 \\
\hline Brachystegia microphylla & $2.01^{2}$ & & & & & & 4,8 \\
\hline Brachystegia spiciformis & $2.13^{5}$ & $0.21^{3}$ & 1.70 & & -20 & & $3,4,5,6,7,8,9$ \\
\hline Brachystegia utilis & 2.85 & & 1.63 & & -43 & & 9 \\
\hline Cassia abbreviata & & 0.12 & & & & & 3 \\
\hline Combretum molle & & 0.11 & & & & & 3 \\
\hline Combretum zeyheri & 1.60 & & & & & & 8 \\
\hline Cussonia arborea & 1.70 & 0.28 & & & & & 3,8 \\
\hline Diplorhynchus condylocarpon & $1.94^{4}$ & $0.22^{2}$ & 1.21 & & -38 & & $3,4,5,8,9$ \\
\hline Isoberlinia angolensis & $2.06^{3}$ & $0.31^{2}$ & $1.36^{2}$ & $0.10^{2}$ & -34 & -68 & $1,2,9$ \\
\hline Julbernardia globiflora & $1.94^{6}$ & $0.19^{4}$ & $1.45^{2}$ & $0.16^{2}$ & -25 & -16 & $1,2,3,4,5,6,8$ \\
\hline Julbernardia paniculata & $2.13^{3}$ & 0.24 & 1.78 & & -16 & & 5,9 \\
\hline Monotes sp. & & & 1.23 & & & & 9 \\
\hline Piliostigma thonningii & & 0.11 & & & & & 3 \\
\hline Pseudolachnostylis maprouneifolia & 1.40 & & & & & & 8 \\
\hline Terminalia sericea & 1.40 & & & & & & 8 \\
\hline Uapaca kirkiana & 1.47 & $0.14^{2}$ & 0.63 & 0.13 & -57 & -7 & 2,3 \\
\hline Uapaca nitida & $2.09^{3}$ & 0.16 & $1.17^{2}$ & 0.11 & -44 & -31 & 2,9 \\
\hline \multicolumn{8}{|l|}{ NITROGEN FIXING SPECIES } \\
\hline Acacia goetzii & 2.30 & & & & & & 8 \\
\hline Albizia adiantifolia & 4.66 & 0.35 & & & & & 5 \\
\hline Albizia amara & 2.15 & 0.11 & & & & & 5 \\
\hline Albizia antunesiana & & 0.04 & & & & & 3 \\
\hline Albizia versicolor & 2.70 & & & & & & 8 \\
\hline Dalbergia nitidula & $2.37^{2}$ & & & & & & 8,9 \\
\hline Dichrostachys cinerea & $1.90^{2}$ & & & & & & 4,8 \\
\hline Erythrophleum africanum & 2.30 & & & & & & 8 \\
\hline Pterocarpus angolensis & $2.97^{2}$ & & & & & & 4,8 \\
\hline Pterocarpus rotundifolius & 3.20 & & & & & & 8 \\
\hline Xeroderris stuhlmannii & $2.68^{2}$ & & & & & & 4,8 \\
\hline \multicolumn{8}{|l|}{ UNDERSTOREY SPECIES } \\
\hline Baphia baequartii & $3.95^{3}$ & 0.31 & & & & & 5,9 \\
\hline Baphia massaiensis & 3.84 & 0.24 & & & & & 5 \\
\hline Bauhinia petersiana & 1.60 & & & & & & 8 \\
\hline Eriosema engleranum & & 0.25 & & & & & 3 \\
\hline Grewia sp. & 3.60 & 0.22 & & & & & 5 \\
\hline Ochthocosтus lemaireanus & 1.81 & & 1.46 & & -19 & & 9 \\
\hline
\end{tabular}

Sources: 1. Chidumayo (1993a); 2. Chidumayo (1994a); 3. Ernst (1975); 4. Högberg (1986); 5. Lawton (1980); 6. Mtambanengwe and Kirchmann (1995); 7. Nyathi and Campbell (1993); 8. Palo et al. (1993); 9. Rees (1974) 
0.5-0.8\% during the early dry season, crude fibre remains relatively constant throughout the year at 37\% (Weinmann 1948; Rees 1974; Frost et al. in prep.). The nitrogen content of grass declines rapidly as the leaves expand and soon falls below $0.8 \%$, the approximate level required to maintain ungulates on natural range in Africa (Bransby 1981). Regular defoliation of the grasses improves forage quality, but this is offset by a reduction in dry matter yield with more than two defoliations in a growing season (Weinmann 1949).

\section{Litterfall}

The low nutrient quality of both woody-plant and grass leaves is a major constraint on herbivory. This means that most of the nutrients in plants are recycled either through litterfall and decay or through oxidation by fire. The data on litterfall in miombo woodland is sparse (Table 2.9). Total woody litterfall is $2.6-4.3 \mathrm{Mg} \mathrm{DM} \mathrm{ha}^{-1}$, of which leaves make up 66-95\%. Leaf fall at the drier sites is $81-88 \%$ of the estimated leaf biomass on the trees at these sites (Tables 2.6 and 2.9). Leaf fall at the wet miombo woodland site is 1.3 times the only published value for leaf biomass at this site (Malaisse and Strand 1973); the data probably do not come from the same stand.

Estimated annual nitrogen and phosphorus fluxes in litterfall at the two dry miombo sites and the drier Burkea-Ochna savanna range from 24.6-35.3 $\mathrm{kg} \mathrm{N}^{-1}$ and 1.2-4.2 $\mathrm{kg} \mathrm{P} \mathrm{ha}^{-1}$. The corresponding nutrient-use efficiencies (indexed by litterfall dry mass divided by the mass of the nutrient concerned: Vitousek 1982; 1984) are 70-92 for $\mathrm{N}$ and 768-1467 for $\mathrm{P}$. The values for $\mathrm{N}$-use efficiency at the two miombo sites are higher than those of other African dry forest and savanna sites, while the P-use efficiency values are lower (Table 2.10). Overall though, when these nutrient-use efficiency values for miombo woodland and the dry savanna sites are plotted against their respective figures for $\mathrm{N}$ and $\mathrm{P}$ fluxes in litterfall, they fall below the general negative exponential trend for tropical forests shown by Vitousek (1984). Miombo woodland and other dry tropical vegetation types are therefore somewhat less efficient in the use of nutrients than moist tropical forests despite, in the case of miombo woodland, the substantial recovery of nutrients from leaves prior to leaf fall. This may indicate that moisture availability is an overriding constraint on both primary production and nutrient use (Vitousek 1984).

\section{Litter decay}

The withdrawal of nutrients prior to leaf fall nevertheless reduces the quantity of nutrients being recycled and lowers the quality of the plant material to decomposers, thereby potentially slowing down the rate of decomposition. The $\mathrm{C}: \mathrm{N}$ ratio of woody plant leaves prior to leaf fall is about 50, compared with average $\mathrm{C}: \mathrm{N}$ ratios in mature functioning leaves and in soil organic matter of 21 and 17 respectively (Rees 1974; Ernst 1975; Högberg 1986). A study of microbial decomposition of various miombo woodland litter components in microcosms showed that carbon mineralisation was positively correlated with the initial ash-free available $\mathrm{C}$ (total ashfree carbon minus lignin- $\mathrm{C}$, polyphenol- $\mathrm{C}$ and cellulose-C) and negatively correlated with lignin, cellulose, and lignin+polyphenol content (both total and relative to the amount of carbon in each constituent: Mtambanengwe and Kirchmann 1995). Likewise, N mineralisation was positively correlated with initial $\mathrm{N}$ content and negatively correlated with $\mathrm{C}: \mathrm{N}$, cellulose: $\mathrm{N}$, cellulose-C:N, lignin: $\mathrm{N}$ and lignin-C:N ratios, among others. Leaves of B. spiciformis and $J$. globiflora decomposed faster than grass litter in the microcosms (Mtambanengwe and Kirchmann 1995) whereas the opposite happened in a litterbag experiment (decay rates: $\mathrm{k}_{\text {tree }}=-0.49 \mathrm{yr}^{-1}$, $\mathrm{k}_{\text {grass }}=-0.88 \mathrm{yr}^{-1}$, measured over the first year: M.J. Swift, pers. comm.). 


\begin{tabular}{|c|c|c|c|c|}
\hline Locality & $\begin{array}{l}\text { Lubumbashi, } \\
\text { Zaire }\end{array}$ & $\begin{array}{l}\text { Chakwenga, } \\
\text { Zambia }\end{array}$ & $\begin{array}{l}\text { Marondera, } \\
\text { Zimbabwe }\end{array}$ & $\begin{array}{l}\text { Nylsvley, } \\
\text { South Africa }\end{array}$ \\
\hline Latitude & $11^{\circ} 29^{\prime} \mathrm{S}$ & $15^{\circ} 13^{\prime} \mathrm{S}$ & $18^{\circ} 11^{\prime} \mathrm{S}$ & $24^{\circ} 39^{\prime} \mathrm{S}$ \\
\hline Longitude & $27^{\circ} 36^{\prime} \mathrm{E}$ & $29^{\circ} 11^{\prime} \mathrm{E}$ & $31^{\circ} 28^{\prime} \mathrm{E}$ & $28^{\circ} 42^{\prime} \mathrm{E}$ \\
\hline Altitude (m) & 1208 & 1220 & 1640 & 1097 \\
\hline Mean annual precipitation (mm) & 1270 & $\sim 750$ & 885 & 623 \\
\hline Mean annual temperature $\left({ }^{\circ} \mathrm{C}\right)$ & 20.3 & $\sim 20.7$ & 17.2 & 19.0 \\
\hline $\begin{array}{l}\text { Leaf litter (+ rachides) } \\
\text { (range) }\end{array}$ & $\begin{array}{l}2.88 \\
(2.6-3.4)\end{array}$ & $\begin{array}{l}2.49 \\
(-)\end{array}$ & $\begin{array}{l}2.12 \\
(1.97-2.27)\end{array}$ & $\begin{array}{l}1.38 \\
(1.21-1.59)\end{array}$ \\
\hline $\begin{array}{l}\text { Flowers, fruit, pods, 'other' } \\
\text { (range) }\end{array}$ & $\begin{array}{l}0.51 \\
(0.1-2.0)\end{array}$ & 0.09 & $\begin{array}{l}0.47 \\
(0.12-0.97)\end{array}$ & $\begin{array}{l}0.10 \\
(0.01-0.14)\end{array}$ \\
\hline $\begin{array}{c}\text { Wood }(<2 \mathrm{~cm}) \\
\quad(\text { range })\end{array}$ & $\begin{array}{l}0.87 \\
(0.79-0.97)\end{array}$ & $\begin{array}{l}0.03 \\
(-)\end{array}$ & $\begin{array}{l}0.64 \\
(0.41-0.80)\end{array}$ & $\begin{array}{l}0.28 \\
(0.19-0.36)\end{array}$ \\
\hline Total woody litterfall & 4.26 & 2.61 & 3.23 & 1.76 \\
\hline \multicolumn{5}{|l|}{ Woody litter standing crop } \\
\hline Dry season (May-Sept) & 1.67 & & 5.74 & \\
\hline Wet season (Oct-April) & 4.42 & & 8.32 & \\
\hline Annual average & 3.27 & 5.48 & 7.03 & 12.00 \\
\hline Decay constant, $\mathrm{k}\left(\mathrm{yr}^{-1}\right)^{1}$ & $-1.30^{2}$ & $-0.48^{2}$ & $-0.46^{3}$ & $-0.15^{3}$ \\
\hline $\mathrm{N}$ input in litterfall $\left(\mathrm{kg} \mathrm{ha}^{-1}\right)$ & & $29.7^{4}$ & $\begin{array}{l}35.3 \\
(29.3-45.7)\end{array}$ & 24.6 \\
\hline $\mathrm{P}$ input in litterfall $\left(\mathrm{kg} \mathrm{ha}^{-1}\right)$ & & $3.4^{4}$ & $\begin{array}{l}4.2 \\
(3.0-5.6)\end{array}$ & 1.2 \\
\hline
\end{tabular}

Notes:

1. Decay constant calculated by dividing total litterfall by the annual average litter standing crop (assuming that leaf litter inputs and standing crop are relatively constant from year to year)

2. Litter layer dynamics affected by annual fires

3. Litter layer dynamics in absence of fire

4. Nutrient fluxes calculated assuming the following nutrient concentrations: leaf $(1.15 \% \mathrm{~N}$, $0.13 \% \mathrm{P})$, twigs $(0.58 \% \mathrm{~N}, 0.15 \% \mathrm{P})$ and flowers/fruits $(1.03 \% \mathrm{~N}, 0.15 \% \mathrm{P})$; data for leaves and twigs from Chidumayo (1994a) and for flowers/fruits based on data from dry miombo in Zimbabwe (Frost, unpublished data) 
The recorded rates of leaf litter decomposition are not particularly slow, (Table 2.9). In wet miombo woodland more than $90 \%$ of leaf litter decays within a year although there are marked differences in decomposition rates among species (Malaisse et al. 1975). Decay rates in dry miombo woodland are lower, about $40 \%$ of the leaf litter remaining after one year (M.J. Swift, pers. comm.). Termites accounted for almost $40 \%$ of the litter decay in wet miombo woodland but were much less active at the dry miombo woodland site. The decay constants, $\mathrm{k}$, for the wet and dry miombo sites are -1.3 and an average of $-0.47 \mathrm{y}^{-1}$ respectively (Table 2.9). The constant for the wet miombo woodland site is less than that calculated from a litter decay experiment at the same site $(\mathrm{k}=-2.3$ : Malaisse et al. 1975) but the constants for the drier sites are similar to that measured in litter bags (M.J. Swift pers. comm.)

Decomposition rates in miombo woodland may be controlled as much by seasonal moisture and temperature regimes as by litter quality. Both the absolute amount of moisture present and the temporal pattern of soil moisture fluctuations affect mineralisation rates in miombo woodland, with microbial activity being low during the dry season (Campbell et al. 1988). Immediately following the first rains, however, there is a flush of nitrogen mineralisation (Birch 1958 in Young 1976; Hatton and Swift, pers. comm.). This soon declines although subsequent smaller peaks of mineralisation associated with rewetting of the soil at the end of occasional dry spells, occur throughout the wet season. The longer the preceding dry spell, the larger the pulse of mineralised nitrogen (Young 1976). The net effect of this over a wet season has not been determined.

\section{Mycorrhizae}

Miombo woodland is notable among dry tropical woodlands and forests for the number of tree species having ectomycorrhizal rather than vesicular-arbuscular mycorrhizal associations (Högberg and Nylund 1981; Högberg 1982; 1992; Högberg and Piearce 1986). Most of the dominant tree species, including species of Brachystegia, Julbernardia, Isoberlinia (Fabaceae: Caesalpinioideae), Marquesia and Monotes (Dipterocarpaceae) and Uapaca (Euphorbiaceae), have ectomycorrhizae. An interesting sidelight on this predominance of ectomycorrhizae in miombo woodland is that many of the fungal species involved produce mushrooms, some of which are edible (Amanita zambiana, Cantharellus spp. Boletus spp.: Högberg and Piearce 1986). This has given rise to a culture of mushroom gathering which is widespread among people in miombo woodland but largely absent in other tropical African dry woodlands (Chapter 5).

Fewer tree species in miombo woodland have vesicular-arbuscular mycorrhizal, some of which form nitrogen-fixing nodules (e.g. Albizia spp., Erythrophleum africanum, Pericopsis angolensis, Pterocarpus angolensis and P. rotundifolius: Corby 1974; Högberg and Nylund 1981; Högberg 1986). There are a number of anomalies, however: Pericopsis angolensis has been recorded as being ectomycorrhizal in Zambia (Högberg and Piearce 1986) but endomycorrhizal and nodulated in Tanzania (Högberg 1982); it is nodulated in Zimbabwe (Corby 1974). Uapaca kirkiana has also been recorded as ect-endomycorrhizal in Tanzania (Högberg 1982) but, together with $U$. nitida and $U$. sansibarica, as only ectomycorrhizal in Zambia (Högberg and Piearce 1986). Afzelia quanzensis in Tanzania has both ectomycorrhizae and potentially N-fixing root nodules (Högberg and Nylund 1981), an extremely unusual feature which needs confirmation (Högberg 1992). Many of the dominant understorey shrubs and herbs are nodulated (e.g. species of Aeschynomene, Dolichos, Elephantorrhiza, Eriosema, Indigofera and Rhynchosia: Corby 1974), particularly in regularly burnt communities 
Table 2.10 Comparison of litterfall and nitrogen- and phosphorus-use efficiencies among miombo and various other tropical dry forest and savanna ecosystems. Nutrient-use efficiency is indexed by the ratio of the mass of litterfall to the mass of an element in the litterfall. 'Fine' litter fraction comprised leaves, flowers, fruits, and small wood $(<2 \mathrm{~cm}$ diameter).

\begin{tabular}{|c|c|c|c|c|c|c|}
\hline \multirow{2}{*}{$\begin{array}{l}\text { Site (mean annual rainfall) } \\
\text { Litter fraction, Vegetation }\end{array}$} & \multirow{2}{*}{$\begin{array}{l}\text { Litterfall mass } \\
\left(\mathrm{g} \mathrm{m}^{2} \mathrm{yr}^{-1}\right)\end{array}$} & \multicolumn{2}{|c|}{$\begin{array}{l}\text { Nutrient flux } \\
\left(\mathrm{g} \mathrm{m}^{-2} \mathrm{yr}^{-1}\right)\end{array}$} & \multicolumn{2}{|c|}{$\begin{array}{l}\text { Nutrient-use } \\
\text { efficiency }\end{array}$} & \multirow[b]{2}{*}{ Source } \\
\hline & & $\mathrm{N}$ & $\mathrm{P}$ & $\mathrm{N}$ & $\mathrm{P}$ & \\
\hline \multicolumn{7}{|l|}{ AFRICA } \\
\hline \multicolumn{7}{|l|}{ Senegal $(300 \mathrm{~mm})$} \\
\hline Fine, Acacia & 120 & 1.9 & 0.12 & 63 & 1000 & 1 \\
\hline \multicolumn{7}{|l|}{ Senegal $(460 \mathrm{~mm})$} \\
\hline Fine, Acacia & 200 & 2.9 & 0.15 & 69 & 1333 & 1 \\
\hline \multicolumn{7}{|l|}{ Senegal $(500 \mathrm{~mm})$} \\
\hline Fine, A. albida & 270 & 4.3 & 0.09 & 63 & 3000 & 2 \\
\hline \multicolumn{7}{|l|}{ South Africa $(620 \mathrm{~mm})$} \\
\hline Fine, Acacia & 37 & 0.9 & 0.04 & 41 & 925 & 3 \\
\hline Leaf & 26 & 0.6 & 0.03 & 43 & 867 & \\
\hline \multicolumn{7}{|l|}{ South Africa (620 mm) } \\
\hline Fine, Burkea & 176 & 2.5 & 0.12 & 70 & 1467 & 3,4 \\
\hline Leaf & 138 & 2.0 & 0.10 & 69 & 1380 & \\
\hline \multicolumn{7}{|l|}{ Zambia (750 mm) } \\
\hline Fine, miombo & 261 & 3.0 & 0.34 & 87 & 768 & 5,6 \\
\hline Leaf & 249 & 2.9 & 0.32 & 86 & 778 & \\
\hline \multicolumn{7}{|l|}{ Zimbabwe (757 mm) } \\
\hline Fine, A. albida & 134 & 2.9 & 0.20 & 46 & 670 & 7 \\
\hline \multicolumn{7}{|l|}{ Zimbabwe (885 mm) } \\
\hline Fine, miombo & 323 & 3.5 & 0.42 & 92 & 769 & 6 \\
\hline Leaf (-rachides) & 192 & 2.4 & 0.23 & 80 & 835 & \\
\hline \multicolumn{7}{|l|}{ Tanzania (1400 mm) } \\
\hline Fine, mixed forest & 880 & 14.2 & 0.80 & 62 & 1100 & 8 \\
\hline \multicolumn{7}{|l|}{ Nigeria $(1413 \mathrm{~mm})$} \\
\hline Fine, dry deciduous forest & 640 & 11.2 & 0.51 & 57 & 1255 & 9 \\
\hline Leaf & 545 & 10.3 & 0.45 & 53 & 1211 & \\
\hline \multicolumn{7}{|l|}{ Zaire $(1700 \mathrm{~mm})$} \\
\hline Fine, Brachystegia forest & 1230 & 22.3 & 0.70 & 55 & 1757 & 10 \\
\hline \multicolumn{7}{|l|}{ SOUTH AMERICA } \\
\hline \multicolumn{7}{|l|}{ Mexico $(707 \mathrm{~mm})$} \\
\hline Fine, deciduous forest & 258 & 6.4 & 0.92 & 40 & 760 & 11 \\
\hline \multicolumn{7}{|l|}{ Puerto Rico $(860 \mathrm{~mm})$} \\
\hline Leaf, dry forest & 430 & 4.4 & 0.07 & 98 & 6143 & 11 \\
\hline \multicolumn{7}{|l|}{ Belize $(1480 \mathrm{~mm})$} \\
\hline Fine, deciduous forest & 1260 & 15.6 & 0.92 & 81 & 1355 & 12 \\
\hline
\end{tabular}

Sources: 1. Bernard-Reversat (1982); 2. Jung (1969); 3. Frost (unpublished data); 4. Scholes and Walker (1993); 5. Chidumayo (1995); 6. This study (Table 2.8); 7. Dunham (1989); 8. Lundgren (1978 cited by Vitousek 1984); 9. Muoghalu et al. (1993, slope site); 10. Laudelot and Mayer (1954 cited by Vitousek 1984); 11. Jaramillo and Sanford (1995); 12. Lambert et al. (1980 cited by Vitousek 1984) 
(e.g. in fire-adapted chipya: Högberg and Piearce 1986; and on experimental fire plots at Marondera, Zimbabwe: Frost pers. obs.).

The dominance of ectomycorrhizal tree species in miombo woodland may reflect the advantage that such species have on seasonally dry infertile soils; the few other tropical ecosystems dominated by ectomycorrhizal tree species all tend to occur also on infertile soils (Högberg 1982). Ectomycorrhizae may be particularly important in enabling plants to take up P directly from organic matter in phosphorus-deficient soils. In contrast, N-fixing species are usually limited by $\mathrm{P}$ availability (Högberg 1986), which may explain the relative paucity of such species among canopy trees in miombo woodland. The frequency of nodulation among shallower rooted shrub and herb species, and among species on regularly burnt sites, probably reflects the slightly higher levels of extractable $\mathrm{P}$ in the topsoils (Tables 2.2 and 2.3), a consequence of the increase in soil $\mathrm{pH}$ on regularly burnt sites, due to cation enrichment, as well as periodic inputs of inorganic $\mathrm{P}$ at the surface after fire (Trapnell et al. 1976; Frost and Robertson 1987).

Ectomycorrhizae depend on carbon supplied by the host plant but the cost of maintenance to the plants has seldom been measured, and not in miombo woodland. The cost may be substantial and may represent a significant carbon sink. Photosynthetic rates of non-nodulating legume species such as Brachystegia spiciformis(11 $\left.\mu \mathrm{mol} \mathrm{CO} \mathrm{Cm}^{-2} \mathrm{~s}^{-1}\right)$ and Julbernardia globiflora $(10$ $\mu \mathrm{mol} \mathrm{CO}_{2} \mathrm{~m}^{-2} \mathrm{~s}^{-1}$ ) are lower than those on nodulated (and presumed $\mathrm{N}$-fixing) species (average assimilation rates of $14 \mu \mathrm{mol} \mathrm{CO}_{2} \mathrm{~m}^{-2} \mathrm{~s}^{-1}$ ), primarily because of lower leaf nitrogen concentrations (Tuohy et al. 1991). The dominance of tree species with ectomycorrhizae may therefore be limited to phosphorus-deficient soils with a high water-holding capacity under moderate to high rainfall. Such conditions may give these species an advantage over $\mathrm{N}$-fixing vesicular-arbuscular mycorrhizal species, by enabling them to have an extended growing season which could offset their lower instantaneous rates of carbon gain.

\section{Termites, fire and nutrient cycling}

In view of the amount of litterfall and the low quality of the litter, it seems surprising at first that organic matter levels in miombo woodland soils are generally so low. This is a consequence of two factors: the widespread occurrence and abundance of termites; and the frequent incidence of fire (Trapnell et al. 1976; Jones 1989). The size, density and regularity of tall termitaria is one of the prominent features of miombo woodland landscapes. In Zaire, the tallest mounds, made by Macrotermes species, occur at densities of 35 mounds $\mathrm{ha}^{-1}$, covering up to $8 \%$ of the area (Malaisse 1973). Assuming a colony size of 2 million individuals, Goffinet (1976) calculated that each mound contained about $9.5 \mathrm{~kg}$ of termites (dry mass). Thus the biomass of Macrotermes ranged from $26-46 \mathrm{~kg} \mathrm{ha}^{-1}$, outweighing other soil fauna groups except humivorous termites (Goffinet 1976; Malaisse 1978a). These figures may not be typical for all miombo sites, particularly those lacking the deep, well-drained soils required by Macrotermes for building their mounds, but they illustrate the potential.

The importance of Macrotermes and other Macrotermitinae lies in their dependence on cellulose-decomposing fungi which they cultivate in their mounds. To maintain the fungi the termites forage widely, collecting surface litter and dried grass which is carried back to the mounds and decomposed by the fungi. Because of the ability of the fungi to produce cellulase, almost all of this organic matter is decomposed. Some organic matter may be incorporated into the structure of the mound in faecal pellets but this is probably a minor sink (Jones 1990).

Given the density of mounds and the wide foraging range of the workers, almos all areas are widely affected by termites (Jones 1989). As a 
result of the concentration and decomposition of litter in mounds, the levels of soil organic matter, nitrogen, phosphorus and exchangeable cations in areas between mounds are much lower than in areas from which termites are absent (Table 2.11). Some of the differences in soil properties may reflect intrinsic differences due to parent material, landform and position in the landscape which also affect the occurrence of termites, but even when these environmental factors are taken into account, the conclusion that termites have had a significant effect on soil properties still holds (Trapnell et al. 1976; Jones 1989).

Fungus-growing Macrotermitinae are not the only group of termites that can affect soil properties and nutrient cycling. Humivorous termites are also abundant in miombo woodlands. The biomass of Cubitermes in wet miombo woodland in Zaire, for example, has been estimated to be 17-61 kg ha-1 (Goffinet 1976). They feed on soil organic matter and line the walls of their nests with carbon-rich faecal material, thereby also depleting the soil of organic matter and associated nitrogen, phosphorus and cations. The accumulation of nutrients in termite mounds, both through the concentration and subsequent decomposition of organic matter (Jones 1989), and through the concentration of minerals in groundwater by evaporation within the mounds and chimneys (Weir 1973), produces nutrient-rich patches within an otherwise nutrient-poor landscape. Mound soils have significantly higher total $\mathrm{N}$, acidextractable $\mathrm{P}$ and basic cation levels than surrounding soils (Trapnell et al. 1976; Watson 1977; Jones 1989).

The creation of nutrient 'hot spots' by termites has far-reaching consequences. They invariably support vegetation which is distinctly different in both composition and structure from the surrounding woodlands (Wild 1952; Fanshawe 1968; 1969; Malaisse 1978b; Malaisse and Anastassiou-Socquet 1983). In contrast to miombo woodland generally, there is a greater incidence of species with spines or prickles, small or sclerophyllous leaves, and animal-dispersed seeds. In Zambia, some 700 woody species are associated with termitaria, many of them rare or absent from the surrounding vegetation (Fanshawe 1968). The vegetation on the mounds is often the focus of activity for birds and other animals, enabling these species to exist in an otherwise largely unproductive environment. In addition, soil from termite mounds is widely used by farmers as an amendment to their fields (Watson 1977).

Frequent dry season fires also affect organic matter levels by oxidising litter before it can be broken down by decomposers (Trapnell et al. 1976). Although the nutrients in standing dead material and litter are mineralised, some, such

Table 2.11 Chemical properties of A-horizon soils under miombo woodland in central Tanzania where termites are present (+) and absent (-). The figures are average values for the number of pedons sampled (n). Data from Jones (1989).

\begin{tabular}{|c|c|c|c|c|c|c|c|c|}
\hline & \multirow[b]{2}{*}{$\mathrm{n}$} & $\mathrm{C}$ & $\mathrm{N}$ & \multirow{2}{*}{$\begin{array}{l}\mathrm{P} \\
\mathrm{ppm}\end{array}$} & $\mathrm{Ca}$ & $\mathrm{Mg}$ & $\mathrm{K}$ & $\mathrm{Al}$ \\
\hline & & \multicolumn{2}{|c|}{$\mathrm{g} \mathrm{kg}^{-1}$} & & \multicolumn{4}{|c|}{ meq $100 \mathrm{~g}^{-1}$} \\
\hline termites - & 31 & 21.1 & 2.2 & 16.5 & 8.3 & 2.4 & 0.5 & 0.01 \\
\hline termites + & 6 & 2.3 & 0.4 & 1.3 & 1.1 & 0.4 & 0.2 & 0.54 \\
\hline
\end{tabular}


as nitrogen and sulphur (and to a lesser extent phosphorus), are volatilised (Frost and Robertson 1987). Some carbon is incorporated into the soil in the form of charcoal but this is chemically inert and contributes little, if at all, to soil properties, though it might be a minor sink for the long-term sequestration of carbon (Box 2.3).

In some respects termites and fire have a complementary effect on miombo functioning. Where fire occurs regularly much of the grass and litter is consumed before it can be removed by termites. In the absence of fire, more material is available for termites to transport to their mounds. In other respects, however, termites and fire differ in their impact on nutrient cycling. While termites concentrate exchangeable bases in termitarium soils, from which they are only slowly released, annual burning releases nutrients in a single pulse which raises the nutrient status and $\mathrm{pH}$ of the surface soil. Extractable $\mathrm{P}$ and exchangeable $\mathrm{Ca}$ levels in particular are both higher on regularly burnt sites (Frost and Robertson 1987). Regular burning also results in more rapid cycling of nutrients, though how much is lost through volatilisation is not known precisely. It will vary with the concentration of nutrients in the fuel, the amount of fuel consumed and the timing and intensity of the fire.

\section{Ash-fertilisation agriculture}

The low nutrient status of miombo woodland soils is reflected in the widespread traditional practice of various forms of shifting agriculture. The best known of these is chitemene which is practised in one form or another throughout the wetter miombo woodland along the ZaireZambezi watershed (Box 2.4). Lopping branches and foliage from the trees, rather than chopping the trees down at ground-level, ensures more rapid regeneration during the following fallow period.

Conventional wisdom has long held that the adoption of shifting agriculture in much of tropical Africa has been a direct result of the presence of tsetse fly (Box 2.5). This has led, it has been argued, to shortages of animal draught power provided elsewhere on the continent by cattle and donkeys; inefficient hand cultivation of small plots; topsoil exhaustion and erosion; and ultimately abandonment in favour of virgin woodland elsewhere (critically reviewed by Ford 1971). Given the low nutrient status and high acidity of many tropical soils it seems more appropriate to view ash-fertilisation agriculture as a well-adapted strategy through which people with limited resources overcome the constraints of their environment by capitalising on the nutrients stored in the vegetation.

The system relies on a long fallow period to replenish the nutrients in the soil and vegetation (Robertson 1984). Under increasing human population pressures, fallow periods are becoming shorter while people are exploiting the vegetation more intensively, indicating that this form of agriculture is becoming increasingly difficult to sustain (Stromgaard 1985c; 1989; Chidumayo 1987a). It is now gradually being replaced by long-term or permanent cultivation as the pressures of expanding human populations reduce the availability of unoccupied land (Box 5.4; Lawton 1982). Permanent cultivation of these soils, in the absence of more intensive soil fertility management, is likely to result in a gradual and longlasting decline in fertility.

\section{Herbivory}

The generally poor nutritional quality of forage in miombo woodland is reflected in the low biomass of both wild and domestic herbivores, and corresponding low levels of consumption. Only about $1 \%$ of available browse (amounting to an average $13 \mathrm{~kg} \mathrm{ha}^{-1} \mathrm{yr}^{-1}$ ) was consumed by large herbivores over a number of years in miombo woodland in the Sengwa Wildlife Research Area, Zimbabwe (Martin 1974). More than $70 \%$ of this browse was taken from below $2.5 \mathrm{~m}$, although this zone contained only $24 \%$ of the total browseable mate- 
rial. Even then, the amount consumed amounted to only $4 \%$ of the browse present in this zone. In Burkea-Ochna savanna, large herbivores consumed only $3.4 \%$ of woody leaf production (Scholes and Walker 1993).

Much of the browsing, and therefore its potential impacts, is selective. Even a species such as the elephant, which because of its large body size ought to be able to tolerate low quality forage, browses relatively selectively. For example, in Kasungu National Park, Malawi, elephants feed on about $85 \%$ of the more com-

\section{Box 2.4 \\ Ash-fertilisation for agriculture}

\section{Emmanuel Chidumayo}

Woody biomass is commonly burnt when clearing miombo woodland for cultivation. In chitemene cultivation in northern Zambia, biomass burning is intended to fertilise the soil for millet production. Chitemene (meaning to cut) denotes a shifting cultivation system in which crops are grown in an ash garden (infield) made from the burning of a pile of branches obtained by lopping and chopping trees from an area (outfield) that is about ten times larger than the garden. In mature miombo woodland about $31 \%$ of the aboveground biomass, roughly $25-30 \mathrm{t} \mathrm{ha}^{-1}$ in the form of branches, is used to make an ash garden, while in regrowth of about ten years with less branch wood biomass, about $15 \mathrm{t} \mathrm{ha}^{-1}$ is available (Araki 1992). The potential macronutrient ( $\mathrm{N}, \mathrm{P}, \mathrm{K}, \mathrm{Ca}, \mathrm{Mg}, \mathrm{Na}$ ) content is approximately $1.3 \mathrm{t} \mathrm{ha}^{-1}$ and $0.75 \mathrm{t} \mathrm{ha}^{-1}$ from old-growth and regrowth miombo woodland, respectively (Chidumayo unpublished data).

The piled woody biomass at the future garden site is burnt in October/November just before the onset of the rainy season. In spite of losses during burning, the ash contains considerable amounts of nutrients. For example, Stromgaard (1984b) found that the ash on a chitemene infield contained $44 \mathrm{~kg} \mathrm{ha}^{-1} \mathrm{~N}, 1 \mathrm{~kg} \mathrm{ha}^{-1} \mathrm{P}$ and $219 \mathrm{~kg} \mathrm{ha}^{-1} \mathrm{~K}$. There is a positive correlation between the amount of ash used and yield of finger millet (Eleusine coracana) (Araki 1992).

The heat generated during biomass burning also regulates soil nutrient dynamics in favour of millet production. Apparently the heat kills the bacteria in the top soil and the bacteria population does not recover until the millet crop is already established. In the meantime, the crop can access the valuable ammonium $\mathrm{N}$ without great competition from the bacteria. Indeed the content of ammonium $\mathrm{N}$ in soil in burnt plots may be double that in unburnt soil (Chidumayo 1987a), although the process which causes this difference is poorly understood. The heat also raises soil $\mathrm{pH}$ by 1-2 units (Stromgaard 1984b; Chidumayo 1994b). Millet yield is therefore affected by both nutrient release from biomass burning and heat, but the effect of ash on millet yield is twice as large as that of heat (Araki 1992). Thus release of nutrients from miombo woodland plays a significant role in millet production in the chitemene system.

In the second year cassava, which matures over a 2-3 year period, succeeds millet before the ash garden is abandoned. During the cultivation period of 3-4 years the soil $\mathrm{pH}$ gradually decreases to the pre-burn level and this factor triggers abandonment of the ash garden (Lungu and Chinene 1993). Population pressure has caused the fallow period to be reduced from 25 years under low population density to 12 years, and the frequency of making new gardens has decreased from yearly to once in two years (Stromgaard 1985b; Chidumayo 1987a). 
mon trees and shrubs, but only thirteen species (32\%) are preferred; Brachystegia manga, B. boehmii, Uapaca spp. and Markhamia obtusifolia are among the preferred species (Jachmann and Bell 1985). In Zimbabwe, B. boehmii and to a lesser extent Diplorhynchus condylocarpon are particularly favoured (Anderson and Walker 1974; Thomson 1975; Guy 1976; 1989).

The food preferences of elephants studied in Zimbabwe were not correlated with any of the chemical elements or crude protein content of the plants (Anderson and Walker 1974;
Thomson 1975). Conversely, in Malawi, the selection of mature leaves of miombo trees by elephants was significantly correlated with the sugar and mineral content of the leaves, and negatively correlated with the total polyphenol, lignin and steroidal saponin contents (Jachmann 1989). Immature leaves generally had higher levels of proanthocyanidin, lignin and saponin levels than mature leaves, and were avoided. More such studies are needed to reveal the extent to which plant chemistry controls the pattern of consumption and, in so doing, influences

\section{Box 2.5 \\ Trypanosomiasis}

\section{Peter Frost}

The presence of blood-sucking tsetse fly, Glossina spp., vectors of the protozoan parasites Trypanosoma rhodesiense and T. brucei, which cause the disease trypanosomiasis in humans (sleeping sickness) and in domestic livestock (nagana), respectively, has been presumed to have a major impact on the patterns of land use in miombo. The trypanosomes are transmitted in the saliva of tsetse flies. The main vector in miombo is G. morsitans, although G. palpalis and G. pallidipes also occur but more locally in riverine and more-densely wooded habitats. Trypanosomiasis occurs in both chronic and acute forms in man and domestic animals but is benign in trypano-tolerant wildlife, which thereby act as reservoirs of the disease. Some indigenous cattle breeds are trypano-tolerant but in many areas they have been largely replaced by susceptible exotic breeds.

The widespread occurrence of tsetse flies and trypanosomiasis has often been advanced as a major factor limiting human settlement and the keeping of domestic livestock in miombo and other warm, moist, well-wooded tropical African environments (Ford 1971). Conventional wisdom holds that the adoption of shifting agriculture in much of this region has been a direct response to the shortage of draught power provided elsewhere by cattle and donkeys. Reality, however, may be more complex. Ford (1971), has argued that the advent of colonialism caused widespread social and ecological dislocation of African societies (Chapters 4 and 8). Simultaneously, the spread of rinderpest, an acute viral disease of ungulates, resulted in the almost complete destruction of cattle populations and the loss thereby of the means to keep the vegetation open and unsuitable for tsetse fly (Chapter 4).

People can modify their environments sufficiently, through bush clearing, to eradicate tsetse fly locally. It appears that areas where this has been done successfully are the drier areas, often on relatively shallow soils, where conditions for woody plant regrowth are sub-optimal (Box 4.3). In these areas the land, once cleared, has been fairly easy to keep open. In moister areas, on deep, well-drained soils where conditions are optimal for tree growth, it is more difficult to prevent woodland regeneration after clearing and tsetse fly generally persist. 
both the amount and quality of material available to other trophic groups.

Although the amount of browse eaten by large herbivores is generally low, the selective nature of browsing can result in changes to vegetation structure and composition. Apart from the impact of elephants, which is dealt with in more detail later, most information is available on the impacts of domestic livestock. Livestock readily browse woody regrowth, particularly during the dry season when the grass is dry, unpalatable and low in crude protein (Ward and Cleghorn 1970; Rees 1974; Lawton 1980). Dominant plant species such as B. spiciformis and Julbernardia spp., and common browse species such as Baphia bequaertii, do not tolerate frequent defoliation and are either killed or grow much less vigorously if browsed continuously throughout the year (Lawton 1980; Grundy 1995a). The effects depend on the browsers involved and their preferences among the woody species. Goats, but not cattle, can suppress the regrowth of B. spiciformis, whereas cattle are more efficient than goats at suppressing the regrowth of J. globiflora and Burkea africana (Ward and Cleghorn 1970). Repeated defoliation has been shown to reduce carbon:nutrient and polyphenol:nutrient ratios in B. africana, Ochna pulchra and Euclea natalensis, all species of dystrophic soils (including miombo woodland), making the plants less resistant to subsequent defoliation (Bryant et al. 1991). Plants with a low capacity to replace carbon lost in tissues consumed by herbivores may therefore be constrained in their ability to respond to herbivory by increasing production of polyphenols or other carbon-based chemical defenses (Bryant et al. 1991). A similar phenomenon may occur in other slow-growing species occurring on dystrophic soils.

Invertebrates probably consume more foliage in miombo woodland than that eaten by large mammals, though the supporting data are limited. At Sengwa, Zimbabwe, invertebrates consumed up to $30 \mathrm{~kg} \mathrm{ha}^{-1} \mathrm{yr}^{-1}$, more than double that eaten by mammals (Martin 1974). Caterpillars of the notodontid moth Elaphrodes lactea consumed $98 \mathrm{~kg} \mathrm{ha}^{-1}$ of leaves during an outbreak on $B$. boehmii in Zaire (Malaisse-Mousset et al. 1970). At Marondera, Zimbabwe, $4.5 \%$ of leaf area in $B$. spiciformis, the dominant species, had been eaten by insect herbivores by mid-summer, amounting to an estimated loss of $80 \mathrm{~kg} \mathrm{ha}^{-1}$ of leaf (Frost, unpublished data). In Burkea-Ochna savanna, lepidopteran larvae consume about $22 \mathrm{~kg} \mathrm{ha}^{-1}(1.7 \%$ of annual woody leaf production) in non-outbreak years, but up to $430 \mathrm{~kg} \mathrm{ha}^{-1} \mathrm{yr}^{-1}$ in outbreak years (every 2-4 years: Scholes and Walker 1993).

Some lepidoptera larvae feed on a wide range of plant species (for example, in Zaire, Gonimbrasia richelmanni and E. lactea feed on 10 and 15 plant species respectively: Malaisse 1983), but most feed relatively selectively. More than $75 \%$ of 153 lepidopteran species recorded in Zairean miombo woodland were found on only one or two plant species (Malaisse 1983). At the same time, about $80 \%$ of the 159 plant species surveyed were found to host the larvae of only one or two lepidopteran species, although the dominant trees supported many species (J. paniculata, 30 species; B. spiciformis, 16 species: Malaisse 1983).

Consumption by invertebrates is distributed differently in time and space to that by mammals. Mammals are active throughout the year but, except for elephants, their feeding is concentrated in the woodland understorey and is patchily distributed (Martin 1974). In contrast, invertebrate herbivory is confined largely to the wet season and tends to be more uniformly distributed among suitable plants at a given locality. It also varies greatly from year to year; periodic population outbreaks of insects are a characteristic feature of miombo woodlands. Examples include outbreaks of the moth, E. lactea, on Brachystegia and Julbernardia species in Zaire (MalaisseMousset et al. 1970) and, in Zimbabwe, extensive 
defoliation of B. spiciformis by the moths Eutelia polychorda and an unidentified related species (Frost pers. obs.), and by the chrysomelid beetle Melasoma quadralineata (Reeler et al. 1991). Large areas of woodland can be defoliated during these outbreaks, resulting both in the loss of photosynthetic area at the height of the growing season, and in a sudden flux of nutrients from the trees to the litter layer where they may stimulate microbial decomposition of both new and old litter (Malaisse-Mousset et al. 1970).

\section{Fire}

Dry-season fires in the understorey occur regularly and frequently in miombo woodland (Trapnell 1959; Kikula 1986b). Many of the fires originate accidentally from people preparing land for cultivation, collecting honey or making charcoal (Chidumayo 1995). Fires are also set deliberately by hunters, either to drive animals or to attract them later to the regrowing grass on burnt areas. Livestock owners likewise burn areas to provide a green flush for their livestock, and to control pests such as ticks. More generally, people use fire to clear areas alongside paths between settlements. Such practices have probably been carried out in these systems for millennia (Clark and van Zinderen Bakker 1964).

Fires in miombo woodland in Zambia occur throughout the dry season, from May to November, with most occurring during the hot dry season (August-October: Chidumayo 1995). They are fuelled largely by grass (woody material contributes little to the main fire front, but may continue burning long afterwards, creating localised, deep, sterile ash beds). Fire intensity is therefore linked through grass production to the previous season's rainfall, the intensity of grazing, and the extent of woody plant cover. Fires tend to be more frequent and intense in areas of low woodland cover and high mean annual rainfall, where grass production is high but where grass quality and therefore grazing pressure is low.

There is a paucity of reliable data on the frequency of fire. Chidumayo (1995) records a mean fire-return interval of 1.6 years at four closely situated sites in central Zambia over a four-year period. Analyses of satellite imagery, sampling a large area, reveal no more than $37 \%$ of the land being burnt in any one year (R.J. Scholes, pers. comm.). This gives a regional fire-return interval of about 3 years. Fire-return intervals at any one point are likely to be more variable than this, depending on fuel accumulation rates, both at the site and in the surrounding vegetation, as well as on proximity to potential sources of ignition.

The impact of fire on plants depends on the intensity and timing in relation to plant phenology. Fire intensity varies with the season of burn and with the amount of fuel. Late dry-season fires in

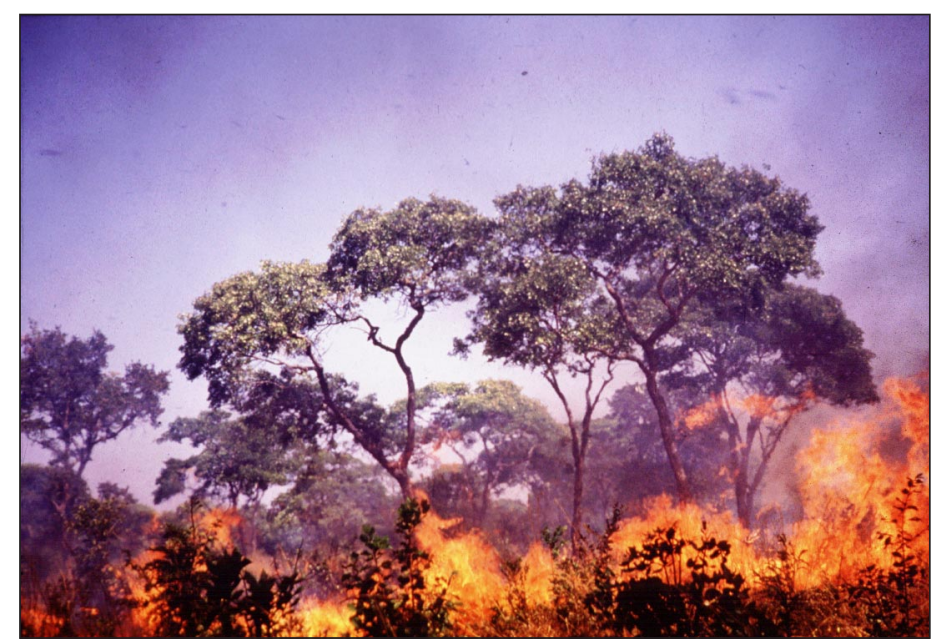

Dry-season fires are frequent in miombo and are fuelled mainly by herbaceous material. Repeated late dry-season fires can severely damage trees and suppress recruitment of saplings to the canopy (photo: P. Frost) 
miombo woodland are more intense and destructive than fires burning in early dry season when much of the vegetation is still green and moist. For example, in miombo woodland in Zimbabwe, fire intensities during late wet season and early dry season (March-June) fires were 100-300 $\mathrm{W} \mathrm{m}^{-1}$, compared with $500-5000 \mathrm{~W} \mathrm{~m}^{-1}$ during the late dry season in October (Robertson 1993). Late dry-season fires occurring after many of the trees have flushed, which they do some months prior to the rains, are particularly destructive. Stem mortality measured over a two-year period in wet miombo woodland was only $3-4 \%$ when both woodland and coppice plots were burned in mid-June (early-burnt), but $18 \%$ and $40 \%$ respectively when burned in mid-October (Chidumayo 1989b).

Much of our knowledge of the response of miombo plants to fire comes from Trapnell's (1959) analysis of the Ndola fire experiments, set up in 1933 to compare the effects of burning mature and coppicing miombo woodland in the cool, early dry season (June/July) and the hot, late dry season (October), with complete protection from fire. Four groups of species, based on their degree of tolerance to fire, were identified. Fire-intolerant species cannot survive fire and therefore occur only where completely protected. Most of these are evergreen trees (e.g. Parinari excelsa, Entandophragma delevoyi and Syzygium guineense) and lianes (e.g. Artabotrys monteiroae, Landolphia spp. and Opilia celtidifolia). Fire-tender species are those which decline under regular burning and increase under complete protection. Most of the dominant canopy species (e.g. Julbernardia paniculata, Isoberlinia angolensis, Brachystegia spiciformis and $B$. longifolia) are considered to be fire-tender, with higher mortality rates of mature trees under late dry-season burning $\left(2.5 \% \mathrm{yr}^{-1}\right)$ than under complete protection $\left(0.5 \% \mathrm{yr}^{-1}\right)$ or early dry-season burning $\left(0.2 \% \mathrm{yr}^{-1}\right)$ (Trapnell 1959). The regeneration of saplings of these species was also greatly reduced, the number of saplings under late dry-season burning being less than $7 \%$ of the number surviving under early dry-season burning and only $2 \%$ of the number present under complete protection (Trapnell 1959). Semi-tolerant species such as Maranthes polyandra, Uapaca kirkiana, U. pilosa, Baphia bequaertii, Pseudolachnostylis maprouneifolia and Strychnos pungens are likewise relatively unaffected by early dry-season fires but are reduced somewhat under late dry-season burning. Finally, the fire-tolerant species are those able to survive regular late dry season fires as adults, saplings and regrowth. They include canopy trees such as Pterocarpus angolensis, Erythrophleum africanum, Pericopsis angolensis and Parinari curatellifolia, and understorey trees and shrubs such as Uapaca nitida, Anisophyllea boehmii, Diplorhynchus condylocarpon, Strychnos innocua and Maprounea africana (Trapnell 1959).

In addition to changes in species composition, changes also occur in vegetation structure. Frequent late dry-season fires eventually transform woodland into open, tall grass savanna with only isolated, fire-tolerant canopy trees and scattered understorey trees and shrubs. In contrast, woody plants are favoured by both early burning and complete protection. The early-burn plots at Ndola comprised open woodland with thickets of less fire-tolerant species able to survive because grass growth is suppressed in the thickets, thereby effectively excluding fire (Trapnell 1959).

Much has been made of the results from the Ndola fire plots and they have served as the basis for interpreting vegetation changes at other sites in miombo woodland (Lawton 1978; Kikula 1986b; Stromgaard 1986). But the burning conditions in these plots are more extreme than those occurring generally in miombo woodland. A given site seldom burns at the same time every year; the interval between fires and the seasonal timing both vary. Moreover, the complete 
absence of fire is rare and likely to be limited to stands of dense miombo woodland with an evergreen understorey and little grass. Actual measures of damage and mortality, and how these relate to components of fire behaviour, such as the rate of spread, mean and maximum flame heights, fireline intensities, and to prior and subsequent events such a drought and frost, are needed from a range of sites (Frost and Robertson 1987). The extended timeframe of most fire experiments in Africa is extremely valuable, but the possibility that the outcomes are due more to singular events (often unrecorded) occurring during the experiments, rather than to slow cumulative effect of numerous fires, needs to be considered.

\section{Dynamics}

\section{Equilibrium or non-equilibrium dynamics?}

Early interpretations of the dynamics of miombo woodland were based largely on a single-state equilibrium model of a regional climax vegetation, dense woodland in drier regions and semievergreen or evergreen forest in wetter areas, to which miombo woodland was considered to be successional (Freson et al. 1974; Strang 1974; Lawton 1978). Fire and disturbance by man were considered to be the principal agents maintaining the vegetation in a sub-climax state. More recently, Stromgaard (1986) implied a possible multi-state model with a transition from woodland dominated by Brachystegia and Julbernardia to one dominated by Combretum following cultivation and abandonment of fields under shifting agriculture. Starfield et al. (1993) suggested a similar transition in escarpment woodlands of the Zambezi Valley, from Brachystegia boehmii-dominated woodland to grassland and bushland dominated by Combretum apiculatum, but caused by the combination of elephants and fire. In more general terms, there can be multiple quasi-stable states, each with its own characteristics, dynamics and a threshold beyond which a shift occurs to a dif- ferent state (Westoby et al. 1989). This multi-state model has been applied more broadly within African savannas (e.g. Dublin et al. 1990). A related development has been the widespread advocacy for the concept that African savannas are fundamentally disequilibrium systems whose dynamics are externally driven by frequent, unpredictable fluctuations in rainfall which continually perturb the dynamics and prevent them from reaching any equilibrium (Ellis and Swift 1988; Behnke et al. 1993; Scoones 1994). This paradigm stems largely from research showing non-equilibrium dynamics in arid, eutrophic, pastoral systems in northern Kenya and other arid areas (Ellis and Swift 1988; Behnke et al. 1993). The question remains, however, as to how widely applicable this model is and, in particular, whether it applies to moist, nutrient-limited systems such as miombo woodland.

Much of the functioning of miombo woodland is clearly linked to rainfall, and although there is evidence to suggest that nutrient availability is a limiting factor, that too is partly a function of moisture regime. Ellis (1994) has suggested that non-equilibrium dynamics generally prevail in regions in which the coefficient of variation (CV) of annual rainfall is greater than $30-33 \%$. The $\mathrm{CV}$ of annual rainfall in the miombo region is about $15-25 \%$ so that extreme rainfall events occur less frequently than in more variable arid systems (though what constitutes an extreme event in one system is almost certainly not the same as that in another system). Set against this lower frequency, however, are the generally longer lifespans of miombo trees; a tree would still experience a number of extreme events during its lifetime and must have the capacity to withstand them. One buffering mechanism might be storage of carbohydrates and internal recycling of nutrients. Given the ability of some trees to rapidly replace foliage destroyed by fire or insects, these stores appear to be substantial. Perhaps a succession of drought years might deplete such 
stores, increasing the plants' susceptibility to herbivory, fire and pathogens, but such multi-year events are even rarer than single-year droughts.

This does not imply that miombo woodland cannot be disturbed, only that rainfall fluctuations are unlikely to have the same direct impact that they do in drier regions. The impacts are more likely to be indirect, interacting with phenomena such as fire. In this case, it may be the frequency of above- rather than below-average rainfall events which is significant. One hypothesis, for example, is that fire intensity is higher following a very wet season, not only because of greater grass production and therefore fuel loads, but because the grass takes longer to cure so that the fires occur later in the dry season when ambient conditions promote a hotter fire. Understanding such interactions is likely to be the key to understanding miombo woodland dynamics.

\section{Disturbance of woodland cover}

The dynamics of miombo woodlands are largely the dynamics of the woody component, which in turn is affected by three interacting factors: people, fire and elephants. Through the clearance of land for cultivation, subsequent abandonment, and selective harvesting of trees for various purposes, people directly affect woodland cover. They are also the main initiators of fire. Fire can damage woodland and prevent or slow down its recovery. Elephants can also damage woodland, often in refuges where their populations have become compressed as a result of hunting and changes in land cover in adjacent areas. Woodland damaged by elephants is in turn usually more prone to fire. The use of miombo woodland by people is reviewed elsewhere in this book (Chapters 4 and 5). Discussion here focuses primarily on the disturbances induced by fire and elephants.

\section{Fire}

The tolerance or susceptibility of miombo plants to fire is a function of their growth form, developmental stage, size, physiological condition and phenological state at the time of burning (Chapter 3). Grasses and many non-woody herbs tolerate intense, late dry-season fires better than most woody plants, and plants burnt when they are physiologically active or stressed are generally less tolerant than those burnt when they are dormant (Frost and Robertson 1987). The combined effects of season and frequency of burning on the composition and structure of miombo woodland are not well known (the Ndola fire experiment only considered annual burning and complete protection). Casual observations suggest that longer intervals between fires generally favour woody plants, particularly under high rainfall and on soils favourable to tree growth. Since grass biomass declines sharply as tree cover increases (Figure 2.7), a period of undisturbed regrowth by woody plants would lead to gradual canopy closure and the suppression of grass growth and fuel loads. Lower fuel loads mean less-intense fires, less damage to woody plants, uninterrupted woody regrowth and continued canopy closure. Conversely, declines in woody plant cover result in increases in grass production and standing crop which, in the absence of herbivory, provide more potential fuel for fire. Higher fuel loads in turn mean more intense fires, greater suppression of woody plant regrowth and therefore, more grass.

The presence of such a threshold in tree density is apparent in the vegetation changes which have occurred on a long-term fire experiment at Marondera, Zimbabwe, in which replicated plots in a coppiced woodland have been burnt regularly during the late dry season (mid-October) at 1-4 year intervals since 1952 (see Barnes 1965 for details). The vegetation on the plots has still to be surveyed in detail but the general trends are obvious in the field. Woody plants, other than firesuppressed coppice, are almost completely absent from the grass-dominated, annually burnt plots, and somewhat more abundant on the 2-yearly and 3 -yearly fire plots, where they occur mostly as 
suppressed saplings. Conversely, most of the 4yearly fire plots and a few of the 3-yearly fire plots have an almost closed canopy of trees, with a similar composition to, but a less-mature structure than, the vegetation on the protected plots. The contrast between the grass-dominated plots burnt at 1-2 year intervals and the woodland dominated plots burnt at 4 year intervals is striking, and supports the idea that once woody plants reach a size where they are relatively resistant to fire (>2 m) woodland develops rapidly through suppression of grass growth, lower fuel loads, less-severe fires and reduced damage to trees.

Herbivores may modify these patterns. Heavy grazing can lower the dry-season standing crop of grass, and hence the fuel for fire. This would reduce fire intensities and damage to woody plants, even at low densities. In a combined grazing and burning experiment at Henderson Research Station, Zimbabwe, significantly fewer J. globiflora were recorded on the more lightly grazed plots after 15 years of grazing and late dry-season burning at 2- and 3-year intervals than on more-heavily grazed plots (Boultwood and Rodel 1981). Similar but not statistically significant trends were apparent in other species. Overall though, fire was the dominant influence: a significant reduction in tree density, averaging $28 \%$, occurred on plots grazed and burnt annually in the late dry season for 15 years. Over the same period, woody plant densities on ungrazed, unburnt plots increased by an average of $87 \%$. Average tree densities declined less on the grazed, biennially burnt plots and increased slightly on grazed plots burnt every three years (Boultwood and Rodel 1981).

\section{Elephants}

Elephants are notable for being able to change dramatically the nature of woody vegetation by breaking, ringbarking, pushing over and uprooting trees and shrubs (Buechner and Dawkins 1961; Laws 1970; Thomson 1975; Guy 1989, among others). Why elephants push over such large numbers of trees is not fully understood. Males are responsible for most trees pushed over. Not all of the felled trees are preferred forage species, nor do the elephants necessarily feed from each one. This has lead to suggestions that treefelling is a form of social display (Guy 1976). Conversely, individuals of preferred forage species taller than $3 \mathrm{~m}$ are pushed over proportionately more often than individuals of non-preferred species, which are felled indiscriminately. This suggests that felling of trees is part of feeding (Jachmann and Bell 1985). Elephants browse mainly on foliage 1-3 m above ground (Guy 1976; Jachmann and Bell 1985). Since many of the trees coppice if their stems are broken or debarked, tree-felling may stimulate plant production within the preferred feeding zone, though this takes time to materialise, especially if the vegetation is frequently burnt (Guy 1981a; 1989). Rutherford (1981) has shown that resprouting trees have a higher proportion of shoot biomass than the trees before they were damaged. The nutritional quality of the regrowth is also often higher, with lower concentrations of secondary chemicals (Bryant et al. 1991; Jachmann 1989). Thus the benefits of felling trees may accrue later (Bell 1984).

Whatever its causes, damage to trees by elephants has resulted in dramatic changes in woodland cover. In one year in Chizarira National Park, Zimbabwe, elephants killed $18 \%$ of the dominant tree species, B. boehmii (Thomson 1975). In similar vegetation at Sengwa in the neighbouring Chirisa Safari Area, the rate of new damage to trees and shrubs caused by elephants was estimated to be about $7-8 \% \mathrm{yr}^{-1}$ respectively (Anderson and Walker 1974). In a later study in the same area, Guy (1981a) recorded a $46 \%$ decline in the biomass of canopy trees, a $42 \%$ decline in basal area, and a $23 \%$ decline in density due to elephants over a 4-year period. Shrub biomass also decreased by $34 \%$ although density more than doubled (Guy 1981a). 
The overall effect in these cases has been to transform relatively dense woodlands into more open wooded grasslands with scattered tall trees, resprouting tree stumps, and a dense layer of low growing shrubs. The changes have occurred both as a direct result of felling and debarking of trees, and as an indirect effect of changes in fire regime brought about by higher grass production under a more open tree canopy (Anderson and Walker 1974; Thomson 1975; Guy 1981a; 1989; Jachmann and Bell 1985). The nutritional quality of the grass is generally too low to support substantial numbers of grazers, other than during the early growing season. In the absence of compensatory increases in grazing pressure, therefore, the increase in grass production leads to higher dry season fuel loads, more frequent and intense fires, suppression of woody regrowth, and more vigorous grass growth. Repeated fires may eventually eliminate most of the woody plants, particularly on soils with low permeability where conditions for rapid regrowth are constrained. On freely draining soil, however, the surviving woody plants may persist, either as a community of dense coppice growth maintained by browsing and periodic fires, or as a re-establishing woodland in which grass growth is gradually suppressed by the regrowing woody plants (Bell 1982).

\section{Recovery from disturbance}

The dominant trend in regenerating miombo woodland in the absence of frequent hot fires or other intense disturbances is towards the development of woodland (Strang 1974). Unless the plants have been thoroughly uprooted during the initial disturbance, most of the subsequent development of woodland derives from regrowth of coppice from the surviving stems and rootstocks. Marked changes in composition and very slow, if any, recovery to the original state is likely in areas where Brachystegia, Julbernardia and other Caesalpinioideae have been eradicated because these trees have extremely low dispersability
(Chapter 3) and short-lived seeds. It is not easy to eradicate the trees, however.

Four phases can be identified in regenerating woodland (Figure 2.12): initial regrowth; dense coppice; tall sapling phase; and mature woodland (Robertson 1984; Trapnell 1959). The vegetation immediately following abandonment is relatively open, with much grass, more so in areas cleared mechanically, cultivated intensively, or both (Strang 1974). Most woody plants in the initial regrowth phase are less than $1 \mathrm{~m}$ tall. Regular, intense, late dry-season fires can suppress recovery, restricting the vegetation to this phase. Protection from fire or relatively cool early dryseason fires enable a dense coppice phase to emerge, with 1-3 m tall woody plants. These tend to suppress grass growth, though not to the point where a fire cannot be supported. A change in fire regime at this stage to one of predominantly late dry-season fires may be sufficient to suppress coppice regrowth and return the vegetation to the open phase.

Uninterrupted growth of coppice leads eventually to the development of a tall sapling phase, with woody plants 3-6 m high. Closure of the canopy further suppresses grass production and allows fire-sensitive species to establish. Finally, a mature woodland phase develops, marked by thinning of the intermediate size classes and the suppression, but not elimination, of saplings. Fire alone does not divert the development of woodland though it may retard it.

The number of woody species present on fields derived from miombo woodland apparently changes little during this secondary succession (Robertson 1984), though Stromgaard (1986) suggests otherwise. Lawton (1978) interpreted the composition of miombo woodland communities in northern Zambia in terms of a post-fire successional model involving a dynamic relationship between different ecological groups of species, most of them dominating a different stage in the succession and producing gradual 
closure of the tree canopy, thereby diminishing the effects of fire and facilitating the establishment of later successional, fire-sensitive species. Five groups of species were proposed, based on their susceptibility or tolerance to fire, as determined largely from the results of the Ndola fire experiments (Trapnell 1959).

Group 1, the chipya species, comprises species which can survive intense late dry-season fires but which are intolerant of shade and therefore depend on regular fires to maintain an open woody canopy. Group 2 is made up entirely of the moderately fire-resistant Uapaca species which can establish in lightly wooded habitats, such as mature chipya, but cannot establish or persist in tall grassland which is subject to intense dryseason fires. When mature, Group 2 species form a low dense canopy beneath which grass production is reduced. These conditions are presumed to favour the establishment and growth to maturity of the firetender Group 3 species, which include most of the dominant Brachystegia, Julbernardia and Isoberlinia species characteristic of mature miombo woodland. Lawton (1978) notes that although they can invade the Uapaca-dominated communities, they cannot invade or persist under chipya. Group 4 comprises species which are intolerant of fire. Many of these are species characteristic of the evergreen and semi-deciduous forest patches found alongside wet

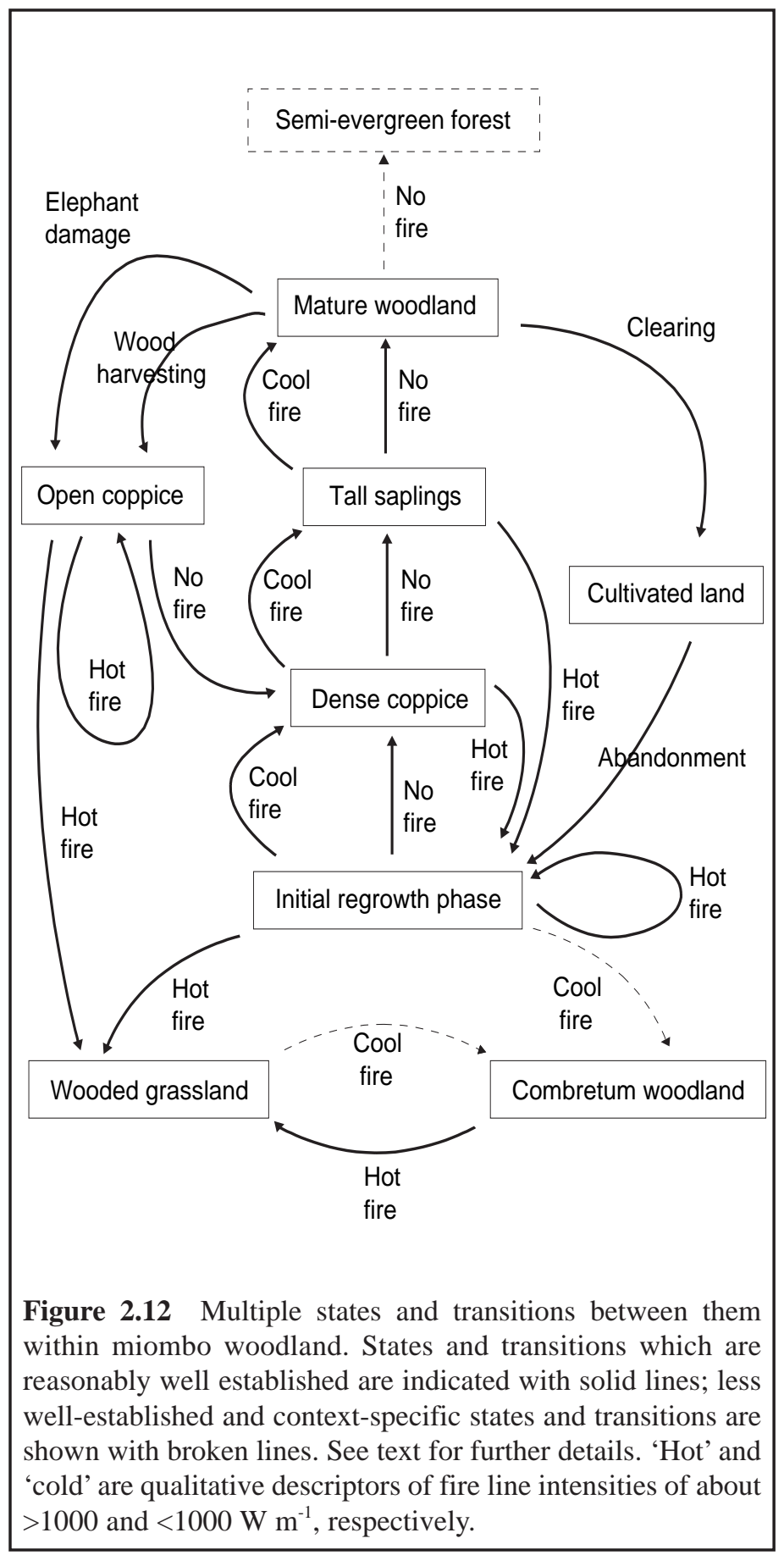


miombo woodland. Group 5 is made up of a suite of ubiquitous species which persist throughout. Within any one stand, however, there is considerable overlap in the occurrence of these species groups (Lawton 1978; Robertson 1984; Kikula 1986b; Stromgaard 1986), which begs the question as to their discreteness.

Stromgaard (1986) surveyed the vegetation on shifting cultivators' plots that had been abandoned for various periods of time from 1 to 25 years, from which the early secondary successional changes were inferred. Woody diversity was lowest at the beginning, implying that some species were eliminated by clearing. Most interestingly, the abundance of the dominant miombo species declined during the succession, whereas the abundance of Combretum species increased. This led Stromgaard (1986) to question whether secondary succession in miombo woodland does indeed lead to the re-establishment of miombo woodland proper.

The weakness of all these studies of vegetation change has been in the substitution of space for time to infer the patterns of temporal change. There is the implicit assumption that the composition of the vegetation was relatively uniform at the outset, and that any differences that did exist were not themselves a basis for differential use through time. These are tenuous assumptions. Robertson (1984) showed that in Malawi the more fertile soils towards the footslopes, on which Combretum is dominant, are used by shifting cultivators first, and that only later, after the plots have been abandoned, do the farmers cultivate woodland dominated by Brachystegia and Julbernardia. This could easily account for why Stromgaard (1986) found Combretum dominant on the older abandoned plots. Clearly, there are dangers in trying to infer temporal trends in vegetation from spatial pattern alone. Given the longevity of at least the dominant species in miombo woodland, their dynamics are not likely to be easily determined from short-term studies.
Long-term monitoring of secure sites, together with modelling of plant community dynamics (Desanker and Prentice 1994; Box 2.6), is clearly needed.

\section{Future research directions}

Many questions about miombo woodland ecology remain to be answered. What are the biogeographic, historical and ecological circumstances responsible for the uniqueness of miombo woodland? To what extent do the details of ecological functioning of miombo woodland vary across its wide geographic range, and what are the associated environmental driving forces? Is miombo woodland a nutrient-limited system or is it, like some other African savannas, primarily waterand therefore carbon-limited? Of course, the limiting factors might vary geographically, at a number of scales, or over time, seasonally or with the stage of development of the vegetation. Whatever the ultimate constraint to ecosystem productivity, nutrients are clearly critical to many aspects of miombo functioning. More information is needed on the patterns of availability, what controls these, and how they vary across the diversity of miombo ecosystems. In particular, we need to be able to contrast the internal (within-plant) and external (plant-litter-soil) cycling of nutrients. What amounts of nutrients in leaves are recycled prior to senescence, and what constrains the process? Likewise, there is a need for more information on the processes of, and controls on, decomposition and mineralisation.

One particularly fascinating area for further work in this regard concerns the question of ectomycorrhizae. Peter Högberg's pioneering work in miombo woodland (summarised in Högberg 1992) needs to be extended. What are the various functions of these ectomycorrhizae, and why is miombo woodland dominated by species with ecto- rather than endo-mycorrhizae? What is their contribution to the mineral nutrition of the host 
plants? Most interestingly, why are the dominant Caesalpinioideae in miombo woodland ectomycorrhizal, but those on equally nutrient-poor Kalahari Sand endomycorrhizal? What are the costs to the plants of supporting these mycorrhizae, and what are the concomitant benefits?

Then there are questions concerning vegetation dynamics. Is there a single equilibrium state for miombo woodland, in which the dynamics are strongly internally regulated and buffered against unpredictable changes in driving forces, or are there multiple states with or without nonequilibrium dynamics? If there are multiple states, how many and what kinds are there, what are the possible transitions between them, and what are the conditions under which these occur? Answering such questions at a time when most research projects are constrained by being of short duration will be difficult but has to be attempted. Perhaps the new technologies of remote sensing, coupled with detailed surveys of sites with a known land-use history, and simulation modelling of vegetation dynamics, will prove to be a way forward. Understanding the population biology of the plants will be crucial in this regard (Chapter 3).

Finally, in addition to understanding how miombo woodland functions, to facilitate the sustainable use and management of its resources, there is a need to consider this functioning in the broader context of global change. In particular, information is needed on the size and disposition of the carbon pool, its dynamics, and the extent to which miombo woodland may serve as a source or a sink for carbon (Justice et al. 1994). Some preliminary measurements have been made of gaseous and particulate carbon emissions from late dry-season fires in miombo woodland (Ward et al. in press) but more such measurements are needed over a wider range of plant communities and environmental conditions (particularly different times in the dry season). This work also needs to be extended to other gaseous components

\section{Box 2.6 \\ Modelling the dynamics of miombo woodlands}

\section{Paul V. Desanker}

Patch (gap) models simulate the fundamental forest processes of regeneration, growth and mortality at spatial scales of the order 100-1000 $\mathrm{m}^{2}$ (Botkin et al. 1972; Shugart 1984; Botkin 1993). These models are based on the concept that if all growth conditions are not limiting, a tree of a given species will achieve a pre-defined maximum size, which can be approximated by the largest tree ever observed for that species within its geographic range. Various growth-limiting factors, such as crowding, shading, moisture, nutrients and temperature, then reduce the optimal annual growth.

Desanker and Prentice (1994) applied a gap model to miombo woodlands using miombo characteristics derived from the literature, and work is in progress to validate and evaluate the model performance in different stands of miombo. Collaborators throughout the region are required for this project.

Models based on plant functional types, as opposed to individual species, hold promise for the future, if adequate types can be identified for miombo, as such models would require less species-level information. Models that are based on physiological measurements are also gaining prominence, as direct effects of climate and carbon dioxide concentrations can be explicitly incorporated into the models. An IGBP Miombo Transect Project will explore plant functional types and physiological characteristics of miombo species in more detail in the development of models for miombo structure and functioning 
exchanged with the atmosphere, such as nitrogen oxides $\left(\mathrm{NO}_{\mathrm{x}}\right)$, both from fires and more generally from the soil, vegetation and animals.

Research into these questions is needed at two levels: further documentation of the patterns of ecosystem functioning; and studies of the mechanisms producing these patterns. Research into mechanisms will require experimentation, both in the field and under more controlled laboratory conditions. To complete such a diverse research agenda will need common purpose, a range of skills, cooperation and funding. 


\title{
Chapter
}

POPULATION BIOLOGY OF MIOMBO TREES

\author{
Emmanuel Chidumayo and Peter Frost
}

\section{Introduction}

While an understanding of how miombo ecosystems function (Chapter 2) will go some way towards the development of sustainable woodland management practices, we need to predict the dynamics of miombo under different management options and circumstances. This requires an in-depth knowledge of the population biology of the dominant trees, in particular the mechanisms of establishment, growth, reproduction and recovery from disturbance. Moreover, the distinctive feature of mature miombo woodland is the dominance of species in Fabaceae, subfamily Caesalpinioideae, raising the question as to what unique combination of features has enabled these species to become so dominant under prevailing environmental conditions. Unfortunately, our current understanding is rudimentary and fragmented. This chapter aims to identify what is currently known and what are the outstanding key questions. The chapter concludes with a discussion of the gaps in our knowledge.

\section{Phenology}

We distinguish five main phenological seasons for miombo woodland: warm, dry pre-rains season (September-October); early rainy season (November-December); mid-rainy season (January-February); late rainy season (MarchApril); and cool dry season (May-August) (Boaler 1966b; Astle 1969; Malaisse 1974; Guy et al. 1979; Chidumayo 1993a). In addition to rainfall and temperature, the phenology of miombo plants is influenced by seasonal variations in soil moisture (Chapter 2).

\section{Leaf fall and flush}

Most trees and shrubs, including all the dominant species, are deciduous, shedding their leaves during the dry season. Only $9 \%$ of the 89 tree species and $12 \%$ of the 34 shrub species in Zimbabwean woodlands are evergreen. An additional $21 \%$ of the trees and $15 \%$ of the shrubs are semi-deciduous. The proportion of evergreen species is slightly higher in wet miombo woodland: $24 \%$ of 67 tree species and $17 \%$ of 18 shrub species in northern Zambian miombo woodlands are evergreen (Astle 1969). 
Leaf fall is concentrated during AugustOctober (Chidumayo 1993a; Malaisse et al. 1975). However, in drier climates and on shallow soils the timing of leaf fall and the duration of the leafless period varies from year to year, depending on prevailing weather conditions and on the species. In years of below-average rainfall, leaves are shed early in the dry season, whereas, following years of above-average rainfall, many species retain their leaves late into the dry season. The patterns of leaf fall have never been analysed in relation to rooting characteristics.

Most of the dominant canopy trees produce new leaves during the warm, dry, pre-rains season, weeks to a month or more before the onset of the wet season. Leaf emergence is generally well synchronised within a species, although individual plants growing on shallow soils over impermeable bedrock or solid laterite flush later than those growing on deeper soils. The factors regulating leaf flush have not been determined, though photoperiod may be involved. In B. spiciformis,

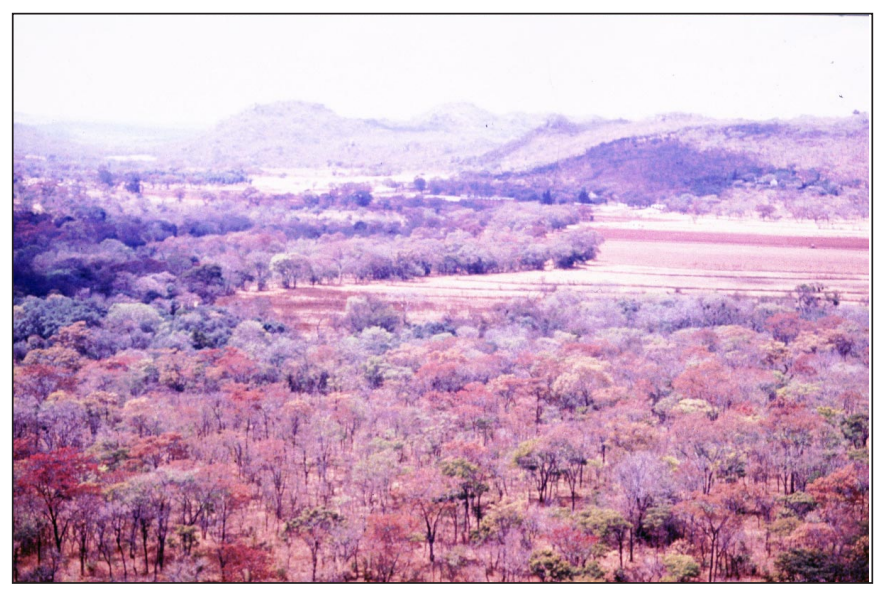

Spring colours in canopy of miombo woodland, Christonbank, Zimbabwe. Land cleared for commercial agriculture (maize and tobacco) is visible in the background. The red colour of the leaves is due to the presence of proanthocyanidins, the functions of which are still unclear: they may protect the leaves from herbivory or against damage by UV radiation (photo: P. Frost). new leaves appear earlier in years when late winter skies are clear than when they are predominantly cloudy (I. Robertson, pers. comm.). Bud opening in Burkea africana and Ochna pulchra, two minor species in miombo woodland occurs shortly before the spring equinox, when the daily temperature range and rate of increase in daily temperatures are maximum (Rutherford and Panagos 1982). The young leaves of Brachystegia are saturated with anthocyanins, giving rise to spectacular reddish spring foliage. The function of the anthocyanins and the associated physiological and structural changes occurring in the leaves as they mature are not known (but see Tuohy and Choinski 1990; Chapter 2).

\section{Flowering}

Most trees and shrubs in miombo woodland flower during the warm, dry pre-rains season (SeptemberOctober). Julbernardia species are notable exceptions. J. paniculata flowers in the latter half of the wet season from February to April (Figure 3.1), while J. globiflora flowers from November to April (Chidumayo unpublished data; Campbell et al. 1988; Figure 3.1). Some shrubs species also flower in the mid and late wet season. A few trees and shrubs (e.g. Pterocarpus angolensis) and herbs (e.g. Rhynchosia insignis and Boophone disticha) flower before leaf flush but for most trees and shrubs, flowering is synchronous with, or follows immediately after, leaf emergence. Bird-pollinated plants such as Aloe spp. and Erythrina spp. flower during the dry season, in the case of Erythrina, when the trees are leafless.

In contrast to the dry-season pattern of flowering of the deep-rooted trees and shrubs, most shallow-rooted woody suffrutices, perennial forbs, sedges and bulbous plants flower during 
the rains. The majority of grasses and annual herbs flower during the latter half of the wet season (Boaler 1966b; Astle 1969; Malaisse 1974). Few species flower during the cool dry season, other than those pyrophytes which flower after fire in response to higher soil temperatures.

\section{Fruiting and dispersal}

Julbernardia globiflora reproduces while still a small sapling, especially when of coppice origin, with plants as small as $1.5 \mathrm{~m}$ high producing seed. In contrast, Brachystegia only reproduces when the plant emerges in the canopy, $4 \mathrm{~m}$ or more high (Frost, pers. obs.). In miombo woodland, fruit production varies greatly from year to year, particularly in Brachystegia, Julbernardia and Isoberlinia (Figure 3.2) (Malaisse 1978a; Campbell et al. 1988; Ernst 1988). Annual fluctu- ations in fruit production among miombo trees have also been inferred from annual variations in pod valve litter fall in both dry and wet miombo woodland (Malaisse et al. 1975; Campbell et al. 1988). The fluctuation between years is more pronounced in old-growth than in immature regrowth miombo woodland (Chidumayo 1993a).

The mast fruiting is thought to be a biennial phenomenon (Malaisse 1978a; Ernst 1988), but this is not necessarily so (B.M. Campbell pers. comm.). Fruiting failure may be caused by lack of flowering and/or flower abortion. Brachystegia species often flower profusely without producing a correspondingly large seed crop. In Julbernardia paniculata and perhaps Brachystegia species also, flower abortion may be caused by bud infestation by Curculionid beetle larvae and imagoes (Clauss 1992). Mast fruiting may therefore reflect interannual variations in pollinator activity, bud predation, flower abortion or the resources available for pod and seed production, rather than physiologically entrained events. Seeds of herbaceous species mature very quickly and are shed soon after flowering, before the dry season. Fruit and seed maturation is slower among the taller woody species which retain their seed in the canopy until the cool dry season.

In the majority of miombo trees, the fruit takes at least six months to mature but in a few species, such as $J$. paniculata, fruits mature in less than six
Figure 3.1 Reproductive phenology of some important miombo trees (Chidumayo, unpublished data). Shading $=$ flowering; Solid $=$ ripe fruits. 


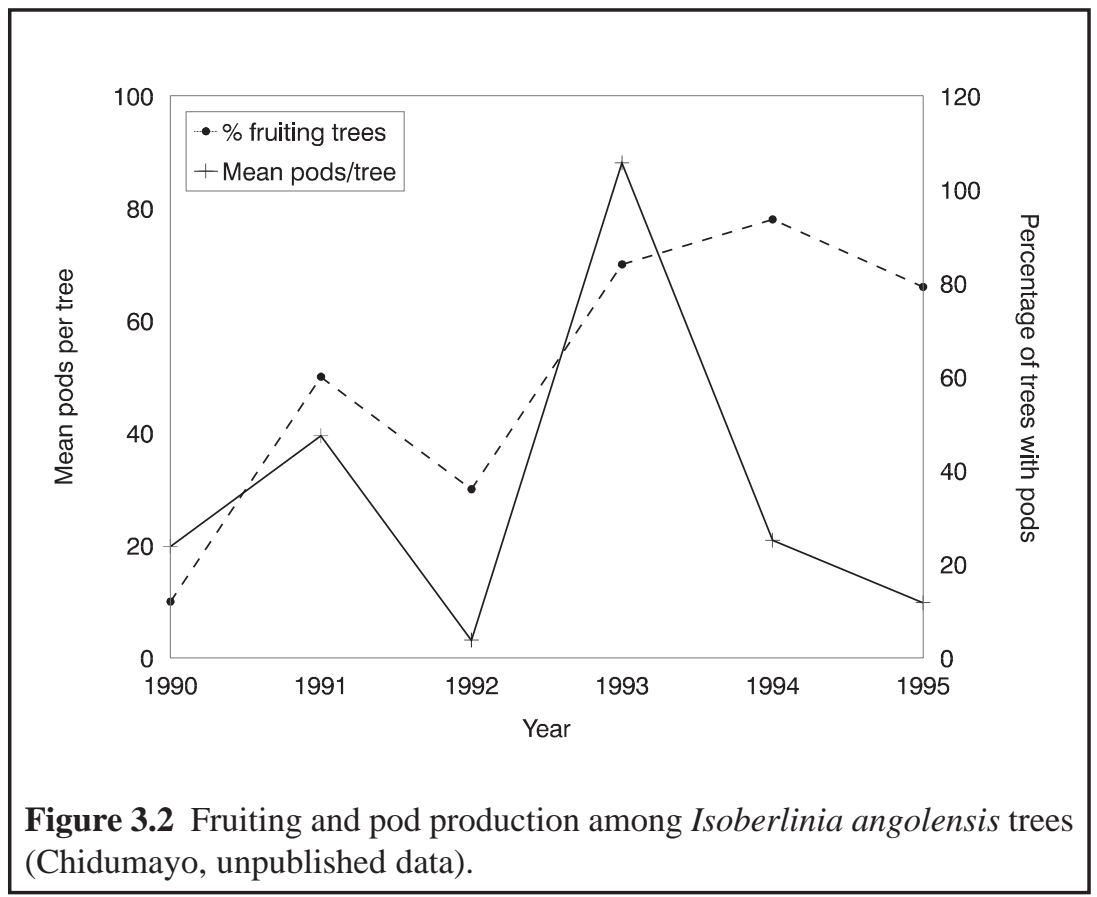

months (Figure 3.1). Fruit and seed dispersal is concentrated in the late dry season (AugustNovember), although in exceptional cases (e.g. I. angolensis) seed dispersal continues into the early rainy season.

There is great diversity in fruit types and dispersal mechanisms among miombo trees (Table 3.1). Among canopy species the pod is the most common fruit type. Seed dispersal in most of the dominant canopy tree species in miombo wood- land, including Brachystegia, Isoberlinia and Julbernardia, is by explosive dehiscence of the pods. There are also a number of canopy species dispersed by wind (e.g. Albizia and Pterocarpus species). Fleshy fruits, including fruits with seeds surrounded by pulp, are common among understorey and shrub species and animals are the common dispersal agents.

Seed-dispersal distance is limited. Strang (1969) recorded a maximum dispersal distance of

Table 3.1 Diversity of fruit and seed dispersal types (\%) among miombo woodland trees and shrubs (based on White 1962).

\begin{tabular}{|c|c|c|c|c|c|c|}
\hline \multirow[b]{3}{*}{ Tree class } & \multicolumn{3}{|c|}{ Fruit type } & \multicolumn{3}{|c|}{ Seed dispersal agent } \\
\hline & \multirow[t]{2}{*}{ Fleshy } & \multicolumn{2}{|c|}{ Dry } & \multirow[t]{2}{*}{ Wind } & \multirow{2}{*}{$\begin{array}{c}\text { Explosive } \\
\text { pod }\end{array}$} & \multirow[t]{2}{*}{ Animal } \\
\hline & & Pod & Other & & & \\
\hline Canopy & 15 & 78 & 7 & 22 & 59 & 19 \\
\hline Understorey & 48 & 24 & 28 & 42 & 4 & 54 \\
\hline Shrub & 67 & 24 & 9 & 9 & 9 & 82 \\
\hline
\end{tabular}


$22 \mathrm{~m}$ for Julbernardia globiflora seeds dispersed from seed pods suspended $5.5 \mathrm{~m}$ above the ground. Most seeds, however, were recovered within $3 \mathrm{~m}$ of the point of dispersal. Ernst (1988) recorded seeds of Brachystegia spiciformis up to $5.6 \mathrm{~m}$ from the bole, though most seeds fell within 2-4 m. Malaisse (1978a) reports a maximum dispersal distance of $20 \mathrm{~m}$ for this species in tall miombo woodland in Zaire. Even under the ideal conditions of dispersal from an isolated tree, with no surrounding canopies to interfere, few seeds are dispersed more than $20 \mathrm{~m}$ (Figure 3.3). Malaisse (1978a) found that the longest dispersal distances of 28-103 m were among wind-dispersed species, followed by those with an explosive pod with distances of 10-20 m and were shortest $(5-10 \mathrm{~m})$ among animal-dispersed species, though these may be the unsuccessfully dispersed seeds. It is difficult to trace the destination of seeds ingested by animals. The limited dispersability of dominant trees of miombo woodland implies that complete clearing of miombo woodland is likely to lead to a somewhat irreversible change in woodland composition.

Seed production and dispersal are not always good indicators of the seed crop available for germination because of both preand post-dispersal seed damage and predation. These can differ considerably among species (Table 3.2). Chidumayo (1993a) found that the proportion of mature seeds that was damaged by either disease or predators before dispersal was $14 \%$ in $U$. kirkiana and $17 \%$ in B. boehmii. The highest seed loss of $74 \%$ was observed in $I$. angolensis over a four-year period. The main predators of I. angolensis seeds were beetle larvae. Chidumayo (1993a) also observed that although damage to J. globiflora seeds before dispersal was $13 \%$, a survey of post-dispersal seeds revealed that $33 \%$ were damaged by beetle larvae. Consequently, the seed crop available for germination in miombo woodland is usually far less than actual seed production.

\section{Seed germination}

Seeds of the majority of miombo trees and shrubs germinate immediately after dispersal, as long as there is adequate water supply, for example after a heavy rain (Strang 1966; Ernst 1988; Chidumayo 1991a; 1992a). Artificially germinated seeds with an intact outer integument start germinating 4-5

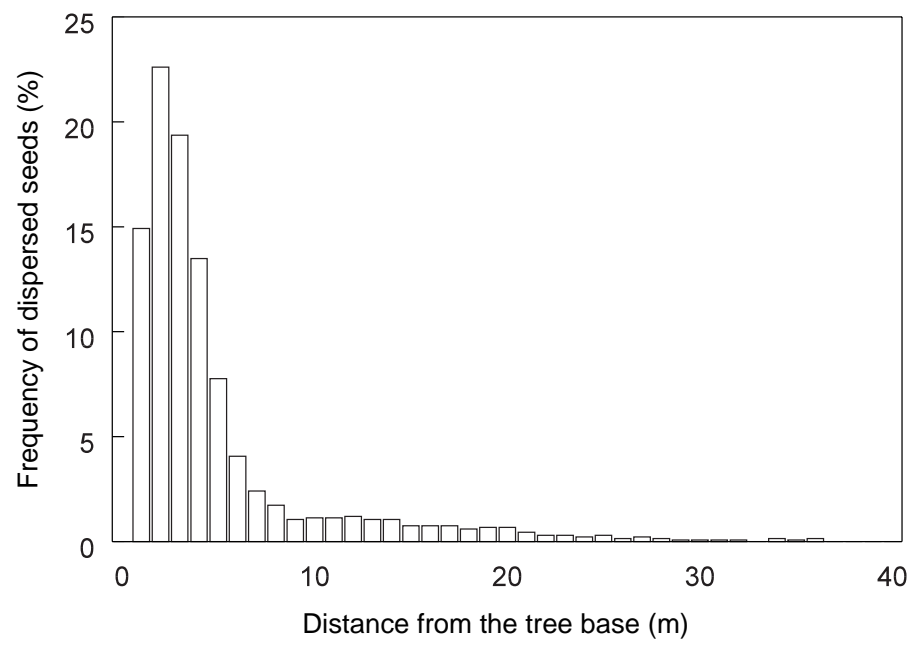

Figure 3.3 Frequency distribution (\%) of seeds dispersed from an isolated Brachystegia spiciformis, National Botanic Gardens, Harare, October 1989 (Tree height $=9.0 \mathrm{~m}, \mathrm{DBH}=0.33 \mathrm{~m}$, canopy diameter $=9.8 \mathrm{~m}, \mathrm{~N}=1327$ seeds); $78.2 \%$ of seeds were dispersed within the canopy zone (Frost, unpublished data). 
Table 3.2 Characteristics, production and pre-dispersal survival of seeds of Brachystegia allenii, $B$. boehmii, B. spiciformis and Julbernardia globiflora at three localities in Zimbabwe, July-September 1987 (Frost, unpublished data). Standard deviations in brackets.

\begin{tabular}{|c|c|c|c|c|c|c|c|c|}
\hline \multirow{2}{*}{$\overline{\text { Marongora }}$} & \multirow[t]{2}{*}{$\begin{array}{r}\mathrm{N} \\
\text { (pods) }\end{array}$} & \multicolumn{2}{|c|}{$\begin{array}{l}\text { Mean ovules } \\
\text { pod }^{-1}\end{array}$} & \multirow[t]{2}{*}{$\begin{array}{r}\text { Unfert. } \\
\%\end{array}$} & \multicolumn{2}{|c|}{$\begin{array}{l}\text { Mean seeds } \\
\text { pod }^{-1}\end{array}$} & \multirow[t]{2}{*}{$\begin{array}{r}\text { Aborted } \\
\%\end{array}$} & \multirow[t]{2}{*}{$\begin{array}{r}\text { Parasitised } \\
\%\end{array}$} \\
\hline & & & & & & & & \\
\hline B. allenii & 551 & 7.1 & $(1.1)$ & 41 & 4.2 & (1.6) & 1.2 & 11.7 \\
\hline J. globiflora & 652 & 4.4 & $(0.8)$ & 20 & 3.5 & (1.1) & 3.2 & 7.2 \\
\hline Christon Bank & & & & & & & & \\
\hline B. boehmii & 114 & 4.1 & $(1.7)$ & 22 & 3.2 & (1.8) & 13.7 & 14.3 \\
\hline B. glaucescens & 283 & 5.2 & $(0.9)$ & 37 & 3.2 & $(1.2)$ & 2.2 & 63.5 \\
\hline B. spiciformis & 234 & 6.0 & (1.3) & 44 & 3.4 & (1.4) & 3.3 & 64.2 \\
\hline J. globiflora & 286 & 5.0 & (1.0) & 15 & 4.2 & (1.2) & 5.7 & 14.5 \\
\hline Marondera & & & & & & & & \\
\hline B. spiciformis & 36 & 5.9 & (1.1) & 47 & 3.1 & $(1.2)$ & 0.9 & 70.5 \\
\hline J. globiflora & 95 & 4.4 & $(0.8)$ & 33 & 2.9 & (1.1) & 13.9 & 5.7 \\
\hline
\end{tabular}

days after imbibition while scarified seeds germinate slightly earlier, 3 days after imbibition. Covering the micropyle with nail varnish doubles the time taken for the seeds to germinate (Frost, pers. obs.). The seeds do not appear to have any inherent dormancy.

Seed germination rate among miombo trees, as determined by seedling emergence, ranges from 10-99\% and some species show differences in germination between field and laboratory conditions (Table 3.3). Chidumayo (1993a) found that dried seeds of $I$. angolensis failed to germinate under field conditions and only $20 \%$ germinated in the laboratory. Apparently, this species minimises the danger of seed desiccation under natural conditions by dispersing some seeds at the beginning of the rainy season (Figure 3.1 ).

There is no extended dormancy and no extensive store of seeds in the soils, at least among the canopy species. By mid-summer, no viable seeds of $B$. spiciformis remain in the soil (Ernst 1988; E. Chidumayo, pers. obs.). Seed viability under uncontrolled storage conditions is variable. Brachystegia and Julbernardia species lose viability within a few years, while no loss of viability was observed in Afzelia quanzensis and Swartzia madagascariensis (Chidumayo 1993a). Storage of B. spiciformis seeds at $20^{\circ} \mathrm{C}$ extended viability to five years (Ernst 1988).

The seed germination period in the majority of miombo trees ranges from 2-6 weeks, although this may be extended to 10 weeks under drought conditions (Chidumayo 1993a). Germination rates under field conditions may be lower than under laboratory conditions due to mortality during the germination period induced by dry spells at the beginning of the rainy season (Strang 1966). However, Pterocarpus angolensis seeds in Tanzania are known to germinate during the second rainy season after surviving through the first rainy season following dispersal (Boaler 1966a). For the majority of miombo trees, seeds die and decompose if they fail to germinate during the first rainy season. For this reason seeds are scarce in miombo woodland at the end of the rainy season. 
Table 3.3 Seedling emergence rate from seeds of miombo trees sown in miombo woodland soil immediately after seed ripening or dispersal (from Chidumayo 1993a).

\begin{tabular}{lcc}
\hline & \multicolumn{2}{c}{$\begin{array}{c}\text { Germination } \\
\text { percentage }\end{array}$} \\
\cline { 2 - 3 } Species & Field & Laboratory \\
\hline Afzelia quanzensis & 99 & 86 \\
Albizia antunesiana & 40 & 33 \\
Brachystegia boehmii & 10 & 69 \\
Brachystegia spiciformis & 90 & 83 \\
Brachystegia utilis & 30 & 79 \\
Isoberlinia angolensis & 74 & 73 \\
Julbernardia globiflora & 73 & 73 \\
Julbernardia paniculata & 67 & 69 \\
Pterocarpus angolensis & 25 & - \\
Swartzia madagascariensis & 36 & - \\
Uapaca kirkiana & 43 & - \\
\hline
\end{tabular}

\section{Regeneration}

Fanshawe (1971) noted that miombo woodland regrows virtually unchanged following clearing. This is because regeneration consists of stump/root sucker shoots and recruitment from old stunted seedlings already present in the grass layer at the time of cutting. Coppice shoots can be produced anywhere along the stem and branches, not just around the root collar. Coppice production and growth is affected by the height above the ground at which the stem is broken. In B. spiciformis and J. globiflora, plants which are cut close to the ground $(<5 \mathrm{~cm})$ produce less coppice growth than plants cut higher up at $1.3 \mathrm{~m}$ (Grundy 1990).

Significantly greater numbers of $B$. spiciformis seedlings are found beneath the tree canopies than in the open (Grundy et al. 1994), either because of greater seedling survival in more mesic and fertile environment under tree canopies (Campbell et al. 1988), or because of higher initial seed input (Ernst 1988). In contrast, however, recruitment of $J$. globiflora appears to be independent of canopy closure (Grundy et al. 1994), despite apparently similar limitations to those of Brachystegia spiciformis for seed dispersal and susceptibility of seedlings to desiccation (Strang 1969).

Seedlings of miombo trees generally grow slowly (Figure 3.4), even in the absence of shoot die-back (Chidumayo 1992a). Little aboveground growth occurs in the first year, most plants producing no more than two leaves. Most growth appears to be concentrated belowground.
Figure 3.4 Growth rates of Afzelia quanzensis and Julbernardia globiflora seedlings. 
In recently germinated seedlings, the radicle grows two to three times faster than the hypocotyl (Ernst 1988). Roots of seedlings of many miombo woodland trees grow faster than shoots (Chidumayo 1993a). The ability of the seedlings to survive the first dry season may be related to their ability to put down deep enough roots to give them access to subsoil moisture for at least part of the dry season.

During the prolonged seedling phase, shoot growth is largely confined to the rainy season, although the shoot extension period in saplings and trees occurs during the hot dry season (Boaler 1966a; Rutherford and Panagos 1982; Chidumayo 1993a). Afzelia quanzensis is an exception because the growing season for seedling shoots is similar to that of saplings and adult trees (Chidumayo 1992b).

Most species show a consistent increment in root biomass with some, such as A. quanzensis and $B$. spiciformis, more than doubling the biomass during the first few years (Figure 3.4). But

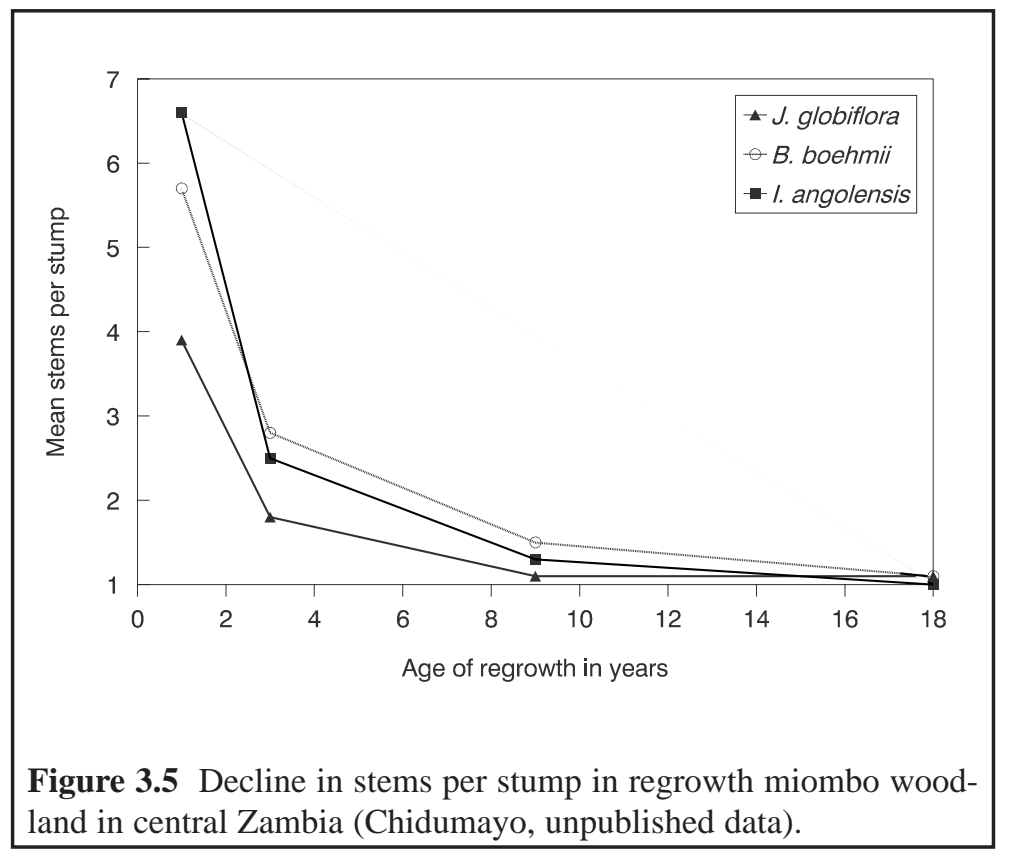

root growth in J. globiflora seedlings is inconsistent. Comparison of ring counts of root stocks and their established shoots indicates that at least eight years may be required for miombo woodland seedlings to reach the sapling phase (Lees 1962). It follows therefore that only seedlings that are eight years or older at the time of cutting miombo woodland have the chance of contributing to the next regrowth.

Miombo species regenerate largely through coppice regrowth and root suckers rather than through seeds (Trapnell 1959; Boaler and Sciwale 1966; Strang 1974; Robertson 1984). Stumps of almost all miombo woodland trees have the ability to produce sucker shoots (Trapnell 1959; Lees 1962; Boaler and Sciwale 1966; Hood 1972; Strang 1974; Banda 1988; Chidumayo 1989b). Sucker shoots arise from buds which develop on roots and stem bases. Stump survival rate in regrowth is high. Chidumayo (1989b; 1993a) recorded rates of over $95 \%$ in woodland of under 25 years, while in old-growth miombo woodland the range was $65-75 \%$. Grundy (1995a) recorded rates of $97 \%$ for $B$. spiciformis and J. globiflora in mature woodland.

Stumps produce many sucker shoots (Chidumayo 1988a; 1989b), but during the establishment period the number of shoots decreases due to inter-shoot competition and only dominant shoots contribute to the next generation of regrowth miombo woodland (Figure 3.5). Stem density per plant therefore declines slowly with age of regrowth. However, fire can either slow or accelerate this process. If a destructive fire 


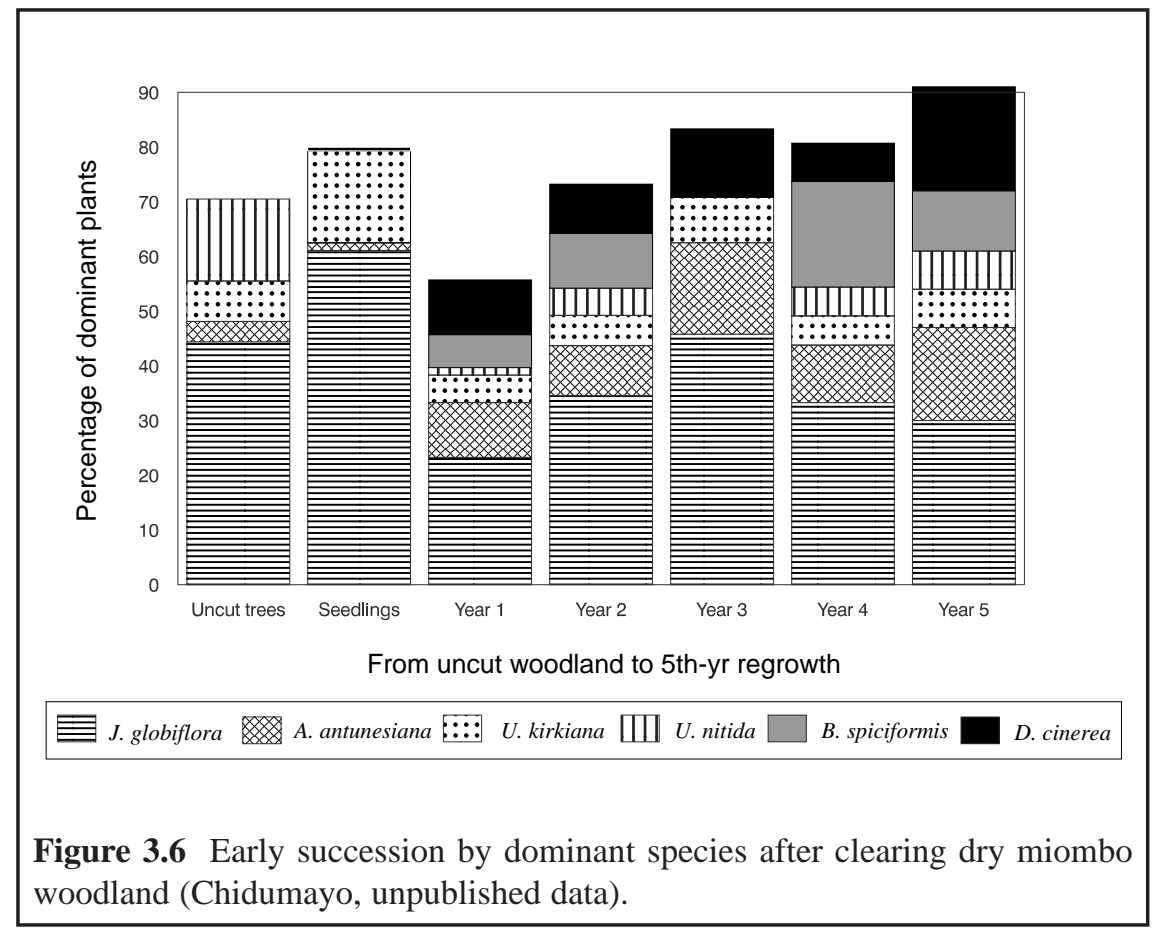

occurs before dominant shoots attain a safe height to escape mortality, the process of sucker shoot domination reverts to the initial stage and stumps respond by producing an equal or larger number of replacement shoots (Chidumayo 1988a).

After one year the sapling population in regrowth may consist of one-third coppiced stumps and two-thirds seedlings recruited from the seedling pool (Chidumayo 1993a). As a result tree density in regrowth miombo woodland is higher than in mature miombo woodland. The high level of recruitment of saplings from the seedling pool that have hitherto been stunted suggests that further development of seedlings with well-established roots is suppressed by the woodland canopy. Lees (1962) also observed that old but stunted seedlings of many miombo woodland trees are heliophytic and require high light intensities to develop and grow. An example of early succession at a dry miombo woodland plot is given in Figure 3.6. The pre-felling stand and the seedling pool was dominated by Julbernardia globiflora and this species continued to dominate the early succession in regrowth, indicating that species which are dominant at the time of felling miombo woodland are likely to dominate regrowth. Little is known about late succession in miombo woodland under natural conditions though fire is known to alter the pattern of miombo woodland regeneration and succession (Trapnell 1959).

Miombo species show a remarkable capacity to sustain regrowth, even when regrowth is regularly cut back. The response of trees to stem breakage, either from elephant damage or from chopping depends, among other things, on the species concerned, climate, soil conditions and tree size and shape. The implication of this capacity to sustain regrowth is that miombo woodland can sustain heavy cutting pressures. 
Table 3.4 Stem height growth in regrowth dry miombo woodland (based on Chidumayo 1993a).

\begin{tabular}{lrrrrrr}
\hline & \multicolumn{7}{c}{ Mean stem height $\begin{array}{c}(\mathrm{cm}) \text { of regrowth of different ages } \\
\text { (years after cutting) }\end{array}$} \\
\cline { 2 - 7 } Species & 1 & 2 & 3 & 6 & 9 & 18 \\
\hline Brachystegia boehmii & 39 & 62 & 100 & 251 & 254 & 329 \\
Julbernardia globiflora & 67 & 110 & 141 & - & 247 & 517 \\
Isoberlinia angolensis & 52 & 81 & 121 & 340 & 323 & 541 \\
Uapaca kirkiana & 60 & 75 & - & 245 & 268 & 460 \\
All species & 51 & 73 & 111 & 269 & 259 & 435 \\
& & & & & &
\end{tabular}

\section{Growth}

Stem height increments in regrowth miombo woodland are highest in the first or second year and decline thereafter (Table 3.4). Mean stem height may reach $4-5 \mathrm{~m}$ by $15-18$ years in regrowth dry miombo woodland (Robertson 1984; Chidumayo 1993a; Grundy 1995a). The slow height growth in regrowth miombo woodland increases the risk of stem mortality by wild fires.

The annual increment of girth at $1.3 \mathrm{~m}$ aboveground in Zambian miombo trees in a 49 year-old stand maintained under early and no-burn regimes, ranged from $1.1-1.5 \mathrm{~cm}$ and $0.6-1.0 \mathrm{~cm}$ for canopy and understorey species, respectively (Chidumayo 1988b). The corresponding figures for unmanaged 9 year-old coppice plots were 1.4-2.2 cm and 1.1-1.7 cm per annum for canopy and understorey species, respectively (Chidumayo 1993a). In central Zimbabwe, the relative annual girth increment was very variable, depending on site conditions. The mean growth for all trees in an area protected from fire and human disturbance was $0.27 \mathrm{~cm}^{-1}$ year-1 (Grundy 1995a).

It has generally been assumed that tropical trees do not make reliable annual rings (Lilly 1977; Celander 1983). Grundy (1995a) found that B. spiciformis in Zimbabwe forms one growth ring per year, marked by marginal parenchyma cells, even in severe droughts and in years with marked intra-wet seasonal dry periods. The rings are often very fine and difficult to discern, particularly when false rings are present. Further research is required on growth rings, which could be a valuable tool in management.

\section{Mortality}

The success of seedling establishment is low. Mortality of seedlings is initially high, during the establishment phase, but is low thereafter, even during the following dry season (Robertson 1984). The main cause of death appears to be moisture and heat stress. Seedling survival depends on the pattern of rainfall after the seeds have germinated. Early dry-season rainfall is highly unpredictable in timing, frequency, and amount, and it is usual for heavy early rains to be followed by a variable, prolonged period without significant rain before the start of the wet season proper (Strang 1969). The period between these first rains and the start of the wet season proper is usually marked by a return to the hot, dry weather that characterises the pre-rains period. Both soil moisture and temperature fluctuate greatly during the early wet season. Because most of the seeds germinate on the soil surface or on litter, the radi- 


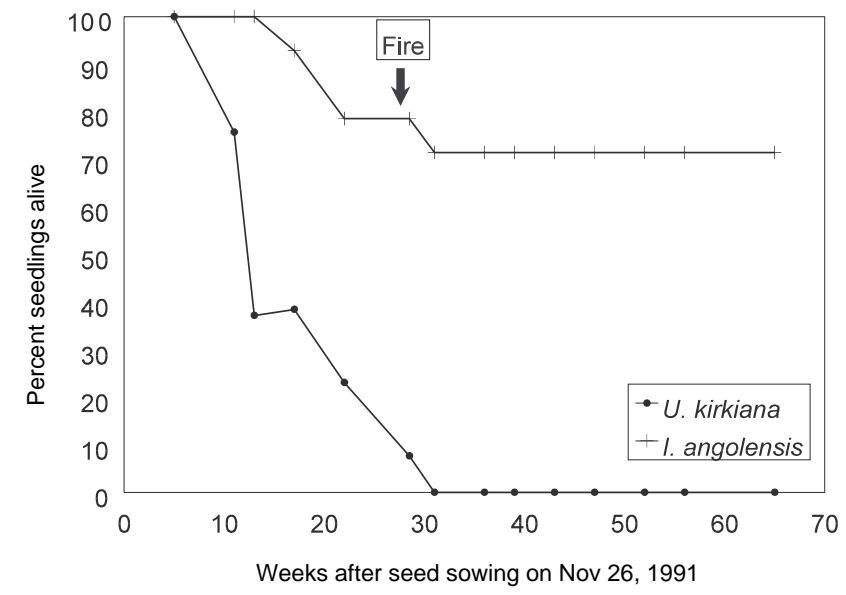

Figure 3.7 Survival of Isoberlinia and Uapaca seedlings during the first year (Chidumayo, unpublished data). 1991a; 1992a; 1992b). Under experimental field conditions tree seedling mortality rate ranged from $12 \%$ in Afzelia quanzensis to $22 \%$ in Brachystegia spiciformis, $33 \%$ in Isoberlinia angolensis, $55 \%$ in Julbernardia paniculata, $67 \%$ in Julbernardia globiflora and $100 \%$ in Uapaca kirkiana during the first year. Generally, the mortality rate declines in subsequent years. For example, none of the $J$. globiflora seedlings died in the second year while $7 \%$ died in the third year. Similarly no mortality was observed among Afzelia quanzensis seedlings in the second and third years.

Seedling mortality in miombo woodland has been attributed cle must penetrate the soil soon after germination, before the soils begin to dry out. Many seedlings fail at this stage, particularly if the soil is compacted or capped. The length of the dry season is critical. Seedlings of B. spiciformis 2-5 weeks old can survive up to 12 days drought but very few survive beyond this (Makoni 1992).

The majority of miombo woodland tree seedlings, notably Brachystegia and Julbernardia, have non-foliaceous and non-chlorophyllous cotyledons with a short life span. The cotyledons are shed at 38-75 days after germination (mean 51 days: Ernst 1988), by which time the seedlings must be sufficiently well established to survive alone. Both Brachystegia and Julbernardia have ectomycorrhizae and it also possible that the early death of some seedlings may be because these seedlings fail to establish an association with mycorrhizae by the time they shed their cotyledons.

There is considerable inter-specific variation in survival rates of miombo tree seedlings, especially during the first year (Chidumayo to drought, water stress and fire (Trapnell 1959; Strang 1966; Ernst 1988; Chidumayo 1991a; 1992a; 1992b). Inter-specific resistance to these environmental factors varies. Whereas $U$. kirkiana seedlings die from drought, I. angolensis seedlings survive both drought and fire (Figure 3.7). Similarly, B. spiciformis seedlings lack fire resistance even in the second year, while the majority of $J$. paniculata seedlings are resistant to fire. In all cases the shoots of the surviving seedlings are killed by fire but seedlings produce sucker shoots the following growing season.

The majority of seedlings of miombo trees experience a prolonged period of successive shoot die-backs during their development phase. Shoot die-back is caused by water stress and/or fire during the dry season (Trapnell 1959; Boaler 1966a; Chidumayo 1991a; 1992a; 1992b). All the shoots of J. globiflora and J. paniculata seedlings die during the first year compared to $67 \%$ among B. spiciformis seedlings (Chidumayo 1991a; 1992a). However, shoot die-back does not neces- 
Table 3.5 Stem mortality after two years of early and late burning in old-growth wet miombo woodland in the Zambian Copperbelt (after Chidumayo 1989b).

Annual mortality rate

$(\%)$

Species $\begin{gathered}\text { Early } \\ \text { burning }\end{gathered} \begin{gathered}\text { Late } \\ \text { burning }\end{gathered}$

\begin{tabular}{lrr} 
Albizia adianthifolia & 3.6 & 30.6 \\
Baphia bequaertii & 0.0 & 14.3 \\
Brachystegia spp. & 5.0 & 0.0 \\
Erythrophleum africanum & 0.0 & 16.7 \\
Marquesia macroura & 1.3 & 6.9 \\
Monotes africanus & 0.0 & 3.4 \\
Parinari curatellifolia & 0.0 & 16.7 \\
Pericopsis angolensis & 0.0 & 25.0 \\
Strychnos spp. & 0.0 & 0.0 \\
Uapaca kirkiana & 1.4 & 8.6 \\
Other species & 1.5 & 3.3 \\
\hline All species & 1.6 & 9.0
\end{tabular}

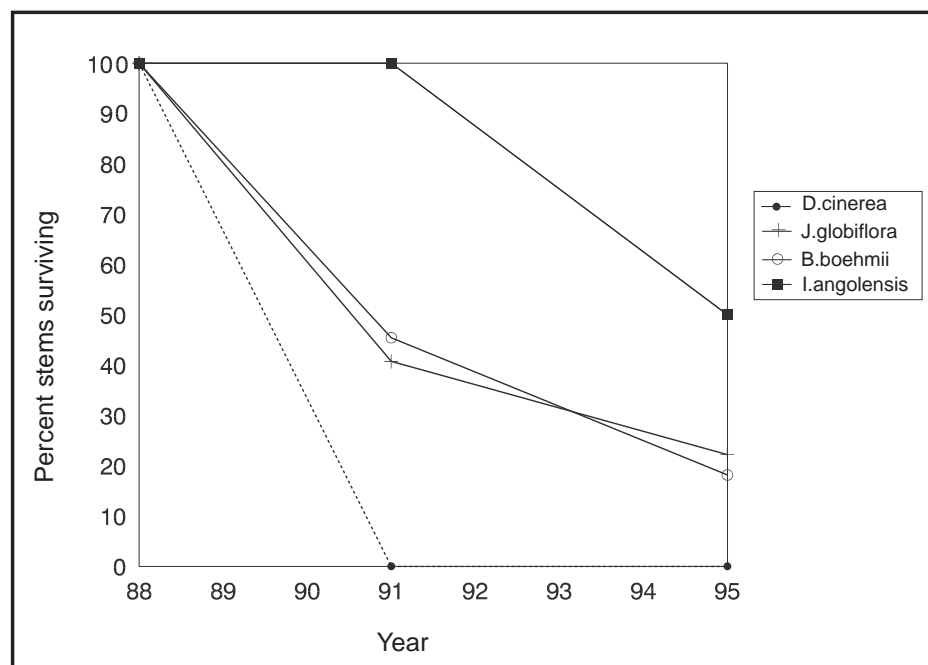

Figure 3.8 Fire-induced stem mortality in a Zambian miombo woodland stand aged 18-25 years (Chidumayo, unpublished data). sarily result in seedling death because the root often survives and produces a new shoot the following growing season. This is an important adaptation in an environment that is subject to regular annual fires and drought.

Observed tree mortality in miombo woodland under fire protection has been estimated at $0.4 \%$ per annum but early and late burning over an eleven-year period increased this to $0.6 \%$ and $1.6 \%$, respectively (Trapnell 1959). Fire is therefore a significant cause of tree mortality in miombo. In a different study, stem mortality under late burning was 5-6 times higher than under early burning but mortality varied among species (Table 3.5) and stem sizes. The mean girth at $0.3 \mathrm{~m}$ aboveground of dead stems in oldgrowth woodland was $17.0 \mathrm{~cm}(\mathrm{SD}=15.6)$ and $83 \%$ of these had a girth of less than $31 \mathrm{~cm}$ while only making up $64 \%$ of the total stem population Chidumayo 1989b). In regrowth miombo, fire may completely eliminate stems of fire intolerant species and drastically reduce stem density (Figure 3.8). Browsing pressure on preferred trees can have similar results (Hood 1972; Chidumayo 1995).

Mortality among broken or pushed-over trees is greater in drier climates and on more-fertile clayey soils with low infiltration rates (Bell 1982). The dominant canopy species in Zimbabwean miombo woodland, Brachystegia spiciformis, B. boehmii and Julbernardia globiflora all coppice profusely if the main stem is broken or chopped. What is less certain is whether these species regenerate at the same rate. Many species also produce root suckers, especially if the roots are damaged or exposed (Robertson 1984). The dynamics of re-covery from disturbance 
will therefore be governed largely by which individuals, of what species and in what numbers, survive the disturbance.

\section{Discussion and conclusions}

The size-frequency distributions of mature miombo woodlands generally show the reverse-J distribution characteristics of self-replacing stands (see Figure 7.1). Not shown in such diagrams is the large number of small shrubs and suffrutices, many of which are juveniles and suppressed saplings of canopy trees. These comprise $70-90 \%$ of the total number of woody plants in a miombo stand (Ward and Cleghorn 1964; Boaler and Sciwale 1966; Guy 1981a; Robertson 1984). Miombo woodlands, if cut or grazed, are remarkably resilient to these disturbances, because the trees produce profuse coppice shoots and root suckers. In addition, miombo woodlands have vast numbers of suppressed seedlings and saplings.

On the other hand, miombo woodland depends on regeneration from existing root stocks, seeds have low dispersability, there is no long-lived seed store, and there is low survival of seedlings early in life.

The widespread clearance of the miombo woodlands presently under way will dramatically affect the nature of plant cover in the future. The eventual death of resprouts/root stocks or exhaustion of seed resources will eliminate many miombo species locally. Because of their low dispersability, they will not easily reinvade these areas, making the recovery of woodland slow and uncertain. This makes miombo woodland susceptible to invasion by woody weeds. Lantana camara is already a widespread invasive

\section{Box 3.1}

\section{Functional attributes of miombo trees requiring documentation}

- Maximum size

- Crown diameter

- Vertical position of crown (canopy, subcanopy, understorey)

- Crown shape

- Shade tolerance (seedlings, adults)

- Longevity

- Sensitivity to moisture stress

- Sensitivity to temperature stress (low temperatures)

- Sensitivity to nutrient stress

- Maximum and mean growth rates (seedlings, saplings and mature trees)

- Sensitivity to fire

- Sensitivity to herbivory

- Specific leaf area $\left(\mathrm{cm}^{2} \mathrm{~g}^{-1}\right)$

- Photosynthetic rates

- Half saturation point

- Compensation point

- Transpiration rates

- Respiration rates

- Rooting characteristics weed in Zambia (Lawton 1982) and in the wetter parts of Zimbabwe (P.G.H. Frost, pers. obs.).

This chapter is based on scattered pieces of information for different species. While it is possible to identify general trends, a full understanding of the population ecology of individual species is lacking. Such information will be essential for developing technical options for miombo woodland management (Chapter 7), as well as feeding into models of woodland dynamics (Box 2.6). It is timely to consider developing a research agenda that will address the full spectrum of biological traits of some key miombo species (Box 3.1). 


\title{
Chapter 4
}

\section{MIOMBO WOODLANDS IN THE WIDER CONTEXT: MACRO-ECONOMIC AND INTER-SECTORAL INFLUENCES}

\author{
Salome Misana, Claude Mung'ong'o and Billy Mukamuri
}

\section{Introduction}

Much of the miombo woodlands have been subjected to intensive use, such that there is very little unmodified miombo woodland remaining (Plate 4.1). Dewees (1994), referring to a number of land use studies in the region, reveals that over 95\% of existing woodland cover in Malawi has been heavily modified, while mature miombo woodland in the Tabora region in Tanzania is mostly secondary. Similarly, extensive areas of miombo woodland in Zimbabwe are secondary, after formerly cultivated areas were depopulated during the early 19th century because of the Ngoni invasions (Lawton 1982). Although it is generally agreed that miombo and associated woodlands are increasingly being cleared, the extent of such deforestation is unknown due to paucity of data on woodland areas, stocks and yields (Chapter 2). It is not only the woodlands that are changing; the key wetland resources (dambos) are also undergoing much modification (Box 4.1).

Local patterns of utilisation (Chapter 5) and many of the changes in miombo woodland have been driven by macro-level phenomena. This chapter discusses the changing patterns of miombo woodland utilisation and cover over time, and explores how these are related to changes in social, political and economic processes. Emphasis is placed on national policies such as those related to land, agriculture, forestry, energy and population, as these form the framework for life in the miombo region.

\section{Historical perspectives on miombo woodland utilisation}

Taking an historical time perspective, it is postulated that changes in miombo woodland have taken place in phases, in response to various factors. Among the major factors are the precolonial long distance caravan trade, the Ngoni penetration, the great rinderpest epidemic, the colonial intervention, the introduction of the plough, the introduction of the market economy, growing rural populations and post-independence restructuring. Some of these factors are highlighted below. 


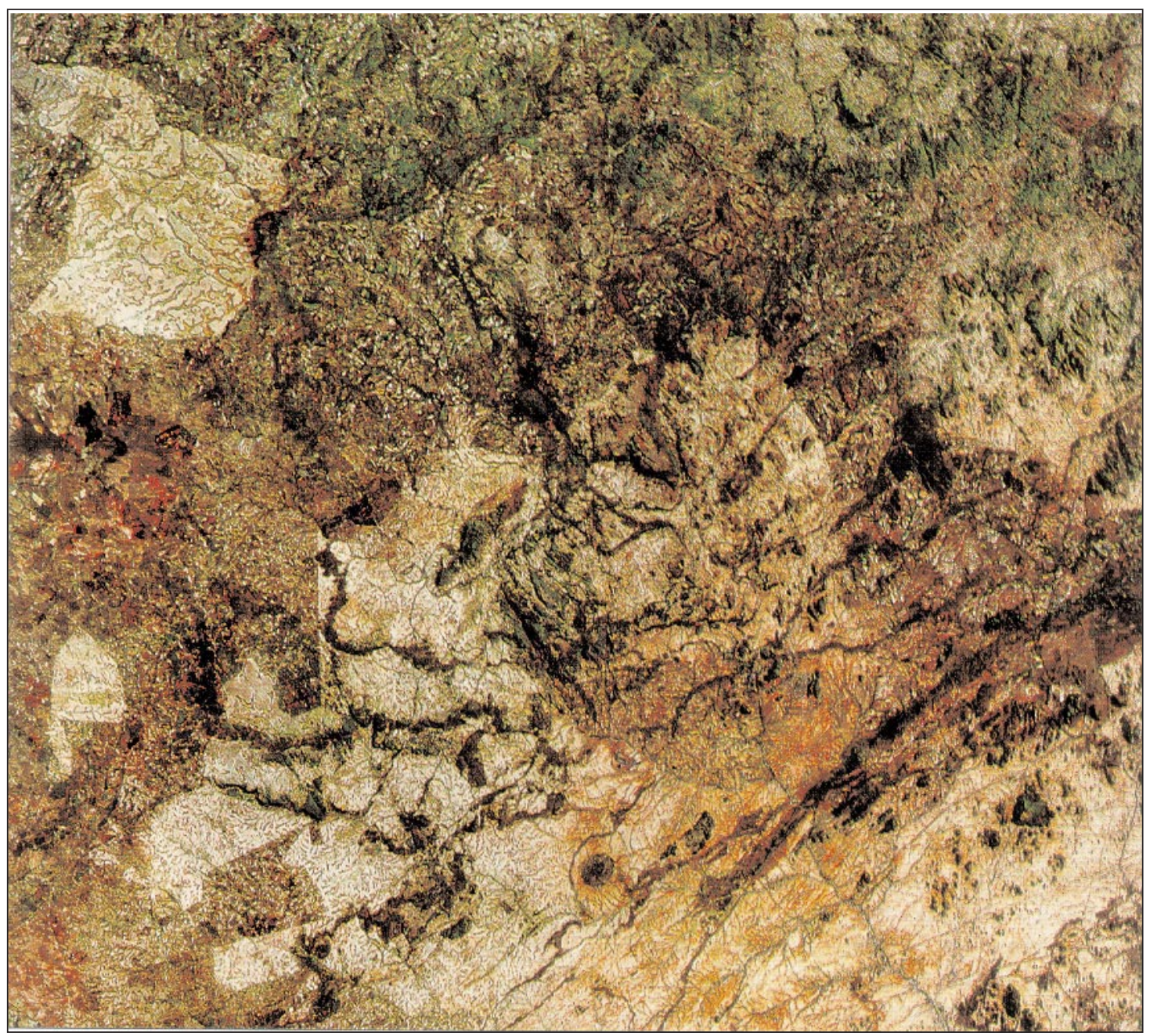

This satellite image vividly displays the impact that land policies have had on miombo woodlands in Zimbabwe. The light colours are communal areas where most of the woodland has been removed due to a long history of dense settlement. The dark green areas are large-scale commercial farms, formerly European land. The boundaries between the areas can be easily seen.

\section{The long-distance caravan trade}

Until the end of the 18th century, trade in products was limited. Production and trade were controlled by local kinship systems, largely based on iron tools and a few exotic luxury goods that were assimilated into categories of bride-wealth (Gray and Birmingham 1970). Ethnic groups were politically organised either around kinship relationships, or around neighbourhood community institutions, or in highly stratified power structures. Equivalent systems of land tenure and ideological control of the use of the land resource base were also developed. 


\section{Box 4.1 \\ Are dambos drying out? Farmers' perceptions in Zimbabwe}

Bevyline Sithole

Environmental changes in the miombo landscape are reflected in the drying out of dambos. Early observations of desiccation of dambos in commercial agricultural areas prompted the passing of legislation to prohibit cultivation of these areas (Water Act of 1927; Natural Resources Act of 1952) (Whitlow 1985b). Similar observations were made in communal areas (Grobler 1945; Rattray et al. 1953). Many researchers have claimed that it is local patterns of use of dambos that have resulted in desiccation (Rattray et al. 1953; Elwell and Davey 1972). These researchers argue for limited dambo use as a safe policy, until the causes and extent of desiccation can be determined. A number of recent studies dispute the claims that extensive desiccation has occurred, and that local use of dambos by communal farmers is the cause (Bell et al. 1987; Whitlow 1983; Scoones and Cousins 1994). The opposing views are highly speculative, emotive and not supported by any empirical data.

While researchers seem divided about dambo desiccation, farmers seem very sure that desiccation has occurred and have strong opinions about the causes and impacts. Using weight ranking on time charts, communal farmers in Mutoko and Chiduku in Zimbabwe, discussed the changes they have observed on dambos (see figure). Severe desiccation was said to be reflected by the increasing depth to moist soil and the lower frequency of occurrence of sponge areas. In addition, farmers felt that there had been drastic deforestation of the small woodland groves on the dambos (mostly Syzygium).

$\because$ Depth of soil moisture ('unyoro')

$\equiv$ Numbers of trees

$\square$ Availability of sponges
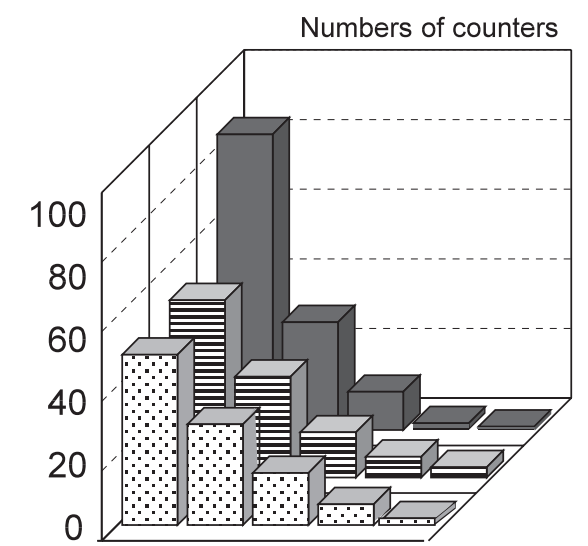

0

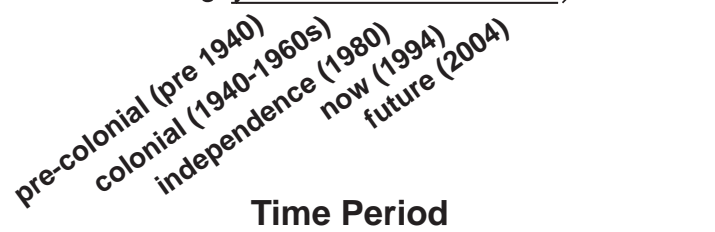

Patterns of change on dambos, as reflected by farmers using markers on a time chart 
Are dambos drying out? (continued)

Farmers give four main reasons for dambo desiccation. One reason is decreasing rainfall which is discussed by the farmers in terms of four locally recognised kinds of rain, differing in intensity, amount, period and purpose. The different types of rainfall are said to have changed in character and occurrence. When emphasising decreasing rainfall trends, farmers refer to desiccation on dambos in commercial farms where no cropping is occurring. However, analyses of rainfall data show no decreasing trend, at least for the period prior to the 1980-1990s (Wilson 1989b).

Another reason is associated with events after independence in Zimbabwe in 1980, when there were widespread encroachments on areas where cropping had been prohibited. During this period, water-yielding areas on dambos were drained to open up more land for wetland cultivation. In Chiduku, farmers would construct ridges and grow tsenza (Cleus esculentus) or sweet potatoes for two years, before they used the land for other crops. None of the conservation techniques which had been previously promoted by the government were practised as these were regarded as elements of the colonial past. Drying out is said to have been accelerated during this period.

Farmers also see dambo desiccation as punishment for not following traditional practices and rules. This view is expressed by many of the older members of the community, who claim that many sacred areas have been desecrated. People have broken taboos, disregarded rules about harvesting products, and started encroaching on the prohibited areas. The culprits are said to be largely women from other ethnic groups who have married into the village, young men and migrants.

Finally, farmers blame government policies which promoted widespread fencing of dambos, particularly tree groves, during the 1940s and 1950s. Some farmers say fencing of certain resource units on dambos angered the mhondoros (ancestral spirits) who could no longer access their drinking places. Farmers in Chivi communal area explain that "wet areas should not be fenced because the njuzu (water sprite) will flee in fear of the wire.....these places are protected by the njuzu" (Scoones and Cousins 1994).

For example, in central Tanzania during the pre-colonial period, all land in Kondoa Irangi was deemed a social property for the whole ethnic group. Individual heads of homesteads could, however, have inheritable rights to some of this land. Among the Rangi of Kondoa District heads of homesteads had inheritable rights to the 'blood-earned land' (Mung'ong'o 1995). These were clan lands that the 'founder' had cleared the bush and generally made suitable for living in and for cultivation. Such clan lands also existed in Zimbabwe (Gumbo 1993).

By 1780 , only one inland long-distance trade route existed in the miombo region, starting from Kilwa on the southern Tanzanian coast and leading into the densely populated country around Lake Nyasa, south-western Malawi, eastern
Zambia and northern Mozambique (Iliffe 1979). This route was dominated by the Yao who carried ivory, slaves and grain from the central African region to the Indian Ocean coast.

The most active trade route was perhaps the central route in Tanzania (Figure 4.1). Pioneered around 1800 by the Sumbwa and the Nyamwezi of the western plateau of Tanzania this route was, by 1825 , dominated by Arab and wangwana traders (Arab half-castes and Swahili people from the coast who had converted to Islam). Traders exchanged coastal wares, especially cloth from India and firearms from Europe, for ivory, rhinoceros horn, slaves, iron hoes and work in the Arab plantations at the coast (Iliffe 1979). Feeder routes were joined to it from northern Zambia and Malawi, Rwanda and Burundi. 


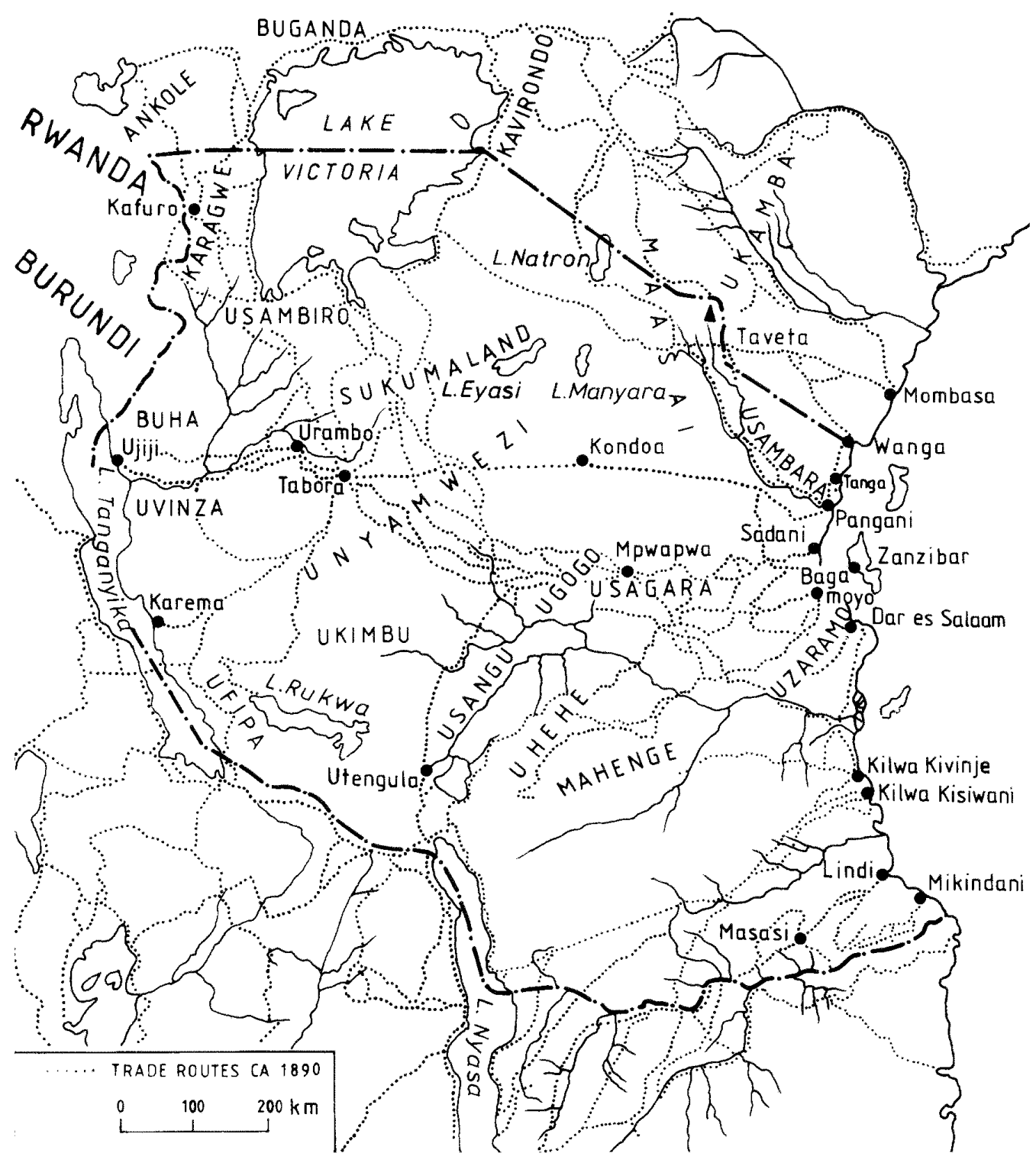

Figure 4.1 Trade routes in Tanzania in the late 19th century. 
In the western part of central Africa, the most influential route was the one originating from Kasanji and Bihe in western Angola. This route was opened up around the mid-19th century by the Ovimbundu traders who came to purchase slaves and beeswax (Turner 1962).

The long-distance trade had a major impact on the local economy, creating new forms of economic specialisation and disrupting traditional farm labour regimes. The involvement of large numbers of able-bodied indigenous people in the trade withdrew experienced labour from the existing farming systems, leaving agricultural production in the hands of women, the elderly and, in some places, slaves (Gray and Birmingham 1970). On the other hand, with the increase in the caravan population, the demands for foodstuffs and merchant goods such as grain, iron hoes and ivory also multiplied. At supply points there was massive clearing of the miombo woodland, both for expanded agricultural production and for woodfuel supplies to the iron-smelting kilns. The luxuriant woodland that sprawled over a large part of Kondoa District in central Tanzania was debarked for the manufacture of vyome, traditional grain storage structures that were needed for increased grain storage (Ostberg 1986).

Traditionally, the fields in the miombo woodlands under the various shifting cultivation systems were left fallow for at least eight years. In that period $90 \%$ of the plant biomass would regenerate (Moran 1979). With changing land use and growing population pressure, the length of fallow was, in many instances, shortened so that the farming system moved from woodland fallow to bush fallow and, in cases like Kasulu in Western Tanzania, to grass fallow (Lyaruu 1995; Yanda and Mung'ong'o 1995). Such a process of intensification led not only to decreased soil productivity, but also to increased labour demands. Territorial expansion seems to have been the natural response by people living in the miombo woodlands of east and central Africa to such dwindling soil productivity.
The adoption of the wangwana culture in the east and central African hinterland also affected the local natural resource management systems (Raum 1965). For example, the introduction of a money economy promoted the cultivation of crops for sale and thus extra demands on land, leading to further clearing of the miombo woodland. New crops, such as maize, sugar cane, bananas and mangoes were introduced to the hinterland, leading to different demands on land and labour. In areas which acted as sources for slaves, such as north eastern Zambia and Malawi, slave hunting brought great social disorganisation and a sense of insecurity (Vail 1977). For instance, in Zambia, many people living to the west of the Luangwa River fled to other areas to escape the slave-hunting ravages of a certain slave trader, leaving vast areas of agricultural land to revert to woodland.

Trade in ivory probably also had an impact on the woodlands. Ivory exports from the east and central African region are said to have risen considerably in the 19th century. Thus a large number of elephants, averaging between 40000 and 50 000, were slaughtered (Koponen 1994). Elephants are highly destructive of woodlands due to their size and feeding habits (Cumming 1982). The decline in elephant populations probably led to regeneration of woodlands in many areas.

\section{The Ngoni penetration}

One of the many early migrations was that of the Ngoni. Around 1855 the area between the Luangwa River and Lake Nyasa in Malawi and Zambia was inhabited by scattered populations of the Chewa, Nsenga, Tumbuka and other minor ethnic groups (Fields 1985). While the plateau supported a denser population due to its fertile soils and moderate climate, the Luangwa Valley had a sparser human population and a wealth of game. In the mid-19th century the Ngoni invaded this country from the south, causing much social disorganisation (Vail 1977). To defend themselves 
the Chewa and other indigenous peoples crowded into stockaded villages, and their agricultural systems possibly also changed from shifting cultivation to a more permanent form of settled cultivation. Similar processes occurred in Mozambique and Zimbabwe. For example, in Mozambique such invasions accounted for the concentration of large population clusters at Metonia and Unango which were strategically located for defensive measures in mountain tops or river islands (Coelho 1987). In Zimbabwe during the late 19th century, most Shona people settled around hill fortresses so as to protect themselves from raiders (Wilson 1989b; Campbell et al. 1995b). Agriculture was largely based on permanent cultivation of wetlands. Shifting agriculture only re-emerged in the early 20th century with the arrival of the colonialists who subjugated the raiders.

As the Ngoni settled permanently in the areas they had conquered, the settlement patterns also changed. The Mpezeni Ngoni and their assimilated peoples, for example, are said to have lived in densely-settled areas surrounded by broad, empty zones, once inhabited but no longer so. As the woodland flourished in the empty zone, so it was denuded in the areas in the immediate vicinity of the settlements (Vail 1977; Box 4.2).

\section{Box 4.2 \\ A miombo landscape at the turn of century \\ from Crawford (1899)}

"Before us lay an undulating valley some miles in breadth, which, as the heavily timbered hills on either side proclaimed, had once been covered with forest, but was denuded of every vestige of a tree. Village after village surrounded by waving cornfields and green plains dotted with herds of cattle stretched away into the distance."
In southern Mozambique where the soils were poorer, such concentrations of people during the 19th century resulted in extensive clearing of woodland. For example, throughout Muzila's and Ngungunyane's regimes, the densely populated settlements in Gaza caused so much degradation of land that the groups had to continually move on, not staying in one place for more than three or four years (Coelho 1987).

\section{The great rinderpest epidemic}

The territorial expansions described above seem to have continued and grown in magnitude until the outbreak of the great rinderpest epidemic in the region. The epidemic seems to have first entered East Africa in a two-pronged thrust via Ethiopia and Somaliland. In both instances its entrance was associated with European wars in the two countries. Once it became established in Kenya and Uganda the disease spread rapidly all over the rest of east and central Africa, reaching present-day Botswana in 1896 (van Onselen 1972).

Its ravages were as widespread. With the decimation of more than $90 \%$ of the region's cattle herd, the economic backbone of many of the prosperous and relatively advanced communities was broken. People who depended totally on livestock for a livelihood were the worst hit. Apart from the inevitable famines that ensued as a result of the calamity, the epidemic changed the entire way of life of these otherwise proud people. For example, in the Mpezeni's country wild game, on which the local people depended for protein, were decimated, and large numbers of cattle, the Ngoni's main form of wealth, were killed (Vail 1977). A large number of the Hima pastoralists of Karagwe and the Maasai in East Africa perished. Those who survived did so by resorting to hunting, begging or even stealing from their agricultural neighbours. In the more favourable environments many pastoralists barely survived by taking up crop cultivation (Berntsen 1976). 
The bovine and human depopulation, as a result of the epidemic, eased grazing pressures on the land, and abandoned grazing and farm lands were once more covered by regenerating woodland. However, this woodland offered excellent habitat for the tsetse fly, Glossina morsitans, which brought with it the dreaded human and animal sleeping sickness. As a result, the remaining population became more and more concentrated in smaller but safer areas, thus probably also increasing the extent of local clearing of the miombo woodland (Fosbrooke 1954; Mushala 1980). Interviews in central Tanzania confirm, for example, that for some time the advance of the tsetse fly belt halted the Rangi expansion into the lowlands, and concentrated woodland clearing for agriculture and grazing activities within the ecologically fragile Kondoa Irangi Hills (Mung'ong'o 1995).

\section{The colonial intervention}

The relationship between the various communities in pre-colonial east and central Africa and the outside world goes back many centuries. The coastal communities, for example, are documented as having had some trading in ivory, copra and slaves with the Arabs as early as the 11th century. However, these early relationships were more of an economic nature than political. The colonial involvement in the political affairs of African societies dates from the last decade of the 19th century (Iliffe 1979).

De facto colonial rule over the vast east, central and southern African region, dating from the late part of the 19th century was not uniform and was not easily established. It was only after a series of wars, punitive expeditions, scorchedearth policies and oppressive campaigns that a semblance of obedience to foreign rule was accepted by many of the indigenous communities. During the period of pacification, populations were mobile and agricultural systems were disrupted, with concomitant impacts on woodlands and tsetse infestation (Kjekshus 1977).
Land-use decision making changed with the introduction of a wide range of policies and legal acts. For example, The Land Ordinance (1923) in Tanzania, declared the whole of the land in the country to be Public Land under the control and subject to the disposition of the King. It was in the wake of these changed decision-making powers that the colonial state embarked on tsetse eradication campaigns, and mass evacuation of populations at risk of sleeping sickness, in areas like the Luangwa Valley in Zambia (Vail 1977) and Kigoma and Liwale in Tanzania, resettling the populations in concentrated villages in tsetsefree areas. Tsetse eradication programmes involved bush clearing (Williams et al. 1995; Box 4.3), while population movements led to regenerating woodlands in some areas and woodland clearance in others.

Numerous programmes were initiated in the name of development. In Tanzania, the 'land reclamation' programme was implemented in two phases. In the first phase the land that had previously been invaded by the tsetse fly in the miombo woodlands was reclaimed by the clearing of the woody biomass. This reclamation process facilitated, in the second phase of the programme, the destocking of cattle and the resettlement of the human population from the badly eroded mountainous areas. The clearing of woodland was done through forced mobilisation of local labour, creating an enduring stigma on present day local perceptions of woodlands and afforestation campaigns (Mung'ong'o 1995). By 1952 the tsetse flies had almost been eliminated in the cleared areas. Regenerating vegetation was slashed to ensure that the areas did not revert to woodland again. Thus the woodlands which had previously formed suitable habitats for tsetse flies were reduced to open vegetation types. The introduction of the ox-plough further encouraged the opening up of new lands further into the miombo woodlands.

Most colonial governments immediately adopted land-alienation policies which led to 


\section{Box 4.3 Impacts of tsetse eradication programmes}

\section{Gordon Matzke}

Miombo landscapes offer ideal habitat for tsetse fly (Glossina spp.) of the morsitans group. Accordingly, tsetse are resident in much of Mozambique, Tanzania, Zaire and Zambia, while occupying smaller areas of countryside in Angola, Zimbabwe, Namibia and Botswana. Tsetse ranges are dynamic, with documented episodes of substantial contraction and expansion during the last century (Ford 1971; Kjekshus 1977; Jordan 1986). While the biggest range shifts are accounted for by unplanned changes in ecological conditions, other shifts result from planned attempts to eradicate tsetse populations. Tsetse are a vector for Trypanosomiasis, a disease that effectively precludes cattle use of most miombo landscapes north of the Zambezi River.

On a continental scale, tsetse eradication programmes have been most successful in achieving long-term fly suppression on the spatial margins of tsetse range. As a substantial portion of miombo woodland is in core tsetse range, it has been less affected by control efforts than have the forested riverine habitats on the arid margins. This pattern is likely to remain true for the foreseeable future.

Any assessment of the impact of tsetse control is difficult and must be conditioned by the time, place, methods, goals, scale and values under consideration. Broad-scale tsetse eradication is not always a wise and effective expenditure of revenue to stimulate rural development (Matzke 1983; Jordan 1986). The development value of tsetse suppression is low in the absence of a sufficient human agricultural population with the means to effectively utilise the treated landscapes. As many miombo landscapes have poor agricultural prospects and few people, the cost-effectiveness of tsetse control expenditures must be closely examined for most sites.

The environmental impacts of anti-tsetse operations are equally problematic and situational. Although wildlife have been heavily affected in the past (Matthiessen and Douthwaite 1985), history is not a perfect guide to the future as tsetse suppression methods are changing. Formerly criticised methods like the decimation of wildlife hosts, ruthless bush clearing and the widespread use of persistent pesticides have fallen out of favour. Currently-favoured approaches centre on the use of targets/traps (often following aerial spraying of low dose non-persistent insecticides), with increased consideration of local community involvement in the deployment and maintenance of targets/traps (Jordan 1990; Green 1994). Although targets/traps avoid most direct decimation of plant and animal communities, the placement and service of traps requires extensive access road networks even in uninhabited wildland locations. Once access is provided, the de facto protections provided by isolation are removed, and unauthorised hunting, tree cutting and settlement may increase.

The direct environmental impacts of successful tsetse control are likely to be outweighed by the far greater environmental alterations resulting from the invasion of cattle and associated spontaneous settlement into areas newly liberated from the fly. The purpose of tsetse control is to provide for new land-use options. The establishment of new land use patterns extends the impact of tsetse control operations beyond the lifetime of the tsetse eradication programmes themselves. 
much of the land, especially the more fertile, being reserved for European settlers, concession companies and as Crown Lands, resulting in a highly inequitable distribution of land. Peasants were displaced onto less fertile, marginal lands (Moyo et al. 1993). In Tanzania, for instance, some $40 \%$ of total land under cultivation by 1956 was appropriated by settlers (Mbilinyi 1988). In Zimbabwe, large tracts of fertile land were wrested from the local population and allocated to the British South Africa Company. This process concentrated an estimated 530000 of the indigenous population in 8.4 million hectares of marginal land, leaving most of the country in the hands of a few thousand settlers (Mpofu 1987). These land changes led to the establishment of African Reserves in Zimbabwe, Zambia and Malawi (Moyo et al. 1993).

In the south western part of Zimbabwe, the first African Reserves were established in 1895 in the infertile and low-rainfall areas of Shangani and Gwaii (Riddell 1979). The Land Appropriation Act of 1930 further marginalised a large number of people who were forced out of their original homelands (Mukamuri 1995a) (Table 4.1). The Act made tenancy illegal, thereby undermining the ability of landless people to access land (IIED 1994). It also sharply reduced the supply of land to black Africans by depriving them the right to buy farms outside the 'African Purchase Areas'. Landlessness became a problem in the African reserves. By the late 1950s, 30\% of the African population in Zimbabwe was already landless (Moyo et al. 1993).

Ironically, while the areas allocated to Africans became overcrowded, severely deforested and degraded, much of the land under European occupancy, excluding that where tobacco was cultivated, reverted to forest (Vail 1977). For example, of the total 14.9 million hectares owned by the settlers in Zimbabwe in 1973, only 4\% were under crops (Riddell 1979).

In Zambia the creation of Crown Lands and Native Reserves during 1928-1929 led to the expulsion of large numbers of the indigenous population from their former lands and their resettlement in the Eastern and Southern Provinces (Vail 1977). In eastern Zambia, for example, some $9000 \mathrm{~km}^{2}$ of the most inferior land was set aside as a reserve for more than 150000 Africans. Meanwhile, about $17000 \mathrm{~km}^{2}$ of the best land was allotted to 80 European settlers. The resulting overpopulation of the reserves led to reduced fallow periods and over-cultivation of the miombo woodlands in the two provinces (Chidumayo 1987b). An extensive programme of woodland clearing, game shooting and accelerated resettlement of Africans on empty lands was attempted in 1944. However, lack of manpower due to labour migrations hampered large-scale clearing (Vail 1977).

The colonial intervention was also marked by wide-ranging changes of institutional arrangements for the control of land and natural resources. These issues are dealt with in detail in Chapter 8.

\section{Globalisation of economies}

Since the early 20th century, one of the main foci of colonial governments was increased agricultural production. Policies were set in place to encourage cultivation, mainly in the settler sector, of export crops such as tea, tobacco, coffee and cotton (Moyo et al. 1993). Economies were increasingly drawn into the world market.

Table 4.1 Land distribution patterns in Zimbabwe following the 1930 Land Appropriation Act (Riddell 1979).

\begin{tabular}{lr}
\hline Category & $\%$ \\
\hline Unassigned & 18.5 \\
Settler farms & 51.0 \\
African Reserves & 22.0 \\
African Purchase Areas & 7.8 \\
(freehold titles) & \\
State forest & 0.6 \\
Undetermined & 0.1
\end{tabular}


The introduction of Hut or Poll taxes by the colonial governments forced peasant farmers to sell their labour or to grow cash crops. In Zambia, Malawi and Mozambique, many young people were forced to migrate for wage labour to the farms, mines and factories of Southern Rhodesia (now Zimbabwe) and South Africa (Moyo et al. 1993). What emerged was a dual economy comprising a relatively developed European sector and an underdeveloped African sector.

The integration of national economies into the world market led to intensification of agriculture in both commercial and smallholder farms in order to meet market demands for export crops. Tobacco became an important crop in the woodland areas of Tanzania, Malawi and Zimbabwe, and its increased production was encouraged through incentive schemes such as technical assistance and financial credit for mechanised operations, fertilisers and other equipment (Misana 1988; Moyo et al. 1993). Such intensification led to accelerated conversion of woodland areas to crops and pasture lands, and increased demand for fuel for tobacco curing.

In northern Mozambique, for example, forced expansion of peasant cultivation of peanuts and cotton for export to South Africa and Britain led to serious deforestation of the miombo woodlands in the 1940s (Coelho 1987). State officials introduced cotton farming in such unsuitable areas as the Moribane highlands, to the detriment of the woodlands. Meanwhile, a cotton market was established in the Derre forest reserve. In the Cheringoma ward officials promoted the felling of a dense woodland for dryland rice plantations. By 1951 the Mogovolas District of Nampula Province had lost over 52\% of its 570000 hectares of woodland (Coelho 1987).

The large quantities of exploitable minerals and high potential for agriculture in Zambia and Zimbabwe attracted interest in mining and commercial farming. In Zambia, the opening up of copper mining activities in the Copperbelt area in
1937 led to an unprecedented urbanisation in the province (Chidumayo 1989a). The urban areas required huge amounts of woodfuel harvested from the woodland in the area (Chapter 6).

In order to enhance agricultural development and mining activities, the colonial governments constructed roads and railways to access areas with great potential in terms of agriculture and minerals. It is at this time that the central railway in Tanzania was constructed by the Germans linking the port of Dar es Salaam with the hinterland, while the British South Africa Company constructed the railway line to Katanga in Zambia linking up the territory north of Zambezi (Christiansson 1988; Moyo et al. 1993). The construction of the railway line in Zambia determined the geographical pattern of development that persists to the present day.

The railway line in Zambia was developed to serve the better soils stretching from Livingstone in the south of the country to the Copperbelt in the north (Moyo et. al. 1993). Thus most of the economic activities including commercial agriculture, mining and industries became concentrated along the line of rail, resulting in population concentrations, rapid urbanisation and high rates of deforestation (Moyo et al. 1993; Mupimpila et al. 1995). In both Tanzania and Zambia construction of the railway lines contributed to clearance of woodlands as prime hardwoods were cut for railway sleepers (Chidumayo 1987c; Christiansson 1988). The locomotives also consumed huge amounts of wood. In Zambia and Zimbabwe, large quantities of wood were used for mining construction and pit props (Chidumayo 1987c; McGregor 1991; Moyo et al. 1993).

\section{Summary of historical influences}

What emerges from the discussion is that since the 18th century, miombo woodlands have been expanding and contracting in extent, in response to diverse influences. The expansions that were characteristic of the pre-colonial and early colonial 
periods have now given way to continuous contraction in response to the ever expanding subsistence and commercial activities. By 1994 about $40 \%$ of the total miombo woodland of 2.8 million $\mathrm{km}^{2}$ had come under anthropogenic domination (Hannah et al. 1994). In the more densely populated districts of Malawi, Tanzania, Zambia and Zimbabwe, the formerly dense miombo woodland had been replaced by dry and open 'cultivation savannas' (comprising mainly grain and tobacco cultivation, exotic fruit trees) and grasslands interlaced with miombo woodland patches and bushy thickets (SADCC Energy Sector 1987).

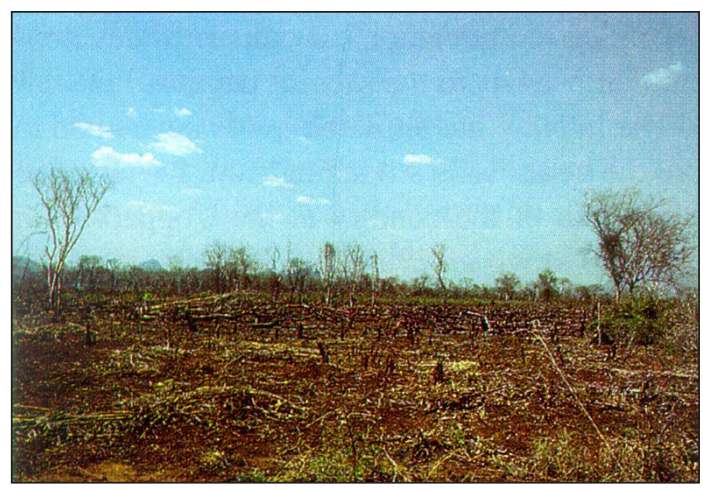

The major cause of deforestation is clearance for crop production, as shown here in Mozambique (photo: A. Sitoe)

\section{National policies and their impact on woodland use and cover}

Much of contemporary policy and legislation governing land use in the region is a continuation of colonial policy (Chapter 8). The current policies mirror the dualistic nature of the colonial period and have inherent weaknesses characteristic also of colonial policy. The land tenure regimes reflect the legacy of colonial land distribution, and despite the changes that have taken place in the post-independence era, inequitable land distribution is still a feature. The agricultural sector is still dominated by colonial agrarian structures, and has continued to be divided into two types, the smallholder and estate sub-sectors, distinguished by legal and institutional rules pertaining to crop production, marketing, pricing and land tenure (Moyo et al. 1993).

\section{Land tenure and distribution}

Land tenure issues and questions of access, use, control and benefit distribution are fundamental to the sustainable utilisation and management of woodland and other natural resources, and are discussed separately in Chapter 8.

Private land is land which is individually owned, either as freehold or leasehold, with granted rights of occupancy (title deeds). In Zimbabwe, it encompasses large-scale commercial farms (formerly white-owned and upward of 5000 ha each) and small-scale commercial areas (formerly African Purchase Areas with farms of less than 100 ha each) (Table 4.1). In Malawi, private land is in three classes: freehold, leasehold and customary land (Eschweiler 1993; Moyo et al. 1993; Table 4.2). The latter has been converted to private lands under the Customary (Land Development) Act of 1967.

State land is land held in trust by the government for the preservation and development of public resources. It comprises gazetted forest areas, national parks, game reserves, state roads and land in urban areas as well as rural growth centres. In Tanzania and Mozambique, unlike in the other countries, all land belongs to the state through the legally elected government. State land may be granted to individuals on a leasehold system with leases ranging from 1 to 99 years. In Tanzania, leases are issued for 1-5 years, 33 years or 99 years. In Zimbabwe, Zambia and Malawi leases are usually for 99 years, while in Mozambique leases are usually 50 years (Republica Popular de Mocambique 1988). In 
Zambia in 1975, the state transferred freehold and pre-existing leases to uniform 99-year leases (Table 4.3).

Customary land is held, used or occupied under customary laws and embodies usufruct rights (Moyo et al. 1993). Such rights, though inheritable, are not transferable and do not constitute the right of ownership. This type of tenure prevails in the 'traditional' sector (see Chapter 8 for more details).

The majority of the people in southern Africa live on customary or communal land and depend on resources found on these lands. However, they do not have any title deeds which would allow them to own land. Although the national governments recognise the customary laws which grant the people rights to use land, the state controls all the land, and has the final decision declaring any land for public use. In Mozambique, for example, although the law protects the areas occupied by small farmers, in practice they are displaced without reimbursement when a concessionaire makes a successful application to the government (Myers 1993). The situation in Mozambique has been aggravated by the system of shifting cultivation and the civil war. Peasants who practise shifting cultivation do not register the land they traditionally use (Dejene and Oliveres 1991). Shifting cultivators, when they return several years later to the land they had left to regenerate, are increasingly finding their plots taken by commercial farmers who have been given leases by the government. People who have been displaced by war generally do not have access to land by traditional rules (Carrilho 1990).

Because of increasing population in the communal areas, land clearance for cultivation and wood extraction has increased over time, resulting in widespread deforestation. Woodlands in the government reserves and commercial areas, at least in the case of Zimbabwe, however, have remained almost intact. Private land tenure, particularly in Zambia and Zimbabwe, has resulted
Table 4.2 Distribution of land in tenure categories in Malawi 1979 (Riddell and Dickerman 1986).

\begin{tabular}{lcr}
\hline Category & $\begin{array}{c}\text { Area } \\
\text { (million ha) }\end{array}$ & $\%$ \\
\hline Customary Land & 8.091 & 86.02 \\
Public Land & 1.119 & 11.88 \\
Freehold & 0.198 & 2.10 \\
Total & 9.408 & 100.00 \\
\hline
\end{tabular}

Table 4.3 Areas under various types of tenure in Zambia (Riddell and Dickerman 1986).

\begin{tabular}{lcr}
\hline Land category & $\begin{array}{c}\text { Area } \\
\text { (million ha) }\end{array}$ & $\%$ \\
\hline State land & 1.02 & 2.50 \\
Alienated in freehold & 1.28 & 3.10 \\
Alienated in leasehold & 0.51 & 1.20 \\
State land under tribal & & \\
occupation & 0.13 & 0.30 \\
Unalienated state land & 0.22 & 0.50 \\
Inundated by water & 0.55 & 1.30 \\
Forest Reserves & & \\
Reserves & 0.69 & 1.70 \\
Protected Forest areas & 26.73 & 65.00 \\
$\begin{array}{l}\text { Others (land under } \\
\text { traditional systems) }\end{array}$ & & \\
Trust land & & \\
Protected Forest areas & 4.25 & 10.30 \\
Forest Reserves & 0.03 & 0.07 \\
Parks and others & 5.83 & 14.20 \\
\hline
\end{tabular}

in much land lying idle or fallow, while there is scarcity of land in the communal areas and reserves. Privatisation of land has also reduced access rights to trees for many people. At the same time, accessibility to gazetted forest reserves is regulated and controlled by the governments, who are often geared toward protecting 
the forest resource rather than planning for sustainable management to meet people's needs (Leach and Mearns 1988). Thus the majority of people have been left to rely on woodland resources on land that is currently largely used for agriculture and pastoralism. This has imposed enormous pressure on resource use in the customary/communal lands with spill-over effects on state forests (Vermeulen 1993).

Forest reserves have become sites of considerable tenurial conflict because local farmers believe they have the right to use the land and the trees or other forest products by virtue of their proximity or historical connection to the land (Fortmann and Bruce 1993). Such conflicts are widespread throughout the region. In Malawi, for example, there are reports of encroachment by smallholders on estate lands for poles, firewood, thatch or small animals, grazing and even cultivation (Mkandawire 1990, in Eschweiler 1993). The frequency of such encroachment suggests that the creation of estates has restricted smallholders' access to forests and other resources as well as their access to arable land presently needed to meet their food requirements.

\section{Agriculture}

With independence, the nationalist governments inherited agricultural sectors that were highly cash-crop oriented and based on large-scale farming. They also inherited an infrastructure that had been developed to serve the interests of largescale farming and mining. These colonial agrarian systems have prevailed long after independence, and have been reinforced by agricultural policies which, like their predecessors, have emphasised cultivation of export crops like tea, coffee, tobacco, sisal and cotton in order to generate foreign exchange.

In Malawi in the late 1960s, for example, the government, encouraged establishment of estates which it was felt would expand output of tobacco and other primary export crops (Moyo et al.
1993). This policy was strengthened by other measures such as leasing large tracts of land to individuals and co-operatives at very little cost, increased market opportunities to estate leaseholders, the imposition of a licensing system which eliminated competition from smallholders by restricting the production of burley and fluecured tobacco to the estate sector alone, and access to low-cost finance. The government also introduced price controls on agricultural inputs and exports. A policy of uniform pricing of agricultural producer goods, especially maize meal, was introduced with the objective of protecting the urban consumer and consumers in food deficit rural areas (Mupimpila et al. 1995). In almost all countries, the governments became involved in agricultural marketing through the marketing boards. In these ways the state transformed agrarian relations and agricultural production (Moyo et al. 1993).

Such economic policies were common throughout the region; smallholder farmers had little incentive to intensify production. Any increase of production to meet household and cash income needs was through increased area of cultivation at the expense of the woodland.

Today, agriculture continues to be the dominant sector of the economies of the region. Even countries like Zambia and Zimbabwe, whose economies were heavily dependent on the mining sector are now according high priority to agriculture. Smallholder production of food and cash crops has increased over time, particularly since the mid-1980s. The period from the 1980s has been marked by policy reforms aimed at increasing agricultural production of both export and subsistence crops, especially maize. This has led to increased acreage of cultivated land at the expense of woodlands. In Malawi, the total area under rainfed crops and fallow increased from 3.5 million ha $(37.5 \%$ of the total land area) in $1965-67$ to 4.7 million ha $(49.2 \%)$ in $1988-90$ (Eschweiler 1993). Marginal and unsuitable land 
has increasingly been brought under cultivation. The trend is heightened by the stagnating formal sectors which are not absorbing most of the work force (Box 4.4).

Tobacco is becoming increasingly important as an export crop in the miombo zone in Tanzania, Malawi and Zimbabwe. Growth in output has been recorded in both the large-scale commercial sector and small-scale farms. More small-scale farmers in Malawi and Zimbabwe appear to be turning to this crop in response to the governments' drive to improve the agriculture sector (Katerere et al. 1993; Moyo et al. 1993). The expansion of estate agriculture in Malawi is believed to have grown at nearly $7 \%$ per year since 1980, with smallholder farms increasingly being converted into estates mainly for tobacco growing. Tobacco continues to be the leading export crop in Malawi, accounting for $63 \%$ of total exports in 1990 (Forest Policy Review 1993). Estate tobacco presently accounts for $45 \%$ of all exports, up from $32 \%$ in 1978-79. Since 1991, smallholder tobacco production has increased because smallholders are now legally permitted to grow burley tobacco.

In the predominantly miombo woodland areas of central and western Tanzania, where more than $60 \%$ of the country's tobacco is produced, areas for cultivation have shown a staggering increase, rising from 228000 ha in 1985-86 to 1374000 ha in 1991-92. The largest increase was in the season 1990-91 when a change of $112 \%$ was recorded (World Bank 1994b; Shechambo and Kulindwa 1995).

Increased tobacco production has had farreaching consequences on miombo woodlands. It has led to large losses of woodlands, for land and woodfuel (Misana 1988; Moyo et al. 1993). In 1986, the Malawian tobacco industry alone contributed to $23 \%$ of the total wood demand. However, given the increased production of burley tobacco following the government's decision in 1990-91 to allow burley to be grown by small- holder farmers, wood consumption for tobacco curing has been reduced drastically (Forest Policy Review 1993.). While tobacco production has nearly doubled in the last ten years, wood consumption for curing and storing has increased by only $29 \%$ (Table 4.4), as burley tobacco uses only one-third to one-quarter of the wood used in flue-cured tobacco.

There is evidence in the communal areas of Zimbabwe that the drive to grow tobacco is leading to the use of unsuitable areas of land and is increasing demands for wood and bricks which are already scarce (Katerere et al. 1993). Woodland losses are amplified by the need for fresh land each year in order to avoid the risk of root-knot nematodes. Tobacco cropping in the commercial sector in Zimbabwe, unlike in other countries, is currently largely cured using coal, though in the past wood was the dominant energy source (IFSC 1987). Agricultural policy with respect to tobacco production has, unfortunately, not incorporated any aspects of woodland management for sustained woodfuel production.

Related to agricultural policies are the policies adopted in times of drought. Most governments attempt to provide for their rural population during drought. Drought policies may have decreased reliance on forest products, as households receive food from government rather than having to rely on famine foods (Campbell 1987; Zinyama et al. 1990).

\section{Livestock}

The miombo region supports considerable livestock populations (Chapter 2). High livestock numbers are reported in Zimbabwe, Tanzania and Zambia where large tracts of land are said to be overstocked and overgrazed (Moyo et al. 1993). The livestock population in Tanzania far exceeds the local carrying capacity (Bagachwa et al. 1995). In Zimbabwe, about $60 \%$ of the national cattle herd is located in the communal lands (Bradley and Dewees 1993). 


\section{Box 4.4 \\ Employment, population growth and the demand for land in communal Areas Ivan Bond}

Communal land in the countries with miombo woodlands provides five key services to residents: a dwelling place, a source of raw materials, land for cultivation, grazing for livestock and a social security net for individuals and dependants (Low 1986). The establishment of a 'home base' from which labour can be allocated to both on- and off-farm activities on the basis of its comparative advantage is crucial to communal land households.

Economic theory predicts that when the marginal return per unit area of land declines beyond the marginal urban wage rate, then wage labour will shift from agricultural to urban employment (Hartwicke and Olewiler 1986). In Zimbabwe, the proportion of the total population in formal employment has fallen steadily from $15.6 \%$ in 1977 to $11.6 \%$ in 1993 (Central Statistical Office 1995). The real average wage, including wages in the large-scale commercial farming sector, has fallen by $35 \%$ between 1985 and 1993 (see figure). The low and diminishing probability of formal-sector employment and the declining real wage rate suggest that households will continue to opt for a home base in the communal areas. Consequently there is a high demand for land in the communal areas, even in areas of marginal agricultural potential, a demand which cannot be relieved by the current resettlement programme.

At a micro-level, government subsidises communal agriculture through numerous production subsidies, such as the provision of drought relief, seed, fertiliser and tillage (AGRITEX, n.d.; Dept of Social Welfare 1993). These subsidies provide important incentives to communal land farmers to cultivate virgin land and/or to expand areas of cultivation. The provision of drought relief, in the form of food, provides a buffer to households in areas which are unsuitable for settlement and agriculture. The prevailing economic conditions have resulted in a rate of employment creation below the level of population growth and a declining real wage. Together with farm-level incentives to cultivate, this has resulted in the expansion of settlement and concomitant agro-pastoralism into previously wildland, including miombo woodlands. Cultivation has also extended into the grazing areas and other marginal agricultural areas throughout the communal areas in Zimbabwe. Given the structure of subsidies and the lack of alternatives, individual households are acting in a wholly rational manner by settling and cultivating marginal agricultural land. The future of miombo woodlands in Zimbabwe in the communal sector, under current socio-economic conditions, is bleak.

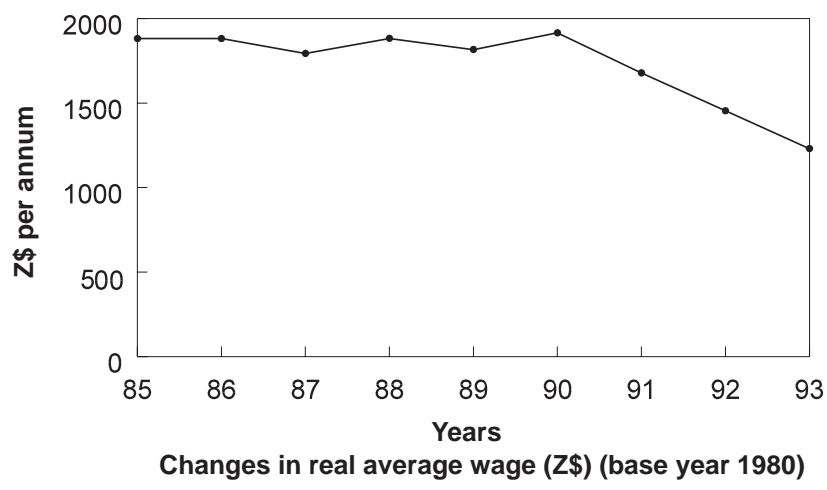


Government policies on livestock in many countries have emphasised destocking as a means to relieve pressure on overstocked land. Such measures were implemented in Tanzania, Zimbabwe and Zambia by the British Colonial governments from the 1930s (Berry and Townshend 1973). On the other hand, provision of infrastructure for livestock, including watering points and veterinary services, was provided, resulting in increases in livestock numbers.

Current livestock policy in Tanzania is almost a replica of colonial policy. Emphasis is placed on destocking, particularly in the areas of livestock concentrations, and bush clearing to control the advance of tsetse flies (United Republic of Tanzania 1986). Pastoralists are encouraged to migrate to less-populated areas. Thus new villages have been established by the government, for example in Morogoro Region, to cater for excessive livestock populations in the Maasai areas. In places where overgrazing is severe, pastoralists have migrated to less populated areas such as the Usangu plains in Mbeya Region.

The implication of such policy measures is that the problem of land degradation, which is characteristic of the livestock concentration zones, has simply been exported to other areas, where conflicts between the migrants and local farmers over the use of land are already prevalent and land degradation has ensued. In addition, bush clearing for tsetse control has hindered reestablishment of woodlands and created an impetus for further woodland clearance. The policy on destocking has failed in many areas, as people are reluctant to destock because livestock represent their chief source of livelihood.

\section{Wildlife}

The wildlife policies in Tanzania, Zambia and Zimbabwe have, until the 1970s, mainly focused on the preservation of animals and their habitats (Ministry of Lands, Natural Resources and Tourism 1989a; Moyo et al. 1993; Mupimpila et al. 1995). In Zambia, for example, the main objectives of the wildlife policy have been to establish a comprehensive national parks system, to control game management areas and game cropping, and to educate the public in the conservation of natural resources (Mupimpila et al. 1995). Similarly in Tanzania, focus has been on conserving protected areas, regulating hunting and enforcing wildlife laws (Ministry of Lands, Natural Resources and Tourism 1989a). National

Table 4.4 Use of wood for curing tobacco in Malawi (Forest Policy Review 1993).

\begin{tabular}{lrrrrrr}
\hline $\begin{array}{l}\text { Type of } \\
\text { Tobacco }\end{array}$ & \multicolumn{2}{c}{$\begin{array}{c}\text { Tobacco production } \\
\text { (tonnes) }\end{array}$} & $\begin{array}{c}\text { Wood consumed per tonne } \\
\text { tobacco }\left(\text { solid m }{ }^{3}\right)\end{array}$ & \multicolumn{2}{c}{$\begin{array}{c}\text { Total wood consumed } \\
\left(\text { solid m }^{3}\right)\end{array}$} \\
\cline { 2 - 7 } & 1983 & 1992 & 1983 & 1992 & 1983 & 1992 \\
\hline Burley & 41600 & 99200 & 4 & 4 & 166100 & 396900 \\
Flue & 21700 & 25700 & 19 & 14 & 411500 & 360000 \\
Fire & 8400 & 10300 & 17 & 17 & 142500 & 175400 \\
Sun/air & 700 & 1000 & 1 & 1 & 700 & 1000 \\
Oriental & 200 & 400 & 1 & 1 & 200 & 400 \\
Total & 72400 & 136600 & & & 721000 & 933700 \\
& & & & & & \\
\hline
\end{tabular}


parks in all these countries have been established for conservation purposes, while commercial hunting is permitted in game reserves or safari areas. Tanzania has 13 national parks covering $103000 \mathrm{~km}^{2}$ (11\% of the total land area) and 16 game reserves occupying $40000 \mathrm{~km}^{2}$. Similar proportions of Zimbabwe and Zambia are covered by national parks or safari areas.

Common to all these countries has been the policy that limits local people from benefiting from wildlife resources. There has been no incentive for local people to manage and utilise the resource sustainably, and the policies have for the most part disregarded traditional hunting cultures. The consequences of such protectionist policies have been increased poaching of animals to supply a variety of products such as meat, skins and ivory. This has resulted in a severe loss of animals, particularly elephants and black rhinoceros (Figure 4.2). The lack of law enforcement, the low opportunity cost of poaching because of a lack of alternative income, and the high trophy prices have contributed to the depletion of elephant and rhinoceros populations in Zambia and the other miombo countries (Mupimpila et al. 1995).
Encroachment on national parks for grazing, wood cutting for woodfuel and farming by neighbouring local communities has also increased. With increasing population of both human and livestock numbers and the pressure exerted on their limited land, the only way for communities to survive has been to encroach on these protected areas. Consequently this has led to degradation of the wildlife habitat and impoverishment of species numbers and diversity as the resources are unsustainably utilised. Conflicts over use of these resources between the state and local communities have been on the increase.

The governments in many countries are aware of the problems in wildlife areas, and efforts are being made to address them. A range of new initiatives have been implemented, discussed in detail in Chapter 8.

\section{Settlement}

Any discussions on settlement policies in southern Africa have to be related to policies on land distribution, and agricultural and rural development. People have been settled or resettled in order to achieve specific objectives which include, among others, to increase agricultural production and, as in the case of Zimbabwe recently, to resolve the problem of landlessness. Although the nationalist ruling elites during the post-independence period sought ways and means to promote the objectives they had promised during the independence struggles, the initial rural development policies were more characterised by continuity rather than change. Several schemes were introduced or revived in various parts of the region based on donor recommendations and a 
developmental ideology strongly influenced by the outgoing colonial regimes (Payer 1982). Thus the resettlement schemes in Zimbabwe and villagisation programmes in Tanzania were based on models developed in colonial times. In Malawi and Tanzania, there were no such largescale resettlement programmes.

In Tanzania, settlement programmes were implemented as early as 1963 in response to donor-based improvement and transformation programmes. These involved establishment of village settlement schemes which formed a prelude to the villagisation programme of ten years later. Tanzania adopted the villagisation policy in 1967 as part of a strategy for the development of the nation. The policy was intended to integrate, in a holistic manner, a settlement and agricultural development programme, a resource management programme and a population distribution policy (Mlay 1986). It required all people outside the areas of dense settlement to be resettled in Ujamaa villages. In both the settlement schemes of 1963 and the villagisation programme implemented during 1974-76, nucleated villages were established, some in virgin lands, which necessitated extensive clearance of woodlands for farmland and settlement expansion (Kikula 1986a; Shao 1986). Thus by 1975 over $75 \%$ of the population was already settled in Ujamaa villages (Mlay 1986).

The Villagisation Programme, and the Villages and Ujamaa Villages Act (1975) that franchised it, had a particular impact on the distribution and use of miombo woodlands. Due to the lack of commonly accepted woodland management strategies in the villages, the woodland resources became no-man's land open for exploitation by one and all from within the villages themselves and from outside (see Chapter 8).

In Zimbabwe the resettlement programme was introduced after independence in 1980 to redress inequalities in land distribution and to improve productivity of agriculture (Hofstad
1993; Katerere et al. 1993). The government of Zimbabwe bought farms from white farmers and designated them as state property. Rural households were then allocated permits to occupy a residential stand, cultivate a designated 5 ha arable land and raise livestock on grazing commons. By July 1991, some 52000 households had been allocated resettlement land. The Kaerezi Resettlement Scheme in the Eastern Highlands, for example, became the home of 1200 households spread across 18500 ha of miombo and other woodland (Moore 1993). Only a very limited system of tenure over the trees and woodlands found on the resettlement areas was developed. This has led to conflicts between settlers and residents of adjacent communal areas, the adjacent people asserting rights based on historical proximity and use, or on their prior employment on the farm bought for resettlement (Fortmann and Bruce 1993). Scoones and Matose (1993) report that in some areas commercial extraction of wood for sale to urban areas or neighbouring communal lands has been initiated. Apart from the formal resettlement areas, independence also brought widespread movement of people from the most crowded and disadvantaged communal areas. These people moved to State Forests and the less-populated communal areas. In Gokwe large groups of resettled peasants established their own colonies (Mukamuri 1995a).

Widespread woodland destruction has followed in all centres receiving newly-settled people (Grundy et al. 1993; Moyo et al. 1993; Grundy 1995a). This was initially due to clearance of woodland for cultivation and home construction, but has now been followed by exploitation of the woodlands for woodfuel sales. The resettlement areas in Zimbabwe are undergoing the most rapid rates of woodland clearance (McNamara 1993). Apparently, the resettlement policy has placed emphasis on land clearance for agriculture, with settlers being encouraged to destump their fields completely. No woodland management policies 
were established for resettlement areas, with the result that the communal woodlands are largely being used unsustainably (Grundy 1995a).

Land resettlement policies that involve the settlement of people in marginal agricultural land, as has occurred in Zimbabwe in the resettlement programme, are likely to have a negative impact on woodland cover. The will also have negative impacts on state financial resources because of the endemic nature of drought in these regions and the continual need for food and emergency aid.

\section{Services and infrastructure}

The state of infrastructure partially determines the development path that a given country will take. Issues related to diversification of production, expanding trade, coping with population growth, reducing poverty or improving environmental conditions, which have been major problems in the miombo region, are all linked to infrastructure development (World Bank 1994a). In many of the miombo countries, rural areas have received little investment, and had fewer services than urban areas. With the exception of Zimbabwe, transport and communications infrastructure in rural areas of the miombo countries has been all but neglected. Many rural roads are in poor condition due to poor maintenance (United Nations 1995).

This has led to rural-urban inequalities, escalating the poverty problem in rural areas and creating avenues for rapid urbanisation. Improvement of farm productivity and growth of non-farm rural employment are linked closely to infrastructure provision. Consequently, the rural poor have been forced to rely almost wholly on dwindling natural resources for their food and energy needs creating enormous pressure on the resources as populations increase.

\section{Forestry}

All the national forest policies in the miombo countries are directed towards limiting commercial exploitation of woodlands (Dewees 1994). They focus more on regulating woodland use and protecting against wanton cutting of trees and encroachment, rather than on sustainable management and use. Limited exploitation of selected hardwoods is allowed in forest reserves (Lowore 1993). The limitations extend even to woodlands on customary or communal lands through control regimes, licensing, traffic checkpoints, road blocks and increased royalty collection from users of woodland products. This means that farmers have no rights to exploit trees growing on land allocated to them except to cut them down in order to cultivate land (Dewees 1994).

One of the provisions of the forest policies has been demarcation and reservation of forest reserves (Ministry of Lands, Natural Resources and Tourism 1989b; Katerere et al. 1993; Lowore 1993). However, this has been done at the expense of the local people, who might have used these lands to meet their local needs. People were removed from state forests and access to resources on state land was either prohibited or controlled through a licensing and permit system (Katerere 1994). In Tanzania, for example, the creation of forest reserves has entailed the evacuation of the local people and the denial of access to what were formerly common-property or open-access resources (Leach and Mearns 1988). Similarly, the current forest policy in Zimbabwe calls for relocation of all forest occupants, whether ex-tenants or squatters, out of the State Forests (Matose and Clarke 1993).

As a result of such exclusion, many people have viewed the gazetted forest reserves as government property and 'no-go areas for them' (Lowore 1993). This has led to conflicts between the government and communities surrounding the reserves as they encroach on these resources due to pressure and depletion of resources in communal areas (Moyo et al. 1993; Vermeulen 1993; Matose 1994).

Most countries have attempted to protect state and other forests from illegal cutters by a licensing system. Thus, for example, commercial woodfuel collectors and charcoal makers should 
pay royalties for any trees being felled (Leach and Mearns 1988). However, most of the charcoal makers and dealers do not obtain licences as required. Consequently, much of the charcoal business is conducted illegally. Because of the difficulties of policing woodfuel cutters and charcoal makers, who are widely scattered and often work in remote locations, many governments focus their control and taxation of woodfuel on the transporters.

Timber concessions continue to be a source of revenue for many governments in the region. Exploitation of wood through concessions which involved private concessionaire companies began to supply the mines and railways during the late-19th century (Katerere et al. 1993; Moyo et al. 1993; Dewees 1994) and has continued to the present day. Such concessions have led to widespread degradation of large areas of miombo woodland throughout the region particularly in Zambia, Angola and Zimbabwe (Moyo et al. 1993), as concessionaires will, if not regulated, maximise profits at the expense of the environment.

Concessionaires are required to pay royalty fees which accrue to the respective authorities where the timber is cut. In Zimbabwe, in the communal sector, the revenue generated by cutting trees from a farmer's holding reverts to the local authority, while the farmer has no benefits (Katerere et al. 1993).

One of the major problems with the revenue systems have been the low fees being charged, fees which do not correspond to the value of the wood (Chapter 6). According to Leach and Mearns (1988), the revenues, if paid, were rarely more than $5 \%$ of the final consumer price. Low fees have contributed to wasteful practices during logging and processing. In addition, the mechanisms which have been used to set stumpage fees and to control exploitation have not encouraged the best and most efficient use of the woodland resources (Bradley and Dewees 1993). In many countries, royalty fees do not seem to have been based on any economic or ecological analysis (Ministry of Lands, Natural Resources and Tourism 1989c; Mujakachi 1993). In Zimbabwe, for example, Mujakachi (1993) reports of unchanged royalty fees for about 60 years with increases only since the 1970s. The low fee levels have further encouraged the increased sale of licences by authorities to obtain badly needed revenues.

In addition, governments have often accorded a variety of subsidies to the concessionaires and woodfuel sellers (Mujakachi 1993; Leach and Mearns 1988). The government of Malawi has been subsidising sales of wood for use as fuel on the grounds that it was a basic need (Leach and Mearns 1988). Squeezed between the high labour costs and the low price which the truckers from the city would pay for charcoal, the primary interest of a charcoal maker was to save time, not forests. Such subsidies have encouraged over-exploitation of woodland resources. In addition, short-term leases (one year), such as those granted to concessionaires in Zimbabwe, have encouraged the unsustainable exploitation of the woodlands (Mujakachi 1993).

Recently, however, many governments have attempted to adjust the stumpage prices so as to reflect the actual market value of the products and to protect the forests from further damage. In Malawi, for example, the government raised the stumpage royalty for commercial woodfuel from state forests by $50 \%$ in 1986 (Leach and Mearns 1988). Similarly in Zimbabwe, Bradley and Dewees (1993) report that real stumpage prices increased over twenty-fold since the mid1970s. Mujakachi (1993) also reports of increases in stumpage prices since 1989 following the introduction of a tender system for determining such prices. In Malawi, on the other hand, stumpage rates for indigenous wood used in the tobacco industry are still heavily subsidised, not reflecting the real value of the resources. Many tobacco producers continue to have access to indigenous woodland at a price which is marginal 
in relation to total costs of production (Forest Policy Review 1993). In Tanzania, despite the adjustment of prices carried out in recent years, the levels are still low, and do not reflect the regional or local demand for forest products (Ministry of Lands, Natural Resources and Tourism 1989c).

Chapter 8 discusses institutional arrangements governing woodland use in greater detail.

\section{Energy}

The commercial sector in the miombo region depends almost entirely on conventional fuels, including hydropower, petroleum and coal, while the traditional sector largely relies on woodfuel. Woodfuel is the most important source of energy in the region. Over $80 \%$ of the population depends on woodfuel for cooking, heating and lighting requirements (Shaba 1993). Wood supplies $70 \%$ of the energy consumed in the region and most of it is obtained from miombo woodland. The demand for woodfuel has steadily increased over the years and the situation is not likely to change in the near future, given the poverty situation and the low levels of income that prevail in most rural and urban areas (see Chapter 6 for a detailed discussion of the woodfuel trade).

Although other energy sources such as solar, wind and biogas have been pursued, their development is still at an early stage; in any case, the vast majority of woodfuel consumers cannot afford the high investment costs associated with other forms of energy (Moyo et al. 1993). Energy policies that have been implemented in the region have mostly focused on the commercial energy sector. In Zambia, for example, there was very little mention of the rural energy problem prior to the Fourth National Development Plan (1986-90) (Moyo et al. 1993). Focus was on the development of hydropower as a source of electricity. This is even reflected in the legislation on energy, where the Electricity Act is the only energy legislation that exists (Moyo et al. 1993).
The inadequacies of energy policies in addressing woodfuel problems have contributed to the depletion of miombo woodlands, particularly around major cities/towns and in more distant areas close to main roads and rail (Leach and Mearns 1988). Firewood gathering by rural households for domestic use does not generally lead to deforestation (du Toit et al. 1984). If woodfuel use is causing deforestation, it is usually related to urban demand and the cutting of trees for sale as firewood or charcoal (Chidumayo 1983).

The urban demand for woodfuel cannot be related solely to inadequacies of the energy policies. High demand is closely linked to policies that encourage rapid urbanisation (Box 4.5). So the woodfuel demand from urban areas should be placed within the framework of under-investment in rural areas, poor agricultural policies and rural landlessness.

As a result of high rates of deforestation around major cities and towns, charcoal is now being transported from as far away as 100-400 km (Chidumayo 1983; Monela et al. 1993; Leach and Mearns 1988). Dar es Salaam, for example, was getting charcoal supplies from within a radius of $50 \mathrm{~km}$ some 15-20 years ago (Mashalla 1978). Today, however, charcoal is brought in from distances of up to $200 \mathrm{~km}$ (Kilahama 1988; Misana and Nyaki 1993; Monela et al. 1993). It is estimated that, on average, over 75000 ha of woodland are being cleared annually to meet the woodfuel needs for Dar es Salaam alone (Hagman 1984). In Zimbabwe, the situation is slightly different with widespread urban electrification and cheap subsidised kerosene, resulting in less demand for woodfuel (Campbell and Mangono 1994).

Recently, many governments have recognised the environmental consequences of woodfuel harvesting, and deliberate policy initiatives have been undertaken to alleviate these problems. Thus in Zambia, the Fourth National Development Plan (1986-90) incorporates some objectives and strategies aimed at solving the problems of rural 


\section{Box 4.5 Urbanisation, charcoal production and deforestation}

\section{Emmanuel Chidumayo}

Charcoal derived from miombo woodland has been used for metal smelting since the iron age, but its use for cooking is recent. Urbanisation in Zambia emerged during the 1930s following the discovery of large copper deposits in the Copperbelt earlier in the century. Charcoal as a cooking fuel was introduced in the Copperbelt towns around 1947 and in Lusaka, to the south, around 1960, and has since become a major urban household fuel in Zambia with $85 \%$ of households dependent on it (Chidumayo and Chidumayo 1984).

The production method involves tree felling, stem cross-cutting, kiln building by piling logs and covering with soil, wood carbonisation and kiln breaking to recover the charcoal. The efficiency of the kilns is $23 \%$ on an oven dry weight basis, thus giving a yield of $0.23 \mathrm{~kg}$ charcoal per $1.0 \mathrm{~kg}$ of wood.

The urban population in Zambia increased from 1.2 million in 1969 to 2.3 million in 1980 and 3.3 million in 1990 (Central Statistical Office 1992) and on the basis of the 1980-1990 growth rate is projected to reach 4.5 million in the year 2000. Average annual charcoal consumption in urban Zambia during 1983-1994 remained at about $1046 \mathrm{~kg}$ per household but total consumption increased from $260000 \mathrm{t}$ in 1969 to $450000 \mathrm{t}$ in 1980 and $480000 \mathrm{t}$ in 1990 and is projected to increase to $500000 \mathrm{t}$ in the year 2000 (Chidumayo 1994a).

Miombo woodland is the main source of wood used in charcoal production in Zambia and this woodland has a weighted cord wood biomass of $62.5 \mathrm{t} \mathrm{ha}^{-1}$ (Chidumayo 1994a). However, when selective felling is practised, about $90 \%$ or $56.2 \mathrm{t} \mathrm{ha}^{-1}$ of the cord wood biomass is used for charcoal production (Chidumayo 1991b). On the basis of the increase in urban households, annual woodland clearing for charcoal production for urban Zambia increased from 20730 ha in 1969 to 32200 ha in 1980, and 34630 ha in 1990, and is expected to increase to 35670 ha in the year 2000. It is also estimated that between 1937 and 1983, a total of 391000 ha of woodland, representing $51 \%$ of the 769000 ha in the Zambia Copperbelt, had been deforested for both industrial and household woodfuel (Chidumayo 1987c).

and household energy demand and supply (Moyo et al. 1993). The energy policy for Malawi implemented since 1988 aims at, among other things, meeting future woodfuel demand and developing other resources such as coal. In Tanzania, the main thrust of the energy policy of 1992 is the development and use of indigenous energy sources including bio-energy, coal, natural gas and hydropower, and efficient utilisation of energy. One aim of the policy is to arrest woodfuel depletion by evolving more appropriate land management practices and more efficient woodfuel technologies (United Republic of Tanzania 1992a). Almost all the energy policies recognise technology, pricing and the preservation of the environment as key factors.

\section{Population}

The population of southern Africa has been growing at a rapid rate, between $2.67 \%$ in Angola to $3.7 \%$ in Zambia (World Bank 1992). One of the causes of such rapid population growth rates is the high fertility levels and the reduced mortality rates experienced throughout the region. Malawi, for example, has the second highest birth rate in Africa (Eschweiler 1993). 
Coupled with high intrinsic growth rates is the movement of refugees. In Malawi the influx of at least one million refugees from war-torn Mozambique created enormous pressures on natural resources in the communal areas near the Mozambique border (Moyo et al. 1993). In Tanzania, an influx of refugees from neighbouring Rwanda and Burundi has had a devastating effect on some of the woodland areas in Kagera, Kigoma and Tabora Regions. About 4000 ha of forests were cleared by the recent influx of these refugees (Ministry of Tourism, Natural Resources and Environment 1994).

The majority of the population lives in rural areas. However, one of the most striking changes in the miombo region is the rapidly-increasing urban population, a result of the very high rate of urban growth (Table 4.5). In Angola, the urban population is estimated to have grown at $7.6 \%$ per annum over the 1980 s compared with a $0.8 \%$ growth rate for the rural population, a result mainly of war (Moyo et al. 1993). Zambia is the most urbanised country in the region, ranking as Africa's third most urbanised country after Algeria and South Africa (Mupimpila et al. 1995). A little over $50 \%$ of its population live in urban areas of which $78 \%$ were concentrated in

Table 4.5 Population growth and urbanisation in selected southern African countries (World Bank 1992).

\begin{tabular}{lrrr}
\hline Country & $\begin{array}{r}\text { Total } \\
\text { population } \\
\text { in 1990 } \\
\text { (millions) }\end{array}$ & $\begin{array}{r}\text { \% growth } \\
(1980-90)\end{array}$ & $\begin{array}{r}\text { \% urban } \\
\text { population } \\
\text { growth rate } \\
(1980-90)\end{array}$ \\
\hline Angola & 10 & 2.6 & 5.8 \\
Malawi & 9 & 3.4 & 6.2 \\
Mozambique & 16 & 2.6 & 10.4 \\
Tanzania & 25 & 3.1 & 10.5 \\
Zambia & 8 & 3.7 & 6.2 \\
Zimbabwe & 10 & 3.4 & 5.9
\end{tabular}

the central and Copperbelt regions in 1980 (Chidumayo 1983; Moyo et al. 1993). The annual average rate of urbanisation was $8.9 \%$ and $6.7 \%$ during 1963-1969 and 1969-1980, respectively (Chidumayo 1983). The rural population only increased at an average rate of $1.1 \%$ during 1969 1980. With increased urban population comes increased woodfuel demand, usually in the form of charcoal, and increased deforestation in the vicinity of the urban areas (see Energy above; Box 4.5).

Despite the high rates of population growth and urbanisation very few effective measures have been implemented to address the problem. Malawi, recently adopted a family-planning programme aimed at reducing the high fertility levels and thus controlling population growth in order to reduce the level of population pressure on land (Moyo et al. 1993). Emphasis has been on the spacing of births, a result of which the rate of population growth has declined from $3.7 \%$ in 1987 to 3.4\% in 1990 (World Bank 1992; Moyo et al. 1993). Tanzania has also recently formulated a national population policy, the overall goal of which is to regulate population growth rate, enhance population quality and improve the health and welfare of women and children (United Republic of Tanzania 1992b). Again, as in Malawi, more emphasis has been placed on family planning to reduce fertility levels, rather than on curbing rural-urban migration.

\section{National economic and trade policies}

Since the mid-1980s, many countries in the region have adopted structural adjustment programmes aimed at rectifying severe macro-economic problems, including falling export earnings, worsening balance of payments, mounting debts and declining economic growth. It was assumed that the economic problems that have been experienced in these countries were a result of economic distortions and rigidities, and that the removal of these by allowing price flexibility would enhance efficiency in resource allocation and 
use (Moyo et al. 1993; Bagachwa et al. 1995; Mupimpila et al. 1995).

The reforms have come through policies related to pricing, trade, privatisation of major sectors of national economies, removal of state monopolies, restructuring of labour markets and formation of domestic capital markets.

\section{Pricing policies}

Pricing policies have mainly concentrated on the removal of price controls on all consumer goods previously regulated by the government, and the raising of producer prices for export crops in real terms. Consequently, prices of many agricultural commodities and consumer goods have been decontrolled and subsidies have been largely removed. In Zimbabwe, for example, prices of white maize, white and red sorghum and finger millet have been decontrolled (Katerere et al. 1993). Subsidies still remain in the form of seed and fertiliser subsidies and food relief (Box 4.4).

In Zambia, the government eliminated subsidies in 1993 on all agricultural commodities including maize, maize meal and inputs, and liberalised maize marketing and pricing (Mupimpila et al. 1995). Similarly in Malawi and Tanzania, subsidies on agricultural inputs and other consumer goods have been removed. This has led to soaring prices of fertilisers which increased by around 300\% during 1990-92 in Tanzania (Bagachwa et al. 1995). Such increases in input prices have made fertilisers unaffordable to many small-scale farmers, who rely on extensive rather than intensive farming to expand crop production, with the resultant destruction of woodland.

Since the adoption of structural adjustment, the prices of export crops like cotton, tobacco, coffee and tea have risen (Katerere et al. 1993; Moyo et al. 1993; Kilindo 1994). In Tanzania, for example, producer prices of major agricultural exports increased by 200-400\% between 1985 and 1992 (Bagachwa et al. 1995). The favourable prices for tobacco led to a $13 \%$ increase in the area under this crop during the same period, resulting in high wood consumption rates. The increases in prices did not necessarily lead to improved incomes for farmers, as the price rises have not compensated for high rates of inflation (Kilindo 1994).

\section{Liberalisation of trade}

When trade is liberalised, it is argued that the market will be able to allocate resources more efficiently. Many countries in the region have removed most trade and market restrictions, both internally and internationally. This encouraged increased production of non-traditional crops, such as flowers and other horticultural crops, to capture European markets. Market liberalisation has also led to a dramatic increase in timber exports in Tanzania, from $2500 \mathrm{t}$ in 1986 to $33000 \mathrm{t}$ in 1989 (Bagachwa et al. 1995). Trade liberalisation also allows for easier importation of goods. Woodland-based fibres and packaging may be substituted by imported plastics.

\section{Privatisation of state companies}

The policy on privatisation has aimed at restructuring parastatals. In Zambia, for example, these dominated $80 \%$ of production; thus the policy is likely to have far-reaching effects.

\section{Restructuring of labour markets}

One of the measures advocated for reducing budget deficits is the reduction of government expenditure. Implementation of this has meant restructuring the labour market and cutting down on government employees. Privatisation of parastatals has also led to redundancy in the civil service. In Tanzania, some $15 \%$ of the civil service has been made redundant because of this policy. Consequently, formal-sector employment has fallen and the fall is yet to be halted by the supposed increase in employment as a result of structural adjustment. In Tanzania, for example, formal-sector job creation has fallen from $5 \%$ per year between 1970 and 1980 to less than $2 \%$ 
per year between 1984 and 1992 (Bagachwa et al. 1995). Similarly in Zambia, formal-sector employment fell from $27 \%$ of the labour force in 1974 to $18 \%$ in 1985 (Mupimpila et al. 1995). The proportion of total population in formal employment in Zimbabwe has fallen from $15.6 \%$ in 1977 to $11.6 \%$ in 1993 (Box 4.4). Real wages have also declined because of inflation.

Thus, urban economies and the labour market have, in recent years, undergone massive changes, with drastic reductions in real wages. Regular wage employment has become precarious. The limited employment opportunities in towns and the removal of wage-earning opportunities in the key neighbouring states of South Africa and Zimbabwe have resulted in the mushrooming of shanty towns in the peri-urban areas where many people live in extreme poverty and depend on woodfuel as the major source of energy (Moyo et al. 1993). Many countries may also be experiencing migration back to the rural areas given the limited employment opportunities in towns.

\section{Environmental implications of structural adjustment}

The implications of the various reforms under structural adjustment are many-fold, but no detailed studies of the processes have been undertaken. Higher crop prices may result in the increased land clearance as new land is opened up for cultivation. The removal of subsidies on agricultural inputs will probably lead to more extensive systems of cultivation, further increasing woodland clearance. Even for the commercial farmers, land has become cheaper than inputs such as fertilisers and machinery. With the liberalisation of markets and the mushrooming of non-traditional crops like flowers, however, there is a possibility that in certain areas cropping areas will be reduced as people opt for intensification of specific crops.

Privatisation and the restructuring of labour markets will, at least in the short term, increase unemployment and poverty. Woodfuel use is likely to remain the dominant source of fuel for urban and rural people. If unemployment continues, many people may opt to return to rural areas thus increasing pressure for land. In Zimbabwe, there is some evidence that structural adjustment programmes are resulting in commercialisation of woodland products (Chapter 6), as households look for alternative income sources, but the impacts of economic pressures and drought are difficult to separate (Matose et al. 1996).

Devaluation of a country's currency may make it lucrative to export valuable hardwoods and timber products (Dewees 1994).

\section{Inter-sectoral linkages and conclusions}

Although the responsibilities for woodland management falls within the mandate of the Ministry responsible for the forestry sector, the activities and policies of other sector ministries may have a direct or an indirect bearing on the forestry resource. The discussion above indicates the wide-ranging policies that can have impacts on woodlands and forests. Dewees (1994) argues that the most profound impacts on woodland cover in southern Africa were not the result of forestry policies, but of other attempts to regulate and control agricultural and other land uses.

Thus, for example, woodland clearance has been caused by tsetse eradication programmes, villagisation, politically inspired resettlement, pricing policies and the stimulation of certain crops (e.g. tobacco), an economic environment which has favoured rapid urbanisation with woodfuel as the chief energy source of the urban population, etc.

This situation is a reflection of the lack of co-ordination among different sectors, where each sector fosters its own interests without due consideration of their impacts. As a result, some of the policies in the different sectors are 
incompatible and sometimes conflicting. In Tanzania, for example, while the Forest Policy endeavours to reserve sufficient forest land in perpetuity, for the benefit of people, to improve local climates and watersheds, and to stabilise land liable to deterioration, the Livestock Policy is advocating clearing of woodland to eradicate tsetse flies and the agricultural sector continues to advocate destumping of arable fields (Ministry of Lands, Natural Resources and Tourism 1989b; United Republic of Tanzania 1986).

Another example comes from Malawi where the wood energy policy is geared towards limiting woodland extraction by increasing investments in plantations and woodlots in wood-deficit areas (Dewees 1994). However, the government also controls the price of plantation-produced firewood in order to mitigate the impacts of price increases on urban consumers. With low prices for plantation-produced firewood there is little incentive to embark on tree planting, leading to over-exploitation of the remaining woodland resources.

In addition to incompatibility of policies, there is often overlap of responsibilities among government ministries and other institutions, without any co-ordination of activities. In Zambia for example, Moyo et al. (1993) report that the Ministry of Water, Lands and Natural Resources is responsible for forest and woodland resource management, including rural energy policy making. However, it is the Ministry of Agriculture which is responsible for agro-forestry, while the Ministry of Power, Transport and Communications is responsible for other sources of energy, such as electricity and petroleum. A similar overlap is found in Zimbabwe.

Many of the problems currently surrounding the utilisation and management of woodlands are intimately bound up in the wider issues of land access and control, and this topic is returned to in Chapter 8. Patterns of land allocation have imposed enormous pressure on resource use, creating adverse implications for management. The situation has been exacerbated by government policies which have often encouraged unsustainable resource utilisation and management.

The history of the factors influencing resource use and management is rich and largely unexplored, ranging from early trade routes to structural adjustment. The legacy of colonial policies can be found throughout the current policy environment. More in-depth research is required to explore the impact of the policy framework on woodland use and management. How are changes in urban-rural relationships (migration, remittances, urban product demand) influencing livelihood systems of miombo woodland dwellers? How are structural adjustment programmes influencing the environment? What policies have had a major impact on woodland cover? How has the dependency of national economies on miombo woodland changed through time? 


\title{
Chapter
}

\section{RURAL HOUSEHOLDS AND MIOMBO WOODLANDS: USE, VALUE AND MANAGEMENT}

\author{
Jeanette Clarke, William Cavendish and Claire Coote
}

\section{Introduction}

Throughout the miombo region, the woodlands supply many products and services essential to the well-being of rural communities, some products acting as subsidies to agriculture (browse, leaf mulch), with others providing for basic needs, such as food, shelter and health (Figure 5.1). The first part of this chapter looks at the products and services derived from woodlands, who benefits from them and how people are responding to changes in availability.

Households in rural areas depend on a mix of activities to meet livelihood needs, including off-farm activities (urban remittances, craftwork etc.), harvesting products from woodlands, and crop and livestock production, the latter two often being intricately linked (Bradley and Dewees 1993). The actual mixture of activities depends on a variety of factors, ranging from socioeconomic (e.g. distance to markets, population densities) to bio-physical (e.g. presence of trypnosomiasis, crop production potential). There are few systematic studies which attempt to

from Campbell et al. 1991b). 
measure the overall value of miombo woodlands to rural households and compare woodlands as a source of economic value to other, more 'standard', activities such as crop and livestock production, craftwork and wage income. Even less attention has been paid to the socio-economic differentiation of miombo woodland use, namely which households are dependent on what resources and why this is the case. The second part of this chapter examines these issues, mostly using quantitative data from Zimbabwe because no such studies have been done elsewhere in the miombo region.

Given the importance of the benefits derived from miombo woodlands, it is not surprising to find management practices and forms of social control endemic to rural populations. This variety of forms of woodland and tree management range from the communal to the individual, and from the traditional to the modern. We outline some of these practices in the third part of the chapter, with more attention given to institutional arrangements in Chapter 8.

The chapter ends with a consideration of the complex determinants of use and management of woodland resources. We conclude that there is still much to learn about the interaction between rural households and miombo woodlands.

\section{Goods and services derived from miombo woodlands}

Miombo woodlands are the primary source of energy, in the form of firewood and charcoal, and a crucial source of essential subsistence goods (Gauslaa 1989; Dewees 1994; Morris 1995). Important products include poles and construction products, timber, materials for tool handles and household utensils, foods, medicines, leaf litter, grazing and browse. In addition woodlands have a service role in controlling soil erosion, providing shade, modifying hydrological cycles and maintaining soil fertility. Religious and cultural customs which relate to designated woodland areas and certain tree species are vital to the spiritual well-being and effective functioning of rural communities.

A number of studies have been carried out on species use and the species preferences of users (Campbell and du Toit 1988; Wilson 1989a; McGregor 1991; Coote et al. 1993a; 1993b; Lowore et al. 1995b). These studies show that species use is highly selective, providing preferred species are still available. A study at various sites in central and eastern Zimbabwe found that for each of the wood uses investigated a total of 35-60 species were named as the most commonly used species in an area estimated to have over 500 species (Campbell and du Toit 1988). In a study in Malawi nearly 90 tree and shrub species were identified by villagers and a number of uses or attributes ascribed to each of them though the number of preferred species for a variety of uses was relatively few (Lowore et al. 1995b).

Bradley and Dewees (1993) suggest that households in heavily populated rural areas face a difficult decision when deciding the fate of woodlands growing on land allocated to the family; the usual choice being to clear it to increase the supply of agricultural land. If the woodland is retained then the family forgoes short-term benefits of lost agricultural production. If woodlands are cleared, access to essential products is reduced or even lost, including essential inputs into the cropping system via livestock (browse for livestock which in turn provide draftpower and manure, as well as direct fertility inputs from leaf litter).

\section{Poles and construction materials}

The supply of construction material is still a vital role of miombo woodlands, though in places where the resource has become degraded, the large-diameter posts of durable timber traditionally used have become scarce or unavailable. House and barn construction requires many poles of many different dimensions, weights and 
durability, as well as rope fibre for tying them together and grass for thatching, which has to be replaced at frequent intervals (Grundy et al. 1993; Vermeulen 1993). Research in Malawi (Lowore et al. 1995b) found the highest demand for poles appeared to be from trees above five centimetres basal diameter and any recruitment (growth from younger trees) into these larger sizes is utilised rapidly. Withies, tough flexible branches, are required for weaving granaries and animal pens and reeds are used for fencing. Rope fibre, made by peeling strips from beneath the bark, needs to be strong, long and easily separated from the tree stem and the bark. Species common-

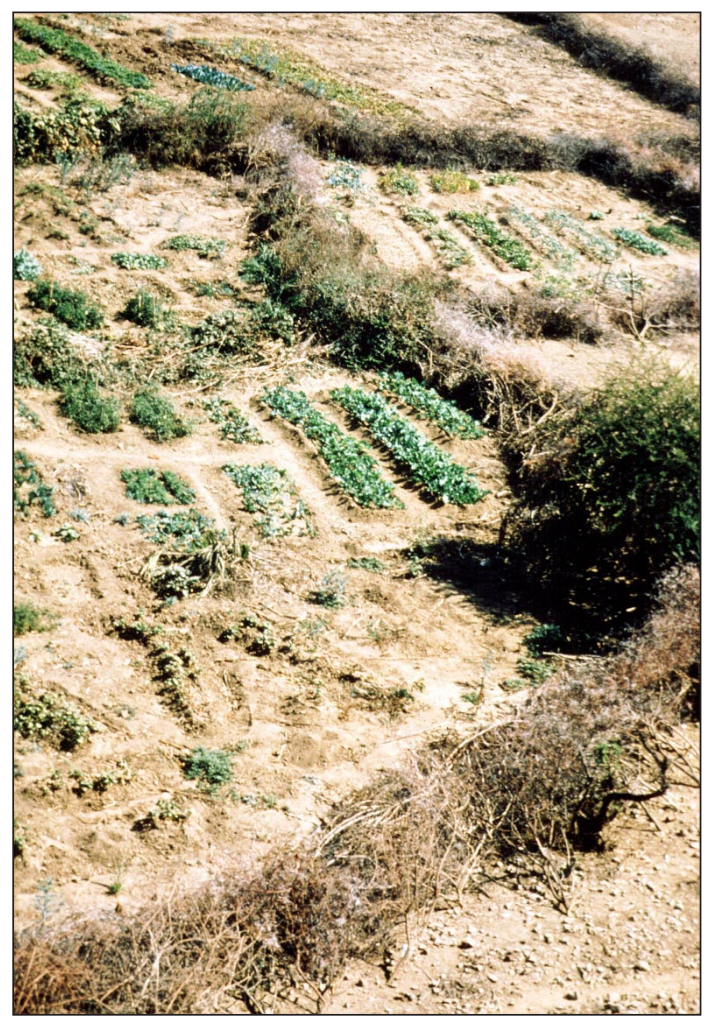

Many types of fencing are based on materials derived from miombo woodland. In this case use is made of branches to protect vegetables from livestock damage (photo: J. Clarke) ly used for the desired attributes of fibre strength and ease of peeling are Brachystegia boehmii, $B$. longifolia, B. spiciformis, B. utilis, B. microthyrsa and Bauhinia petersiana. Rope fibre can be harvested from young coppice shoots.

\section{Firewood}

Women are the principal collectors and consumers of firewood for domestic uses, and are highly selective in the species used. Typically, there are three or four preferred firewood species. In the Mutanda Resettlement Area in south east Zimbabwe the most frequently used species were Julbernardia globiflora, Colophospermum mopane and Brachystegia boehmii which were also the most abundant (Grundy et al. 1993). In two areas of Malawi the most-mentioned species was Julbernardia paniculata, followed by Brachystegia boehmii and B. spiciformis (Coote et al. 1993a; Lowore et al. 1995b).

The characteristics of favoured firewood include a hot flame, burning with little smoke and having long-lasting embers (Lowore et al. 1995b). Different sizes and species of wood are selected for different purposes: smaller pieces which catch fire easily are used for kindling, large logs are used for preparing food which has to cook for a long time, and hot or cool burning wood may be selected depending on the type of cooking required (McGregor 1991). Dry wood of small dimensions is preferred, as it is easier to collect and transport than wood of living trees (McGregor 1991; Abbot 1996). Field work in Malawi showed that fuelwood log diameters range from two centimetres for kindling to large billets used for food requiring long cooking. The most common size collected in headloads was three to five centimetres in diameter (Lowore et al. 1995b).

Wood is stockpiled in the dry season for use during the rainy season when people are busy working in their fields (Campbell et al. 1993). When accumulating this wood, women are 
selective about the species they gather whereas if they collect wood during the wet season they are more likely to take whatever they can find (Abbot 1996). Men are generally responsible for the collection of firewood in larger quantities and diameters, such as for brick burning or fish smoking, often using a sledge or cart, and are not so particular about the species collected (Campbell and Mangono 1994; Lowore et al. 1995b).

Traditional beliefs forbid the use of certain species. For example, in Malawi it is taboo to use the wood of Psorospermum febrifugum for fires, as it is believed that its smoke causes family conflicts (its local name means 'trouble stirrer') (Lowore et al. 1995b). Taboos on use of certain species for firewood are also widespread in Zimbabwe, for example Lonchocarpus capassa, Ochna and Maytenus (McGregor 1995a).

\section{Timber}

The main miombo timber species are Pterocarpus angolensis, whose timber is very durable, works well and shrinks very little in drying and is one of the most valuable timbers in Africa (Gauslaa 1989; Rodgers in press a), Afzelia quanzensis, whose timber is straight-grained, hard and used for internal and external joinery as well as being favoured for dug-out canoes (Williamson 1975), and Dalbergia melanoxylon, considered one of the best turnery woods in the world and used for making musical instruments. Other fine hardwood species from miombo and associated vegetation include Combretum imberbe, Diospyros mespiliformis, Androstachys johnsonii, Khaya anthotheca (syn. nyasica), Milletia stuhlmannii and Terminalia sericea.

In Malawi few of these species exist in large numbers in spite of their protected status. Pit-sawing is noted as causing local pockets of high-density cutting as a large number of stems are cut to support the felling and sawing of the target timber trees (Hall and Rodgers 1986). Most of the accessible stock of Pterocarpus angolensis has been felled in southern Malawi and the fur- niture industry relies on supplies from across the border in Mozambique (Lowore et al. 1994b). In Zimbabwe, where Pterocarpus angolensis has been heavily exploited in the past, warning has been given that the exploitable stock will be exhausted by the turn of the century if current extraction rates are continued (Bradley and Dewees 1993). Mozambique still has large stocks of valuable indigenous hardwoods, and commercial logging operations are on the increase since the cessation of the war. The timber is being exported in the form of logs to South Africa, Portugal and Germany (Sitoe and Ribeiro 1995; Chapter 6).

Other miombo timber species are pit-sawn, including Faurea species, Uapaca nitida and $U$. kirkiana for making door frames and Brachystegia spiciformis and Rauvolfia caffra (not strictly in the miombo woodland) for rough timber (Lowore et al. 1995b) though now, exotic timbers are increasingly used in Malawi for door frames, doors, ox-carts and furniture.

In most countries in the region, harvesting rights for commercial timber species are controlled by the state, typically through the forestry departments, and are sold to commercial logging companies. Local people are generally prohibited from cutting these species and only benefit marginally from commercial logging operations in their home areas (there may be some employment, and local people may collect the parts of the tree not removed by the logging operation). In Zimbabwe, ownership and control of timber resources has been devolved to the District Council level, and revenues from timber royalties accrue directly to the District Council, with the Forestry Commission playing a supervisory role. It is argued, however, that decentralisation needs to be taken further to the village level, so that villagers affected by logging operations directly benefit (Bradley and Dewees 1993). In Malawi, there is very little commercial logging of miombo trees and the Forestry Department does issue licences to individuals to cut single hardwood trees. 


\section{Household implements and curios}

Wood is the principal material for making domestic implements: hoe and axe handles, pestles and mortars, cooking sticks, plates, bowls, bows and arrows, drums, knobkerries, walking sticks, ox harnesses and ox-carts. It is also important for carved curios, an important income earner and sometime source of foreign exchange (Chapter 6).

As with firewood, specific attributes are required of the wood for each express purpose (Grundy et al. 1993; Vermeulen 1993; Lowore et al. 1995b): hunting tools, such as knobkerries and arrows are made from dense heartwoods such as that of Swartzia madagascariensis and bows made from light, durable and flexible woods such as Diplorhynchus condylocarpon and Cordia abyssinica. For axe and hoe handles, species with interlocked grain at the root collar, and which are strong, resistant to splitting and can be sanded to a smooth finish, such as Julbernardia paniculata, are preferred. Terminalia sericea is the preferred species for yoke making, because of its flexibility. In Zimbabwe, Artabotrys brachypetalus and Sterculia quinquiloba are commonly selected to make musical instruments (Grundy et al. 1993). For carving utility items a durable wood, with good form and density, is desired, such as Pericopsis angolensis and Sclerocarya birrea for pestles and mortars.

\section{Wild foods}

Miombo woodland of the Lumbumbashi region in Zaire reportedly produces more than 50 edible plants: including fruits of Strychnos and Chrysophyllum bangweolense, drupes of Vitex, Parinari and Uapaca, flowers and seeds of Stenostylis, tubers of Dioscorea, bulbs of Cyanastrum johnstonii, and young shoots of Adenia gummifera (Malaisse 1978a). In Malawi, during the great famine of 1949, a wide variety of emergency foods were gathered in the bush including wild yam and a type of grass. Some of these edible grasses, fungi and roots required long and careful preparation to make them safely edible (White 1987). Drought relief schemes by governments tend to take the place of 'famine' foods (Zinyama et al. 1990). While the consumption of fresh fruit is still very important, some publications indicate that the use of other edible woodland products has declined. In southern Zimbabwe, McGregor (1995a) found a shift from foodstuff gathered in woodlands towards 'weeds' and 'pests' collected from arable and disturbed land.

\section{Fruit}

Miombo woodlands are rich in variety and quantity of fruit trees (Campbell 1987). In Tanzania a total of 83 species of indigenous fruit trees have been recorded, most of which occur in miombo woodlands (Temu and Msanga 1994). During a survey in the Kasungu District in Malawi, villagers identified twenty species of fruit trees (Lowore et al. 1995a). Of the five preferred species, four were indigenous (Syzygium owariense, Parinari curatellifolia, Uapaca kirkiana and Flacourtia indica). Wild fruits are mostly consumed by children, but also eaten by adults when walking through the bush, herding animals or collecting other products (Campbell 1987). Fruit may be taken home for family consumption (Lowore et al. 1995a).

Wild fruit is not normally a major constituent in the diet but is an important supplementary source of food, as well as supplying vitamins and nutrients. Many fruits are a major source of iron and some, particularly Parinari curatellifolia, have a high crude protein and calcium content (Saka and Msonthi 1991). Wild fruit is consumed mainly in the hot dry season and early rainy season before the cultivated crops are ripe. Wild fruits are more important in remote areas and during times of famine (Campbell 1987; Coote et al. 1993b). Grewia flavescens fruits, ground and made into a porridge, comprised nearly $25 \%$ of the food items during the dry season in a 
remote communal area in northern Zimbabwe after the 1981-82 drought (Clarke 1983). Few examples are reported of fruit processing, one being processing of Parinari fruit to make a type of porridge (Lowore et al. 1995a), another the processing of Zizyphus mucronata fruit into a distilled spirit (Williamson 1975). Sclerocarya birrea is made into a beer (Gumbo et al. 1990; Grundy et al. 1993). Uapaca kirkiana is widely traded in Malawi (Coote 1994), as are other wild fruits throughout the region (Chapter 6).

\section{Mushrooms}

Moist miombo woodlands have abundant and diverse mushroom populations (Pegler and Piearce 1980). In Malawi 60 species of edible fungi have been documented (Williamson 1975). In the Boni area, Kasungu district, 26 species of edible mushrooms were identified (Lowore et al. 1995a). In Zimbabwe, research in the Shurugwi area found mushroom populations to be declining. The decline is probably due to factors such as the decrease in woodland height and structure, compaction of woodland soils under heavy grazing, felling of trees or collecting leaf litter (some mushroom species have mycorrhizal associations with the leaf litter of particular tree species). Nonetheless, 21 species were collected during one rainy season (McGregor 1995a).

The mushroom season begins at the start of the rains, November-December, and continues to March-April. Mushrooms are eaten fresh and also dried (Lowore et al. 1995b). McGregor (1995a) notes that fresh mushrooms are eaten by both richer and poorer households, but dried mushrooms were eaten only by poorer households. In a village in the Kasungu District of Malawi, Lowore et al. (1995a) found that $16 \%$ of journeys to the woodlands in a six-month period were for mushroom collection which was second only to firewood collection trips. During the rains, mushrooms are widely sold along roadsides, particularly by women and children (Chapter 6).

\section{Insects}

Edible insects harvested from miombo woodlands are an important source of protein, vitamins and energy for local people (Box 5.1). Fourteen species of edible caterpillars were recorded in Kasungu district, Malawi (Lowore et al. 1995a) of which four species were preferred, partly due to taste, partly to availability. Caterpillars are consumed fresh and are also dried and stored for up to 6 months; they are an important source of protein and are much appreciated.

The most important caterpillars (Saturniidae species) live on one of the most common trees, Julbernardia paniculata (Gauslaa 1989). Some species are host-specific; others feed from a variety of vegetation (Lowore et al. 1995a). In Zimbabwe the availability of caterpillars is reported to have diminished markedly; McGregor (1995a) found that of 14 species commonly said to have been consumed in the past, most have decreased in abundance and some are very rare. Caterpillars are harvested by shaking the tree or branch, though there are cases reported of people cutting trees to obtain the caterpillars (Lowore et al. 1995a). Some trees are defoliated by edible caterpillars but recover after the rains have started (Holden 1991). Termites are another important source of relish. In Zimbabwe soldier termites are considered a food for the poor and elderly (McGregor 1995a).

\section{Leaves and roots}

Wild plant leaves and roots are other important sources of food derived from miombo woodlands. Rural households in Lushoto, Tanzania were found to consume 15 species of wild leaves (Fleuet 1979). In central Zambia, Sørensen (1993) recorded ten species of edible wild leaves and four species of edible roots. McGregor (1995a) points out, however, that only a few of the many wild vegetables eaten actually come from the woodlands, the rest are found in disturbed areas growing as weeds. She found only two out 


\title{
Box 5.1 \\ Saturniid subsidy: cash and protein from edible caterpillars of Zambesian woodlands
}

\author{
Tony Cunningham
}

Insects are widely consumed in Africa, providing a valuable source of protein, vitamins and energy. They are often eaten as a 'relish' to supplement a generally starchy staple diet (DeFoliart 1995). Although miombo woodlands are well known as a source of honey (Clauss 1991), the value of mopane and miombo woodlands as the major source of edible caterpillars in Africa is less widely recognised amongst planners and policy makers. To rural people, however, this is a resource of great importance which influences public attitudes to management and conservation of miombo woodlands. A recent survey of public attitudes to Kasungu National Park in Malawi, which is dominated by miombo woodland, found that the resources that the majority of people wanted to harvest from the park were honey and caterpillars (see table), with fuelwood, building materials and mushrooms all of lesser importance to subsistence and commercial collectors from rural areas (Mkanda and Munthali 1994).

The top five natural resources from Kasungu National Park, Malawi, in highest demand from subsistence and commercial collectors, and town residents (Mkanda and Munthali 1994).

\begin{tabular}{lcccc} 
Resource & \multicolumn{4}{c}{ Number of users } \\
Honey & Subsistence & Commercial & Town & Total \\
Caterpillars & 38 & 30 & 5 & 73 \\
Firewood & 37 & 28 & 6 & 71 \\
Building materials & 25 & 28 & 23 & 69 \\
Mushrooms & 26 & 18 & 18 & 62 \\
& 28 & 25 & 1 & 40
\end{tabular}

The Saturniidae, a family of giant silk moths, is the most important source of edible caterpillars, with fewer caterpillar species in the Nocutuidae, Sphingidae and Limacodidae being consumed. In southern Zaire, 35 caterpillar species are eaten (Malaisse and Parent 1980) and 13 species are collected in miombo woodland in Malawi (Mkanda and Munthali 1994), but relatively few caterpillar species provide the major source of income and protein from Zambesian woodlands. The best known of these is the 'mopane worm', Gonimbrasia belina, which is the main commercial species in mopane woodlands (Quin 1959), but which is also collected from miombo woodlands (Mkanda and Munthali 1994). Five caterpillar species dominate collections from miombo woodland. First, Cerina forda, which is the most widely eaten caterpillar (Nigeria, Zaire, Zambia, Zimbabwe, South Africa), followed by the 'mopane worm' Gonimbrasia belina, then Bunaeopsis aurantiaca, the most important species exported from southern Zaire, Gynanisa maia, which is very popular in Malawi and finally, an unidentified species locally known as muтра, which is the most the important caterpillar collected from miombo woodland in northern Zambia (Quin 1959; Holden 1991; Mkanda and Munthali 1994; DeFoliart 1995). Zambezian woodland trees that are the most important foodplants for these edible caterpillars are Colophospermum mopane, Burkea africana and Erythrophleum africanum, with Sclerocarya birrea, Julbernardia paniculata, J. globiflora, Brachystegia boehmii, B. longifolia and Isoberlinia angolensis of lesser importance. 
Saturniid subsidy (continued)

Traditional management practices by local chiefs to control the season of collection are recorded from Zambia (Holden 1991) and from Zaire, where a magical fetish (kehal) is used to prevent collection until the caterpillars have reached near-maximum size (Muyay 1981). Customary regulations amongst Yansi people in Zaire also prohibit the cutting of live branches from certain tree species during caterpillar collection. Yansi women are also recorded burning savanna woodland to promote the leaf regrowth and increase caterpillar abundance (Muyay 1981).

As commercial harvesting for local markets or export has escalated, these controls have weakened under massive demand for the seasonally available resource. The quantities harvested are immense. In south western Zaire, commercial harvest of dried caterpillars averaged 185 tons $\mathrm{yr}^{-1}$ (Leleup and Daems 1969). 'Mopane worm' sales of 1600 tons $\mathrm{yr}^{-1}$ are recorded sold in South Africa (DeFoliart 1995), while in Botswana, one businessman is recorded buying 5000 bags of mopane worms per year at R120-150 per bag (Styles 1995). Harvesters are mainly women, who collect on average $18 \mathrm{~kg}$ (wet weight) of caterpillars per hour which are then eviscerated, dried and sometimes smoked for a longer shelf-life (Quin 1959). Recent records from mopane woodland in South Africa, show that harvesters can earn R2500 (US\$715) in seven weeks, almost 95\% of the average farm workers income in this area (Styles 1995). As each bag contains about 80000 caterpillars, and up to 600 women are recorded harvesting from one area on Colophospermum mopane woodland, there is concern that edible caterpillars "are too profitable for their own good" (Styles 1995).

Major problems are the effects of late-season burning on miombo woodland, felling of trees or large branches to collect the caterpillars and over-utilisation of the caterpillars (Leleup and Daems 1969; Holden 1991; Styles 1995). Resource management proposals are important, including early rather than late burning, a ban on tree felling to harvest caterpillars and on harvest of pupae and creation of 'reserve' areas where no harvest takes place (Styles 1995). As a protein-rich resource generating valuable income, it is important that this natural subsidy is retained, and taken into account by scientists and land-use planners as much as it is by local people.

of a total of 39 species of gathered vegetables came from the woodland in Shurugwi, Zimbabwe. In Malawi two species of edible leaves, one of Ormocarpum species, and one tuber, Habenaria walleri, have been recorded (Lowore et al. 1995b).

\section{Antelope, hares, birds and mice}

Meat from wild animals such as antelope and hares has long been an important source of protein for rural dwellers. Hunting is usually undertaken in the dry season, although guinea fowl and bush pigs are hunted in the rainy season to stop them spoiling the maize crop (Lowore et al. 1995b).

Hunting in some areas is hedged with ritual to prevent attack by wild mammals, particularly kudu and eland, and offerings must be made to the spirits prior to the hunt. In addition, protective medicines are used and one must enter the woodland, considered a cool environment, in a 'cool' condition with no feelings of anger or discord (Morris 1995). Young boys hunt for birds with catapults as an additional food source (Coote $e t$ al. 1993a). Populations of game animals, other than rodents, have become very depleted in most areas of dense human settlement as a result of hunting and habitat destruction.

\section{Honey and beeswax}

Apiculture is a traditional occupation throughout the miombo zone but rapidly disappearing forests 
have led to a decline in honey and beeswax production in some areas (Banda and De Boer 1993). A stand of mature miombo woodland has high potential for producing honey and beeswax. Important nectar-producing genera include Acacia, Brachystegia, Julbernardia, Syzygium and Combretum. Productivity estimates from Tanzania indicate that one square mile can support 44 bee colonies producing 0.1 tons of beeswax and 1.3 tons of honey per year (Lowore et al. 1995a). Export of honey and beeswax is an important foreign currency earner in Tanzania (Chihongo 1995).

\section{Medicines}

The roots, leaves and bark of many different species are used in health care, both as medicine and for magic (Box 6.6; Gelfand et al. 1985; Coote et al. 1993a; 1993b). Plant material combinations are used in self-treatment of common ailments, such as coughs, headaches, sores and diarrhoea, and people are generally very knowledgeable about which plants can be used and how to prepare them. In a number of African languages the word for tree and medicine is the same or similar (Morris 1995).

In Malawi, traditional birth attendants offer plant medicines to women for contraceptives, for barrenness and for childbirth (Abbot 1996). Traditional healers are consulted for more serious complaints and they travel long distances to find materials they need. The general lack of formal health care facilities in the rural areas means that people are very dependent on plant medicines which are normally regarded as more effective than 'European' methods. The disappearance of woodlands makes it harder to find the traditional materials and is identified by rural people as a factor in reducing their well-being (Coote, pers. obs.). Parts of miombo trees and shrubs are also important constituents in the treatment of people suffering from spirit possession (Coote, pers. obs.; Gelfand et al. 1985).
In addition to the importance of medicinal plant compounds for local use, some are internationally marketed, such as quinine, which is a foreign currency earner for Tanzania (Chihongo 1995).

\section{Leaf litter}

Nyathi and Campbell (1993) found small-scale farmers in Masvingo province of Zimbabwe use miombo woodland leaf litter to increase soil fertility in arable lands. It was found that households owning cattle collect more litter than those who do not own cattle, as the former have greater access to transport and much of the litter is cured in cattle pens, decomposing together with manure. McGregor (1995a) found that the use of leaf litter to enrich arable lands is becoming more important in the Shurugwi area of Zimbabwe, despite decreasing supply. Leaf litter is of particular value to farmers who lack access to other soil fertilising inputs and critical to those who have no land other than their home yards. No written evidence of the use of miombo leaf litter has been found in other countries in the region.

\section{Browse}

The dry-season flush of leaves that occurs in miombo woodlands during September to November is a vital forage resource at a time when grasses are dry, a month or two before the rains. At this time cattle can spend up to $60 \%$ of their feeding time using trees (Scoones 1990). The new leaves are high in crude protein and mineral content (Walker 1980; Lowore et al. 1995a; Chapter 7). Cattle, goats and wild animals browse leaves from regeneration, short trees and shrubs (Table 5.1).

\section{Tannins, dyes, oils, resins, gums}

There is a wide range of other useful products which come from trees in miombo woodlands, including a variety of tannins, dyes, oils, resins and gums. Many of these products are unknown outside of the area in which they are used, and there exists a high potential for added value and commercialisation (Chikami 1995). 
Table 5.1 Important fodder species from miombo and associated woodlands (information from surveys in Zvishavane, southern Zimbabwe [Wilson 1989a] and Boni, Kasungu, Malawi [Lowore et al. 1995b]).

\begin{tabular}{|c|c|c|}
\hline Species & Fruit/pods & Leaves \\
\hline Acacia tortilis & Important to all livestock & Heavily browsed by goats \\
\hline Afzelia quanzensis & & Flushes early, very palatable \\
\hline Bauhinia thoningii & Eaten by cattle and goats & \\
\hline Brachystegia spiciformis & & Important early-season browse \\
\hline Combretum apiculatum & & $\begin{array}{l}\text { Flushes early in season and dry fallen } \\
\text { leaves can also be eaten if damp }\end{array}$ \\
\hline Cussonia arborea & & Browse cut for cattle \\
\hline Dichrostachys cinerea & Eaten by cattle and goats & Lopped and fed to cattle in droughts \\
\hline Ficus sycomorus & Eaten by cattle and goats & \\
\hline Julbernardia globiflora & & $\begin{array}{l}\text { Less palatable than } B \text {. spiciformis, but } \\
\text { still an important early-season browse }\end{array}$ \\
\hline Julbernardia paniculata & & $\begin{array}{l}\text { Young leaves important browse for } \\
\text { cattle }\end{array}$ \\
\hline Kigelia africana & $\begin{array}{l}\text { Can be stored; cut and added } \\
\text { to maize stalks in dry season }\end{array}$ & $\begin{array}{l}\text { Flushes early in late dry season,when } \\
\text { there is shortage of graze and browse; } \\
\text { branches are lopped to feed livestock }\end{array}$ \\
\hline $\begin{array}{l}\text { Pseudolachnostylis } \\
\text { maprouneifolia }\end{array}$ & & Good browse \\
\hline Steganotaenia araliacea & Eaten by livestock & Good browse \\
\hline Strychnos spinosa & & Good browse \\
\hline Zahna africana & & Good browse \\
\hline
\end{tabular}

\section{Service functions of miombo woodlands}

Other benefits of miombo woodlands, termed semi-public benefits (Bojö 1993; Dewees 1994), include soil retention, streamflow regulation, shade and shelter from strong winds. Miombo woodland provides watershed protection to soils prone to erosion by heavy seasonal rains, and rapid regrowth from well-developed root stocks provides bush fallow for shifting cultivation (Gauslaa 1989). Water conservation is a frequent justification for protection and miombo trees play a role in protecting the sources of streams.

\section{Spiritual and cultural values}

Throughout the miombo zone, trees and woodlands are important in the spiritual and cultural life of local residents (Mukamuri 1989; Sørensen 1993; Sitoe and Ribeiro 1995). Territorial cult religions, in which natural resources are believed to be guarded by the spirits of the ancestors, are common to most of the indigenous peoples of the miombo woodland areas (Scholoffers 1978; Wilson 1990; Mukamuri 1995b). There are a variety of rules and taboos which govern the use of resources, and these must be obeyed or 
misfortune and disaster are said to result. Sacred groves, often burial sites for the ancestors, are used for a variety of important cultural and religious ceremonies (see below).

\section{The value of miombo woodlands to rural households}

\section{The total value of miombo woodlands}

The literature reviewed in the preceding sections of this chapter has charted the multiple uses that miombo woodlands offer rural households. Given this extensive list of possible uses, and the generic low income status of most rural households living in miombo areas, it is reasonable to assume that miombo woodlands play an important role in contributing to rural welfare.

Attempts have recently been made in Zimbabwe to estimate an overall value of wood- lands. One study assigned values to woodland use on the basis of assumed consumption levels derived from the secondary literature, and used local market trading prices (or farm-gate prices, if necessary) to convert quantities to values (Campbell et al. 1991b; Figure 5.2). The results of this exercise suggested that tree products and services had an imputed gross value (i.e. extraction costs were not subtracted from total values) of about US\$320 per household per year, a figure considerably higher than the median income levels for rural households that appear in a variety of studies. However, this figure is probably an over-estimate (Cavendish 1996).

The second study was methodologically more ambitious, in that it used a Contingent Valuation Methodology (CVM) to attempt a valuation of a broader set of goods and services than were covered in the first study (e.g. browse,

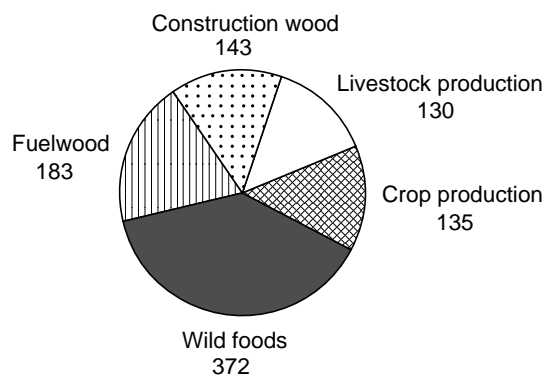

Farm-gate values for tree products (Z\$ per household per annum)

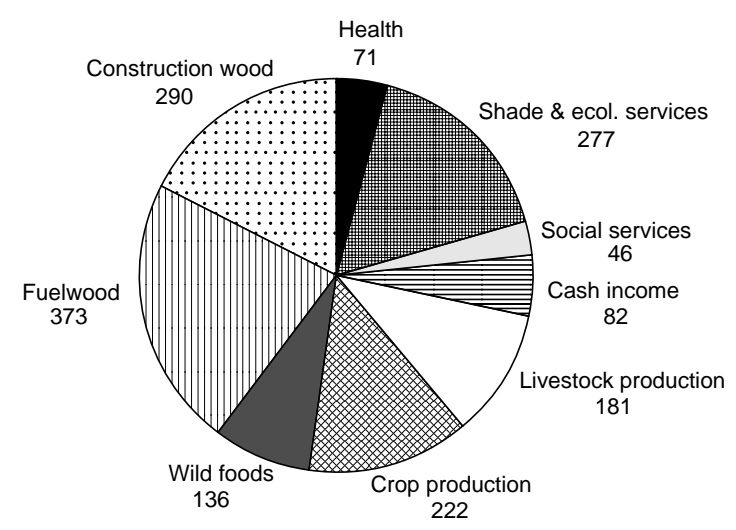

Willingness-to-pay for all tree products (Undiscounted Z\$ per household)

Figure 5.2 Value of woodland products to households as derived through farm-gate prices (Campbell et al. 1991b) and willingness-to-pay (Lynam et al. 1994). 
shade, erosion control) (Lynam et al. 1994; Figure 5.2). The CVM technique used was to establish a benchmark rural value (in this case the willingness-to-pay for borehole sinking and handpump installation), and then ask respondents to trade off various tree and woodland uses against this value, thereby establishing a consistent hierarchy of miombo woodland values.

In the end, the overall values produced by the CVM study were (at any reasonable discount rate) lower than those of the first study. Even so, using a $20 \%$ discount rate, the CVM study values implied an annual income flow of about US\$100, which was greater than the cash incomes in three out of the four study areas. A considerable portion of total value is given to ecological services.

This study has its methodological limitations. First, the use of CVM in largely subsistence rural areas is questionable. Second, even if the use of CVM is appropriate, it is not clear that the Lynam et al. (1994) study was careful enough in distinguishing between stock (resource availability) versus flow (resource use) values, and in eliminating double-counting.

A third study used a derived demand approach to estimate woodland values (Campbell et al. 1995a). Using a smaller set of products and focusing only on producer surplus, the net value of woodland, i.e. the value minus extraction costs (labour), was estimated at US\$ 50-85 per household per year. Ranking exercises in a participatory rural appraisal exercise suggest that the total economic value may be many times these figures, given the full spectrum of goods and services that woodlands provide. In the derived demand approach, firewood was the most valued good, while in the ranking exercise a number of nonmarket values were rated higher than firewood (e.g. water retention, rain-making functions, inheritance, sacred sites).

To reinforce the conclusion that the overall value of woodlands is considerable, note that these valuation studies are far from complete, as they are mostly concerned with purely private use values, and mostly do not include the non-use, option and existence values (e.g. species maintenance, carbon sequestration, non-locals' recreation) that are also associated with miombo woodlands. For a rough estimation of the potential magnitude of these values, see Bojö (1993).

\section{Woodland resource use and socio-economic differentiation}

While the studies reported in the previous section do support the suggestion that miombo woodlands may play a significant role in underpinning rural welfare, they provide figures only on the 'average' household. Thus, they do not reveal the relationship between woodland utilisation and household socio-economic indicators such as wealth, income, expenditure or production structure.

An understanding of the relationship between woodland utilisation and socio-economic status is critical to a full understanding of the dynamics of woodland change. Cavendish (1996), working in southern Chivi in Zimbabwe, has attempted to integrate miombo woodland resource use into a broader rural household analysis. His findings are discussed in detail as it is the only study of this kind in the region. The data are taken from a 213household study across 29 villages in Shindi Ward, Chivi Communal Area. Data were collected over a one-year period on each household's actual (or reported) use of environmental goods and services, in the context of a questionnaire covering the household's income, consumption and expenditure. All prices used are either local trading prices or the household's own reported prices for environmental goods and services, except for that of the value of livestock browse and graze, which is calculated with reference to livestock asset values. The values reported here, unlike those in Campbell et al. (1995a), have not been reduced by subtracting labour costs involved in extraction. 
At an aggregate level, the contribution of woodland resources to cash income is not large, reaching only $8.2 \%$ of the total cash income of about US\$ 200 per household per year. However, this average figure masks important differences across households, as demonstrated by the cash income breakdown by households ranked by cash income quintile (Figure 5.3). Thus, whereas the top $20 \%$ of households derive less than $5 \%$ of their total cash income of about US\$ 570 per household per year from woodland uses, the lowest $20 \%$ derive nearly $20 \%$ of their income of about US\$ 50 per household per year from woodland sources, and this percentage drops systematically as one moves down the cash income quintiles.
Equally interestingly, the composition of woodland-derived cash income also differs across income quintiles (Cavendish 1996). First, for the three lowest quintiles, the largest source of woodland-derived cash income is labour income based on woodland products (i.e. thatching, carving, roof-mending, carpentry and digging termitaria). This is consistent with the common observation that the poorest in rural societies are often those with the lowest education and skills who can only sell their unskilled labour at low wage rates (the cross-quintile percentages for unskilled labour income also support this conjecture).

Second, excluding the top $20 \%$, there are some activities whose importance rises with
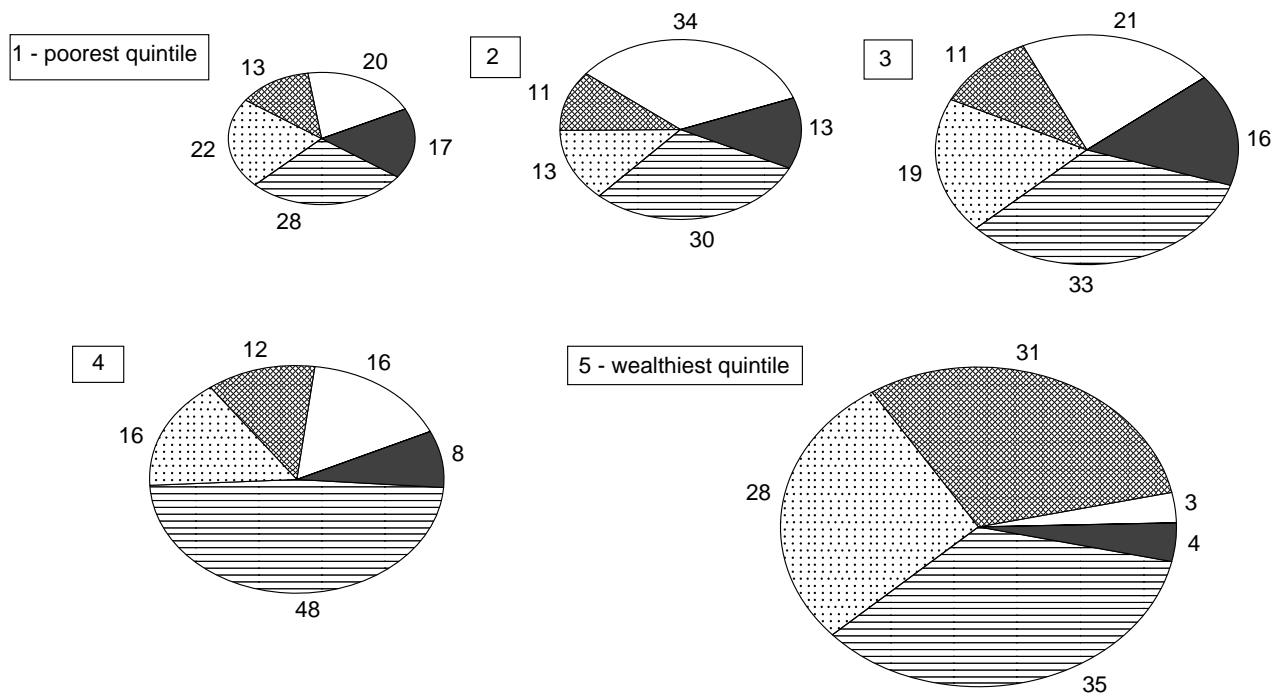

Agriculture

Labour (excluding natural resource-based)

Remittances, income from gifts, other

Cash from local woodland resources (sales of products and labour based on such resources)

Gold panning, crafts, small-scale enterprises

Figure 5.3 Sources of household cash income, expressed as percentages, across income quintiles: Shindi Ward, southern Zimbabwe, 1993-94 (Cavendish 1996). Sizes of pie diagrams are proportional to absolute income levels. The final category ('Gold panning,....) excludes crafts and enterprises based on woodland-based products. 
income while seemingly similar activities decline with income. For example, shares of cash income derived from sales of large carpentry items and large wild animals rise as income rises, whilst those derived from small carpentry items and small wild animals fall as income rises.

The explanation of this lies largely in the different nature of these activities. Making small carpentry items (e.g. implement handles, yokes, skeys, cooking sticks) is a low-skill, low-return activity with flexibility of species inputs, little time commitment required and thus zero entry barriers. These types of activities are more likely to be carried out for cash generation by lowerincome, more constrained households who are unable to exploit more-lucrative opportunities.

By contrast, making large carpentry items (e.g. carts, doors, tables, furniture, mortars etc.) requires skill, investment of time in searching for rarer species and working on the wood, and investment of capital in tools. Such activities have higher entry costs and can only be carried out by households that have sufficient access to capital and have a sufficient labour pool to spare the diversion of (usually male) labour that skilled carpentry requires.

Likewise, hunting and selling smaller animals (mice, birds, rock rabbits) is an opportunistic activity which can be carried out by many household members, usually children. Hunting and selling larger animals (game) is highly risky due to its illegality and is only carried out by adult males.

Finally, there is a range of activities whose importance in cash income generation declines as income rises, such as sales of wild vegetables and fruits, sales of wood, sales of thatching grass, and sales of wine. Some of these, namely thatching grass and wine, are largely carried out by women and reflect the preponderance of de jure femaleheaded households amongst the rural poor. Indeed it may be that access to and use of miombo resources are crucial to these households' survival. Other products, for example sales of wild fruits, again point to the dependence of the lowest income households on opportunistic, low-skill, low-return activities.

All such generalisations are not without their problems. For instance, producers of small wooden items are not always an homogenous group, and may include those who are producing for local markets as well as those producing for urban markets, with concomitant differences in species selectivity, distances to sources, quality considerations, etc. (Brigham 1994).

Looking at the contribution of miombo woodland resources to the broader total income measure (Table 5.2), it is clear that these resources make a significant contribution to the total welfare of rural households, producing on average across all households $22.9 \%$, about US\$ 115 per household per year, of total income. ${ }^{1}$ While the variation of woodland share across households is less than that for cash income, it is still significant, and generally the importance of miombo resources increases as total income decreases. Indeed, for the three lowest quintiles, woodland resources have a higher total value than (non-woodland) cash income. Once again, there are also notable differences in the composition of woodland-derived income. For example, lower-income households depend proportionately more on the consumption of wild foods and wild goods than do higher-income households, evidence possibly that these households are unable to allocate as high a share of cash income to purchased foods as wealthier households.

Likewise, while the total value of fuelwood use consistently rises with total income, its relative importance consistently falls. Perhaps most

\footnotetext{
${ }^{1}$ Total income refers to the sum of cash income, of the consumption of own produced produce (e.g. crops and livestock produce) and of the consumption of 'free' environmental resources, including woodland resources (firewood, wild foods, livestock browse and graze etc).
} 


\begin{tabular}{|c|c|c|c|c|c|c|}
\hline & \multicolumn{5}{|c|}{ Household quintile (total income ranking) } & \multirow{3}{*}{$\begin{array}{r}\text { All } \\
\text { households }\end{array}$} \\
\hline & Lowest & & & & Upper & \\
\hline & $20 \%$ & $20-40 \%$ & $40-60 \%$ & $60-80 \%$ & $20 \%$ & \\
\hline \multicolumn{7}{|l|}{ Total cash income } \\
\hline (excluding environmental cash income) & 21.9 & 19.0 & 24.8 & 29.7 & 46.5 & 33.8 \\
\hline Crop income & 2.8 & 1.8 & 3.3 & 3.2 & 12.5 & 6.9 \\
\hline Livestock income & 1.7 & 1.9 & 1.0 & 1.5 & 3.7 & 2.4 \\
\hline Unskilled labour income & 4.4 & 3.1 & 3.2 & 1.8 & 1.5 & 2.3 \\
\hline Skilled labour income (teaching) & . & . & . & . & 12.0 & 5.0 \\
\hline Crafts and small-scale enterprises & 3.1 & 1.5 & 4.4 & 4.3 & 1.6 & 2.7 \\
\hline Remittances, gifts, miscellaneous & 9.9 & 10.6 & 13.0 & 18.8 & 15.3 & 14.5 \\
\hline Total own-produced goods & 43.5 & 44.8 & 41.6 & 42.0 & 30.8 & 37.8 \\
\hline Consumption of own-produced goods & 35.6 & 37.2 & 35.4 & 35.5 & 27.3 & 32.3 \\
\hline Input use of own-produced goods & 7.9 & 7.6 & 6.1 & 6.5 & 3.5 & 5.5 \\
\hline Total environmental income & 34.6 & 36.2 & 33.6 & 28.3 & 22.6 & 28.4 \\
\hline Gold panning & 7.0 & 12.0 & 8.1 & 6.3 & 1.5 & 5.4 \\
\hline \multicolumn{7}{|l|}{ Natural habitat utilisation cash income } \\
\hline Consumption of own-collected wild foods & 8.8 & 7.5 & 6.3 & 4.4 & 2.5 & 4.7 \\
\hline Consumption of own-collected fuelwood & 9.7 & 8.1 & 7.1 & 6.0 & 3.1 & 5.6 \\
\hline $\begin{array}{l}\text { Consumption of own-collected wild goods } \\
\text { (e,g thatching grass, bark, medicines) }\end{array}$ & 1.4 & 0.8 & 0.9 & 0.7 & 0.3 & 0.6 \\
\hline Livestock browse and graze & 1.9 & 3.4 & 5.0 & 7.8 & 13.3 & 8.5 \\
\hline Total income & 100.0 & 100.0 & 100.0 & 100.0 & 100.0 & 100.0 \\
\hline \multirow{4}{*}{$\begin{array}{l}\text { Miombo woodland-derived income }(\%) * * \\
\text { Ditto, minus livestock browse and graze }(\%) \\
\text { Average total income } \\
\text { (Z\$ per household per year)*** }\end{array}$} & 27.3 & 24.1 & 25.4 & 21.9 & 21.1 & 22.9 \\
\hline & 25.5 & 20.8 & 20.4 & 14.1 & 7.8 & 14.4 \\
\hline & & & & & & \\
\hline & 1595 & 2297 & 2847 & 3555 & 7284 & 3528 \\
\hline \multirow{2}{*}{\multicolumn{7}{|c|}{$\begin{array}{l}\text { * The values presented exclude certain direct woodland-derived values, namely the value of organic crop } \\
\text { inputs, the (imputed) rental of woodland-derived housing and the (imputed) rental of woodland-derived } \\
\text { durables (e.g. pestles and mortars), and also exclude all indirect values (ecological functions, cultural } \\
\text { values etc.). Incorporating these would not change the cash income results, but would raise the importance } \\
\text { of miombo woodland-derived resources in total income still further. } \\
\text { ** Miombo woodland-derived income equals 'Total environmental income' minus environmental income that } \\
\text { is not woodland-based (e.g. gold panning, pottery). }\end{array}$}} \\
\hline & & & & & & \\
\hline *** US\$ $1=$ Z\$ 6.5 (September 1993); US\$ & $1=\mathrm{Z} \$ 8$ & 09 (Janua & 1994). & & & \\
\hline
\end{tabular}


significant, though, are the figures for the value of livestock browse and graze, which rise powerfully as income rises, such that for the top $20 \%$ of households, livestock browse and graze contribute roughly two-thirds of miombo woodland values, and the browse and graze use alone is as valuable as remittances or crop sales.

These figures suggest two important points. The first is that the nature of household resource dependence, and hence demands on miombo woodlands resources, will alter as households' socio-economic status changes: the 'povertyenvironment' relationship underlying woodland change will not be static. The second is that incentives to manage an heterogeneous woodland resource will differ quite markedly across socioeconomic groups within the same community, and that we may expect resource management rules to be marked by struggle as different groups seek to impose or retain rules that benefit their resource demands at the possible expense of others.

\section{Other dimensions of differentiation}

Although other studies do not examine woodland resource use within the context of the total household economy, there are studies of woodland resource use which support the point made above, that socio-economic differentiation leads to significant differences in woodland resource use and value. These studies also indicate other dimensions of differentiation, including age and gender.

A number of studies have documented differential resource use by certain groups. For example, studies of children in miombo areas have demonstrated how wild fruits, rodents, insects and birds can form a crucial source of foods for children from poorer households while at school (those from better-off households being sent to school with food or money) or while herding (Campbell et al. 1991a; Coote et al. 1993a; McGregor 1995a). It is partly for this reason that children can display remarkable knowledge of the local woodland resource, with mental fruit tree maps and nicknames for the sweetest fruit trees (Wilson 1989a).

A significant difference across gender has been found in the evaluation of shrinking woodland access, on account of the different resource demands of men and women (Box 5.2; Fortmann and Nabane 1992). In an echo of this point, it has also been found that widows and widowers, though both resource-dependent, utilise quite different products, the former utilise fruits and grass, while the latter rely on hunting and fishing (Cavendish 1996).

The studies indicate that patterns may differ from one area to the next. In the case of firewood, while McGregor (1991) found that wealthier households use more firewood than poorer households at all times of the year, Campbell and Mangono (1994) found that this result is areadependent. In deforested areas near cities, wealthier households are more likely to shift to purchased substitutes such as kerosene.

Use of cattle manure, representing a transfer of nutrients from woodland to fields, is positively correlated with income (Bradley and Dewees 1993), as is the use of termitaria as a soil amendment (McGregor 1991). However, variations in leaf litter use are not explained simply by wealth. For example, Wilson (1990) and Nyathi and Campbell (1993) found a positive correlation between leaf litter use and wealth. However, Musvoto and Campbell (1995) found no correlation of this type in Mangwende, while in Shurugwi, poorer households were found to use leaf litter more (McGregor 1995a). Explanation of these differences lies not just in socio-economic variation, but also in other factors. In Masvingo, where leaf litter is largely cured in cattle pens before use, and in Mazvihwa, where large volumes of leaf litter must be transported by cattledrawn cart, quantities deployed will be positively correlated with cattle ownership and, in turn, wealth. In Mangwende, by contrast, leaf litter is mostly applied as a leaf mulch on gardens, an 


\section{Box 5.2 Gender and trees}

\section{Louise Fortmann}

Interviews in two Mhondoro villages, Zimbabwe, showed that while women and men used trees for similar purposes, women tended to know more uses for individual tree species than men, utilised more different tree species than men, and utilised different places from men (Chidari et al. 1992; Fortmann and Nabane 1992). For example, in key informant interviews, men identified four uses for Ficus thonningii: fruit, rope, poles and firewood, while women identified four additional uses: shade, bird food and two different medicinal uses. In the case of Gardenia volkensii, men identified five uses: poles, firewood, household utensils, rakes and one medicinal use. Women identified seven additional uses: animal browse, shade, weaning and four different medicinal uses.

For 114 species, women in a sample survey consistently named more uses for trees than men and were particularly knowledgeable about medicinal uses. With the exception of making agricultural implements, women used a wider variety of tree species than men (Table A). The larger differences (firewood, fertiliser and agricultural implements) suggest clearly gender-based knowledge (some of the smaller differences may be due to the different sample sizes). Similar percentages of women and men sell fruit, but men were more likely to be involved in sales to outsiders or in distant places, while women were more likely to sell in areas near the village (Table B).

Table A Number of tree species used by women and men in villages in Mhondoro, Zimbabwe, 1990-91.

\begin{tabular}{lcccc}
\hline \multirow{2}{*}{ Use } & \multicolumn{2}{c}{ Village 1 } & \multicolumn{2}{c}{ Village 2 } \\
& $\begin{array}{l}\text { Women } \\
\text { N=61 }\end{array}$ & Men & Women & Men \\
& & N=44 & N=12 \\
\hline \multirow{2}{*}{ Fruit to eat } & 35 & 32 & 34 & 28 \\
Medicine & 42 & 41 & 45 & 21 \\
Firewood & 51 & 35 & 56 & 25 \\
Browse & 43 & 37 & 28 & 24 \\
Poles & 25 & 20 & 27 & 19 \\
Agricultural implements & 18 & 18 & 2 & 10 \\
Fertiliser & 22 & 11 & 41 & 12
\end{tabular}

Table B Locations where women ( $\mathrm{N}=35)$ and men $(\mathrm{N}=13)$ sell fruits (percentage selling in each place).

\begin{tabular}{lrr}
\hline Sold where & Women & Men \\
\hline Inside community & $57 \%$ & $62 \%$ \\
Harare City market & $6 \%$ & $46 \%$ \\
Nearby areas & $20 \%$ & $8 \%$ \\
To outsider buyers & $20 \%$ & $30 \%$
\end{tabular}

activity in which almost all households are involved. Finally, in Shurugwi, high levels of deforestation make leaf litter harder to find, with the result that wealthier households prefer other sources of fertiliser to leaf litter.
The dimensions of differentiation in resource use are broader than just the socio-economic. Box 5.3 demonstrates the impact of woodland cover on resource use and access, but deforestation effects are overlain by a range of other determinants. 
Gender and trees (continued)

Although common lands were an important source of tree products for everyone, women were more likely than men to utilise tree species located on their individually controlled land such as land around the homestead or the arable lands (Table C). Since men often obtain tree products in large amounts on 'expeditions', this is not a surprising difference.

These data clearly show that trees are not the preserve of men. Women and men use trees for the same range of purposes, although gender division of labour is clearly reflected in the number of species used and number of uses. The gender division of space is also reflected in these data, with women being more likely to be active in the spaces closer to home. The message is that any activity involving trees must take the gender division of labour, space and knowledge carefully into account and must involve both women and men as active participants.

Table C Gender differences in tenure of location of tree species used (percent of tree species locations)

\begin{tabular}{|c|c|c|c|c|c|}
\hline Use & Women & Men & Use & Women & Men \\
\hline $\begin{array}{l}\text { Fruit to eat } \\
\mathrm{x}^{2}=23.54 * * *\end{array}$ & $\begin{array}{l}\mathrm{N}=1321 \\
53 \% \text { Individual } \\
47 \% \text { Communal }\end{array}$ & $\begin{array}{l}\mathrm{N}=649 \\
41 \% \text { Individual } \\
59 \% \text { Communal }\end{array}$ & $\begin{array}{l}\text { Firewood } \\
x^{2}=6.43^{* *}\end{array}$ & $\begin{array}{l}\mathrm{N}=971 \\
20 \% \text { Individual } \\
80 \% \text { Communal }\end{array}$ & $\begin{array}{l}\mathrm{N}=357 \\
14 \% \text { Individual } \\
86 \% \text { Communal }\end{array}$ \\
\hline $\begin{array}{l}\text { Medicine } \\
\mathrm{x}^{2}=21.18^{* * *}\end{array}$ & $\begin{array}{l}\mathrm{N}=563 \\
59 \% \text { Individual } \\
41 \% \text { Communal }\end{array}$ & $\begin{array}{l}\mathrm{N}=359 \\
43 \% \text { Individual } \\
57 \% \text { Communal }\end{array}$ & $\begin{array}{l}\text { Browse } \\
x^{2}=17.33 * *\end{array}$ & $\begin{array}{l}\mathrm{N}=399 \\
32 \% \text { Individual } \\
68 \% \text { Communal }\end{array}$ & $\begin{array}{l}\mathrm{N}=309 \\
18 \% \text { Individual } \\
82 \% \text { Communal }\end{array}$ \\
\hline $\begin{array}{l}\text { Poles } \\
x^{2}=28.43 * * *\end{array}$ & $\begin{array}{l}\mathrm{N}=375 \\
38 \% \text { Individual } \\
62 \% \text { Communal }\end{array}$ & $\begin{array}{l}\mathrm{N}=231 \\
10 \% \text { Individual } \\
90 \% \text { Communal }\end{array}$ & $\begin{array}{l}\text { Ag. implements } \\
\mathrm{x}^{2}=2.23 \mathrm{~ns}\end{array}$ & $\begin{array}{l}\mathrm{N}=78 \\
19 \% \text { Individual } \\
81 \% \text { Communal }\end{array}$ & $\begin{array}{l}\mathrm{N}=121 \\
12 \% \text { Individual } \\
88 \% \text { Communal }\end{array}$ \\
\hline $\begin{array}{l}\text { House. utensils } \\
\mathrm{x}^{2}=4.7^{*}\end{array}$ & $\begin{array}{l}\mathrm{N}=94 \\
24 \% \text { Individual } \\
76 \% \text { Communal }\end{array}$ & $\begin{array}{l}\mathrm{N}=129 \\
13 \% \text { Individual } \\
87 \% \text { Communal }\end{array}$ & $\begin{array}{l}\text { Edible insects } \\
\mathrm{x}^{2}=15.30 * * *\end{array}$ & $\begin{array}{l}\mathrm{N}=153 \\
29 \% \text { Individual } \\
61 \% \text { Communal }\end{array}$ & $\begin{array}{l}\mathrm{N}=126 \\
10 \% \text { Individual } \\
90 \% \text { Communal }\end{array}$ \\
\hline $\begin{array}{l}\text { Firewood } \\
x^{2}=28.43 * * *\end{array}$ & $\begin{array}{l}\mathrm{N}=172 \\
34 \% \text { Individual } \\
66 \% \text { Communal }\end{array}$ & $\begin{array}{l}\mathrm{N}=37 \\
32 \% \text { Individual } \\
68 \% \text { Communal }\end{array}$ & & & \\
\hline
\end{tabular}

Customary woodland management practices

Given the value of miombo woodland to rural households, it is not surprising that a whole range of local management practices exist. It is only relatively recently, however, that indigenous knowledge and practice has come to be taken seriously by foresters and to be incorporated into social forestry programmes (Shepherd 1992).

Woodland management practised in the context of indigenous agriculture in Africa differs substantially from classical western models, which partly explains their invisibility in the past 


\section{Box 5.3 \\ Relationships between deforestation and use of woodland resources in Zimbabwe \\ Bruce Campbell}

The simplistic notion that deforestation results in harvesters of forest products, often women, having to spend longer time, at greater distances, collecting larger loads, needs to be questioned (McGregor 1991; 1995a; Campbell et al. 1993; Campbell and Mangono 1994). While trends in distance and time may be detected, as for firewood, these are only a small part of a complex of change involving changing gender roles, changing transport modes, increased commercialisation, use of alternative resources and decreased consumption (Campbell and Mangono 1994). Furthermore, the complex of changes evident in the use of forest products may be driven by factors other than deforestation, as shown by the change in use of gathered products over time. As important, or more so in certain cases, have been changing preferences, improved drought relief programmes, the quest for labour-saving strategies and the desire to be modern (McGregor 1991; 1995a). To add to the complexity, the nature of change in use patterns is spatially differentiated (e.g. kerosene partially replaces firewood only in those deforested areas near cities) and is differentiated within the community (e.g. the wealthiest households shift to kerosene, the poorer households using more agricultural residues) (Campbell and Mangono 1994).

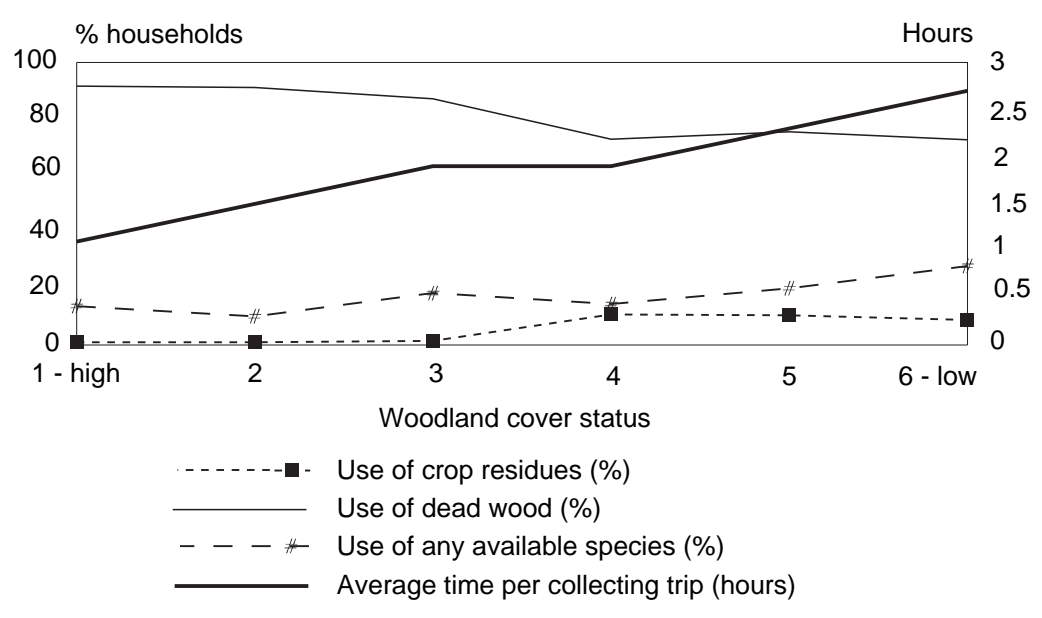

Patterns of change in relation to deforestation status (du Toit et al. 1984).

to western-trained professional foresters. The major difference is that trees/woodlands are inextricably linked into cropping and livestock management systems in Africa, whilst classical forestry considers agriculture and forestry as separate management units (Shepherd 1992).
Shepherd (1992) has conducted a comprehensive review of indigenous forest management practices throughout the tropical dry forest ecosystems of Africa, and we borrow her framework to describe practices which occur within miombo. Woodland management is defined as 
"any planned and deliberate activity which enhances the quality and quantity of woodland or makes its use more sustainable".

Indigenous technical knowledge clearly underlies both use and management of trees and woodlands. Knowledge about the taxonomy, ecology, silviculture and uses of trees and woodlands is widespread amongst rural populations throughout the region, as ethnobotanical surveys testify (Wilson 1989a; Tuite and Gardiner 1990a; Matowanyika 1991; McGregor 1991; Coote et al. 1993a; Sørensen 1993).

\section{Fallows and rotations}

The chitemene system, common in north-western Zambia, is a characteristic feature of miombo woodlands (Box 2.4; Box 5.4). In the past this was a sustainable system of agriculture, but is now under threat as a result of increasing population densities. Chidumayo (1987a) reports that the fallow period has been reduced, and the area of cropped land per family has also declined in response to land shortage. These adaptations have enabled the system to perpetuate despite exceeding the 'critical population density', a term coined to denote the optimal ratio of population

\section{Deforestation and woodland resource use (continued)}

In spite of the complexity, certain trends can be recognised in relation to increasing deforestation:

- a change in source areas for woodland products (McGregor 1991), including greater value being placed on on-farm resources (McGregor 1991) (e.g. mango trees being valued more highly for poles in deforested areas, Musvoto and Campbell 1995);

- less use of woodland litter as a mulch to exotic fruit trees (but not less use in cropland) (Musvoto and Campbell 1995);

- increased use and planting of exotic trees for construction (du Toit et al. 1984; McGregor 1991);

- increased purchasing of construction wood and firewood (Campbell and Mangono 1994);

- modification of building styles, to less wood-consuming structures (McGregor 1991; Campbell and Mangono 1994);

- increased wood conservation through recycling, e.g. use of old construction wood for fuel (McGregor 1991);

- less selectivity and a greater diversity of species for fuelwood, including increased use of wild fruit trees as sources of fuelwood and increased use of poor quality fuelwood (du Toit et al. 1984; McGregor 1991);

- increased use of cut wood (rather than dead wood), dung, crop residues and kerosene for fuel (du Toit et al. 1984; Campbell and Mangono 1994);

- abandonment of large wood stores (McGregor 1991);

- increased involvement of men in wood collection and increased use of ox-carts (du Toit et al. 1984; Campbell and Mangono 1994);

- changed cooking habits, e.g. lowering of grates to achieve greater fuel efficiency (Hancock 1990; McGregor 1991), extinguishing embers to conserve wood (Campbell and Mangono 1994);

- reduced abundance of game, mushrooms and caterpillars in the diet (McGregor 1995a; Wilson 1990);

- increased abundance of rodents and insects other than caterpillars in the diet (McGregor 1995a; Wilson 1990). 
Slash-and-burn agriculture is widely practised in the wetter parts of the miombo region. Fire is used to burn felled trees and slash to produce a fertilising ash bed into which crops are planted - in this

case, cassava - Kaoma district, Zambia (photo: P. Frost).

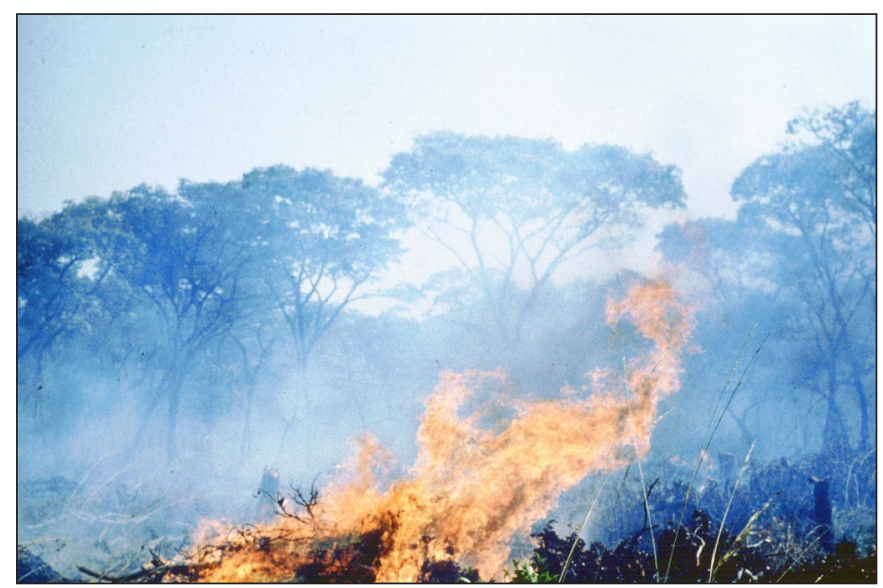

to land where chitemene is practised. Another adaptation has been the switch to the use of grass for fertility inputs, known as the fundikila system (Box 5.4). The changes that have taken place within the cropping systems should not only be interpreted in the light of population pressure, as a host of other social and cultural factors are at play (Moore and Vaughan 1994).

\section{Box 5.4}

\section{The evolution of the fundikila cultivation system in Zambia}

\section{Bright Mwakalombe}

The chitemene is a lop-and-burn traditional cultivation system, dependent on having sufficiently large areas of miombo woodland (Box 2.4). Due to increased population and consequent degradation of the miombo woodland, the fundikila system evolved. This system is practised in the open savanna where grass is abundant. It involves nutrient cycling using low-quality grass of Hyparrhenia which is buried in mounds. It is a semi-permanent cultivation system. It has been estimated that it can support 20-40 persons per $\mathrm{km}^{-2}$ (Mansfield et al. 1975) which is considerably more than the chitemene system.

Prior to cultivation, grass is cut and stacked around trees or stumps. These are burnt later during the dry season. Thus within the fundikila are found some 'micro-chitemene' on which crops such as pumpkins are planted. Towards the end of the rainy season, about March-April, grass mounds are made by burying the turf. The grass in the mounds is left to decompose until the beginning of the next rainy season. When the rains begin, the mounds are spread for the flat cultivation of millet (Stromgaard 1991). Beans are usually planted in the second year on mounds.

Three major factors limit the productivity of the fundikila system. These are the predominantly marginal soils that are used, the low nutritive value of the main organic input (Hyparrhenia grass) and perhaps the timing of incorporation.

The change from chitemene to fundikila is perceived as a continuum from shifting cultivation to semi-permanent and permanent farming systems. The fundikila system was exclusive to the Mambwe people in the north east of Zambia. However, it is now being practised by both rural and urban people in other densely populated areas (Holden 1988). 


\section{Conservative and judicious use of resources}

Rules and agreements ensuring the judicious use of important woodland resources are commonly found amongst miombo dwellers, and adherence to these indicates a form of management. Generally, trees with specific high value products should not be wasted by using them for lessvaluable products which can be obtained from other sources. For example, fuelwood collection is commonly restricted to dead wood, either straight from the tree or from the re-use of wooden articles which need to be replaced, such as fences and tobacco barns (Hancock 1989; McGregor 1991; Sørensen 1993).

In some areas, tree cutting is controlled by local leaders, who give permission for trees to be cut for specific purposes, and then only if they are satisfied that the applicant has a genuine personal need for the timber. They will also monitor where and how the trees are cut to ensure minimum impact (Grundy 1990). There is a belief in some places that bark should only be removed from a strip on the west and east sides of the trunk of a tree, because this is where the most potent medicine is found (Mukamuri 1995b). In effect this is a way of preventing ringbarking, although with pressures of commercialisation, such practices are increasingly coming under threat.

\section{Selective clearance of woodlands and promotion of valuable species}

Throughout the miombo zone, clearing of naturally occurring woodland for purposes of settlement is highly selective. Woodland is retained in grazing areas and between fields and around home plots. In addition, individual trees of high-value species are selectively retained wherever they occur. Protection and management of important species are more intensive in and around fields and around homes than in communal grazing areas (Maghembe and Seyani 1991; Campbell et al. 1993).
Campbell (1987) reports 8\% canopy cover of trees in croplands in Chiweshe, southern Zimbabwe. Most of this occurs on contour ridges, and the remainder comprises individual large fruit trees within fields, which cover $1 \%$ of cropland. The survey found that there was no significant reduction in cover of the three most important fruit trees within croplands as compared with a neighbouring area of uncleared Julbernardia woodland. A survey carried out by Minae et al. (1994) in Malawi found that of the 52 species of trees retained in fields, 17 are indigenous fruit trees. Important fruit tree species which are commonly retained in fields throughout the region include Azanza garckeana, Strychnos spp., Parinari curatellifolia, Uapaca kirkiana, Diospyros mespiliformis, Vitex spp. and Sclerocarya birrea (Campbell 1987; Minae et al. 1994; Temu and Msanga 1994; Cunningham et al. in prep.).

Species with high fodder value are retained in grazing areas and on field boundaries, and Kigelia africana is protected wherever it occurs in the farm landscape, including fields, as it is an important source of browse in the late dry season (Clarke 1995). Individual trees may be retained for other products and benefits such as edible caterpillars, shade and medicinal purposes. Strips of woodlands retained on field contours and boundaries act as windbreaks and provide a convenient supply of fuelwood, construction timber, fruits, fencing materials, etc. (McGregor 1991). Some families even devote a portion of their arable land to woodland and manage this intensively for various products including wild game (Clarke 1995; Sørensen 1993). Others may go so far as to 'annex' portions of wooded common land adjacent to their home fields (Matose 1992; Campbell et al. 1993).

\section{Management by taboo or religious sanction} Throughout Africa, natural resource management practices are traditionally enforced by means of religious sanction. Rules and regulations are believed to emanate from the ancestors and from 
God, through the medium of living authorities. The use of religious language is a means to give added weight to the rules (Shepherd 1992). Mukamuri (1995b) challenges the view of some authors that environmental religion is a means by which traditional leaders manage important resources for the benefit of their subjects. He argues that ruling lineages use environmental religion to strengthen their authority and for personal economic gain. In many cases, however, these rules and taboos do have important pragmatic value, and have ensured the survival of valuable trees and woodland areas.

\section{Individual trees}

Taboos on cutting fruit trees is widespread in the region, and is of obvious practical significance. There are also taboos on cutting other types of trees, whose retention for more-valuable purposes is seen as important. In Zimbabwe, trees which grow around important ('sacred') water springs may not be cut, for fear of causing the water source to dry up (Matose 1992). This taboo has also been reported in Zambia (Sørensen 1993), Tanzania (Gerden and Mtallo 1990), and Mozambique (Sitoe and Ribeiro 1995).

Individual large trees are associated with the spirits in many areas and cannot be cut. They are frequently used for rainmaking ceremonies (Gerden and Mtallo 1990; Matose 1992). There are also taboos on cutting or use of certain species, for example some species which cannot be brought into the home or used for firewood (Matose 1992; McGregor 1991). Kajembe (1994) lists eleven species of trees which are traditionally protected from cutting in the Dodoma District in Tanzania. These species are all used in traditional rituals of one kind or another, as well as having other important functions. In drought-prone areas, particular species may be protected from cutting, as a buffer against drought. In south western Zimbabwe, Boscia albitrunca is strictly protected from cutting. The roots of this species are ground into meal in times of extreme drought when crops have failed.

\section{Reservation and sacred groves}

The term 'traditional forest reserves' is used by Gerden and Mtallo (1990) to describe woodlands that are protected by local communities for a variety of purposes in the Babati District of Tanzania. Seven types of traditional forest reserves are distinguished, each having a specific function for which it is protected. These areas are protected for the following functions: male circumcision ceremonies (the most common type); meeting places for male elders; burial grounds; natural springs; private reserves for particular uses such as for obtaining medicinal plants; rainmaking ceremonies; places for teaching young women. The cutting of trees is strictly prohibited in all these areas, and limited access to other resources is allowed, subject to harvesting rules.

Sacred groves, described as dwelling places for ancestral spirits, burial grounds, protection of springs and as sites for rainmaking ceremonies, are also widespread in Zimbabwe (Matose 1992; Clarke 1995; Mukamuri 1995b), Zambia (Sørensen 1993) and Mozambique (Sitoe and Ribeiro 1995). Sacred groves are protected using religious sanction (fear of angering the gods) and, failing this, through fines imposed on violators by the chief (Gerden and Mtallo 1990; Sørensen 1993). Sacred groves tend to be on hills or in river valleys and often where large and/or important tree species already occur. For example, in southern Zimbabwe, pure stands of Uapaca kirkiana, an important fruit tree species, are often sacred groves (Matose 1992). In areas where much of the woodland area has been cleared to make way for settlement, sacred groves are sources of woodland products, and have important ecological and social functions (Gerden and Mtallo 1990).

\section{Management by time and season}

Seasonality is an important factor in agricultural systems in the miombo zone, revolving around the very distinct wet and dry seasons. With respect to woodlands, the availability of browse and grazing in the late dry season is of particular 
importance. A transhumance grazing system is still practised on the Kafue flats in Zambia, where livestock graze in woodlands in the wet season and on the low-lying flood plains in the dry season (Sørensen 1993). In the Shinyanga region, Tanzania, portions of the communal grazing area are closed to livestock during the rainy season, to allow for the accumulation of biomass (Kilahama 1994). Similar patterns of cattle grazing are found in Zimbabwe (Scoones 1990).

\section{Management by fire}

In Zimbabwe, fire is no longer commonly used as a woodland management tool by communal land inhabitants. This practice has died out because it was made an offence by the colonial authorities in the 1920s and, furthermore, there is very little grass to burn on most communal lands as a result of the very high density of livestock (Scoones and Wilson 1988). Kilahama (1994) also found a decline in the use of fire as a management tool in the rangelands of Shinyanga, Tanzania, as a result of reduced grass biomass. In the past, grass was burnt to promote new growth and keep down tick populations; neither practice is appropriate with decreased grass biomass. Fires were also used for cultural reasons (Box 7.1).

\section{Management of individual trees}

Fruit trees retained in fields are pruned, lopped and pollarded in order to reduce competition with crops and/or to provide other products such as wood or fodder (Kajembe 1994; Minae et al. 1994; Clarke 1995). In south western Zimbabwe, farmers prune the lower branches of Acacia regrowth to encourage vertical growth, increased grass growth and improve accessibility to grass by livestock (Clarke et al. 1996). Lopping of branches of valuable fodder trees such as Brachystegia spiciformis, Julbernardia globiflora, Kigelia africana and Colophospermum mopane is carried out in the late dry season to make browse accessible to livestock (Wilson 1989a; Clarke 1995).

\section{Exclusive use rights in common land}

As we have seen above, it is common for families to protect and manage portions of woodlands on their home plot and fields. There also exist various mechanisms whereby individuals or groups can secure exclusive use rights to certain trees or woodland areas in common lands. For instance, in many parts of Zimbabwe it is accepted that the trees growing near to the home plot 'belong' to that family and should not be cut or disturbed by other people. In Ntabazinduna and Gwanda, for example, families often have small groves of Acacia woodlands adjacent to their home plots. In Goromonzi, families commonly have a strip of woodland between their home plot and the road (Clarke 1995). Rights to products from individual trees in grazing areas, such as honey, caterpillars or fruit, can also be secured by making some sort of mark on the tree, either by tying a rope around the trunk, sweeping around the base or lopping the lower branches (McGregor 1991; Mukamuri 1995a; Coote, pers. obs.). Shepherd (1992) explains these and other examples as ways of securing tenure through performing labour. Even the act of protecting regrowth and pruning can confer ownership, as it is a visible sign that someone is investing labour in these trees. In some places, agreements are made amongst specific resource users about exclusive collection areas, such as firewood collection areas used by women from different family groups, or fruit collection routes used by children (Matowanyika, pers. comm.)

\section{Determinants of miombo woodland use and management}

The literature reviewed in the previous sections, though partial, supports three claims, namely that miombo woodland resources are important to rural households, that there is strong differentiation in resource use and that there is a wide range of customary forms of control and management. 
A number of questions remain. What are the determinants of resource use and management? To what extent do customary practices contribute to sustainability of local woodland resources? What are the social, ecological and economic determinants of these practices, and how are these changing?

In reality, there are no general answers to these questions. In any one place there is a complex and dynamic interplay of factors influencing local use and practices, and the impact of these practices on the farming system. Customary woodland management practices are highly variable from place to place. In any one place, practices are continually changing and evolving in response to changing circumstances. Mechanisms of state control of resources have been superimposed on existing local control mechanisms, to varying degrees (Chapter 8). Furthermore, the use and management of woodlands is inextricably linked to the management of the entire farming system.

Given the complexity and diversity of indigenous farming systems in a rapidly changing socio-political climate (Campbell et al. 1995b), an understanding of sustainability and trends of indigenous management practices is best rooted within a discussion of the key determinants of use and management practices. Unlike the plethora of accounts describing use and management practices, more analytical literature on the determinants is minimal.

In this section the focus is on six critical determinants of households' resource demands and use: (i) local authority and state legislation; (ii) tenure; (iii) income, wealth and household preferences (and modernisation); (iv) the costs of collection; (v) species substitutions and the existence of backstops; and (vi) commercialisation. Each of these points is illustrated with reference to case studies from the literature. However, in interpreting these case studies it should be remembered that the determinants interact in explaining any particular observation.

\section{Local authority and state legislation}

Indigenous management practices depend on the ability of communities to make and defend management rules (Chapter 8). Having effective and credible local authorities is one such requirement. In the past these were traditional leaders who derived authority from the ancestors (Box 8.4). In most countries, traditional leaders no longer have any legal power to enforce natural resource management regulations, but in many areas the chiefs still do have this power de facto (Chapter 8). For example in northern Zimbabwe, a local chief still effectively enforces the full spectrum of traditional woodland management rules (Clarke 1995). Continued effectiveness of traditional authorities in protecting woodland resources is also reported from Tanzania (Gerden and Mtallo 1990) and Zambia (Sørensen 1993). Mukamuri (1995b) and McGregor (1991) provide evidence for the almost total breakdown of this authority in areas of southern Zimbabwe. Mukamuri (1995b) cites the state of 'political anarchy' arising from the lack of effective leadership from either state or traditional institutions, coupled with severe shortage of woodland resources as the reason for breakdown of traditional rules. There is, however, evidence that 'modern' local leaders (those from state-driven institutions) are able to promote new woodland management initiatives, as in the case of the Ntabazinduna community in Zimbabwe (Clarke 1995).

The legal framework for natural resource management is another factor which impinges directly on indigenous woodland use and management (Chapter 8). The effect of removing control from the local level to the state has overall been one of undermining indigenous management (Kajembe 1994; Mukamuri 1995a). Dewees (1994) argues that policies limiting commercial exploitation of forest products limit the growth of potentially important forest-based enterprises. Furthermore, such policies do not serve to limit 
woodland clearance rates anyway, since many products can be harvested with minimal or no impact on woodlands, and most clearance is due to agriculture (Chapter 4; du Toit et al. 1984). In fact, there is evidence that criminalising use and sale of woodland products can result in the breakdown of indigenous systems of judicious use and management. Reduced benefits to local people will inevitably lead to reduced incentives for investing in local management. Villagers illegally collecting honey and mushrooms in a protected forest area in Zimbabwe reported that they deliberately used wasteful and destructive methods of harvesting in retaliation for what they considered to be unfair harassment from forest guards (Matose 1994). There are some examples, however, of using statutes to support and strengthen indigenous rules, as in the case where the marketing of Uapaca fruit by outsiders was prevented using a forestry statute (Clarke 1995).

\section{Tenure}

Securing tenure is a means to ensure security of benefits (Chapter 8; Bruce et al. 1993). As common property regimes have become less secure (as a result of breakdown of traditional rules and loss of authority of local leaders), and less available (as a result of the conversion of common land to privately controlled land), there has been a trend towards increasing privatisation of what were common property resources (Box 5.5). On the other hand, in some cases, the reverse may also apply; under conditions of extreme scarcity, resources that were privatised are taken back for public use (Box 5.6).

\section{Wealth/income effects and household preferences}

The previous sections cited a range of studies which demonstrated correlations between income or wealth and resource use. These correlations arise for one of two reasons, namely either that the change in a household's income or wealth alters its composition or production structure such that its demands for woodland resources change, or that a household's (pure) preferences vary as income and wealth change. There is evidence of both these effects.

With regard to household composition, as households get richer they tend to get larger, both as a consequence of a man marrying more wives, and wealthier households looking after dependants from other parts of the extended family. It is not surprising, then, to find the volume of firewood used increasing as household income rises (McGregor 1991; Table 5.2).

Likewise, as rural households grow richer, so they enter riskier or higher-return activities. Such shifts in production activities will lead to a host of changes in woodland resource uses, which are connected in a variety of ways to different activities. For example, considerations of this type were used to explain the varying pattern of resource use by cash income quintile presented in Figure 5.3, where certain woodland-based activities increased in importance as income rose, while others decreased. Another such result is reported from Zimbabwe by McGregor (1995a), where poorer households depend more on the sale of various gathered products than the rich. Of course, one of the most important assets in rural areas is cattle. As wealth rises, so too will demands for woodland-derived goods that are necessary for cattle maintenance and use (such as livestock graze and browse, wooden cart frames, poles for cattle kraals, yokes and skeys, etc.) or complements to such uses, such as leaf litter to compost with manure (Nyathi and Campbell 1993).

With regard to household preferences, the evidence is more anecdotal but still suggestive. Linked to a discussion of preferences is the issue of modernisation. From conventional studies of rural households' food demands, it is known that as income rises the type of foods consumed changes, and this seems to hold also for wild foods. There are many wild foods that would be 


\section{Box 5.5 \\ Relationships between deforestation and access to woodland resources in Zimbabwe \\ Bruce Campbell}

In the past, researchers and policy makers have inferred certain changes in resource use as a result of deforestation. One reason for rejecting simplistic notions of changes in harvesting strategies and use patterns in relation to deforestation concerns the complex relationships between levels of deforestation and degree of access to woodland resources. So, for instance, a decrease in woodland cover may show no relationship to the abundance of specific resources (Wilson 1990). The best documented example is that of favoured wild fruit trees, the abundance of which does not decrease with deforestation, because of the selective conservation of certain wild fruit trees around homesteads and in croplands, including the nurturing of young saplings (Campbell 1987; Wilson 1989a; McGregor 1991; Price, submitted). The figure below illustrates the final impact of nurturing and preservation; households with longer residence periods have more indigenous fruit trees in their homefields, and less non-fruit trees, due to continual cutting of these.

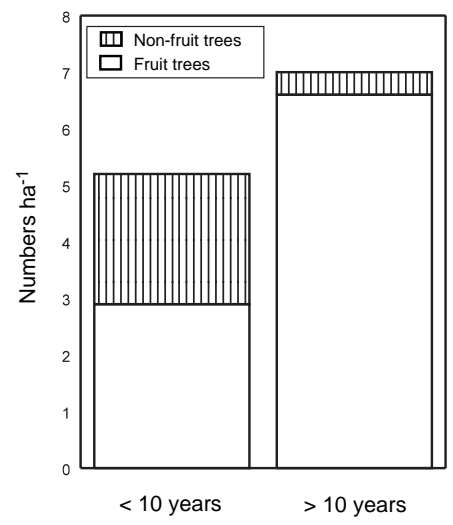

Numbers of indigenous fruit and non-fruit trees in homefields in Mutoko in relation to length of residence period (Price, submitted)

Alternatively, resource abundance may decline with deforestation, but changing tenurial arrangements result in greater access to the resource by certain individuals. For instance, in some communities in deforested areas, certain households, often the more powerful ones, have annexed communal woodlands (through extending the area that they have under fencing), thereby ensuring the annexed woodland is for their sole use (Matose 1992; Campbell et al. 1993). These annexations are often regularised through existing institutional arrangements (Gadgil and Guha 1992; Matose 1992; Mukamuri 1995a). Products in homestead areas and in fields are, in some instances, becoming increasingly privatised. These include brushwood for fences, firewood, litter and agricultural residues (for animal feed) (McGregor 1991). Wilson (1990) also records the privatisation of caterpillars by their transferral to a tree nearer the home. 


\section{Box 5.6 \\ Scarcity and tenure over wild fruit on dambos}

\section{Bevlyne Sithole}

Some research in Zimbabwe suggests that in situations of scarcity there is a tendency to privatise resources (Box 5.5; Scoones and Wilson 1988; Mukamuri 1995a). Scoones and Wilson (1988) write about scarcity breeding a new kind of individualism and differentiation. Shepherd (1992) describes how woodland scarcity in other parts of Africa results in increased management of privatised woodlands.

On the other hand, van den Brink and Bromley (1992) suggest an opposite trend, which they argue is more characteristic of Africa, where scarcity may induce a re-assertion of the commons. Results from research on water and wild fruit trees scattered on dambos in Mutoko and Chiduku communal areas in Zimbabwe, concur with this trend, and suggest that privatisation is a more common feature during periods of abundance rather than during periods of scarcity. During periods of scarcity, resources that are private or have been privatised revert back to the commons.

The farmers regard wild fruit as a "resource for everyone which belongs to God. No one has a right to exclude others from accessing fruit". In reality, access to fruit is controlled even in periods of abundance. Anyone will have rights to collect as much fruit from an indigenous tree as they want to eat, even on private property like gardens, without asking permission. However, when fruit is abundant, people are supposed to use fruit on common land, not on private land. Collecting fruit on private property is considered suspicious if there are other fruit trees available in the commons. Harvesting too much fruit is not acceptable, and harvesting during the evening, at night or during the early hours would be regarded as theft and trespassing.

Planted fruit trees on dambos cannot be harvested in the same way. Permission to harvest must be obtained from the owner.

In sacred woodland groves, there are rules about who may collect fruits, the method of collection, the utensils used, dress code, body scent, menstruation cycle and manner of speech while collecting. For example, it is believed that disparaging language about the fruit being harvested in sacred groves can bring misfortune to the person harvesting.

In circumstances of scarcity, there is increased competition for resources. On dambos, wild fruit which is on individual plots becomes the focus of contested exclusion and inclusion rights. For example, farmers who live or farm on the edge of tree groves and who have had the exclusive use of those trees, find themselves having to defend their rights to the trees. Farmers may harvest all the ripe fruit so there is none for others. Some may try to guard their trees continuously or barricade their garden plots against entry, but this has limited success. Generally, the phase when an individual tries to restrict access is short, except where the resources are in control of an influential person. Farmers have observed that individuals who try to restrict access to common resources do not succeed because many people steal from the trees. Once the individual opens up the fruit trees for use by others, there appears to be a regular sequence of persons coming to use the resource. First come the relatives, then the friends and before long the friends of friends. At that point the resource has reverted back to the commons. 
classified by economists as inferior goods (i.e. as income rises, consumption decreases), such as the majority of edible insects, small wild animals, wild soda, roots and bulbs and certain wild leaf vegetables (Wilson 1990). Such foods are frequently regarded as children's foods, or suitable only for the poor. Indeed, one problem with asking about the consumption of wild foods through standard questionnaire techniques is that adults will often hide their consumption of certain foods as it is thought beneath their status to eat them.

However, this is not true of all wild foods: it may be that consumption of game meat, which is largely purchased, rises with income for rural households. Wild food demands also differ inter-seasonally: during the late dry and early rainy seasons, when other sources of nutrients are scarce, wild fruit consumption is at its highest (Campbell 1987; Gumbo et al. 1990; McGregor 1995a).

Finally, there are other reasons for shifts in household preferences. Some evangelical Christian sects ban the consumption of certain wild goods (such as insects, mice, fruit-based wines and traditional medicines) as 'heathen' practices. The spread of these groups in rural areas is bound to have an impact on resource demands. Many traditional practices rest on spiritual beliefs and taboos, and changes such as the adoption of Christianity and population movements which undermine local belief systems. Sørensen (1993) reports a case of violation of traditional taboos on cutting trees in a sacred grove by a church group in the Kafue basin area in Zambia. Western education systems teach children to disdain indigenous practices and this contributes directly to the demise of some indigenous conservation practices (Mukamuri 1995a). However, there is evidence that recent severe droughts in southern African have won converts back to traditional practices and rules regarding resource management practices (Gumbo et al. 1990; Clarke 1995).
Calamities such as drought and famine are believed to be the result of disobeying rules regarding the use of natural resources, such as cutting down of fruit trees. Despite the breakdown of traditional religions, many of the indigenous management practices still survive as they are clearly pragmatic (Sørensen 1993; Mukamuri 1995a).

\section{Costs of collection}

For the constrained, low-income, rural household, a chief concern is how to allocate its labour time between a range of possible activities in order to get the highest returns. A major factor in deciding these returns will be the costs of undertaking each activity. Thus, a further important determinant of the household's demand for miombo woodland resources will be the costs of collection. The higher these are, the less will be demanded, until at some point the household may withdraw from an activity altogether. However, the costs of collection are themselves related to a variety of factors, which we discuss in turn.

\section{Labour availability}

As most miombo woodland resources are collected and processed predominantly using household labour, the availability (and opportunity cost) of such labour is one determinant of the cost to the household of collecting and using resources. Though the woodland literature has not in general been concerned with the connection between labour allocation and resource use, the point has been implicitly well-established by studies of seasonality in labour-intensive woodland resource use. Thus, the construction of housing, granaries, livestock pens and wood fencing, and thatching occurs in the dry season, when agricultural labour demands are at a minimum (Grundy et al. 1993), as do other labour-intensive activities such as fishing and hunting. Similarly, as Wilson (1989a) and McGregor (1991) show, the characteristics of fuelwood demand differ between seasons in response to changing (mostly 
female) labour scarcities. In the cold season, when agricultural labour demands are low, more time is spent searching for fuelwood, larger fuelwood pieces are collected, and the species desired are those which burn slowly and smokelessly, to warm people through the cold nights. By contrast, in the rainy season when agricultural labour demands are intense, fuelwood is collected opportunistically (for example while walking home from the fields), more twigs and small branches are collected, and the species desired are those which spark when wet and burn more intensively, as there is less time for cooking available (McGregor 1991).

\section{Harvesting and processing technologies}

A second determinant of the costs of collecting and using resources are the harvesting and processing technologies available to resource users. Acquisition of these technologies can play an important role in explaining differentiation in resource use. The classic instance of this is the shift from headloading in fuelwood collection to transport by scotch cart (Campbell and Mangono 1994). Use of scotch carts allows greater volumes of fuelwood to be collected per visit than headloading, and allows greater distances to be travelled in the search for fuelwood, thereby expanding the potential woodland resource base economically available to a household. The shift to scotch cart collection may also be one part of a more deliberate fuelwood collection strategy adopted by the household, including greater use of cut wood rather than dead wood and the greater use of fuelwood stores. However, scotch cart acquisition can also have an impact on other resource use. As noted above, Wilson (1990) relates variations in leaf litter use in Mazvihwa to scotch cart ownership, and a similar suggestion has been made by McGregor (1991) in explaining the lesser use of termitaria by poorer households.

On another front, Arnold and Easton (1993) analyse forest-based enterprises in rural Zimbabwe, and demonstrate that the chief constraint to the activities of enterprises is not an adequate supply of woodland materials, but rather access to tools, hardware and management skills. Acquisition of these production inputs can significantly alter production activities and woodland resource demands. A spectacular example of this point is given in Campbell et al. (1995a), concerning a truck owner in Jinga, Southern Zimbabwe. This person is the only one with a truck in Jinga village, and consequently has a unique livelihood strategy, being the only person in the village trading in firewood. Finally, there is anecdotal evidence that the absence of technologies for processing wild fruit is a cause of their decline in consumption relative to exotic fruit, at least for certain species. Wilson (1989a) records that the absence of nut-cracking technologies is responsible for a decline in the consumption of the fruit of Sclerocarya birrea, and the same factor may well explain the reduction in the frequency of wild fruit porridge meals observed by McGregor (1995a). However, such declines in use can also be related to the increase in availability of agricultural substitutes (see below).

\section{Distances and spatial variation}

Collection costs are also related systematically to distances to woodlands and spatial variation in woodland resource availability (though as described in the previous section, distance costs will be conditional on the type of technology available for transportation). Several studies have demonstrated the impact these factors have both on the pattern of woodland resource use and on the woodland itself. Grundy et al. (1993) examined the spatial effects of fuel and construction wood use for six villages in Mutanda Resettlement Area. This research showed how the number of live trees per hectare is positively correlated with the distance moved away from the village, suggesting that increased distance to woodland resources raises collection costs and thus mediates resource demands. Likewise, Wilson (1989a) working in Mazvihwa demonstrated that the 
existence and composition of a household's fuelwood stocks are systematically related to the location of the household within the rural geography, so that the probability of a household establishing a fuelwood stock increased as the distance from a good-quality woodland increased.

Fortmann and Nabane (1992) found a clear relationship between spatial factors, gender and woodland resource use (Box 5.2). Thus, for the same type of product, women were significantly more likely to use resources found on homesteads and fields, reflecting their work primarily as agricultural producers and domestic workers and hence the lower distance costs of collecting from these areas. Finally, studies of woodland change over long periods (Wilson 1989a; Scoones 1990) have shown the importance of national government interventions through reorganisation of the settlement pattern of villages across ecological zones for the distribution of woodlands, resulting in localised patterns of scarcity and surplus as a consequence of changing distance costs of collection and hence of resource demands.

\section{Resource scarcity}

A final determinant of collection costs is changing resource availability. As resources become more scarce, so collection costs rise and, in response, households may alter their patterns of resource use in a variety of ways. The most extensive documentation of this effect comes from the substantial literature on fuelwood use and deforestation (Box 5.3). Some of these involve species substitutions and the transition to backstops, which we discuss later. However, others involve changed practices (lowering grates, extinguishing embers, building windbreaks) which can bring improvements in the technical efficiency of resource use of up to $50 \%$. Actions that were not economical beforehand become so as fuelwood becomes more scarce. As a result, as Hancock (1990) shows, household fuelwood consumption can be reduced by up to $40 \%$. Rising scarcities as the cause of changing resource use practices have been found elsewhere as well. McGregor (1995a) explains the shift in household consumption of wild vegetables from dambo-based species to field-based in Shurugwi, Zimbabwe, as a consequence of a dramatic reduction in the former's availability. The same study suggests that decreased per capita availability of wild fruit has led to more thorough harvesting and the creation of secret holes for burying and ripening fruit.

Some practices depend on abundance of resources, for example the taboo on using wet firewood or wood from particular species for firewood. In situations of resource scarcity, women may be forced to break these taboos (McGregor 1991; Mukamuri 1995a). On the other hand, resource scarcity can also be an incentive for new innovations in judicious use. This has been well-documented in the case of firewood use, where women adopt energy conserving measures during cooking, and switch to alternative fuel sources such as dung and crop residues (Hancock 1989; McGregor 1991). Once woodland resources become very scarce, communities may be galvanised into taking collective action to redress the situation. In many parts of Zimbabwe and Malawi, families and communities are taking action to promote natural regeneration of degraded woodlands, saying they want to see the return of the woodlands they remember from their youth. Forestry Extension Officers have reported on numerous examples of this from all over Zimbabwe (Clarke 1995).

\section{Species substitutions and the existence of backstops}

The importance of species substitutions and the existence and costs of backstops as determinants of woodland resource use has gone largely unremarked as an organising principle in the literature on woodland use. However, these factors play a strong role in determining how income-induced changes in resource demands or changes in collection costs affect a given woodland resource, by 
determining the degree to which rising demands or rising supply costs can be absorbed by or spill over into other species or economic activities. Broadly speaking, the greater the degree of species substitutability and the lower the ratio of backstop costs to resource use costs, the more any pressure on a particular woodland resource will be 'softened' by diversion to other activities.

These points can be illustrated by comparing fuelwood versus construction wood use. For fuelwood, desired characteristics (being a good, smoke-free burn) imply that in any given region, there are preferred species. However, there are many species substitutes that offer an acceptable alternative (Box 5.7; du Toit et al. 1984). Also, as Box 5.3 demonstrates, in response to scarcities there is a range of low-cost ways (alongside the technical efficiency improvements discussed above) in which households can react, including greater recycling within the household of wood used elsewhere (cattle kraals, fencing, old buildings), greater use of smaller branches and twigs, abandonment of wood stores and greater use of cut wood. It is for this reason that fuelwood scarcities only emerge after considerable woodland clearance has occurred. Furthermore, there is a range of backstop technologies for the provision of household energy needs, such as the use of dung, crop residues, kerosene and solar power, each of which has a different unit cost of energy provision, and each of which will therefore be adopted by households at differing levels of income and fuelwood scarcity. It is this combination of species substitutes and backstops that explains the patterns of household energy provision with respect to income and deforestation observed by du Toit et al. (1984) and Campbell and Mangono (1994).

However, while fuelwood can be described as a 'flexible' resource use for these reasons, very different conditions hold for construction wood. Here, the necessity for poles to be strong, straight and insect resistant results in a much narrower range of useable species (Grundy et al. 1993), so that species substitution possibilities are circumscribed. At the same time, the only backstop is a shift to purchased inputs, and the cost of these is often high. Thus, it is the lack of flexibility of resource use that explains the common observation that it is construction wood scarcities which emerge a long time before fuelwood scarcities (Grundy 1990; Bradley and Dewees 1993), despite the lower overall volumes of wood needed per household for construction purposes. Households desire only a limited range of species, and they will keep searching further for these until collection costs rise high enough to make adoption of the backstop economically rational.

The importance of species substitutes and backstops to an analysis of woodland resource use is quite general. For example, there is a variety of durable goods that many rural households make from wood, including carts, doors, furniture, mortars and pestles, kitchen utensils, yokes and agricultural implements. The smaller of these can usually be made from a wide range of species, while the larger durables use a more restricted set. However, given the generally high costs of purchased backstops (equivalent durables sold in stores), it is the resource demands for larger durables that may result in greater stress on certain species. There are some cases where the introduction of a preferred backstop which is a substitute in consumption has considerably affected resource demands. A case in point is McGregor's (1995a) observation that the spread of exotic leaf vegetables has reduced demand for wild vegetables. Of course, the extreme case of this is where the provision of a cheap backstop completely replaces an older woodland resource use. This has happened with the use of bark from Adansonia digitata to make clothing, the use of tree-based glues, the use of wild soda (from Sclerocarya birrea and Tabernaemontana elegans) and the use of bark to make fishing lines, all of which have declined in the face of cheap, preferred, purchased substitutes. 


\title{
Box 5.7 \\ Domestication of forest products in Zimbabwe: extent and driving forces
}

\author{
Bruce Campbell
}

\section{Does domestication occur?}

At present there is active management of a wide range of miombo resources in Zimbabwe, but there is little evidence of domestication (Campbell et al. 1993). Management is beginning to extend to species or products which were traditionally not very actively managed in the past, for example, pruning of on-farm trees for firewood, and the nurturing of edible caterpillars (McGregor 1991). Two of the driving forces for such management are resource scarcity and commercialisation. For many products little evidence of domestication can be found: wild vegetables, mushrooms, game birds, medicinal plants, craft resources. However, there are usually isolated examples of domestication attempts, a study of which may provide a basis for further research (Clarke 1995).

One reason for infrequent domestication is related to substitution. Thus, increased or maintained levels of consumption are often achieved by switching among species, rather than by increased management or domestication of any particular species. Greater access to fruit is achieved by planting exotic fruit tree species; increased honey production is achieved by switching to bee-hives with Apis, rather than by domestication of the indigenous stingless bees; access to gathered vegetables is maintained by switching from the wild vegetables of miombo woodlands and wetlands to the weedy species associated with croplands; and access to edible insects is maintained by switching from the woodland caterpillars to those insects associated with croplands and termitaria (Wilson 1990; McGregor 1995a).

\section{Tree planting and nurturing}

Tree-planting by households is widespread. In the case of indigenous species, this represents a first step towards domestication. However, tree planting is mostly directed towards exotic fruit trees and not indigenous ones. Within any community, there are usually only between 1 and $10 \%$ of households that have planted indigenous fruit trees (Campbell et al. 1993; Brigham 1994; Price submitted), though in some areas with specific programmes the figure may rise to $46 \%$, mostly among schoolchildren (Grundy 1990; McGregor 1991). More common than the practice of planting indigenous fruit trees, is the nurturing of self-sown individuals of these species (McGregor 1991; Box 5.5). In the case of Uapaca kirkiana, sweet-fruiting individuals may be left in fields while other individuals are cut (McGregor 1991). There is widespread planting of truncheons of species such as Lannea and Commiphora for live fences (Clarke 1995).

Deforestation status has no influence on the planting of exotic fruit trees (du Toit et al. 1984; McGregor 1991; Musvoto and Campbell 1995). People plant exotic species not because they are replacements for indigenous fruit trees, but because they have attributes which people favour (Brigham 1994). Brigham goes on to argue that much of the drive for planting exotic fruit trees relates to commercialisation and the potential income that can be derived from such planting. Similarly, planting of indigenous fruit trees in Shurugwi was related to commercialisation potential (McGregor 1991). 
Ellert (1984) provides a comprehensive description of the range of pre-colonial artefacts made in Zimbabwe, many of them from miombo woodland resources and most of which have disappeared. But the reverse can also occur. When a consumption-substitute becomes harder to acquire, the demand for wild resources can rise in consequence. This may occur during a drought or during seasonal scarcities. The price of purchased foods rises, and in response people increase their demands for wild resources (Wilson 1990; Zinyama et al. 1990). A similar framework can be used to explain Scoones' (1989) observations of inter-seasonal rangeland patch grazing by cattle. Herders switch cattle between woodland browsing, grassland grazing, crop residue consumption and dambo feeding according to the relative availability (or 'prices') of these resources.

A final case of species substitutions and backstop use is the widely observed tree planting (Box 5.7). In addition there is preservation of wild fruit trees.
Extensive planting of exotic fruit trees and less-extensive planting of eucalypts (both investments in backstops) has occurred in rural Zimbabwe, and preservation of favoured indigenous fruit trees has maintained species numbers in the face of continuous deforestation. However, there is insufficient evidence on the economics either of tree planting or of low-cost tree preservation to say more on this issue (Bradley and Dewees 1994).

\section{Commercialisation}

The guarantee of economic benefits has, in some cases, resulted in the survival of customary management practices. Makuku (1993) describes how a valuable resource, an edible insect, has enabled local traditional leadership to maintain strict control over the harvesting of these insects and the protection and management of the forest in which they occur, in the Norumedzo area of Bikita, southern Zimbabwe. Unlike in many other parts of Zimbabwe, where traditional resource

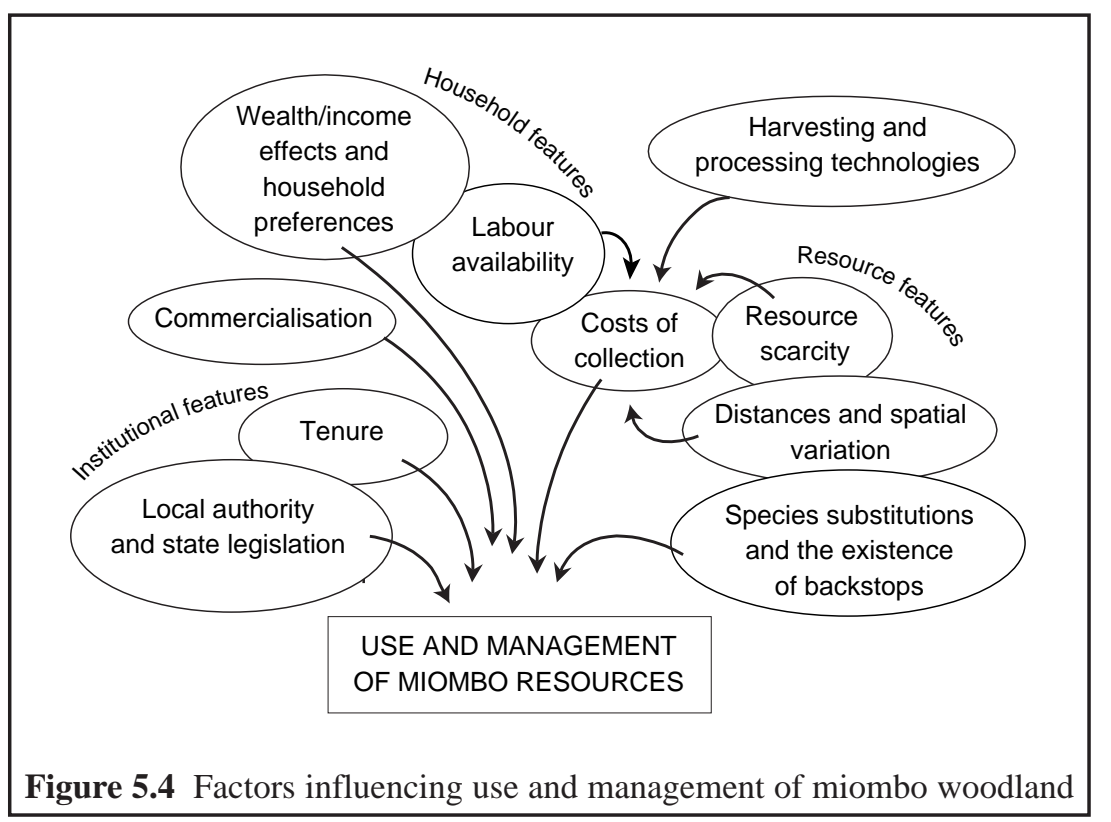


management rulings have broken down, in this area they are still strictly enforced by the local chief. The chief and his aides ensure ongoing support for their role in regulating harvest of these insects by ensuring that key individuals in modern-day institutions receive a share of the insect harvest too! In this case, economic incentives have assisted to maintain an indigenous management system.

On the other hand, commercialisation of a resource can have the effect of destroying management practices under the pressure of increased demand (Box 5.1). Large-scale marketing in towns of products such as wild fruit, firewood and charcoal can undermine local conservation and judicious use practices. In the Makoni District in Zimbabwe, for example, commercial operators began to remove truck loads of Uapaca kirkiana fruit for sale in town. This had the effect of undermining long respected rules which ensured that all members of the community had access to fruit for home consumption and that the trees where not damaged during harvesting (Clarke 1995). These issues are further discussed in Chapter 6.

\section{Conclusions}

While the descriptive aspects of miombo woodland use and management have now received much attention throughout the region, a detailed understanding of how miombo woodland products contribute to livelihood systems is only now emerging, and largely just in Zimbabwe, as this chapter has shown. Analytical work on the determinants of miombo resource use and management should be a top priority for future research in the miombo region. The literature is rich in descriptive detail; we need to go beyond this stage of research.

Our current understanding of the determinants of miombo resource use and management is summarised in Figure 5.4. We see the determinants falling into three broad categories: household features, institutional aspects (see Chapter 8 for more detail) and characteristics of the resource. This complex of determinants is itself set within the wider macro-economic framework, as spelt out in Chapter 4.

Local management has been dealt with in this chapter; it is returned to in Chapter 7 where further management options are discussed. 


\section{Chapter}

\section{TRADE IN WOODLAND PRODUCTS FROM THE MIOMBO REGION}

\section{Tim Brigham, Alex Chihongo and Emmanuel Chidumayo}

\section{Introduction}

The miombo woodlands constitute the main source of timber and woodfuel in Zambia, Angola, Zimbabwe, Malawi, Mozambique, Tanzania and southern Zaire. In addition, these woodlands provide a wide range of non-timber products including beeswax, honey, edible fruits, edible insects, vegetables, game animals, mushrooms, traditional medicine, and fibres and wood for handicrafts (Chapter 5). Although there is significant variation within and between the countries in the degree to which these products enter the market, the products play a large and essential role in the national economies of the region.

Trade in woodland products in the region can be roughly divided into two, not necessarily exclusive, areas: the formal sector, largely con-

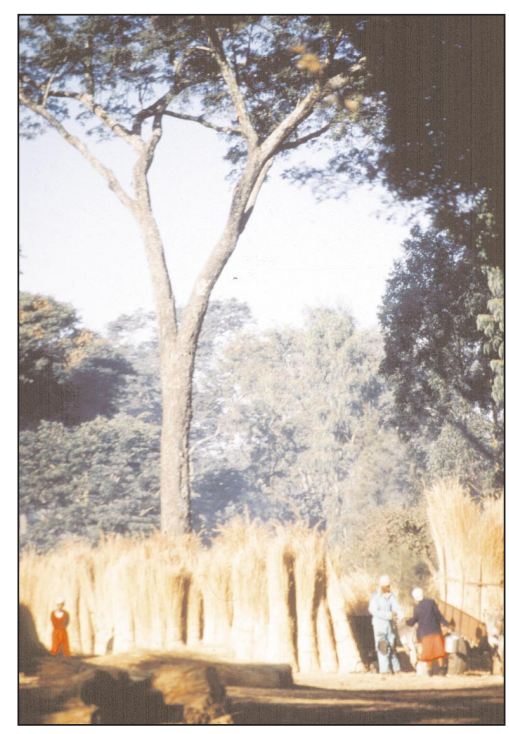

Miombo woodlands provide a wide range of products, including thatching grass and wooden utensils for the local market (photos: J. Clarke and T. Brigham)

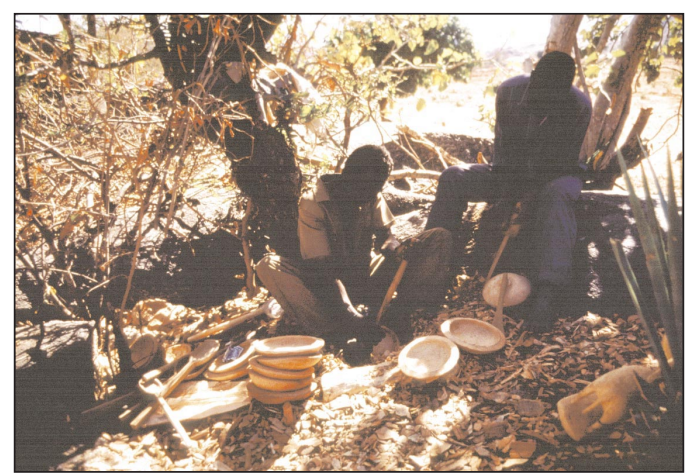


cerned with trade at the national and international levels; and the informal sector, which is largely involved in local trade, with a proportion of national trade and to a much smaller extent, international trade. In both sectors, woodland products support large- and small-scale enterprises, creating employment for thousands of people. Providing an accurate assessment of participation in these industries, as well as determining the overall value of trade in these products is a difficult task. Products traded in the formal sector, and therefore recorded in official statistics, are in the minority; much greater value is realised in the goods traded in the informal sector, although little can be said about the value of such trade (see Chapter 5 for a case study of cash income from sale of woodland products). Assessing participation in the trade is also difficult because participants often move into and out of these activities as conditions warrant. The sale of woodland products for many people is but one of a host of livelihood strategies called upon to meet specific cash needs, as a contingency in case of crop failure or simply as opportunities present themselves (Chapter 5; Fischer 1993; McGregor 1995a). The emergence and/or expansion of markets for woodland products previously viewed largely as 'subsistence goods' is complex. More than simply a reflection of absolute physical scarcity, the process of commoditisation is related to a host of factors including processes of specialisation and exchange which accompany the expansion of the wage labour economy, the emergence of markets in urban areas, and alterations in market access due to infrastructural development or other factors (Falconer 1990; Dewees 1993; Packham 1993; McGregor 1995a).

The discussion of trade in woodland products from the miombo region is organised around a production-to-consumption framework, which attempts to provide an analysis of the entire commodity system, from the primary producer to the consumer (Sellen et al. 1993). Analysing the entire commodity system allows us to move beyond the strictly supply/production focus that has informed much of past research and policy surrounding non-timber forest products (Dewees and Scherr 1994). The production-to-consumption approach encourages a focus on the entire system, recognising the relationships between activities and participants (Sellen et al. 1993), and stressing an understanding of the political and economic contexts within which these activities take place. Although other commodity systems are obviously affected by a range of factors outside the 'farm gate' or production site, non-timber woodland products are arguably an extreme example of this case. For example, extraction often occurs on land over which harvesters may have little control, rendering them vulnerable to policy shifts or other changes (Arnold 1994). Production-toconsumption systems are extremely complex due to the inclusion of three subsystems: the ecosystem, social structure and economic organisation (Sellen et al. 1993).

The first section, on the production of nontimber woodland products, outlines key issues affecting the initial step of the production-toconsumption chain, encompassing factors that affect exploitation up to and including the harvest of materials. The next section explores the potential transformations of the products in time, space, form and ownership, following their harvest but prior to their consumption. It thus covers processing, transporting and marketing. The following section deals with the final step in the chain, consumption. Although the three sections are organised in a linear fashion, production-toconsumption systems function as a host of interacting components, each participant or factor in a system potentially influencing others regardless of position within that system.

The final section in the chapter deals with the potential impacts on economic sustainability of 
these resources, including the response to perceived threats to these resources at the local, national and international levels.

While there is substantial information on marketing of woodland products, much of it in the grey literature, the data is often incomplete or lacking sufficient depth to allow more rigorous analyses. This problem is discussed further in Chapter 9.

\section{Production/harvesting of miombo products}

\section{Wood-based products: fuel, timber and crafts}

\section{Firewood and charcoal}

The miombo woodlands are a vital source of woodfuel (both firewood and charcoal) for rural and urban populations. While woodfuel markets are relatively uncommon in rural areas, urban households are generally dependent on the market to meet their energy needs (Dewees 1993;

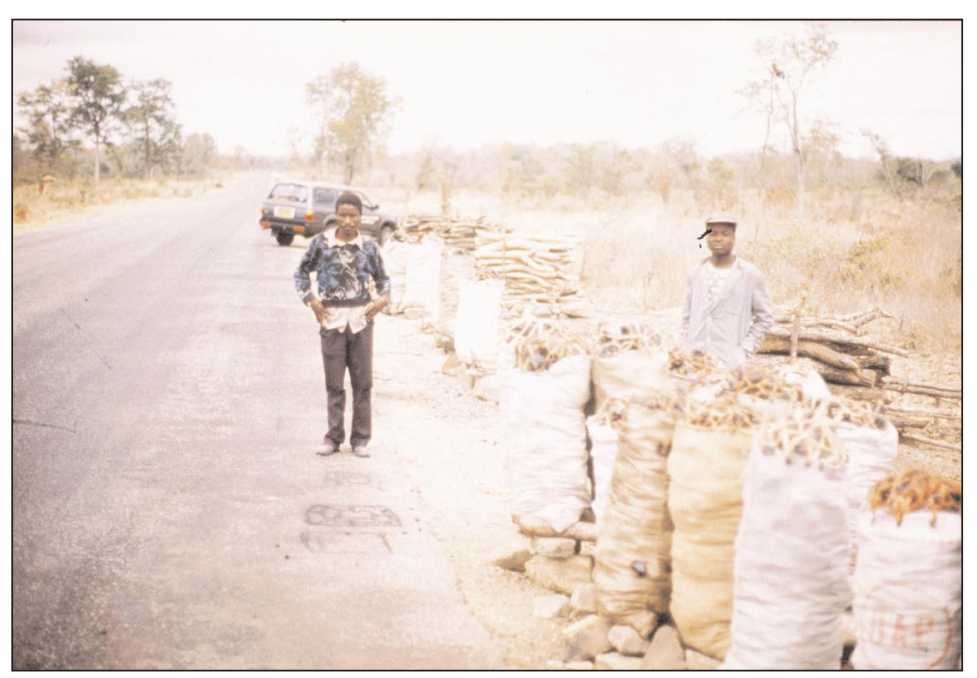

Firewood and charcoal being sold by rural producers on the road to Lusaka. Miombo woodlands provide the bulk of energy requirements in the region (photo: B. Campbell)
Hines and Eckman 1993; Brigham 1994). In Mozambique, annual woodfuel consumption is estimated at 16 million $\mathrm{m}^{3}$, with miombo woodlands accounting for $85 \%$ of total household energy requirements. About $70-80 \%$ of the urban population depend upon woodfuel (Sitoe and Ribeiro 1995). In Tanzania, around $91 \%$ of all energy consumed in the country is woodfuel; miombo woodlands account for $60-70 \%$ of the annual consumption of firewood and for 3.5 million $\mathrm{m}^{3}$ of wood for charcoal production. Miombo woodlands are the chief source for woodfuel utilised by the urban population (Temu and Kaale 1985; Monela et al. 1993). Similarly, little of the woodfuel consumed by the urban population of Zambia is derived from plantations (Chidumayo 1989a; Hibajene 1994). Although it is unclear to what extent urban woodfuel demand in Malawi is met from natural woodland, indications are that the percentage is high (Dewees 1993).

It is likely that a large proportion of the miombo woodlands cut for woodfuel is found on communal lands (Leach and Mearns 1988), though some may be derived as a by-product of land clearance for agriculture. Dewees (1993) notes that the cheapest source of fuel for the Malawian tobacco industry is woodfuel. Wood for tobacco curing comes from the unlicensed clearance of woodlands on communal lands. A study on deforestation in Zambia's Copperbelt (Chidumayo 1989a) also suggests that woodland clearance attributable to urban woodfuel demand took place more on communal and other lands than from woodlands within forest reserves. However, caution must be used in generalising about 
woodfuel source areas because there is considerable regional variation in the utilisation of woodland resources. Although the percentage of total volumes is unknown, government plantations are relied upon quite frequently as a source of supply by urban firewood traders in Blantyre and Lilongwe (Dewees 1993). While $85-90 \%$ of the firewood entering the Harare market is from miombo woodlands, the majority of supply, over $70 \%$ in the late 1980 s, originated from the largescale commercial farms south east and south west of the city (Attwell et al. 1989).

To allow for ease of transportation and sale, harvesting and production of woodfuel will generally be carried out as close to roads as permitted by existing supplies of suitable species (Leach and Mearns 1988; Hibajene and Ellegård 1994). As with firewood, particular species are favoured for charcoal production due to the dense and hard charcoal they produce. In the case of charcoal supplies for the Dar es Salaam market, the best trees for charcoal production have been depleted close to the Dar es SalaamMorogoro highway, leading to a pattern of extensive deforestation up to $30 \mathrm{~km}$ from the road (Monela et al. 1993). While the location of production sites for charcoal will vary even within a country, in general, distances have been found to range from $5-15 \mathrm{~km}$ from main roads in Tanzania (Boberg 1993) and Zambia (Hibajene and Ellegård 1994).

The initial harvesting of wood for sale as firewood or charcoal is undertaken predominantly by men (Hines and Eckman 1993). Harvesting is mainly by local people, but Sitoe and Ribeiro (1995) note that some harvesting for urban markets in Mozambique is by urban residents. In the charcoal market there are three main producers: full-time, seasonal and occasional producers. Full-time producers live in forest areas and make charcoal throughout the year, shifting to new areas when the need arises, such as when the resource becomes depleted. Seasonal producers practise agriculture as their main occupation and produce charcoal outside the cultivation season (Leach and Mearns 1988; Monela et al. 1993). Occasional producers make charcoal to meet specific cash needs during the year. In a similar vein, the only exception to the low level of firewood supply for the market originating from Zimbabwe's communal lands appears to occur during drought years when harvesting firewood for the market is undertaken as a survival strategy by some rural residents (Mazambani 1984; Katerere 1988). Dewees (1993) also reports for Malawi that charcoal and firewood sales are important coping strategies in the face of limited alternatives for poor rural households to generate cash for food purchases after their stocks are depleted.

The woodfuel trade is a major employer in some of the countries covered by this study. The initial production of woodfuel appears to be the largest source of employment in the trade; in Zambia, out of a total of 45500 people engaged in the industry full-time, perhaps 41000 are engaged in charcoal production (Hibajene and Ellegård 1994). Given that these figures are estimates for full-time employment and that many charcoal producers undertake production seasonally, the actual number of rural people working on charcoal production is likely to be much greater. Rural producers of charcoal for the Dar es Salaam market may also number in the thousands (Monela et al. 1993). In the countries for which information is available, it appears only in Zimbabwe is the woodfuel trade of very limited importance to rural employment, as most of the supplies for the urban market originate on large-scale commercial farms (Attwell et al. 1989). There is, however, some local trade in firewood between wood-rich resettlement areas and the neighbouring deforested communal areas (Nhira and Fortmann 1993; Grundy 1995a). 
Sawlogs, poles and craft wood

A number of different tree species are harvested from miombo and associated woodlands for their timber for use in both the large-scale and smallscale manufacturing sectors. Among the more valuable species extracted are Afzelia quanzensis, Diospyros mespiliformis, Dalbergia melanoxylon, Milicia excelsa, Pterocarpus angolensis, Spirostachys africana and Swartzia madagascariensis. Dalbergia melanoxylon (African ebony) is, in fact, widely considered to be the world's most expensive wood (Moore and Hall 1987; White 1988). Up to $85 \%$ of the total sawnwood consumed by the furniture industry in Tanzania is composed of Pterocarpus angolensis.

These valuable wood resources are found under a range of tenure regimes, in reserved forests, in communal lands and on private farms (Bradley and Dewees 1993). Rights to access wood resources vary according to the location of the trees and the species involved. The use of valuable species such as $D$. melanoxylon or Pterocarpus angolensis is generally reserved. Therefore, in theory, utilisation of the wood is only allowed by permit (Moore and Hall 1987; Nhira and Fortmann 1993; Clarke 1995). Rights to harvest commercial timber on communal lands in Zimbabwe are granted to concessionaires by District Councils (Nhira and Fortmann 1993). In Tanzania, anyone wishing to utilise timber for sawmilling or other commercial use must first obtain a license to do so from the District Forest Office (White 1988). However, in many cases the state has little local legitimacy (Chapter 8), and licensing and permits have little relevance at the local level.

Limited information was found about the market for building poles from woodlands. Pole requirements for durability, straightness, length and resistance to insects can be quite stringent (Grundy 1990; McGregor 1991). Therefore, the development of a market for construction poles in some areas may be related to the state of wood- land cover and the availability of relatively cheap Eucalyptus wood. Although numerous local-level rules appear to exist restricting the cutting of trees for construction poles, disregard for these rules is common (McGregor 1991; Campbell et al. 1993; Chapters 5 and 8).

A number of different species, among them $D$. melanoxylon, Pterocarpus angolensis, S. africana, Afzelia quanzensis and Swartzia madagascariensis, are being used in Zimbabwe, Tanzania, Malawi, Mozambique, Zambia and South Africa for processing into wood carvings or furniture for the market (Moore and Hall 1987; Hines and Eckman 1993; Marshall and Jenkins 1994; Sitoe and Ribeiro 1995; Matose et al. 1996; Boxes 6.1, $6.2,6.5)$. Communal lands appear to be the major source of wood for these activities (Moore and Hall 1987; Brigham 1994; Matose et al. 1996) and there is little indication of planted trees being the source of raw materials. Research on carvers in Zimbabwe (Brigham 1994), revealed that none obtained their raw materials from land which had been allocated to their household and most travelled long distances, up to $11 \mathrm{~km}$ in one case, though the average was closer to $5-6 \mathrm{~km}$, to obtain the specific wood required. Trees for carving and furniture making are mostly harvested illegally, at least from the perspective of the state, indicating that some tenure systems lack legitimacy in the eyes of local people (Moore and Hall 1987; Nhira and Fortmann 1993; Matose et al. 1996). In Tanzania in the late 1980 s, it was estimated that the illegal harvest of $D$. melanoxylon was at least equal to the legal harvest (Moore and Hall 1987). The harvesting of trees for furniture making and carving, as well as the actual manufacture of products, is overwhelmingly a male pursuit (Helmsing 1987; Mhone 1991; Matose et al. 1996).

The harvesting methods for trees used for timber, furniture making or carving have often been blamed for poor utilisation of the resource. Where timber resources are dispersed, as they appear to be with many of the species discussed 


\title{
Box 6.1
}

\section{Income generation from carvings, fruits, herbs and woodroses from the Bushbuckridge region, South Africa}

\author{
Sheona Shackleton, Charlie Shackleton and Cathy Dzerefos
}

South of the miombo region, ongoing work in the Bushbuckridge region, South Africa, is investigating the total commercial value of woodland products consumed and/or traded locally or further afield, and exploring development opportunities from these. For all the products examined, income varies by several orders of magnitude from month to month, depending on a variety of factors, including seasonality of the resource, availability of transport to markets, tourist season, availability and condition of tools, competing demands for time, and availability of extra labour when required. Thus, total yearly income may be spread over only two or three months rather than a regular and reliable flow. Total household annual incomes from all sources vary from village to village, from US\$ 1848 to US\$ 3480 (see figures opposite page).

Seventeen species are used in the wood-carving and furniture-making industries. The most widely used are Pterocarpus angolensis, Spirostachys africana, Dalbergia melanoxylon, Berchemia discolor and Olea europaea. Mean net annual incomes for wood carvers is estimated as US\$496, and for furniture makers US\$ 1958 (assuming income for 6 months of the year only).

Traders in indigenous fruits and herbs earn approximately US\$ 654 and US\$ 997 per annum, respectively. However, there is markedly less effort required per unit return in selling edible herbs and fruits relative to carving or furniture-making, and there are almost no capital overheads or tools required. Principal herbs sold are Cleome gynandra and Momordica balsamina, and principal fruits are Sclerocarya birrea, Strychnos madagascariensis and S. spinosa. Many herbs and fruits are dried or processed and sold during the dry season or during droughts.

Woodroses are a swollen, flower-like, host-tissue response to parasitic mistletoes. Local entrepreneurs cut these diseased branches from the host tree, clean away the mistletoe and sell the product to curio outlets in the region. Mean annual income is approximately US\$ 843 (assuming three highincome months, and nine low-income months per year, in relation to tourist seasons).

The use of indigenous resources can substitute for, or supplement, other sources of cash income. Earnings of furniture makers are well above the mean incomes for households in the local business centres, while earnings for wood carvers and woodrose vendors are at the lower end of the scale. However, even these low incomes must be seen against the background that few formal employment opportunities exist in the area and unemployment is greater than $50 \%$. Thus, extra income from the sale of locally harvested resources, however small, is important for many households.

here, economic exploitation favours small units like those operated by pit sawyers. Such locallevel cutting of trees to supply sawmills in Tanzania has resulted in only $60 \%$ of possible wood being recovered, the rest being lost through improperly rejected $\log s$, cutting with axes instead of saws, cutting high on the stumps, and leaving behind branches and tops which could be readily utilised by carvers (Moore and Hall 1987). However, recovery rates by commercial sawmillers for roundwood production are even lower, dropping to some $30 \%$. 
Income generation (continued)

(a) Wood carvers

Mean $=496 \mathrm{SE}=65 \mathrm{n}=17$

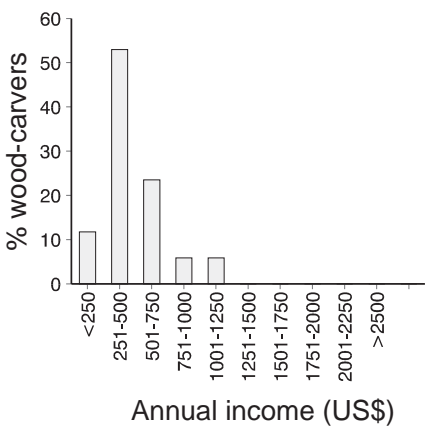

(b) Furniture makers

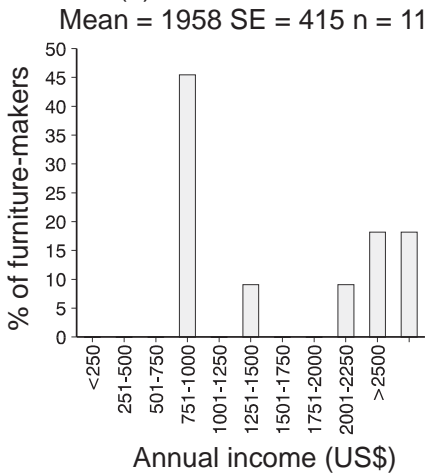

(c) Woodroses Mean $=70 \mathrm{SE}=11.8 \mathrm{n}=15$

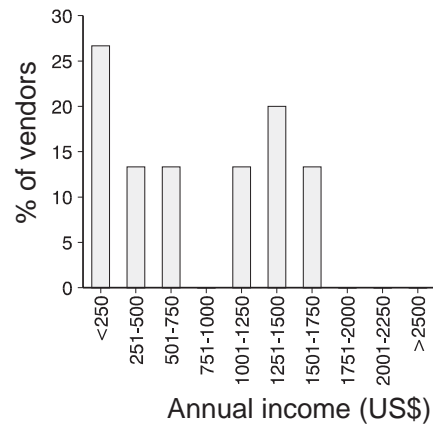

(d) Edible herbs Mean $=997 \mathrm{SE}=165 \mathrm{n}=46$

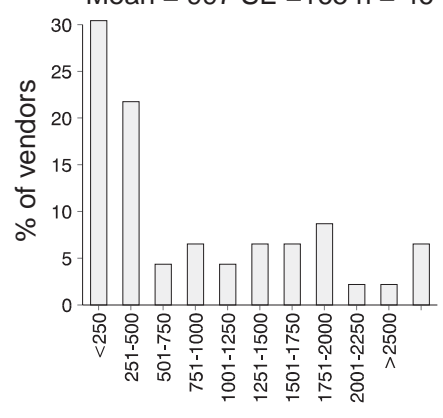

Annual income (US\$) (e) Edible fruits

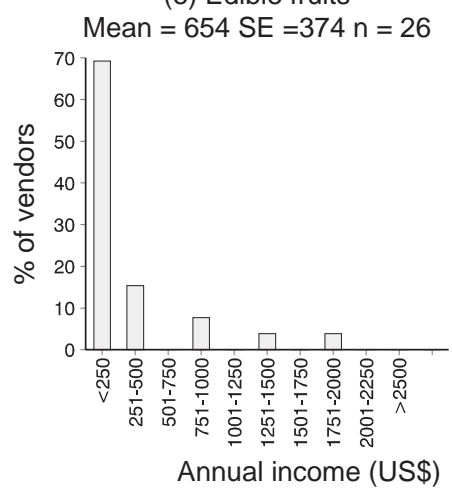

Annual income from several indigenous resources from the Bushbuckridge region, South Africa. Values obtained prior to 1995 corrected at $10 \%$ p.a. inflation rate. Local currency values converted to US\$ at a rate of US\$ $1=\mathrm{R} 3.65$.

Because of the lack of controls over the location of harvesting, the most accessible wood is harvested first, leading to increasing costs of harvesting over time and the depletion of the resource in certain areas (Moore and Hall 1987; White 1988). Although perceptions vary by area, there is concern among producers that supplies of some species are becoming depleted due to over-harvesting, agricultural expansion, hot fires, etc. (Bradley and Dewees 1993; Hines and Eckman 1993; Brigham 1994; Matose et al. 1996; Box 6.5). 


\title{
Box 6.2
}

\section{Marketing of forest products from Zimbabwe's communal lands}

\author{
Timothy E. Brigham
}

Data on a variety of aspects of tree-product marketing were obtained in three adjacent Communal Areas north east of Harare through both quantitative and qualitative research involving 443 households (Brigham 1994). The number of households involved in craftwork activities for sale is limited: only $4 \%$ reported selling tree-based products (see table opposite page). While the small number of households selling these goods appears to imply a limited role for this sector, the extensive market for these products demonstrates their local importance. Nearly $79 \%$ of households surveyed had purchased at least one of the products, while one-third of purchasing households stated they had purchased five out of the six products.

Data from producers indicates most production is locally consumed, although sizeable markets exist for these goods in areas over $100 \mathrm{~km}$ away. Market outlets depend to a degree on the nature of the product. For example, tool handles tend to be sold locally whereas kitchen utensils (wooden spoons and bowls) are sold in rural and urban areas including, in the latter, to large retailers. Mortars are also marketed outside rural areas in large centres including Harare; some producers supply local middlemen with mortars which are sold as far away as Botswana and South Africa.

The marketing practices described challenge perceptions that craftwork is a localised, limited activity. A significant proportion of craft sellers rely largely on income earned through these sales and, as Mhone (1991) suggests, display considerable enterprise and ingenuity in their activities. Craftmakers will act on perceived market opportunities in the hopes of expanding their business or addressing business problems. These options included new products which provided higher cash returns to labour or a focus on expansion into other markets to reduce time and travel expenses.

The most frequent complaints reported by craftworkers centred on a lack of marketing infrastructure. Those selling goods outside their local area face problems with the cost and availability of transport. Another difficulty is finding outlets which provide fair returns for products; many complained of traders in Harare's Mbare market who coerce craftmakers into surrendering products for low prices. Scarcity of raw materials is also a concern. Shortages of certain species are often localised; producers respond by shifting collection sites, often travelling further afield, rather than substituting with species they consider inferior. Many expressed a concern that in the future certain species would no longer be locally available. Even now, conflicts arise where craftworkers attempt to access wood resources claimed by neighbouring communities.

\section{Edible plant products and mushrooms}

Indigenous fruits of the miombo woodland are of great importance in the diet of rural people (Campbell 1987; Wilson 1989a; Campbell et al. 1991a; McGregor 1991; Chapter 5). Their role in the cash economy, on the other hand, appears to be much more variable, although a number of indigenous fruits of the miombo woodland do enter into trade. Species whose fruit is marketed include Uapaca kirkiana, Azanza garckeana and Strychnos cocculoides (Campbell 1987; Njovu 1993; Packham 1993).

As is the case with fruits harvested for personal consumption, most indigenous fruits destined for the market are harvested from communal land. There is an intricate set of rules about harvesting 


\section{Marketing of forest products (continued)}

Little research has been done on environmental consequences of craft enterprises (Mhone 1991). Site-specific research is required to assess the sustainability of current exploitation rates of craft species. Producers have considerable knowledge of craft species, both in terms of suitability and ecology. Such knowledge could assist in evaluating interventions in the craft sector, including those involving species substitution or enhancement. Questions regarding the benefits and costs for various interest groups and the community will also have to be addressed. Local communities, as those most affected by alterations to the forest resource, should be at the centre of any planning activities.

Numbers of households (and percentages in brackets) in the craft trade in north eastern Zimbabwe.

\begin{tabular}{lrr}
\hline Product & Buyers & Sellers \\
\hline Mortars & $312(70.4 \%)$ & $4(0.9 \%)$ \\
Kitchen utensils & $284(64.1 \%)$ & $5(1.1 \%)$ \\
Yokes & $230(51.9 \%)$ & $3(0.7 \%)$ \\
Furniture & $216(48.8 \%)$ & $4(0.9 \%)$ \\
Tool handles & $214(48.3 \%)$ & $6(1.4 \%)$ \\
Bark ${ }^{1}$ & $61(13.7 \%)$ & $4(0.9 \%)$ \\
Totals(all products) & $349(78.8 \%)$ & $16(3.6 \%)$
\end{tabular}

\footnotetext{
${ }^{1}$ Refers to products made exclusively from bark (e.g. bags) or bark in combination with other materials (e.g. mats woven with bark twine).
}

wild fruits (Box 5.6; Chapters 5 and 8) but, in circumstances where there is open access, there can be considerable competition to harvest the fruits if the supply is limited (Gumbo et al. 1990). The fruits of Strychnos cocculoides, which have a hard shell, are sometimes harvested while still green and then buried to finish ripening before being sold. As with other non-timber woodland products in Zimbabwe, localised shortages of indigenous fruits in the communal areas may be compensated for by illegal harvests on nearby commercial farms or ranches (Gumbo et al. 1990). Although indigenous fruit trees are infrequently planted by rural households, they are commonly selectively retained during land clearance for agriculture and in fact make up the bulk of trees left standing in many agricultural landscapes (Box 5.5; Chapter 5). The importance of fruit production in decisions surrounding tree clearance is suggested by the removal of male (non-fruiting) Sclerocarya birrea from arable lands (Cunningham et al., in prep.; Wilson 1989a). The wood of male trees is used for making stools or drums (Gumbo et al. 1990).

Some indigenous fruit species are heavy producers; a single specimen of Sclerocarya birrea has been recorded as producing over 90000 fruits, for a total production in the range of two tons (Quin 1959). An advantage of many indigenous fruits is their availability during the dry season 
when labour demands are lower and more flexible than during the main agricultural season (Gumbo et al. 1990). However, the labour required to harvest these fruits is generally higher than for exotic fruits due to the former being more scattered throughout farm fields, grazing land and remaining natural woodlands. Harvesting is usually done by children and, to a lesser degree, women (Campbell 1987; Gumbo et al. 1990).

Although indigenous fruits are the most important edible plant resource of miombo woodlands (Campbell and Brigham 1993), other edible, non-animal resources marketed from the region include mushrooms, leafy vegetables and roots (Sørensen 1993; McGregor 1995a). Miombo woodlands contain abundant and diverse mushroom populations; in Zimbabwe upwards of 45 different species from the miombo woodlands are thought to be edible (Wilson 1990; McGregor 1995a), and in Tanzania the figure may be even higher (Chihongo 1993). The edible mushrooms of Zambia have also been widely documented (Pegler and Piearce 1980; Piearce 1987).

However, there is a perception in some areas of Zimbabwe that the abundance and availability of mushrooms have diminished due to a combination of woodland clearance, soil compaction by cattle and leaf litter collection for use as fertiliser (McGregor 1991). The fact that mushrooms are still widely gathered by rural people suggests that large-scale commercial farms and relatively uncleared resettlement areas are key sources of these products (McGregor 1991). Mushroom collection for personal consumption or sale takes place during the rainy season (Chihongo 1993). Mushrooms are commonly dried for later use (McGregor 1995a), and in Zambia at least, the dried product can be seen for sale in town markets (Sørensen 1993).

Leafy vegetables are sold, sometimes in dried form (Sørensen 1993; McGregor 1995a). In Zambia, the roots of the shrub Rhynchosia insignis are used as an essential input into sweet maize 'beer' known as munkoyo (Njovu 1993; Sørensen 1993). As with indigenous fruits, women and children appear to be the main harvesters of these other edible products.

\section{Other plant products: fibre and medicinal plants}

Important sources of fibre in miombo woodlands include the bark of Brachystegia spp. and Julbernardia globiflora (McGregor 1991). Bark fibre has a small market in rural areas where it is used to bind leafy vegetables together and is also marketed as a component of handicrafts (Campbell et al. 1991a; McGregor 1991; Brigham 1994). The leaves of various palms such as Phoenix reclinata, Hyphaene petersiana and Borassus aethiopium are also utilised in the rural areas to weave handicrafts (Chihongo 1993; Sørensen 1993). Leaves can be harvested sustainably by climbing the palms, but harvesting is sometimes done by cutting down the entire tree (Sørensen 1993). It is not known to what degree the harvesting of bark fibre actually destroys the tree, but the degree of damage probably depends on the age of the tree and the part used. Whole saplings are sometimes cut for their fibre, while stems of older trees stripped of bark are usually unsuitable for poles due to the damage (Campbell et al. 1993).

Most of the trade in medicinal plants is conducted in the informal sector and therefore actual trading practices are unknown for many areas (Chihongo 1993). In Zimbabwe, indigenous woodlands are the major source of herbal medicines; perhaps $10 \%$ of the country's flora is used by traditional healers with roots and bark of native trees and shrubs making up a significant proportion of the total (Gelfand et al. 1985). Traditional collection of medicinal herbs aimed to ensure the sustainability of the resource, but increasing scarcity of these plants, whether due to deforestation or over-harvesting, has led to the abandonment in many areas of sustainable harvesting methods especially for the more rare and/or 
lucrative species (Campbell et al. 1993). Suppliers of medicinal herbs often are forced to travel far in search of prized species (Gelfand et al. 1985); Cunningham (1993) reports some medicinal plants are transported more than 200 kilometres.

\section{Animals: insect products}

\section{Honey and beeswax}

Miombo woodlands are a prime location for beekeeping due to the presence of a large number of excellent bee forage species including Brachystegia spiciformis, Julbernardia globiflora, Julbernardia paniculata and, to a lesser but still important extent, Vitex doniana, Uapaca kirkiana and Parinari excelsa (Smith 1966; Hines and Eckman 1993; Njovu 1993).

Honey has been described as one of the most important commercial products from Tanzania's woodlands, and the untapped potential of the miombo region for honey and beeswax production appears enormous (Kowero and O'kting' ati 1990; Ntenga and Mugongo 1991; Hines and Eckman 1993). Beekeeping and honey hunting are widespread practices in many areas of the

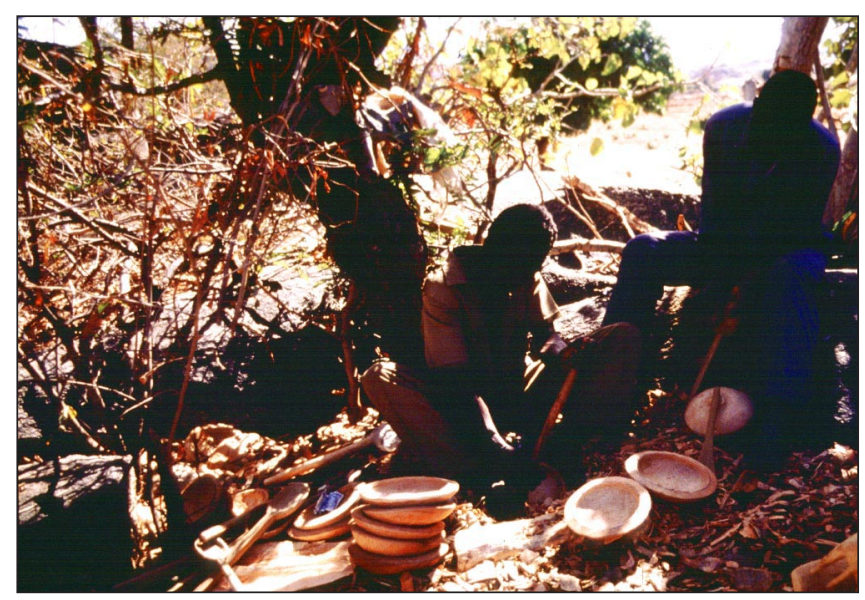

One of the main income-generating activities in miombo woodland is honey production. Hives are often produced from the bark of miombo trees (photo: T. Brigham) miombo region and both have a long history of traditional practice (Wilson 1990; McGregor 1991; Ntenga and Mugongo 1991; Banda and De Boer 1993; Fischer 1993). While honey hunting is often done on an opportunistic basis, beekeeping is perceived as more of a 'specialist enterprise' with skills passed on within families from father to son (Fischer 1993; Brigham 1994).

Honey hunting and beekeeping both have traditionally been considered as male pursuits, although women may occasionally participate in processing and transporting the product (Ntenga and Mugongo 1991; Fischer 1993; Njovu 1993). Women's participation in beekeeping may also be on the rise in densely populated agricultural areas where bee colonies tend to be more stable (Fischer 1993). Clauss (1992) reports from some areas of Zambia that members of female-headed households are participating more in honey hunting to supplement household income. As is the case with other non-timber woodland product enterprises, most beekeepers are also farmers and thus must balance the efforts expended on beekeeping with the demands of agricultural production. The time spent on beekeeping is also affected by the household's need for cash, the relative profitability of beekeeping in relation to other potential income-earning activities and other considerations (Fischer 1993).

As an income generating strategy, traditional beekeeping, utilising bark hives, has the attraction of involving little or no investment other than time (Fischer 1993). For policy makers concerned with sustainable development, beekeeping has the advantage of not competing with most other potential land uses and of generally being compatible with the maintenance of other resources (Fischer 1993; Hines and Eckman 1993). As will be discussed in more depth later in the chapter, envi- 
ronmental concerns regarding the debarking of large numbers of trees for hive construction, which led to government prohibitions on beekeeping in many areas, appear to have been over-stated to some degree (McGregor 1991; Clauss 1992; Banda and De Boer 1993).

The majority of beekeepers are concerned with forest conservation and appear to be receptive to extension messages such as maximising the number of hives made per tree (Clauss 1992; Njovu 1993). The fact that forest conservation and beekeeping are compatible, coupled with the recognition that restricting access to protected forests is difficult or impossible without local support, has prompted managers of conservation areas to allow beekeepers to establish hives within reserves in exchange for curbing other uses deemed incompatible with conservation objectives (Banda and De Boer 1993; Chihongo 1993; Fischer 1993; McNeely 1993; Nyirenda 1993). Low population pressures within reserves makes them excellent sites for beekeeping, while a benefit to park administrators can be the de facto monitoring by local people of potentially harmful woodland activities (Banda and De Boer 1993; Chihongo 1993). Illegal honey hunting continues in many parks and other reserves, perhaps due to restrictions on numbers of beekeepers allowed into approved programmes or the lack of suitable trees for hive construction in the vicinity of villages (Ntenga and Mugongo 1991; Banda and De Boer 1993).

\section{Edible insects}

Little information was obtained on the trade in edible insects. The most important edible insects in Zimbabwe include species of caterpillars and termites, as well as some crickets and grasshoppers (Campbell and Brigham 1993). Caterpillar yields are highly seasonal and demonstrate considerable yearly variation (Munthali and Mughogho 1992; McGregor 1995a). Munthali and Mughogho (1992) also report from Malawi that the practice of early burning can markedly increase the yield of at least one species of marketed caterpillar.

As with edible mushrooms, deforestation and, to some degree, over-harvesting have been blamed for declining availability of commonly consumed caterpillar species (Wilson 1990; McGregor 1991). McGregor (1995a) notes that. in Shurugwi Communal Area, Zimbabwe, supply of all the 14 caterpillar species consumed in the past has declined markedly. Although mopane 'worms' (Box 5.1) may be exceptional due to their high value, the harvesting of these caterpillars for sale is sometimes accomplished through highly destructive means such as cutting whole trees (Wilson 1990; Campbell et al. 1993). Overall, the availability of insect foods is difficult to assess. While some species appear to be in decline, other consumed insects which do not rely on woodlands, but are found in agricultural or other disturbed ground, may actually be increasing in importance (McGregor 1991; Wilson 1990).

With deforestation and loss of habitat for some species, a shift in the location of harvesting may occur. As with mushrooms, more wooded commercial farms and resettlement areas can be important sources of insects (McGregor 1995a; Brigham 1994), although the harvest is probably illegal. Along with the right to establish bee hives, rural communities on the border of certain national parks in Malawi have been given permission to enter the park to collect caterpillars for sale (McNeely 1993; Nyirenda 1993).

\section{Animals: birds and mammals}

\section{Live bird and animal trade}

Information on the trade in live animals in the miombo region is limited. In Zimbabwe, there is much trade in large mammals in the formal sector, with purchases being used to build up stocks of species on private farms in the burgeoning safari industry (Campbell and Brigham 1993). 
Tanzania is one of Africa's major sources of wild birds sold on the international market (Rosser and Milliken 1995), but it was not possible to determine from the literature to what degree these birds can be considered as miombo species. Tanzania's trade in live birds increased steadily from the early 1980 s to 1987 , then declined until 1990. Unfortunately the full range of species traded as well as the volumes involved are not known (Kowero and O'kting' ati 1990; Rosser and Milliken 1995). It does appear however, that the trade in some species has been occurring at unsustainable levels (Rosser and Milliken 1995).

\section{Game animals}

Birds, rodents and other mammals are important components of rural diets in many areas (Wilson 1990; McGregor 1991; Chihongo 1993; Graham 1995; Chapter 5). Although hunting may be conducted over long periods of the year, different game will be hunted during different seasons. Hunting for larger mammals and rodents is generally done during the dry season, while during the rains bush pig and guinea fowl are hunted to limit damage to crops, and harvest time is when granivorous birds are at their most abundant (Wilson 1990; McGregor 1995a). Deforestation and hunting have reduced many game populations but rodents have grown in importance as a food source, especially as arable landscapes generally have higher densities of these animals than woodlands (Wilson 1990; McGregor 1995a; see Falconer 1990 for similar impacts of forest conversion in West Africa). Mammals and birds known to have entered into the informal, small-scale market in Zimbabwe include rodents, specifically mice and Quelea quelea, a granivorous bird perceived as a crop pest (Campbell et al. 1995a). Game hunting under licence also occurs in the region, in some cases for marketing to urban areas, in others as part of the tourist trade (Chihongo 1993). It is likely that formal-sector records for hunting of game animals is only a part of the actual hunting that takes place due to the significant level of poaching in some areas (Campbell and Brigham 1993; Kowero and O'kting' ati 1990).

\section{The transformation of miombo products (processing, transporting and marketing)}

\author{
Wood-based products: fuel, timber and \\ crafts
}

\section{Firewood and charcoal}

The most common marketing channels for the production-to-consumption system for charcoal have been summarised in Figure 6.1. In many of the countries of the region, the charcoal industry has the characteristics of a competitive market: large numbers of producers, transporters and sellers serve the urban market with little government regulation in practice, even in countries where regulatory laws exist (Boberg 1993; Hibajene and Ellegård 1994). In Malawi, charcoal markets are much smaller than firewood markets and are less well understood, in part because it has been driven underground by the government's attempts at control (Dewees 1993).

The bulk of the charcoal used is produced in earth kilns made by covering a pile of logs with earth, igniting the kiln and allowing carbonisation under limited air supply. Charcoal production in earth kilns requires only simple tools. Labour is usually drawn from household members or other producers co-operating for specific tasks in the production process. The majority of production activities, such as tree felling, stem cross-cutting and kiln building are done by men but women participate in breaking the kiln after carbonisation, as well as in recovering and bagging the charcoal.

Road transportation is the primary method for moving woodfuel from production sites to urban consumption centres, although some char- 
coal in Malawi and Tanzania is moved by rail. Woodfuel is also occasionally transported to market by bicycle, wheelbarrow and ox-cart especially by 'hawker-producers' who harvest/ produce woodfuel relatively close to the urban market (Dewees 1993; Hibajene and Ellegård 1994). Charcoal may be moved direct from the kiln site to the urban market, or to the roadside to await pick-up. The latter involves moving the charcoal short distances $(5-15 \mathrm{~km})$ by ox-carts, wheelbarrows, bicycles or on foot. Due to the increased labour costs involved in moving the charcoal to the roadside, charcoal will sell for a higher price than at the kiln site (Monela et al. 1993).

Transportation to urban markets is usually by vehicles hired by traders who are licensed to transport and trade in charcoal or firewood (Monela et al. 1993; Sitoe and Ribeiro 1995). Some traders also have their own vehicles (Figure 6.1). In Zambia, close to $99 \%$ of charcoal is transported by motor vehicles and an estimated 3500 people are employed in charcoal transportation (Chidumayo and Chidumayo 1984; Hibajene and Ellegård 1994).

Transportation arrangements depend on the degree of integration of the producer in the retail trade. In the case where a producer is also a retail trader, the producer will hire a transporter to carry charcoal to the urban market; the producer therefore splits his time between periods of production and sale. Where there is no integration of the producer in retail trading, the urban trader hires transport to collect charcoal after buying it from the producer. Arrangements between transporters, traders and producers are informal and do not involve long-term contracts. Many charcoal producers will only make charcoal on order, and organising the entire transaction often involves traders making several trips to the production area (Hibajene 1994; Hibajene and Ellegård 1994). Cases of producers being controlled by wholesalers or merchants, as reported by Boberg (1993) in Mbeya, Tanzania and Ribot (1993) in
Senegal, are not common in the other southern African countries discussed here.

After the trader locates a producer, he or she will provide empty maize sacks to hold the charcoal and will make a down-payment to the producer before hiring transport. 'Back hauliers' (trucks returning from carrying other goods from the city) are often used in transporting woodfuel (Leach and Mearns 1988).

Transport charges vary depending on the commodity. Hibajene and Ellegård (1994) found that transportation rates for charcoal are very high compared to other commodities in Zambia. Poor operating conditions in the producer areas, problems with multiple collection points and the

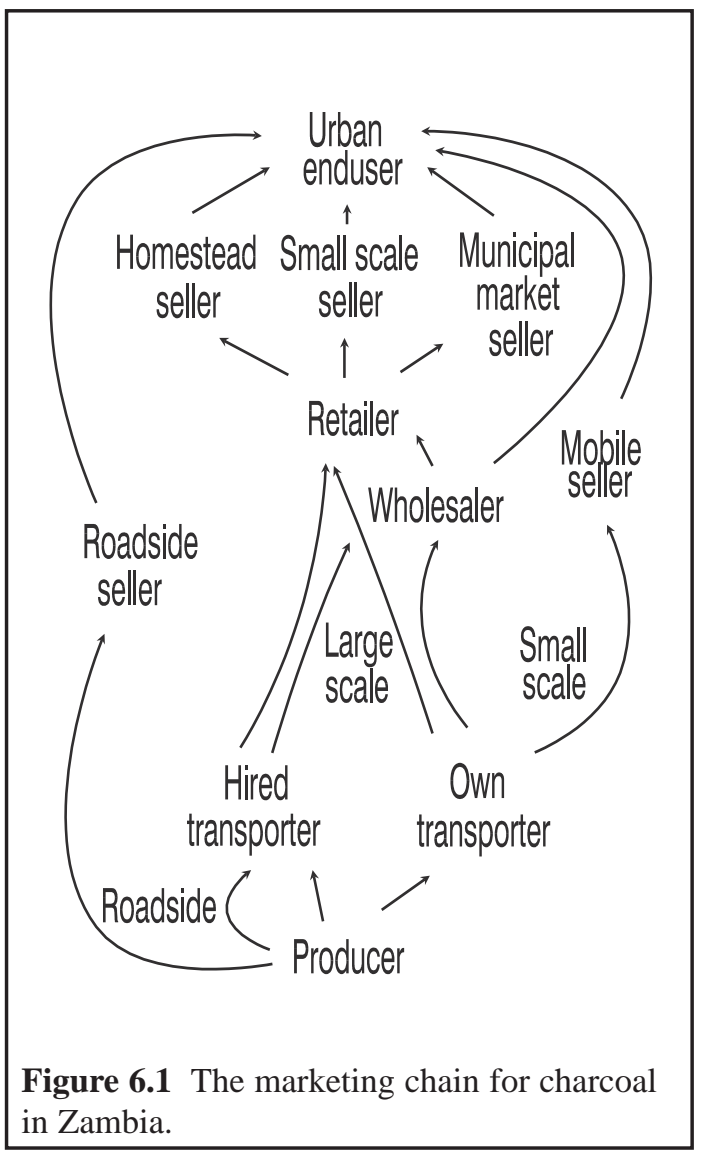


unorganised state of the trade may result in higher charges. The difficult conditions under which transporters must operate also helps to explain why the vehicles used in charcoal transportation are usually more than 15 years old; owners of newer vehicles are reluctant to risk vehicle damage. The age of the charcoal-transporting fleet results in unreliability and frequent vehicle breakdown during transport (Boberg 1993; Hibajene and Ellegård 1994). During the rainy season, many vehicles fail to reach production areas because of the poor state of access roads, resulting in a reduction in charcoal supply. In Lusaka, the drop in charcoal haulage during a normal rainy season is estimated at $23 \%$ but the drop may be $50 \%$ in years with above-average rainfall (Hibajene and Ellegård 1994). In Tanzania, no significant increase in charcoal transportation costs were observed during the rainy season, suggesting that roads do not frequently become impassable to vehicles (Monela et al. 1993). Some of the reduced production of charcoal at this time likely results from a shift to agricultural activities by seasonal producers. Transport charges are also affected by distance, as seen in Zambia where unit charges decline with increasing distance to production areas (Table 6.1).

The different classes of charcoal traders include main traders who hire trucks and obtain

Table 6.1 Charcoal transport charges (in Zambia kwacha) per tonne-km in Zambia (Hibajene and Ellegård 1994) (the kwacha devalued significantly over the period, from US\$ $1=\mathrm{K} 7$ in 1988 to US\$ $1=\mathrm{K} 270$ in 1992).

\begin{tabular}{llll}
\hline Distance to production & 1988 & 1990 & 1992 \\
\hline $1-50$ & 4.15 & 50.00 & 75.00 \\
$51-100$ & 2.08 & 25.00 & 37.50 \\
$101-200$ & 1.04 & 12.50 & 18.75 \\
$>200$ & 0.99 & 12.44 & 18.65 \\
\hline
\end{tabular}

charcoal from production areas, transporters who perform some retailing, producers who transport their charcoal into urban markets and conduct retailing, and small-scale retailers who purchase charcoal from the main traders in urban areas and sell in small quantities (tins and heaps) (Figure 6.1). Most consumers appear to purchase from small-scale retailers, including door-to-door traders, central market traders and mobile sellers. Occasionally, consumers buy charcoal from roadside sellers located near production sites but this accounts for an insignificant proportion of total urban charcoal consumption. Door-to-door traders are an important feature of firewood sales in Malawi (Dewees 1993). Both men and women participate in marketing woodfuel. Small-scale retailers in Tanzania and Malawi sell at a valueadded price due to the breaking of the charcoal sacks into smaller quantities, but in the process they may lose $15-33 \%$ of the charcoal in fines and dust (Energy Studies Unit 1985; Boberg 1993). In Zambia it is estimated that about 1000 people are involved in the charcoal retail trade (Hibajene and Ellegård 1994) but it seems likely this figure fails to take into account all the participants involved in small-scale marketing activities.

As suggested earlier for rural areas, fuel selling is also an important coping strategy for urban dwellers (Dewees 1993). Although earnings are low, a survey of low-income households in Malawi's urban areas (Roe 1992, in Dewees 1993 ) found that nearly $12 \%$ are engaged in selling firewood, participants moving in and out of the activity as conditions warrant. The same survey found that split wood was being purchased and split again to increase returns 1.5 to 2 times. While prices per piece have remained fairly constant, the size of pieces has steadily declined. Dewees (1993) notes for Malawi that the informal sector, as exemplified by the firewood sales discussed above, is becoming more attractive to urban residents as earnings have not deteriorated as badly as in the formal sector. 
No government price controls on woodfuel were noted for Zambia, Tanzania, Zimbabwe or Malawi although Blantyre City Council had controlled the wholesale price of charcoal during the 1980s (Energy Studies Unit 1985; Katerere 1988; Dewees 1993; Hines and Eckman 1993; Hibajene and Ellegård 1994). The government in Malawi has attempted to influence woodfuel prices by selling plantation-produced wood for prices below those of wood obtained from communal land (Dewees 1993). There is insufficient information to assess the impact of the Malawian government's actions in regard to fuel prices but indications are that the impact has been uneven at best.

Although the market for woodfuel has been described as competitive, collective price fixing by traders has occurred in Zambia. Even with price fixing, retail mark up over the past decade in the Lusaka charcoal market appears to be reasonably modest (Table 6.2) (Hibajene and Ellegård 1994). In contrast to the pricing structure in Zambia, each step in the marketing chain for firewood destined for the Harare market involves a doubling of price with the cost at the roadside in the production areas only amounting to $12 \%$ of the total. Transport charges and the retail mark up account for $27 \%$ and $47 \%$ respectively of the retail price (Attwell et al. 1989). While the retail mark up may seem excessive, it has been suggested that licensed vendors have

Table 6.2 Charcoal price structure in Lusaka, Zambia, during 1983-1994. Chidumayo and Chidumayo (1984), Hibajene and Ellegård (1994) and Kalumiana (1994). Retail price per bag of charcoal is shown in brackets.

\begin{tabular}{lrrrrr}
\hline $\begin{array}{l}\text { Price } \\
\text { component }\end{array}$ & $\begin{array}{r}1983 \\
(\mathrm{~K} 4.50)\end{array}$ & $\begin{array}{r}1988 \\
(\mathrm{~K} 30)\end{array}$ & $\begin{array}{r}1989 \\
(\mathrm{~K} 100)\end{array}$ & $\begin{array}{r}1992 \\
(\mathrm{~K} 350)\end{array}$ & $\begin{array}{r}1994 \\
(\mathrm{~K} 1750)\end{array}$ \\
\hline Price at kiln & $56 \%$ & $49 \%$ & $49 \%$ & $43 \%$ & $45 \%$ \\
Transport fee & $22 \%$ & $32 \%$ & $29 \%$ & $43 \%$ & $33 \%$ \\
Price of sack & $13 \%$ & $7 \%$ & $2 \%$ & $6 \%$ & $18 \%$ \\
Retail mark-up & $10 \%$ & $13 \%$ & $22 \%$ & $9 \%$ & $4 \%$ \\
\hline
\end{tabular}

seen their share of the market decline due to the proliferation of unlicensed sellers and other changes in the firewood marketing structure, and are merely trying to maintain earnings in the face of increasingly unregulated competition (Mazambani 1984; Katerere 1988).

Charcoal prices in Lusaka remained reasonably constant in real terms through the 1980s and this source of fuel appears to have remained largely affordable in spite of seasonal price increases (Hibajene 1994). Constant prices for charcoal in Zambia are in contrast to the situation in Malawi, where prices are highly volatile, and where government interventions have probably increased this volatility (Dewees 1993). In Zimbabwe, fuel prices remained more or less constant in real terms in the 1980s (Attwell et al. 1989).

Price variations in the Tanzanian charcoal market have been suggested as resulting from a highly competitive market, differences in the economies of scale and the degree to which the different marketing levels are integrated (Hines and Eckman 1993). A host of other factors also come into play in pricing: quality of the product, including the species used and the amount of 'fines' or dust, transport method, distance from production site and whether or not the operation is licensed. Seasonal price fluctuations with increases in the rainy season are also common and are exacerbated by above-average rainfall.

During the excessively wet rainy season of 1988-89, the price of charcoal in Lusaka rose by $400 \%$ (Hibajene and Ellegård 1994). Apart from problems with transportation, other factors reducing the flow of charcoal and creating upward pressure on prices included part-time pro- 
ducers returning to agricultural work, the extra time needed for wet wood to carbonise, and the need to pay producers and transporters a premium to work under the more difficult working conditions encountered during the rains (Monela et al. 1993; Hibajene and Ellegård 1994).

Woodfuel also makes an important contribution to income as an input into small-scale processing enterprises such as brick making, tobacco curing, beer brewing, black-smithing and fish smoking (Helmsing 1987; Hines and Eckman 1993; Sitoe and Ribeiro 1995). These activities play a significant role in local economies of the region (Dewees 1993). In a survey of nonagricultural enterprises in Zimbabwe's communal areas, of the approximately $40 \%$ of enterprises directly or indirectly dependent on tree-based inputs for their production, one-half require the use of firewood in the production process (Helmsing 1987). Beer making can be an important source of income for rural women not only through the initial production for sale but also because women act as market intermediaries, purchasing the beer and selling it to beer stalls (Hines and Eckman 1993). The amount of woodfuel consumed in processing activities can be significant; for example, the cutting of wood for tobacco curing has been blamed for extensive clearing of miombo woodlands in some areas. Although much of this impact is probably due to the large-scale tobacco sector (Dewees 1993), no discussion of the differential impacts of the largescale versus small-scale tobacco sectors was located. Enormous quantities of woodfuel are required by the commercial fishing industry (Box 6.3). For example, the inland fisheries on Lakes Chilwa and Chiuta in Malawi yield approximately 18000 tons of fish annually of which about $65 \%$ is smoked, requiring 6000 to 8000 tons of hardwood for processing (SADCC 1994).

Woodfuel production and sales, as well as sales of goods which use wood energy, make important contributions to the income of many rural people and to some urban residents. Even where production and sale is a part-time activity, as it often is, the sale of these goods makes an important contribution to income (Monela et al. 1993). Activities such as charcoal production are also important because, with minimal investments required, entry and exit into production and processing is fairly unrestricted, even for the poor. The income redistribution from urban areas to surrounding source areas can be large for activities such as charcoal production, even more so when the added benefits of paid labour for loading and unloading of the product is factored in (Monela et al. 1993).

Sawlogs, poles and craft wood

Local people can be the first link in the chain of supply for valuable timber species by cutting the trees for sale either on their own initiative, or as hired labourers felling on behalf of buyers such as sawmills (Moore and Hall 1987; Sitoe and Ribeiro 1995). Where they are not obtaining their own wood from communal land (Brigham 1994), woodcarvers may also purchase trees that have been cleared from fields (Matose et al. 1996). In other cases, timber merchants will buy or harvest trees which they then re-sell to carving groups or other buyers (Moore and Hall 1987).

Transportation problems present a major challenge to those dependent on many of the timber species discussed here, as these enterprises often operate where transportation is constrained and where raw materials are dispersed (Dewees 1994). Transportation problems can affect both large and small enterprises: in Tanzania, the expense of $\log$ transport was identified as a major overhead expense by small-scale carvers while sawmills considered transportation problems to be the limiting factor on production during the mid-1980s (Moore and Hall 1987).

Research on rural woodcarvers in Zimbabwe (Brigham 1994), showed that raw materials frequently undergo some preliminary processing at the cutting site before being transported back 


\title{
Box 6.3 \\ The impact of commercial and domestic uses of woodfuel on miombo woodland: a case study from Malawi.
}

\author{
Joanne Abbot
}

Harvesting of domestic woodfuel is often perceived as a major cause of woodland degradation in southern Africa. The impact of woodfuel use by local communities in Lake Malawi National Park was investigated using participatory and formal research methods (Abbot 1996). Aerial photographic analysis revealed that $8.5 \%$ of the closed-canopy miombo woodland had been converted to sparse woodland in just eight years (1982-1990). Amongst these lakeshore communities, woodfuel is used domestically and for fish smoking, the latter to preserve fish for transportation to inland markets. This commercial activity is an important economic activity for rural communities but also provides a major protein source for inland Malawi.

In spite of their conspicuous collection patterns, it appears that domestic wood collectors have limited destructive impact on miombo woodland because they utilise small-sized branches and show a broader species selection (see table). They also lack the tools required for felling trees and tend to lop branches to compile their bundles. By contrast, the wood selected for fish smoking is of narrow species base, with one species, Brachystegia microphylla, utilised more than half the time. It was also biased towards wood of a very large size class, which requires the felling of canopy trees. This activity was carried out by men who, unlike rural women, have access to both the tools necessary for tree felling and vehicles for transporting their heavy loads. Thus, fish smoking appears to be a major factor contributing to woodland decline in Lake Malawi National Park. It is a commercial enterprise made profitable because it depends entirely on the free extraction of the Park's natural resources.

This study demonstrates the importance of local conditions in assessing sustainability of resource use. Using participatory research methods, this study initiated a forum through which revised management policies could be debated. These included: providing alternative sources of woodfuel, shifting the emphasis of law enforcement and community extension efforts towards the more damaging form of wood use (for fish processing) and reducing the communities' demand for woodfuel by installing improved, fuel-efficient fish smoking kilns.

The different patterns of selection and harvesting associated with woodfuel used domestically and commercially on the shores of Lake Malawi.

\begin{tabular}{lll}
\hline Variable & Domestic woodfuel & Commercial woodfuel \\
\hline Mean amount used per week & $9.9 \mathrm{~kg}$ per person & $108.2 \mathrm{~kg}$ per station \\
Mean midpoint diameter & $3.6 \mathrm{~cm}$ & $23.8 \mathrm{~cm}$ \\
Number of species selected & 28 & 14 \\
Species most frequently used & Brachystegia microphylla & Brachystegia microphylla \\
Frequency of encountering most & $40.9 \%$ & $56.9 \%$ \\
frequently used species (\% of logs) & & \\
Tools used for harvesting & Hands, sticks and large knives & Large knives, axes and saws \\
Harvesters and transporters & Women and their daughters & Men \\
Transport mode & Headload & Bicycles, boats and dugout canoes
\end{tabular}


to the home for the balance of the manufacturing. Only limited stocks of inputs tend to be maintained where production takes place. Although circumstances vary, stocks are kept at a low level because the time required to build up large supplies detracts from the time needed during the week for product manufacturing. A number of carvers described collecting trips to obtain wood as taking a full day; transport limitations mean that only a maximum of one week's supply could be carried at any one time.

None of the carvers interviewed in the Zimbabwean study employed motorised transport to obtain wood and, while some might use carts to move logs part of the way, many of the source areas are only accessible on foot. Some respondents load bicycles with wood and then walk them back to the work site, a practice with the advantage of allowing source areas to be reached fairly quickly and increasing the amounts that can be transported at one time (Brigham 1994).

As was the case with the harvesting of these resources, the supply system and processing for the products tend to result in large amounts of wood being poorly utilised. Initial processing at the harvesting site, such as to reduce logs to a reasonable size for transport and processing, can lead to large amounts of wastage due to the use of axes and to the desire to bring back only the best quality pieces because of the effort involved in transport (pers. obs.). The better the returns that can accrue to suppliers from larger pieces of wood, the more likely it is that smaller, irregular pieces are left in the forest to rot even though such pieces could be used effectively by carvers (Moore and Hall 1987). Poor integration between the different users of wood also means the resource is not utilised to its best potential. For example, much of the D. melanoxylon not used in sawmilling activities could still be used in carving; co-ordinating the needs of these two industries would go some way to encourage maximum utilisation of a valuable resource (Moore and
Hall 1987). Some sawmilling operations in the region produce lower quality hardwood sawn timber in comparison with that of other hardwood producers in the world. Mills often do not produce export quality lumber, and when they do so, costs of production are generally high. The mills processing $D$. melanoxylon for export are focused on a single product, woodwind sets, which leaves at least half of the raw material unused. No alternative markets for the discarded wood have been developed (Moore and Hall 1987).

The literature points to much higher participation in employment in the informal sector compared to the formal sector. In fact, although growth is uneven, employment in some woodlandbased informal-sector enterprises is increasing (Box 6.4), whereas in the formal sector, at least in Zimbabwe, employment appears to be contracting, mainly due to supply problems (Arnold and Easton 1993).

Employment in enterprises based on inputs from forests and woodlands is an important part of total employment in some of these countries. Dewees (1993) notes for Malawi that these enterprises are estimated to employ over 150000 people, perhaps $15 \%$ of the total number employed in the small- and medium-scale enterprise sector. Research in Zimbabwe (Mhone 1991) found a roughly comparable percentage of $15-25 \%$ of non-agricultural enterprise in the rural areas being based on tree inputs. These small-scale woodland-based enterprises offer significant scope for the rural household to supplement and diversify their sources of income, often with low investment and operating costs (Dewees 1993; 1994). Furthermore, for some households, as has been shown for refugees in Malawi, these enterprises may be the only options available for generating income (Dewees 1993).

Although it is clear that a pole market does exist in some areas, little is known about its size or how it functions. Hines and Eckman (1993) note for Tanzania that rural households do not 


\section{Box 6.4}

\section{Patterns of growth in forest product enterprise activities in Africa}

\section{Mike Arnold}

In six countries surveyed recently, Botswana, Kenya, Lesotho, Malawi, Swaziland and Zimbabwe, an estimated 763000 persons were employed in 408000 small enterprise units engaged in the transformation or commercialisation of forest products (Arnold et al. 1994; figure below). As 86\% of this employment was in rural areas, a very large number of rural households was thus obtaining some income from woodland and forests.
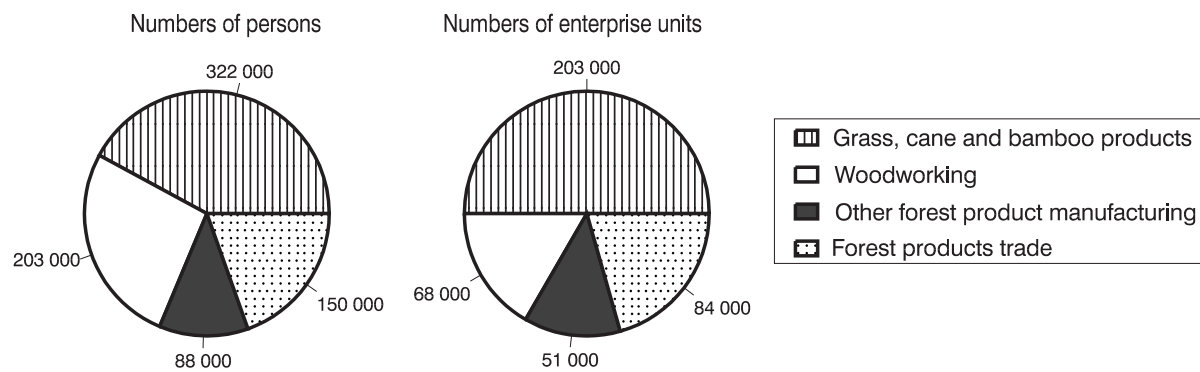

Persons and enterprise units engaged in forest-based activities in six countries of southern and eastern Africa.

There were marked differences in growth patterns of the various activities. Employment in woodworking showed a much faster rate of growth (30.6\%) than employment in grass, cane and bamboo manufacturing $(3.1 \%)$ and in forest products trade $(18.5 \%)$. Most of the growth in employment in the latter two came from new enterprises, rather than from increases in the numbers employed in existing units; only a small proportion of enterprises in fact had growth in size. In the enterprises covered by the surveys, about $80 \%$ of jobs in grass, cane and bamboo activity, and $78 \%$ in forest products trade, came from new start-ups. In woodworking, in contrast, 55\% came from expansion of existing enterprises. Woodworking was also the only activity in which a substantial share (30\%) of the growth in employment comes from enterprises that graduated from being very small to intermediatesized enterprises.

Above-average growth rates were found to be more likely to occur in enterprises that were young, and those that started out small. Enterprises located in commercial districts were more likely to have higher growth rates than their counterparts operating out of the home. Female-headed enterprises were likely to grow less rapidly that those operated by males.

Only about half of the enterprises that had closed reported having done so due to 'bad business conditions' (most of the other closures being to take up other options, or for health or other personal reasons). Many of the entrepreneurs who closed enterprises, particularly among those engaged in woodworking, subsequently started new enterprises. 
generally purchase building materials but will sell materials to traders who take the product to town. In Zimbabwe, du Toit et al. (1984) found a strong correlation between a construction wood market and the state of local woodland cover; more deforested areas appeared to have a significantly larger market for poles. Prices for construction wood are higher in more deforested areas.

\section{Edible plant products and mushrooms}

Edible plants and mushrooms are processed in a variety of ways including simple drying, morecomplex preservation techniques and the production of beverages (Gumbo et al. 1990; ENDA 1991; Sørensen 1993). Drying and other methods of preservation for indigenous fruits for consumption outside their normal season appears to be quite common in parts of Zimbabwe (Gumbo et al. 1990; ENDA 1991), but there is no indication of the nature of the markets for such products. One product with considerable requirements for processing prior to sale is the nut of Sclerocarya birrea. Nuts are extracted manually, an arduous task given the hardness of the shell and the need to extract whole nuts for the best prices. Twentyfour working hours are required to fill a tin that holds 800 grams of the nut (Gumbo et al. 1990). A few products may be purchased and then processed further. One is the root of Rhynchosia insignis, sold fresh or dried for processing into munkoyo beer in Zambia (Njovu 1993). Also in Zambia, National Breweries buy Uapaca kirkiana fruits from rural people for processing into 'musuku wine' (Packham 1993). Sclerocarya birrea fruit can be used to make an alcoholic drink, which is used for work parties and occasionally sold (Gumbo et al. 1990). Zizyphus mucronata fruit is also made into an alcoholic drink which is sold locally.

Edible miombo woodland products have both rural and urban markets although indications are that urban markets, and other markets at some distance from production sites, are the strongest for most of these goods. As expected, indigenous fruits and other gathered products often have a low unit price in rural areas because of generally high supply, competition amongst sellers and low rural demand, at least during the production season.

High perishability of certain goods will also result in low prices as sellers try to realise some return before the product spoils (McGregor 1995a). As value may only be realised outside the immediate area, marketing these products can involve significant effort in organising and paying for transport to the location, such as an urban market, where fruit can be sold. Children from areas with a poor supply of fruit trees may travel a considerable distance to harvest fruit from ranches or other well-wooded areas, 'importing' it into their home area for sale at local business centres (Gumbo et al. 1990). Apart from large-scale buyers, e.g. National Breweries of Zambia, market intermediaries who buy and re-sell indigenous fruit may also travel to source areas. Research in Harare's largest market (Brigham 1994), revealed a group of middlemen who arrange their own transport and travel to rural areas to purchase the fruit of Zizyphus mauritiana, generally in exchange for used clothing. The fruit was then re-sold in Harare either to sidewalk vendors or direct to the public.

The degree to which indigenous fruit is marketed differs depending on availability, shelf life, control over the resource, demand patterns and access to markets, sale price and the effectiveness of social controls regulating the sale of these products (Gumbo et al. 1990). Levels of fruit sales appear to vary markedly between areas; in Zimbabwe, results from different sites of miombo woodland gave sales figures for indigenous fruit ranging from $1 \%$ of households (Brigham 1994) to 9\% (Campbell et al. 1991a) up to 25\% (Campbell 1987). The reasons for these differences are not clear. A high degree of marketing of indigenous fruit may be related to the relative availability 
of exotic and indigenous fruits. In the research undertaken by Brigham (1994), very low indigenous sales $(1 \%)$ are combined with high sales of exotic fruits (56\% of households), while the Campbell et al. (1991a) study had more indigenous fruit sales $(9 \%)$ but considerably less $(37 \%)$ exotic fruit sales.

Income generated through the sale of gathered produce may not be large. For example, households selling indigenous fruits may earn less than half of what households selling exotic fruits earn per year (Campbell et al. 1991a). Nevertheless, fruit sales can be an important source of cash to buy farm inputs and meet other household needs, especially during the 'hungry season' (Packham 1993). In general, the sale of gathered produce is of most importance to poorer rural households (Chapter 5; McGregor 1995a). Within households, because the marketing of these products appears to be controlled by women (Gumbo et al. 1990; Brigham 1994), the cash generated amounts to an important source of women's income (Sørensen 1993). However, not all gathered produce provides only small returns. With labour valued at the prevailing rural wages for farm work, returns to beer brewing and nut extraction from the fruit of Sclerocarya birrea in Zimbabwe are 2-9 times what could be earned through farm labour over the same period. A further advantage to these products is that both have a rural market. Given the small proportion of potential fruit production actually utilised, returns could be much larger. Maintaining the tree for fruit and nut production provides much better returns than converting it into products made from the wood (Gumbo et al. 1990).

\section{Other plant products: fibre and medicinal plants}

The simplest processing of bark fibre is the production of bark 'string' (McGregor 1991). More complex processing involves the production of handbags or reed mats utilising bark twine in their construction (Brigham 1994). Brigham (1994) found very limited participation, about $1 \%$ of households, in the trade in bark fibre in three of Zimbabwe's communal areas.

Medicinal plants appear to be widely traded in the southern Africa region, although in-depth information is lacking. Plant medicines are often sold dried or occasionally kept in water. Urban traditional herbalists now frequently purchase their supplies from wholesale collectors who move far afield in search of prized species (Gelfand et al. 1985; Campbell et al. 1993; Cunningham 1993). Sitoe and Ribeiro (1995) even identify an informal export trade in medicinal plants from Mozambique to neighbouring countries, mostly South Africa and Zimbabwe. Unfortunately, no more-detailed information on trade in medicinal plants is available. Reported participation in the trade in Zimbabwe is low. Brigham (1994) found only two households out of a sample size of 443 across three communal areas who acknowledged selling these products. Campbell et al. (1991a) on the other hand, found $7 \%$ of households claiming to sell herbal medicines. Only one of the two households from the Brigham (1994) study provided specific information on the trade: 130 teaspoons of herbs were sold in a year for a total of nearly US\$ 20.00. Apart from sales to local customers, sales were also made to middlemen from the local area and from outside the community who purchased herbal medicines for re-selling in Harare. The sales pattern showed a peak during the main agricultural season, perhaps because certain herbs appear only with the onset of the rains.

\section{Animals: insect products}

\section{Honey and beeswax}

Following the honey harvest after nectar trees have flowered, honey is sold either unprocessed as an input for other products, or is sold semi- 
processed. Would-be buyers distribute containers prior to harvest. In some cases, such as through honey development and marketing projects, beekeepers have been provided with presses to produce liquid honey for sale as a semi-processed product. The remaining comb and any others such as those from abandoned hives, are then rendered into beeswax by melting them in boiling water, straining the liquid and allowing the wax to solidify on top of the water. While harvesting is essentially a male-dominated activity, honey and beeswax processing may involve other family members (Clauss 1992; Fischer 1993; Njovu 1993). Labour demands are not constant, but peak during harvesting and swarm prevention aimed at maintaining the colony in the hive (Banda and De Boer 1993).

Honey is also widely used for making beer, an important source of income for rural inhabitants (Chihongo 1993; Fischer 1993). Fischer (1993) notes that the production of beer from honey has tended to be viewed in a negative light by development workers, probably due to the habit of selling the comb included, uncleaned and without the wax separated, the latter either being thrown away after brewing or sold by the brewer (Ntenga and Mugongo 1991; Clauss 1992). However, the presence of brood and pollen are necessary to provide the protein for the yeast to develop (Fischer 1993). Where beeswax is discarded following brewing, some action, such as educating brewers as to the value of, and the market for, this product, might be desirable to improve the utilisation of this valuable export.

However, from the perspective of honey producers close to the brewing market in Zambia, the loss of extra income from beeswax is not of much concern, as brewers pay much more for the honey with comb included than is paid by the regional beekeeping development project for the separated products (Clauss 1992).
Although beekeeping may be perceived as a way of earning supplementary income, in some areas there is a strong dependence on honey and beeswax for cash earnings which can be sizeable (Ntenga and Mugongo 1991; Banda and De Boer 1993; Fischer 1993; Campbell et al. 1995a). However, while earnings can be large, the risks involved in investing in new technologies may be too high for small-scale beekeepers. As such, attempts to promote frame hive beekeeping has met with limited success in many areas due to the financial outlay required (Fischer 1993; Njovu 1993). Beekeeping development projects appear to have had a greater impact when they have focused on marketing structures, especially in remote areas where transporting honey to market presents significant problems (Ntenga and Mugongo 1991; Clauss 1992; Fischer 1993).

However, developing effective marketing programmes has presented a number of challenges (Banda and De Boer 1993). Large variations in nectar secretion by dominant miombo species have been noted, with drastic declines over wide areas possible every 10-15 years. Marketing programmes must plan for such an eventuality by improving crop forecasting techniques and determining ways of securing adequate supplies through widening the purchasing area (Clauss 1992). In some areas, after low or even moderate nectar flows, marketing programmes are sometimes in the position of buying only honey that is excess to the needs of local brewers (Clauss 1992).

\section{Edible insects}

Only a limited number of rural people appear to participate in the trade in edible insects. In Zimbabwe, one survey found only 5\% of rural inhabitants reporting they sold insects (Campbell et al. 1991a). Insects are sold to both rural and urban markets and in Tanzania some insects are even exported to Uganda. McGregor (1991) lists five different insect species found in Shurugwi 
Communal Area, Zimbabwe, which have an urban market, three of them also being sold locally. Termites are very popular as a snack in beer halls and, with their sizeable market, can provide a good source of income. Cropping of the colonies of the winged reproductive termites to be sold on the market is a common practice in some parts of Tanzania (Chihongo 1993). Indications are that it is mainly women and children who market edible insects (McGregor 1995a).

In Kasungu National Park, Malawi, approximately 170 people participated in the legal harvest of caterpillars during the 1991 season, gathering close to $1850 \mathrm{~kg}$ which were sold for between US\$ 2 and US\$ 7 per kg (Nyirenda 1993). Each person earned nearly US\$ 50 from the sale of these insects. No indication was provided of the number of hours expended on caterpillar collection but the returns appear to be attractive, given that Malawi's minimum daily wage in the early 1990s was less than US\$ 1 (Banda and De Boer 1993). Trade in insects is made possible due to their ability to be stored for a period of time following processing by frying, grilling or drying (Wilson 1990; McGregor 1991; Bradley and Dewees 1993; Chihongo 1993).

\section{Animals: birds and mammals}

\section{Wild bird trade}

Dealers in live wild birds in Tanzania must have evidence of firm orders for specific species prior to the issuance of the permits required to allow capture of the birds (Rosser and Milliken 1995). Following capture, birds are transferred to holding grounds prior to export.

Before 1993, no records were kept of the numbers and destination of live animal exports; after that time, record keeping has improved but still provides only a low estimate of actual exports. Over 180000 birds representing 116 species were recorded as exported via Dar es Salaam Airport between January and October
1994, mainly to Europe and North America. Pressure on the resource increased up until the early 1990s with a nearly four-fold increase in dealers from 1984 to 1991 . There is very low return to Tanzania of the true economic value of each bird, perhaps only 2-3\%, as a result of deliberate under-pricing (Rosser and Milliken 1995).

\section{Game animals}

Information on the trade in game animals is limited. For Quelea birds in Zimbabwe, trapping begins at the end of the harvest in June and continues through to September, a function of bird availability (Campbell et al. 1995a). The hunters claim that on a poor day they trap 10-20 birds and on a good day up to 200; they spend 4 hours per day on trapping, almost every day of the season. Birds are sold processed (plucked and roasted) and unprocessed in the village or in nearby towns. Processed birds sell for 50-100\% higher prices than unprocessed. If all the birds caught are sold, on 'poor' catch days earnings would be less than US\$ 0.50 for unprocessed birds, perhaps double for processed, while on good days the value of all birds sold would be between US\$ 3 for unprocessed and US\$ 5-7 for processed. Approximate seasonal earnings from trapping on 'good' days can be considered significant given annual cash incomes of well under US\$ 250 in the area (Campbell et al. 1995a).

No reports of widespread trade in game meat were found for any countries of the miombo region although there has, of course, been widespread poaching in many areas for ivory and other products. Unlike West Africa where the trade in game meat is widespread (Falconer 1990), Zimbabwe has been suggested as having no vibrant bushmeat market within the smallholder sector because the trade in most species is illegal (Campbell and Brigham 1993). There is, however, a widespread trade in dried meat in the formal sector in Zimbabwe. 


\section{Consumption of miombo woodland products}

\author{
Wood-based products: fuel, timber and \\ crafts
}

\section{Firewood and charcoal}

There is considerable variation in how wood is used for energy in the region. Charcoal is of major importance in the urban markets of Tanzania and Zambia, while firewood is the preferred fuel in the urban areas of Malawi and, to the extent that it is used, Zimbabwe (Katerere 1988; Attwell et al. 1989; Chidumayo 1989a; Dewees 1993; Monela et al. 1993). Differences in usage can be dramatic. In Tanzania, $75-80 \%$ of urban residents use charcoal, although most also use other fuels (Boberg 1993; Hines and Eckman 1993; Monela et al. 1993). In Zambia, about $80 \%$ of the charcoal produced is consumed by urban households (Hibajene and Ellegård 1994). In Zimbabwe the market for charcoal is essentially non-existent, limited to the wealthy who use charcoal from exotic wood for barbecues (Attwell et al. 1989).

Charcoal is a major household fuel for cooking and space heating in urban areas of Tanzania and Zambia, and charcoal demands peak in the latter during the cool season due to the need for space heating. Users of charcoal in Lusaka are found throughout the city, in low, medium- and high-cost residential areas (Hibajene and Ellegård 1994). However, usage does vary by residency and therefore apparently by wealth; while $98 \%$ of households in the low-income areas of Lusaka rely on charcoal, usage drops to $84 \%$ in medium-income areas and to $66 \%$ for households in high-income areas. Purchase of firewood is also lower among better-off households in Harare (Attwell et al. 1989), and Dewees (1993) suggests that the urban poor in Malawi are most dependent on firewood.
While price may be the single greatest factor affecting fuel choice by urban residents, the total decision-making process surrounding fuel use and fuel 'switching' is, in fact, more complex. Studies on energy use and costs for urban dwellers in Dar es Salaam showed that the cost of using electricity was comparable to that of charcoal, even with differences in stove costs, and electricity is the cheaper option based on useful energy per unit purchased (Leach and Mearns 1988; Monela et al. 1993). However, for a number of reasons, charcoal retains its dominant position as the fuel of choice. Frequent electricity cuts mean that charcoal is more dependable, while difficulties in obtaining liquid fuels such as kerosene led a number of consumers to switch back to charcoal (Leach and Mearns 1988; Monela et al. 1993). It also seems likely that the large capital outlay required at one time to purchase an electric stove, 38 times the price of a charcoal burner in 1992 (Monela et al. 1993), would restrict the ability of many households to purchase stoves, although running costs of stoves are equal or lower than running costs of charcoal burners. In Zambia, $40 \%$ of electrified households cook with charcoal because they cannot afford to purchase an electric stove (Hibajene and Ellegård 1994). Charcoal stoves in Dar es Salaam have further advantages in that they are more commonly available on the market and are more reliable to operate (Monela et al. 1993).

With their greater dependence on woodfuel and their reduced ability to switch over to other types of fuel, poorer households are hit disproportionately hard by fuel price increases and may be constrained in their ability to buy fuel (Dewees 1993; Hines and Eckman 1993; Hibajene 1994). Although the figures must be treated with caution due to the inaccuracy of information on household income, the trend in Malawi appears to show an increasing share of declining urban incomes being spent on energy purchases (Dewees 1993). 
A problem in Zambia, where prices for woodfuel do not appear to have increased in real terms, is the sudden price shocks experienced at the start of the rains. As the charcoal supply is interrupted, as discussed earlier, prices in Lusaka can treble or quadruple, bringing about significant hardship on poorer households in the city. During the rainy season, low-income households may spend as much as $19 \%$ of their income on charcoal (World Bank 1990; Hibajene 1994; Hibajene and Ellegård 1994). In the end, the urban poor are less able to switch to alternative fuels during periods of increased costs because they lack the capital to purchase the equipment needed or to pay connection charges for electricity (Hibajene 1994). Therefore, the urban poor are forced to absorb higher fuel costs, much as they do when they are forced to buy charcoal in smaller, more costly portions on a daily basis because of their inability to purchase in bulk (Leach and Mearns 1988).

Numerous factors have led to increasing demands for woodfuel in many areas: escalating oil prices, rapid population growth and especially urbanisation and the lack of realistic alternatives. Even in the large-scale sector there may have been a switch to these fuels. The inability of Tanzania by the mid-1980s to import adequate fossil fuel supplies led some industries, including tea plantations, to switch to firewood for fuel (Temu and Kaale 1985). There is reason to believe that these fuels will continue to play a major role in energy needs, especially for meeting the needs of lower-income urban dwellers.

\section{Sawlogs, poles and craft wood}

Significant quantities of hardwood originating from woodlands in the miombo region have been exported to overseas markets after being minimally processed. To what degree restrictions on the export of unprocessed logs have been effective is not known. Regional trade has also been a feature of this trade, including the importation of Tanzanian and Mozambican hardwood by Kenya and Zimbabwe, respectively (Arnold and Easton 1993; Marshall and Jenkins 1994). Main importers of Mozambican timber are South Africa, Portugal and Germany (Sitoe and Ribeiro 1995). Tanzanian hardwood, as lumber, flooring strips and carvings is exported to a number of countries (Table 6.3). Following trade liberalisation policies enacted since 1986 in Tanzania, there has been an increase in the production of forest products, resulting in increased quantities of most hardwoods being exported (Kowero and O'kting' ati 1990). These developments have increased the private sector's participation in the trade for timber and other wood products in Tanzania. For instance, in 1994, out of a total export value of US\$ 5.81 million of wood products mainly from miombo woodlands, only about US\$ 0.07 million (1.2\%) were exported by state corporation, TWICO.

Building timbers cut from hardwood are also utilised in-country; the main consumers of building timbers in Mozambique are the large cities, especially Maputo and Beira (Sitoe and Ribeiro

Table 6.3 Tanzanian hardwood exports, 1989-1994

\begin{tabular}{|c|c|c|c|c|}
\hline & \multicolumn{3}{|c|}{$\begin{array}{c}\text { Value of exports } \\
\text { (US\$ million) }\end{array}$} & \multirow{2}{*}{$\begin{array}{l}\text { Main } \\
\text { importing } \\
\text { countries }\end{array}$} \\
\hline & 1989 & 1991 & 1994 & \\
\hline Lumber & 1.2 & 0.6 & 1.0 & $\begin{array}{l}\text { UK, } \\
\text { Germany, } \\
\text { USA, } \\
\text { Japan }\end{array}$ \\
\hline $\begin{array}{l}\text { Flooring } \\
\text { strips }\end{array}$ & 0.4 & 0.6 & 2.8 & $\begin{array}{l}\text { Italy, } \\
\text { Germany, } \\
\text { Japan, } \\
\text { Spain }\end{array}$ \\
\hline Carvings & $?$ & 0.2 & 0.3 & $\begin{array}{l}\text { UK, USA, } \\
\text { Japan, } \\
\text { Germany }\end{array}$ \\
\hline
\end{tabular}


1995). Fine hardwoods destined mainly for the domestic markets include Milletia stuhlmannii, Pterocarpus angolensis, Dalbergia melanoxylon and Afzelia quanzensis. The wood is used mostly in the building industry with only small percentages being exported (Sitoe and Ribeiro 1995).

There is some suggestion that miombo woodland hardwoods face significant competition in international markets from other decorative tropical hardwoods. Sawn timbers of Pterocarpus angolensis, for example, face severe competition from fine hardwoods sold to European markets from Malaysia, Indonesia and some West African countries. There is also competition for markets for flooring timber and competition between producers within the region. No real competition is encountered for Dalbergia melanoxylon in the musical-instrument market (Moore and Hall 1987).

While decorative carvings are often produced largely for the tourist and export market, utilitarian products like some furniture and a host of other wood-based products have much more varied

\section{Box 6.5 \\ The woodcraft industry in the Bushbuckridge district of the Mpumalanga lowveld, South Africa}

\section{Sheona Shackleton}

Over 2500 people in the Bushbuckridge district $\left(2400 \mathrm{~km}^{2}\right.$ ) of the Mpumalanga lowveld (south of the miombo region) are directly or indirectly involved in or supported by the local woodcraft industry (Shackleton 1993). This represents $0.5 \%$ of an estimated total population of 500000 . Considering that unemployment rates of $67-79 \%$ in the area, the contribution of the industry is significant. Total income generated by local woodworking enterprises is approximately US\$100 000 per annum.

Wood is harvested by local carvers and furniture manufacturers from the communal grazing lands. In the case of indigenous hardwood species, a complex licence and permit system applies, including payment for wood. The system is enforced by the Tribal Authorities and local conservation rangers.

The wood is converted into a range of marketable products by the woodworkers with the help of their families and/or, particularly in the case of furniture manufacturers, part-time or full-time employees. Some of the furniture businesses employ up to 17 people. In contrast, the woodcarving enterprises are mainly small (1-2 employees) and family based. In general, women and children are responsible for the sanding and polishing of articles, although most paid employees are men. Carvers produce mainly undecorated, utility items such as salad bowls, spoons, platters, trays and walking sticks. Furniture manufacturers can produce almost any piece of furniture to order. Their standard products are dining-room suites, benches, armchairs and occasional tables. All the craftsmen market their own goods, although some also utilise local middlemen/women who are often other craft producers. Woodcarvers target the numerous craft outlets in the tourist centres of the region, whilst furniture makers sell mainly to individuals throughout the country, relying on 'word-of-mouth' to advertise their work. The cost of transporting their products to the market constitutes one of the largest overheads for most woodworkers although, in the case of furniture manufacturers, customers often collect their goods direct from the manufacturer. Exotic softwoods are sometimes used by furniture manufacturers for local orders. This generates less income than similar products made from the widely used Pterocarpus angolensis, and causes cash-flow problems for producers as few buyers can afford to pay up front and instead utilise an installment system. 
markets (Box 6.5). A study in Zimbabwe (Mhone 1991) roughly divided outputs from woodlandbased enterprises into four categories: traditional products made by rural specialists and purchased by local households; lower-cost goods which substitute for formal-sector goods like furniture; higher-value handicrafts with a generally urban, possibly more-affluent market; and products purchased by a wide range of buyers, perhaps in both urban and rural markets.

The woodcraft industry (continued)

Production and income is erratic, characterised by peaks and troughs influenced by factors such as: tourist season, dryness of wood (Pterocarpus angolensis takes approximately six months to dry), size and species of wood, working order of machinery (which is old and unreliable), cash-flow situation, success with selling stocks, and number and size of orders. In 'good' months, of which there are approximately six per year, carvers earn an average of US\$ 78 and furniture makers US\$ 326 per month. The major constraints to the industry, as perceived by the woodworkers, include: a lack of credit facilities, and consequently the inability to purchase or hire machinery, tools, wood and transport; difficulties obtaining licences to harvest wood; a lack of access to electricity; a lack of business and organisational skills; and a limited market. The latter has been addressed, to some extent, through the formation of a woodworkers association, leading to a contract with the Kruger National Park. Since April 1994, the park has purchased about US\$ 11000 worth of goods from local woodworkers. Potential production figures indicate that if some of the other constraints are addressed, income could be increased by 2 to 10 times.

The industry is affecting the resource base, and most woodworkers $(75 \%)$ perceive a decrease in the availability of wood, especially large trees. There is also evidence of local depletion of favoured species in some areas. The woodworkers recognise the need for controlled utilisation of the resource (50\% carvers and $80 \%$ furniture makers). They stress the need to protect it from illegal exploitation by outsiders who are allegedly cutting and removing the wood from the region. However, they are not supportive of aspects of the present monitoring system ( $88 \%$ and $68 \%$ respectively) for a number of reasons including: harassment by rangers, lack of communication particularly on the issue of licences, alleged corruption in the system, a lack of clarity on how the system works, dissatisfaction with the way in which the wood is measured, and that they cannot buy wood on credit. As a result, a large proportion of the wood used is harvested illegally, some from a nearby nature reserve. To ensure long-term sustainability, new approaches to the management of the wood resources are required. These should encourage and facilitate the participation of the woodworkers in the process and ensure effective communication between all parties.

Recently, the woodcarving industry in the former KaNgwane area, south of Bushbuckridge, has undergone expansion, a result of increasing numbers of people recognising it as an option for income generation (Clark and Magagula 1994). In contrast to the Bushbuckridge woodworkers, these carvers are producing mainly animal and bird carvings made from softer wood species such as Sclerocarya birrea and Erythrina lysistemon. These are sold at the roadside (by the carvers themselves) on the main tourist roads such as those leading to the Kruger Park. Otherwise, the carvers operate under similar conditions and constraints to those outlined above. The recent growth of this industry significantly increases the importance of informal, small-scale wood enterprises for the livelihoods of rural populations in the Mpumalanga lowveld, and adds to the complex problem of management of indigenous wood resources in the region. 
Information on the pole market is limited. Rural pole consumption is large, but the proportion of these needs met through the market seems to be fairly small, with the proportion met through marketed indigenous woods probably even smaller. As Hines and Eckman (1993) point out, rural households are more likely to participate in the market for building poles by acting as suppliers, rather than as consumers of poles.

Trends in consumption for these products are difficult to ascertain. Unlike the market for woodfuel in some areas, where consumption is increasing due to the growth in urban population, less-clear factors may be at work in the markets for products from small-scale woodland and forest-based enterprises. Traditional goods may be perceived as inferior goods to be substituted with mass-produced goods, or they may be preferred for cultural reasons (Brigham 1994). Furthermore, market trends are likely to be constantly shifting and, quite possibly, highly product- and location-dependent.

\section{Edible plant products and mushrooms}

Falconer (1990) argues that the growth in markets for these goods outside their source areas is a function of the cultural importance of these products and the trend to increasing urbanisation since urban migrants can only access these goods through the market. In only one case, nuts derived from Sclerocarya birrea, was it indicated in the literature that the market for an edible food product was limited by supply (Campbell and Brigham 1993). If technical constraints on extraction could be overcome the market potential of these nuts is very high, possibly for export and import substitution.

\section{Other plant products: fibre and medicinal plants}

Fibre-based products made from bark or leaves have both rural and urban markets. Although bark string on its own appears to have only a local market, items such as mats, bags and baskets have both local and urban markets. Due to the tourist trade in handicrafts, some of these products will end up overseas after being purchased in craft shops or from roadside stands. Medicinal plants are sold in both rural and urban areas. Although no consumption figures were obtained for urban populations, use is believed to be high (Box 6.6). Rural use of medicinal plants is also high, partly due to a lack of 'modern' medical facilities in these areas (Bradley and Dewees 1993), a belief in the superiority of herbal remedies and the cost of purchasing western drugs (Brigham, pers. obs.; Falconer 1990). Chihongo (1993) suggests perhaps $80 \%$ of Tanzania's rural population rely on herbal traditional medicine for their healthcare needs.

Although a large percentage of rural dwellers clearly depend on traditional medicine, it is not clear whether many need to resort to the market to meet their requirements for these products. In a study by Brigham (1994) in north east Zimbabwe, $11 \%$ of rural households across three communal areas reported purchasing these products in the previous year.

As is the case with a number of traditional products, among some people there is a stigma attached to using traditional medicines which are considered 'not modern' (Chidari et al. 1992). One traditional healer, interviewed in Zimbabwe (Brigham 1994), suggested that the use of medicinal herbs had declined over the past two decades largely due to the preference of younger people for western medicine. Religion also appears to be a factor in people's attitudes towards herbal medicines. Brigham (1994) found a number of households did not use or participate in the trade of medicinal plants because of their religious beliefs. It is not known to what degree these negative perceptions of medicinal plants have an impact on the market-place. 


\section{Box 6.6 \\ Medicinal plants and miombo woodland: species, symbolism and trade Tony Cunningham}

Miombo woodland, seen through the eyes of diviners and herbalists, is much more than the sum of species with various uses. It is also a link through certain plants with the supernatural world. It is this link that is described in detail in Victor Turner's classic anthropological work The Forest of Symbols, describing Ndembu ritual processes in miombo woodland of Mwinilunga district, Zambia (Turner 1967). Symbolic use of traditional medicines for ritual strengthening, protection or purification rituals is particularly important during periods of conflict, social upheaval or uncertainty when it is important to draw on supernatural power.

In rural areas, for example, plants are used to protect homes and crops, in hunting or warfare or to promote success (or failure of opponents). An example from miombo woodland is the key role played by mhondoro spirit mediums during the liberation war in Zimbabwe (Lan 1985). Traditional medicines are also used and traded in urban areas for medical as well as symbolic and traditional religious purposes, and it is important to understand the background behind the 'magical' use of traditional medicines. High unemployment, a psychologically stressful environment and often crowded living conditions are a feature of many urban areas in Africa. Labour migrancy also creates the need to maintain relationships with wives, or find girlfriends in the urban environment. For these reasons, much of the traditional medicinal plant and animal material sold in urban markets is for symbolic or psychosomatic value. The protective and cleansing function of medicinal plants use is one way of dealing with this conflict-ridden and competitive environment, where individuals become 'polluted' through proximity to undesirable people, discarded medicinal charms or the activity of sorcerers. It is not surprising, therefore, that employment options for traditional healers increase. In Zimbabwe, the urban demand for traditional remedies is reflected in a higher traditional healer to total population ratio (1:234) than in rural areas (1:956) (Gelfand et al. 1985). Many miombo woodland medicinal plants sold in urban markets in Zimbabwe, Zambia and Malawi today also had importance in the past, for example in iron smelting rituals in Malawi (van der Merwe and Avery 1987) or Ndembu rites of passage in Zambia (Turner 1967).

\section{Animals: insect products}

\section{Honey and beeswax}

A constant refrain in much of the literature discussing honey and beeswax production in the region is that demand for these products is often greater than supply (Ntenga and Mugongo 1991; Banda and De Boer 1993; Fischer 1993; Hines and Eckman 1993). Apart from the strong local demand for honey as an ingredient in beer, as discussed earlier, any other surplus will generally find a market in urban areas (Ntenga and Mugongo 1991). National demand for honey in Malawi is clearly not being met through domestic sources: $80 \%$ of honey consumed and $95 \%$ of beeswax marketed within the country is imported (Banda and De Boer 1993). Increasing production to meet demand must be accompanied by a careful understanding of the market. Honey must be processed to certain standards in order to satisfy the urban market's demands, one of which is for clear honey (Fischer 1993). Although honey prices dropped in Malawi between 1989 and 1992 from US\$ 2.50 per kg to US\$ 1.70 , prices would still need to be halved to the world market price if honey is not to remain the preserve of a small, wealthy market. On 


\section{Medicinal plants (continued)}

The symbolic, religious or magical links to miombo woodland plant species are apparent through characteristics such as milky latex, red sap, hard timber, aromatic qualities or prolific fruiting. Also important is the symbolic colour triad of red, white and black which applies throughout the Zambesian woodland region. Red and black seeds of Abrus precatorius and Afzelia quanzensis, for example, feature widely in traditional medicines for this reason. In the miombo woodland of northern Zambia, the red sap of Pterocarpus angolensis is the symbolic key to its role in Ndembu circumcision rituals and to cure menstrual disorders. It is also used for burns as the "red gum dries like a scab". Diplorhyncus condylocarpon, which produces milky latex, is central to Ndembu young girls puberty rituals, the latex symbolic of human breast milk. Ochna pulchra is used as a strengthening medicine due to its tough, termite-resistant wood and "because string cannot be made from the bark to tie up huntsmanship and fertility" (Turner 1967). The symbolic uses, biological characteristics or even habitat of these plants are alluded to in their names.

In the miombo woodland near Kasungu National Park, Malawi, Steganotaenia araliacea is called mphinga ('to bar access') referring to its use as a protective medicine buried under a path or doorway against witchcraft (van der Merwe and Avery 1987). In northern Zambia, Vangueriopsis lanciflora (musoli) is named for its ability to 'make visible' ( $k u$-solola), revealing animals to hunters or used to treat barren women to 'make children visible'. O. pulchra (museng'u) and Xylopia odoratissima (mututambululu), on the other hand, are named for biological characteristics. The name for $O$. pulchra, for example, refers to its prolific flowers and fruits (kuseng'uka 'to multiply') while $X$. odoratissima is named for the stingless Meliponid bees that congregate in gathering Xylopia nectar just as many people come to a drum ritual (Turner 1967).

In this way, plant species richness is linked to a rich cultural tradition which provides a social link to the miombo landscape. Pterocarpus angolensis and D. condylocarpon, for example, are central to traditional Ndembu ritual and without them, the symbolic value of those rituals would be greatly diminished. Although all cultures are dynamic, the strong continuity of use is demonstrated through the continued sale of favoured medicinal plants in urban markets. Continued access to these plant resources is an important consideration in maintaining links between culture and nature.

the other hand, increasing production of beeswax will provide import-substitution benefits, as Malawian beeswax at US\$ 1.84 per kg is only $79 \%$ of the world price (Banda and De Boer 1993).

Honey and beeswax also have good export potential in some countries (Clauss 1992). Combined, these products earned Tanzania approximately US\$ 0.5 million and US\$ 2.6 million through exports in 1989 and 1991, respectively, with beeswax accounting for much the larger share. Tanzania's exports were destined for the Middle East, Japan, Germany and the United Kingdom.

\section{Edible insects}

Edible insects are purchased and consumed in both rural and urban areas although the market in urban areas appears to more extensive (Box 5.1; McGregor 1995a). Of some interest to the discussion of the trade in edible insects is the perceptions of these products held by potential consumers. McGregor (1991) notes that certain insect foods are stigmatised as a food for the poor and the elderly if consumed as part of a main meal, but the same stigma may not be attached to these insects when consumed as a 'snack' such as in beer halls where they remain 
very popular (McGregor 1991). Wilson (1990) also claims for Zimbabwe that consuming caterpillars is beginning to be seen as 'not modern' among some rural people who reject the practice. Certainly the strong and perhaps growing urban market for mopane caterpillars suggests that the trade in edible insects is unlikely to disappear (Wilson 1990).

\section{Animals: birds and mammals}

\section{Wild bird trade}

During 1994, Europe and North America accounted for $88 \%$ of reported exports from Tanzania, with Germany, Netherlands, USA, France and Italy accounting for the top five destinations by number of birds in descending order (Rosser and Milliken 1995). Only two African countries, South Africa and Zimbabwe, in sixth and sixteenth position, respectively, are on the list of 22 known importing countries. Thirty-five percent of the species listed on the Tanzanian export quota for 1994 did not appear to be in demand that year as there were no requests for capture permits involving these species nor any record of any export via Dar es Salaam Airport.

\section{Game animals}

Little information was obtained on the end market for traded game animals. Most wild game meat sold in Zimbabwe appears to be marketed locally, including in small towns or business centres. Some may be sold as snack food in bars, much as termites are (Mukamuri, pers. comm.). Although many wild-gathered foods in Zimbabwe are viewed as inferior by at least part of the rural population (Wilson 1990; McGregor 1991), this stigma does not appear to be attached to eating mice, at least as a snack. Both rich and poor households were found to eat mice in one area of Zimbabwe, with no significant difference between rich and poor households in levels of consumption (McGregor 1995a).

\section{Impacts on economic sustainability}

Impacts on the economic sustainability of the various products discussed above can be a direct result of the commercialisation of these products, through harvesting practices for example, or unrelated to commercialisation. The impact of activities unrelated to the direct utilisation of the resource may be very large; for example, expansion in agricultural land and the resulting clearance of woodland (Chapter 4), seasonal fires which reduce regeneration and have other impacts (Chapter 2), and a wide range of other factors (Moore and Hall 1987; White 1988; Clauss 1992; Dewees 1993; Fischer 1993; McGregor 1995a). In many cases, the lack of even the most basic knowledge of what is in the woodland and how it is distributed makes assessing the importance of various impacts on economic sustainability difficult at best (White 1988). Even markets for woodfuel which, of the woodland products, potentially poses the greatest threat to the miombo resource, have not been adequately studied (Dewees 1994).

It is useful to make a distinction between high-impact resource extraction activities which rely on the clearance of woodland to meet market demands, and low-impact resource extraction activities with generally lower impacts on the woodland resource (Dewees 1994). It is important to note, however, that although a group of products may share similar conditions, constraints on economic sustainability will usually have to be assessed on a case-by-case basis. The various constraints on economic sustainability will be explored in the following discussion for both high-impact and low-impact activities. Finally, the institutional response to impacts on sustainability will be explored in more detail at the local, national and, briefly, the international levels.

\section{Low-impact resource extraction}

Market activities involving insects, wild fruits, mushrooms and honey generally have low impacts on the resources. 


\section{Harvesting}

Over-harvesting for the market has been blamed for a reduction in the population of the resource in some cases (McGregor 1995a). The method of harvesting can also lead to resource decline, such as by pulling rather than cutting mushrooms (Campbell et al. 1993) or by cutting excessive amounts of branches or entire trees to harvest caterpillars (Nhira and Fortmann 1993). The sudden increase in demand brought about by the establishment of an organised, large-scale market for Uapaca kirkiana fruit in Zambia has led to concerns that the area in question is being stripped of its fruit (Packham 1993), which may potentially have long-term repercussions for the sustainability of the fruit-tree resource.

\section{Technological constraints}

In some cases, traditional methods of production, such as for honey produced from traditional hives, result in much lower productivity than would be possible with other methods (Ntenga and Mugongo 1991). Technological constraints were also recognised as restricting the full utilisation of the nuts from Sclerocarya birrea (Gumbo et al. 1990; Campbell and Brigham 1993). One potential problem for these products in urban markets is that many of the preservation/processing techniques currently used for wild harvested foods may not meet the hygiene or quality standards required (ENDA 1991). It is not known to what degree these standards are a crucial factor. Much may depend on the degree of effective control exerted by municipal governments over these issues, and how demanding consumers become.

\section{Impacts on woodland}

Apart from the cutting of trees for harvesting caterpillars already mentioned, a topic of considerable interest in the literature is the impact of traditional beekeeping methods on the tree cover of the woodland. Although large numbers of trees are killed through debarking each year, perhaps 273000 in the $88800 \mathrm{~km}^{2}$ North Western Province of Zambia, the impact of tree destruction for hive making on the structure of the forest appears quite modest, especially in relation to the potential damage from logging, clearance for agriculture and charcoal making (Clauss 1992; Fischer 1993; Njovu 1993). Fischer (1993) even suggests that the practice of selectively utilising particular trees for hive making creates small gaps in the woodland canopy, beneficial to the regeneration of valuable timber species such as Pterocarpus angolensis. However, although the impacts when considered over large areas may appear small, these impacts are likely to be uneven. Around some of the older population centres, suitable bark resources can only be found at a distance of $8 \mathrm{~km}$.

Beekeepers have also been suggested as the cause of damaging fires in the miombo woodlands (Fischer 1993; Hines and Eckman 1993). Grundy (1995a) found that a woodland in north-west Zimbabwe suffered annual fires as a consequence of honey-hunting activities. As a result, the majority of trees were hollow and therefore useless for timber. However, as fire is utilised for many purposes in the subsistence economy (Box 7.1), it is very difficult to determine which fires are the result of careless beekeeping activities (Fischer 1993). In any case, burning at inappropriate times is also a major concern for beekeepers themselves (Clauss 1992).

\section{Marketing}

The lack of organised marketing structures for a number of products has been identified as a significant constraint. During the production season for goods such as indigenous fruits, mushrooms and other seasonal products there is often little or no local demand for their purchase. Only by 'exporting' the products some distance to markets where demand exists or perhaps by processing the products for sale outside of the regular season, 
will some value be obtained for these products. A further potential impact on marketing is the stigma attached to the consumption of some gathered products, although the negative perceptions appear to be largely held in rural areas, and not urban areas.

\section{Other impacts on sustainability}

Activities unrelated to the utilisation of the product in question can often have quite significant impacts on that resource. The practice of late burning (Chapter 7) to improve pasture or prepare a previously wooded plot for cultivation can have the undesirable impact from the perspective of beekeepers of scorching nectar-bearing flowers or destroying branches and reducing flowering in the following season. The result is a serious reduction of bee forage in some areas (Clauss 1992). Deforestation, often as a result of expansion in arable land (Chapter 4), has dramatically reduced mushroom abundance and contributed to declining caterpillar populations (McGregor 1995a).

\section{High-impact resource extraction}

Products harvested by large-scale extraction and/or clearance of woodlands pose real threats to the maintenance of the woodland (Dewees 1994).

\section{Harvesting}

Although the impacts are uneven, in some areas specific markets for woodfuel are contributing to deforestation of miombo woodlands (Dewees 1993). Tobacco growing in Tanzania, Zambia, Zimbabwe, Malawi, Mozambique and Angola is a widespread and highly economic activity within the small-scale farming system, but requires substantial quantities of wood for curing and has led to massive clearance and destruction of the miombo woodlands (Chapter 4; Hines and Eckman 1993). When farmers grow tobacco as a cash crop, clearing continues to the point that they have been forced to hire lorries to transport wood from the retreating miombo resource
(Temu 1979). Charcoal production for the urban market has also led to woodland depletion in parts of Tanzania (Hines and Eckman 1993), where deforestation due to charcoal production can take on an extensive rather than an intensive nature due to the wide-ranging search for suitable species for conversion (Monela et al. 1993). In some areas, over-exploitation of the woodland has forced previous charcoal makers to look for alternative sources of income (Hines and Eckman 1993).

Resource depletion has also become a factor in the production of fine hardwoods. Hines and Eckman (1993) note for Tanzania that the use of indigenous timber is declining along with the supply. In Zimbabwe, the share of indigenous woods from domestic sources in overall industrial wood supply fell from $17.2 \%\left(108500 \mathrm{~m}^{3}\right)$ to $5.4 \%\left(34600 \mathrm{~m}^{3}\right)$ between 1975 and 1990 (Arnold and Easton 1993). The decline in production of fine hardwoods reflects growing depletion of the stocks. Production in sawmills processing indigenous hardwoods in parts of Tanzania has dropped well below capacity, in part due to the depletion of wood resources in the vicinity of the mills (Kowero and O'kting'ati 1990).

\section{Raw-material supply}

For many woodland-based enterprises, obtaining adequate raw materials was the number one constraint on their business (Dewees 1993). Not all issues of raw-material supply are related to depletion of the resource, however. In some cases, problems in obtaining adequate raw materials stem from the lack of co-ordination or integration in the supply of wood, as has been discussed for Dalbergia melanoxylon (Moore and Hall 1987).

Other factors affecting economic sustainability A number of other factors affect economic sustainability in the high-impact resource extraction sector. In the sawmilling sector of Tanzania, antiquated equipment, the lack of foreign exchange and transportation problems means that mills run well below capacity (Kowero and O'kting'ati 
1990). In the small-scale sector, the benefit of generally easy access to these enterprises, due to low start-up costs and easy entry and exit, increases competition and potentially reduces the likelihood of enterprises being able to make the transition to larger, more-viable businesses (Dewees 1994). Small-scale enterprises also suffer frequently from a lack of operating funds, low prices for their products, limited markets and limited government support (Dewees 1993; 1994). Another major constraint on the growth and viability of these enterprises are the restrictions placed on woodland use by governments in the region (Dewees 1994).

\section{The institutional response}

\section{Local controls}

In many areas, numerous controls exist on the use of woodland resources (Chapters 5 and 8). The local controls discussed here will be restricted to those with direct relevance to commercialisation.

There are sometimes controls within communities on the use of products for other than household purposes. In a community in Zambia, trees are not to be cut down for use in incomegenerating activities such as brewing beer, making charcoal or burning bricks, unless the wood is from trees cut down in the process of clearing land for crops (Sørensen 1993). Not only do strong taboos exist against cutting indigenous fruit trees in many parts of Zimbabwe, but in some areas controls still exist on the sale of indigenous fruits (Gumbo et al. 1990). The basis of these controls is that the trees involved are owned by the whole community, not only the present and future inhabitants but also the ancestors, and therefore no individual has the right to cut them (Campbell et al. 1993). Similarly, as fruit trees belong to God and not any individual, it is offensive to the ancestors to market indigenous fruit (Gumbo et al. 1990). In spite of these prohibitions, indigenous fruit is gathered for sale in many areas. Much may depend on a community's degree of integration with and proximity to markets, as well as the presence of immigrants in the community who may have a different belief system (Clarke 1995). Of considerable interest is the dynamic nature of controls on the fruit resource (Chapters 5 and 8). Gumbo et al. (1990) note that taboos may fade, only to regain importance following a natural disaster which is interpreted as a sign of disapproval from the ancestors. Therefore, in one area in Zimbabwe, after a period of widespread sale of fruit in the early 1970s, strong restrictions again took hold following the 1982-3 drought.

Concerns over the breakdown of customary law governing the sale of fruit during the 1991-92 drought in Zimbabwe led to the headman of one village organising village leaders to control the practice (Clarke 1995). Trees were being damaged and village members were losing access to fruits as outsiders came to harvest Uapaca kirkiana fruit for the nearby town market. Utilising the rarely enforced Communal Land Forest Produce Act, which prohibits the sale of forest produce, village leaders were able to effectively halt the trade in fruit and discipline the culprits in line with customary law.

McGregor (1991) notes for Zimbabwe that in some areas it is considered illegal to cut poles from communal grazing land or nearby resettlement areas instead of from land under the individual control of the cutter. In other areas, cutting poles is only allowed with the permission of local authorities. As is the case with restrictions on indigenous fruit sales, the degree to which these rules are followed varies. Illegal cutting in the cases described above is actually quite widespread and requirements for obtaining permission are frequently disregarded (Campbell et al. 1993). It appears that in areas where pressure on wood resources is high, illegal cutting will be greater (Grundy 1990). 
A further example involving outsiders coming to access products for the market involves the leaves of the palm Hyphaene petersiana used for making baskets (Sørensen 1993). In two villages in Zambia, outsiders came to harvest leaves for basket making, causing considerable damage to the plants in the process. New conservation practices in the villages have been developed and access to the plants is only by permission. From the previous examples, it appears local controls can still be effective in managing access to resources; what is less clear is under what conditions local controls are most likely to be effective.

\section{State policies and legislation}

A wide range of state-sanctioned controls are brought to bear on the use of woodland resources for commercial purposes. In many cases, these controls have been marked by failure.

Much legislation affecting natural resource use by communities is more restrictive than enabling (Scoones and Matose 1993; Dewees 1994; Dewees and Scherr 1994). Legislation is based on the assumption that commercial harvesting damages the resource; while this is undoubtedly true for some products under some conditions, by no means is it an accurate reflection of all harvesting activities. In combination with the pressures already existing on woodlands in a number of areas, the restrictions placed on woodland use by the state have contributed to growing problems in the supply of inputs for small-scale, woodland-based income-generating activities.

In spite of the extensive investments made in some cases, control measures on the utilisation of a wide range of woodland products have often met with little success. Although control measures may be on the books, the lack of awareness of harvesting activities on the part of regulating authorities often brought about by a shortage of resources for enforcement, means that illegal harvesting is widespread (Moore and Hall 1987; White 1988; Njovu 1993; Sitoe and Ribeiro 1995). In Malawi, Tanzania and Zambia laws exist which require any producer making charcoal for sale to buy a government licence or permit from the Forest Department but enforcement is weak and unlicensed cutting is common. Controls do not exist for all cases; for example, in the late 1980s, there were no controls available in Tanzania on the use of $D$. melanoxylon as an input for charcoal production, the result being that the wood described as the most expensive in the world has appeared as charcoal for the Dar es Salaam urban market (Moore and Hall 1987).

In some circumstances, regulations may not be enforced because of reasons other than the inability of the enforcement agencies. There is a reluctance on the part of some local authorities to prosecute people who have no alternative but to use trees (Katerere et al. 1992). As one Natural Resources Officer in Zimbabwe stated "you can't stop people from doing these things, they do them to survive" (Brigham 1994). Locally elected bodies may shy away from implementing regulations because of the effect 'unpopular' enforcement activities will have on their support base (Katerere et al. 1992). While the harvest of many products for sale is often only legal if licensed and royalties are collected (Dewees 1993), the process of obtaining rights to harvest can be extremely onerous and therefore widely flouted with a resulting loss of revenue (Moore and Hall 1987; White 1988). Suggestions have been made that streamlining the permit process may reduce illegal harvesting (Moore and Hall 1987) but no firm evidence was available on this issue in the context of woodland products.

One issue that is of considerable concern is the inequitable sharing of revenue that can result from the forest department's or district council's right to sell timber from communal lands. Often, the local inhabitants are neither consulted nor compensated for the removal by concessionaires 
of valuable timber from their area (Clarke 1995). As Dewees (1994) argues, there is no incentive for households to retain valuable timber trees on their land because any revenues generated from tree removal accrues to District Councils. In fact, there may be an incentive for 'illegal' harvesting before concessionaires can harvest the timber (Clarke 1995). Nhira and Fortmann (1993) report such an occurrence for one area of Zimbabwe where local people have been prohibited from harvesting trees they use to make bowls and doors for sale because the District Council has given a concession on the trees to a commercial timber company. Local people, angry at the poorly shaped and small trees left behind, have continued to cut the trees despite the prohibition and the risk of arrest and fines.

In Tanzania, the inequitable practice of revenues from timber harvesting being paid directly to the Central Government while District Councils absorb the entire cost of revenue collection has resulted in less than thorough collection of fees (White 1988). The revenues that are collected for these valuable timber species through stumpage rates often bear no relation to the actual value of the timber and are, in some cases, set ridiculously low. Sitoe and Ribeiro (1995) report for Mozambique that stumpage rates are extremely low on precious timber, due in part to the sharp devaluation of the local currency and a failure to adjust stumpage over long periods. The result has been massive profits for timber merchants. A similar situation has been recognised for Zimbabwe where "rents are accruing to the private sector, and not to local authorities, who seem particularly badly informed about prices and markets" (Bradley and Dewees 1993).

In an attempt to obtain higher value for those trees still being harvested and perhaps to reduce the rate of exploitation of the resource, some jurisdictions have applied controls on access to and use of specific timber trees over the past decade. Tanzania, Mozambique, Zimbabwe and
Zambia have all imposed bans on the exports of unprocessed lumber of at least some species (Moore and Hall 1987; Arnold and Easton 1993; Marshall and Jenkins 1994). Following the 1993 ban on exports of logs from Tanzania, more semiprocessed wood products were exported in 1994. As a share of wood exports, the value of Tanzania exports of flooring timbers increased from 21.8 to 48.7\% between 1989 and 1994; at the same time $\log$ exports decreased from $46.0 \%$ to about $27 \%$. However, in terms of generating and maintaining employment in processing enterprises through these regulations, the impact could be uneven. Zimbabwe's 1992 ban on the export of semiprocessed hardwoods, as requested by the furniture industry, was designed to conserve stocks for domestic use. While higher value will be obtained for wood exports, the impact of the ban, coupled with a planned expansion by the largest sawmills into more wood manufacturing, could mean the disappearance of the large numbers of small-scale mills that cut timber into balks for export (Arnold and Easton 1993).

The impact of government controls on the economic sustainability of woodland product extraction for the market is not simple to assess in all cases and needs further study (Dewees 1993). Clearly, there appears to be a need for governments to be much more selective in the manner that controls are applied in order to support less-destructive activities while improving controls, where feasible, on high-impact extractive industries. As Dewees (1993) argues, although they have often been used as such, controls and licensing arrangements on extractive uses are no substitute for effective woodland management.

\section{International restrictions}

The impact of international regulations on the utilisation of woodland products appear limited to only one sector, wildlife, although the impact within this market can be considered large. Trade in listed species of wild birds is controlled under the 
Convention on International Trade in Endangered Species (CITES) which regulates the international market in endangered flora and fauna (Rosser and Milliken 1995). If international regulations are not followed in bird exports, markets will be closed to Tanzanian exports. The international ban on trade in ivory may be costing Zimbabwe US\$ 4 million per annum in lost revenue (Child 1992 in Campbell and Brigham 1993).

\section{Suggestions for further research}

The trade in miombo woodland products is clearly an important part of the economy of the countries of this region. While this review indicates that considerable information is available, more detailed analytical understanding is lacking, and cannot be obtained from the current literature (see Chapter 9). Little is known about the structure of the trade for many of these products, even those with enormous markets such as woodfuel, which have a very significant impact on the miombo resource.

Apart from more general research on how the markets for woodland products are structured and operate, specific research is also needed on a host of issues affecting the trade in these products. Research is required into the constraints on sustainable woodland management for the market at the local level and how these constraints might be removed (Dewees 1994). In many cases, the important contributions made by the small-scale woodland-based sector to employment and the larger economy have been in spite of, not because of, government action. What scope is there for relevant policies to be modified to take into account actual and potential use of woodland resources by communities and what examples exist of successful policy 'realignments' that could provide lessons for such an approach? These issues are discussed further in Chapter 8. Although its focus has been on the generation of revenue from wildlife, Zimbabwe's Communal Areas Management Programme for Indigenous Resources (CAMPFIRE) has been cited as potentially providing a useful model for woodland management (Bradley and Dewees 1993; Campbell and Brigham 1993; Nhira and Fortmann 1993). The sustainability of, and access to, rawmaterial supplies for different types of enterprises are prerequisites to improved marketing of woodland products; improving this access may also call for significant changes to forest policies including the allocation of contested resources.

For individual products, research is needed into improved handling and storage methods, improved utilisation of resources and expansion into new markets with both existing products and new products (Moore and Hall 1987). There is also the need for research into the scope for improving yields and resource sustainability through different management regimes (Dewees 1993).

Finally, research must take a more differentiated view of the household economy, exploring who is dependent on which goods, what are the characteristics of the different households utilising these products, what is constraining their access to these goods and what are the social costs of limiting market operation (Bradley and Dewees 1993; Dewees 1994). 


\section{Chapter \\ 7}

\section{MANAGING MIOMBO WOODLANDS}

\section{Emmanuel Chidumayo, James Gambiza and Isla Grundy}

\section{Introduction}

Miombo woodlands should not only be seen from the perspective of traditional forestry: the woodlands provide a wide range of products and services (Chapter 5), the woodlands differ markedly in time and space (Chapter 2) and most of the woodlands occur under communal forms of utilisation (Chapter 8). Timber in reserved forests is only a very small component of the broader picture. The diverse uses of miombo woodland and the need to optimise the sustainable flow of benefits to communities living in the miombo environment (Whitlow 1979; Bradley and Dewees 1993; Hofstad 1993) pose a challenge to managers of the woodland, including, of course, local people themselves. The situation requires the development of multi-institutional and holistic approaches to management.

In the past, foresters in the miombo region have focused on the management of hardwoods and exotic species for timber production (Grundy 1990; Tuite and Gardiner 1990a; McGregor 1991; Lowore 1993). Their efforts at management of communally owned woodlands have often been based on inappropriate technologies, many of which involved little interaction with local people. As awareness of the importance of the diverse nature of goods and services from miombo woodland to the welfare of rural communities has deepened, it has become evident that a narrow approach to management is inappropriate.

Reforestation programmes which have concentrated on planting programmes using exotic species have been found to be both expensive and ineffective in achieving their goal of providing woody biomass (Haney 1983; Tuite and Gardiner 1990a). Despite this, however, extension workers still tend to focus on disseminating technical tree-planting packages, combined with the enforcement of existing state rules governing the use of the indigenous woodland (Grundy 1990; McGregor 1991; Scoones et al. 1993). Fastgrowing exotic species are important in rural areas for the production of poles which the indigenous woodland can no longer supply (Grundy 1990), but there is a need for a moreequitable emphasis between the management of indigenous miombo woodland and the planting of introduced species (Tuite and Gardiner 1994).

Local management practices by communities have already been dealt with in Chapter 5. In this chapter, the first section examines the nature of the desired wood products and the means by 
which they can be produced, focusing on harvesting practices, managing regeneration and demand management. One of the key functions of miombo woodland is as a source of feed for livestock and wildlife. In the second section we examine grazing management. Fire is endemic to the miombo region (Chapter 2), and in the third section we investigate the role of fire management. The fourth section focuses on the management of non-wood forest products. Finally, we return to the theme of resolving conflicting management objectives.

\section{Managing woody resources}

\section{The nature of the wood products}

The important wood products obtained from miombo woodland include timber, firewood, charcoal, fencing materials and materials for making farm tools and household items (Chapter 5). The sustainable utilisation of miombo woodland for these products is limited by the productivity and the quality of the resource base. Management for wood products should aim at the enhancement of biomass regeneration and the improvement of the quality of wood products.

Like other savanna ecosystems, productivity in miombo woodland is primarily a function of soil moisture and nutrient availability (Chapter 2). Given the seasonal pattern of rainfall and the inherent low availability of soil nutrients in miombo woodland, these factors are likely to constrain productivity and sustainable utilisation. Other constraints to high productivity include the regular occurrence of fire which damages and kills trees, and biomass removal by herbivores. Miombo trees often respond to fire and herbivore damage by compensatory growth, which is achieved by the reallocation of resources within the tree (Chapter 3).

Wood production in miombo woodland is also affected by the way miombo trees respond to harvesting. Responses depend on the phenological state, degree of resistance to fire, ability to resprout, seeding patterns, seed germination characteristics and seedling development (Chapter 3). Miombo woodland usually responds to wood harvesting by coppice regeneration, but the rate of regeneration is affected by human activities. There is need to promote harvesting techniques and post-harvest husbandry practices that promote regeneration.

\section{Timber}

Sawn timber is derived from sawlogs, which Lees (1962) defined as boles with over $63 \mathrm{~cm}$ girth at breast height (1.3 $\mathrm{m}$ above ground) $(\mathrm{GBH})$ and a length of over $1.5 \mathrm{~m}$. Among the valuable timber species in miombo woodland are Albizia adianthifolia, A. versicolor, Afzelia quanzensis, Amblygonocarpus andongensis, Burkea africana, Dalbergia melanoxylon, Entandrophragma delevoyi, Erythrophleum africanum, E. guineense, Faurea intermedia, F. saligna, Parinari curatellifolia, Pericopsis angolensis, Pterocarpus angolensis, Syzygium guineense and Vitex spp. In spite of this diversity of timber trees, the stocking rate of sawlogs in miombo woodland is usually low. Lees (1962) estimated a stocking rate of $5.9 \mathrm{~m}^{3} \mathrm{ha}^{-1}$ solid volume over bark in wet miombo woodland in the Zambian Copperbelt area, representing less than $4 \%$ of aboveground wood biomass (conversion factors from Chidumayo 1990; 1995). Boaler (1966a) estimated that Pterocarpus angolensis constituted about $8 \%$ by biomass of trees with over $5.0 \mathrm{~cm}$ diameter at breast height (or $15.1 \mathrm{~cm}$ $\mathrm{GBH})$ at sixteen miombo woodland sites in Tanzania. The density of timber-sized trees was $0.04 \mathrm{ha}^{-1}$. In a country-wide inventory of eighty 0.4 ha miombo woodland plots in Zambia (Chidumayo, unpublished), Pterocarpus angolensis occurred in $74 \%$ of the plots with an average density of $16.5 \mathrm{ha}^{-1}(\mathrm{SD}=24.31)$, while the density of all valuable timber species was $103.2 \mathrm{ha}^{-1}$ $(\mathrm{SD}=56.3)$. The high coefficient of variation 
suggests great variability in the density of timber trees in miombo woodland. The stem size structure is also dominated by small trees $(<31 \mathrm{~cm} \mathrm{GBH})$ (Figure 7.1). This low stocking rate of sawlogs of valuable timber species may limit the scale of exploitation of timber in miombo areas. However, the stem size structure, which is dominated by small stems, indicates the potential for high regeneration of sawlogs given appropriate management.

\section{Poles}

The size of poles harvested from miombo woodland depends on the end use (Grundy et al. 1993; Vermeulen 1993). Pole sizes can be categorised as large (76-183 cm mid-length girth over bark and > $1.8 \mathrm{~m}$ long) and small (7.6-76 $\mathrm{cm}$ mid-length girth and $<2.4 \mathrm{~m}$ long) (Lees 1962). Estimates of pole stocks in miombo woodland are few and variations due to age, species and past use can be large (Table 7.1). Methodologies at inventory which incorporate local people as enumerators (Campbell et al. 1995a) should be encouraged, as they can provide rapid estimates of stocks of wood products.

In Malawi it was observed that most poles harvested in miombo woodland by local communities had a diameter at breast height of 6-15 cm (19-47 cm GBH) and $4.0 \mathrm{~m}$ long but yield varied with species (Werren et al. 1995). Brachystegia floribunda and Uapaca nitida yielded the highest number of poles per tree and offtake was a function of species, age and size. Pole quality and durability are also important considerations. For example, in Zimbabwe hut roof poles are chosen where possible from tall straight stems, which are also strong and termite resistant (Grundy et al. 1993). The highest density of small poles occurs in immature regrowth miombo woodland (Table 7.1) while mature woodland is more important for large poles. Management for pole production should therefore aim at the maintenance of woodland of different ages to provide adequate amounts of both small and large poles.

\section{Firewood}

One of the major uses of miombo woodland is firewood (Bradley and Dewees 1993; Campbell et al. 1993; Coote 1995), with households in the region using an estimated 5-7 t of dry wood per

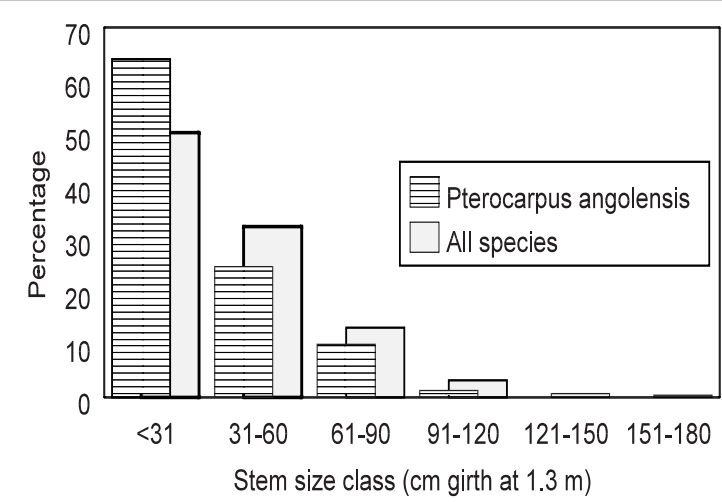

Figure 7.1 Stem size distribution of sixteen valuable timber trees (listed under Timber in the text) in eighty 0.4 ha miombo woodland plots in different parts of Zambia (Chidumayo, unpublished).
Table 7.1 Structure of poles in $20 \times 10 \mathrm{~m}$ sample plots in dry miombo woodland in central Zambia (Chidumayo 1995).

\begin{tabular}{|c|c|c|c|c|c|}
\hline \multirow[t]{2}{*}{ Miombo type } & \multirow[t]{2}{*}{$\begin{array}{l}\text { Sample } \\
\text { plots }\end{array}$} & \multicolumn{2}{|c|}{ Pole length (m) } & \multicolumn{2}{|c|}{$\begin{array}{l}\text { Estimated density } \\
\quad\left(\text { no. } \mathrm{ha}^{-1}\right)\end{array}$} \\
\hline & & Mean & SD & Mean & $\mathrm{SD}$ \\
\hline 6-10 years old & 3 & 1.33 & 0.54 & 3125 & 815 \\
\hline $16-20$ years old & 3 & 2.61 & 1.38 & 2075 & 479 \\
\hline Uneven age old-growth & & & & & \\
\hline boles only & 16 & 2.81 & 0.35 & 42 & 11 \\
\hline boles + branches & 16 & 4.98 & 2.46 & 690 & 191 \\
\hline
\end{tabular}


household per year (McGregor 1991; Grundy et al. 1993; Coote 1995). Although wood characteristics, such as density and flammability, vary among miombo trees, many can be used for firewood. However, certain species are selected for their burning qualities (McGregor 1991; Coote 1995) and these are often also the dominants of the woodland. Werren et al. (1995) found that a bundle of firewood in rural Malawi contained 12-25 species which were the most common in the woodland. People also tend to prefer small stems which require less labour to cut than large ones. But when small stems are scarce, large ones are used. Thus in deforested areas, people have less options to be selective, as has been observed in both Tanzania and Zimbabwe (Hancock and Kaeser-Hancock 1985; Campbell and du Toit 1988; Tuite and Gardiner 1990b; McGregor 1995a).

\section{Charcoal}

In all countries in the miombo region, except Zimbabwe, charcoal is one of the major products in the indigenous woodland, and provides an important income for rural dwellers (Chapter 6). The bulk of this charcoal is made in traditional earth kilns. Ninety percent of the aboveground biomass in miombo woodland is suitable for charcoal making by the earth kiln method (Chidumayo 1990; 1991b). Usually only logs with a butt girth of greater than $10 \mathrm{~cm}$ are used. Smaller branches with butt girths of less than 10 $\mathrm{cm}$ and main stems with girths of less than $30 \mathrm{~cm}$ are not used (Chidumayo 1991b). Deforestation and scarcity of large stems may result in the use of small stems and branches for charcoal production.

\section{Wood-ash fertiliser}

Wood biomass used for ash-fertilisation in slashand-burn cultivation depends on the height at which trees are cut. In the slash-and-burn chitemene cultivation in northern Zambia, trees are lopped by cutting branches and the actual aboveground biomass used has been estimated at $28 \%$ of the total (Araki 1992; Box 2.4).

\section{Other wood products}

Traditionally, rural dwellers utilise a wide variety of species from the woodland to meet their broad range of other household wood needs (Wilson 1990; Tuite and Gardiner 1990b; Coote et al. 1993a; Grundy et al. 1993; McGregor 1994). Often harvesting for these products is selective for species and sizes. A marked degree of wood selection for making household utensils, implements, musical instruments and handicrafts has been reported in Tanzania (Tuite and Gardiner 1990b) and Zimbabwe (Grundy et al. 1993). In Mozambique the most sought out miombo tree for woodcrafts is Dalbergia melanoxylon (Sitoe and Ribeiro 1995). Holden (1988) observed that whereas seven species (Burkea africana, Dalbergia nitidula, Isoberlinia angolensis, Julbernardia globiflora, J. paniculata, Lonchocarpus capassa and Swartzia madagascariensis) were preferred by a Bemba community in northern Zambia for making tool handles, only two species (Albizia antunesiana and I. angolensis) were preferred for mortars. Such preferences imply that some miombo woodland species may be over-exploited while others are under-exploited. Thus it is in the interests of local people to maintain as high a diversity of species in the woodland as possible. In this regard, mature woodland, with its range of size classes and diversity of understorey plants, provides a wider variety of products than younger coppice regrowth (Coote 1995).

\section{Harvesting practices}

\section{Tree cutting height}

The height at which a tree is cut affects the nature and rate of regeneration. In miombo woodland the higher the tree is cut the less biomass is removed and the faster the recovery. Pollarding is practised throughout the miombo region, to a greater or lesser extent. It is used in woodland management in parts of southern Tanzania (Tuite and Gardiner 1990b; 1994) and in Zambia trees 
in mature woodland are still pollarded and lopped in the preparation of ash gardens in the traditional chitemene shifting cultivation system (Lawton 1982; Stromgaard 1989). In Zimbabwe, branches are lopped for a variety of reasons: for fuelwood in areas where trees are scarce and where the felling of whole trees is prohibited (McGregor 1991); for browse in winter months and in drought years when alternative sources of animal feed are dwindling (Balderrama et al. 1988; Scoones 1990); to obtain fibre for rope without destroying the whole tree (Grundy et al. 1993); and to harvest fruits such as Uapaca kirkiana (McGregor 1991) or mopane worms (Hobane 1994).

Lopping could be encouraged as part of an intensive woodland management scheme. Lopped trees regenerate faster and produce a greater biomass over a shorter period than trees cut close to the ground. In addition, selective branch removal could yield wood and leaf products with much less disturbance to the overall woodland than the removal of the whole tree (Chidumayo, pers. obs.).

However, in some cases trees are cut at waist/breast height when clearing land for cultivation. In such cases the regrowth stems or branches are invariably defective at the point of cutting. Consequently the pole and timber value of the regrowth is low although the regrowth is useful as natural fallow for ash-fertilisation. These cutting techniques are not suitable for pole and timber regeneration.

Tree cutting for fuelwood, poles and timber is usually done by cutting close to the ground. Similar cutting practices or even tree uprooting are used when clearing land for semi-permanent and permanent cultivation. At such sites miombo woodland regeneration is predominantly of root and coppice origin and, unless damaged by fire, the regeneration produces straight poles. Under such conditions, Hursh (1960) recommended that stands should be managed for the production of small poles in the intermediate term through selective thinning, and for large poles and sawlogs in the long term. He further noted that in the absence of good management, old-growth miombo woodland stands tend to be dominated by defective stems and that the improvement of the pole and timber value of such stands requires clear cutting close to the ground to encourage the production of straight poles and timber stems. Trees should therefore be felled at $15 \mathrm{~cm}$ and at an angle of $45^{\circ}$ from the ground, using a sharp axe or saw to encourage vigorous regrowth from the stump (Grundy 1990). The 'nicking' of the cut edge will encourage sprouting from the stump (Lowore and Abbot 1995), while deep ploughing will increase the stocking rate by causing root suckers to develop (Hursh 1960; Strang 1966).

\section{Time of cutting}

The effect of time of cutting on regeneration has not been adequately studied in miombo woodlands. Anecdotal observations indicate that both climatic factors, such as temperature, frost and soil moisture, and phenology affect coppicing vigour and productivity of suckers after cutting, especially during the first year. Chidumayo (1993a) found that plots $(20 \times 10 \mathrm{~m})$ cut in November had a productivity of $34.5 \mathrm{~g} \mathrm{~m}^{-2}(\mathrm{SD}=20.5)$ during the first growing season while plots cut in July had a productivity of $104.6 \mathrm{~g} \mathrm{~m}^{-2} \quad(\mathrm{SD}=89.0)$. These production figures are equivalent to $8.6 \mathrm{~g}$ and $13.1 \mathrm{~g} \mathrm{~m}^{-2}$ per month for plots cut in November and July, respectively. Similar observations have been made in Malawi where trees cut late in the dry season after leaf flush had limited regrowth in the first year (Werren et al. 1995). The difference may be related to both the duration of the growing season after cutting and the phenological phase of trees at the time of cutting. Miombo trees will have flushed and used up some of their stored resources by November, which may constrain production during the first growing season, while in July most trees will be 
dormant or nearly so and cutting may not significantly affect resources stored belowground.

\section{Selective and clear cutting}

The impacts of selective and clear cutting on miombo woodland regeneration depend on the characteristics of the trees. Most inventories in miombo woodland have tended to exclude plants in the pre-sapling phase which probably form the largest reservoir for the future tree crop. Chidumayo (unpublished) enumerated woody plants (excluding suffrutices) in three $200 \mathrm{~m}^{2}$ plots at each of two sites in old-growth dry miombo woodland in central Zambia and classified the plants into suppressed saplings, including seedlings $(<0.5 \mathrm{~m}$ tall $)$, saplings $(0.5-2.0 \mathrm{~m})$ and trees $(>2.0 \mathrm{~m})$. About $95 \%$ of the plants at these sites were suppressed saplings (Table 7.2), of which canopy species constituted $44 \%$ and $84 \%$ of total species and plants, respectively.

Shoot growth among suppressed miombo saplings is slow. In the meantime these plants accumulate a relatively large belowground biomass which constitutes the perennating organ that regenerates new shoots following repeated shoot die-back during the dry season (Chidumayo 1993a). Most seedlings require at least eight years to develop an adequate root system to support

Table 7.2 Structure of woody plants (excluding suffrutices) in six $20 \times 10 \mathrm{~m}$ plots in old-growth dry miombo woodland at two sites in central Zambia (Chidumayo, unpublished data). Standard deviation is shown in brackets.

\begin{tabular}{lccrr}
\hline & $\begin{array}{c}\text { Suppressed } \\
\text { saplings } \\
(<0.5 \mathrm{~m})\end{array}$ & $\begin{array}{c}\text { Saplings } \\
(0.5-2.0 \mathrm{~m})\end{array}$ & $\begin{array}{c}\text { Trees } \\
(>2.0 \mathrm{~m})\end{array}$ & Total \\
\hline Plants ha $^{-1}$ & 20233 & 83 & 733 & 21050 \\
Species per plot & 18.33 & 1.50 & 7.50 & 27.33 \\
& $(6.28)$ & $(1.05)$ & $(1.64)$ & $(7.50)$ \\
\hline
\end{tabular}

sustained aerial growth. However, even after such root development, these plants remain in a suppressed sapling phase indefinitely until canopy trees are cleared (Lees 1962; Chidumayo 1993a). It has therefore been suggested that shading by canopy trees contributes to slow shoot growth of suppressed saplings in miombo woodland (Lees 1962; Werren et al. 1995), although competition for nutrients and water stress during the long dry season probably also contribute to this retardation. Whatever the cause, removal of canopy trees accelerates the rate of recruitment from suppressed saplings to sapling and tree phases (Trapnell 1959; Lees 1962; Chidumayo 1993a; Werren et al. 1995). However, there have been no detailed site-specific, long-term successional studies to determine which species and/or suppressed saplings compete successfully to grow into trees following canopy clearance.

Stumps of most miombo trees have the ability to produce coppice shoots (Trapnell 1959; Lees 1962; Boaler and Sciwale 1966; Hood 1972; Strang 1974; Banda 1988; Chidumayo 1989b). It is unclear whether stump survival rate is correlated with size and/or age. For example, Chidumayo (1993a) found that survival rate, as determined by the presence of coppice shoots one year after tree cutting, declined from $100 \%$ in regrowth of nine years to $98 \%$ in regrowth of 18 years and $79 \%$ in oldgrowth miombo woodland in central Zambia. However, a study in central Zimbabwe showed that $97 \%$ of cut stumps produced viable shoots, and larger stumps produced more shoots than smaller ones. Lowore and Abbot (1995) found that stumps of more than $30 \mathrm{~cm}$ in diameter produced fewer coppice shoots. But it is also likely that species composi- 
tion and land treatment, such as ploughing, may affect stump survival in miombo woodland.

Given the large pool of suppressed saplings (Table 7.2) in old-growth miombo woodland, and the ability of stumps and roots of cut trees to resprout, the woodland has a high potential to regenerate after tree harvesting. Because of the additional tree recruitment from suppressed saplings after tree cutting, tree density in young regrowth is usually very high. This is a temporary phenomenon because density eventually returns to the pre-felling level at maturity. For example, Trapnell (1959) recorded a very high tree density in 11 year-old regrowth but after about 50 years the density had declined to $86-95 \%$ of the prefelling tree density (Chidumayo 1995). Thinning of stems in regrowth woodland is therefore a desirable silvicultural practice that replaces the slow natural thinning process during woodland maturation from regrowth.

Selective cutting is the predominant form of harvesting for specific wood products, such as timber, poles and materials for farm tools and household items, including handicrafts. Usually only a small proportion of the biomass is removed and therefore selective cutting often does not significantly reduce canopy cover, and shading by uncut trees may continue to suppress the regeneration of the exploited species. In woodland where the proportion of valuable timber species is small, selective cutting can endanger the regeneration of these species because the continued presence of the dominant trees may retard the development of stunted saplings of the selectively cut species. This danger can be reduced if the site is clear cut, or alternatively if trees are cleared around the cut tree to create larger canopy openings. Although miombo woodland regenerates vigorously after clear cutting in spite of damage done to seedlings and suppressed saplings, cutting should be done carefully to avoid damage to saplings if they exist. In situations where the exploited species has no suppressed saplings, consideration should be given to enrichment planting by the introduction of nursery seedlings or wildlings to the site. Wildlings regenerate naturally from dispersed seeds and can be carefully uprooted with soil around the roots and transplanted. Current year's wildlings should be used as older ones rarely survive transplantation (Mwamba et al. 1992).

Complete clear cutting removes the entire canopy. In Malawi research has shown that the best woody regrowth after felling is obtained after clear cutting (Werren et al. 1995). This is therefore the best way of encouraging regeneration from stumps and suppressed saplings. But this management technique is unsuitable for large areas, steep slopes, or in riverine vegetation because of the increased erosion which occurs in the first years after cutting. A coppice-withstandards system in which some stems are retained within a stand while the rest are coppiced is advocated for such sites. The regrowth has the same pole and timber qualities as that from complete clear cutting near the ground. This management technique is also appropriate in situations where a wider variety of woodland products is required (Tuite and Gardiner 1990b; Lowore and Abbot 1995). In these cases, the reserved trees or standards could be earmarked for specific purposes. For example, in Zambia reserved trees are either legally protected timber species or fruit species, such as Anisophyllea boehmii, Parinari curatellifolia, Strychnos cocculoides and Uapaca kirkiana. A coppice-withstandards system is practised in many traditional farming systems where the reserved trees serve many functions and belong to a variety of species. In Zimbabwe, for example, when clearing land trees are left for fruit, shade, fertility from leaf litter and for spiritual reasons (Campbell et al. 1993).

Ecological degradation caused by tree harvesting in miombo woodland has not been adequately 
studied (Chapter 2). Anecdotal observations suggest that selective harvesting causes less ecological disruption than clear cutting. Over a two-year period after clear cutting in $20 \times 10 \mathrm{~m}$ miombo woodland plots, Chidumayo (1993a; 1993b) did not observe any major changes in soil nutrient status that could be attributed to woodland clearing. However, there was less soil moisture in the upper layers of soil (0-60 cm depth) in clear-cut plots than in adjacent uncut plots (Chidumayo 1993a; 1995). Although Chidumayo attributed this to the coppiced trees using more water in the upper soil layers, it is probable that clear cutting also exposed the top soil to desiccation by the sun.

Serious ecological disruption often occurs after clear cutting is followed by cultivation. At such sites soil crusting, erosion and reduction in soil-water infiltration occur (Hosier 1993). It has also been observed that removal of $70-75 \%$ of canopy cover in wet miombo woodland, accompanied by subsistence cultivation, increased stream peak flows and reduced flow duration on catchments in the Zambian Copperbelt (Mumeka 1986; Figure 7.2). By implication, increased runoff on such catchments can be expected to increase soil erosion. Clear cutting also may increase the incidence and intensity of fire due to increased herbage production (Ward and Cleghorn 1970; Barnes 1979) and possibly desiccation by the sun. These factors can contribute to the accelerated loss of moisture in the top soil.

Such negative ecological impacts can be minimised by alternating cleared strips or coupes with uncut shelterbelts. Once leaf-area development in coupes reaches the pre-felling level, which usu- ally takes ten years or more (Chidumayo 1990; 1991b), the shelterbelts may be cleared while the regrowth strips act as shelterbelts. The effectiveness of the shelterbelts can be enhanced by demarcating them across the slope. The coupes in many Zambian forest reserves in the past were twice as wide as shelterbelts but the usefulness of this technique has not been evaluated.

\section{Cutting cycles}

In selectively cut areas it is difficult to apply the concept of cutting cycles, and since trees in oldgrowth miombo woodland vary in age/size (Figure 7.1), determining cutting cycles is difficult. In selective cutting, each tree is selected on the basis of its size and suitability for the intended product. Thus selection criteria will vary by species and tree within species. Other factors can also influence selectivity. Generally an increase in the net price of a wood product, improvement in the harvesting or processing technology, or increased poverty among harvesters tend to reduce selectivity, affect cutting cycles and may cause over-exploitation of a species (Hosier 1993).

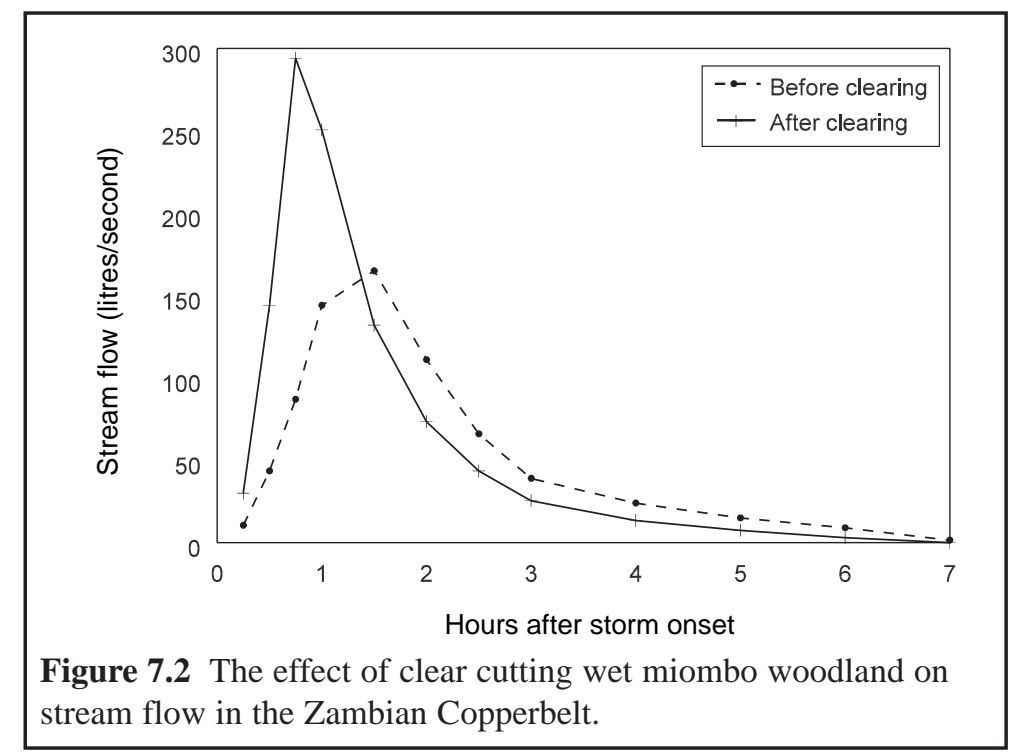


Cutting cycles for regrowth woodland in clear-cut sites depends on the wood product to be harvested. Given that natural regeneration and productivity are highly variable in space and time, it is difficult to prescribe precise cutting cycles on the basis of the limited production data that are available. Obviously there are great variations in stem expansion rates in miombo trees but generally younger stems have a higher expansion rate than older stems. This age-linked difference is probably more pronounced than the difference between dry and wet miombo woodland. Nevertheless, climatic and site quality differences should be considered in determining cutting cycles for different wood products in miombo woodland. Grundy (1995a) found, not surprisingly, that trees growing on deep soils in Zimbabwe were able to regrow faster than those on shallow soils, while some species fared better on shallow soils than others. Julbernardia globiflora, for example, grows better in the more xeric environment of shallow soils than Brachystegia spiciformis (Timberlake et al. 1993; McGregor 1994; Grundy 1995a). Tall trees indicate deep soils and good biomass production and where

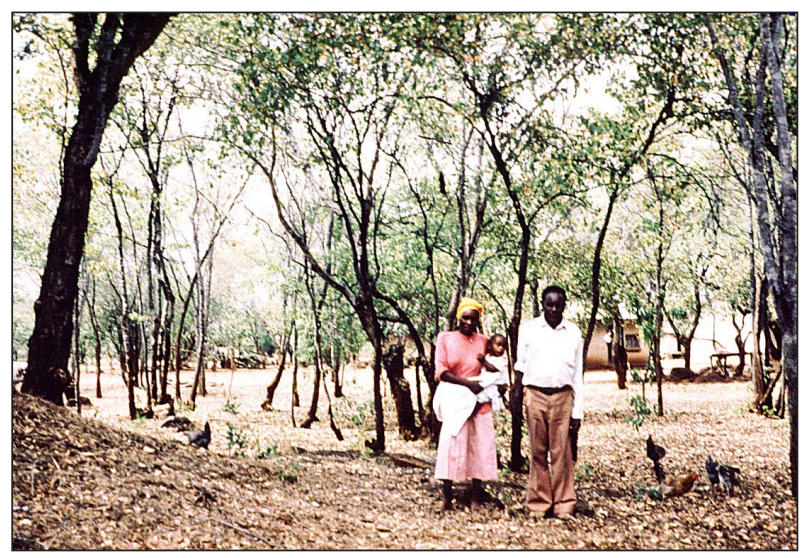

Regrowth miombo woodland usually has multiple-stemmed saplings. One possible management tool is coppice reduction, as depicted here in the homestead of a farmer (photo: J. Clarke). More research needs to be conducted on the effectiveness of this kind of management available these sites should be utilised for wood production. Small pockets of deeper soils may be found in mid-catena positions. These pockets may be too small to be usefully cultivated for agriculture, but could be used for coppice management.

Given the high stem densities in regrowth miombo woodland, small wood products (small poles) can be harvested as part of a thinning regime and the remaining stems managed for large wood products (large poles, sawlogs and cord wood for charcoal). For example, regrowth can be thinned at 10-20 years by selective harvesting of small poles (Werren et al. 1995), while reserving other stems for the production of large wood products.

\section{Managing regeneration}

\section{Coppice management}

Stumps of miombo trees produce many coppice shoots (Chidumayo 1988a; 1989b) but the number decreases over time due to inter-shoot competition and eventually only the dominant shoots contribute to the next generation of regrowth woodland. Depending on species, four to five years are required for the emergence of one or two dominant shoots (Chapter 3). This suggests that trimming coppice shoots to one or two after sprouting would enhance the growth of the remaining shoots. However, Grundy (1995a) found that in dry miombo woodland in central Zimbabwe this management technique did not necessarily improve the growth of the remaining shoots during the first three years of regrowth. The use of coppice reduction therefore requires further investigation.

Although coppice management practices are not common in the miombo region (Hosier 1993), coppice reduction has been observed to be beneficial for pole and bark production in mid-rotation (Grundy 1995a). Coppice reduction is practised informally in 
Zimbabwe's indigenous woodlands in smallscale farming areas where farmers remove a few coppice stems at a time from a coppice stool as a conservation measure (McGregor 1991). Coppice management also involves protection of shoots from browsing.

\section{Natural and plantation regeneration}

In contrast to seedlings of most miombo trees which grow slowly, coppice regrowth is relatively fast. However, comparative studies to determine differential performance of miombo trees under natural and plantation conditions have not been done. In the absence of such studies, data in Table 7.3 have been included to give a rough idea of the growth rate of some miombo trees under natural and plantation conditions in the Zambian Copperbelt.

The coppice regrowth data are based on measurements of stems at five 10 year-old regrowth stands with unknown management histories. Seedlings of plantation trees were raised in the nursery and transplanted into field plots where they were managed by application of fertiliser, weeding and protection from fire. The data suggest that Brachystegia and Julbernardia species performed poorly in the first ten years under plantation conditions because of their very slow growth rate from seed. These species appear to perform better under natural regeneration as coppiced regrowth. Perhaps managed stands of such species can be established from coppice and suppressed saplings, after clear cutting miombo woodland and subjecting the regrowth to silvicultural selective thinning. As Tuite and Gardiner (1990a) noted, although local firewood harvesting relies heavily on the coppicing properties of miombo trees, there are no large-scale firewood projects based on coppice management in miombo woodland. The fruit trees Parinari curatellifolia and Strychnos cocculoides perform better under plantation conditions, while Pterocarpus angolensis and Uapaca kirkiana seem to perform equally well under both types of regeneration conditions. However, further research is required on the economic feasibility of natural versus plantation regeneration of miombo trees under equivalent management practices.

Selection of plantation trees for timber is primarily determined by growth rate, form and timber characteristics. Other factors that determine suitability to plantation silviculture include seed availability and germination rate, seedling survival rate and timber characteristics. Based on Chidumayo (1993a) and unpublished data of the Zambia Forest Department, an attempt to rank some miombo trees on the basis of some of these criteria has been made in Table 7.4. From the table it is apparent that species that are relatively fast growing (A. adianthifolia, P. curatellifolia and $E$. africanum) have low seed germination
Table 7.3 Stem size of 10 year-old miombo trees in five coppice regrowth stands and in plantation plots in the Zambian Copperbelt. Standard deviation is shown in brackets for coppiced regrowth but corresponding data were not available for plantation trees (Chidumayo, unpublished and Forest Department Research Division, Kitwe).

\begin{tabular}{|c|c|c|c|}
\hline \multirow[t]{2}{*}{ Species } & \multicolumn{3}{|c|}{ Mean girth $(\mathrm{cm})$ at $1.3 \mathrm{~m}$ aboveground } \\
\hline & \multicolumn{2}{|c|}{ Coppice regrowth } & Plantation \\
\hline Brachystegia utilis & 12.7 & $(6.5)$ & Too small $(<1.0)$ \\
\hline Julbernardia paniculata & 11.7 & $(6.7)$ & Too small $(<1.0)$ \\
\hline Parinari curatellifolia & 19.1 & (7.8) & 30.8 \\
\hline Pterocarpus angolensis & 16.0 & $(7.2)$ & 12.9 \\
\hline Strychnos cocculoides & 8.8 & $(5.8)$ & 25.5 \\
\hline Uapaca kirkiana & 14.1 & $(7.1)$ & 12.9 \\
\hline
\end{tabular}


rates. Seed treatment to enhance germination may therefore be necessary for these species. Apparently, seedling survival in miombo trees in general is good (Chidumayo 1993a). However, seedling die-back may discourage the growing of these trees. With the limited experience in plantation management of miombo trees to date, careful species selection will be necessary.

\section{Bush fallow system}

Bush fallows, where natural woody regrowth is allowed to establish on abandoned cultivated land in an attempt to improve the chemical and physical structure of the soil, were common in traditional farming systems in the miombo region in the past (Chidumayo 1988c; Campbell et al. 1993; McGregor 1994; Tuite and Gardiner 1994). More recently, the practice of leaving a fallow has become rarer because of the lack of land. Bush

Table 7.4 Some performance criteria to guide the selection of miombo trees for plantation regeneration (Chidumayo 1995).

\begin{tabular}{llrlccc}
\hline Species & $\begin{array}{l}\text { Maximum } \\
\text { seed } \\
\text { germination } \\
\text { rate }\end{array}$ & $\begin{array}{l}\text { Recorded } \\
\text { seedling } \\
\text { survival } \\
\text { rate after } \\
\text { one year }\end{array}$ & $\begin{array}{l}\text { Mean DBH } \\
\text { in plantation } \\
\text { trials after } \\
\text { ten years }\end{array}$ \\
\cline { 2 - 8 }$\%$ & rank & $\%$ & rank & cm & rank \\
\hline Afzelia quanzensis & 99 & 1 & 88 & 2 & 3.9 & 6 \\
Albizia adianthifolia & 30 & 9 & 90 & 1 & 10.1 & 1 \\
Brachystegia boehmii & 69 & 5 & na & - & $<1.0$ & 7 \\
Brachystegia spiciformis & 83 & 3 & 78 & 5 & $<1.0$ & 7 \\
Brachystegia utilis & 79 & 4 & na & - & $<1.0$ & 7 \\
Erythrophleum africanum & 10 & 10 & na & - & 6.3 & 4 \\
Julbernardia paniculata & 95 & 2 & 45 & 6 & $<1.0$ & 7 \\
Parinari curatellifolia & 10 & 10 & 80 & 4 & 9.8 & 2 \\
Pericopsis angolensis & 40 & 8 & 90 & 1 & 3.9 & 6 \\
Pterocarpus angolensis & 60 & 6 & 85 & 3 & 4.1 & 5 \\
Strychnos cocculoides & 60 & 6 & 90 & 1 & 8.1 & 3 \\
\hline Notes: & & & & & &
\end{tabular}

Notes:

$\mathrm{DBH}$ is diameter at $1.3 \mathrm{~m}$ aboveground. na denotes data not available fallows produce useful by-products of wood, ash and browse, among others, and can be enriched by interplanting the natural regeneration with other useful trees. Fruit trees are commonly planted in bush fallows in Zambia (Chidumayo 1988c). Destumping of fields has retarded the woody coppice regrowth on old fields in the past. Coppicing of trees on contour ridges in fields to provide poles and firewood is common in Zimbabwe (McGregor 1994; Clarke 1995) and this should be encouraged, especially in areas where bush fallows are no longer possible due to population pressure.

\section{Managing demand for wood products}

Given the inherently slow growth rates of miombo trees, it is necessary not only to consider supply management; as important is the need to manage the demand for wood products. A number of practices are used by rural people to reduce demand for or to prolong the life of wood products in the miombo region. Nowhere is this clearer than in the management of fuel consumption (Chapter 5).

In Zimbabwe, poles are debarked, soaked in water, and flamed to render them more resistant to termite and borer attack (Campbell et al. 1993). When sinking fence posts, the holes are often filled with ash to deter termites. In Zambia bark fibre is soaked in black clay to increase its durability and strength (Chidumayo, pers. obs.). These and other local practices that are aimed at lengthening the life of forest products should be encouraged. 


\section{Grazing management}

Grazing management has been defined as the manipulation of grazing or browsing animals in order to accomplish a defined objective or desired result (Heitschmidt 1993). Although objectives vary among grazing enterprises, sustainability is one of the major goals of management (Heitschmidt 1993).

Grazing management aims at balancing plant and animal production. Thus the concept of carrying capacity (Caughley 1979; Lamprey 1983; Trollope et al. 1990) was developed to facilitate management decisions on numbers of herbivores that could be kept in a given area on a sustained basis. However, some workers have questioned the validity of this concept, especially in arid and semi-arid areas where climate and episodic events are the major factors influencing vegetation functioning and structure (Behnke et al. 1993). In general, carrying capacity is questioned in areas that have much lower rainfall than miombo woodland (Chapter 2).

Selective grazing is thought to be the major process influencing the intensity and frequency of defoliation of plants for a given stocking rate. Several grazing management systems have been designed in order to control the degree and intensity of defoliation of plants. These include rotational grazing, short-duration grazing, and split-season rotational resting systems (Gammon 1978). However, Gammon (1976) found that the scope to control defoliation patterns through grazing management systems was limited.

Several features of miombo woodland influence its utilisation by herbivores. These features include variable herbage production, seasonal changes in plant quality, leaf fall during the dry season, presence of tsetse fly and the diversity of uses (including clearing trees for cropping). The major objective of management is to maximise animal production on a sustained basis by modifying those features of miombo woodland that constrain secondary production.

\section{Herbage production}

In the miombo region the amount and distribution of rainfall is a major factor influencing herbage production, which therefore tends to fluctuate with annual rainfall, especially in dry miombo woodland (Chapter 2). Several workers (Coe et al. 1976; Dye and Spear 1982; Lamprey 1983) have shown that there is a linear relation between herbage production and annual rainfall. The relation is modified by soil type and the ratio of trees to grasses.

Since it is difficult to adjust stocking rates in relation to variations in annual rainfall, conventional rangeland management advocates stocking at a conservative rate. This involves stocking at a rate that ensures adequate animal production in critical years when annual rainfall is below average. The major cost of this strategy is the under-utilisation of herbage in years of aboveaverage annual rainfall.

An opportunistic strategy has also been advocated in order to cater for variable herbage production (Behnke et al. 1993). This strategy involves the use of variable stocking rates in line with variations in herbage production. Livestock mobility across extensive areas or regions is encouraged in order to exploit the spatial variation in herbage production. The major advantage of this strategy is that herbage is adequately utilised during above-average rainfall years. However, its major cost is massive livestock mortality during drought years. Movement of livestock across regions in order to reduce mortality, practised extensively in the past, is becoming increasingly difficult because of the development of sedentary agriculture and strict veterinary regulations.

The optimum stocking rate will depend on the farmer's objectives since it has been demonstrated that maximum individual performance and maximum gain per hectare occur at different optima (Jones and Sandland 1974). However, making community-wide management strategies 
as regards desired stocking rates has not been simple in communally owned grazing areas (B. Cousins, pers. comm.).

Another major factor influencing herbage production is tree cover. Bush clearance has been shown to increase grass yields by up to $400 \%$ (Barnes 1979). However, such increases tend to be associated with adverse changes in herbaceous species composition (O'Connor 1985). For example, bush clearance in a dry miombo woodland site in Central Zimbabwe led to the replacement of Panicum maximum, a palatable grass species, by unpalatable species. In dry miombo woodland, tree clearance could also reduce the amount of forage available during drought years since trees tend to be more drought tolerant than herbaceous plants (Walker 1980). In wet miombo woodland tree clearance is unlikely to have this negative impact (Hood 1972).

Some workers have shown that the relation between tree density and grass production is not negatively linear, but this is in arid-eutrophic savannas (e.g. Stewart-Hill 1987). Whether this is the situation in miombo woodland is less clear. Nonetheless trees are an essential component of the grazing ecosystem, as they provide browse and maintain nutrient-rich patches under their canopies (Campbell et al. 1988). There is a need to establish the tree density that leads to optimum production of forage and other products derived from miombo woodland, and to investigate the optimum spatial arrangement of trees in a grazing system (e.g. scattered individuals or in patches).

\section{Plant quality}

Several workers have shown that there are seasonal changes in plant quality (Weinmann 1948; Plowes 1957; Elliot and Folkertsen 1961). The crude protein content of grasses decreases from about $10 \%$ during the growing season to about $3 \%$ during the dry season. The decline in protein content is accompanied by an increase in the fibre content of the grasses. The net effect of these changes is that animals subsisting on grass gain body weight in the wet season and lose weight during the dry season.

Browse from miombo species maintains a crude protein content greater than $10 \%$ throughout the year (Table 7.5). However, some browse species contain secondary metabolites such as condensed tannins which tend to reduce the availability of nitrogen to ruminants (Reid 1986; Woodward and Reed 1989; Owen-Smith 1993). Owen-Smith (1993) suggested severe browsing or pruning, and the stocking of several species of browsers adapted in different ways to woody plant defences, as a means of coping with the adverse effects of condensed tannins. It has been shown that severe browsing has differential effects on the condensed tannin content of some woody species (Bryant et al. 1991).

Common methods of improving plant quality include rangeland reinforcement with forage legumes (Grant and Clatworthy 1984; Clatworthy 1986) and cultivation of multi-purpose trees (Topps 1992) such as Leucaena species, Gliricidia sepium, Acacia angustissima and Calliandra calothyrsus. Major problems are the poor establishment and persistence of these legumes. Some of the browse species (e.g. A. anguistissima) contain high levels of condensed tannins.

Some farmers collect wild fruits (e.g. Swartzia madagascariensis, Piliostigma thonningii, Dichrostachys cinerea and Acacia nilotica) for use during the dry season. High-quality supplements such as groundnut tops could also be used (Manyuchi 1994), especially among small-scale farmers who cannot afford to purchase commercial protein concentrates. Retention of important browse trees when clearing woodland and collection of fruits and leaves for use as supplements should be encouraged.

Polyethylene glycol (PEG) which preferentially binds with tannins has been used to improve the utilisation of tannin-rich browse. 
Table 7.5 Chemical composition (percent of dry matter) of leaves of commonly browsed plants in a dry miombo woodland site at Makoholi, central Zimbabwe (average annual rainfall $600 \mathrm{~mm}$ ) (Gambiza, unpublished).

\begin{tabular}{lllll}
\hline Species & $\begin{array}{l}\text { Crude } \\
\text { protein }\end{array}$ & $\begin{array}{l}\text { Neutral- } \\
\text { detergent } \\
\text { fibre }\end{array}$ & Acid- & detergent \\
& fibre & tannins \\
& $($ A550luble \\
& & & $\left.\mathrm{g}^{-1} \mathrm{NDF}\right)$
\end{tabular}

Cool dry season (23/6/94)

Lecaniodiscus fraxinifolius

Dichrostachys cinerea

13.2

33.3

24.5

7.0

Strychnos spinosa

Securinega virosa

13.0

51.0

34.5

$11.4 \quad 23.0$

18.6

$15.5 \quad 21.1$

13.2

13.6

33.9

26.2

12.6

49.4

23.1

$13.3 \quad 26.3$

na

$9.9 \quad 32.6$

28.1

S. madagascariensis

Hot dry season (23/10/94)

Lecaniodiscus fraxinifolius

Dichrostachys cinerea

15.8

14.1

43.4

26.9

9.6

Strychnos spinosa

12.0

41.4

31.3

15.0

Securinega virosa

19.0

20.5

11.0

2.2

2.8

18.0

25.2

13.9

5.0

A. nilotica

A. karroo

13.0

43.8

30.1

10.0

11.4

34.6

28.0

26.0

Warm wet season (23/3/95)

Lecaniodiscus fraxinifolius

Dichrostachys cinerea

10.3

14.3

40.3

30.8

5.9

11.5

46.5

45.1

34.0

Strychnos spinosa

Securinega virosa

$17.4 \quad 21.2$

21.8

2.8

11.8

$9.4 \quad 31.0$

14.1

35.8

19.4

64.1

22.3

20.0

14.5

20.7

43.2

6.8

10.4
15.7

29.2
There are conflicting claims about the efficacy of PEG and other related 'digestive modifiers'. More studies are needed on the effects of these modifiers on the utilisation of browse in miombo woodland. Australian experience is that the practice seriously destabilises the woodland by making previously unpalatable reserves edible (R.J. Scholes, pers. comm.).

\section{Leaf fall during the dry season}

Most miombo woodland browse species are deciduous (Chapter 2 and 3). This creates a nutrient bottleneck during the dry season. Although animals have been observed to feed on leaf litter during the dry season (Scoones 1990), dispersal and mingling of fallen leaves increases search time which could reduce intake of large ruminants (Owen-Smith 1993). OwenSmith (1993) has suggested that falling leaves could be collected in leaf traps and stored for later feeding. Fresh leaves could also be collected and stored for use during the dry season. However, labour for harvesting adequate quantities of browse could be limiting, and studies are required to determine the effects of time of harvesting and methods of storage on the quality of browse. 


\section{Inaccessibility of browse}

The annual leaf flush, and new coppice shoots, are important sources of browse in miombo woodland, particularly in the dry season when alternative sources are scarce (Lawton 1980; Scoones 1990; Tuite and Gardiner 1990a; Nyirenda 1995). A large proportion of leaves on trees are out of reach of domestic and wild herbivores which tend to browse up to a height of $2 \mathrm{~m}$ and $5 \mathrm{~m}$, respectively (Pellew 1980). OwenSmith (1993) has suggested that trees could be lopped to restrict their heights. However, the lopping of trees to facilitate browsing could conflict with other uses of trees such as the provision of timber and poles, at least in the early stages of regrowth (Grundy 1995a). Because browsers are usually selective, overexploitation of preferred species can retard regeneration of these species. In dry miombo woodland in central Zimbabwe browsing significantly reduced the biomass of Julbernardia globiflora, a palatable species, while Brachystegia spiciformis was less affected (Grundy 1995a). In a browsing experiment carried out in a Zambian wet miombo woodland Baphia bequaertii and Brachystegia spiciformis died off within two years due to heavy browsing of coppiced stumps by cattle (Hood 1972). In Malawi it has been observed that heavy browsing in miombo woodland is detrimental to tree regeneration, especially of preferred species, but with proper managed grazing rotations woodland regeneration is possible (Werren et al. 1995). Rotational grazing may therefore be necessary to ensure species diversity, conservation and sustainable production of browse for herbivores in miombo woodland. In cattle areas, livestock are often herded away from cropping areas during the growing season. This practice could be extended to include woodland management areas under a coppice or coppice-with-standards system, so that the new coppice shoots have a chance to become established in the first growing season and to prevent local extinction of palatable browse species. Where alternative areas for browsing are not available, trees could be pollarded at $2 \mathrm{~m}$ so that the new shoots are out of reach of most browsers.

\section{Presence of tsetse fly}

The presence of tsetse fly in some miombo woodlands limits the rearing of livestock (Chapter 2). Tsetse fly, which prefers woodland habitats, transmit trypanosomiasis to cattle. Various methods for controlling the fly have been tested (Box 4.3). These include bush clearing, sterilisation of male flies and the use of traps impregnated with toxic chemicals. The effectiveness of these methods has been variable. Bush clearance is a futile exercise since tsetse flies re-invade an area once woody plants re-establish (Lawton 1980). Bush clearance is also a severe disturbance which leads to loss of products and services derived from trees (Box 4.3). Use of trypanosome-tolerant cattle in areas infested with tsetse fly should be investigated (ILCA 1995).

\section{Fire management}

Productivity and the quality of poles in regrowth miombo woodland can be reduced by fire, especially late dry-season fires (Hursh 1960; Chidumayo 1993a; Figure 7.3). Grundy (1995a) found that 4 year-old trees that had been burnt produced significantly less basal area than unburnt trees of the same age in Zimbabwe. Fire is therefore a principal agent in killing regeneration and crippling young stems. According to Hursh (1960) this crippling effect takes place in the early stages of regeneration while in older trees fires also cause basal scars and stem lesions which produce defective stems of poor pole and timber quality.

Although complete fire exclusion from young regrowth may be necessary, it is not practical, both because of the increased build up of fuel and, in certain circumstances, the role that 


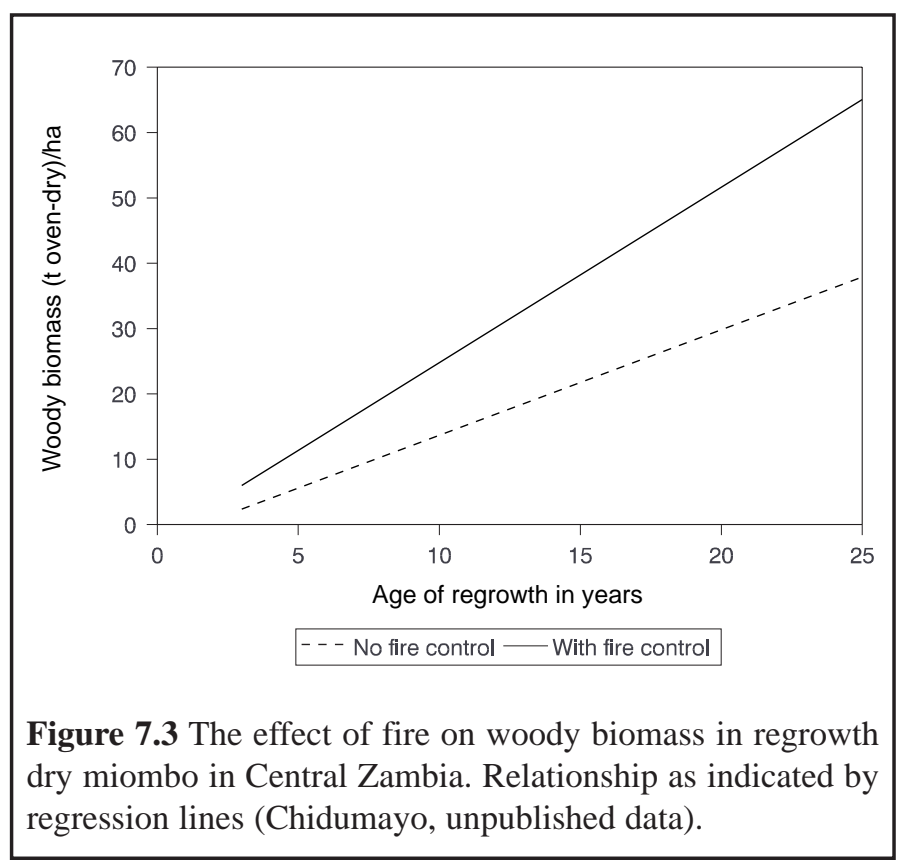

should be burnt annually before leaf flush (September) to minimise damage to new leaves and reduce the build-up of litter biomass that occurs when areas are not burnt. Burning may not be necessary where livestock grazing or litter harvesting removes most of the fuel biomass.

Use of fire as a management tool will depend on whether an area is being managed for timber production or for grazing. A high-intensity fire in the late dry season tends to damage woody plants while grasses are not adversely affected. In contrast, a low-intensity fire in the early dry season tends to cause least damage to woody plants but damages grasses. In many areas, farmers will burn the dry and unpalatable grasses at fires have in the cultural life of a community (Box 7.1). Fierce fires, and therefore the most damaging, occur during the late dry season because of the high quantities of extremely dry litter biomass (Trapnell 1959; Chidumayo 1995). In recently cut-over areas the amount of wood debris is usually high and even an early dryseason fire can be fierce and damaging to young regeneration. Fire management in miombo woodland should therefore take into account the age of the woodland, the phenology of the dominant and/or desirable species, the type of land use and the management objectives of the area. During harvesting all discarded wood, if not used for other purposes, should be piled away from stumps and patches of dense saplings and burnt. Young regrowth areas should be protected from late dry-season fires by early dry-season burning which should be continued until leaf production has reached that level found in old-growth miombo woodland. This usually occurs when the regrowth is $10-15$ years old. Older regrowth areas the end of the dry season to produce new shoots for livestock (Lowore and Abbot 1995). In woodland, this will have a detrimental effect on woody seedlings and coppice regrowth. If burning is carried out in woodland areas where wood is a desired product, it should be done at the end of the rainy season, when the moisture levels in both grass and tree layer are relatively high (Trapnell 1959).

Grazing instead of burning is recommended to maintain low grass levels and maximum woody production in miombo woodland. According to Allan (1965), under normal chitemene practices in Zambia, woodland would not be repeatedly late burnt. Only areas around new cuttings were protected from fire until later in the season, while elsewhere burning was begun earlier. This created a mosaic effect, where woodland would only be subjected to late burning occasionally. In Zimbabwe, the use of fire in most small-scale farming areas is prohibited by law (Burford 1989; Wilson 1990). 


\section{Box 7.1}

\section{Early burning of miombo woodlands: technical and cultural conflict? Claire Coote}

It is generally agreed that one of the best ways of protecting and managing miombo woodlands is to carry out early burning, that is, to burn patches of grass and undergrowth in the early dry season before the grass gets too dry in order to avoid more-intense, more-damaging fires later in the season.

However, Morris (1995) states that in Malawi the burning of the woodland at the end of the dry season has both pragmatic value and symbolic significance. Burning of the bush has significance in the regeneration of the cosmic cycle and the subsequent coming of the rains (Schoffeleers 1971). People burn the bush for preparing their gardens for planting, hunting animals and calling the rains. In Malawian cosmology the appearance and the movement of the rains and bush fires appear to replicate a cyclical movement between sky and earth which is associated with a similar movement of the spirits. Fires establish on earth a mirror image of the desired conditions in the sky. They are manifestations of ancestral spirits representing their ascent to the sky in their capacity as rain providers. Schoffeleers (1971) concludes that bush fires are far more than an economic proposition and that it may be that their religious significance, perceived both consciously and unconsciously by the population, is one of the reasons why people still continue to burn the bush in spite of official prohibition and the considerable damage they cause (Schoffeleers 1971). Morris (1995) rests his case by explaining that burnt woodland is referred to as lupsya; the verb ku-psya meaning not only to cook, roast or burn, but also to ripen.

Rangely (1948) concurs that the burning of the grass was left until the late dry season and explains that the Acewa were very reluctant to start burning before the chief had given the order. This allowed people time to construct firebreaks and protect their families before the appointed day when, as the grass was fired, the escaping game was hunted. Any person who fired the grass before the order was given would have to pay compensation to the owner of any huts or grain bins that were damaged. He concluded that few people cared to risk this and complied with the law on early burning. Potter (1987) talking about local conservation methods in earlier times in Malawi suggests more pragmatic reasons for the late burning of the bush. The ash produced from burning not only yields large amounts of nutrients to the soil but increases $\mathrm{pH}$ levels.

\section{Managing non-wood forest products}

Miombo woodland provides a wide range of other products besides wood and forage (Chapter 5). Roots, bark, leaves, flowers and fruits are collected for various uses. Campbell et al. (1993) found that traditional protocols of collecting certain products are increasingly being flouted for a variety of reasons, including exploitation by outsiders selling to an urban market, increased scarcity and breakdown of traditional institutions. Methods of harvesting for bark are usually destructive. In Zimbabwe, bark stripping of young live saplings is commonplace and destroys or deforms many young trees (McGregor 1991; Grundy 1995a). The preferred trees are Brachystegia sp. in wetter areas and Acacia sp. in 
drier areas. In some cases whole trees are cut (Campbell, et al. 1993). In Malawi, few trees are cut specifically for bark fibre; in most cases it is a secondary product of pole cutting (Lowore and Abbot 1995). If the Malawian practice could be encouraged, so that bark was only stripped from young stems removed in a thinning or coppicereduction process, the overall productivity of the woodland could be increased.

Traditional bee hives are made of bark, cut from the trunks of large miombo trees. The practice renders the trees more susceptible to fungal attack (Fischer 1993). He maintains that this use of bark, together with the damage inflicted by hacking steps in the trunk of the tree for easier access to hives, represents an acceptable use of the woodland. This is likely to be true only of large tracts of indigenous woodland. One of the most damaging effects of beekeeping in miombo woodland is the accidental spread of fire during honey collection (Fischer 1993; Grundy, pers. obs.). Fire not only kills seedlings and retards coppice regrowth, but also damages the base of the trees and increases the chance of fungal infection (Van Wyk et al. 1993). In more-intensively managed woodlands where coppiced trees are managed on short rotations, the number of large trees with trunks of a suitable size to make hives would be reduced, while in a coppicewith-standards system where the standards have been carefully selected for seed or timber production, bark removal may have a detrimental effect on their survival. In such cases, alternative materials for hive making should be sought.

Leaf litter is sometimes collected from miombo woodland for composting in cattle pens or for application on arable land in order to improve fertility (Nyathi and Campbell 1993; Campbell et al. 1993). Although there is little information on quantities of leaf litter collected from miombo woodland, the practice could adversely affect nutrient cycling.
Nyathi and Campbell (1993) calculate that, because the litter has relatively low crude protein levels combined with high lignin and fibre contents, 3 ha of closed canopy woodland would be required to supply sufficient leaf litter as the sole fertiliser on 1 ha of agricultural land. Coppicing, in reducing the amount of canopy area, will decrease the amount of leaf litter available. Nyathi and Campbell (1994) found, however, that coppice leaves have a higher nitrogen content than older leaves; this may compensate in part for the diminished supply of litter.

\section{Resolving conflicting management objectives in the face of scarcity}

In increasing the intensity of one particular management strategy, inevitably the production of certain woodland products suffers (Tuite and Gardiner 1990b). There are a number of examples in the miombo region which demonstrate the difficulty of managing woodland resources for different purposes, especially at high levels of exploitation.

Demand for fuel and construction wood in deforested and urban areas is high in south central Africa. Studies from Zimbabwe and Malawi show that many households augment their annual incomes by selling wood (McGregor 1991; Dewees 1993; Nhira and Fortmann 1993; Grundy 1995a). The sustainable management of communally owned woodlands in resettlement areas in Zimbabwe is threatened by an overwhelming demand for wood from neighbouring deforested farming areas (Grundy 1995a), exacerbated by a need for a cash income by the resettlement farmers (Nhira and Fortmann 1993). An opportunity exists here for farmers to take advantage of the market for wood products, and plant fastgrowing tree species as a cash crop, in addition to any communal management programme within the indigenous woodland. From past experience 
in such situations, however, tree planting is not seen as a viable option while there are still indigenous resources left to exploit.

Over-exploitation of miombo woodland for charcoal has resulted in localised deforestation (Chidumayo 1987d; McGregor 1995b). In Mozambique the civil war resulted in much of the farmland in miombo areas being abandoned. These and other woodland areas are now being heavily exploited, largely on an open-access system, to meet the demand for charcoal from urban areas, and to provide an income for thousands of jobless returnees at the end of the war. In some areas even fruit trees and trees on ancestral graves have been cut (McGregor 1995b).

In a recent review of indigenous woodland management in Africa, Shepherd (1992) described how the intensity of management increases as the resource diminishes. In Zimbabwe, under certain circumstances, the opposite has been found to be true of the communally managed woodlands, where the degree of control over wood cutting weakens in moredeforested miombo areas (Campbell et al. 1993). Increasingly in deforested areas, the tendency has not been to augment management of the communal woodlands, but to increase the intensity of management of trees and woodlands on private land (Wilson 1990; Campbell et al. 1993). Fruit and timber trees are planted in vegetable gardens and around the homestead, where they are more secure, while areas of formerly communal land are increasingly incorporated into private farmlands. In this way, farmers attempt to ensure a good return for the labour invested in management. Tree planting on private land can reduce the level of demand for certain products from the communal woodlands, but an increase in the privatisation of the natural woodland can also result in the alienation of the landless and the poor from essential natural resources (Arnold 1993; Bradley and Dewees 1993).

\section{Conclusions}

Access rights influence decisions on grazing and woodland management. For common property, decisions on management issues such as lopping of trees, rangeland reinforcement, use of fire and optimum stocking rates have to be agreed on by the majority of users before they can be implemented. Chapter 8 investigates institutional arrangements in greater detail.

Any management of communally owned miombo woodland, especially in small-scale farming areas, must necessarily attempt to enhance all products and services in the face of strong competition from alternative land uses. Successful management is likely to be based on low costs, easy execution, local acceptance, and environmentally sound interventions.

The way forward to sustainable management should be to build on existing practices (Chapter 5). Past experience indicates that the imposition of new management regimes is unlikely to be successful (Clarke 1995).

Certain features of miombo woodland must be considered in managing the woodlands. Characteristics of the trees that influence management include phenology, resistance to fire, ability to resprout, seeding patterns and browse quality (Chapter 3). Features of the ecosystem that affect management include low soil-nutrient status, the regular occurrence of droughts, fire and insect outbreaks (e.g. army worm and locusts), the presence of tsetse fly and the prolonged dry season (Chapter 2). The main management issues in miombo woodland largely relate to harvesting, regeneration, coppice management, fire management, grazing management and access and rights to woodland resources. Because of the diversity of uses of miombo woodland, the intensification of any one particular management strategy is likely to affect the production of other woodland products. 


\title{
Chapter
}

8

\section{INSTITUTIONAL ARRANGEMENTS GOVERNING THE USE AND MANAGEMENT OF MIOMBO WOODLANDS}

\author{
Frank Matose and Liz Wily
}

\section{Introduction}

Central to the sustainable use of miombo woodlands are the institutional arrangements which govern use. Throughout the region, new models of natural resource management are being explored. How can forest policy become more enabling to local communities? Do the solutions lie in increasing local community involvement, and how can this be implemented?

Underlying these questions is the issue of resource ownership and control: who, or which institutions, own the resources, control access to them, and how are these institutional arrangements embedded in law? In the first part of the chapter, the tenure systems within which miombo woodlands are institutionally lodged are described. The second part explores the historical changes in institutional arrangements. The following sections present some case-study material of the legislative frameworks in the region, and describe promising developments in the region and elsewhere. Finally, current trends in community-based systems are analysed, and a way forward is proposed. Further details about local institutional arrangements can be found in Chapters 5 and 6, where they are discussed within the context of local management practices and marketing, respectively.

\section{Property regimes and tenurial niches}

\section{Property regimes}

There are various ways of analysing property rights in the African context. Bromley and Cernea (1989) follow convention in categorising land tenure in terms of state, private and communal property, and add a more complex category, of open access. They emphasise that property is not so much an object, such as land, "but rather it is a right to a benefit stream that is only as secure as the duty of all others to respect the conditions that protect that stream". Thus, those with the right have expectations under the law for their claims to be respected by those with the duty.

\section{State property}

The state property regime occurs where the ownership and control of the resource lies with the state. Individuals and groups may be able to make use of the resources, but only "through the forbearance of the state" (Bromley and Cernea 1989). Government makes decisions concerning access, including the level and nature of their exploitation (Feeny et al. 1990). Typically, the state may lease the resources to groups or individuals who are 
issued with usufruct rights for specific periods of time. Such usufruct rights may not bestow longterm tenurial security. In most countries in the region, between $10-15 \%$ of land falls under state control, in the form of state forests, national parks and safari areas. Roughly half of this is miombo woodland.

In practice, natural resources are rarely managed solely within one property regime (Murphree 1993). State lands have characteristics of both state and private property regimes, and even characteristics of open-access regimes, where the state is unable to exercise the authority of exclusion or control, or to secure compliance with its rules. Documented problems associated with the state property regimes over woodlands, forests and wildlife areas are steadily accumulating throughout the miombo region (Dewees 1993; Moyo et al. 1993; Matose 1994).

Given the political and economic climate that exists in most countries of the region, forest departments increasingly find it difficult to exercise their authority in the face of intrusions by surrounding non-owners. In many cases, local populations consider themselves the original owners of the woodlands that have been nationalised, and still depend upon them for elements of their livelihood. A common scenario is one of conflict as well as encroachment and illegal harvesting of woodland products.

\section{Private property}

The essence of private property regimes is simply the legal and socially sanctioned right to exclude others (Bromley and Cernea 1989). Exclusion of other resource users and the regulation of resource use results in the concentration of ownership of land in a few hands, often a source of landlessness and conflict. For much of this century, privatisation of property has been considered a desirable objective, but it is now more widely appreciated in sub-Saharan Africa that it is not necessarily the means to optimal use of land or resources, and in many circumstances, particularly in the case of forests and woodland, may be simply inappropriate. The amount of miombo woodland falling under the private property regime differs significantly among countries. Zimbabwe probably has the largest percentage of woodland on private land, and Tanzania the smallest.

\section{Communal property}

Communal property regimes, as defined by Bromley and Cernea (1989) are those in which resources are held by an identifiable community of interdependent users, in which outsiders to that community are excluded and in which use by members is regulated by cultural norms. In contrast to state or private property, rights under a communal property system are not transferable nor are they exclusive. The majority of miombo woodlands comes under the category of communal property.

The nature of communal property resources (CPR) is arguably one of the most thoroughly debated constructs of colonial and post-colonial rural development and political economy this century, and has produced a vast literature, the most well-known milestone of which was Hardin's thesis of the 'tragedy of the commons'. In summary, Hardin (1968), using communal grazing as his model, equated communal property effectively with no-ownership and therefore no responsibility, leading to over-utilisation and degradation of the communal resource. Hardin and other proponents of this view provided much support for a spate of privatisation land reforms in developing countries, including the miombo region, where over-grazing of semi-arid lands and woodlands is an important aspect of public policy and planning. Subsequent structural analyses of property relations provide a more nuanced framework, and draw distinctions between various conditions of communal property, a critical determinant of which is the extent to which the community or group retain the capacity to regulate use (Wily 1988; Bromley 1989; Lawry 1990). 
Sanctions and incentives for resource use and regulation may become inoperative when local institutional arrangements are disrupted by pressures and forces beyond the control of such communities. The breakdown of local arrangements may indeed lead to resource mismanagement along the lines of Hardin's thesis. In sub-Saharan Africa, prominent agents of breakdown have been a lack of recognition by the modern state of the natural resource management roles of traditional communities, and the widespread reconstruction of governance with new local government institutions, leading to conditions in which the locus of responsibility is confused. Often such areas, including many miombo woodland areas, fall under the category of public lands. Traditional rules of resource use are typically further undermined by the imposition of overriding regulations by the state as to how miombo woodlands may and may not be used.

Feeny et al. (1990) point out two characteristics of common property resources, in the broad sense of the concept, that are problematic. In the first instance, it is difficult to control access by potential users because of the physical nature of resources, although they can be fenced or protected. This is the problem of exclusion. The second problem relates to subtractability. Even with co-operation, there is always the difficulty arising that exploitation of resources by one user affects other users' capabilities to do the same. That is, one user subtracts from the welfare of other users through exclusion. This is central to the analysis of institutional and legal structures in many countries of the miombo region. Frameworks which promote co-operation and agreement among users would seem to be essential.

\section{Open access}

Open access represents "the absence, or the breakdown, of a management and authority system whose very purpose was to introduce and enforce a set of norms of behaviour among participants with respect to the natural resource" (Bromley and Cernea 1989). Under this regime, there are no well-defined property rights, such that access is unregulated or "free and open to everyone". There are no clear statements in the literature as to the prevalence of open-access regimes in the miombo region. While open access may often be assumed, more-detailed work indicates a wide variety of local rules and regulations (Campbell et al. 1995a). The intensity and efficacy of these rules varies greatly however, and there remain in some countries quite large areas of miombo woodland which are barely subject to traditional regulation at all (Wily 1995d).

\section{Tenurial niches}

The concept of a tenurial niche (Bruce et al. 1993) allows a different perspective of property regimes than is offered by the typology presented above and one that is useful in sub-Saharan Africa where traditional tenure systems tend to operate side by side with western conceptions of tenure, introduced by colonial governments and embedded today in statutory law (Gluckman 1969; Pitblado 1970; Colson 1971; Cohen 1980). State laws vary in the extent to which they recognise customary law as governing local natural resource use. In practice, when conflict arises, statutory law tends to supersede customary law (Pitblado 1970).

Bruce et al. (1993) define a tenurial niche as a space in which access to and use of a resource is governed by a common set of rules. Under traditional tenure systems, land areas are divided into different uses, with different rules and regulations applying to the areas. Thus, within the same community, there may be woodlands that are communally managed or accessed and there are pieces of woodland that fall under individual control. Moreover, different rules might apply to the same area of land at different times of the year, or to different resources within the area. Gluckman (1965), examining tenure systems in Zambia, referred to the result as 'different estates in land' as 
early as the 1940s. With the nation-making of this century came national perspectives and national laws, and these often provided another level of regulation and practice governing rights of access and use. In the miombo region, this is most commonly manifest in rules governing the extraction of valuable timber species or reserving threatened species (as perceived by the state) against any use at all. Such rules may or may not be consistent with local systems of individual tree management and regulation, customary rights, local religious sanctions, or pragmatic controls, which themselves do not necessarily coincide.

Whether the resource is subject to over-arching national control (such as is the case with reserves), a 'communal' woodland, a sacred site (to some), a woodland considered worthy of full protection as a valuable ecological refugium, a woodland or series of species 'administered' by a local authority, or a woodland on private land, there is usually a degree of conflict and competing claims. These conflicts may be dormant or active, depending upon which tenurial niche is threatened. Different actors (the state, national and local elites, peasants) may appeal to different legal systems to support their claims (Bruce et al. 1993), and the history of natural resource management and the regimes which govern their use, and resulting condition, may be usefully analysed in these terms.

\section{Historical changes in institutional arrangements in the miombo region}

Customarily, it appears that chiefs had authority over all land resources in systems which were based on clan groupings (Chenje and Johnson 1994). Whenever a cultural group or sub-group expanded into an area, and established its authority, this was prominently manifest in the exercise of control over how associated land and forest areas were inhabited and used (Abrahams 1967; Kjekshus 1977; Wily 1988). Particularly where forests were concerned, religious leaders were often influential. This was partly the result of the use of forests for socio-cultural purposes and partly because they tended to have greater powers of sanction. For example, among the Shona peoples of Zimbabwe, spirit mediums had strong control over proper resource use, and would work under the political leadership of the chiefs (Chapter 5; Mukamuri 1995b). The control by mediums was based on powers from ancestral spirits. The mediums could invoke or summon to cast bad omens like pests and epidemics, if resources like woodlands were improperly utilised. This system was heavily dependent on religious beliefs, which were often to change.

In many areas, a prime concern of communities and their leaders was to maintain intact woodland as a means of securing a flow of wild meat and other forest resources. This was the case among the Barotse and Lozi of Zambia (Gluckman 1969) and the Nyamwezi of central Tanzania (Abrahams 1967). In yet other cases, the maintenance of large tracts of uncultivated woodland consciously served as buffer zones among antagonistic or expanding communities. Miombo woodlands separated the Iraqw, Nyaturu, Sandawe and Barabaig of northern Tanzania (Winter 1968).

Throughout the region, small, specific tracts of forest or groves attained special status, usually for religious or socio-ritual purposes, such as rainmaking, the conduct of adolescent male initiation ceremonies, or as secluded places where ritual dances and ceremonies could be held (Chapter 5; Shepherd 1992). Casual entry into such areas, grazing, hunting or even fuelwood collection, were normally prevented. Some of the larger groves, 100 ha or more, were directly controlled by religious figures (Matose 1992). In other cases, the community maintained protection through threat of heavy sanctions against unauthorised entry or use of the area (Brandstom 1994). As miombo woodlands continue to be cleared, many of these sacred groves stand out today as isolated islands 
of intact woodland (Wily 1995b). Such areas and associated traditional management regimes have been identified in Malawi, Mozambique, Tanzania, Zambia and Zimbabwe (Chenje and Johnson 1994). Their existence is significant, suggesting both an element of continuity with pre-colonial mechanisms of natural resource management, and a continuing capacity of local communities to conserve miombo woodland if necessary.

Finally, individual miombo species were frequently subject to regulation. The rules, and the species they targeted varied throughout the region, but there is some commonality in the regular occurrence of rules against felling species considered helpful to water conservation and the maintenance of stream flow, rare shade trees, trees considered especially attractive to bees, or of special medicinal import, and those associated with special historical events, all tended to be consistently protected (Messerschmidt et al. 1993).

Overall, there is little doubt that an institutional capacity to control and manage woodland existed customarily in pre-colonial sub-Saharan Africa, and was exercised. It would be incorrect however, to assume such regimes were comprehensive, or always driven by a desire to conserve; it is arguable that a desire to control people, to keep them within a manageable socio-spatial sphere, drove many of the limitations placed upon expansion into woodland areas in particular. After all, for most societies, the woodland was unlimited and represented first and foremost a source of grazing or cultivation land.

\section{The impact of colonialism}

The impact of colonialism upon African society represents perhaps the major subject of historiography in sub-Saharan Africa and hardly needs recounting here. Each country has literature on this subject. In terms of how colonialism affected the institutional framework for forest and woodland management, the following general trends of the period may be noted, albeit at some risk of over-generalisation.

\section{Reservation}

In the first instance, colonialism represented a state-making and centralising force which was to bring previously largely autonomous cultural groups into 'nation' frameworks, subjecting those people, and their resources, thereafter to national perspectives, governance and rule-making. Moreover, this was to occur in an alien, European and capitalist mode, from which peasant land use and management was ultimately never to escape. The most tangible manifestation of such control in relation to miombo woodlands was the act of reserving land against agricultural use that occurred throughout Anglophone sub-Saharan Africa between the 1920s and 1950s, a process which withdrew vast tracts of natural forest out of the hands of local people into the hands of the state, either as Game or Forest Reserves or simply as State Land (Wily 1988).

The reasons varied but frequently aimed to secure vast areas of land for future reallocation in the interests of the state, often to white settlers (see below). Wildlife and Forest Reserves were often established for conservation purposes, as means of securing water catchment (especially where montane forest was involved), to secure the conservation of a valued area against settlement or agricultural expansion, or as a revenue-generating mechanism, government controlling the extraction of wildlife, timber and other wood products from the area. Although the land in question was possibly genuinely not owned and even unused in some cases, in others, the forest or woodland in question fell within the sphere of one or other local community. The act of removing local tenure or control over such areas had the effect of removing or at least seriously undermining any sense of local responsibility for the maintenance of the area, a legacy which has proved increasingly problematic, right up to the present.

\section{Reconstruction of custom and authority}

In those areas where colonial state control did not divest local communities of their interests, 
the local framework within which woodlands were perceived, used and managed was nonetheless as dramatically transformed. Especially in Anglophone colonial Africa, each decade saw a burgeoning of rules, sometimes directed towards land-use management and the consistent drive to increase productivity, and later, to promote soil and water conservation, and sometimes through the codification of assumed 'customary' laws (Snyder 1982; Ranger 1984).

Furthermore, although British colonial governments saw themselves as merely making very good use of local leaders and chiefs, the strategy of Indirect Rule thoroughly reconstructed the identity and governance systems of traditional authority (Colson 1971). Indeed, as Ranger (1984) has observed, "the most far-reaching inventions of tradition in colonial Africa took place when the Europeans believed themselves to be respecting age-old African custom". A central sphere of reconstruction was land and resource tenure. As a consequence it is difficult today to know the measure of pre-colonial continuity that in reality pertains in terms of customary practices or traditions relating to miombo woodlands or resources (Chanock 1982; Wily 1988). Even where local interests and responsibility over adjacent woodlands were maintained in one form or another, such practices or institutions acquired their legitimacy and direction more and more from the centre than from the community. The longstanding capacity of traditional or locally derived authority to expand or alter to meet changing demands was in this way truncated (Wily 1988).

\section{Economic transformation}

There was, however, a more fundamental transformation under way in the colonial period which was to reshape the way in which natural forest and woodland areas and resources were perceived, used and controlled more thoroughly and irrevocably than direct institutional reconstruction could attain. This was capitalisation of African social relations, which slowly but surely trans- formed society and economy throughout the region (Kjekshus 1977; Bryceson 1980; Harriss 1982). The commercial agriculture of white settlers, and the expansion schemes of the colonial governments which ate into large areas of natural forest and woodland were but early phenomena and stimuli to a comprehensive subordination of pre-colonial peasant economy to capital, and eventually to a world economy (Harriss 1982). In the process, land and resource use itself was transformed and woodland became a source of income as well as subsistence, and a sphere of accelerated agricultural expansion (Wily 1988).

\section{The post-independence era}

With the attainment of independence, it was inevitable that the governance systems and institutions of the colonial period would be subject to change, at all levels. Although the ideologies of the new governments varied, two forces were consistently prominent. The first was democratisation, which sought to remove appointment or inheritance as the means through which local leaders were recognised. Villagers everywhere began to vote for and elect their leaders. The village development committee, or village council, was to become the common institutional framework of authority and governance at the most local level.

The second force was more complex in that at one and the same time it embodied a further centralisation of authority into the commonwealth and policies of the state, and the decentralisation of authority. The principal institution of this force was the ubiquitous county or district council, which has taken powers both from the new central government and from the village or local community. Depending upon the issue and how it is perceived, local government is, up to the present, either a tool of central authority or a tool of its local constituency. In either case, traditional authority as operational in the colonial period, was consistently and deliberately diminished, retained at most as a ritual or advisory office (Fortmann 1980). 
Many elements that make up governance and many subjects upon which decisions had traditionally been made, were not formally identified or handed over as the responsibility of local leaders or authorities. Acquiring their legitimacy from central governments, local authorities and leaders tended to avoid acting upon issues where not explicitly directed to do so (Walsh 1985). In other cases, new leaders did not feel they possessed the customary legitimacy of their predecessors to act. In this way, many matters fell through the cracks, unmanaged. This was in effect the case with many miombo woodlands, which fell neither in the sphere of the village, tribal authority, local government or national government authority. It is ironic that, despite such areas continuing to be utilised and subject to some regulations, they often became in effect more genuinely no-mans land or public or common land as conventionally conceived than was ever the case in the past.

In the 1970s or 1980s, land-use planning, including systems for the allocation of agricultural land, and the management of natural resources such as woodland, came to the forefront of development agenda in the region, and in most states, a responsibility of one or other agency or level of government. As had been the case in regard to the agricultural regulations of colonial states, the regimes handed down have often proved inappropriate to local conditions. More pervasively, deriving from outside the local community, such regimes have lacked the incentive of local conviction to be satisfactorily implemented (Hyden 1980; Lwoga 1985).

Particularly in those independent states which established demanding socialist agenda, policy and institutional changes were generally even more transformatory at the local level than was generally the case throughout the miombo region. Following the Arusha Declaration in 1967, development planning in Tanzania was centred around the village. By the early seventies rural people were often forcibly aggregated into planned settlements, both to facilitate provision of water, education and health facilities, and to make way for egalitarian landholding and co-operative farming in accordance with President Nyerere's vision of raising agricultural productivity through gradual collectivisation (Bryceson 1982; Shivji 1995). A critical feature of villagisation was the registration of villages as corporate entities under the Villages and Ujamaa Villages Act of 1975. The act also provided for the legal establishment and powers of each village's government, an elected Village Council. Although the members were freely elected by the constituent village members, the powerful positions of chairman and secretary of each village government were by law filled by the chairman and secretary of the local branch of the ruling party.

In 1982, with the re-introduction of District Councils, Village Councils became a statutory arm of local government, thus thoroughly incorporating village government into national government. In the process, remaining pre-colonial or colonial traditional authority was undermined, although in many cases, traditional leaders filled the new local governance positions (Fortmann 1980; Lwoga 1985; Walsh 1985). The spheres of their authority and the manner in which they governed were new, however, proscribed and prescribed by the dictates of national policy. Their management functions extended only to farming areas, which were at first loosely identified. Land-use planning was dominated by agricultural requirements, and such woodlands that existed in or near the villages were considered reserved lands for further agricultural expansion (Tibaijuka et al. 1993).

By the late eighties new agricultural policies permitted the disaggregation of households from central settlements within the village area and most households attempted to return to their previous homes, where these were still available (Wily 1988; Tibaijuka et al. 1993). Tenurial issues surrounding the status of lands owned prior to villagisation abound and continue as a subject of 
much litigation in local and higher courts (Shivji 1995). For a period in the late 1980s and early 1990s the construct of 'villages' was weakened, and the authority of village councils frequently disregarded by member villagers. Rarely however, did this give rise to a resurgence of traditional authority, per se, or a breakdown in community. After all, the majority of villages in Tanzania have existed for more than twenty years. Both through design, and in default of assistance from government, many have become active vehicles of local organisation, self-reliance, public activity and decision making. Social relations, and the identity of community, often built upon pre-villagisation, and even pre-colonial formations, have consolidated in the intervening years since formal villagisation of the 1970s. Many of the community's assets, such as the village school, health clinic, wells, and roads, have been communally established, maintained, and owned. Indeed, with the abandonment of the one-Party state, the village council has become a fully democratic organ of village governance (1992) and attained a new lease of life. The spatial nature of the modern Tanzanian village has also been consolidated rather than undermined, with the steady issue of Title Deeds over the demarcated village area to village councils (Shivji 1995). The new 1995 National Land Policy locates the village assembly (the constituency which elects the council) as the future holder of the Title Deed (Government of Tanzania 1995).

Thus, although the original tenets of villagisation have steadily diminished over the last twenty years, the institution of 'village' and village government has in fact consolidated, and as described later, villagers are beginning to use the unusual leverage they have as corporate entities in statutory law to exercise full control and management over natural resources within their vicinity. An interesting element of this is revival of traditional mechanisms in support of communitybased management, suggesting that traditional institutions not so much disappeared as lay in abeyance, and once again are being reconstructed to meet current needs.

In Mozambique and Zimbabwe, similar reforms were made after independence, which included supposed diminution in the powers of traditional leaders. In 1984 a prime ministerial decree was issued in Zimbabwe, ordering the creation of Village Development Committees (VIDCOs), following the Tanzanian model. The idea was that VIDCOs were to be the smallest units to coordinate rural development, control the management of natural resources and be channels for local people's demands to the state. In reality, VIDCOs became structures largely to channel state demands to the people. Local communities failed to separate these new structures from the ruling party, as had been the case in Tanzania and Mozambique (Sitoe and Ribeiro 1995). In many cases, VIDCO leadership coincided with that of the ruling party. VIDCOs had the mandate to distribute land and manage natural resources, mandates which had been the domain of traditional leaders. In this way, VIDCOs were reduced to arenas of contest between local lineages and the new structures, and have proved largely ineffective in implementing natural resource management. Some communities resolved the problem by appointing traditional leaders to be chairpersons of the VIDCOs, in which case, the traditional leaders can play both traditional and modern state roles. There are moves in place to return greater power to traditional leaders.

The attempts by post-independent governments in Mozambique, Tanzania and Zimbabwe to democratise local-level institutions were also aimed at improving the communication between central government and local people, and to generate sound planning processes. In practice the decentralised planning activity that was supposed to start at the village level, has not functioned well and plans tend to be generated by sectors at the central/national level and implemented at the district level, with little local consultation. 
The Zimbabwean strategy offered under the Communal Land Act of 1982, through the Communal Land Model Land Use and Conservation By-Laws, is one mechanism that allows resource management plans to be generated at the district level, and then endorsed at the national level through the requisite statutory instruments (Clarke 1995). In Zimbabwe, however, the model that was intended for district council use was adopted country-wide with little relevance to local circumstances. In Mozambique, the co-option into the administrative system of former traditional leaders and the post-independence Grupo Dinamizadores, offers opportunities for improved woodland management (Sitoe and Ribeiro 1995). In Tanzania, as we have seen, recent improvements in the institutional construct of village and village government may also be seen to have opened the way for older mechanisms of natural resource management and local responsibility.

\section{Forest legislative framework: case studies}

Woodlands do not exist in isolation from national policy and law, but are subject to them. In most cases forest acts provide the overriding legal framework, although statutes under property, mining, and administrative laws also play a role. In many cases the national forestry acts derive from the early colonial period, and although amendments have been made since, some key principles and parameters of those old acts still pertain. This section reviews the legal framework existing today in three of the miombo countries, Malawi, Tanzania and Zimbabwe.

\section{Malawi}

Forest management in Malawi is currently governed by the Forest Act of 1984 and the accompanying Forest Rules (Moyo et al. 1993). The authority for the Act lies with the Forestry Department whose officers are given police powers for the purposes of controlling use of forest produce. The Act covers the establishment of forest reserves and the use of forest products. The Forestry Department has the control over the exploitation of resources from forest reserves and persons have to hold licences in order to access products from such reserves. On leasehold land, the leaseholder has control and management rights, but these are governed by the Forestry Department through licences to fell protected trees.

On customary land, the Act gives responsibility for managing and controlling forest and woodland produce to headmen. Such woodlands are managed by communities through customary arrangements and through legal rights conferred under the Village Forest Areas (VFAs) (Dewees 1993). Legislation for the establishment of VFAs was pronounced in 1926, and resulted in rights of tenure over woodlands being conferred to communities. The VFA strategy was derived from traditional management practices whereby chiefs used to maintain small protected areas for hunting purposes (Hardcastle 1993). Sacred sites are also protected through similar arrangements. Whereas in 1934 there were 2900 VFAs covering 64000 ha, the 1950s and 1960s saw the demise of these areas. Today, in only a few areas does the VFA concept remain important, depending partly on the level of interest of the headmen.

Moyo et al. (1993) identify four major weaknesses surrounding the Forest Act:

- The Act is ineffective in dealing with major offences within forest reserves, including the extraction of fuelwood for commercial agricultural estates.

- Where overlap or duplication exists with other acts, these seem to have precedence.

- In several respects the Act is obsolete. Reserve boundaries are outdated. The Forestry Department no longer has the powers to enforce regulations in the light of the government encouraging persuasion and co-operation with resource users. 
- There is no provision for the security of endangered species and the export of forest produce. Some of the measures that the Malawi government has recently taken to improve the management of indigenous woodlands include the limiting of commercial exploitation, licensing of and increased royalty collection from users of customary-held woodland products, and greater emphasis on local empowerment (Dewees 1993). The future of woodland-based enterprises is unlikely to be assured until improved institutional and legislative mechanisms for sustainable management are in place (Dewees 1993).

\section{Tanzania}

Tanzania shares a similar legacy of colonial forest legislation. The principal legislation was first promulgated in 1957 and has, with the exception of minor amendments and a stream of Orders issued under its auspices, remained fundamentally unchanged. The Act is thus out of date with the changed conditions and perceptions that now surround forest and woodlands, and even out of step, if not directly contradictory, with emerging new forest management policies.

The Forest Act is typical of many principal forest acts in the region, in that it is mainly concerned with the creation of Forest Reserves and the licensing procedures for extracting timber from those reserves. Forest Reserves, however, encompass probably less than half of the considerable miombo woodland estate of Tanzania (estimated as up to 20 million ha). There is little doubt that montane forests were rated more highly than miombo woodland in Tanzania throughout the colonial period and early post-independence period, and it has been the former that have been the main target of reservation.

Miombo woodlands outside Reserves are largely on so-called public land, with a minor proportion under individual private leasehold tenure. The Minister may enter a management covenant with a private owner of miombo woodland, but his virtually sole authority over forest or woodland outside reserved or private land is to declare a particular species reserved and unable to be cut or felled without a licence. This instrument has been fully used by respective Ministers and as of mid1995, 24 miombo woodland species are now fully reserved against unlicensed extraction. Licensing is generally handled at the district level.

Most of Tanzania's 540 Forest Reserves (which together comprise around 13 million ha) and virtually all those comprising miombo woodland, are also managed by district councils. These bodies, to whom a considerable degree of government authority has been devolved in a wide range of spheres, also have the legal right to designate Preserved Areas, supposedly in consultation with local communities. In virtually all of Tanzania's 80 or more districts, at least one such preserved miombo woodland exists. Preservation Orders issued by District Councils tend to come in the form of Soil and Water Regulations covering the area. However, the purpose of such preservation is increasingly to facilitate revenue generation for the council, through timber licensing fees. Once a woodland is subject to such an area, it is usually managed by a Forest Guard, employed by the district council. This tends to crystallise conflict between communities and local government, who consider themselves dispossessed.

District councils are designed to be selffunding agencies, obtaining revenue through a variety of taxation and licensing routes, but in practice consistently lack funds, manpower or transport to manage Local Authority Forest Reserves, promulgate appropriate preservation orders or to supervise timber extraction on other public land. The vast majority of Forest Reserves, both montane and miombo woodland, are in poor condition today, heavily degraded and subject to creeping agricultural encroachment and a multitude of illegal, if not necessarily always damaging, consumptive uses. Users of Forest Reserves and miombo woodland outside Reserves are not only 
local communities, but commercial extractors of timber and wildlife.

An important administrative and jural legacy of the Ujamaa and rural development policies of the seventies exists in the fact that virtually the entire land estate of Tanzania outside urban areas or gazetted government-owned Wildlife or Forest Reserves falls within the territorial ambit of registered villages. It has been noted above that the Tanzanian village community is unlike villages elsewhere in most of Africa in that once it is registered, it exists, through its village council, as a corporate entity, able to sue and be sued, start commercial enterprises and own land, forest and other assets. The village council is also able to pass village by-laws, which enter statutory law on approval by the district council, and the contents of which must be upheld by all courts of law.

If the Tanzanian village is unusual in the definition of its social form, it is equally unusual in that it has a clear territorial basis, equally able to attain legal form through statutory entitlement. At the point of registration, each village defines its village area, the sphere over which is agreed with neighbouring villages that it has control. National policy (mainly the 1983 Agricultural Policy) has sought to assist villages to demarcate, survey and map their village area, and to secure statutory entitlement (Village Title Deed).

The issue of the Deed confirms the village as the private owner of the land. In practice the process has been slow, with less than one-quarter of Tanzania's 8471 villages surveyed, some $15 \%$ of title deeds prepared, and less than $4 \%$ fully registered (Shivji 1995). The logical and appropriate nature of communal tenure, especially where resources such as woodlands are held and used by communities, not individuals, has not been lost on politicians, government officers or advisors, and the Presidential Commission of Inquiry into Land Matters (1992-1995) strongly recommended its consolidation. The subsequent new National Land Policy (1995) commits the state to fully formalise this in statutory law. The procedures for issuing Certificates of Title will be streamlined through the already-drafted Basic Land Act, and communal landholding will be fully democratised through the establishment under constitutional law of the village assembly (all adults in the community of 18 years or more) as the corporate entity, rather than its elected village council, as is currently the case. When this is achieved in law, the village assembly will then be deed-holder, and in full control of all land resources falling within its village area. In this way, a precise and firm statutory legal basis will be given to communal land tenure. These features of the Tanzania legal environment are of obvious significance in the emergence of communitybased forest and woodland management, and are already being utilised in this way (Box 8.3).

Meanwhile, as Kajembe (1994) has described, forest management by central government is largely confined to those Reserves considered of special water catchment or conservation importance. These tend to be montane forests. Central government complains of having little authority over District Foresters who are employed by district councils. Kajembe, among others, considers the forest service as a whole to be characterised by administrative fragmentation and duplication, and its regimes restrictive, worsening the breakdown of traditional management systems (Kajembe 1994; East African Biodiversity Project 1995; Wildlife Conservation Society of Tanzania 1995). It is generally acknowledged in government that its capacity to manage natural forest and woodlands, either inside or outside Reserves, is severely constrained, and the forest service itself vulnerable to corruption. These conditions re-emphasise the need to find alternative management strategies.

\section{Zimbabwe}

Like Malawi and Tanzania, colonial history, natural resource policy and law, and property law, all play a role in the way miombo woodland 
has been administered and is administered today. There are three main areas that are pertinent to the discussion of institutional matters around woodland management in the country: (i) the historical setting; (ii) the legal and administrative framework, which is not enabling to local people; and (iii) the land and tenurial background.

Several legal statutes and policies that were passed during the colonial period and retained after 1980, had a negative impact on resource management. In the first place, the creation of the then Native Reserves through the Land Apportionment Act of 1930, marked the translocation of indigenous people onto marginally productive land, in terms of agricultural potential. To this day, not much has been done to alleviate the land and resource pressures which exist in the communal areas (the former native reserves).

At the same time, there were also changes to institutions that were responsible for woodland management. After the colonial conquest, chiefs and other lineage leaders broadened their political and spiritual control over wider areas, with the assistance of colonial authorities (Wilson 1990). Up to the 1950s, such institutions were accepted by the state as land and resource managers in the communal areas. However, for a period in the 1950s after the Native Land Husbandry Act, up to the 1970 Land Tenure Act, these functions were transferred to government agents. After the 1970 Act, the powers were returned to the chiefs, who were again only to be discredited during the war of liberation in the 1970s. During that period, there were extensive expansions of cropping into grazing and woodland areas due to the institutional vacuum that resulted from the discrediting of traditional leaders.

After independence in 1980, the circumstances changed again, with resource control powers being given to the state. The state thus vested its power in the elected Village Development Committees (VIDCOs) and Ward Development Committees (WADCOs). Thus the history of institutions for woodland management is marked with confusion, alternating between empowerment and disempowerment of local structures.

In terms of legislation, there are a number of Acts that affect institutional arrangements governing woodland use (Scoones and Matose 1993), as follows:

- The Communal Land Act of 1982 and the Rural District Councils Act of 1988 assign power to the councils, rather than chiefs and other lineage leaders, for all control over land and natural resources. Although there are opportunities for decentralised proprietorship for resource management through the VIDCOs and WADCOs, control over woodland resources is still concentrated at the District Council level given the lack of participation by local people in the formulation of by-laws.

- The Regional and Town Planning Act of 1976 includes objectives of conservation of the environment and control of development through plans by the local planning authority. The Act is largely inappropriate for "local settings of rural Zimbabwe" and empowers the planning authority "to do anything necessary to implement an operative master plan or local plan" (Scoones and Matose 1993). Such plans often do not have sustainable woodland management as their focus.

- The Natural Resources Act of 1942 is “..a highly interventionist piece of legislation, particularly as it applies to the communal areas. ...Such a level of intervention is a poor basis for the foundation of effective incentives for spontaneous resource management at the local level ..." (Scoones and Matose 1993). The Act sets out a series of rules regarding land use and provides the basis for the enforcement regime (unlike in the large-scale commercial areas where the act establishes a form of community-based management).

- The Forest Act of 1948 (amended 1982) gives power to the Forestry Commission to protect forests/woodlands and govern the use of such demarcated forests. 
- The Communal Land Forest Produce Act of 1928 was amended in 1987 with minimal changes to its colonial predecessor. The major tenet of the Act is the restrictions it places on use of forest products in communal areas, confining them to 'own use' which provides disincentives for managing and utilising woodlands sustainably. For instance, persons with easy access to Forestry Commission offices, can more readily obtain permits to exploit miombo woodlands than local persons living in the woodlands.

- The National Parks and Wildlife Act of 1975 bestowed proprietorship of wildlife resources to "owners and occupiers of alienated land". The latter are represented by the large-scale commercial farmers (mostly white), the Department of National Parks and Wildlife Management and recently the District Councils, through the granting of the 'appropriate authority' to manage a resource. Attempts to overcome the lack of rights of communal dwellers to benefit from wildlife resources from their own woodlands, because of the legal underpinnings of the Act, have recently been addressed through the CAMPFIRE initiative (see below).

\section{Summary of current situation}

In summary, therefore, what is the institutional situation with regard to miombo woodland? The seven countries in which miombo woodland occurs are diverse in history and modern socio-political systems. Nonetheless, there is commonality in the way natural forest and woodlands have been regarded, in the institutions of their administration, and in terms of where ownership and rights are vested. A singular influence throughout has been the colonial legacy. Despite quite radical socio-political transformation in some countries, it is arguable that there has been more institutional continuity than change over the last half-century in terms of who controls and who manages miom- bo woodlands. A common characteristic has been the centralisation of control and regulation, resulting in a continuing tug of war between national laws and customary practice, between central and local government authority, and between state and local perceptions of the role, utility and even ownership of woodland resources. In most countries, miombo woodland, like communal land in general, tends to fall uneasily among different categories of landholding and different levels of administration and control. Lack of clarity, ambivalence, and sometimes outright contradiction and conflict, characterise its administration.

Meanwhile, all seven countries have experienced the same increasing pressure upon natural woodland resources in the face of expanding population and agriculture, and a similar growing interest over the last decade in halting further unbridled extraction, degradation and encroachment in favour of sustainable forest use regimes. The efficacy of direct government ownership, control and day-to-day management of forest and woodlands is visibly declining in many places and the extent to which centralised systems may be financially sustained is a growing concern of forestry departments. At the same time, local communities are emerging as more organised and articulate than in the past and less accepting of regimes or regulation, which are inappropriate to local conditions. For many interested parties, both within and outside, the logical way forward is apparent, and involves an institutional, legal and practical movement towards local communities as natural resource managers, as those with the most vested interest in the sustained existence and utility of local woodlands. A variety of local initiatives in woodland management or in the management of specific woodland resources such as wildlife, consistently reflect these trends.

Conceptual shifts in ideas and practice towards community involvement are not confined to countries where miombo woodland occurs. On the contrary, a widespread reconsideration of forest management strategies and related institu- 
tional concerns is occurring throughout the Asian and African continents. These changes are being driven by the same concerns of dwindling natural forest and woodland resources and growing doubts that national or government agencies are, at this point in time, the most appropriate institutions to secure these resources and their sound management into the next century. An array of initiatives in upwards of thirty different states is under way which shares a similar process of devolving management, or control and, in some cases, ownership of natural forest or woodland resources to local communities. The following section provides some examples: firstly, the early initiatives in South Asia (India and Nepal); an example of changed national policy towards community-based forest management in Africa (Ghana); and one of the earlier initiatives involving local people in natural resource management in the miombo region (Zimbabwe).

\section{Lessons from elsewhere}

\section{Joint forest management: experiences from India and Nepal}

There has been a long history of joint management in India, Nepal and elsewhere in Asia. There is widespread recognition that forest-dependent communities cannot be excluded from the care and control of forests that surround them, regardless of the legal ownership of the forest, which may rest with the government. This is in contrast to the situation in the miombo region where state forests should be free from local people, and in which local people have no management role. In Asia, it is realised that old custodial protection systems are not successful in protecting forests.

In India the catalyst to the emergence of new policies came with acknowledgement in the seventies that despite the employment of more than 100000 Forest Guards, an average of 1.5 million hectares of forest land was being denuded annually (Poffenberger 1990). One by one, Indian states began to enter partnership agreements with communities, through which responsibility for protection and management of local forests was placed largely in the hands of communities, in return for the right to harvest certain species and areas sustainably, and to receive a fixed percentage of revenue from harvesting by the State Forest Department (Roy 1989; Mukerji 1992). By the mid-eighties, evaluations began to show with indisputable clarity that where communities had been encouraged to share custodian functions, degradation had declined and often come to a total halt. Where communities were not involved, degradation had accelerated (Arnold 1990; Poffenberger et al. 1990). In 1988 the national government of India responded to these experiences by approving an entirely new National Forest Policy which emphasised local involvement and provided state Forest Departments with guidelines (1990).

Joint Management Agreements between communities and Forest Departments have become the main tool of this collaboration. The agreements outline what products the community may use, the planting regimes, the procedures for resolving conflicts between community and Forest Department, and so on. The critical institutional entity throughout India is the Forest Protection Committee, formed either at the village level or where a number of communities are involved, at the wider, panchayat, level depending upon requirements. By 1992 nearly 2 million hectares of forested lands were being protected, managed and used by more than 10000 community institutions (Sarin 1995).

Similar reconstruction of the strategies and related institutions of forest management and utilisation has also occurred in Nepal. Nepal was one of the last countries in the world to nationalise natural forests (1956), and immediately began to feel the consequences (Bartlett 1992). Decentralised and collaborative forest management was launched in the seventies. In 1978 the 
government promulgated new Forest Rules to promote the handover of forests to local panchayat authorities. Ten years later a new Forestry Master Plan was approved promoting the protection and handover of forests directly to user communities. In early 1990 Operational Guidelines were published, revised in 1992, and a new Forest Act promulgated in 1993, all supporting and refining community-based forest management. The core institutional development at the local level is the Forest User Group. In 1994 there were at least 3000 registered in 69 of the total 75 Districts (Wily 1995a). Two-thirds had prepared Operational Plans covering the use and management of plantation and natural forest areas, although less than half of the Forest User Groups had been formally designated as Managers of the forest in question.

The following features of the Indian and Nepalese experiences are of special note:

- Recognition that forests cannot be satisfactorily retained, conserved or managed by governments alone is the explicit basis of the shifts in policy, institutional development and statutory amendment. Senior officials have even publicly observed that the single biggest mistake over the last 100 years has been the removal of authority over forest land from communities to state (Roy 1989).

- Much of the forests under community management are plantation forests, bamboo or natural sal forests (Shorea robusta). These are fast-regenerating forests, much faster than miombo woodlands (Chapter 2).

- The size of forests under collaborative or community management is generally small. In Nepal these average only 23 ha (Wily 1995a).

- The range of forests subject to collaborative management and utilisation is proscribed by national policy. Wet, montane forests, considered important for water catchment or biodiversity have tended to remain under full government protection and management.
- The extent of utilisation and economic dependence upon sal, bamboo and related wood and non-wood products (especially leaf litter) is unusually high, especially for poorer members of the community, and the incentive for communities to use the forests sustainably is considerable. Recognition of the role of non-timber forest products in local production systems has been a consistent feature of appraisal and management regimes.

- Although community-based forest management is now national policy in both countries, these changes began at the local level, and those experiences prompted changes in state policies and then national policy. A range of agencies have been involved and are still involved with promotion of community-based forest management. In India, NGOs have played a crucial role as mediators and mobilisers of local institutional capacity and Indian policy recognises and promotes this role (Poffenberger 1990). In Nepal, multilateral and especially bilateral projects have played a major role and success is generally greater where such projects operate (Wily 1995a). Academic institutions are also involved and invited to conduct research (Campbell 1992). The roles of state Forest Departments, and the roles of communities, are increasingly well-defined.

- In both countries, the involvement of communities stops short of divesting ownership of the forests from state to local communities. In India the dominant mode is collaboration with government, revenue-sharing being a prominent feature. In Nepal, whilst the Forest User Group is formally mandated as Forest Manager, and for all intents and purposes may be considered the 'owner' of its forest, state law and policy makes it clear that the forest remains in the national estate (Talbott and Khadka 1994).

- In both countries, an important element of the processes of establishing local management 
has been the re-articulation of traditional systems of management and use (Bartlett et al. 1993). An important factor in success has been repeatedly identified as the extent to which local forestry officials are willing and capable of promoting and supporting locallevel forest management (Bartlett et al. 1993; Talbott and Khadka 1994).

- Those involved in joint management schemes in India and Nepal reiterate the importance of attitudinal change within tradition-bound forest departments, as well as in communities which have been disallowed from managing their traditional forest areas for sometimes many generations (Roy 1989, Poffenberger 1990; Mukerji 1992; Asia Sustainable Forest Management Network 1994). There is also widespread recognition that whilst communitybased forest management is indisputably an improvement on past regimes and fundamentally sound as a cost-effective and sustainable conservation and management strategy, it is not problem-free and a multitude of challenges remain (Sarin 1995). Recognition is growing that the initiative represents a dynamic process which needs flexibility, time and opportunity to evolve and mature, and to diverge to fit different local circumstances and needs. The role of government in the partnership is acknowledged as one key area still requiring address. It is notable that with each year, the spheres over which Forest Departments exercise regulatory control decline.

\section{Collaborative management in Ghana}

Many other governments around the world have begun to adopt collaborative or community-based forest management strategies to one degree or another. One such case is Ghana. From 1993, the Ghana Forestry Department determined to begin working directly and collaboratively with communities in the management of forests, as a mechanism for making more real its policy that all sections of society should be able to benefit from the nation's forest estate (Forestry Department 1995). Quite far-reaching policy and legislative changes have already been made to facilitate this commitment, particularly in terms of determining to increase forest values to farmers, land owners and rural communities, through new management strategies of timber and non-timber products, on and off farm.

This included a substantive review and update of the policy, planning and control systems of the Forestry Department, leading to the decentralisation of planning. Unreserved forests have been directly included in the management of timber production, rather than allowing them to dwindle through issue of unmanaged and unmonitored concessions. Recognition of the importance of such forests to local communities is explicit in the steps taken to significantly reduce the distrust that has grown between Forest Department and local people. A Collaborative Forest Management Unit has been established in the department to promote partnership with local people and to increase the benefits to them. Communities and their chiefs are directly involved in processes designed to reduce illegal felling on unreserved land. Schemes increasing the value of non-timber forest products are being promoted (Forestry Department 1995).

\section{The CAMPFIRE initiative in Zimbabwe}

An early and influential initiative in the miombo region enabling local people to benefit from their natural resources has been centred on wildlife. The CAMPFIRE programme of Zimbabwe emerged under the aegis of a legal mechanism which granted 'appropriate authority' to rural councils under the Parks and Wildlife Act (1975) and sought to ensure that revenue derived from wildlife (hunting concessions, safaris, trophies and ecotourism) reaches councils and communities, not just the Treasury. Councils thus gained an incentive to promote and invest in wildlife schemes, receiving support from NGOs and the Department of National Parks and Wildlife Management. 
Reviewing operation, Scoones and Matose (1993) observed that greatest success has occurred where authority, benefits and management have been devolved to the communities producing or affected by wildlife, and that the smaller the unit of proprietorship of the resource, such as the traditional village (usually about 20-120 households), the more likely the success. They also noted the importance of institutional capacity building to the programme and urged that this go below the district council level; that the local management group requires a collective identity; that those living within the resource area should have the major benefits from the revenue derived, through a decentralised revenue distribution system; and that incentives for resource management should be established at the local level, including access to technical skill improvement. Multi-sectoral involvement and participation was considered helpful to the success of co-management schemes.

The CAMPFIRE initiative has provided a useful example to many other miombo countries and a range of similar revenue-sharing schemes has evolved (Box 8.1). Many observers consider the principles of the programme applicable to woodland management in general, not just wildlife.

\section{Current trends: towards community-based management}

The last years of this century are proving to be an exciting period in terms of strategies of forest management and supporting institutional innovations. Examples given above, and in Boxes 8.1, 8.2 and 8.3 , illustrate the major direction of the changes that are taking place; a clear move away from the centralised and state-driven forest and woodland management of the colonial period towards decentralised, and mainly community-based regimes. In the course of this shift, the social formation of 'community' and the institutions and mechanisms which support its functioning as a management entity, are being defined in new and significant ways.
Overall, the lead institutional transformations appear to be at the local level, with government and non-government agencies accordingly reshaping their own functions away from direct management functions towards supporting technical and advisory roles. The nature of institutional change varies from place to place, as does the speed at which it is occurring. Nonetheless, the singularity of direction towards community-based forest and woodland management is startling.

Over the last decade local user groups have become co-partners in forest management, or the management authority of one or other natural forest in at least thirty different countries across the world and probably more (Messerschmidt et al. 1993; Wily 1993a; Fisher 1995). Significantly, there does not appear to be a comparable momentum in devolution of forest conservation and management responsibilities to the private sector or to private individuals within the small-scale sector (devolution is widely acknowledged as a successful strategy within the large-scale commercial sector in Zimbabwe, where local conservation committees oversee resource use issues, and where a major stimulus to wildlife use and conservation came with giving control over use to individual farmers). Everywhere there seems to be implicit recognition that forests and woodlands are by nature, size and use, not well-suited to individual tenure or management within the small-scale sector. Even in more developed economies such as Portugal and Italy, situations where communities continue to manage local forest resources are receiving encouragement rather than hastened demise (Brouwer 1995; Merlo 1995).

The driving forces in this change have been propelled by conservation objectives. There has been growing awareness that forests are dwindling in scale and quality, and that there is concern to retain what remains intact and to find ways to use the resource more sustainably. Whilst the role governments have played in the past as forest conservators, mainly through creation of reserves, 


\title{
Box 8.1 \\ Community resource use in the miombo woodlands of Tanzania
}

\author{
Alan Rodgers and J. Salehe
}

Miombo woodlands cover some $45 \%$ of Tanzania, of which about half is made up of some form of protected area (National Park, Game Reserve or Forest Reserve). Protected areas have historically excluded resource use rights for local people, and remain under control of central government, although management may be entrusted to district government staff. However, district control has collapsed in recent years and illegal exploitation has increased.

Modern paradigms for resource conservation stress community involvement to ensure sustainable resource use (IIED 1994). A number of trial, participatory models have been initiated in Tanzania, largely within the wildlife sector, but these have not led to an understanding of the conditions necessary for successful schemes.

The Selous Game Reserve Conservation Programme has invested heavily in village-level wildlife utilisation schemes. These are designed to offset people's resentment at being excluded from the Game Reserve and suffering considerable crop loss from wildlife moving out of the reserve. The scheme makes no attempt at empowering local people; even the animals harvested for meat are shot by the project staff 'on behalf of the people'.

The Management Support Project for Ruaha National Park has a large community component. However, there are serious institutional difficulties arising from Tanzania's separate wildlife authorities. The Park is controlled by the National Parks Authority who will not countenance any form of peripheral buffer zone within the Park itself. When an animal moves out of the Park, it is under the control of the District Wildlife Officer, with only advisory input from the Wildlife Division in central government. While villagers should be given control and access to many of the resources on village land, this does not include wildlife, even if wildlife is causing crop damage. Village lands are open for hunting by tourists and wealthy residents, but no fees are returned to villagers. Central government advocates greater community participation, but decisions are made at district level, where greater weight is given to lobby groups of local and outside hunters than to villagers. In addition, wildlife densities are low, and the lack of wildlife resources increases competition and so exacerbates the conflict between hunter and villager, and gives minimal returns to individual people in the villages.

Ugalla Game Reserve in Tabora Region now permits regulated utilisation, by registered cooperative organisations, of honey, and fish from Ugalla River. Wildlife hunting is restricted to tourists (sable, roan, kudu) and timber harvesting of Pterocarpus angolensis is forbidden. This pattern of exploitation is new, having been approved in the official 1994 Management Plan for the reserve. Unfortunately, there is no investment in the co-operatives themselves, little socio-economic analysis, and no mechanism for monitoring resource use or local perceptions of the scheme.

In the forest sector, community forestry initiatives began in the late 1970s. These had limited success, linked to poor performance of co-operative ventures, lack of clear title deeds, etc. The programme has now narrowed to three regions, Arusha, Singida and Dodoma. The joint management scheme in Babati District, Arusha Region, of previously unreserved and degrading miombo woodland, indicates the potential for success of such schemes, given appropriate incentives (Wily 1995c). Here local people within 16 hamlets have the power to protect and potentially manage the woodland resources, with advice and support from District forest staff (Box 8.3). It is anticipated that this pattern of resource management will spread in Tanzania. 


\title{
Box 8.2 \\ A preliminary prognosis of the incentive structure in a pilot resource sharing project in Zimbabwe
}

\author{
Calvin Nhira
}

The incentives that are required for joint management (resource sharing) programmes for natural resources can be broken down into two major categories: user-enabling incentives which are largely material, and policy-enabling incentives which are largely institutional (Barbier 1988). With regard to forestry-based programmes, user-enabling incentives would refer, briefly, to the promotion of multiple uses and multiple products as outputs of forests (implying that management objectives would have changed to responding to both people's needs and to ecological functions). Policy-enabling incentives can be collapsed into the granting of support to communities to enable them to take over proprietorship and management responsibilities for forests (IUCN/UNEP/WWF 1991; Murphree 1993; Martin 1994).

With respect to policy-enabling incentives, political imperatives may necessitate 'transitional' arrangements under which a partnership is struck between government agencies responsible for managing the reserved forests and local communities, either because local institutions are not perceived as robust enough to take over sole management responsibilities or the resource is deemed too important to be left to communities alone.

In Zimbabwe, in the pilot resource sharing project around Mafungabusi State Forest, significantly fewer benefits are on offer compared, firstly, to what communities obtained illegally from the forest reserve before the orchestration of the project and, secondly, to community demands made during the feasibility study for the project (Nhira and Matose 1995). This is largely because the statutory agency responsible for forests demands a project that would be friendly to its current mandate, whose emphasis is on the maintenance of the ecological functions of forests. Thus there is hesitancy to undertake activities whose ecological impacts are unknown. With respect to policy-enabling incentives, the statutory agency has tended to sideline activities that would build capacity within communities, increase their negotiation capabilities and create a more balanced partnership between the state agency and communities. This is shown through unilateral powers of veto held by the statutory agency over what can or cannot be implemented in the forest reserve.

The incentive structure for the Mafungabusi project needs to be revisited and remedial action taken. Such action will have to take as its guiding principles: i) that all components of the project should be negotiated with communities at every stage; and ii) that an adaptive management framework which uses feedback from monitoring and evaluation activities is necessary since all relationships (ecological, economic, social) cannot be predicted.

is respected, there is recognition that governments and government agencies have not ultimately proved to be the most effective custodians in retaining forests free from encroachment and degradation. Even where they have been effective, this has rarely been through means that are costeffective or sustainable in the current environment of economic stress. The policing strategies that form the core of most state forest management regimes have been a particular focus of reassessment. It is frequently concluded that the institutional frameworks required to operate these regimes are financially no longer viable, and the principles of state protection they embody actually encourage conflict, and thus expense.

In some countries, the driving force has been indigenous land rights, usually combined with the need to find more sustainable and cost-effective 
means of timber harvesting. These have been key factors in regard to Canadian forests (Haley and Luckert 1992; Bombay 1993; Bray and Irvine 1993; Kosek 1993), some forests in the United States (Davis 1993), Mexico (Richards 1992; Bray et al. 1993), Peru (Lazaro et al. 1993), Bolivia (Chase Smith 1993; Davies and Johnson 1994), Ecuador (Shigunango et al. 1993) and Venezuela (Dunn 1994a). Aside from the prominent cases of India and Nepal, community-based forest management is emerging as the dominant strategy for conservation and sustainable utilisation regimes in Sri Lanka (Carter et al. 1994), Thailand (Poffenberger and McGean 1993a) and the Philippines (Poffenberger and McGean 1993b).

The establishment of communities as active partners in forest management has been more recent and less widespread in Africa, and derives mainly from individual, donor-funded initiatives (with CAMPFIRE the exception), not from the implementation of new forest or natural resource policies or related institutional reforms. Moreover, in virtually all cases, specific forests have been the target of innovative, community-based approaches. Nonetheless the trend is clearly establishing itself, one project after another finding recourse to the local level and to local people as the logical way out of spiralling forest degradation, unsustainable harvesting of resources, and costly protection regimes.

Current examples exist in the Cameroon with regard to the valuable montane forests of Kilum and Ijim and where there is now recent supporting legislation (Nurse et al. 1994), the forests of the Senegal Valley (Diouf 1994), the Gshaka Gumti Park in Nigeria (Dunn 1994b), woodlands near Mopti in Mali (Skinner 1988), the Gusselbodi forest in Niger (Kerkhof 1990), the Toumousseni forest in Burkina Faso (Hagberg 1992), the El Ain woodlands of Sudan (El Din and Shanks 1992), Mt Elgon of Uganda (Wily 1993b) and the DuruHaitemba and Mgori Miombo forests of Tanzania (Sjoholm and Wily 1995; Wily and Haule 1995).
The above are examples of cases where local communities have a clear role in management, in some cases full responsibility, and in the last case (Tanzania), as the owner-managers of miombo woodlands (see Box 8.3). There are, in addition, a number of cases where local people are recognised as having legitimate claim to use local forests in certain ways through the establishment of use zones on the periphery of governmentowned forests, or where they are beneficiaries of revenue-generation agreements, or recipients of accelerated investments into areas directly adjacent to forests (buffer zones, and displacement activities). These are limited forms of community involvement. They do, however, at least acknowledge the importance of local communities in conservation and sustainable use management and often provide a stepping stone to more direct transfer of responsibilities and authority. As Fisher (1995) has observed, collaborative approaches to natural resource management involve recognition of, firstly, the need to integrate conservation and development, secondly, the legitimacy of the rights of local people to secure their economic future, and thirdly, the value of seeking the active involvement of local people in environmental care and management.

The nature of the strategic and institutional shifts that are occurring in forest and woodland management have given rise to widespread interest in two previously unexplored areas: ways in which rural peoples may have owned and regulated access to forests prior to state co-option of control; and interest in the role and value of non-timber forest and woodland products. A burgeoning literature on both are available (Messerschmidt et al. 1993). There are elements of current communitybased strategies that represent a revival of traditional natural resource management regimes. These authors would caution against over-emphasis of this aspect, however, for whilst there is consistency in the overall framework (community) and key actors (leaders) between the pre-colonial 


\section{Box 8.3 \\ Village forest reserves: a new forest and woodland management strategy in Tanzania}

Rogers Malimbwi

The management of natural forests and woodlands in Tanzania is becoming increasingly ineffective due to growing pressure from local communities through encroachment and unplanned harvesting. Under a forestry programme in Tanzania a form of natural forest management that is cheap, sustainable and effective is emerging, manifest in what is becoming the first Village Forest Reserve in Tanzania. A case study is presented for Duru-Haitemba forest (Sjoholm and Wily 1995).

Duru-Haitemba forest, $9 \mathrm{~km}^{2}$ in area, is one of the few remaining tracts of dry miombo woodland in the well-settled and agriculturally important Babati District of Arusha Region. The forest is degraded with little timber. Nonetheless, the forest remains important to the local community, providing upwards of seventy different items for household use, acting as a source of water and ensuring soil protection.

During the colonial period, if not before, hamlet elders had regulated the use of forest resources through a series of social-environmental rules. Some areas such as the Quaymanda were completely protected for spiritual purposes. At least thirty such untouched forest patches remain operational in Duru-Haitemba forest today. Certain tree species, often those with water catchment functions such as Ficus sp., were protected throughout the forest, and there was a fine for damaging such a tree. A move by the government in 1992 to demarcate the area as a proposed forest reserve provoked serious consequences. Within two years the forest changed from a once magnificently conserved area to a major source of charcoal and timber, with rampant encroachment. Villagers wanted to remove what they could as fast as possible, before they lost the forest to the state.

It took little time to realise that the conservation status of the forest could only be secured through the 'return' of ownership of the forest to the people. The logical framework for this was on a village-by-village basis, each village managing the part of Duru-Haitemba Forest which had traditionally fallen within their village boundaries. These boundaries were physically demarcated in preparation for the issue of Village Title Deeds for which the villages had applied.

Within a week each of three villages came up with a practical management plan for conserving their part of the forest. Rules were laid down and these fell into the following main categories:

- forest uses which could continue unhindered given their non-damaging nature (e.g. the collection of wild fruits and deadwood);

- forest uses for which permits should be issued by village governments (e.g. collection of poles, which would be limited by area, species and number of poles); and

- forest uses which could no longer be carried out and for which major fines and other punishments would be imposed (e.g. forest clearing for farming, charcoal burning, bark stripping, tree felling and pit-sawing).

Within six months village-based forest management became strong, with little advisory input from the government or other technical officers, and no financial support. The only fear of the villagers was that their success would result in a rehabilitated forest which would then become attractive to the state.

The Tanzanian experience supports the contention of Dewees (1994) that "a growing body of evidence strongly suggests that the only way of preventing the complete loss of these woodlands is to empower local people to manage them or to otherwise legitimise local management". 
past and modern regimes, the conditions of the present require exercise of a level of consciously directed management that was almost certainly neither required nor the case in the less-stressed conditions of pre-colonial times. In any event, as touched upon earlier in this chapter, it is difficult to reliably identify how far supposed pre-colonial regimes are in reality reconstructions of the colonial period.

A similar caution is urged in respect of the economic determinism that has come to permeate every consideration of strategic and institutional forest and woodland management in the late 20th century. There is no doubt at all that the local use values of forests have been seriously underestimated and even misunderstood up until the recent present. The recent spate of forest use assessments and valuations, and the emergence of a whole new discipline of forest conservation and utilisation economics, has redressed this lacuna. It has also possibly given rise to a sometimes dangerous assumption that unless a forest is of direct economic utility to the local community, it has no vested interest in conserving, managing and sustainably using the resource. Economic utility does represent an important incentive. However, where community-based forest and woodland authority has been well-established, it is frequently apparent that less tangible sociocultural or simple tenurial interests ('it is ours'), play as important roles in sustained community management.

\section{The way forward}

Several conclusions arise logically from the preceding review of institutional frameworks and change. Firstly, it may reasonably be concluded that conventional institutional frameworks for woodland management are proving decreasingly satisfactory in today's conditions, and subject to growing review, not only by academics, but by concerned government foresters and by people living in and around the woodlands themselves. Secondly, far from a way forward being unknown, a clear direction of institutional change is slowly but surely suggesting itself throughout the miombo region. Moreover, it is one that is logical and not a financial drain on the state and, above all, directed towards resolving the very conflicts in institutional rights and authority that have inhibited woodland conservation and sustainable utilisation.

Focal elements of desirable institutional change include the following.

- A shift in the locus of control, from central government to the local level.

- A change in the institutional framework within which woodland management is administered, from state institutions to local institutions.

- A change in the conceptual framework within which woodland management is conceived and developed, away from the dominance of state or commercial concerns towards one which acknowledges and supports the functions of woodlands in the household economy and local society.

- Change in mode of day-to-day woodland management, away from the conflict-inducing regime of policeman against user, to one in which the user has the incentive to be selfregulating and party to decisions and implementation of protection activity.

There are a number of practical steps which miombo region countries could adopt to secure progress. Firstly, there are ample opportunities from which to learn. Preceding sections have shown that there are already under way small but significant initiatives, within the miombo region and on the continent, quite aside from those elsewhere. Secondly, there is a need for each country to experiment itself, to try out new approaches of user-centred management and regulation, and to evolve workable examples of experience in the local context. Elsewhere it has been argued that in the same way as legal frameworks cannot be satisfactorily amended without the guidance of policy, 
policies themselves will be most productively reconstructed on the basis of example and the clarity of experience, not hypothesis (Wily 1995b).

A range of supporting activities will be increasingly required: policy reform, enabling legislation, institutional development and capacity building at the most local level, refined planning processes that support local-level, communitybased woodland management authority and implementation, and investment in natural resource management and sustainable utilisation. A paragraph on each of these is provided below.

\section{Policy reform}

An important element of institutional change will be policy reforms which empower communities to control and utilise resources within their areas, and facilitate the emergence of functional locallevel resource management capacity. Reform processes for management of miombo woodlands cannot be divorced from issues of common property management. Nor may they be divorced from planning procedures which, despite supposed devolution and decentralisation of authority, continue to pre-empt community-level decision making, control and capacity. In some of the miombo countries, such as Zimbabwe, where topdown processes still apply, structural institutional reform may ultimately be necessary. In others, such as Tanzania, where villages have already attained a considerable level of authority, initiatives will be needed to help them make full use of their administrative and statutory powers.

\section{Enabling legislation for woodland management}

Linked to a need to ensure an accountable and participatory planning process (Scoones and Matose 1993) is the need for legislation that allows and promotes proprietorship for woodland management to local-level institutions. Rules and regulations that unreasonably restrict or prohibit local use, or the local right to control and manage local woodlands need amendment. Regulatory frameworks will need to be more appropriately orientated towards the incentives of sound management and utilisation, and flexible enough to permit local variations.

\section{Investment in rural resource management}

Arguably, any discussion on woodland management requires an analysis of rural investment, and of income-generation opportunities and options (Scoones and Matose 1993; Dewees 1994). Zimbabwe's experiences of the Intensive Conservation Area system, based in commercial farming areas, point to effective resource management being dependent on a productive investment environment. Investment to the management system took the form of issuing advantageous credits, providing subsidies for labour, and having major capital inputs and tax incentives (Moyo et al. 1993). Structural adjustment policies, currently operating in Zambia, Malawi and Zimbabwe, could provide the basis for investment in sectors that enhance the management of miombo woodlands. Options for investment in woodland spheres most obviously include livestock, wildlife management and small-scale, forest-based enterprise developments.

\section{Institutional reform and capacity building at the local level}

The most important institutional changes required relate to the local community itself, and the ways and means in which it identifies and manages itself and is able to organise, regulate and sustain woodland management effectively. The legal, political and administrative situation at the village level varies from country to country, and the ways in which communities may now or in the future secure rights and responsibilities, will vary accordingly. In some situations where local level community institutions do not exist, the appropriate framework may need to be a collaborative agreement between a group of iden- 


\title{
Box 8.4 \\ Traditional institutions and woodland management
}

\author{
Bevlyne Sithole
}

Murphree (1993) describes communities in Zimbabwe as traditional institutions, comprising individual actors who collectively make decisions about use and management of resources. The character and function of traditional institutions is highly variable throughout Africa. In some countries, the impact of the state on the traditional institution has been profound, bringing into question any purity of tradition. Many post-independence governments created new institutions which were superimposed on existing ones. Traditional institutions were viewed as colonial constructs and/or reactionary. Nevertheless, after independence, many traditional institutions persisted, though most assumed a reduced role in natural resource management. In the southern parts of Zimbabwe, Makuku (1993) found that traditional institutions retained control over the management and use of forestry products, in spite of superimposed state institutions. Undoubtedly, changing political and socio-economic circumstances have left their impacts on the systems of traditional control, leaving them weaker than in pre-colonial days.

Most of the incumbents, advisors and perpetuators of traditional institutions are elderly and believe in the guidance provided by the spirits, who in turn are the ultimate guardians of resources and the community. The belief systems associated with traditional institutions are attacked on two fronts, from the perspectives of modern science and agriculture, and from the Christian perspective. Wilson (1993) describes a traditional institution in charge of sacred woodlands in eastern Africa, which is composed of elderly men. He suggests that when these guardians of the woodlands die, the woodlands will disappear. However, religious control of woodlands for sacred purposes has remained in many areas in spite of the widespread modernisation process (Matose 1992; Wilson 1993; Mukamuri 1995b). For example, Matose (1992) describes how traditional institutions have been protecting vast areas of woodlands as sacred areas (rambotemwa) in the southern part of Zimbabwe, the patches ranging from 20 to 200 ha.

Strong differences in institutional arrangements can be found in neighbouring villages. Campbell et al. (1995a) describe one village in which the traditional structures are strong and effective, comprising a sub-chief, village leader, advisors and resource monitors, while in the neighbouring village decision making is split between traditional and modern systems, with no effective systems of local control. In this case the demise of the traditional system was largely a result of an influx of migrants.

There are many examples in Africa where the government is withdrawing from active management of resources at the local level, largely due to fiscal limitations. Traditional institutions often fill the vacuum created by the departure of the state. For example, in Tanzania, Mlenge and Johansson (1992) document the revitalisation of the dagashida, a traditional institution based on the representation of all social strata on a village assembly. This assembly formulates institutional arrangements to regulate patterns of resource use by the community. The dagashida has become active after 18 years of dormancy.

Current initiatives in the region to empower local institutions have given prominence to traditional institutions. Empowering traditional institutions should not be seen as a panacea. As Murphree (1993) states, expecting traditional institutions to be effective in the contemporary situation is not entirely realistic. 
tified users and the agency which retains supervisory authority. In other cases a slow but sure movement towards woodland community identity may be achievable through initial use of institutional forms such as co-operatives, companies or local NGOs which have an acceptable and workable legal basis. The promotion of the capacity of local-level institutions to generate appropriate management and regulatory regimes may, in some states, require considerable facilitation and even financial support. The experiences of many countries suggest that NGOs are often an appropriate agency in these tasks. However, of all lessons arising from community-based forest management, the most consistently important is quite simply that most successful and sustainable natural resource management emerges where the community itself is the driving force, and generates its own strategies, its own institutional form for regulating woodland use and management, and within a socio-economic context over which it has complete control. As with all rural development, the main challenge will be to prompt and facilitate such empowerment. This chapter has focused on legal frameworks and formal organisations. As important in developing a way forward are informal institutional and organisational forms (Box 8.4). 


\section{Chapter}

9

\section{MIOMBO WOODLANDS AND RURAL LIVELIHOODS: OPTIONS AND OPPORTUNITIES}

\section{Bruce Campbell and Neil Byron ${ }^{1}$}

In this final chapter, we attempt to highlight the linkages between the topics covered in the previous chapters through the development of a conceptual model. This then becomes a basis for the identification of key research questions, as well as the basis for examining the potential impacts of possible reforms.

\section{Determinants of change in miombo woodland use and value}

In Chapter 1 it was argued that our central concern should be with change, given the changing demands of African societies, and the large amount of woodland that is cleared annually. How and why are changes occurring in (i) the area and functioning of miombo woodlands; (ii) people's use patterns and perceptions; and (iii) the benefits derived from miombo woodlands?

We look at miombo woodlands as a complex, interactive ecological-social-economic system. Central to our model of change in the system are resource scarcity, commercialisation, local

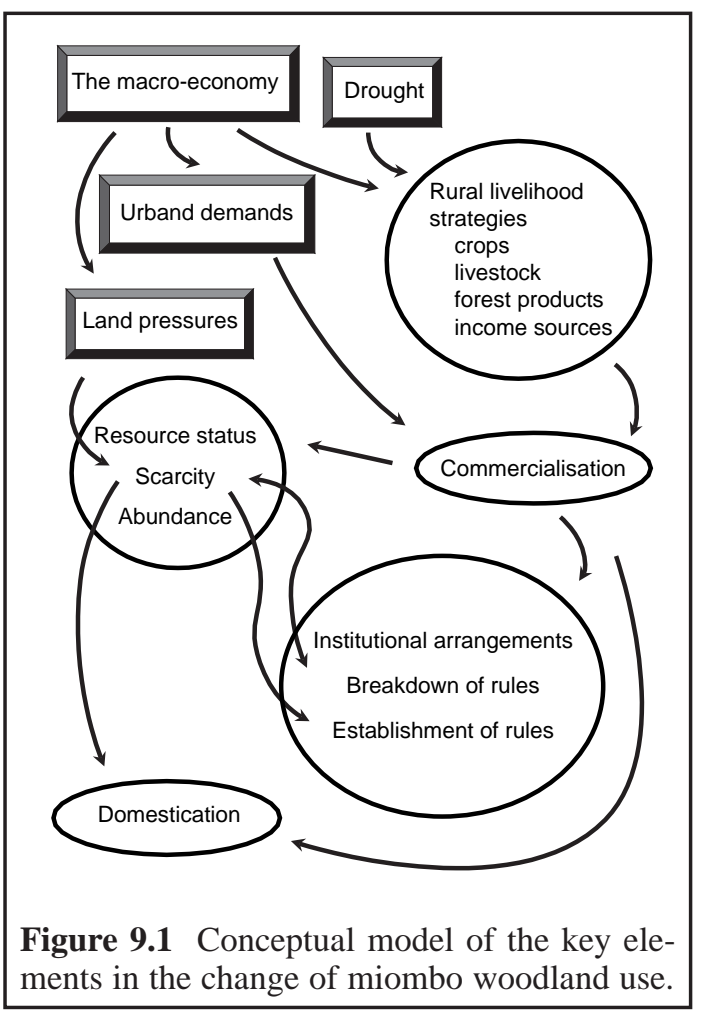

\footnotetext{
${ }^{1}$ In the course of preparing this book, and in conjunction with other regional and international initiatives, the authors attended a series of meetings in which key research questions were identified. This chapter has benefited from such meetings and from the process of developing the preceding chapters with the respective authors.
} 
institutional arrangements, droughts, rural-urban relations and the macro-economic framework (Figure 9.1). This macro-economic framework permeates rural households, determining the kinds of processes that operate, influencing, for instance, land pressures, degree of commercialisation, and the relative value of agricultural and woodland activities (Chapter 4).

Increasing scarcity of miombo woodland resources is largely a function of clearance of woodland for cultivation, and increasing extraction levels of products to satisfy urban demands. Land pressure in the communal lands varies both within and among countries, and is a result of growing populations, limited alternatives to farming and inequitable land distribution.

Policies, both present and past, such as villagisation, resettlement and tsetse control have all contributed to clearance of miombo woodland, often unintentionally. Inappropriate economic policies, subsidies to agricultural production (Box 4.4) and, recently, structural adjustment have increased pressures on woodlands, though the inter-connections have received scant research treatment because the impact of the policy framework on miombo woodlands and those who depend on them, were not considered important enough, or were simply not considered at all.

One characteristic of the miombo woodland environment, the fluctuating rainfall patterns and the frequency of droughts, works to reinforce reliance on woodland products. In times of drought (as in other times of hardship and hunger) rural households turn to woodland products as a source of sustenance and cash income. Woodlands have been an emergency resource and a buffer, providing a livelihood of the last resort when other options retreat. But how long can this role continue under intensifying pressures?

Central to the change in use patterns and the change in the miombo woodlands is commercialisation (Chapter 6). Populations in urban areas have been growing much faster than those in rural areas. Urban households require many products from the woodlands. The urban demand for fuelwood probably has the most widespread negative impact on the woodlands, but the impact of the demand for other products, for example medicinal plants, is likely to have an equally negative effect on specific resources. Stagnating urban economies, as exist throughout the region, generally increase the demand for woodland products. We have witnessed a major upsurge of trade in certain products in the last few years, notably craft products, fuelwood, fruits and medicinal plants, though the patterns have not been well documented. It is unclear who are the primary beneficiaries of such trade. Are the more valuable resources being appropriated by elite groups or urban traders? How is commercialisation influencing rural livelihoods and food security?

In our conceptual model, we explicitly recognise some of the many components of rural livelihoods, as life in the rural areas is a continual shift of emphasis among the different livelihood strategies. In the miombo region, these encompass livestock and crop production, use of woodland resources and off-farm employment (Chapter 5).

If resource scarcity arises, under some circumstances local institutional arrangements tend to collapse, and the situation arises where a diverse range of locally illegal practices emerge (Campbell et al. 1993). With the breakdown of rules and controls, further resource depletion occurs. Some resources are increasingly derived from land under private control, and some communal resources may be privatised. Yet under other circumstances, new institutional arrangements arise (e.g. by-laws), and communities re-assert their rights to communal resources (Box 5.6; Chapter 8). It is not clear which circumstances lead to breakdown of rules and which lead to rules being re-enforced, but we speculate that the basic differences lie in the strength and coherence of the existing community, its self-identity and recognition, on the one hand, 
and on the other, the nature of the market in terms of its speed of change and value.

Increased abundance of resources has, in most cases, not been observed, i.e. the feedback between re-establishment or re-enforcement of rules has yet to lead to increased abundance. In addition, domestication of resources is limited. In the cases where it has been observed it is often driven by interests in commercialisation, in conjunction with resource scarcity.

We find it useful to separate exogenous factors driving change (e.g. macro-economic policies, drought) from endogenous factors (e.g. nature of traditional institutions). These interact, perhaps with the endogenous factors setting up a cycle of events that are modified by the characteristics of the endogenous factors.

\section{Rural livelihoods and miombo woodland products}

In Chapter 5, three crucial points are made. The first is that miombo woodlands provide a wide range of products and services to rural households, and that these are likely to make an appreciable contribution to rural household income and welfare. Miombo woodland products contribute to rural household welfare in a range of direct ways, providing food and non-food consumption goods, durable goods, inputs into income-generating activities, inputs into agricultural and other production activities, and inputs into asset formation and maintenance (construction, livestock, food). In addition, miombo woodlands provide a range of indirect values, whether environmental (watershed protection, soil preservation), aesthetic or spiritual.

The second point is that woodland resource use is characterised by strong differentiation across uses and across households. In order to explain this pattern of resource differentiation, a conceptual model is proposed (Figure 5.4) which suggests that the key driving variables are institutional (tenure and local and state authority), degree of commercialisation, features of the household (such as wealth status or labour availability) and features of the resource (such as scarcity levels, distances to resources and spatial variability, and the existence of substitutions and backstops).

The third point is that as a result of the value of miombo products to households, a range of local practices, rules and institutions have emerged. While a host of practices can be identified, it remains unclear as to how these practices contribute to sustainable management (see Management options below).

While there are many case studies on the use and diversity of miombo products, a household perspective of resource use is extremely limited. Some of our generalisations are derived from a single village in southern Zimbabwe (Cavendish 1996), and the lack of time-series data and historical observations hampers a dynamic perspective. Examining the issue of resource use from the household's perspective has two strengths. The first is that elucidating the range of factors which underpin resource demands leads to a natural explanation of the various dimensions of differentiation which characterise miombo woodland resource use. The second is that, by using this framework, it is possible to synthesise a large section of the case-study literature on miombo woodland resource use. As a matter of urgency, we recommend further studies on household economics and the role that miombo products have in livelihood systems, with emphasis on how and why this role varies in space and time.

The connection between use of miombo products and household decisions concerning risk has been all but ignored in the research to date. The debate on household economics also has to consider broader community organisation. Household decision-making takes place within an arena influenced by a variety of social obligations and cultural norms. 
As a broad key question and as a structure about which to organise new thinking on these issues, we propose:

- How do woodland-based activities contribute to various dimensions of household livelihood systems and strategies (socio-cultural, risk, income and subsistence)?

\section{Changing markets}

Chapter 6 on the trade in miombo products is largely based on the available literature. Since this is limited and uneven in its coverage, the result is that certain products are more thoroughly covered than others. For example, while the coverage in the literature on fuelwood and honey is in some depth, for many other miombo products, such as edible insects, mushrooms and other edible products, coverage in the literature is extremely limited. Coverage is also uneven between countries; while the charcoal trade in Zambia has been covered in enough detail to allow for an adequate discussion of the sector, in Malawi, the market is much less well understood (Dewees 1993). A more in-depth review of the 'grey' literature would only go part way to solving the shortfall in information on the trade in these products. Gaining a clear picture of how products are entering the market, trends in commercialisation and the socio-economic and environmental impact of these processes is not going to be advanced by 'more of the same' kinds of research. An in-depth analytical approach to marketing of woodland products is needed; we do not need more lists of products, descriptions of marketing chains, etc. Our understanding will only be obtained through a cohesive programme of primary research.

Though the literature survey is not exhaustive, it does reveal the inadequacy of the information on the impact of trade on rural households. First, most studies of miombo woodlands have been carried out with the focus explicitly on the resource side rather than the user side, with the result that data relating resource use to socio-economic status are available only for the simplistic stratification of 'wealthy' versus 'poor'. Secondly, few studies of trade in miombo woodland resources offer an analysis of this trade within the context of the total household economy. The results reviewed in Chapter 6 are likely to be conditional on the area and year of study. More studies are needed from other ecological zones, from countries other than Zimbabwe, and across years with varying climatic conditions, before generalised patterns of use can be proposed. Our understanding of the temporal dimensions of markets and marketing channels, their contributions to livelihood strategies and gender differentiation, their impacts on local institutional arrangements and on woodland structure and function is still extremely limited.

There are many customary rules banning the sale of woodland products. When commercialisation occurs, does it result in the general breakdown of local rules and practices (e.g. even those that limit over-exploitation)? Alternatively, is commercialisation more likely in communities where customary institutions and regulations are weak? What drives commercialisation? Is it a case of outsiders (perhaps urban dwellers) coming into rural areas to extract resources (perhaps indiscriminately) or is it local people responding to opportunities and market forces? Is the commercialisation process driven by urban demand or by the quest for cash income by rural households? Dove (1993) depicts commercialisation of forest products in a very negative light, believing that commercialisation works to the benefit of elite groups rather than local communities, and thus in the end provides few incentives for local communities to manage resources on a sustainable basis. Similarly, Cunningham (1993) and Richards (1993) conclude that the outlook for the sustainable extraction of non-wood forest products is poor if left solely to market forces. Commercialisation can provide significant benefits to producers, as 
in the case of charcoal, but is commercialisation to the detriment of the environment (Monela et al. 1993)? Answers to these questions may depend on the policy environment within which commercialisation takes place. Can the state provide an enabling environment for local communities to benefit from commercialisation on a sustainable basis?

Given the rapidly changing environmental and socio-economic conditions in savannas and peasant farming areas (Frost et al. 1986; Campbell et al. 1995b), it is presumed there is considerable flexibility of household activities. Contrary to the notion that specialisation of labour into particular activities should maximise incomes, we hypothesise, following Bradley and Dewees (1993), that diversification and versatility in the miombo environments are the key components to increased incomes from woodland products. Perhaps this is partly a reflection of the relatively low unit values of miombo products, which can support opportunistic, short-term or emergency usage, but would not be sufficiently profitable as a basis for specialisation.

Because of the diversity of marketed products obtained from miombo woodland, there is a need to place the products within a typological framework that explains the patterns of marketing, the nature of extraction, the impacts of the markets on local institutions, the degree to which the markets complement household production strategies, and the impact of markets on ecological sustainability (Ruiz 1995). Classifications of products such as those based on plant parts, or the categorisation into animal and plant products, are becoming increasingly unsatisfactory, as such classifications are information poor and have little predictive value.

As a first step, but based on limited quantitative information, we have used a multivariate technique to explore variation in product type (Figure 9.2). ${ }^{2}$ On the scatter diagram, the distance between the products reflects the differences between the products, in terms of the variables used in the analysis; variables such as the ecological impact of harvesting, the gender of harvesters, whether the good is an inferior product (in economic terms), the complexity of the market chain and processing, the source of the products, etc. From our analysis, we propose two important gradients in products. At one extreme of the first gradient, we have products that are largely marketed by women and children in an opportunistic manner. These are largely wild foods, both plant and animal. At the other extreme are products marketed by males. Unlike the markets dominated by women and children, these male-dominated markets tend to be less opportunistic and less seasonal. In addition, there is greater specialisation within these markets; the entire livelihoods of some producers depend on such markets. Many of these products are wood-based, but also included are wild birds and honey. The second gradient, represents a shift from inferior goods largely consumed in rural areas (bark fibre, wood for utensils) to superior goods consumed in urban areas (as epitomised by honey and mushrooms).

For future research, we believe that priority should be given to understanding the impacts of commercialisation. We believe that trends in commercialisation are going to be at the core of change in rural life. We propose the following broadly defined key question:

- What are the relationships between commercialisation and:

$\Rightarrow$ local institutional arrangements;

$\Rightarrow$ household livelihood strategies, and

$\Rightarrow$ woodland structure and function?

2 We thank Manuel Ruiz Pérez (Center for International Forestry Research) for stimulating this research direction. 


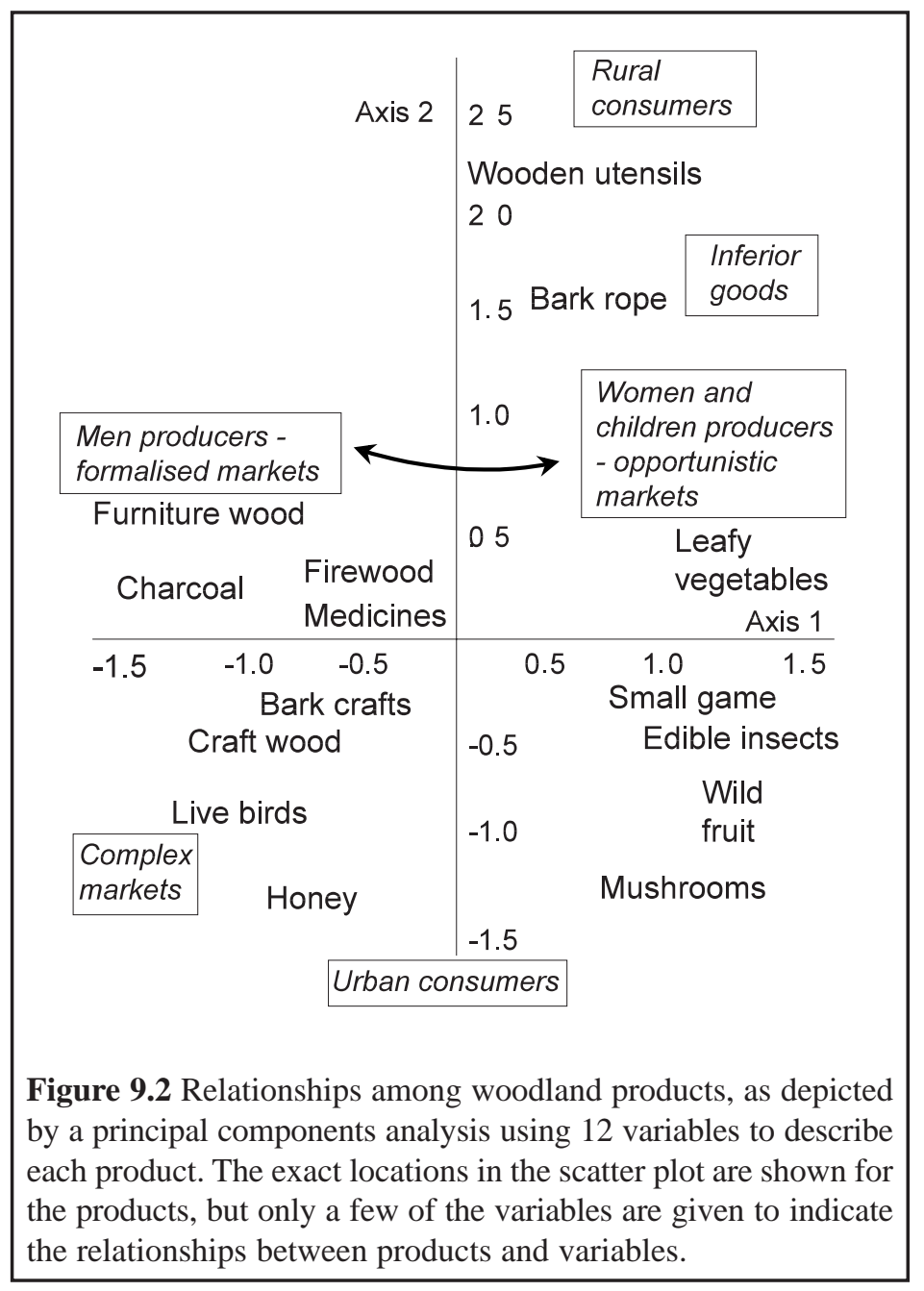

The importance of the contribution from miombo woodland to household welfare is a large part of the ethical basis for moves to hand decision making and some measure of control back to the people who are the local users and managers and/or were the traditional 'owners' of the woodlands in pre-colonial times. There are no local examples, at least for schemes lasting more than ten years, indicating that initiatives to hand back control to local people will result in long-term sustainable extraction. Furthermore, we know that people's use patterns change. We also know that rural communities are undergoing rapid social, economic and political change as the development and modernisation process spreads and deepens. Even if an effective and viable woodland user group exists or can be put in place today, will it survive and persist, in the face of modernisation pressures?

Dewees (1994) suggests that finding equitable mechanisms for devolving natural resource management through processes of local institutional change

\section{Local institutional arrangements}

From the previous discussion it is obvious that local institutional arrangements are at the centre of several themes, and these have been addressed in several chapters $(5,6$ and 8). Our understanding of the dynamism of these arrangements is sorely limited. Under conditions of increasing resource scarcity, it is apparent that diametrically opposite results can occur. should become a central feature of woodland management research. We hypothesise that the 'transaction costs' of establishing and maintaining institutional mechanisms for local resource management may be high, to the point where CAMPFIRE-type arrangements (Chapter 8) would only be possible with high-value resources such as wildlife. Transaction costs include the non-market costs involved in community-level conflict resolution (Sithole and Bradley 1995), 
time spent in meetings to discuss resource management and benefit disbursement, and time spent on resource management. If such a hypothesis holds, what are the chances for local management of low-value resources? We need to identify the kinds of communities in which transaction costs are low, to identify simple, effective mechanisms for strengthening local institutions, and to have methodologies to assess the comparative value of woodland resources, especially in relation to other land uses. We also need to examine institutional mechanisms which ensure that local communities have control over the resources of their landscape in the face of possible appropriation by outside elite groups (Dove 1993).

Key questions for research are:

- How do local institutional arrangements change in the face of resource scarcity and commercialisation?

- What is the nature, extent and potential of local capability for integrated resource management?

\section{Macro-economic and inter-sectoral influences}

Chapter 4 indicates how changes in miombo woodland utilisation and coverage are intricately linked to pre-colonial, colonial and postindependence phenomena. It is believed that processes of economic development which led to the long-distance caravan trade, globalisation of the world economy and structural adjustment programmes, colonial and post-independence government policies; and other factors such as the great rinderpest epidemic and the Ngoni penetration have all had a strong bearing on woodland utilisation and change.

The long-distance caravan trade during the 19th century disrupted the traditional patterns of life. The increased demands for food and other goods led to massive clearance of miombo woodland for expanded agriculture and fuelwood supplies. The coming of Europeans during the late
1800 s and 1900s and the onset of colonial rule marked a new era in the development process. It brought the beginning of a market economy, which integrated peasant agricultural economies and national economies. In this process, highly skewed patterns of resource distribution emerged which left many people living in extreme poverty with limited access to land, credit and other essential goods and services.

Independence does not seem to have brought any significant changes in land-use patterns. Contemporary government policies which aimed at redressing some of the colonial and postindependence imbalances have often been ineffective. This has led to resource-use conflicts with competing demands on land and wood products. This has in turn exerted enormous pressure on natural resources with negative impacts on woodland. Even the structural adjustments programmes do not seem to have brought any relief to the woodlands.

Is it true, as McNamara (1993) states, that policy reforms, backed up by modest investments in forest protection infrastructure and a considerable strengthening and re-orientation of the government's forestry services, can make a decisive contribution to improved management of indigenous woodlands? How can legislative reform provide incentives for improved management?

The miombo region comprises seven countries and therefore, potentially, seven different macroeconomic frameworks, an ideal situation in which to investigate the relationship between the macroeconomic framework and local woodland use. The task is not simple because of the diverse influences on local patterns of use. Chapter 4 draws out the multiple influences that policies have had on miombo woodland use and structure. The next step is to take one or two of the policies and to examine their impacts in much greater depth. Prime candidates for more in-depth research are policies related to: (i) structural adjustment, where the indications are that structural 
adjustment is having a profound influence on miombo woodland use patterns; and (ii) local empowerment, where there are currently a diverse range of 'experiments' throughout the region and where there have been past attempts at 'resource sharing' or 'village management'.

Key research questions are thus:

- How does the policy framework influence livelihood strategies and the contribution of woodland products to such strategies?

- Under what circumstances will local control over woodland resources generate economic, social and ecological benefits?

- What are the underlying causes of deforestation and degradation of the woodlands?

\section{Management options}

We need to ask how the yields of goods and services from miombo woodland can be optimised to ensure their sustainability and their equitable distribution. Given a set of possible technical options, which of these are possible within the socio-economic framework that exists? A number of authors point to the breakdown of indigenous resource management practices as a result of growing resource scarcity and erosion of power of traditional leaders (McGregor 1991; Campbell et al. 1993; Mukamuri 1995a). However, t is clear from Chapter 5 that, rather than relics of a bygone era that are increasingly dying out, in some cases at least, indigenous management practices are continually evolving and changing to meet the needs of changing circumstances. When faced with critical resource scarcity, undermining of traditional authority structures and other changing circumstances, local people are forced to take action, and a new array of conservation and management practices emerge.

The long-term sustainability of these changes is difficult to assess and clearly highly site-specific. In fact, as Campbell et al. (1995b) argue, assessment of the sustainability of a system/practice is likely not only to be very difficult, but also meaningless, given the inherent diversity and dynamism present in farming systems in the region. It makes more sense to enhance our understanding of processes and their outcomes than of the state of a given system at a given time.

Chapter 7 on the management of miombo woodland is limited by the fact that many of the management 'tools' are most easily applied in large tracts of miombo woodland under management of private individuals or state managers. We have to ask whether and how such management tools as fire, coppicing, etc. can feasibly be used to manage miombo woodland in communal areas. Without concurrent development of institutional arrangements and technical options, no progress towards better management, as defined by the resource user, will be feasible.

One technological option is domestication, which can be seen as a gradient from extractivism from natural woodland at the one extreme, to genetically modified planted trees at the other extreme (Ruiz 1995). What are the stages along the domestication gradient, and what are the factors driving technological change along this gradient? We hypothesise that resource scarcity and the existence of markets are the leading forces driving domestication (Ruiz 1995) as, separately or in combination, they signal opportunities to increase net returns (financial or otherwise) to the producers.

The use of a wide range of woodland products at the local level implies substantial indigenous technical knowledge. To what extent, and under what conditions, do local knowledge and customary systems contribute to sustainability (Godoy and Bawa 1993)? What are the social, economic and ecological determinants of judicious use?

\section{The ecological framework and sustainability}

Given the levels of deforestation in miombo woodland, what are the impacts on landscape processes in the region? How important are ecological services provided by miombo woodland, 
ranging from erosion control at the plot level to global climate modification, and how are these services changing with deforestation? There has been little consideration given to the importance of miombo woodland to global interests, e.g. biodiversity conservation, atmospheric chemistry and global climate change.

Miombo woodland shows much variability over short distances, both in structure and functioning (Chapter 2). There is a need to elucidate these spatial patterns, as it is likely that farmers and users of woodlands are exploiting spatial variability.

There is also need to understand temporal variability. In recent years, there has been a major paradigm shift in savanna ecology: from a position in which savannas were seen as systems that, when perturbed, returned to their former equilibrium point, to a position which recognises multiple-equilibria, non-equilibria or dis-equilibria (Westoby et al. 1989; Behnke et al. 1993). Savannas are now almost universally seen as event-driven systems without single stable equilibria. If we are interested in change in miombo woodland, to what extent can change be interpreted in the light of the non-equilibria or multipleequilibria hypotheses? Much of the current interest in the new paradigm has been generated without detailed field work and with a focus on morearid savannas. To what extent can the findings be applied to miombo woodland? Our preliminary suggestion (Chapter 2) is that miombo woodlands are not similar to the even-driven systems first described for much more arid areas (e.g. Ellis and Swift 1988).

There has also been a raging debate about degradation in savanna environments, with disagreement concerning the magnitude, severity and causes of observed changes (Dahlberg 1994), a debate not unconnected to that on the equilibrium status of savannas. Previously, much of the change in savannas was seen as negative, a common perception being that inappropriate management was turning vast areas of Africa into desert (Bourlière 1983). A host of researchers, especially those in the international arena, now question this view, arguing that what we see are shifts from one equilibrium point to another, and that the evidence for degradation is limited (Dahlberg 1994). Is there any evidence to indicate degradation?

Key questions are:

- What are the important ecological processes (for the provision of woodland goods and services and for ecosystem maintenance) and how are these effected by human activities?

- What are the kinds and rates of land-use change in the miombo region, and how do these changes interact with:

$\Rightarrow$ woodland use patterns, and

$\Rightarrow$ miombo woodland functioning?
An advanced stage of degradation in a grazing area in Miombo woodland, where many of the trees have been cut and the area has been overgrazed (photo: J. Clarke). The severity and extent of degradation in the miombo region is much debated 


\section{Options and opportunities}

Miombo woodlands will provide, for many years, key inputs to rural livelihoods. In the face of commercialisation and change, the challenge is to ensure that rural households continue to benefit from the woodlands. Policy development that empowers local people to manage and control the woodlands in their communal landscape is needed. The regulatory framework should give less emphasis to enforcement and more emphasis to providing self-regulating and self-enforcing incentives for management. CAMPFIRE-type schemes cannot be wholly applied to woodland products; a challenge for researchers is to investigate how local empowerment is best achieved, for what products and in what circumstances. Indepth comparative analyses of the divergent models currently being implemented and past models (e.g. the village forest areas of early colonial days in Malawi) would be insightful.

Institutional developments must be coupled with the development of technical options. Surprisingly little research has investigated possible silvicultural tools. The results that do exist must be placed, or in some cases re-interpreted, in the context of a small-scale farmer. Where there is doubt as to appropriate management, a first step would be to thoroughly investigate local management practices and to build technical options on these.
We do not argue that devolution of control and decision making to local users is a panacea which will ensure the conservation, sustainable use, and ongoing social and economic benefits from the woodlands. We believe that there is strong evidence that it may well be a crucial first step, but that much more needs to be known about the institutional and commercial contexts in which miombo users now find themselves, and about the type of support (technical, economic, institutional or political) that will increase the probability of sustainable management of miombo woodland and ensure equitable distribution of benefits from the woodlands.

As the reference list to this book attests, there is a wide variety of studies available on miombo woodlands, though many of the references are difficult-to-obtain 'grey literature'. While the literature is rich in description, it is lacking in analytical insight. Furthermore, there is a limit to what can be done with the present literature. To move from description to analysis and synthesis needs more than just a literature review. To synthesise the current information into a new conceptual framework requires that the full context of each study is understood. This is not available. The challenge for researchers is to move to new heights in analysis and synthesis. This will require research programmes with new visions and fresh insights. 


\section{References}

Abbot, J.I.O. 1996. Rural subsistence and protected areas: community use of the miombo woodlands of Lake Malawi National Park. Ph.D. thesis, University College, University of London.

Abrahams, R. 1967. The political organization of Unyamwezi. Cambridge University Press, Cambridge.

AGRITEX n.d. Drought relief seed packs and fertiliser distribution records. Internal unpublished report, Department of Agricultural, Technical and Extension Services, Harare.

Alexandre, J. 1977. Le bilan de l'eau dans le miombo (forêt claire tropicale). Bulletein de la Société Géographie du Liège 13, 107-126.

Allan, W. 1965. The African husbandman. Oliver and Boyd, Edinburgh.

Allen, J.C. 1986. Soil properties and fast-growing tree species in Tanzania. Forest Ecology and Management 16, 127-141.

Anderson, D.M.W. 1993. Some factors influencing the demand for gum arabic (Acacia senegal (L.) Willd.) and other water-soluble tree exudates. Forest Ecology and Management 58, 1-18.

Anderson, G.D. and Walker, B.H. 1974. Vegetation composition and elephant damage in the Sengwa Wildlife Research Area, Rhodesia. Journal of the Southern African Wildlife Management Association 4, 1-14.

Anderson, I.P., Brinn, P.J., Moyo, M. and Nyamwanza, B. 1993. Physical resource inventory of the communal lands of Zimbabwe - an overview. NRI Bulletin 60, Natural Resources Institute, Chatham, UK.

Andreae, M.O. 1993. The influence of tropical biomass burning on climate and the atmospheric environment. In: Oremland, R.S. (ed.) Biogeochemistry of global change: radiatively active trace gases, 113-150. Chapman \& Hall, New York.

Araki, S. 1992. The role of the miombo woodland ecosystem in chitemene shifting cultivation in northern Zambia. Japan Information for Man and the Biosphere Programme 11, 8-15.

Araki, S. 1993. Effect on soil organic matter and soil fertility of the chitemene slash-and-burn practice used in northern Zambia. In: Mulongoy, K. and Merckx, R. (eds) Soil organic matter dynamics and sustainability of tropical agriculture, 367-375. IITA/K.U., Leuven, Belgium.

Arnold, J.E.M. 1990. Social forestry and communal management in India. Paper 11b, Social Forestry Network, Overseas Development Network, London.

Arnold, J.E.M. 1993. Management of forest resources as common property. Commonwealth Forestry Review 72, 157-161.

Arnold, J.E.M. 1994. Non-farm employment in small-scale forest-based enterprises: policy and environmental issues. Working Paper 11, EPAT/MUCIA, University of Wisconsin, Madison.

Arnold, J.E.M. 1995. Socio-economic benefits and issues in non-wood forest products use. Paper for expert consultation on non-wood forest products, Yogyakarta, 17-27 January, 1995, FAO, Rome.

Arnold, J.E.M. and Easton, J. 1993. Forest industry development and supply of industrial wood. In: Bradley, P.N. and McNamara, K. (eds) Living with trees: policies for forestry management in Zimbabwe, 243-303. World Bank Technical Paper 210, World Bank, Washington, DC.

Arnold, J.E.M., Liedholm, C., Mead, D., and Townson, I.M. 1994. Structure and growth of small enterprises using forest products in southern and eastern Africa. OFI Occasional Papers No 47, Oxford Forestry Institute, Oxford. 
Asia Sustainable Forest Management Network 1994. Policy dialogue on natural forest regeneration and community management. Workshop Proceedings, March 1994, East-West Center, Honolulu.

Astle, W.L. 1969. The vegetation and soils of Chishinga Ranch, Luapula Province, Zambia. Kirkia 7, 73-102.

Asumadu, K. and Weil, R.R. 1988. A comparison of the USDA soil taxonomy and the Zimbabwean soil classification system with reference to some red soils of Zimbabwe. In: Nyamapfene, K., Hussein, J. and Asumadu, K. (eds) The red soils of East and Southern Africa, 413-445. International Development Research Centre, Ottawa.

Attwell, C.A.M., Campbell, B.M., du Toit, R.F. and Lynam, T.J.P. 1989. Patterns of fuelwood utilisation in Harare, Zimbabwe. A report prepared for the Forestry Commission of Zimbabwe and the World Bank, Forestry Commission, Harare.

Bagachwa, M., Shechambo, F., Sosovele, H., Kulindwa, K., Naho, A. and Cromwell, E. 1995. Structural adjustment and sustainable development in Tanzania. Dar es Salaam University Press, Dar es Salaam.

Balderrama, S., Fenta, T., Hussein, A., Jackson, C., Midre, M., Vasquez, C. and de Vos, J. 1988. Farming system dynamics and risk in a low potential area: Chivi South, Masvingo Province, Zimbabwe. ICRA, Bulletin 27, Wageningen, Netherlands.

Ballantyne, A.O. 1956. Report of a soil and land use survey, Copperbelt, Northern Rhodesia (Section 2, Appendix 7). Government Printer, Lusaka.

Banda, A.S.M. and De Boer, H. 1993. Honey for sale. In: Kemf, E. (ed.) Indigenous peoples and protected areas. The law of mother earth, 35-39. Earthscan, London.

Banda, M. 1988. Epicormic and sucker shoots in miombo woodland management in Zambia. M.Sc. dissertation, University of North Wales, Bangor.

Barbier, E.B. 1988. Sustainable agriculture and the resource poor: policy issues and options. IIED/UCL London Environmental Economics Centre Paper 88-02.

Barnes, D.L. 1965. The effects of frequency of burning and mattocking on the control of coppice in the Marandellas sandveld. Rhodesian Journal of Agricultural Research 3, 55-56.

Barnes, D.L. 1972. Bush control and veld productivity I. Modern Farming in Central Africa 9(6), 10 -19.

Barnes, D.L. 1979. Cattle ranching in the semi-arid savannas of East and Southern Africa. In: Walker, B.H. (ed.) Management of semi-arid ecosystems, 9-54. Elsevier, Amsterdam.

Bartlett, A.G. 1992. Review of community forestry advances in Nepal. Commonwealth Forestry Review 71, 95-99.

Bartlett, A., Nurse, M., Chetri, R. and Kharel, S. 1993. Towards effective community forestry through forest user groups. Journal of World Forest Resource Management 7, 49-69.

Bate, G.M. and Ludlow, A.E. 1978. An investigation into the physiological implications of the anthocyanin pigments in spring leaves of Ochna pulchra Hook. (Abstract) Joint Annual Meeting South African Association of Botanists and Grassland Society of Southern Africa, Bloemfontein, South Africa, 1978.

Behnke, R.H., Scoones, I. and Kerven, C. (eds) 1993. Range ecology at disequilibrium. New models of natural variability and pastoral adaptation in African savannas. ODI, London.

Bell, R.H.V. 1981. An outline of a management plan for Kasungu National Park, Malawi. In: Jewell, P.A. and Holt, S. (eds) Problems in the management of locally abundant wild mammals, 69-89. Academic Press, New York.

Bell, R.H.V. 1982. The effect of soil nutrient availability on community structure in African ecosystems. In: Huntley, B.J. and Walker, B.H. (eds) Ecology of tropical savannas, 193-216. Springer-Verlag, Berlin. 
Bell, R.H.V. 1984. Notes on elephant-woodland interactions. In: Cumming, D.H.M. and Jackson, P. (eds) Status and conservation of Africa's elephants and rhinos, 98-103. IUCN, Gland.

Bell, M., Faulkner, R., Hotchkiss, P., Lambert, R., Roberts, N. and Windram, A. 1987. The use of dambos in rural development, with reference to Zimbabwe. Loughborough University, Loughborough.

Benson, C.W. and Stuart Irwin, M.P. 1966. The Brachystegia avifauna. Ostrich Supplement 6, 297-321.

Bernard-Reversat, F. 1982. Biogeochemical cycle of nitrogen in a semi-arid savanna. Oikos 38, 321-332.

Berntsen, J. L. 1976. The Maasai and their neighbours: variables of interaction. African Economic History 2, 1-11.

Berry, L. and Townshend, J. 1973. Soil conservation policies in the semi-arid regions of Tanzania, a historical perspective. In: Rapp, A., Berry, L. and Temple, P.H. (eds) Studies in soil erosion and sedimentation in Tanzania, 54-71. University of Dar es Salaam.

Birch, H.F. 1958. The effect of soil drying on humus decomposition and nitrogen availability. Plant and Soil 10, 9-31.

Boaler, S.B. 1966a. The ecology of Pterocarpus angolensis in Tanzania. Ministry of Overseas Development, London.

Boaler, S.B. 1966b. Ecology of a miombo site, Lupa North Forest Reserve, Tanzania. II. Plant communities and seasonal variation in the vegetation. Journal of Ecology 54, 465-479.

Boaler, S.B. and Sciwale, K.C. 1966. Ecology of a miombo site, Lupa North Forest Reserve, Tanzania. III: effects on the vegetation of local cultivation practices. Journal of Ecology 54, 577-587.

Boberg, J. 1993. Competition in Tanzanian woodfuel markets. Energy Policy 21, 474-490.

Bojö, J. 1993. Economic valuation of indigenous woodlands. In: Bradley, P.N. and McNamara, K. (eds) Living with trees: policies for forestry management in Zimbabwe, 227-241. World Bank Technical Paper 210, World Bank, Washington DC.

Bombay, H. 1993. Many things to many people. Aboriginal forestry in Canada is looking towards balanced solutions. Cultural Survival Quarterly 17, 15-18

Botkin, D.B. 1993. Forest dynamics: an ecological model. Oxford University Press, New York.

Botkin, D.B., Janak, J.F. and Wallis, J.R. 1972. Some ecological consequences of a computer model for forest growth. Journal of Ecology 60, 849-872.

Boultwood, J.N. and Rodel, M.G.W. 1981. Effects of stocking rate and burning frequency on Brachystegia/Julbernardia veld in Zimbabwe. Proceedings of the Grassland Society of Southern Africa 16, 111-115.

Bourlière, F. (ed.) 1983. Tropical savannas. Ecosystems of the World 13. Elsevier, Amsterdam.

Bradley, P.N. and Dewees, P.A. 1993. Indigenous woodlands, agricultural production and household economy in the communal areas. In: Bradley, P.N. and McNamara, K. (eds) Living with trees: policies for forestry management in Zimbabwe, 63-157. World Bank Technical Paper 210, World Bank, Washington DC.

Brandstom, P. 1994. Is there a future role for indigenous institutions in management of natural resources? Forest, Trees and People Programme, IRDC, Swedish University of Agricultural Sciences, Uppsala.

Bransby, D.I. 1981. The value of veld and pasture as animal feed. In: Tainton, N.M. (ed.) Veld and pasture management in South Africa, 171-214. Shuter \& Shooter, Pietermaritzburg, S.A.

Bray, D. and Irvine, D. 1993. Resource and sanctuary: indigenous peoples, ancestral rights, and the forests of the Americas. Cultural Survival Quarterly 17, 12-14. 
Bray, D., Carreon, M., Merino, L. and Santos, V. 1993. On the road to sustainable forestry. The Maya of Quintana Roo strive to combine economic efficiency, ecological sustainability and a democratic society. Cultural Survival Quarterly 17, 38-41.

Brenan, J.P.N. 1978. Some aspects of the phytogeography of Tropical Africa. Annals of Missouri Botanical Gardens. 65, 436-478.

Brigham, T. 1994. Trees in the rural cash economy: a case study from Zimbabwe's communal areas. M.A. thesis, Carleton University, Ottawa.

Britten, P. 1980. The birds of East Africa. East African Natural History Society, Nairobi.

Brocklington, N.R. 1956. Report of a soil and land use survey, Copperbelt, Northern Rhodesia. Government Printer, Lusaka.

Bromley, D. 1989. Property relations and economic development. The other land reform. World Development 17, 866-867.

Bromley, D.W. and Cernea, M.M. 1989. The management of common property natural resources: some conceptual and operational fallacies. World Bank Discussion Paper, No. 57, Washington DC.

Brouwer, R. 1995. Baldios and common property resource management in Portugal. Unasylva 46, $37-43$.

Brown, S. and Lugo, A.E. 1982. The storage and production of organic matter in tropical forests and their role in the global carbon cycle. Biotropica 14, 161-197

Bruce, J., Fortmann, L. and Nhira, C. 1993. Tenures in transition, tenures in conflict: examples from the Zimbabwe social forest. Rural Sociology 8, 626-642.

Bryant, J.P., Heitkonig, I., Kuropant, P. and Owen-Smith, N. 1991. Effects of severe defoliation on the long-term resistance to insect attack and on leaf chemistry in six woody species of southern African savanna. American Naturalist 137, 50-63.

Bryceson, D. 1980. Changes in peasant food production and food supply in relation to the historical development of commodity production in pre-colonial and colonial Tanganyika. Journal of Peasant Studies 7, 281-311.

Bryceson, D. 1982. Peasant commodity production in post-colonial Tanzania. African Affairs 81, 547-567.

Buechner, H.K. and Dawkins, H.C. 1961. Vegetation change induced by elephants and fire in the Murchison Falls National Park, Uganda. Ecology 42, 752-766.

Bullock, S.H., Mooney, H.A. and Medina, E. (eds) 1995. Seasonally dry tropical forests. Cambridge University Press, Cambridge.

Burford, N.F. 1989. Firewood and fence pole acquisition and consumption patterns and tree planting practices in a Zimbabwean village, with reference to their implications to agricultural and woodland productivity, B.Agrofor. thesis, University of Bangor, Wales.

Burrows, P.M. and Strang, R.M. 1964. The relation of crown and basal diameters in Rhodesian Brachystegia woodland. Comonwealth Forestry Review 43, 331-332.

Campbell, B.A. 1973. Phosphate relationships in some Rhodesian soils. D.Phil thesis, University of Rhodesia, Salisbury.

Campbell, B.M. 1987. The use of wild fruits in Zimbabwe. Economic Botany 41, 375-385.

Campbell, B.M. and Brigham, T.E. 1993. Non-wood forest products in Zimbabwe. In: Non-wood forest products: a regional expert consultation for English-speaking African countries, Arusha, 17-22 October, 1993, Annex IV. FAO and the Commonwealth Science Council, Rome and London.

Campbell, B.M. and du Toit, R.F. 1988. Relationships between wood resources and the use of species 
for construction and fuel in the communal lands of Zimbabwe. Monographs in Systemic Botany of the Misssouri. Botanic Gardens 25, 331-341.

Campbell, B.M. and Mangono, J.J. 1994. Working towards a biomass energy strategy for Zimbabwe. Department of Biological Sciences, University of Zimbabwe.

Campbell, B.M., Bradley, P.N. and Carter, S.E. 1995b. Sustainability and peasant farming systems: Some observations from Zimbabwe. In: Ganry, F. and Campbell, B. (eds) Sustainable land management in African semi-arid and subhumid regions. Proceedings of the SCOPE workshop, 1519 November 1993, CIRAD, Montpellier.

Campbell, B.M., Clarke, J.M. and Gumbo, D.J. 1991b. Traditional agroforestry practices in Zimbabwe. Agroforestry Systems 14, 99-111.

Campbell, B.M., Clarke, J., Luckert, M., Matose, F., Musvoto, C. and Scoones, I. 1995a. Local-level economic valuation of savanna woodland resources: village cases from Zimbabwe. Hidden Harvest Project Research Series 3. International Institute for Environment and Development, London.

Campbell, B.M., Cunliffe, R.N. and Gambiza, J. 1995c. Vegetation structure and small-scale pattern in miombo woodland, Marondera. Bothalia 25, 121-126.

Campbell, B.M., Grundy, I. and Matose, F. 1993. Tree and woodland resources - the technical practices of small-scale farmers. In: Bradley, P.N. and McNamara, K. (eds) Living with trees: policies for forestry management in Zimbabwe, 29-62. World Bank Technical Paper No. 210, World Bank, Washington DC.

Campbell, B.M., Swift, M.J., Hatton. J. and Frost, P.G.H. 1988. Small-scale vegetation pattern and nutrient cycling in miombo woodland. In: Verhoeven, J.T.A., Heil, G.W. and Werger, M.J.A. (eds) Vegetation structure in relation to carbon and nutrient economy, 69-85. SPB Academic Publishing, The Hague.

Campbell, B.M., Vermeulen, S.J. and Lynam, T.J.P. 1991a. Value of trees in the small-scale farming sector of Zimbabwe. International Development Research Centre, Ottawa.

Campbell, J.Y. 1992. Joint forest management in India. Social Change 22, 36-54.

Carrilho, J.Z. 1990. Acesso e uso da terra: confliitos entre a tradicao, a lei e a realidade. Maputo Mozambique Extra 4, 14-15.

Carter, J., Connelly, S. and Wilson, N. 1994. Participatory forestry in Sri Lanka: why so limited? Change on the Horizon. Network Paper 17b, Rural Development Forestry Network, Overseas Development Institute, London.

Caughley, G. 1979. What is this thing called carrying capacity? In: Boyce, M.S. and Hayden-Wing, L.D. (eds) North American elk: ecology, behaviour and management, 2-8. University of Wyoming Press, Laramie, Wyoming.

Cavendish,W.P. 1996. Environmental resources and rural household welfare. Mimeo, Centre for the Study of African Economies, University of Oxford.

Celander, N. 1983. Miombo woodlands in Africa - distribution, ecology and patterns of land use. Working Paper 16, Swedish University of Agricultural Sciences, International Rural Development Centre, Uppsala.

Central Statistical Office 1992. Country profile 1992. Central Statistical Office, Lusaka.

Central Statistical Office 1995. Quarterly digest of statistics, December 1994. Government Printers. Harare.

Chanock, M. 1982. Making customary law: men, women and courts in colonial northern Rhodesia. In: Hay, M. and Wright M. (eds) African women and the law, 53-66. African Study Center, Boston University. 
Chase Smith, R. 1993. Indians, forest rights, and lumber mills. Cultural Survival Quarterly 17, 52-55.

Chenje, M. and Johnson, P. 1994. Learning from history. In: State of the environment in southern Africa, 21-38. A report by the Southern African Research and Documentation Centre (SARDC), Harare.

Chidari, G., Chirambaguwa, F., Matsvimbo, P., Mhiripiri, H., Chanakira, J., Mutsvangwa, X., Mvumbe, A., Fortmann, L., Drummond, R. and Nobane, N. 1992. The use of indigenous trees in Mhondoro District. NRM Occasional Paper 5, Centre for Applied Social Science, University of Zimbabwe.

Chidumayo, E.N. 1983. Urbanisation and deforestation in Zambia. Desertification Control Bulletin 9, 40-43.

Chidumayo, E.N. 1985. Structural differentiation of contiguous savanna woodland types in Zambia. Geo-Eco-Trop 9, 51-66.

Chidumayo, E.N. 1987a. A shifting cultivation land use system under population pressure in Zambia. Agroforestry Systems 5, 15-25.

Chidumayo, E.N. 1987b. History of soil conservation in Zambia. In: SADCC (SWCLU) Coordination Unit (ed.) History of soil conservation in the SADCC region, 12-17. Report no. 8, Maseru.

Chidumayo, E.N. 1987c. Woodland structure, destruction and conservation in the copperbelt area of Zambia. Biological Conservation 40, 89-100.

Chidumayo, E.N. 1987d. A survey of wood stocks for charcoal production in the miombo woodlands of Zambia. Forest Ecology and Management 20, 105-115.

Chidumayo, E.N. 1988a. Regeneration of Brachystegia woodland canopy following felling for tsetsefly control in Zambia. Tropical Ecology 29, 24-32.

Chidumayo, E.N. 1988b. A re-assessment of effects of fire on miombo regeneration in the Zambian Copperbelt. Journal of Tropical Ecology 4, 361-372.

Chidumayo, E.N. 1988c. Integration and role of planted trees in a bush-fallow cultivation system in central Zambia. Agroforestry Systems 7, 63-76

Chidumayo, E.N. 1988d. Estimating fuelwood production and yield in regrowth dry miombo woodland in Zambia. Forest Ecology and Management 24, 59-66.

Chidumayo, E.N. 1989a. Land use, deforestation and reforestation in the Zambian Copperbelt. Land Degradation and Rehabilitation 1, 209-216.

Chidumayo, E.N. 1989b. Early post-felling response of Marquesia woodland to burning in the Zambian Copperbelt. Journal of Ecology 77, 430-438.

Chidumayo, E.N. 1990. Above-ground woody biomass structure and productivity in a Zambezian woodland. Forest Ecology and Management 36, 33-46.

Chidumayo, E.N. 1991a. Seedling development of the miombo woodland tree, Julbernardia globiflora. Journal of Vegetation Science 2, 21-26.

Chidumayo, E.N. 1991b. Woody biomass structure and utilisation for charcoal production in a Zambian miombo woodland. Bioresources Technology 37, 43-52.

Chidumayo, E.N. 1992a. Seedling ecology of two miombo woodland trees. Vegetatio 103, 51-58.

Chidumayo, E.N. 1992b. Effects of shoot mortality on the early development of Afzelia quanzensis seedlings. Journal of Applied Ecology 29, 14-20.

Chidumayo, E.N. 1993a. Responses of miombo to harvesting: ecology and management. Stockholm Environment Institute, Stockholm. 
Chidumayo, E.N. 1993b. Zambian charcoal production: miombo woodland recovery. Energy Policy 12, 586-597.

Chidumayo, E.N. 1994a. Inventory of wood used in charcoal production in Zambia. A report for the Biodiversity Support Program, World Wildlife Fund, Washington DC.

Chidumayo, E.N. 1994b. Effect of wood carbonization on soil and seedling productivity in miombo woodland. Forest Ecology and Management 70, 353-357.

Chidumayo, E.N. 1995. Handbook of miombo ecology and management. Draft edition, Stockholm Environment Institute, Stockholm.

Chidumayo, E.N. and Chidumayo, S.B.M. 1984. The status and impact of woodfuel in urban Zambia. Government Printer, Lusaka.

Chihongo, A.W. 1993. Pilot country study on non-wood forest products for Tanzania. In: Non-wood forest products: A regional expert consultation for english-speaking African countries, Arusha, 1722 October, 1993, Annex IV. FAO and the Commonwealth Science Council, Rome and London.

Chihongo, A.W. 1995. Tanzanian perspective towards non-wood forest products. Paper presented to the African Academy of Sciences, 2nd Roundtable Discussion, Pretoria, November, 1995.

Chikami, B. 1995. Plant gums, resins and oils: valuable non-wood forest products from Africa. A resource paper prepared for the African Academy of Sciences round table discussion on non-wood forest products, Pretoria, South Africa, 21-23 November, 1995.

Chileshe, L. and Ting-Tiang, W. 1988. Red soils of Zambia. In: Nyamapfene, K., Hussein, J. and Asumadu, K. (eds), The red soils of East and Southern Africa, 197-215. International Development Research Centre, Ottawa, Canada.

Chinene, V.R.N. and Lungu, O. 1988. Acidity and phosphorus management in the red soils of the humid tropics. In: Nyamapfene, K., Hussein, J. and Asumadu, K. (eds) The red soils of East and Southern Africa, 345-360. International Development Research Centre, Ottawa.

Christiansson, C. 1988. Degradation and rehabilitation of agropastoral land: perspectives on environmental change in semi-arid Tanzania. Ambio 17, 144-152.

Clark, J.D. and van Zinderen Bakker, E.M. 1964. Prehistoric culture and Pleistocene vegetation at Kalambo Falls, Northern Rhodesia. Nature (Lond.) 201, 971-975.

Clark, M.M. and Magagula, L.S. 1994. A review of the woodcarving and furniture manufacturing industry in Zululand and KaNgwane. Forestek, CSIR, Pretoria. 33 pp.

Clarke, J.M. 1983. A socio-ecological study of a rural community in the northern Sebungwe, M.Sc. thesis, University of Zimbabwe.

Clarke, J.M. 1995. Building on indigenous natural resource management: forestry practices in Zimbabwe's communal lands. Zimbabwe Forestry Commission, Harare.

Clarke, J.M., Mukwenhu, S.J. and Ncube, J. 1996. Supporting local initiatives in woodland regeneration: a case study from Ntabazinduna communal land, Zimbabwe, in press. Forestry and Land Use Programme, IIED, London.

Clatworthy, J.N. 1986. Establishment and yields of pasture legumes under cutting in Zimbabwe. I. Stylosanthes species. Zimbabwe Journal of Agricultural Research 24, 131-147.

Clauss, B. 1991. Bees and beekeeping in the North-Western Province of Zambia. Mission Press, Ndola, Zambia. 
Clauss, B. 1992. Bees and beekeeping in the North-Western Province of Zambia. Report on a beekeeping survey, Forest Department and Integrated Rural Development Programme (IRDP), Ndola, Zambia.

Coe, M.J., Cumming, D.H.M. and Phillipson, J. 1976. Biomass and production of large African herbivores in relation to rainfall and primary production. Oecologia 22, 341-354.

Coelho, J.P.B. 1987. Historical notes on the conservation of soil and natural resources in Mozambique. In: SADCC (SWCLU) Coordination Unit (ed.) History of soil conservation in the SADCC Region. Report No. 8, Maseru.

Cohen, J. 1980. Land tenure and rural development in Africa. In: Bates, C. and Lofchie, F. (eds) Agricultural development in Africa, 349-400. Issues of Public Policy, Praeger, New York.

Cole, M. 1986. The savannas: biogeography and geobotany. Academic Press, London.

Coley, P.D. 1983. Herbivory and defensive characteristics of tree species in a lowland tropical forest. Ecological Monographs 53, 209-233.

Coley, P.D. and Aide, T.M. 1989. Red coloration of tropical young leaves: a possible antifungal defense. Journal of Tropical Ecology 5, 293-300.

Colson, E. 1971. The impact of the colonial period on the definition of land rights In: Turner, V. (ed.) Colonialism in Africa, 193-255. Cambridge University Press, Cambridge.

Coote, H.C. 1994. Indigenous fruit marketing - the msuku sellers of Malosa. Socio-economics Research Note No.1, Forest Research Institute of Malawi, Zomba.

Coote, H.C. 1995. Introduction to participatory management and participatory rural appraisal, with reference to a study undertaken in four villages close to Chimaliro Forest Reserve, Malawi. Forest Research Institute of Malawi, Zomba.

Coote, H.C., Lowore, J., Luhanga, J. and Abbot, P.G. 1993b. Community use and management of indigenous forests in Malawi: the case of three villages in the Blantyre City Fuelwood Project area. FRIM report 93007, Forestry Research Institute of Malawi, Zomba.

Coote, H.C., Luhanga, J. and Lowore, J. 1993a. Community use and management of indigenous forests of Malawi: the case of Chemba village forest area. Forest Research Institute of Malawi, Zomba, Malawi.

Corby, H.L. 1974. Systematic implications of nodulation among Rhodesian legumes. Kirkia 9, 301-329.

Crawford, A. 1899. A trip to Northern Angoniland. The Scottish Geographical Magazine 15, 78.

Cumming, D.H.M. 1982. The influence of large herbivores on savanna structure in Africa. In: Huntley, B.J. and Walker, B.H. (eds) Ecology of tropical savannas, 217-245. Springer-Verlag, Berlin.

Cunningham, A.B. 1993. African medicinal plants: setting priorities at the interface between conservation and primary health care. People and Plants Working Paper 1, 1-50, UNESCO, Paris.

Cunningham, A.B., Campbell, B.M. and Bandeira, S. in prep. Sclerocarya birrea (Anacardiaceae) trees, farmers and traditional conservation practices in southern Africa. Draft manuscript.

Dahlberg, A. 1994. Contesting views and changing paradigms: the land degradation debate in Southern Africa. Scandinavian Institute of African Studies, Discussion Paper 6, Uppsala.

Davies, P. and Johnson, J. 1994. Buffer zones in lowland Bolivia: conflicts, alliances and new opportunities. Network Paper 18b, Rural Development Forestry Network, Overseas Development Institute, London.

Davis, S. 1993. Self-determination and resources: a survey of US Indian forestry. Cultural Survival Quarterly 17, 24-27.

de Beer, J.H. and McDermott, M.J. 1989. The economic value of non-timber forest products in South East Asia. Netherlands Committee for IUCN, Amsterdam. 
DeFoliart, G R. 1995. Edible insects as minilivestock. Biodiversity and Conservation 4, 306-321.

Dejene, A. and Olivares, J. 1991. Integrating environmental issues into a strategy for sustainable agricultural development. The case of Mozambique. The World Bank, Washington DC.

Department of Social Welfare 1993. A statistical overview of the Department of Social Welfare drought relief operations, 1982-1983. 8 Volumes. Department of Social Welfare, Harare.

Desanker, P.V. and Prentice, I.C. 1994. MIOMBO - A vegetation dynamics model for the miombo woodlands of Zambezian Africa. Forest Ecology and Management 69, 87-95.

Dewees, P.A. 1993. Economic dimensions to the use and management of trees and woodlands in small-holder agriculture in Malawi. Background paper prepared for the Malawi National Forest Policy Review. World Bank, Washington DC.

Dewees P.A. 1994. Social and economic aspects of miombo woodland management in Southern Africa. Options and opportunities for research. CIFOR Occasional Paper 2, Bogor, Indonesia.

Dewees, P.A. and Scherr, S. 1994. Public policy and NTFP market research: issues and approaches. Paper for the workshop on non-timber tree product market research, Annapolis, Maryland, 12-14 December, 1994. International Food Policy Research Institute, International Centre for Research in Agroforestry, Centre for International Forestry Research and the Natural Resources Institute.

Diouf, B. 1994. The responsibility of local people for the management of forest resources in North Senegal. Network Paper 18d, Rural Development Forestry Network, Overseas Development Institute, London.

Dove, M. 1993. A revisionist view of tropical deforestation and development. Environmental Conservation 20, 17-25.

Dublin, H.T., Sinclair, A.R.E. and McGlade, J. 1990. Elephants and fire as causes of multiple stable states in the Serengeti-Mara woodlands. Journal of Animal Ecology 59, 1147-1164.

Dunham, K.M. 1989. Litterfall, nutrient-fall and production in an Acacia albida woodland in Zimbabwe. Journal of Tropical Ecology 5, 227-238.

du Toit, R.F., Campbell, B.M., Haney, R.A. and Dore, D. 1984. Wood usage and tree planting in Zimbabwe's communal lands. Forestry Commission of Zimbabwe and the World Bank, Harare.

Dunn, A. 1994a. Summaries of some recent project approaches to conservation and development. Network Paper 18d, Rural Development Forestry Network, Overseas Development Institute, London.

Dunn, A. 1994b. Gashala Gumti, Nigeria - from game reserve to national park. Network Paper 18d, Rural Development Forestry Network, Overseas Development Institute, London.

Dye, P.J. and Spear, P.T. 1982. The effect of bush clearing and rainfall on grass yield and composition in south west Zimbabwe. Zimbabwe Journal of Agricultural Research 20, 103-118.

Dynoodt, R.F.P. and Mwambazi, T.M. 1988. The interaction of liming and phosphorus adsorption on two red soils from Zambia. In: Nyamapfene, K., Hussein, J. and Asumadu, K. (eds) The red soils of East and Southern Africa, 402-412. International Development Research Centre, Ottawa.

East African Biodiversity Project 1995. Control of land is the ultimate basis for biodiversity conservation. East African Biodiversity Project 4, Dar es Salaam.

East, R. 1984. Rainfall, soil nutrient status and biomass of large African savanna mammals. African Journal of Ecology 22, 245-270.

El Din, A. and Shanks, E. 1992. Natural forest management project, Kordofan, Sudan. Mid-term review, Overseas Development Institute, London. 
Ellert, H. 1984 The material culture of Zimbabwe. Longman Zimbabwe, Harare.

Elliot, R.C. and Folkertsen, K. 1961. Seasonal changes in composition and yields of veld grasses. Rhodesia Agricultural Journal 58, 186-197.

Ellis, J. 1994. Climate variability and complex ecosystem dynamics: implications for pastoral development. In: Scoones, I. (ed.) Living with uncertainty: new directions in pastoral development in Africa, 37-46. IT Publications, London.

Ellis, J.E. and Swift, D.M. 1988. Stability of African pastoral ecosystems: Alternative paradigms and implications for development. Journal of Range Management 41, 450-459.

Elwell, H.A. 1988. Investigations into the erodibility of a fersiallitic clay soil by rainfall simulation. In: Nyamapfene, K., Hussein, J. and Asumadu, K. (eds) The red soils of East and Southern Africa, 446460. International Development Research Centre, Ottawa, Canada.

Elwell, H.A. and Davey, C.J.N. 1972. Vlei cropping and the soil and water resources. Rhodesian Agricultural Journal, Technical Bulletin No. 15, 155-168.

ENDA 1991. The use and value of fruit trees in the communal areas of Zimbabwe. Report of a survey conducted in selected communal lands, Environment and Development Agency, Zimbabwe.

Endean, F. 1968. The productivity of miombo woodland in Zambia. Forest Research Bulletin 14, Government Printer, Lusaka.

Energy Studies Unit. 1985. The Blantyre charcoal marketing model. Ministry of Forestry and Natural Resources, Lilongwe.

Ernst, W. 1975. Variation in the mineral content of leaves of trees in miombo woodland in South Central Africa. Journal of Ecology 63, 801-807.

Ernst, W. 1988. Seed and seedling ecology of Brachystegia spiciformis, a predominant tree component in miombo woodlands in south central Africa. Forest Ecology and Management 25, 195-210.

Ernst, W. and Walker, B.H. 1973. Studies on the hydrature of trees in miombo woodland in South Central Africa. Journal of Ecology 61, 667-673.

Eschweiler, J.A. 1993. Malawi: Land use issues. Working Paper prepared for the World Bank Forest Sector Review. Lilongwe.

Eswaran, H. 1988. Taxonomy and management related properties of the 'red soils' of Africa. In: Nyampfene, K., Hussein, J. and Asumadu, K. (eds) The red soils of East and Southern Africa, 1-23. International Development Research Centre, Ottawa.

Falconer, J. 1990. The major significance of 'minor' forest products: the local use and value of forests in the West African humid forest zone. Community Forestry Note 6, Forests, Trees and People Programme, FAO, Rome.

Fanshawe, D.B. 1968. The vegetation of Zambian termitaria. Kirkia 6, 169-179.

Fanshawe, D.B. 1969. The vegetation of Zambia. Forestry Research Bulletin, Kitwe, Zambia, 7, 1-67.

Fanshawe, D.B. 1971. The vegetation of Zambia. Government Printer, Lusaka.

FAO-Unesco 1977. Soil map of the world, Volume VI, Africa. Unesco, Paris.

Feeny, D., Bekres, F., McCay, B.J. and Acheson, J.M. 1990. The tragedy of the commons: 22 years later. Human Ecology 18, 1-19.

Fields, K.E. 1985. Revival and rebellion in colonial Central Africa. Princeton University Press, Princeton.

Fischer, F.U. 1993. Beekeeping in the subsistence economy of the miombo savanna woodlands of 
South-Central Africa. Rural Development Forestry Network Paper 15c, 1-12. Overseas Development Institute, London.

Fisher, M.J., Rao, I.M., Ayarza, M.A., Lascano, C.E., Sanz, J.I., Thomas, R.J. and Vera, R.R. 1994. Carbon storage by introduced deep-rooted grasses in the South American savannas. Nature 371, 236-238.

Fisher, R.J. 1995. Collaborative management of forests for conservation and development. IUCN, Gland, Switzerland.

Fleuet, A. 1979. The role of wild foliage plants in the diet: a case study from Lushoto, Tanzania. Ecology of Food and Nutrition 8, 87-93.

Ford, J. 1971. The role of trypanosomiases in African ecology. Clarendon Press, Oxford.

Forest Policy Review 1993. The implications of agricultural activity and policy for forestry. Background paper for policy review in Malawi. World Bank, Washington.

Forestry Department 1995. Made in Ghana: collaborative forest management. Paper prepared for the XVIII Session of the ITTC and XVI Session of the Permanent Committees of the ITTO. Accra, Ghana.

Fortmann, L. 1980. Peasants, officials and participation in rural Tanzania: experience with villagization and decentralization. Rural Development Committee Special Series on Rural Local Organization, Cornell University, New York.

Fortmann, L. and Bruce, J. 1993. Tenure and gender issues in forestry policy. In: Bradley, P.N. and McNamara, K. (eds) Living with trees: policies for forestry management in Zimbabwe, 29-62. World Bank Technical Paper 210, Washington DC.

Fortmann, L. and Nobane, N. 1992. Fruits of their labours: gender, property and trees in Mhondoro District. NRM Occasional Paper 7, Centre for Applied Social Sciences, University of Zimbabwe.

Fosbrooke, H. 1954. Maasai history in relation to tsetse fly. Mimeo.

Freson, R. 1973. Apercu de la biomasse et de la productivite de la strate herbacee au miombo de la Luiswishi. Annales de l'Université de l'Abidjan, series E, 4, 256-277.

Freson, R., Goffinet, G. and Malaisse, F. 1974. Ecological effects of the regressive succession in muhulu-miombo-savanna in Upper Shaba, Zaire. In: Proceedings of the first international congress of ecology. Structure, functioning and management of ecosystems, The Hague, September 1974, 365-371. PUDOC, Wageningen, Netherlands.

Frost, P.G.H. 1985. Organic matter and nutrient dynamics in an broadleaded African savanna. In: Tothill, J.C. and Mott, J.J. (eds) Ecology and management of the world's savannas, 200-206. Australian Academy of Science, Canberra.

Frost, P.G.H. and Robertson, F. 1987. The ecological role of fire in savannas. In: Walker, B.H. (ed.) Determinants of tropical savannas, 93-140. IRL Press, Oxford.

Frost, P.G.H., Frost, S.K. and Nyamande, A.N. in prep. Herbaceous biomass and nutrient dynamics in miombo woodland, Zimbabwe.

Frost, P.G.H., Medina, E., Menaut, J.C., Solbrig, O., Swift, M. and Walker, B. 1986. Responses of savannas to stress and disturbance. Biology International (Special Issue) 10, 1-78.

Gadgil, M. and Guha, R. 1992. This fissured land: an ecological history of India. Oxford University Press, Oxford.

Gammon, D.M. 1976. Studies of the patterns of defoliation, herbage characteristics and grazing behaviour during continuous and rotational grazing of the Matopos sandveld of Rhodesia. D.Sc. Agric. thesis, University of Orange Free State, Bloemfontein. 
Gammon, D.M. 1978. A review of experiments comparing systems of grazing management on natural pastures. Proceedings of the Grassland Society of Southern Africa 13, 75-82.

Gardiner, A.J. 1995. The effect of large mammalian herbivore community structure on the composition and ecological function of the coprophagous scarab beetle fauna (Coleoptera: Scarabaeidae). D.Phil thesis, University of Zimbabwe, Harare.

Gauslaa,Y. 1989. Management and regeneration of tropical woodlands with special references to Tanzanian conditions. A literature review. Lidia 2, 37-112.

Gelfand, M., Mavi, S., Drummond, R.B. and Ndemera, B. 1985. The traditional medical practitioner in Zimbabwe. Mambo Press, Harare.

Gerden, C.A. and Mtallo, S. 1990. Traditional forest reserves in Babati District, Tanzania. A study in human ecology. Working Paper 128, Swedish University of Agricultural Sciences, Uppsala.

Gill, K.S., Hodgins, L. and Aulakh, B.S. 1988. Influence of cropping and particle size distribution on depthwise changes in soil bulk density. In: Nyamapfene, K., Hussein, J. and Asumadu, K. (eds) The red soils of East and Southern Africa, 361-367. International Development Research Centre, Ottawa, Canada.

Gluckman, M. 1965. Status and rights in land of the book. In: The ideas in Barotse jurisprudence, 71112. Yale University Press, New Haven and London.

Gluckman, M. 1969. Ideas in Barotse jurisprudence, 2nd edition. Manchester University Press, Manchester.

Godoy, R.A. and Bawa, K.S. 1993. The economic value and sustainable harvest of plants and animals from the tropical forest: assumptions, hypotheses and methods. Economic Botany 47, 215-219.

Goffinet, G. 1976. Écologie édaphique des écosystèmes naturels du Haut-Shaba (Zaïre). III. - Les peuplements en termites épigés au niveau des latosols. Revue d'Ecologie et de Biologie du Sol 13, 459-475.

Government of Tanzania 1995. National Land Policy. Ministry of Lands, Housing and Urban Development, Dar es Salaam.

Graham, L. 1995. Economic approaches to the valuation of small wildlife resources in communal areas in Zimbabwe. M.Sc thesis, University of Alberta, Canada.

Grant, P.J. and Clatworthy, J.N. 1984. Methods of pasture establishment. In: Kategile, J.A. (ed.) Pasture improvement research in eastern and southern Africa, 349-367. Proceedings of a workshop held in Harare, Zimbabwe, 17-21 September, 1984. IDRC, Ottawa.

Gray, R. and Birmingham, D. 1970. Pre-colonial Africa trade. Oxford University Press, Oxford.

Green, C.H. 1994. Bait methods for tsetse fly control. Advances in Parasitology 34, 229-291.

Grobler, J.H. 1945. General report on Matopo National Park. Unpublished manuscript.

Grundy, I.M. 1990. The potential for management of the indigenous woodland in communal farming areas of Zimbabwe with reference to the regeneration of Brachystegia spiciformis and Julbernardia globiflora. Unpublished M.Sc. thesis, University of Zimbabwe, Harare.

Grundy, I.M. 1995a. Regeneration and management of Brachystegia spiciformis Benth. and Julbernardia globiflora (Benth.) Troupin in miombo woodland, Zimbabwe. D.Phil. thesis, University of Oxford.

Grundy, I.M. 1995b. Wood biomass estimation in dry miombo woodland in Zimbabwe. Forest Ecology and Management 72, 109-117.

Grundy, I.M., Campbell, B.M., Balebereho, S., Cunliffe, R., Tafangenyasha, C., Fergusson, R. and Parry, D. 1993. Availability and use of trees in Mutanda Resettlement Area, Zimbabwe. Forest Ecology 
and Management 56, 243-266.

Grundy, I.M., Campbell, B.M. and Frost, P.G.H. 1994. Spatial pattern, regeneration and growth rates of Brachystegia spiciformis and Julbernardia globiflora. Vegetatio 115, 101-107.

Guijt, I., Hinchcliffe, F. and Melnyk, M. (compilers) 1995. The hidden harvest: the value of wild resources in agricultural systems. Institute for Environment and Development, London.

Gumbo, D.J. 1993. Is there traditional management of indigenous forest resources in the communal lands of Zimbabwe? In: Piearce, G. D. and Gumbo, D. J. (eds) The ecology and management of indigenous forests in Southern Africa, 83-214. Proceedings of an international symposium, Victoria Falls, Zimbabwe, 27-29 July 1992. Zimbabwe Forestry Commission and SAREC, Harare.

Gumbo, D.J., Mukamuri, B.B., Muzondo, M.I. and Scoones, I.C. 1990. Indigenous and exotic fruit trees: why do people want to grow them? In: Prinsley, R.T. (ed) Agroforestry for sustainable production: economic implications, 185-214. Commonwealth Science Council, London.

Guy, P.R. 1976. The feeding behaviour of elephants (Loxodonta africana) in the Sengwa area, Rhodesia. South African Journal of Wildlife Research 6, 55-63.

Guy, P.R. 1981a. Changes in the biomass and productivity of woodlands in the Sengwa Wildlife Research Area, Zimbabwe. Journal of Applied Ecology 18, 507-519.

Guy, P.R. 1981b. The estimation of the above-ground biomass of the trees and shrubs in the Sengwa Wildlife Research Area, Zimbabwe. South African Journal of Wildlife Research 11, 135-142.

Guy, P.R. 1989. The influence of elephants and fire on a Brachystegia-Julbernardia woodland in Zimbabwe. Journal of Tropical Ecology 5, 215-226.

Guy, P.R., Mhlangu, Z. and Charidza, H. 1979. Phenology of some trees and shrubs in the Sengwa Wildlife Research Area, Zimbabwe-Rhodesia. South African Journal of Wildlife Research 9, 47-54.

Hagberg, S. 1992. Management of natural forests. The gazetted forest reserve of Toumousseni, Burkina Faso. Working Paper 215, Swedish University of Agricultural Sciences, Uppsala.

Hagman, H. 1984. Prevention better than cure: report on human and environmental disasters in the third world. Swedish Red Cross, Stockholm.

Haley, D. and Luckert, M. 1992. Property rights and the management of forest resources: the Canadian experience. Commonwealth Forestry Review 71, 91-94.

Hall, J.B. and Rodgers, W.A. 1986. Pole cutting pressure in Tanzanian forest. Forest Ecology and Management 14, 133-140.

Hancock, D. 1989. Rural household energy systems and their relationship with relative state of woodland cover. Unpublished paper, ZERO, Zimbabwe.

Hancock, D. 1990. Stoves, trees and how people manage and use energy supplies. Mimeo, ZERO, Harare.

Hancock, D. and Kaeser-Hancock, G. 1985. Cooking patterns and fuelwood use in Masvingo Province. Agriculture and Rural Development Team, Harare.

Haney, R.A. 1983. A programme for the rehabilitation, re-establishment and new plantings of District Council woodlots and plantations in the Masvingo District. GTZ, Zimbabwe.

Hannah, L.D., Lohse, D., Hutchinson, C., Carr, J.L. and Lankerani, A. 1994. A preliminary inventory of human disturbance of world ecosystems. Ambio 23, 246-250.

Hardcastle, P. 1993. Forestry and tree resources. Working Paper 3, Malawi National Forest Policy Review, World Bank, Washington DC. 
Hardin, G. 1968. The tragedy of the commons. Science 162, 1243-1248.

Harriss, J. (ed.) 1982. Rural development: theories of peasant economy and agrarian change. Hutchinson University Library for Africa, London.

Hartwicke, J.M. and Olewiler, N.D. 1986. The economics of natural resource use. Harper and Row, New York.

Heitschmidt, R.K. 1993. The ecology of grazing management. Proceedings of the XVII International Grassland Congress, 1267-1270.

Helmsing, A.H.J. 1987. Non-agricultural enterprise in the communal lands of Zimbabwe: preliminary results of a survey. RUP Occasional Paper No. 10, Department of Rural and Urban Planning, University of Zimbabwe.

Hibajene, S.H. 1994. Woodfuel transportation and distribution in Zambia. Energy, Environment and Development Series 28, Stockholm Environment Institute, Stockholm.

Hibajene, S.H. and Ellegård, A. 1994. Charcoal transportation and distribution: a study of the Lusaka market. Energy, Environment and Development Series 33, Stockholm Environment Institute, Stockholm. $30 \mathrm{pp}$.

Hines, D.A. and Eckman, K. 1993. Indigenous multipurpose trees of Tanzania: uses and economic benefits for people. Working Paper FAO:Misc/93/9, FAO, Rome.

Hobane, P.A. 1994. Amacimbi: the gathering, processing, consumption and trade of edible caterpillars in Bulilimamangwe District. Centre for Applied Social Sciences, University of Zimbabwe.

Hofstad, O. 1993. Woodland management practices in Zimbabwe. In: Piearce, G.D. and Gumbo, D.J. (eds) The ecology and management of indigenous forests in Southern Africa, 51-61. Proceedings of an international symposium, Victoria Falls, Zimbabwe, 27-29 July 1992. Zimbabwe Forestry Commission and SAREC, Harare.

Högberg, P. 1982. Mycorrhizal associations in some woodland and forest trees and shrubs in Tanzania. New Phytologist 92, 407-415.

Högberg, P. 1986. Nitrogen-fixation and nutrient relations in savanna woodland trees (Tanzania). Journal of Applied Ecology 23, 675-688.

Högberg, P. 1992. Root symbioses of trees in African dry tropical forests. Journal of Vegetation Science 3, 393-400.

Högberg, P. and Nylund, J.E. 1981. Ectomycorrhizae in coastal miombo woodland of Tanzania. Plant and Soil 63, 283-289.

Högberg, P. and Piearce, G.D. 1986. Mycorrhizas in Zambian trees in relation to host taxonomy, vegetation type and successional pattern. Journal of Ecology 74, 775-785.

Holden, S.T. 1988. Farming systems and household economy in New Chambeshi, Old Chambeshi and Yunge villages near Kasama, Northern Zambia: an agroforestry baseline study. Zambia SPRP Studies Occasional Paper Series A (no.9), Noragric, Agricultural University of Norway, Ås.

Holden, S.T. 1991. Edible caterpillars - a potential agroforestry resource? The Food Insects Newsletter IV, 3-4.

Hood, R.J. 1972. The development of a system of beef production for use in the Brachystegia woodlands of northern Zambia. D.Phil. thesis, University of Reading, Reading.

Hosier, R.H. 1993. Charcoal production and environmental degradation. Energy Policy 21, 491-509.

Huntley, B.J. 1982. Southern African savannas. In: Huntley, B.J. and Walker, B.H. (eds) Ecology of 
tropical savannas, 101-109. Springer-Verlag, Berlin.

Hursh, C.R. 1960. The dry woodlands of Nyasaland. International Cooperation Administration, Salisbury.

Hyden, G. 1980. Beyond Ujamaa in Tanzania: underdevelopment and an uncaptured peasantry. Heinemann, London.

IFSC. 1987. The use of wood by the tobacco industry and the ecological implications: a summary. International Forest Science Consultancy, Edinburgh.

IIED. 1994. Whose Eden? An overview of community approaches to wildlife management. International Institute for Environment and Development, London.

ILCA. 1995. Livestock production under trypanosomiasis risk. In: International Livestock Centre for Africa 1993/94. Annual report and programme highlights, 31-41. International Livestock Centre for Africa, Addis Ababa.

Iliffe, J. 1979. A modern history of Tanganyika. Cambridge University Press, Cambridge.

Intergovernmental Panel on Climate Change 1996. Second assessment report. Cambridge University Press, Cambridge.

IUCN/UNEP/WWF. 1991. Caring for the earth: a strategy for sustainable living. IUCN, Gland, Switzerland.

Jachmann, H. 1989. Food selection by elephants in the 'miombo' biome, in relation to leaf chemistry. Biochemical Systematics and Ecology 17, 15-24.

Jachmann, H. and Bell, R.H.V. 1985. Utilization by elephants of the Brachystegia woodlands of the Kasungu National Park, Malawi. African Journal of Ecology 23, 245-258.

Jaramillo, V.J. and Sanford, R.L. Jr. 1995. Nutrient cycling in tropical deciduous forests. In: Bullock, S.H., Mooney, H.A. and Medina, E. (eds) Seasonally dry tropical forests, 346-361. Cambridge University Press, Cambridge.

Jeffers, J.N.R. and Boaler, S.B. 1966. Ecology of a miombo site, Lupa North Forest Reserve, Tanzania. I. Weather and plant growth, 1962-1964. Journal of Ecology 54, 447-463.

Johnson, J.M. and Choinski, J.S. 1993. The spring flush in Zimbabwe's miombo woodland. Zimbabwe Science News 27, 3-6.

Jones, J.A. 1989. Environmental influences on soil chemistry in central semiarid Tanzania. Soil Science Society of America Journal 53, 1748-1758.

Jones, J.A. 1990. Termites, soil fertility and carbon cycling in dry tropical Africa: a hypothesis. Journal of Tropical Ecology 6, 291-305.

Jones, R.J. and Sandland, R.L. 1974. The relation between animal gain and stocking rate: derivation of the relation from the results of grazing trials. Journal of Agricultural Science, Cambridge 83, 335-341.

Jordan, A.M. 1986. Trypanosomiasis control and African rural development. Longman, New York.

Jordan, A.M. 1990. Tsetse research and control. 1910 to 2000. Bulletin of Entomological Research 80, 117-120.

Jung, G. 1969. Cycles biogéochimiques dans un écosystème de région tropicale sèche Acacia albida (Del.) sol ferrugineux tropical peu lessivé (Dior.). Oecologia Plantarum 4, 195-210.

Justice, C., Scholes, B. and Frost, P. 1994. African savannas and the global atmosphere: research agenda. IGBP Report 31. International Geosphere-Biosphere Programme, Stockholm, Sweden. 
Kajembe, G.C. 1994. Indigenous management systems as a basis for community forestry in Tanzania: a case study of Dodoma urban and Lushoto Districts. Tropical Resource Management Paper 6, Wageningen Agricultural University.

Kalumiana, O. 1994. Charcoal supply stabilisation project. Ministry of Energy and Water Development, Department of Energy, Lusaka.

Katerere, Y. 1988. Issues in household energy strategy formulation: the Zimbabwe experience. Paper presented at the UNDP/World Bank Regional Seminar on Household Energy Planning, Harare, February 1-5, 1988.

Katerere, Y. 1994. Who is managing the woodlands in Southern Africa? Forestry is Wealth Newsletter $1,29-31$.

Katerere, Y., Mohamed, J.C., Moyo, S. and Ngobese, P. 1992. Opportunities and constraints to natural resource management and tree planting in Zimbabwe. Unpublished manuscript.

Katerere, Y., Moyo, S. and Mujakachi, L. 1993. The national context: land, agriculture and structural adjustment, and the Forestry Commission. In: Bradley, P.N. and McNamara, K. (eds) Living with trees: policies for forestry management in Zimbabwe, 11-27. World Bank Technical Paper 210, World Bank, Washington DC.

Keay, R.W.J. 1959. Explanatory notes. In: Aubréville, A., Duvigneaud, P., Hoyle, A.C., Keay, R.W.J., Mendonça, F.A. and Pichi-Sermolli, R.E.G. Vegetation map of Africa south of the tropic of Cancer, 1-24. Oxford University Press, Oxford.

Kerkhof, P. 1990. Agroforestry in Africa: a survey of project experiences. Panos, London.

Kikula, I. S. 1986a. Environmental effects of Tanzania's villagization programme. Ph.D. thesis, Griffith University, Brisbane.

Kikula, I.S. 1986b. The influence of fire on the composition of miombo woodland of Southwest Tanzania. Oikos 46, 317-324.

Kilahama, F.B. 1988. Community forestry programmes in Tanzania: organization, philosophies, implementation and experience gained. Forestry and Beekeeping Division, Dar es Salaam.

Kilahama, F.B. 1994. Trees and indigenous ecological knowledge about agroforestry practices in the rangelands of Shinyanga Region, Tanzania. D.Phil thesis, University of Wales, Bangor.

Kilindo, A.A.L. 1994. Structural adjustment, agricultural inputs and supply response in Tanzania. Tanzania Economic Trends 6, 60-81.

King, L.C. 1963. South African scenery. A textbook of geomorphology. Hafner, New York.

King, J.A. and Campbell, B.M. 1994. Soil organic matter relations in five land cover types in the miombo region (Zimbabwe). Forest Ecology and Management 67, 225-239.

King, J.A. and Campbell, B.M. (n.d.) Precipitation and soil moisture regimes for five land cover types in the miombo ecozone of Zimbabwe. Unpublished manuscript, typescript.

Kjekshus, H. 1977. Ecology control and economic development in East African history. University of California Press, Berkeley.

Koponen, J. 1994. Development for exploitation: German colonial policies in mainland Tanzania, 18841914. Finnish Historical Society, Studia Historica 49, Helsinki/Hamburg.

Kosek, J. 1993. Ethics, economics, and ecosystems. Can British Columbia's indigenous people blend the economic potential of forest resources with traditional philosophies? Cultural Survival Quarterly 17, 19-23. 
Kowero, G.S. and O'kting'ati, A. 1990. Production and trade in products from Tanzania's natural forests. In: Mgeni, A.S.M., Abeli, W.S., Chamshama, S.A.O. and Kowero, G.S. (eds) Proceedings of a joint seminar/workshop on management of natural forests of Tanzania, Arusha, 5-10 December, 1988, 102-106. Faculty of Forestry Record 43, Sokoine University of Agriculture, Morogoro.

Lambert, J.D.H., Arnason, J.T. and Gale, J.L. 1980. Leaf litter and changing nutrient levels in a seasonally dry tropical hardwood old forest, Belize, C.A. Plant and Soil 55, 429-443.

Lamprey, H.F. 1983. Pastoralism yesterday and today: the overgrazing problem. In: Bourlière, F. (ed.). Tropical savannas, 643-666. Ecosystems of the World 13, Elsevier, Amsterdam.

Lan, D. 1985. Guns and rain: guerillas and spirit mediums in Zimbabwe. Zimbabwe Publishing House, Harare.

Laudelot, H. and Meyer, J. 1954. Les cycles d'éléments minerales et de matière organique en forêt équatoriale Congolaise. Transactions of the Fifth International Congress on Soil Science II, 267272.

Lawry, S. 1990 Tenure policy towards common property natural resources in Sub-Saharan Africa. Natural Resources Journal 30, 403-422.

Laws, R.M. 1970. Elephants as agents of habitat and landscape change in East Africa. Oikos 21, 1-15.

Lawton, R.M. 1963. Palaeoecological and ecological studies in the Northern Province of Northern Rhodesia. Kirkia 3, 46-77.

Lawton, R.M. 1978. A study of the dynamic ecology of Zambian vegetation. Journal of Ecology 66, 175-198.

Lawton, R.M. 1980. Browse in miombo woodland. In: le Houerou, H.N. (ed.) Browse in Africa: the current state of knowledge, 25-31. ILCA, Addis Ababa.

Lawton, R.M. 1982. Natural resources of miombo woodland and recent changes in agricultural and land-use practices. Forest Ecology and Management 4, 287-297.

Lazaro, M., Pariona, M. and Simeone, R. 1993. A natural harvest. The Yanesha forestry cooperative in Peru combines western science and indigenous knowledge. Cultural Survival Quarterly 17, 48-51.

Leach, G. and Mearns, R. 1988. Beyond the woodfuel crisis: people land and trees in Africa. Earthscan, London.

Lebedev, A.N. (ed.) 1970. The climate of Africa. Part 1. Air temperature, precipitation [Translated from Russian]. Israel Programme for Scientific Translations, Jerusalem.

Lees, H.M.N. 1962. Working plan for the forests supplying the Copperbelt, Western Province. Government Printer, Lusaka.

Leleup, N. and Daems, H. 1969. Les chinelles alimentaires du Kwango. Causes de leur rarefication et mesures preconisees pour remedier. Journal d'Agriculture Tropicale et de Botanique Appliquée. $16,1-21$.

Lenvain, J.S. and Pauwelyn, P.L. 1988. Comparison of the physical properties of two Zambia paleustalfs. In: Nyamapfene, K., Hussein, J. and Asumadu, K. (eds) The red soils of East and Southern Africa, 379-389. International Development Research Centre, Ottawa, Canada.

Lilly, M.A. 1977. An assessment of the dendrochronological potential of indigenous tree species in South Africa. University of Witwatersrand Occasional Paper 18.

Lister, L.A. 1987. The erosion surfaces of Zimbabwe. Zimbabwe Geological Survey Bulletin No. 90. Geological Survey Department, Harare. 
Livingstone, D.A. 1971. A 22,000 year pollen record from the plateau of Zambia. Limnology and Oceanography 16, 349-356.

Low, A.R.C 1986. Agricultural development in Southern Africa. Farm-household economics and the food crisis. James Curry, London.

Lowore, J. 1993. Problems with management of natural forests in Malawi. In: Piearce, G.D. and Gumbo, D.J., (ed.) The ecology and management of indigenous forests in Southern Africa, 45-47. Zimbabwe Forestry Commission and SAREC, Harare.

Lowore, J. and Abbot, P.G. 1995. Initial regeneration of miombo woodland under three silvicultural systems. Forestry Research Institute of Malawi, Zomba.

Lowore, J.D., Abbott, P.G. and Meke, G. 1995a. Community utilization of non-timber forest products: an example from the miombo woodland of Malawi. Second Crop Science Conference for Eastern and Southern Africa, Blantyre, Malawi.

Lowore, J.D., Abbot, P.G. and Werren, M. 1994a. Stackwood volume estimations for miombo woodlands in Malawi. Commonwealth Forestry Review 73, 193-197.

Lowore, J.D., Coote, H.C., Abbot, P.G., Chapola, G.B. and Malembo, L.N. 1995b. Community use and management of indigenous trees and forest products in Malawi: the case of four villages close to Chimaliro forest reserve. Forestry Research Institute of Malawi Report No. 93008, Zomba.

Lowore, J.D., Coote, H.C. and Siddle, B. 1994b. Production, usage and trade in the fine hardwoods of Malawi: a preliminary review and consideration of technical, economic and social issues. Unpublished paper, Forestry Research Institute of Malawi, Zomba.

Lundgren, B. 1978. Soil conditions and nutrient cycling under natural and plantation forests in Tanzanian Highlands. Reports in Forest Ecology and Forest Soils 31, Swedish University of Agricultural Sciences, Uppsala, Sweden.

Lungu, O.I. and Chinene, V.R.N. 1993. Cropping and soil management systems and their effect on soil productivity in Zambia. Ecology and Development Programme. Agricultural University of Norway, Ås.

Lwoga, C. 1985. Bureaucrats, peasants and land rights: a village's struggle for self-determination. In: Abrahams, R. (ed.) Villagers, villages and the state in modern Tanzania, 25-42. Cambridge African Monograph 4, University of Cambridge.

Lyaruu, H. V. M. 1995. Seed bank dynamics of the formerly overgrazed Kondoa Irangi Hills, Central Tanzania. A preliminary report. EDSU Working Paper No. 29, Stockholm University.

Lynam, T.J.P., Campbell, B.M. and Vermeulen, S.J. 1994. Contingent valuation of multipurpose tree resources in the smallholder farming sector, Zimbabwe. Working Paper Series 1994:8, Studies in Environmental Economics and Development, Department of Economics, Gothenburg University.

Maghembe, J.A. and Seyani, J.H. 1991. Multipurpose trees used by smallholder farmers in Malawi: results of an ethnobotanical survey. AFRENA report 42. ICRAF, Nairobi.

Makoni, P. 1992. Levels of drought resistance in Brachystegia spiciformis seedlings. Unpublished B.Sc Honours project. Department of Biological Sciences, University of Zimbabwe, Harare.

Makuku, S.J. 1993. All this for a bug! Community approaches to common property resources management. The case of the Norumedzo community in Bikita, Zimbabwe. Forest, Trees and People Newsletter 22: 18-23.

Malaisse, F.P. 1973. Contribution à l'étude de l'écosystème forêt claire (miombo). Note 8. Le projet Miombo. Annales Université Abidjan, série E (Ecologie), Tome VI, 227-250. 
Malaisse, F.P. 1974. Phenology of the Zambezian woodland area with emphasis on the miombo ecosystem. In: Leith, H. (ed.) Phenology and seasonality modelling, 269-286. Ecological Studies 8, Chapman and Hall, London.

Malaisse, F.P. 1978a. The miombo ecosystem. Natural Resources Research 14, 589-606, Unesco, Paris.

Malaisse, F. 1978b. High termitaria. In: M.J.A. Werger (ed.) Biogeography and ecology of southern Africa , 1279-1300. Junk, The Hague.

Malaisse, F.P. 1983. Trophic structure in miombo (Zambesian Tropical Woodland). Annales de la Faculté des Sciences à Lubumbashi 3, 119-162.

Malaisse, F. and Anastassiou-Soquet, F. 1983. Contribution à l'étude de l'écosystème forêt claire (Miombo). Note 45: Spectres biologiques, surfaces foliares, types de fruits et modes de dissemination des diaspores des plantes des hautes termitieres etablies en forêts claires du Shaba Meridional. Annales de la Faculté des Sciences à Lubumbashi 3, 13-39.

Malaisse, F. and Parent, G. 1980. Les chenilles comestibles du Shaba meridionale (Zaire). Les Nactual. Belges 61, 2-24.

Malaisse, F.P. and Strand, M.A. 1973. A preliminary miombo forest seasonal model. In: Kern, L. (ed.) Modeling forest ecosystems, 291-295. I.B.P. Woodland Workshop, Oak Ridge, USA.

Malaisse, F.P, Freson, R., Goffinet, G. and Malaisse-Mousset, M. 1975. Litter fall and litter breakage in miombo. In: Golley, F.B. and Medina, E. (eds) Tropical ecological systems: trends in terrestrial and aquatic research, 137-152. Springer-Verlag, New York.

Malaisse-Mousset, M., Malaisse, F. and Watula, C. 1970. Le cycle biologique d'Elaphrodes lactea (Gaede) (Notodontidae) et son influence sur l'écosystème Miombo. Publication de l'Université du Lubumbashi, série B (sciences) 25: 77-85.

Malimbwi, R.E., Solberg, B. and Luoga, E. 1994. Estimation of biomass and volume in miombo woodland at Kitulangalo Forest reserve, Tanzania. Journal of Tropical Forest Science 7, 230-242.

Mansfield, J.E., Bennet, J.G., King, R.B., Lang, D.M. and Lawton, R.M. 1975. Land resources of Northern and Luapula provinces, Zambia. Land Resource Study 19, Land Resources Division, Ministry of Overseas Development, England.

Manyuchi, B. 1994. High quality forages as supplements to low quality forages for ruminants: on intake, digestibility and rumen digesta dynamics. Ph.D thesis, University of Aberdeen.

Mapiki, A. 1988. Some special features of red soils of the high rainfall area of Zambia with reference to their fertility and management problems. In: Nyamapfene, K., Hussein, J. and Asumadu, K. (eds) The red soils of East and Southern Africa, 368-378. International Development Research Centre, Ottawa, Canada.

Marshall, N.T. and Jenkins, M. 1994. Hard times for hardwood: indigenous timber and the timber trade in Kenya. Species in Danger Series, TRAFFIC International, Cambridge.

Martin, R.B. 1974. Structure, biomass and utilization of vegetation in the mopane and miombo woodlands of the Sengwa Wildlife Research Area. Certificate in Field Ecology thesis, University of Rhodesia, Salisbury.

Martin, R.B. 1994. The Influence of governance on conservation and wildlife utilisation. Department of National Parks and Wildlife Management, Harare.

Mashalla, S.K. 1978. Vegetation as a source of fuel in Tanzania: the case of Msua thicket, Coast Region. M.A. Thesis, University of Dar es Salaam. 
Matose, F. 1992. Villagers as woodland managers. In: Piearce, G. D., and Shaw, P. (eds). Forestry research in Zimbabwe, 27-31. Proceedings of the anniversary seminar. Forestry research advances in Zimbabwe, August, 1990. Forestry Commission, Harare.

Matose, F. 1994. Local people and forest resources in Zimbabwe. M.Sc. thesis, Edmonton, University of Alberta..

Matose, F. and Clarke, J. 1993. Who is the guardian of the indigenous forests? In: Piearce, G.D. and Gumbo, D.J. (eds) The ecology and management of indigenous forests in Southern Africa, 62-70. Proceedings of an international symposium, Victoria Falls, Zimbabwe, 27-29 July 1992. Zimbabwe Forestry Commission and SAREC.

Matose, F., Mudhara, M., and Mushove, P. 1996. Woodcraft industry study report. Unpublished manuscript, Forestry Commission of Zimbabwe.

Matowanyika, J.Z.Z. 1991. Indigenous resource management and sustainability in rural Zimbabwe: an exploration of practices and concepts in commonlands. Ph.D. thesis, University of Waterloo, Waterloo, Canada.

Matthiessen, P. and Douthwaite, B. 1985. The impact of tsetse fly control campaigns on African wildlife. Oryx 19, 202.

Matzke, G.E. 1983. A reassessment of the expected development consequences of tsetse control efforts in Africa. Social Science and Medicine 17, 531-537.

Mazambani, D. 1984. Commodification of woodfuel in Zimbabwe's urban areas: a case study of Harare and Chitungwiza, 1980-1984. Zimbabwe Energy Accounting Project Working Paper No. 9, Harare.

Mbilinyi, M. 1988. Agribusiness and women peasants in Tanzania. Development and Change 19, 549-583.

McGregor, J. 1991. Woodland resources: ecology, policy and ideology. A historical case study of woodland use in Shurugwi communal area, Zimbabwe. Ph.D. thesis, Loughborough University of Technology, Loughborough.

McGregor, J. 1994. Woodland pattern and structure in a peasant farming area of Zimbabwe: ecological determinants and present and past use. Forest Ecology and Management 63, 97-133.

McGregor, J. 1995a. Gathered produce in Zimbabwe's communal areas: changing resource availability and use. Ecology of Food and Nutrition 33, 163-193.

McGregor, J. 1995b. Staking their claims: land disputes in Southern Mozambique. St. Anthony's College, Oxford.

McNamara, K. 1993. Key policy issues. In: Bradley, P.N. and McNamara, K. (eds) Living with trees: policies for forestry management in Zimbabwe, 1-10. World Bank Technical Paper 210, World Bank, Washington DC.

McNaughton, S.J. and Georgiadis, N.J. 1986. Ecology of African grazing and browsing mammals. Annual Review of Ecology and Systematics 17, 39-65.

McNeely, J.A. 1993. Economic incentives for conserving biodiversity: lessons for Africa. Ambio 22, 144-150.

Merlo, M. 1995. Common property forest management in northern Italy: a historical and economic profile. Unasylva 46, 48-63.

Messerschmidt, D., Mol, P., Wiersum, K., Shepherd, G., Watts, J., Ifeka, A., Blais, D., Rodriquez, S., Vargas, A., Dedina, S. and Stanfield, D. 1993. Common forest resource management. Annotated bibliography of Asia, Africa and Latin America. FAO, Rome. 
Mhone, G.C.Z. 1991. Forest based small scale activities engaged in marketing products: a review of valuation considerations. Background paper prepared for the Forestry Commission of Zimbabwe.

Millington, A.C., Critchley, R.W, Douglas, T.D. and Ryan, P. 1994. Estimating woody biomass in SubSaharan Africa. The World Bank, Washington DC.

Minae, S., Sambo, E.Y., Munthali, D.H. and Ng'ong'ola, D.H. 1994. Prioritization of indigenous fruit trees species based on farmers evaluation criteria: some preliminary results from central region, Malawi. In: Proceedings of the regional conference on indigenous fruit trees of the miombo ecozone of Southern Africa, Mangochi, Malawi, January 23-27 1994, 97-105. ICRAF, Nairobi.

Ministry of Lands, Natural Resources and Tourism 1989a. Tanzania Forestry Action Plan Technical Annexes Vol. 2. Dar es Salaam.

Ministry of Lands, Natural Resources and Tourism 1989b. Tanzania Forestry Action Plan 1990/91 2007/08. Dar es Salaam.

Ministry of Lands, Natural Resources and Tourism 1989c. Tanzania Forestry Action Plan Technical Annexes Vol. 1. Dar es Salaam.

Ministry of Tourism, Natural Resources and Environment 1994. Tanzania Forestry Action Plan 1989/90 - 2007/08 Update. Third Draft, Dar es Salaam.

Misana, S.B. 1988. Agricultural development versus environmental conservation in Tanzania: the case of tobacco production. The African Review 15, 1-10.

Misana, S.B. and Nyaki, F.R. 1993. Population and deforestation in Tanzania. In: University of Dar es Salaam and United Nations (eds) Population, environment and development in Tanzania, 41-60. United Nations, New York.

Mitchell, B.L. 1980. Report on a survey of the termites of Zimbabwe. Occasional Papers of the National Museums and Monuments of Rhodesia (Series B, Natural Sciences) 6, 187-323.

Mkanda, F.X. and Munthali, S.M. 1994. Public attitudes and needs around Kasungu National Park, Malawi. Biodiversity and Conservation 3, 29-44.

Mlay, W.F.I. 1986. Environmental implications of land-use patterns in the new villages in Tanzania. In: Arntzen, J.W., Ngcongco, L.D. and Turner, S.D. (eds) Land policy and agriculture in Eastern and Southern Africa, 100-107. The United Nations University, Tokyo.

Mlenge, W. and Johansson, L. 1992. Empowering customary community institutions to manage natural resources in Tanzania: a case study from Bariadi District. Paper presented at a SAREC workshop on people's participation in management of natural resources, 1-7. Stockholm.

Mnkeni, P.N.S. and Akulumuka, V.C.A. 1988. Sorption of ortho- and pyrophosphate by two highly weathered Tanzanian soils. In: Nyamapfene, K., Hussein, J. and Asumadu, K. (eds) The red soils of East and Southern Africa, 303-316. International Development Research Centre, Ottawa, Canada.

Monela, G..C., O'Kting'ati, A. and Kiwele, P.M. 1993. Socio-economic aspects of charcoal consumption and environmental consequences along the Dar es Salaam-Morogoro highway, Tanzania. Forest Ecology and Management 58, 249-258.

Moore, D. S. 1993. Contesting terrain in Zimbabwe's Eastern Highlands: political, ecological, ethnography and peasant resource struggles. Economic Geography 69, 380-401.

Moore, H.L. and Vaughan, M. 1994. Cutting down trees. Heinemann, Portsmouth.

Moore, K. and Hall, J. 1987. Report of a mission to assess the management and conservation of Dalbergia melanoxylon, or the mpingo, in Tanzania. Document No. 3016e, United Nations Environment Programme, Nairobi. 
Moran, E.F. 1979. An introduction to African agriculture. In: Moran, E.F. (ed.) Changing agricultural systems in Africa. Studies in Third World Societies, 7-19. Department of Anthropology, College of William and Mary, Virginia.

Morris, B. 1970. Nature and origins of Brachystegia woodland. Commonwealth Forestry Review 49, 155-158.

Morris, B. 1995. Woodland and village: reflections on the 'animal estate' in rural Malawi. Journal of the Royal Anthropological Institute (N.S.) 1, 301-315.

Moyo, S., O'Keefe, P. and Sill, M. 1993. The Southern African environment: profiles of the SADC Countries. Earthscan, London.

Mpofu, T.P.Z. 1987. History of soil conservation in Zimbabwe. In: SADCC (SWCLU) Coordination Unit (ed.) History of soil conservation in the SADCC Region. Report No. 8, Maseru.

Mtambanengwe, F. and Kirchmann, H. 1995. Litter from a tropical savanna woodland (miombo): chemical composition and $\mathrm{C}$ and $\mathrm{N}$ mineralization. Soil Biology and Biochemistry 27, 1639-1651.

Mujakachi, L.R. 1993. A preliminary investigation of valuation considerations for indigenous woodlands in Zimbabwe. In: Piearce, G.D. and Gumbo, D.J. (eds) The ecology and management of indigenous forests in Southern Africa, 301-311. Proceedings of an international symposium, Victoria Falls, Zimbabwe, 27-29 July, 1992. Zimbabwe Forestry Commission and SAREC, Harare.

Mukamuri, B.B. 1989. Rural conservation strategies in south-central Zimbabwe: an attempt to describe Karanga thought patterns, perceptions and environmental control. In: Grove, R. (ed.) Conservation and rural people in Zimbabwe, 134-149. Cambridge African Monographs and Baobab Press, Cambridge.

Mukamuri, B.B. 1995a. Making sense of social forestry. Acta Universitatis Tamperensis ser A 438, Tampere.

Mukamuri, B.B. 1995b. Local environmental conservation strategies: Karanga religion, politics and environmental control. Environment and History 1, 297-311.

Mukerji, I.F.S. 1992. Greening of Himalayas through people's participation in the state of Himachal Pradesh (Western Himalayas). Paper prepared for the conference on wise management of tropical forests, Oxford, 1992.

Mumeka, A. 1986. Effect of deforestation and subsistence agriculture on runoff of the Kafue river headwaters, Zambia. Hydrological Sciences J. 31, 543-554.

Mung'ong'o, C.G. 1995. Social processes and ecology in the Kondoa Irangi Hills, Central Tanzania. Meddelanden series B93, Department of Human Geography, Stockholm University, Stockholm.

Munthali, J.T.K. and Mughogho, D.E.C. 1992. Economic incentives for conservation: beekeeping and Saturniidae caterpillar utilisation by rural communities. Biodiversity and Conservation 1, 143-154.

Muoghalu, J.I., Akanni, S.O. and Eretan, O.O. 1993. Litter fall and nutrient dynamics in a Nigerian rain forest seven years after a ground fire. Journal of Vegetation Science 4, 323-328.

Mupimpila, M., Sheshamani, V., Mwanza, A., Chidumayo, E., Mwanawina, I. and Cronwell, E. 1995. Structural adjustment and sustainable development in Zambia. Overseas Development Institute, London.

Murombedzi, J. 1991. Decentralising common property resources management: a case study of the Nyaminyami District Council of Zimbabwe's Wildlife Management Programme. Dryland Network Issues Paper 30, International Institute for Environment and Development, London.

Murphree, M. 1993. Communities as resource management institutions. Gatekeeper Series No. 36, International Institute for Environment and Development, London.

Mushala, H.M. 1980. Soil erosion and control: lessons from Kondoa. Mimeo, Department of 
Geography, University of Dar es Salaam.

Musvoto, C. and Campbell, B.M. 1995. Mango trees as components of agroforestry systems in Mangwende, Zimbabwe. Agroforestry Systems 32, 247-260.

Muyay, T. 1981. Les insectes comme Ailments de 1'homme. CEEBA Publications Serie ii, vol. 69, Bandundu, Zaire [translation by D Turk in The Food Insects Newsletter IV, 5-6].

Mwamba, C.K., Zgamba, Y. and Chongo, G. 1992. Effects of seedling source on post-planting growth of Uapaca kirkiana Muell. Arg. South African Forestry Journal 161, 35-40.

Myers, G.W. 1993. A posse de terra no Mocambique pos-guerra: limitantes e conflictos. Mozambique Extra 13, 8-29.

Nhira, C. and Fortmann, L. 1993. Local woodland management: realities at the grass roots. In: Bradley, P.N. and McNamara, K. (eds) Living with trees: policies for forestry management in Zimbabwe, 139-156. World Bank Technical Paper 210, World Bank, Washington DC.

Nhira, C. and Matose, F. 1995. Lessons for the resource sharing project in Zimbabwe from the Indian Joint Forest Management and CAMPFIRE programme experiences. Occasional Paper, Centre for Applied Social Sciences, Harare.

Njovu, F.C. 1993. Non-wood forest products: Zambia. In: Non-wood forest products: A regional expert consultation for english-speaking African countries, Arusha, 17-22 October, 1993, Annex IV. FAO and the Commonwealth Science Council, Rome and London.

Ntenga, G.M. and Mugongo, B.T. 1991. Honey hunters and beekeepers: a study of traditional beekeeping in Babati District, Tanzania. Working Paper No. 161, International Rural Development Centre, Swedish University of Agricultural Sciences, Uppsala.

Nurse, M., McKay, C., Young, J. and Asanaga, C. 1994. Biodiversity conservation through community forestry in the montane forests of Cameroon. Network Paper 18d, Rural Development Forestry Network, Overseas Development Institute, London.

Nyamapfene, K. 1991. Soils of Zimbabwe. Nehanda Press, Harare.

Nyamapfene, K., Hussein, J. and Asumadu, K. 1988. The red soils of East and Southern Africa. International Development Research Centre, Ottawa, Canada.

Nyathi, P. and Campbell, B.M. 1993. The acquisition and use of miombo litter by small-scale farmers in Masvingo, Zimbabwe. Agroforestry Systems 22, 43-48.

Nyathi, P. and Campbell, B.M. 1994. Leaf quality of Sesbania sesban, Leucaena leucocephala and Brachystegia spiciformis: potential agroforestry species. For. Ecol. Manage. 64, 259-264.

Nyirenda, R.W.S. 1993. Non-wood forest product development in Malawi. In: Non-wood forest products. A regional expert consultation for english-speaking African countries, Arusha, 17-22 October, 1993, Annex IV. FAO and the Commonwealth Science Council, Rome and London.

Nyirenda, W. 1995. Effect of licensed grazing on seasonal variation in cattle weight. Forestry Research Institute, Malawi, Zomba.

O'Connor, T.G. 1985. A synthesis of field experiments concerning the grass layer in the savanna regions of southern Africa. South African National Scientific Programmes Report No. 114, CSIR, Pretoria.

Ostberg, W. 1986. The Kondoa transformation: coming to grips with soil erosion in central Tanzania. Research Report no. 76, Scandinavian Institute of African Studies, Uppsala.

Owen-Smith, N. 1993. Overcoming limitations on the productivity of browsing ungulates in African savanna vegetation. Proceedings of the XVII International Grassland Congress, 2094-2095. 
Packham, J. 1993. The value of indigenous fruit-bearing trees in miombo woodland areas of SouthCentral Africa. Rural Development Forestry Network Paper 15c, 13-20. Overseas Development Institute, London.

Palo, R.T., Gowda, J. and Högberg, P. 1993. Species height and root symbiosis, two factors influencing antiherbivore defense of woody plants in East African savanna. Oecologia 93, 322-326.

Payer, C. 1982. Tanzania and the World Bank. The Chr. Michelsen Institute, Bergen.

Pegler, D.N. and Piearce, G.D. 1980. The edible mushrooms of Zambia. Kew Bulletin 35, 475-491

Pellew, R. 1980. The production and consumption of Acacia browse for protein production. In: Le Houerou, H.N. (ed.) Browse in Africa. The current state of knowledge, 223-231. International Livestock Centre for Africa, Addis Ababa.

Peters, C.M. 1994. Sustainable harvest of non-timber plant resources in tropical moist forest: an ecological primer. World Wildlife Fund, Washington DC.

Piearce, G.D. 1987. The genus Termitomyces in Zambia. The Mycologist 1, 111-116.

Pinhey, E.C.G. 1962. Hawk moths of central and southern Africa. Longman, Cape Town.

Pitblado, J. 1970. A review of agricultural land use and land tenure in Tanzania. Bureau of Resource Assessment and Land Use, University of Dar es Salaam.

Plowes, D.C.H. 1957. The seasonal variation in twenty common veld grasses at Matopos, southern Rhodesia, and related observations. Rhodesia Agricultural Journal 54, 33-55.

Poffenberger, M. 1990. Joint management for forest lands: experiences from South Asia. Ford Foundation, New York.

Poffenberger, M., Bhatia, K. and McGean, B. (eds) 1990. Forest management partnerships: regenerating India's Forests. Ford Foundation, New Delhi.

Poffenberger, M. and McGean, B. (eds) 1993a. Community allies: forest co-management in Thailand. Southeast Asia Sustainable Forest Management Network, Center for Southeast Asia Studies, University of California, Berkeley.

Poffenberger, M. and McGean, B. (eds) 1993b. Upland Phillipine communities: guardians of the final forest frontiers. Southeast Asia Sustainable Forest Management Network, East-West Center, Honolulu.

Potter, J.R. 1987. Mizimu: demarcated forests in contour profiles: conservation in Malawi 1800-1960. Thesis, Williams College, Mass.

Price L. (submitted). Household tree holdings and seedling acquisition: a case study in Mutoko Communal Area, Zimbabwe.

Purves, W.D., Fullstone, M.J., Godwin, R.G.H. and Wells, J.D. 1981. Soils of the Banket area. Zimbabwe Agricultural Journal Technical Handbook 4. Government Printer, Harare.

Puzo, B. 1978. Patterns of man-land relations. In: Werger, M.J.A. (ed.) Biogeography and ecology of Southern Africa, 1049-1113. Junk, The Hague.

Quin, P J. 1959. Foods and feeding habits of the Pedi. Witwatersrand University Press, Johannesburg.

Rangely, W.H. 1948. Notes on Chewa tribal law. Nyasaland Journal 3, 5-68.

Ranger, T. 1984. The invention of tradition in colonial Africa. In: Hobsbawn, E. and Ranger, T. (eds) The invention of tradition, 9-25. Cambridge University Press, Cambridge.

Rattray, J.M., Cormack, R.M.M. and Staples, R.R. 1953. The vlei areas of Southern Rhodesia and their uses. Rhodesian Agricultural Journal 50, 456-483. 
Raum, O. F. 1965. German East Africa: changes in African life under German administration, 1892-1914. In: Harlow, V. (ed.) History of East Africa Vol II, 163-209. Clarendon University Press, Oxford.

Reeler, B., Campbell, B. and Price, L. 1991. Defoliation of Brachystegia spiciformis by a species-specific insect Melasoma quadralineata, over two growing seasons. African Journal of Ecology 29, 271-274.

Rees, W.A. 1974. Preliminary studies into bush utilization by cattle in Zambia. Journal of Applied Ecology 11, 207-214.

Reid, J.D. 1986. Relationship among soluble phenolics, insoluble proanthocynidins and fiber in East African browse species. Journal of Range Management 39, 5-7.

Republica Popular de Mocambique 1988. Legislacao sobre o uso e aproveitamento da terra - Lei no. 6/79 de 3 de Julho. Imprensa Nacional de Mocambique, Maputo.

Ribot, J.C. 1993. Forestry policy and charcoal production in Senegal. Energy Policy 21, 559-585.

Richards, E.M. 1992. The forest ejidos of South-East Mexico: A case study of participatory natural forest management. Network Paper 13c, Rural Development Forestry Network, Overseas Development Institute, London.

Richards, M. 1993. The potential of non-timber forest products in sustainable natural forest management in Amazonia. Commonwealth Forestry Review 72, 21-27.

Riddell, J.C. 1979. Land tenure issues in the Rhodesia/Zimbabwe transition. In: Moran, E.F. (ed.) Changing agricultural systems in Africa, 97-125. Studies in Third World Societies, Department of Anthropology, College of William and Mary, Virginia.

Riddell, J.C. and Dickermann, P.E. 1986. Country profiles of land tenure: Africa. University of Wisconsin-Madison. Wisconsin.

Robertson, E.F. 1984. Regrowth of two African woodland types after shifting cultivation. Ph.D thesis, University of Aberdeen.

Robertson, E.F. 1993. Early-burning in the Brachystegia woodland of the Parks and Wild Life Estate. Zimbabwe Science News 27, 68-71.

Rodgers, W.A. (in press a). The miombo woodlands. In: Mclanahan, T. and Young, T. (eds) The habitats of East Africa, Nairobi. Longmans, Harare.

Rodgers, W.A. (in press b). The conservation of biodiversity in East Africa: the approaches of forestry and wildlife sectors compared. In: Benun, L. and Crafter, S. (eds) Biodiversity in Africa. The National Museums of Kenya Press, Nairobi.

Rosser, A.M. and Milliken, T. 1995. Implementation of Tanzania's new policy on trade in live birds. Traffic Bulletin 15, 83-89.

Roy, B. 1989. Arabari experience. A model for forest management with people's participation. Unpublished manuscript.

Ruiz, M.R. 1995. A conceptual framework for CIFOR's research on non-wood forest products. CIFOR Working Paper 6, Center for International Forestry Research, Bogor.

Rutherford, M.C. 1981. Survival, regeneration and leaf biomass changes in woody plants following spring burns in Burkea africana-Ochna pulchra savanna. Bothalia 13, 531-552.

Rutherford, M.C. 1984. Relative allocation and seasonal phasing of growth of woody plant components in a South African savanna. Progress in Biometeorology 3, 200-221.

Rutherford, M.C. and Panagos, M.D. 1982. Seasonal woody plant shoot growth in Burkea africanaOchna pulchra savanna. South African Journal of Botany 1, 104-116. 
SADCC 1994. SADCC Natural Resources Newsletter No. 5. Southern African Development Coordination Conference. Maseru, Lesotho.

SADCC Energy Sector 1987. Wood energy development: biomass assessment. A study of the SADCC Region. ETC-Foundation, Leusden.

Saka, J. and Msonthi, J. 1991. Nutritional value of edible fruits of indigenous wild trees in Malawi. Agroforestry research in the miombo ecozone. Proceedings of a regional conference, Lilongwe.

Sarin, M. 1995. Joint forest management in India: achievements and unaddressed challenges. Unasylva 46, 30-36.

Savory, B.M. 1963. Site quality and tree root morphology in Northern Rhodesia. Rhodesian Journal of Agricultural Research 1, 55-64.

Schoffeleers, J. 1971. The religious significance of bushfires in Malawi. Cahiers des Religions Africanes 10, 271-287.

Scholes, R.J. and Walker, B.H. 1993. An African savanna: synthesis of the Nylsvley study. Cambridge University Press, Cambridge.

Scholes, R.J., Ward, D. and Justice, C.O. (in press) Trace gas emissions from biomass burning in southern-hemisphere Africa. Journal of Geophysical Research.

Scholoffers, J.M. 1978. Guardians of the land. Mambo, Gwelo.

Scoones, I. 1989. Patch use by cattle in a dryland environment: farmer knowledge and ecological theory. In: Cousins, B. (ed.) People, land and livestock, 277-309. Centre for Applied Social Studies, University of Zimbabwe, Harare.

Scoones, I. 1990. Livestock populations and the household economy: a case study from southern Zimbabwe. Ph.D. thesis, Imperial College, London.

Scoones, I. 1994. Living with uncertainty: new directions in pastoral development in Africa. IT Publications, London.

Scoones, I., Clark, J., Matose, F., Phiri, C., Hofstad, O., Makoni, I. and Mvududu, S. 1993. Future directions for forestry extension. In: Bradley, P.N. and McNamara, K. (eds) Living with trees: policies for forestry management in Zimbabwe, 211-226. World Bank Technical Paper 210, World Bank, Washington DC.

Scoones, I. and Cousins, B. 1994. Struggle for control over wetland resources in Zimbabwe. Society and Natural Resources 7, 579-594.

Scoones, I. and Matose, F. 1993. Local woodland management: constraints and opportunities for sustainable resource use. In: Bradley, P.N. and McNamara, K. (eds) Living with trees: policies for forestry management in Zimbabwe, 157-198. World Bank Technical Paper 210, World Bank, Washington DC.

Scoones, I. and Wilson, K.B. 1988. Households, lineage groups and ecological dynamics: issues for livestock research and development in Zimbabwe's communal lands. In: Cousins, B. (ed.) People, land and livestock. Proceedings of the workshop on the socio-economic dimensions of livestock production in the communal areas of Zimbabwe, 17-122. Centre for Applied Social Sciences, Harare.

Scott, L. 1982. A late Quaternary pollen record from the Transavaal bushveld, South Africa. Quaternary Research 17, 339-370.

Scott, L. 1983. Late Quaternary palaeoenvironments in the Transvaal on the basis of palynological evidence. In: Vogel, J.C. (ed.) Late Cainozoic palaeoclimates of the southern hemisphere, 317-327. A.A. Balkema, Rotterdam. 
Scott, L. 1984. Palynological evidence for Quaternary palaeoenvironments in southern Africa. In: Klein, R.G. (ed.) Southern African prehistory and paleoenvironments, 65-80. A.A. Balkema, Rotterdam.

Sellen, D., Howard, W. and Goddard, E. 1993. Production to consumption systems research: a review of methods and approaches. Report prepared for the International Development Research Centre, Ottawa.

Shaba, M.W.M. 1993. A perspective of indigenous forests management in the SADCC Region. In: Piearce, G.D. and Gumbo, D.J. (eds) The ecology and management of indigenous forests in Southern Africa, 29-37. Proceedings of an international symposium, Victoria Falls, Zimbabwe, 2729 July 1992. Zimbabwe Forestry Commission and SAREC, Harare.

Shackleton, S.E. 1993. A situation analysis of the woodcraft in the Bushbuckridge district of the Eastern Transvaal, with particular reference to resource use. Wits Rural Facility, Klaserie.

Shao, J. 1986. The villagization programme and the disruption of the ecological balance in Tanzania. Canadian Journal of African Studies 20, 243-58

Shechambo, F. and Kulindwa, K. 1995. Environmental implications of economic reform policies for agricultural development in Tanzania. Mimeo.

Shepherd, G. 1991. The communal management of forests in the semi-arid and sub-humid regions of Africa: past practice and prospects for the future. Development Policy Review, Sage, London.

Shepherd, G. 1992. Managing Africa's tropical dry forests: a review of indigenous methods. ODI Agricultural Occasional Paper 14, ODI, London.

Shigunango, J., Aviles, C. and Irvine, D. 1993. An experiment in rainforest conservation in Ecuador. Cultural Survival Quarterly 17, 56-59.

Shivji, I. 1995. Problems of land tenure in Tanzania. A review and appraisal of the report of the Presidential Commission of Inquiry into Land Matters, 1992. Dar es Salaam.

Shugart, H.H. 1984. A theory of forest dynamics. Springer-Verlag, New York.

Sibanda, H. and le Mare, J. 1984. Phosphate adsorption as a function of soil mineralogy and soil organic matter in some Zimbabwean soils. Zimbabwean Journal of Agricultural Research 22, 157-162.

Sithole, B. and Bradley, P.N. 1995. Institutional conflicts over the management of communal resources in Zimbabwe. Stockholm Environment Institute, Stockholm.

Sitoe, A. and Ribeiro, N. 1995. Miombo book project: case study of Mozambique. Country study prepared for the current book. Unpublished.

Sjoholm, H. and Wily, L. 1995. Finding a way forward in natural forest management in Tanzania. The emergence of village forest reserves. IRDC Currents 10, International Rural Development Centre, Swedish University of Agricultural Sciences, Uppsala.

Skinner, J. 1988. Towards better woodland management in the Sahelian Mali. Network Paper 25d, Pastoral Development Network, Overseas Development Institute, London.

Smith, F.G. 1966. Beekeeping as a forest industry. East African Agricultural and Forestry Journal 31: 238-244.

Smithers, R.H.N. and Wilson, V.J. 1979. Check list and atlas of the mammals of Zimbabwe Rhodesia. Museum Memoir 9, National Museum and Monuments of Zimbabwe Rhodesia, Salisbury.

Snyder, F. 1982. Colonialism and legal form: the creation of 'customary law' in Senegal. In: Sumner, C. (ed.) Crime, justice and underdevelopment, 54-63. Heinemann, London.

Solomon, A.M., Prentice, I.C., Leemans., R. and Cramer, W.P. 1993 The interaction of climate and land use in future carbon storage and release. Water, Air and Soil Pollution 70, 595-614. 
Sørensen, C. 1993. Controls and sanctions over the use of forest products in the Kafue River Basin of Zambia. Rural Development Forestry Network Paper 15a, Overseas Development Institute, London.

Starfield, A.M., Cumming, D.H.M., Taylor, R.D. and Quadling, M.S. 1993. A frame-based paradigm for dynamic ecosystem models. AI Applications 7 (2\&3), 1-13.

Stewart-Hill, G.C. 1987. Refinement of a model describing forage production, animal production and profitability as a function of bush density in the False Thornveld of the Eastern Cape. Journal of the Grassland Society of Southern Africa 4, 18-24.

Strang, R.M. 1965. Bush encroachment and secondary succession in the southern Rhodesian highveld with special reference to soil moisture relations. Ph.D. thesis, University of London.

Strang, R.M. 1966. The spread and establishment of Brachystegia spiciformis and Julbernardia globiflora in the Rhodesian Highveld. Commonwealth Forestry Review 45, 253-256.

Strang, R.M. 1969. Soil moisture relations under grassland and under woodland in the Rhodesian highveld. Commonwealth Forestry Review 48, 26-40.

Strang, R.M. 1974. Some man-made changes in successional trends on the Rhodesian highveld. Journal of Applied Ecology 111, 249-263.

Stromgaard, P. 1984a. Field studies of land use under chitemene shifting cultivation, Zambia. Geografiks Tidsskrift 84, 78-85.

Stromgaard, P. 1984b. The immediate effect of burning and ash-fertilization. Plant and Soil 80, 307-320.

Stromgaard, P. 1985a. Biomass estimation equations for miombo woodland, Zambia. Agroforestry Systems 3, 3-13.

Stromgaard, P. 1985b. Biomass, growth and burning of woodland in a shifting cultivation area of South Central Africa. Forest Ecology and Management 12, 163-178.

Stromgaard, P. 1985c. A subsistence society under pressure: the Bemba of northern Zambia. Africa 55, 40-59.

Stromgaard, P. 1986. Early secondary succession on abandoned shifting cultivator's plots in the miombo of South Central Africa. Biotropica 18, 97-106.

Stromgaard, P. 1989. Adaptive strategies in the breakdown of shifting cultivation: the case of Mabwe, Lamba, and Lala of Northern Zambia. Human Ecology 17, 427-444.

Stromgaard, P. 1991. Soil nutrient accumulation under traditional African agriculture in the miombo woodland of Zambia. Tropical Agriculture Trinidad 68, 74-80.

Styles, C. 1995. The mopane worm: too profitable for its own good? Our Living World.

Swift, M.J., Frost, S.K. and Frost, P.G.H. in prep. Tree litterfall, decomposition and nutrient dynamics in a miombo woodland in Zimbabwe.

Talbott, K. and Khadka, S. 1994. 'Handing it over': an analysis of the legal and policy framework of community forestry in Nepal. World Resources Institute Center for International Development and Environment, New York.

Temu, A.B. 1979. Fuelwood scarcity and other problems associated with tobacco cultivation in Tabora Region. SUA Forestry Record No. 12, Morogoro, Tanzania.

Temu, A.B. and Kaale, E. 1985. Guidelines for compiling regional and district afforestation plans in Tanzania. Ministry of Lands, Natural Resources and Tourism, Dar-es-Salaam.

Temu, R.P.C. and Msanga, H.P. 1994. Available information and research priorities for indigenous fruit trees in Tanzania. In: Proceedings of the regional conference on indigenous fruit trees of the miombo ecozone of Southern Africa, Mangochi, Malawi, January 23-27 1994, 106-111. ICRAF, Nairobi. 
Thomson, P.J. 1975. The role of elephants, fire and other agents in the decline of a Brachystegia boehmii woodland. Journal of the Southern African Wildlife Management Association 5, 11-18.

Thompson, J.G. and Purves, W.D. 1978. A guide to the soils of Rhodesia. Agricultural Journal Technical Handbook No. 3. Government Printer, Salisbury.

Tibaijuka, A., Kaijage, F., Fimbo, M. and Nshala, A. 1993. The implications of the 'Regulation of Land Tenure (Established Villages) Act 1992' for peasant land tenure security and national resource management and conservation in Tanzania. Land Tenure Study Group, University of Dar es Salaam.

Timberlake, J.R. and Calvert, G.M. 1993. Preliminary root atlas for Zimbabwe and Zambia. Zimbabwe Bulletin of Forestry Research No. 10, Forestry Commission, Harare.

Timberlake, J.R., Nobanda, N. and Mapaure, I. 1993. Vegetation survey of the communal lands - north and west Zimbabwe. Kirkia 14, 171-270.

Tomlinson, R.W. 1974. Preliminary biogeographical studies on the Inyanga mountains, Rhodesia. South African Geographical Journal 56, 15-26.

Topps, J. 1992. Potential, composition and use of legume shrubs and trees as fodder for livestock in the tropics. Journal of Agricultural Science, Cambridge 118, 1-8.

Trapnell, C.G. 1959. Ecological results of woodland burning experiments in Northern Rhodesia. Journal of Ecology 47, 129-168.

Trapnell, C.G. and Clothier, P. 1937. The soils, vegetation and agricultural systems of north-western Rhodesia. The Government Printer, Harare.

Trapnell, C.G., Friend, M.T., Chamberlain, G.T. and Birch, H.F. 1976. The effect of fire and termites on a Zambian woodland soil. Journal of Ecology 64, 577-588.

Trollope, W.S.W., Trollope, L.A. and Bosch, O.J.H. 1990. Veld and pasture terminology in southern Africa. Journal of the Grassland Society of Southern Africa. 7, 52-61.

Tuite, P. and Gardiner, J.J. 1990a. A survey of farm regrowth in south-western Tanzania. Department of Forestry, University College, Dublin.

Tuite, P. and Gardiner, J.J. 1990b. The miombo woodlands of central, eastern and southern Africa. Irish Forestry 47, 90-107.

Tuite, P. and Gardiner, J.J. 1994. The persistence of miombo tree and shrub species in land under continuous cultivation in Tanzania. International Tree Crops Journal 8, 13-26.

Tuohy, J.M. and Choinski, J.S. 1990. Comparative photosynthesis in developing leaves of Brachystegia spiciformis Benth. Journal of Experimental Botany 41, 919-923.

Tuohy, J.M., Prior, J.A.B. and Stewart, G.R. 1991. Photosynthesis in relation to leaf nitrogen and phosphorus content in Zimbabwean trees. Oecologia 88, 378-382.

Turner, V. W. 1962. Themes in the symbolism of Ndembu hunting ritual. Anthropology Quarterly 35, 37-57.

Turner, V. 1967. The forest of symbols: aspects of Ndembu ritual. Cornell University Press, Ithaca.

United Nations, 1995. The least developed countries, 1995 Report. UN, New York.

United Republic of Tanzania 1986. Livestock policy of Tanzania. Ministry of Agriculture and Livestock Development, Government Printer, Dar es Salaam.

United Republic of Tanzania 1992a. The energy policy of Tanzania. Ministry of Water, Energy and Minerals, Dar es Salaam. 
United Republic of Tanzania 1992b. National population policy. The Planning Commission, Dar es Salaam. Vail, L. 1977. Ecology and history: the example of eastern Zambia. Journal of Southern African Studies 3, 129-155.

van den Brink, R. and Bromley D.W. 1992. The enclosures revisited: privatisation, titling, and the quest for advantage in Africa. Working Paper No. 19, Cornell Food and Nutrition Policy Program.

van der Merwe, N.J. and Avery, D.H. 1987. Science and magic in African technology: traditional iron smelting in Malawi. Africa 57, 143-172.

van der Meulen, F. and Werger, M.J.A. 1984. Crown characteristics, leaf size and light throughfall of some savanna trees in southern Africa. South African Journal of Botany 3, 208-218.

van Onsellen, C. 1972. Reactions to rinderpest in Southern Africa. Journal of African History 13, 473-488.

van Wambeke, A. 1982. Soil moisture and temperature regimes, Africa. Technical Monograph No. 3. Soil Management Support Services, Washington DC.

van Wyk, M., Campbell, B.M., Calvert, G.M. and Piearce, G.D. 1993. Mukwa dieback in the state forests of western Zimbabwe. In: Piearce, G.D. and Gumbo, D.J. (ed.) The ecology and management of indigenous forests in Southern Africa, 387-401. Zimbabwe Forestry Commission and SAREC, Harare.

van Zinderen Bakker, E.M. and Clark, J.D. 1962. Pleistocene climates and cultures in north-eastern Angola. Nature (Lond) 196, 639-642.

Vermeulen, S. 1993. Consumption, harvesting and abundance of wood along the boundary between manufacturing Mafungautsi State Forest and Gokwe Communal Area, Zimbabwe. M.Sc thesis, University of Zimbabwe, Harare.

Vitousek, P. 1982. Nutrient cycling and nutrient use efficiency. American Naturalist 119, 553-770.

Vitousek, P. 1984. Litterfall, nutrient cycling and nutrient limitation in tropical forests. Ecology 65, 285-298.

Walker, B.H. 1980. A review of browse and its role in livestock production in southern Africa. In: Le Houerou, H.N. (ed). Browse in Africa: the current state of knowledge, 7-24. International Livestock Centre for Africa, Addis Ababa.

Walker, B.H. 1981. Is succession a viable concept in African savanna ecosystems? In: West, D.C., Shugart, H.H. and Botkin, D.B. (eds) Forest succession: concepts and applications, 431-447. Springer-Verlag, New York.

Walsh, M. 1985. Village, state, and traditional authority in Usangu. In: Abrahams, R. (ed.) Villagers, villages and the state in modern Tanzania, 81-89. Cambridge African Monograph No 4, Cambridge.

Ward, H.K. and Cleghorn, W.B. 1964. The effect of ring-barking trees in Brachystegia woodland on the yield of veld grasses. Rhodesia Agricultural Journal 61, 98-107.

Ward, H.K. and Cleghorn, W.B. 1970. The effects of grazing practices on tree regrowth after clearing indigenous woodland. Rhodesian Journal of Agricultural Research 8, 57-65.

Ward, D.E., Hao, W.M., Susott, R.A., Babbitt, R.A., Shea, R.W., Kauffman, J.B. and Justice, C.O. in press. Effect of fuel composition on combustion efficiency and emission factors for African savanna ecosystems. Journal of Geophysical Research - Atmospheres.

Watson, J.P. 1964. A soil catena on granite in Southern Rhodesia. Journal of Soil Science 15, 238-257.

Watson, J.P. 1977. The use of mounds of the termite Macrotermes falciger as a soil amendment. Journal of Soil Science 28, 664-764.

Watson, J.P. and van Wambeke, A. 1982. Soil moisture and soil temperature regimes in Zimbabwe estimated from climate data. Zambezia 10, 41-47. 
Webster, R. 1965. A catena of soils on the Northern Rhodesia plateau. Journal of Soil Science 16, 31-43.

Weinmann, H. 1948. Seasonal growth and changes in chemical composition of the herbage on the Marendellas sandveld. Rhodesia Agricultural Journal 45, 119-131.

Weinmann, H. 1949. Productivity of Marandellas sandveld pasture in relation to frequency of cutting. Rhodesia Agricultural Journal 46, 175-189.

Weir, J.S. 1973. Air flow, evaporation and mineral accumulation in mounds of Macrotermes subhyalinus (Rambur). Journal of Animal Ecology 42, 509-520.

Werger, M.J.A. and Coetzee, B.J. 1978. The Sudano-Zambezian Region. In: Werger, M.J.A. (ed.) Biogeography and ecology of Southern Africa, 301-462. Junk, The Hague.

Werren, M., Lowore, J., Abbot, P., Siddle, B. and Hardcastle, P. 1995. Management of miombo by local communities. University of Aberdeen and Forestry Research Institute of Malawi, Zomba.

Westoby, M., Walker, B. and Noy-Meir, I. 1989. Opportunistic management for rangelands not at equilibrium. Journal of Range Management 42, 266-274.

White, F. 1962. The forest flora of Northern Rhodesia. Oxford University Press, London.

White, F. 1983. The vegetation of Africa. Natural Resources Research 20, UNESCO, Paris.

White, L. 1987. Magomero. Portrait of an African village. Cambridge University Press, Cambridge.

White, R. 1988. Report of the consultant mission to Tanzania - Mpingo (Dalbergia melanoxylon). Document No. 3956e. United Nations Environment Programme, Nairobi.

Whitlow, J.R. 1979. The household use of woodland resources in rural areas. Natural Resources Board, Salisbury.

Whitlow, J.R. 1983. Vlei cultivation in Zimbabwe - reflections on the past or a play with a difference. Zimbabwe Agricultural Journal 80.

Whitlow, J.R. 1985a. Research on dambos in Zimbabwe. Zimbabwe Agricultural Journal 82, 59-65.

Whitlow, J.R. 1985b. Dambos in Zimbabwe: a review. Zimbabwe Geomorphology. N. F. 52, 115-146.

Wild, H. 1952. The vegetation of Southern Rhodesian termitaria. Rhodesian Agricultural Journal 49, 280-292.

Wildlife Conservation Society of Tanzania 1995. Who controls forest resources in Tanzania? Miombo 13, Dar es Salaam.

Williams, B., Campbell, C. and Williams R. 1995. Broken houses: science and development in the African savannahs. Agriculture and Human Values 12, 29-38.

Williamson, J. 1975. Useful plants of Malawi. University of Malawi, Zomba.

Wilson, A. 1993. Sacred forests and the elders. In: Kemf, E. (ed.) The law of the mother: protecting indigenous people's protected areas, 244-248. Sierra Club Books, San Francisco.

Wilson, K.B. 1989a. Trees in fields in Southern Zimbabwe. Journal of Southern African Studies 15, 369-383.

Wilson, K.B. 1989b. Historical dynamics of the farming systems in Mazvihwa in relation to coping with rainfall vulnerability. Unpublished manuscript.

Wilson, K.B. 1990. Ecological dynamics and human welfare: a case study of population, health and human welfare, in southern Zimbabwe. Ph.D. thesis, University of London.

Wily, L. 1988. The political economy of African land tenure. A case study from Tanzania. School of Development Studies, University of East Anglia. 
Wily, L. 1993a. Forest-adjacent communities and the movement towards partnership for natural forest management. Kenya Indigenous Forest Conservation Programme, Government of Kenya.

Wily, L. 1993b. Establishing the basis of joint forest management. Integrating information collection with participatory planning processes in regard to Mount Elgon, Uganda. IUCN, Gland.

Wily, L. 1995a. What future for community forestry in Nepal? Social Development Newsletter 3, Overseas Development Administration, London.

Wily, L. 1995b. Moving forward in African community forestry. Establishing the first village-owned and managed forest reserves. Forest Action Network Tanzania, Forests, Trees and People Programme.

Wily, L. 1995c. Management of natural resources in Tanzania - briefing document. ORGUT, Ministry of Natural Resources, Dar es Salaam.

Wily, L. 1995d. The law and the village in Tanzania. An exploration of the legal framework for community management of natural forests. Orgut and SIDA, Dar es Salaam.

Wily, L. and Haule, H. 1995. Good news from Tanzania. Village forest reserves in the making - the story of Duru-Haitemba. Forest Trees and People Programme, Newsletter No. 29, Uppsala.

Winter, E. 1968. Some aspects of political organization and land tenure amongst the Iraqw. African Studies 2, Kyoto.

Woodward, A. and Reed, J.D. 1989. The influence of polyphenolics on the nutritive value of browse: a summary of research conducted at ILCA. ILCA Bulletin 35, 2-10.

Working Group on Gender and Forestry 1995. Women and men in natural resource management: important gender issues in the forestry sector. Gender Discussion Paper Series No. 3, Development Studies Unit, Stockholm University.

World Bank 1990. Zambia urban household energy strategy. Report no. 121/90, ESMAP/UNDP Washington DC.

World Bank 1992. World development report, 1992: development and the environment. Oxford University Press, New York.

World Bank 1994a. World development report, 1994: infrastructure for development. World Bank, Washington DC.

World Bank 1994b. Tanzania agricultural sector memorandum. Volume II, main report. World Bank, Washington DC.

Xue, Y. and Shukla, J. 1993 The influence of land surface properties on Sahel climate. Part 1. Desertification. Journal of Climate 6, 2232-2245.

Yanda, P.Z. and Mung'ong'o, C.G. 1995. Environmental changes and social development in Kasulu District, western Tanzania. A reconnaissance report, Mimeo.

Young, A. 1976. Tropical soils and soil survey. Cambridge University Press, Cambridge.

Zinyama, L.M., Matiza, T. and Campbell, D.J. 1990. The use of wild foods during periods of food shortage in rural Zimbabwe. Ecology of Food and Nutrition 24, 251-265. 


\section{Index to scientific names}

A

\begin{tabular}{|c|c|}
\hline Abrus precatorius & 167 \\
\hline Acacia & $4,41,109,124,191$ \\
\hline A. albida & 41 \\
\hline A. angustissima & 187 \\
\hline A. karroo & 188 \\
\hline A. nilotica & 187,188 \\
\hline A. tortilis & 110 \\
\hline A. versicolor & 176 \\
\hline Adansonia digitata & 132 \\
\hline Adenia gummifera & 105 \\
\hline Aeschynomene & 40 \\
\hline \multicolumn{2}{|l|}{ Aframomum } \\
\hline biauriculatum & 21 \\
\hline Afzelia quanzensis & $\begin{array}{l}4,40,64-66,69,104,110, \\
141,163,167,176,185\end{array}$ \\
\hline Albizia & 40,62 \\
\hline A. adianthifolia & $70,176,184,185$ \\
\hline A. antunesiana & 65,178 \\
\hline Alcelaphus lichtensteini & 27 \\
\hline Aloe & 60 \\
\hline Amanita zambiana & 40 \\
\hline \multicolumn{2}{|l|}{ Amblygonocarpus } \\
\hline andongensis & 176 \\
\hline Andropogon & 21 \\
\hline Androstachys johnsonii & 104 \\
\hline Anisophyllea boehmii & 49,181 \\
\hline Apis & 133 \\
\hline Artabotrys brachypetalus & 105 \\
\hline Artabotrys monteiroae & 49 \\
\hline Azanza garckeana & 122,144 \\
\hline \multicolumn{2}{|l|}{$\mathbf{B}$} \\
\hline Brachystegia & $\begin{array}{l}2-3,6-7,11-12,19-20,36, \\
40-41,47,50,53-55,60- \\
62,64,69-70,109,146, \\
184,191\end{array}$ \\
\hline B. allenii & 64 \\
\hline B. boehmii & $\begin{array}{l}20,29-30,36,46-47,50, \\
52,63-65,68,70,103 \\
107,185\end{array}$ \\
\hline B. cyanometroides & 7 \\
\hline B. floribunda & 21,177 \\
\hline B. glaberrima & 21 \\
\hline B. glaucescens & 64 \\
\hline B. laurentii & 7 \\
\hline
\end{tabular}

B. leonensis 7

B. longifolia $\quad 21,23,25,49,103,107$

B. manga 46

B. microphylla $\quad 154$

B. microthyrsa $\quad 103$

B. milbraedii 7

B. spiciformis 20-21, 23, 25-26, 29-30,

$33,35-36,38,42,47-49$,

60, 63-66, 68-70, 103-104, $110,124,147,183,185$,

189

B. utilis 23, $65,103,184-185$

B. wangermeeana 21

Baikiaea

B. plurijuga $\quad 4,21$,

Baphia bequaertii $\quad 47,49,70,189$

Bauhinia petersiana 103

Bauhinia thoningii $\quad 110$

Berchemia discolor $\quad 142$

Boletus $\quad 40$

Boophone disticha $\quad 60$

Borassus aethiopium $\quad 146$

Boscia albitrunca $\quad 123$

Bunaeopsis aurantiaca 107

Burkea

$21,29,41$

B. africana $\quad 4,47,60,107,176,178$

C

Calliandra calothyrsus $\quad 187$

Cantharellus $\quad 40$

Cerina forda $\quad 107$

Chrysophyllum

bangweolense $\quad 105$

Cleome gynandra $\quad 142$

Cleus esculentus $\quad 76$

Cliffortia 6

Colophospermum mopane 4, 103, 107-108, 124

Combretum 4, 50, 55, 109

C. apiculatum $\quad 50,110$

C. imberbe $\quad 104$

Commiphora $\quad 133$

Cordia abyssinica $\quad 105$

Crotalaria 12

Cryptosepalum

pseudotaxus 4

Cubitermes 43 
index

Curculionid $\quad 61$

Cussonia arborea $\quad 110$

Cyanastrum johnstonii 105

Cyathea

6

\section{D}

Dalbergia melanoxylon

Dalbergia nitidula

Dichrostachys cinerea

Digitaria

Dioscorea

Diospyros mespiliformis

Diplorhynchus

condylocarpon

Dolichos

E

Elaphrodes lactea

Elephantorrhiza

Eleusine coracana

Entandophragma

delevoyi

Eragrostis

Eriosema

Erythrina

E. lysistemon

Erythrophleum africanum

Erythrophleum guineense

Eucalyptus

Euclea natalensis

Eutelia polychorda

F

Faurea

F. intermedia

F. saligna

Ficus

F. sycomorus

F. thonningii

Flacourtia indica

G

Gardenia volkensii

Gliricidia sepium

Glossina
G. morsitans
G. pallidipes
G. palpalis

104, 141-142, 155, 163,

$170,172,176,178$

178

$110,187-188$

21

105

$104,122,141$

$46,49,105,167$

21,40

47

40

45

49,176

21

21,40

60

164

4, 40, 49, 70, 107, 176, 184- 185

176

141

47

48

104

176

176

215

110

117

105

117

187

46,81

46,80

46

46
Gonimbrasia belina

107

Gonimbrasia richelmanni 47

Grewia flavescens

105

Gynanisa maia

107

\section{H}

Habenaria walleri $\quad 108$

Hippotragus equinus 27

Hippotragus niger $\quad 27$

Hyparrhenia $\quad 21,121$

Hyphaene petersiana $\quad 146,172$

I

Indigofera $\quad 12,21,40$

Isoberlinia

I. angolensis

I. scheffleri

$2,7,11,19,21,40,54$, 61-62, 69

21, 49, 62-65, 68-69, 107, 178

7

\section{J}

Julbernardia

$2-3,7,11,19,36,40,47$, $50,53-55,60-62,64,69$, $109,122,184$

J. globiflora

$20,25,29,33,35-36,38$, $42,47,52,60-61,63-66$, 67-70, 103, 107, 110, 124, 146-147, 178, 183, 189

J. magnistipulata 7

J. paniculata

$21,23,25,47,49,60-61$, $65,69,103,105-107,110$, $147,178,184-185$

J. pellegriniana 7

$\mathbf{K}$

Khaya anthotheca $\quad 104$

Kigelia africana $\quad 110,122,124$

$\mathbf{L}$

Landolphia 49

Lannea 133

L. discolor $\quad 30$

Lantana camara $\quad 71$

Lecaniodiscus

fraxinifolius $\quad 188$

Leucaena $\quad 187$

Lonchocarpus capassa $\quad 104,178$

Loudetia 21

Loxodonta africana 27 
Lupsya

M

Macrotermes 42

Maprounea africana 49

Maranthes polyandra 49

Markhamia obtusifolia 46

Marquesia 40

M. macroura 21,70

Maytenus 104

Melasoma quadralineata 48

Milicia excelsa $\quad 141$

Milletia stuhlmannii $\quad 104,163$

Momordica balsamina 142

Monotes 30, 40

M. africanus $\quad 70$

Morsitans 81

Myrica 6

O

Ochna

O. pulchra

Olea

O. europaea

Opilia celtidifolia

Ormocarpum

$\mathbf{P}$

Panicum maximum

Parinari

P. curatellifolia

P. excelsa

Pericopsis angolensis

Phoenix reclinata

Piliostigma thonningii

Podocarpus

Pseudolachnostylis

maprouneifolia

Psorospermum

febrifugum

Pteridium

$P$. aquilinum

Pterocarpus

$P$. angolensis

$P$. rotundifolius
191

2
9
9
6
0
1,70
04
8
41
04,163
42
0,40
0
1

104

$47,60,167$

6

142

49

108

187

105-106

49, 70, 105, 122, 176, 181, 184-185

49, 147

4, 40, 49, 70, 105, 176, 185,187

146

187

6

$30,49,110$

104

21

21

62

4, 12, 40, 49, 60, 64-65, 104, 141, 142, 163, 167 , $169,176,184-185,212$ 40
Q

Quelea

Q. quelea

160

149

$\mathbf{R}$

Rauvolfia caffra $\quad 104$

Rhynchosia 40

R. insignis $\quad 60,146,157$

$\mathbf{S}$

Sclerocarya birrea 105-107, 122, 130, 132, $142,145,157-158,164-$ 165,169

Sclerocarya caffra $\quad 12$

Securinega virosa $\quad 188$

Shorea robusta 209

Sphenostylis 21

Spirostachys africana 141-142

Steganotaenia araliacea 110, 167

Stenostylis 105

Sterculia quinquiloba 105

Strychnos 70, 105, 122

S. cocculoides 144-145, 181, 184-185

S. innocua 49

S. madagascariensis 142

S. pungens 49

S. spinosa $\quad 110,142,188$

Swartzia

madagascariensis

Syncerus caffer

64-65, 105, 141, 178, 187

27

75,109

49, 176

S. guineense

105

\section{T}

Tabernaemontana elegans

Terminalia sericea

132

Trypanosoma brucei

104-105

Trypanosoma rhodesiense

46

U

Uapaca

U. kirkiana

$40,46,54,69,105,126$

$40,49,63,65,68-70,104-$

106, 122-123, 133, 135,

144, 147, 157, 169, 171,

$179,181,184$

U. nitida

40, 49, 104, 177

U. pilosa

49

U. sansibarica 
index

V

Vangueria infausta $\quad 30$

Vangueriopsis lanciflora 167

Vitex

V. doniana

$105,122,176$

147

$\mathbf{X}$

Xylopia

167

X. odoratissima

167

$\mathbf{Z}$

Zahna africana

Zizyphus mauritiana

110

Zizyphus mucronata

157

106, 157, 188 
Miombo woodlands are the most extensive vegetation type in Africa south of the equator. These dry tropical woodlands cover some 2.5 million hectares and are home to over 40 million people. Miombo products are very important to the livelihoods and basic needs of an additional 15 million urban Africans.

The book demonstrates how much livelihood strategies of rural communities depend on miombo goods and services, and indicates the strong differentiation of uses within communities and in space and time. The ecological constraints to human activity in the region are clearly articulated, ranging from nutrient poor soils to the presence of the tsetse fly. The authors also trace the host of policies that have influenced miombo woodlands and their uses, from pre-colonial times to the present. The current importance of miombo products in markets, both locally and globally, is documented in a chapter on trade patterns. Options for management are outlined, including silvicultural treatment, fire management and grazing regimes. Institutional arrangements, both local and state, for the management of the woodlands are investigated, and the authors examine how local communities can be empowered to manage and benefit from the woodlands. The final chapter proposes a conceptual model of how all the diverse social, economic, political and ecological processes interact to shape how the household and woodland situations are changing. This conceptual framework is then used to identify key issues for research, which will reduce gaps in current understanding and facilitate formulation of new management strategies, policies and institutions.

The Miombo in Transition is a resource for researchers, with over 250 pages reviewing and synthesising over 400 studies. There are numerous figures, tables and plates. The book contains contributions by a number of researchers, and yet has managed to ensure coherence, close linking of chapters and complete coverage of material through authors' workshops and tight editorial control. Each chapter was reviewed by international experts both in draft and final format, resulting in the high quality of the final product. 